Matheus Dias Bastos

\title{
A akrasia antiga e a fraqueza de vontade contemporânea
}

Tese de Doutorado

Tese apresentada ao Programa de Pós-graduação em Filosofia da PUC-Rio como requisito parcial para obtenção do grau de Doutor em Filosofia pelo Programa de PósGraduação em Filosofia do Departamento de Filosofia do Centro de Teologia e Ciências Humanas da PUC-Rio.

Orientador: Prof. Danilo Marcondes de Souza Filho

Rio de Janeiro

Agosto de 2020 


\section{Matheus Dias Bastos}

\section{A akrasia antiga e a fraqueza de vontade contemporânea}

Tese apresentada como requisito parcial para a obtenção do grau de Doutor pelo Programa de Pós-Graduação em Filosofia do Departamento de Filosofia do Centro de Teologia e Ciências Humanas da PUC-Rio. Aprovada pela Comissão Examinadora abaixo assinada.

Prof. Danilo Marcondes de Souza Filho

Orientador

Departamento de Filosofia - PUC-Rio

Prof. Renato Matoso Ribeiro Gomes Brandão

Departamento de Filosofia - PUC-Rio

Prof. Noel Struchiner

Departamento de Direito - PUC-Rio

Prof. Daniel Simão Nascimento

Universidade Federal do Rio de Janeiro - UFRJ

Prof. Fernando Décio Porto Muniz

Universidade Federal Fluminense - UFF

Rio de janeiro, 17 de agosto de 2020 
Todos os direitos reservados. É proibida a reprodução total ou parcial do trabalho sem autorização da universidade, do autor e do orientador.

\section{Matheus Dias Bastos}

Graduou-se em Filosofia pela Universidade Federal Fluminense (2013). Concluiu o mestrado (2016) e o doutorado (2020) em Filosofia pela Pontifícia Universidade Católica do Rio de Janeiro. Atua na área de História da Filosofia, com especial interesse sobre Filosofia Antiga, Filosofia da Ação Contemporânea e Psicologia Moral.

Ficha Catalográfica

Bastos, Matheus Dias

A akrasia antiga e a fraqueza de vontade contemporânea / Matheus Dias Bastos ; orientador: Danilo Marcondes de Souza Filho. -2020.

585 f. ; $30 \mathrm{~cm}$

Tese

(doutorado)-Pontifícia Universidade Católica do Rio de Janeiro, Departamento de Filosofia, 2020.

Inclui bibliografia

1. Filosofia - Teses. 2. Akrasia. 3. Fraqueza de vontade. 4. Problema. 5. Recepção. I. Souza Filho, Danilo Marcondes de. II. Pontifícia Universidade Católica do Rio de Janeiro. Departamento de Filosofia. III. Título. 


\section{Agradecimentos}

Ao meu orientador professor Danilo Marcondes, pela diligência, paciência e incentivo ao longo de todo este trabalho, com suas valiosas críticas e sugestões.

À CAPES e à PUC-Rio, por todo auxílio e por viabilizar o financiamento deste trabalho mesmo diante das crises econômicas e políticas deste país.

Ao professor Fernando Muniz, por ter me acompanhado e assessorado por toda minha carreira acadêmica, mas também por seu grande apreço e amizade.

Aos meus pais, Adalberto Bastos e Elizabeth Dias, por todo o apoio que sempre me deram em minha vida além do extremo zelo pela minha educação.

À minha amada Maria Adriana, pelo carinho, confiança, e extrema paciência não só durante este trabalho, mas também nos desafios e nas conquistas da vida.

Aos meus amigos André Luiz, Mariana Pinheiro, Lauro Augusto e Gabriela Guedes pela paciência e amizade durante esse período. Em especial, gostaria de agradecer à minha psicóloga Ana Carolina pelo apoio em uma fase pessoal difícil.

Aos professores Renato Matoso, Daniel Nascimento, Noel Struchiner, Remo Mannarino e Guilherme Wyllie por terem aceitado fazer parte de minha banca. Especialmente, agradeço aos professores Renato e Daniel pelas críticas e indicações anteriores na primeira parte deste trabalho.

À André Stock, João Gabriel, Guilherme Nogueira e Rhamon Oliveira pelas discussões filosóficas e pelo companheirismo.

Aos meus companheiros Luiz Eduardo, João Bellas, Antônio Kerstentzky, Thiago Passos e Mauro Juarez pelo grande auxílio na revisão de partes deste trabalho.

Aos colegas, funcionários e professores da PUC-Rio. Em especial, gostaria de agradecer aos professores do NUFA, Maura Iglésias, Irley Franco e Luísa Buarque. Além disso, não posso deixar de mencionar meus queridos companheiros da PUCRio: Rodrigo Viana, Deysielle Chagas, Felipe Amâncio, Felipe Gall, Bento Mota, Camila Lima e Carlota Salgadinho.

Aos meus parentes e familiares, especialmente minhas primas Margareth Dias, Fernanda Marques e meus tios Maria Eliza e Salvador Bernardes.

O presente trabalho foi realizado com apoio da Coordenação de Aperfeiçoamento de Pessoal de Nível Superior - Brasil (CAPES) - Código de Financiamento 001 


\section{Resumo}

Bastos Dias, Matheus; Souza Filho, Danilo Marcondes de. A akrasia antiga e a fraqueza de vontade contemporânea. Rio de Janeiro, 2020. 585 p. Tese de Doutorado - Departamento de Filosofia, Pontifícia Universidade Católica do Rio de Janeiro.

A tese pretende examinar a akrasia antiga e a fraqueza de vontade contemporânea. O problema da fraqueza de vontade (weakness of will) contemporânea tem suas raízes no fenômeno denominado de akrasia desde a Ética a Nicômaco de Aristóteles. Tradicionalmente, a história da filosofia retrata a continuidade de um mesmo problema filosófico essencial. A investigação inicial da fraqueza de vontade contemporânea em Richard. M. Hare e Donald Davidson estabelece a retomada do debate da akrasia antiga presente em Platão e Aristóteles. No entanto, há uma distinção fundamental entre ambos os fenômenos: enquanto a 'fraqueza de vontade' reflete apenas à ação contrária ao melhor juízo do agente, a akrasia se refere à submissão da razão aos impulsos irracionais. A minha presente tese estabelece que há dois problemas distintos: o problema antigo da akrasia diante do conhecimento moral e o problema contemporâneo da ação irracional contra o 'melhor juízo' do agente. De fato, a recepção analítica da akrasia antiga marca o restabelecimento da fraqueza de vontade contemporânea a partir das obras de Hare e Davidson. Meu plano de investigação analisa a relação intrínseca entre a akrasia antiga e a fraqueza de vontade contemporânea. Assim, a tese se divide em duas partes. Na primeira parte, examino o conflito interno da akrasia antiga e o estatuto do conhecimento moral em Platão e na Ética de Aristóteles. Na segunda parte, a recepção da akrasia antiga nas obras de Hare e Davidson esclarece a emergência da formulação original da fraqueza de vontade contemporânea em torno do conflito prático da ação irracional contra o melhor juízo.

\section{Palavras-chave}

Akrasia; fraqueza de vontade; problema; recepção. 


\section{Abstract}

Bastos Dias, Matheus; Souza Filho, Danilo Marcondes de (Advisor). Ancient akrasia and contemporary weakness of will. Rio de Janeiro, 2020. 585 p. Doctoral Thesis - Departamento de Filosofia, Pontifícia Universidade Católica do Rio de Janeiro.

This thesis aims at examining ancient akrasia and contemporary weakness of will. The contemporary problem of weakness of will is rooted on the phenomenon called akrasia since Aristotle's Ethics. Traditionally, the history of philosophy depicts the continuity of the same essential philosophical problem. The initial inquiry on contemporary weakness of will in Richard M. Hare and Donald Davidson renewed the ancient akrasia debate as presented in Plato and Aristotle. Nevertheless, there is a fundamental distinction between both phenomena: while weakness of will reflects only action contrary to better judgement, akrasia refers to submission of reason to irrational impulses. My present thesis aims at establishing that there are two distinct philosophical problems: the ancient problem of akrasia in the face of moral knowledge and the contemporary problem of irrational action against better judgment. Indeed, analytic reception of ancient akrasia in Plato and Aristotle marks the reestablishment of contemporary weakness of will on the works of Hare and Davidson. My research plan examines the underlying relation between ancient akrasia and contemporary weakness of will. Therefore, the thesis is divided in two parts. In the first part, I look into ancient akrasia's internal conflict and the status of moral knowledge in Plato and Aristotle's Ethics. In the second part, reception of ancient akrasia in the works of Hare and Davidson informs the emergence of the original formulation of contemporary weakness of will on practical conflict of irrational action against better judgement.

\section{Keywords}

Akrasia; weakness of will; problem; reception. 


\section{Sumário}

1. Introdução 12

1.1. A akrasia antiga e a fraqueza de vontade contemporânea 12

1.2. O problema geral da fraqueza de vontade 15

1.3. Perspectivas históricas do problema 23

1.4. O problema antigo e o problema contemporâneo 28

1.5. Desenvolvimento da tese 35

2. Antecedentes da akrasia antiga 38

2.1. A etimologia do termo akrasia e os pressupostos psicológicos modernos $\quad 40$

2.2. A descrição tradicional da akrasia da opinião dominante grega 44

2.3. Antecedentes da akrasia tradicional na literatura grega: a psicologia grega antiga e a psicologia da vontade 53

2.4. A descrição tradicional da akrasia da opinião dominante grega 78

2.5. Os antecedentes da akrasia antiga e a descrição tradicional no Protágoras de Platão

3. A refutação da descrição tradicional da akrasia no Protágoras de Platão

3.1. O problema da akrasia e a psicologia moral nos Diálogos:

parâmetros interpretativos e contexto dialógico

3.2. O problema da akrasia antiga no contexto do Protágoras de Platão

3.3. O argumento hedonista e o absurdo da akrasia tradicional

3.4. A refutação da akrasía tradicional: a analogia da percepção sensorial (aísthesis) e o hedonismo

3.5. A divergência interpretativa: a classificação do hedonismo e a akrasia tradicional

3.6. A errância da aparência: o estado de ignorância e a ilusão do 
3.7. O paradoxo socrático (358c-d): o 'intelectualismo' motivacional e os desejos irracionais

4. A teoria tripartite da alma e o conflito interno da akrasia na República

4.1. A psicologia moral platônica e a akrasia na República

4.2. O exame da natureza da alma na República: o Desafio da Justiça e a analogia cidade-alma

4.3. A teoria tripartite da alma na República e o paradoxo socrático

232

4.4. O conflito interno da alma e a akrasia na República

4.5. Os problemas da psicologia tripartite na República: as partes-agente e a negação socrática da akrasia no Protágoras

4.6. A unidade platônica do Protágoras e da República: a negação da akrasia e o conflito interno da alma

299

5.O problema da akrasía na Ética a Nicômaco de Aristóteles

302

5.1. O estatuto da akrasia antiga na Ética a Nicômaco

302

5.2. O caráter e a ação moral voluntária da akrasia 306

5.3. A psicologia moral e o conflito interno da alma

5.4. A ignorância e a akrasia voluntária 327

5.5. O 'mal voluntário' e o paradoxo socrático

5.6. O método da ética e a akrasia em EN VII

5.7. A akrasia e os vícios da alma

5.8. A akrasia absoluta e os tipos de akrasia analógica

5.9. EN VII.3: A possibilidade da akrasia e a solução 'progressiva' de Aristóteles

5.10. O 'silogismo prático' e a explicação physikôs da akrasia

5.11. A akrasia e a posição de 'Sócrates': a 'salvação' do conhecimento moral

6. O prescritivismo moral de Hare e a negação da fraqueza de vontade 
6.1. A recepção analítica da akrasia antiga e a fraqueza de vontade contemporânea

6.2. O problema da fraqueza de vontade e o prescritivismo moral de Hare

6.3. O prescritivismo moral e a implicação lógica da ação moral 421

6.4. A inferência prática e o silogismo prático 426

6.5. A fraqueza moral e o sentido 'entre aspas' de dever (ought)

6.6. A classificação da fraqueza moral: o autoengano e a compulsão psicológica

6.7. O conflito moral e a fraqueza moral 447

6.8. O desafio do prescritivismo moral e da fraqueza moral 455

6.9. A crítica de Bernard Williams à fraqueza moral e ao conflito de deveres morais

6.10. As limitações do prescritivismo moral e da fraqueza moral

7. A possibilidade da fraqueza de vontade e a irracionalidade prática em Davidson

7.1. O desafio da fraqueza de vontade e a irracionalidade prática

7.2. O problema da fraqueza de vontade em How is Weakness of Will Possible? (1969)

7.3. A teoria causal da ação e os tipos de juízos avaliativos

7.4. A reestruturação do silogismo prático e a primeira descrição da fraqueza de vontade

7.5. A controvérsia da fraqueza contra o juízo TFC

7.6. O Paradoxo da Irracionalidade e a akrasia antiga em Paradoxes of Irrationality (1982)

7.7. A segunda descrição da fraqueza de vontade: a negligência do princípio da continência

7.8. A causa mental não racional (CMNR) e a partilha da mente

7.9. As inconsistências da partilha da mente e da segunda descrição da fraqueza de vontade

7.10. A irracionalidade internalista de Davidson e a irracionalidade objetiva da psicologia antiga 
8. Conclusão

552

9. Referências bibliográficas

565 
"Oh, dizei-me, quem foi o primeiro a declarar, a proclamar que o homem comete ignomínias unicamente por desconhecer os seus reais interesses, e que bastaria instruílo, abrir-lhe os olhos para seus verdadeiros e reais interesses (...)? E que fazer então dos milhões de fatos que testemunham terem os homens, com conhecimento de causa, isto é, compreendendo plenamente as suas reais vantagens, relegando estas a um plano secundário e se atirando a outro caminho (...), sem serem obrigados a isto por nada e por ninguém, mas como que não desejando o caminho indicado, e aberto a custo um outro, com teimosia e a seu bel-prazer, procurando quase nas trevas esse caminho árduo, absurdo?"

Fiódor Dostoiévski, Memórias do Subsolo VII 


\section{1. Introdução}

\section{1}

\section{A akrasia antiga e a fraqueza de vontade contemporânea}

O problema contemporâneo da fraqueza de vontade (weakness of will) tem suas raízes no debate filosófico de Platão e Aristóteles acerca da akrasia antiga. Em obras dedicadas à história do problema, como nas obras de Charlton (1988) e de Gosling (1990) ${ }^{1}$, a continuidade de um mesmo problema filosófico do contexto antigo ao contexto atual é largamente reconhecida. Apesar de constatarem as diferenças etimológicas de 'akrasia' e a 'fraqueza de vontade', a extensão da descontinuidade da natureza dos problemas filosóficos não tem sido claramente evidenciada.

O debate original da fraqueza de vontade contemporânea se destaca a partir de Richard M. Hare e Donald Davidson. Dentro da tradição analítica, esses dois filósofos apresentam respectivamente dois paradigmas influentes da formulação original do problema da fraqueza de vontade contemporânea, a fraqueza moral e o conflito prático do fenômeno ${ }^{2}$. Paralelamente, Hare e Davidson alegam estar retomando o problema antigo da akrasia tal como apresentado em Platão e Aristóteles. Na realidade, a emergência da fraqueza de vontade contemporânea está atrelada à própria recepção analítica da akrasia antiga. Antes de analisarmos suas diferenças, cabe destacarmos efetivamente o que é relativamente comum e familiar na caracterização fenomenológica da fraqueza de vontade.

\footnotetext{
${ }^{1}$ Sobre as eventuais diferenças do problema antigo e do problema contemporâneo, ver GOSLING, 1990, p. 97-102; CHARLTON, 1988, p. 1-12. Com efeito, apenas Charlton lança hipóteses históricas pertinentes em sua introdução sobre o importante papel de Hare e Davidson na revitalização contemporânea da discussão grega da akrasia. Em todo caso, suas observações ao longo do livro, especialmente em relação a Davidson, não comprovam efetivamente a continuidade de um mesmo problema filosófico.

${ }^{2}$ Sobre a influência de Richard Hare e Donald Davidson na formulação original da fraqueza de vontade contemporânea, ver CHARLTON, 1988, cap. 5-9; GOSLING, 1990, cap. VIII-XIV; STROUD, 2014. Segundo Stroud (2014), que abrange a controvérsia filosófica da 'fraqueza de vontade' do período pós-guerra à época atual, Hare e Davidson são duas referências centrais para a filosofia contemporânea. Em outro importante compêndio sobre o problema da 'fraqueza', organizado por Mortimer (1971), ressalta-se também a relevância de Hare.
} 
Independentemente do contexto histórico-filosófico, estamos certamente familiarizados com a experiência geral e comum da irracionalidade prática. Durante a vida cotidiana, nos deparamos com uma série de exemplos comuns e ordinários de irracionalidade: largar uma dieta rigorosa pela tentação imediata de um doce, a interrupção de uma tarefa profissional importante por fadiga, a insistência em uma paixão destrutiva. Diante disso, essa série de exemplos traz à tona uma caracterização fenomenológica comum da irracionalidade prática. Em geral, notamos características fenomenológicas comuns nos exemplos mencionados: (1) diante de uma situação prática, o agente precisa deliberar entre duas alternativas disponíveis de ação, uma melhor $x$ e outra pior $y$; (2) antes da ação, o agente faz um juízo racional deliberado e consciente pela melhor alternativa, $x$ é melhor que $y$; (3) após a deliberação racional, ele escolhe efetivamente $y$, expressando, em seguida, arrependimento ou remorso pela atitude tomada. O arrependimento posterior do agente revela sua crença no mesmo juízo racional. Por vezes, as ações irracionais precisam ser racionalizadas, isto é, descritas retrospectivamente em função das razões do agente para a realização da ação. A partir dessas características gerais, é preciso traçar algumas diferenças preliminares entre os fenômenos da akrasia e da fraqueza de vontade.

A distinção dos fenômenos da akrasia e da fraqueza de vontade decorrem das diferenças históricas e conceituais de suas categorias psicológicas. Em primeiro lugar, a 'fraqueza de vontade' envolve a ausência da condição oposta, a 'força de vontade'. Em sentido estrito, a 'vontade' é uma faculdade executiva 'intermediária' entre a razão prática e as paixões irracionais. A ausência da vontade moral significa a ausência da capacidade executiva da razão moral. No entanto, a categoria da 'vontade' está ausente do vocabulário grego antigo. Dentro dos estudos helenísticos, os helenistas têm salientando que o conceito moderno de 'vontade' remete a uma categoria mental posterior que não tem nenhum correspondente na psicologia grega ${ }^{3}$. Dentro da psicologia grega, a própria razão e os impulsos

\footnotetext{
${ }^{3}$ Cf. CHARLTON, 1988, p. 5: "What today we call 'the will' plays no part in classical Greek psyhology, but it is all-important in the non-philosophical psychology of the ancient Jews. For them doing what you know to be bad, far from being puzzling, is the standard form of wrong-doing, and since it is will which has the function of ensuring that we know we should, weakness of will is the standard form of failure." Para outras referências sobre a ausência da 'vontade' no contexto antigo, ver também WILLIAMS, 1993, p. 41-43; VERNANT, J-P, 1990, p. 34.
} 
irracionais cumprem a função executiva delegada exclusivamente à 'vontade' moral na psicologia moderna.

Em segundo lugar, a definição clássica da akrasia remete à condição oposta da enkrateia na Ética a Nicômaco de Aristóteles (1145b10-15). De forma mais literal, a enkrateia significa o poder interno de 'autocontrole' dos impulsos irracionais enquanto a akrasia reflete a 'falta de autocontrole' do agente ${ }^{4}$. Como veremos adiante, as categorias da psicologia moderna nos levam a confundir tal fenômeno antigo com outros fenômenos irracionais atuais como a compulsão psicológica e o autoengano. Por conta disso, devemos nos referir a seguir à descrição tradicional da akrasia da opinião dominante grega, ou seja, à falta de domínio da razão sobre os impulsos irracionais na alma (cf. Prot. 352c-d; Ética I 13 1146b1-5). Em comum, a enkrateia e a akrasia refletem o conflito interno da razão e os impulsos irracionais da alma. No entanto, o resultado de suas ações morais é divergente: enquanto a enkrateia representa o sucesso da razão prática na ação moral, a akrasia significa, então, o fracasso da razão prática diante das paixões irracionais. Em face da akrasia, a fraqueza de vontade não reflete necessariamente um conflito interno psicológico, mas se refere à falta de capacidade executiva da 'vontade' moral e da razão prática. De forma semelhante, a 'força de vontade' reflete o sucesso da razão prática na ação moral, enquanto a 'fraqueza de vontade' constitui o fracasso da razão prática na ação.

Em terceiro lugar, os diferentes fenômenos correspondem assim a diferentes problemas filosóficos no contexto antigo e no contexto contemporâneo. De um lado, o problema da akrasia antiga gira em torno do poder prático do conhecimento moral contra os impulsos irracionais na ação moral. De outro lado, o problema contemporâneo reflete a incompatibilidade lógica do 'melhor juízo' (better judgment) do agente e a ação irracional. Nessa esfera, o problema da eficácia do conhecimento moral passa a ser o problema da consistência lógica e a eficácia prática do 'melhor juízo' do agente na ação. De certa forma, a recepção analítica da akrasia antiga de Platão e Aristóteles se faz presente na formulação original da fraqueza de vontade contemporânea de Hare e Davidson. Para deixarmos essa distinção mais explícita, deveremos abordá-la melhor mais adiante. Antes, será

\footnotetext{
${ }^{4}$ Em Ética a Nicômaco VII, Aristóteles contrasta o caráter do akratés com o caráter do enkratés. À luz dessa oposição, podemos compreender mais precisamente o que significa a akrasia grega.
} 
preciso primeiro levantarmos os problemas fundamentais da irracionalidade prática intrinsecamente relacionados à fraqueza de vontade.

Diante dessas indicações, traçamos o plano de investigação da relação akrasia antiga e da fraqueza de vontade contemporânea. Na filosofia antiga, examinamos o problema da akrasia antiga inicialmente nos diálogos platônicos Protágoras e República e, sobretudo, na Ética a Nicômaco de Aristóteles. Dentro da filosofia contemporânea, investigamos a formulação original da fraqueza de vontade nas principais obras de Hare e nos artigos clássicos de Davidson, 'How is Weakness of Will Possible?' (1969) e 'Paradoxes of Irrationality' (1982). Antes de prosseguirmos nesse plano investigativo, precisamos ter consciência do estatuto atual do problema da fraqueza de vontade.

\section{2 \\ O problema geral da fraqueza de vontade}

A fraqueza de vontade contemporânea coloca em pauta os problemas gerais da irracionalidade prática humana. Em geral, há dois conjuntos de problemas filosóficos associados à fraqueza de vontade ${ }^{5}$ : (1) a possibilidade ou a impossibilidade de existência do fenômeno; (2) mesmo assumindo a possibilidade da fraqueza de vontade, é necessário ainda distinguir os casos reais e aparentes do fenômeno. Na sequência, iremos tratar de cada um desses tópicos do problema filosófico e seus reflexos retrospectivos sobre o debate original da akrasia antiga de Platão e Aristóteles.

Em vista do primeiro tópico filosófico, é necessário determinar se há ou não há um problema filosófico acerca da fraqueza de vontade. Em outras palavras, o que interessa saber fundamentalmente é a possibilidade ou a impossibilidade do fenômeno, particularmente, a ação intencional contrária ao 'melhor juízo' do que se considera melhor a fazer no momento da ação. Nesse cenário, surge o seguinte

\footnotetext{
${ }^{5}$ Sobre esses dois tópicos gerais de problemas filosóficos associados à fraqueza de vontade, ver CHARLTON, 1988, p. 3-4; CHARLES, 1984, p. 109-110. Nessa perspectiva, a primeira formulação coloca em xeque a pertinência filosófica do problema diante da possibilidade da inexistência do fenômeno, enquanto a segunda formulação examina a relação e a especificidade da fraqueza de vontade com diversos outros fenômenos irracionais.
} 
conjunto de indagações filosóficas: É possível agir contra o que se julga ser a melhor alternativa de ação? Seria a fraqueza de vontade um fenômeno realmente possível ou impossível? Invariavelmente, a resposta positiva ou negativa a essa questão se reflete no próprio problema filosófico.

A resposta, positiva ou negativa, a essas indagações filosóficas do primeiro tópico afeta inevitavelmente a própria plausibilidade do problema da fraqueza de vontade. Se a resposta é positiva, é preciso fornecer uma descrição plausível da possibilidade da fraqueza em vista da natureza da razão prática. No entanto, se a resposta é negativa, a fraqueza de vontade perde seu estatuto de problema filosófico e passa a ser, consequentemente, um fenômeno inexistente na experiência humana. De fato, os defensores dessa segunda posição negativa rejeitam em reconhecer qualquer problema da fraqueza de vontade por assumirem de antemão uma posição acerca da relação necessária entre o juízo avaliativo e a ação do agente.

A inexistência do problema da fraqueza de vontade não tem grande repercussão dentro da filosofia ocidental. Dentre seus defensores, Lemmon, por exemplo, apresenta uma tese negativa influente: a fraqueza é um "pseudoproblema na literatura filosófica" de tal forma que se nos deparamos com um problema acerca de sua existência, já estaremos "fazendo um equívoco filosófico" Davidson (2001b, p. 23) ressalta que o problema filosófico persiste mesmo diante de um aparente equívoco: "If your assumptions lead to a contradiction, no doubt you have made a mistake, but since you can know you have made a mistake without knowing what the mistake is, your problem may be real.”. Em geral, os equívocos filosóficos são transitórios e, por vezes, imperceptíveis, mas esse problema filosófico permanece vivo porque a fraqueza de vontade faz parte de nossa experiência intuitiva. Naturalmente, a manifestação da fraqueza de vontade colide com outras crenças intuitivas da natureza da razão prática, particularmente, na relação intrínseca entre o juízo avaliativo do bem e a ação realizada pelo agente.

A relação intrínseca entre o juízo avaliativo do bem e a ação realizada do agente entra em conflito com a fraqueza de vontade. Desde a filosofia antiga até atualmente, uma tradição filosófica influente defende o internalismo da razão prática, isto é, a tese de que o juízo prático avaliativo do agente sobre o melhor

${ }^{6}$ Sobre essa observação emblemática da inexistência do fenômeno e de sua implausibilidade enquanto um problema filosófico, ver LEMMON apud DAVIDSON, 2001b, p. 23 
curso de ação implica necessariamente em um desejo de realizar a melhor ação. ${ }^{7}$ Dessa forma, a ação contrária ao 'melhor juízo' efetivamente coloca em xeque a natureza da relação necessária do juízo prático do bem e a realização da melhor ação. Diante da fraqueza de vontade, é necessário compreender o que constitui o 'melhor juízo' (better judgment) na razão prática: qual o estatuto prático e a consistência lógica do 'melhor juízo’ do agente? Será que o 'melhor juízo’ é válido em todas as circunstâncias da ação, ou apenas bom em certos contextos e mal em outros contextos práticos de ação? Seria o ‘melhor juízo’ um juízo moral do bem ou um juízo lógico mais amplo de 'todos os fatores considerados' (all things considered)? Ora, mas qual o valor prático efetivo do 'melhor juízo' na ação? Nessa perspectiva, a defesa da eficácia prática do 'melhor juízo' na ação tem levado à negação da existência do fenômeno.

Ao longo da filosofia ocidental, a relação interna entre o juízo prático avaliativo do bem e a ação tem sustentado posições divergentes acerca da ação contrária ao 'melhor juízo' do agente. Na filosofia contemporânea, a negação absoluta da fraqueza de vontade é defendida sistematicamente nas obras de Hare. Na realidade, o objetivo final de Hare é preservar o prescritivismo moral, isto é, a doutrina de que os juízos morais guiam as ações morais. Dentro da filosofia antiga, a negação socrática da akrasia no Protágoras de Platão reflete princípios semelhantes sobre a eficácia prática do melhor juízo na ação. Nessa esfera, o paradoxo socrático 'ninguém é mal voluntariamente' estabelece que não há efetivamente ação contra o melhor juízo visto que não é possível agir contra o que se considera ser melhor. Da mesma forma, há aqueles que defendem a possibilidade da ação contra o 'melhor juízo'.

Uma outra corrente filosófica tem sustentado a possibilidade da ação contrária ao 'melhor juízo' do agente. Na filosofia contemporânea, a defesa da possibilidade da fraqueza de vontade é apresentada no clássico artigo 'How is Weakness of Will Possible?' (1969) de Davidson. Ao longo desse influente artigo, Davidson sustenta que há uma incompatibilidade lógica inerente entre o 'melhor juízo’ e a ação irracional da fraqueza. De modo semelhante, Aristóteles estabelece

\footnotetext{
7 Sobre a formulação contemporânea do 'internalismo' da razão prática, ver HARE, 1963, p. 71; DAVIDSON, 2001b, p. 23. Como veremos adiante, a psicologia antiga já apresenta um tipo de internalismo da razão prática, mas também atribui um papel significativo aos impulsos irracionais na ação moral. De certa maneira, devemos esclarecer o debate analítico do 'internalismo' e do 'externalismo' na segunda parte desta tese de doutorado.
} 
a possibilidade da akrasia antiga em sua clássica análise da Ética a Nicômaco. Nessa obra, o desafio de Aristóteles é comprovar o conflito prático fundamental entre a consistência do 'melhor juízo' na razão prática e o efeito dos impulsos irracionais no fenômeno da akrasia. Mesmo a possibilidade da ação contrária ao ‘melhor juízo' desperta um novo conjunto de indagações filosóficas sobre os casos reais e aparentes do fenômeno.

Diante do segundo tópico filosófico, é necessário distinguir os casos reais dos casos aparentes da fraqueza de vontade. Nessa esfera, o problema passa a ser destacar o que caracteriza o fenômeno em si mesmo de outros fenômenos irracionais que são, em alguma medida, similares.

Dessa forma, temos um conjunto de questões bastante diferente do tópico anterior: Será que há um conflito interno entre as diferentes forças motivacionais do agente? Ora, será que o agente mantém efetivamente o 'melhor juízo' ao longo de toda sua ação ou será que ele teria mudado de ideia no momento da ação? Nessa medida, seria o agente capaz de enganar a si mesmo a respeito de suas crenças ou do melhor juízo? Ou será que o agente está sendo submetido por um forte impulso irracional a ponto de ser psicologicamente incapaz de agir conforme o melhor juízo na ação? Dessa vez, estamos diante de uma série de fenômenos irracionais próximos à fraqueza de vontade: a hipocrisia ou insinceridade, a imprudência ou intemperança, o autoengano, a compulsão psicológica entre outros. Invariavelmente, é preciso distinguir claramente a fraqueza de vontade desses outros fenômenos irracionais correlatos. Do contrário, corremos o risco de associar o fenômeno a outros tipos de irracionalidade prática e confundir a natureza original e específica de seu conflito prático.

É imprescindível destacar a natureza irracional da fraqueza e dar uma explicação psicológica mais positiva do fenômeno. Em alguma medida, o exame psicológico depende de uma eventual distinção da parte racional e da parte irracional da psicologia humana. Nessa esfera, podemos destacar inclusive a fraqueza de vontade da akrasia antiga de forma mais clara. Em seguida, devemos demarcar as diferenças fundamentais dos outros fenômenos irracionais anteriores relacionados à ação contra o melhor juízo.

Para efeitos de exemplificação, podemos considerar o caso hipotético de um homem que continua bebendo whisky além da conta mesmo tendo bebido o suficiente e possuindo razões suficientes para parar de beber imediatamente devido 
a compromissos e tarefas futuras. ${ }^{8}$ Diante desse exemplo ilustrativo, devemos analisar os diversos tipos de irracionalidade prática próximas à fraqueza de vontade.

Primeiramente, a hipocrisia ou insinceridade claramente não reflete as verdadeiras intenções do agente. Levando em conta o exemplo anterior, o homem pode dizer que pretende parar de beber, mas não acreditar sinceramente no que está dizendo para os outros. Na classificação filosófica atual, ele seria um hipócrita ou insincero acerca de suas verdadeiras intenções de ação (cf. HARE, 1996, cap. 11). Dessa forma, sua conduta é racional já que as crenças do agente condizem com suas atitudes na ação. Supostamente, o homem pode inclusive acreditar plenamente que é melhor continuar bebendo incessantemente do que simplesmente parar de beber.

Diante dessa possibilidade, o hipócrita seria o equivalente ao homem imprudente que não só tem plena consciência como deseja satisfazer seu desejo alcoólico. Nesse ponto, o imprudente expressa claramente a intenção de prosseguir bebendo. A partir disso, estaríamos diante do que é classificado de vício moral (kakía) ou, mais especificamente, de intemperança (akolasía) na Ética de Aristóteles. ${ }^{9}$ No caso da imprudência, não há qualquer conflito entre o 'melhor juízo’ prático e a ação do agente. De acordo com a descrição do caso, o agente deseja continuar bebendo e, ao mesmo tempo, julga que é melhor continuar bebendo do que parar de beber dentro das circunstâncias da ação. Do ponto de vista objetivo, a classificação da ação irracional advém da repreensão externa de acordo com regras morais ou sociais e não em vista das crenças internas do agente.

Nesse limite, a hipocrisia e a imprudência são atitudes irracionais bastante diferentes da fraqueza de vontade. De qualquer forma, há outros exemplos de fenômenos irracionais que se aproximam mais do fenômeno.

Há casos em que o agente não está plenamente ciente do que está fazendo. De fato, o homem pode não ter percebido plenamente no momento da ação porque permanecendo bebendo. Por conta de algum fato particular, o agente pode ter mudado de ideia brevemente no momento da ação julgando que é melhor continuar bebendo esta garrafa de whisky pelo prazer imediato. No entanto, o homem

\footnotetext{
${ }^{8} \mathrm{O}$ exemplo ilustrativo foi retirado do artigo de Pereira (2005) mas o exemplo do embriagado por si só tem raízes mais arcaicas. Com efeito, o exemplo é apropriado para os tipos de casos de irracionalidade que pretendemos tratar. No entanto, devemos extrapolar em certa medida a análise de Pereira, para dar conta de outros tipos de fenômenos irracionais correspondentes à fraqueza.

${ }^{9}$ Para outras referências sobre a atitude moral do caráter vicioso ou intemperante, cf. 1118b101119b15; 1150b25-1151a28.
} 
expressa o mesmo juízo original, isto é, de que é melhor parar de beber whisky antes e depois da ação. De acordo com a classificação contemporânea, estamos diante de um caso de autoengano (self-deception $)^{10}$.

$\mathrm{O}$ autoengano constitui a possibilidade do próprio agente se enganar a respeito de suas crenças durante a ação. $\mathrm{O}$ relato do agente sobre sua própria experiência é equivocado na medida em que não contempla a mudança de suas ideias ao longo da ação irracional. Na realidade, o agente não está em plena consciência do que ocorreu durante a ação porque convenceu-se a si mesmo da impressão errada, isto é, de que manteve sempre o mesmo juízo racional de que devia ter parado de beber whisky. Por isso, a mudança de ideia repentina do agente se mantém de alguma forma inconsciente em sua mente. Supostamente, a breve mudança de ideia no momento da ação se deve ao obscurecimento do 'melhor juízo', desejos inconscientes, ignorância temporária de algum estágio do raciocínio prático no momento da ação. Independente do motivo, o mais fundamental é que o 'melhor juízo' de alguma forma escapa da consciência do agente no autoengano. Sob esse ponto de vista, a irracionalidade da ação está relacionada à inconsistência interna das crenças do agente.

O autoengano constitui uma forma de ignorância do agente acerca de suas próprias crenças durante a ação. Ao contrário, a fraqueza de vontade depende da plena consciência do agente e da preservação do melhor juízo na ação irracional. No entanto, resta ainda investigar outro fenômeno irracional relacionado ao poder dos impulsos irracionais.

Dentre os fenômenos irracionais relatados, a compulsão parece a mais próxima da fraqueza de vontade. É possível que o agente tenha plena consciência do 'melhor juízo' ao longo da ação, mas toma uma atitude contrária ao juízo devido a fortes impulsos irracionais. Retomando o exemplo hipotético anterior, o homem estaria assim resoluto de que precisa parar de beber durante a ação mas, mesmo assim, continua bebendo por causa de um impulso violento de desejo alcóolico. Dentro dessas circunstâncias, o 'melhor juízo' do agente é completamente

\footnotetext{
${ }^{10}$ Sobre a classificação contemporânea de autoengano (self-deception), ver HARE, 1963, cap. 5; Idem, 1999, cap. 9; DAVIDSON, 2004a-c.
} 
subjugado pelo desejo alcoólico impulsivo. Dessa forma, a classificação mais adequada para esse tipo de fenômeno irracional é a compulsão psicológica ${ }^{11}$.

O fenômeno da compulsão psicológica é extremamente familiar aos parâmetros da psicologia moderna. Em alguma medida, os exemplos comuns são extremamente corriqueiros e familiares: os viciados em álcool ou, em geral, à drogas lícitas ou ilícitas, as fobias (o medo de diferentes tipos de objetos, animais, etc.), os comportamentos compulsivos ou obsessivos. Tipicamente, a analogia com a coerção externa física reflete a presença da coerção interna psicológica do forte impulso violento. Por coação interna, os impulsos e desejos irracionais nos levam, de forma irresistível, a agir contra a vontade racional e a consciência do 'melhor juízo'. Dentro desse cenário, a presença de um forte desejo irresistível por álcool poderia atribuída a um alcoolismo crônico. No entanto, estamos nos referindo aqui ainda a um impulso irresistível compulsivo e não mais ao impulso irracional controlável da fraqueza de vontade.

Em alguma medida, todos os fenômenos irracionais estão relacionados à fraqueza de vontade contemporânea. No entanto, a singularidade fraqueza de vontade não se confunde com nenhum dos fenômenos irracionais anteriores. Até agora, tratamos dos casos aparentes e não do caso real da fraqueza de vontade. Mesmo assim, ainda há filósofos que continuam confundindo a natureza da fraqueza de vontade com esses outros fenômenos irracionais. A polêmica da fraqueza de vontade com outros fenômenos irracionais se transfere também à recepção analítica da akrasia antiga. Em especial, isso se deve justamente porque a tradição moderna assimila de certa forma o fenômeno da akrasia à fraqueza de vontade. A tradição analítica enxerga na akrasia a mesma relação da fraqueza de vontade com os diversos tipos de fenômenos irracionais. De fato, nenhum dos casos anteriores contempla a akrasia antiga. De qualquer modo, devemos manter consciência sobretudo das diferenças fundamentais da fraqueza de vontade e da akrasia antiga.

Com base nessa distinção filosófica, a fraqueza de vontade e a akrasia constituem dois fenômenos semelhantes, mas com diferenças significativas. Para esclarecer isso, devemos retornar ao exemplo anterior tendo em vista um caso genuíno de conflito prático do agente. Diante do exemplo anterior, suponhamos que

${ }^{11}$ Para a classificação contemporânea da compulsão psicológica, ver HARE, 1963, cap. 5; Idem, 1992, cap. 9; DAVIDSON, 2001b, p. 27-29; WATSON, 1977. 
o homem tem plena consciência de que é melhor parar de beber e tem a intenção de agir conforme seu 'melhor juízo' durante toda a ação. Mesmo assim, ele continua bebendo sem parar no momento decisivo da ação. Em princípio, descartamos a compulsão psicológica, ou seja, o agente não é alcoólatra e nem está sob efeito de um impulso irresistível por bebida. Diante disso, podemos fornecer duas descrições distintas de sua ação irracional, a fraqueza de vontade e a akrasia.

Em função do exemplo anterior, apresentaremos duas descrições possíveis da ação irracional do agente. Primeiramente, a descrição geral da fraqueza de vontade contemporânea constitui um amplo fenômeno irracional. Nesse cenário, podemos considerar que o 'melhor juízo' do homem equivale logicamente ao juízo de 'todos os fatores considerados' (all things considered): 'é melhor parar de beber do que continuar bebendo, levando em conta todos os fatores'. Como bem sabemos, a ação irracional não corresponde ao 'melhor juízo', mas à uma razão mais fraca do agente. Supostamente, há inumeráveis razões fracas para continuar bebendo, como o sabor do whisky, a companhia para dividir a bebida, o prazer imediato, etc. Nenhuma das razões fracas, no entanto, justifica efetivamente a ação intencional contra o 'melhor juízo'. No cenário contemporâneo, o problema da fraqueza de vontade se constitui em torno do conflito interno da racionalidade prática do agente e a incoerência inerente entre suas crenças, desejos e a ação irracional.

Nesse quadro geral, o problema lógico do 'melhor juízo' independe da vontade moral. Em princípio, faltou ao homem a força de vontade necessária para colocar em prática a norma prática do juízo moral. No entanto, já teríamos assim deslocado o problema geral do 'melhor juízo' ao campo mais restrito da fraqueza moral. ${ }^{12}$ Independente da 'vontade' moral, tal formulação remonta ao fenômeno moral original da akrasia antiga.

Diante do exemplo anterior, seria possível construir um caso típico da akrasia. De acordo com a psicologia antiga, a akrasia é indissociável do conflito prático fundamental entre a razão e os impulsos irracionais na ação. Nessa perspectiva, há um conflito interno no homem entre o ‘melhor juízo’ racional para

\footnotetext{
${ }^{12}$ Por enquanto, ainda não poderei tratar com mais profundidade as conotações morais da psicologia moral da vontade. Na sequência, pretendemos indicar que a história do problema filosófico já tem ressaltado diversos aspectos significativos que indicam os diferentes parâmetros psicológicos e morais que separam a fraqueza de vontade da akrasia antiga. Nos próximos capítulos, deveremos esclarecer a minha crítica à psicologia da vontade e as categorias morais do 'dever' tipicamente associados à fraqueza moral.
} 
parar de beber e o apetite irracional para continuar bebendo o whisky. No caso da akrasia, a submissão da razão pelo desejo irracional leva o agente a continuar bebendo whisky em vez de parar de beber o whisky. Sobretudo, a akrasia reflete uma atitude consciente, livre e intencional contra o desejo racional do agente. Nessa medida, o agente não mantém o controle sobre seus impulsos irracionais, mas não pela submissão completa de impulso irresistível da compulsão psicológica. De certa forma, o agente é capaz de controlar seus desejos irracionais durante a ação. Em princípio, a akrasia emerge de um conflito prático entre os impulsos irracionais e o desejo racional do agente.

Nesse aspecto, há uma diferença notável da akrasia em relação à fraqueza de vontade contemporânea. Assim como outros impulsos irracionais, a própria razão humana expressa a força motivacional de um desejo, o desejo racional. Ao contrário da psicologia moderna, a razão não representa apenas uma categoria mental impassível cuja única função é expressar o juízo avaliativo da ação. Dentro da psicologia antiga, o juízo avaliativo da razão expressa um desejo e uma motivação racioal na ação. Além disso, os próprios impulsos irracionais também podem desempenhar aspectos cognitivos e expressar simultaneamente um juízo avaliativo da ação. Por isso, a akrasia representa um conflito prático de impulsos contrários, o conflito interno da razão e dos desejos irracionais. Em contraste, a fraqueza de vontade não contempla o conflito prático no mesmo sentido que a akrasia. Sobretudo, a razão não expressa mais uma força motivacional distinta e os desejos irracionais perdem sua capacidade cognitiva na psicologia moderna da vontade. De certa forma, o fator decisivo na ação é a força de vontade ou a fraqueza da vontade na execução do 'melhor juízo' racional. Dentro da história do problema filosófico, podemos notar essas significativas diferenças na natureza de ambos os fenômenos.

\section{3 \\ Perspectivas históricas do problema}

Em larga medida, obras dedicadas à história do problema filosófico têm salientado as diferenças notáveis da akrasia e da fraqueza de vontade. De forma 
geral, as obras históricas se dedicam a explorar as significativas diferenças da natureza de ambos os fenômenos. Em especial, Charlton (1988) e Gosling (1990) fizeram uma importante contribuição ao demarcar as diferenças etimológicas, culturais e, sobretudo, as categorias psicológicas distintas que separam a psicologia grega antiga da psicologia moderna da vontade. Ao longo dessas obras, observamos o desenvolvimento progressivo do problema filosófico da fraqueza de vontade.

No entanto, ambos os autores parecem confiar ainda em um pressuposto comum: a continuidade fundamental de um único problema filosófico. ${ }^{13}$ Ao contrário, pretendemos mostrar que a natureza distinta da akrasia e da fraqueza de vontade correspondem à problemas filosóficos essencialmente diferentes. Para isso, devemos estabelecer a descontinuidade da akrasia antiga e da fraqueza de vontade contemporânea. Com base nessa distinção, poderemos compreender de que modo a recepção analítica da akrasia antiga caracteriza a formulação original da fraqueza de vontade contemporânea. Sob essa perspectiva, devemos considerar certas observações preliminares sobre as diferenças da akrasia antiga e da fraqueza de vontade contemporânea.

Em Weakness of Will, Charlton (1988, p. 1-12) demarca a progressiva mudança histórica do problema filosófico da fraqueza de vontade. Em especial, a ausência da concepção da 'vontade' na psicologia grega clássica representa uma mudança crucial na formulação do problema filosófico moderno. De certa forma, essas diferenças são especialmente notáveis em relação à tradição grega antiga e a tradição judaico-cristã tardia. Assim, Charlon traça conclusões gerais que refletem as diferenças psicológicas indicadas anteriormente.

Dentro de suas considerações gerais, Charlton (Ibid., p. 7) ressalta as mudanças crucias entre a psicologia grega e a psicologia judaico-cristã da vontade:

(...) the Greeks conceives the state of mind of the human agent as one in which tought and appetition are logically inseparable (...) When the will was given the task of making our behaviour

\footnotetext{
${ }^{13}$ Sobre a continuidade do problema filosófico, diversos comentadores da filosofia antiga parecem simplesmente assumir que a fraqueza de vontade e a akrasia representam simplesmente o mesmo fenômeno (cf. TAYLOR, 1980; PENNER, 1990; WATSON, 1977). Dessa forma, seus comentários pretendem traçar reflexões mais gerais sobre o estatuto da akrasia antiga a partir da discussão atual da fraqueza de vontade contemporânea. Ao longo da minha investigação, pretendo mostrar que tais comentários nos esclarecem mais sobre o estatuto do problema contemporâneo do que sobre o debate original da akrasia antiga de Platão e Aristóteles. De certa forma, os comentadores aristotélicos, no entanto, têm sido mais cautelosos na distinção de ambos os fenômenos (cf. CHARLES, 2011; BOSTOCK, 2000; PAKALUK, 2005).
} 
conform to what we think best, desire was separated sharply from cognitive thought.

Para Charlton, a emergência da concepção da 'vontade' demarca o desaparecimento do problema filosófico original da akrasia no período moderno. De acordo com Charlton (Ibid., p. 7-9) isso se deve a dois fatores inerentes da psicologia grega: (1) a associação lógica intrínseca entre desejo e cognição; (2) a determinação do comportamento humano pela visão do agente sobre o bem no campo da ação prática. Com o advento da 'vontade' moral, há uma separação estrita do desejo e da cognição justamente porque a própria 'vontade' é responsável pela ação conforme ao melhor juízo prático do agente. Nesse cenário, a fraqueza de vontade deixa de ser um problema à medida que não há mais uma conexão lógica necessária entre a motivação da ação e as crenças do bem. Todavia, Charlton também salienta que a renovação dos estudos clássicos a partir da filosofia analítica anglo-saxã reestabelece a relação da ação e as crenças do bem despertando novamente o interesse contemporâneo sobre a akrasia antiga.

A tradição analítica anglo-saxã gera uma completa renovação dos estudos da filosofia antiga clássica. Aliados a uma formação clássica, filósofos como Gilbert Ryle e J. L. Austin introduziram novos métodos interpretativos analíticos sobre os textos clássicos de Platão e Aristóteles após a década de 1930. Com o rigor da leitura analítica dos textos gregos originais, foi possível se livrar dos equívocos dos métodos interpretativos tradicionais da época baseados no idealismo alemão e no empirismo britânico. A partir da década de 1950 e 1960, Gilbert Ryle e G. E. M. Anscombe dispensaram a categoria da vontade do campo da filosofia da ação e deram maior ênfase a outras categorias mentais fundamentais, como a intenção, os desejos, as crenças e motivações do agente para explicar a ação humana. Dentro dessa nova tradição analítica, surgiram diversos estudos clássicos em torno da akrasia antiga nos textos de Platão e Aristóteles.

A emergência de uma nova filosofia da ação contemporânea despertou o interesse também no problema da akrasia antiga. Dentre outras obras, podemos destacar os estudos da akrasia antiga presentes nas obras de David Charles (1984), C. C. W. Taylor (1980, 1991), Richard Robinson (1956) e Gerasimos Santas (1969, 1979) e até o compêndio Weakness of Will de G. W. Mortimer (1971). Em meio à recepção analítica da akrasia antiga, as obras de Hare e Davidson renovam assim o problema da fraqueza de vontade contemporânea. 
A formulação original da fraqueza de vontade contemporânea formada no debate analítico de Hare e Davidson reflete a renovação de pressupostos tradicionais da psicologia grega antiga. De um lado, o prescritivismo moral de Hare desperta novamente a conexão lógica entre o ‘melhor juízo’ do agente e a motivação da ação. ${ }^{14}$ De outro lado, o clássico artigo de Davidson 'How is Weakness of Will Possible?' (1969) recupera as concepções tradicionais da psicologia antiga da ação e se afasta da psicologia judaico-cristã da vontade. De todo modo, a renovação da fraqueza de vontade contemporânea inevitavelmente envolve uma abstração do contexto moral inerente ao conflito prático da akrasia antiga.

A fraqueza de vontade contemporânea está ligada à razão prática e não se caracteriza pelo conflito interno da alma da akrasia antiga. O problema da akrasia antiga possui uma dimensão moral irredutível à racionalidade prática. Como mostra Broadie (1991, p. 269), o ponto de vista contemporâneo da estrutura lógica (ou ilógica) da razão prática na fraqueza não contempla a ausência do treinamento moral das paixões inerente ao conflito interno da akrasia na Ética de Aristóteles: "From this point of view it is immaterial what sort of wrong impulse is yielded to. But Aristotle's distinction makes sense if we consider moral characteristics as the products, more or less perfect, of moral training.". Do ponto de vista contemporâneo, o problema fundamental da fraqueza de vontade consiste na inconsistência lógica da ação contrária ao 'melhor juízo' do agente. Por isso, a submissão aos desejos irracionais se torna um problema secundário relativo ao campo mais amplo da irracionalidade prática (Ibid., p. 271-274).

$\mathrm{Na}$ Ética de Aristóteles, o conflito da razão prática e dos impulsos irracionais é fundamental na caracterização da akrasia antiga. Em linhas gerais, os desejos irracionais contrários à razão prática refletem a falta de educação moral apropriada do caráter acrático. Por isso, o conflito prático da akrasia depende da distinção crucial do elemento racional e do elemento irracional na psicologia moral de Aristóteles.

\footnotetext{
${ }^{14}$ Cf. CHARLTON, 1988, p. 10: “(...) R. M. Hare $(1952,1963)$ put forward an ethical theory which in temper is closer to Kant than to the Greeks but which re-establishes the Greek 'forward' connection between judging a course good and pursuing it. (...) Davidson tries to show that we can adopt a Greek rather than a Judaeo-Christian psychology of action, that we can dispense with acts of the will and connect acting intentionally with thinking one's line of action good, while still allowing the possibility of absolutely clear-eyed akrasia."
} 
Mesmo o problema mais restrito da fraqueza moral de Hare, não é explicitado no mesmo contexto moral da akrasia antiga de Aristóteles. Em comum, ambos estão preocupados efetivamente com a orientação prática dos juízos morais na ação moral. ${ }^{15}$ No entanto, ambos respondem por categorias morais diferentes: o prescritivismo moral de Hare se ocupa com a eficácia prática dos princípios morais do 'dever' enquanto a ética das virtudes de Aristóteles se volta ao desenvolvimento da virtude moral e a coordenação fundamental da razão prática e das paixões irracionais. Para Hare, o problema da fraqueza moral permanece ligado à racionalidade prática inerente aos juízos morais do agente. Para Aristóteles, o problema da akrasia antiga não se refere apenas à razão prática, mas à ausência da virtude moral e da educação moral das paixões irracionais. Com isso, Hare isola o problema da fraqueza moral do problema geral da akrasia antiga relativo à educação moral dos desejos irracionais. Em vista da racionalidade prática, as diferenças da fraqueza de vontade contemporânea e a akrasia antiga se aprofundam.

Em outra análise histórica do problema da fraqueza de vontade, Gosling (1990, p. 97-102) também destaca as diferenças da akrasia antiga da fraqueza de vontade contemporânea. As diferenças notáveis são observadas desde as raízes etimológicas até a natureza de ambos os fenômenos. Desse modo, Gosling fornece indicações de que o problema da fraqueza de vontade contemporânea é mais abrangente do que o problema da akrasia antiga.

Em Weakness of the Will, Gosling (Ibid., p. 99-100) indica que o problema contemporâneo ultrapassa o campo restrito dos princípios morais: "Since we might be deflected from any pursuit involving reason by other considerations, we can now see that if there is a problem about 'akrasia' it arises more generally than in morals." Nesse cenário, Gosling revela que a formação do problema contemporâneo da fraqueza amplia o campo de atuação da razão prática para além das considerações morais originais da akrasia. Com efeito, a akrasia não é reconhecida originalmente como uma falha da racionalidade prática, mas uma falha prática inerente ao campo da ação moral. No cenário contemporâneo, a noção moderna da razão foi

\footnotetext{
${ }^{15}$ Cf. BOSTOCK, 2000, p. 137: "Thus Hare, like Aristotle (and like Socrates) denies what we ordinarily think of as akrasia ever occurs. And in his case there is a deep reason: the fundamental distinction between what is descriptive and what is prescriptive can only be explained by saying that the one does not lead to action whereas the other does."
} 
progressivamente destacada das considerações dos 'bens humanos' para abarcar de forma geral objetivos práticos de curto e longo prazo no melhor juízo do agente (Ibid., p. 99). De fato, o problema ficou confinado ao campo moral devido à relação intrínseca tradicional entre o desejo e o bem estabelecida desde o Protágoras de Platão. Invariavelmente, o mesmo problema parece ter se mantido de alguma forma: como é possível a ação contrária à determinação da razão?

Em certa medida, o problema efetivamente continua o mesmo em um nível lógico abstrato. $\mathrm{O}$ problema fundamental gira em torno da possibilidade ou impossibilidade da ação contrária ao 'melhor juízo'. Em parte, o reestabelecimento da fraqueza de vontade contemporânea também se reflete na conexão intrínseca das crenças do bem e da ação humana. No entanto, as concepções psicológicas e os códigos morais do contexto antigo e do contexto contemporâneo são tão discrepantes que não há garantia de estarmos lidando com o mesmo problema filosófico.

Dessa forma, insistimos que a akrasia antiga e a fraqueza de vontade contemporânea representam problemas filosóficos essencialmente distintos. $\mathrm{Na}$ sequência, devemos reunir as diferenças fundamentais do problema filosófico no contexto antigo e no contexto contemporâneo.

\section{4 O problema antigo e o problema contemporâneo}

A akrasia antiga e a fraqueza de vontade contemporânea dão origem a problemas filosóficos distintos. Como vimos, a recepção analítica da akrasia antiga certamente marca a formulação original da fraqueza de vontade contemporânea no debate analítico inicial de Hare e Davidson. Mesmo assim, as diferenças entre os dois fenômenos são tão significativas que se refletem, inclusive, na própria formulação de seus problemas filosóficos. Em primeiro lugar, devemos indicar que cada fenômeno abrange um conjunto de diferentes exemplos práticos. Em seguida, devemos revelar a formulação original dos problemas filosóficos no contexto antigo e no contexto contemporâneo. Dessa forma, devemos considerar os exemplos tipicamente associados a cada fenômeno em seu contexto apropriado.

Os exemplos tipicamente relacionados a ambos os fenômenos marcam suas diferenças fundamentais. Como vimos, a akrasia antiga está associada a uma 
descrição tradicional do fenômeno formada pela opinião dominante grega. Segundo a akrasia tradicional, o fenômeno reflete a submissão do desejo racional pelo bem aos maus impulsos irracionais. A akrasia é um fenômeno tipicamente ativo, isto é, refletido em uma motivação do agente para a ação. Dentre os exemplos da akrasia, há vários exemplos intuitivos e familiares do fenômeno: o deslize da dieta pelo prazer imediato de doces, o impulso da bebida contra a preservação da saúde, o apetite sexual de uma paixão destrutiva. Nessas circunstâncias, os exemplos típicos da akrasia são mais restritos do que a fraqueza de vontade contemporânea.

A fraqueza de vontade contemporânea é um fenômeno mais amplo caracterizado pela ação contrária ao 'melhor juízo'. O fenômeno atual reflete apenas a incompatibilidade lógica fundamental da razão prática e da ação irracional do agente. Ao contrário da akrasia, a fraqueza contemporânea reflete uma condição passiva do agente, ou seja, refletida em uma incapacidade de ação. Por conta disso, o fenômeno atual abrange outros exemplos modernos, como a procrastinação, a morosidade, falta de resolução ou coragem e a falha em colocar em prática planos a logo prazo $^{16}$. Nessa medida, nada impede que os casos típicos de akrasia sejam adaptados aos casos contemporâneos da fraqueza. Em última instância, a passividade da fraqueza acaba gerando novas dificuldades especialmente ligadas a outros fenômenos irracionais. Em particular, isso se reflete na recepção analítica da akrasia antiga.

Dentro da perspectiva contemporânea, a akrasia antiga está mais associada à compulsão psicológica do que à fraqueza de vontade. Nesses termos, o conflito interno de desejos da akrasia não é adequadamente contemplado na filosofia contemporânea. Como vimos, isso ocorre por causa dos paradigmas psicológicos modernos da vontade. Em particular, a razão deixa de expressar o desejo racional e a motivação da ação sendo apenas caracterizada pelo juízo avaliativo racional. Enquanto isso, as paixões irracionais perdem sua capacidade cognitiva na formação das crenças do agente, expressando apenas desejos e impulsos motivacionais irracionais na ação. Com isso, já não podemos conceber o conflito original da akrasia, entre a razão e os impulsos irracionais. O problema antigo original da

\footnotetext{
${ }^{16}$ Sobre esses exemplos específicos da fraqueza contemporânea, ver GOSLING, 1990, p. 97-99. Em geral, os autores não costumam deixar muito claro que os casos de fraqueza contemporânea não se aplicam necessariamente a akrasia antiga. Novamente, a maioria dos autores assumem que se trata essencialmente do mesmo problema filosófico.
} 
submissão da razão aos impulsos irracionais, consequentemente, também desparece.

Além disso, a constituição lógica da 'razão' para a ação atinge um alcance mais amplo no contexto contemporâneo do que as considerações do 'bem' humano associadas à akrasia antiga. Mesmo no campo restrito da fraqueza moral, o problema se refere exclusivamente à racionalidade prática dos juízos morais. $\mathrm{Na}$ filosofia contemporânea, o 'melhor juízo' (better judgment) passa a se referir ao juízo de 'todos os fatores considerados' (all thing considered) constituindo assim um cálculo lógico total dos fatores avaliativos da ação. Sob esse ângulo, não temos mais a concepção antiga do 'melhor juízo' prático expresso no desejo racional pelo bem humano. Novamente, os parâmetros contemporâneos não nos fornecem o mesmo problema filosófico anterior. Para todos os efeitos, devemos considerar a formulação dos problemas filosóficos em seus contextos originais próprios.

A akrasia antiga e a fraqueza de vontade contemporânea fornecem diferentes problemas filosóficos. A impressão tradicional de que há um único problema filosófico essencial em ambos os contextos está completamente equivocada. ${ }^{17}$ Diante disso, é imprescindível termos atenção às formulações originais dos problemas filosóficos e as diferentes posições filosóficas em torno de cada problema.

Com isso, destacamos aqui duas formulações gerais do problema antigo e do problema contemporâneo: (1) a formulação do problema antigo em torno do conhecimento ou da ignorância na condição da akrasia; (2) a formulação do problema contemporâneo em torno da incompatibilidade lógica do 'melhor juízo' e a ação irracional da fraqueza. Com isso, teremos a oportunidade de esclarecer sua descontinuidade fundamental e apreciar melhor a recepção analítica da akrasia antiga no contexto contemporâneo. Para isso, mostraremos primeiro a formulação do problema da akrasia antiga em Platão e Aristóteles.

O problema da akrasia antiga necessariamente diz respeito à natureza do conhecimento moral. Para Platão e Aristóteles, a possibilidade da akrasia representa, de alguma forma, uma ameaça à eficácia prática do conhecimento moral. De acordo com a akrasia tradicional, o acrático 'sabe' que está agindo contra o que considera ser melhor a se fazer mas comete um erro moral por conta de seus

${ }^{17}$ Sobre o ceticismo acerca de uma única formulação do problema filosófico da fraqueza de vontade, ver MATTHEWS, 1971, p. 167-172. 
impulsos irracionais. Dessa forma, a filosofia antiga considera as seguintes questões em torno da akrasia: Ora, mas estaria o agente agindo com conhecimento ou sem conhecimento do bem? Se o agente tem o conhecimento do bem porque agiria contra o que considera ser melhor? Qual seria o estatuto do conhecimento moral nesse caso? De que forma os impulsos irracionais podem comprometer o conhecimento moral do agente na ação? Se o agente não tem o conhecimento do bem, estaria ele agindo por alguma forma de ignorância? Qual seria então, o papel dos impulsos irracionais na submissão do desejo racional do bem? Dentro dessa perspectiva, Platão e Aristóteles oferecem suas próprias resoluções do problema filosófico da akrasia antiga.

A preservação filosófica do conhecimento moral diante da akrasia é o mote central da perspectiva filosófica de Platão e Aristóteles. Desde o diálogo Protágoras de Platão, há uma clara distinção entre o conhecimento moral e a akrasia tradicional. Pela preservação do conhecimento, o personagem Sócrates do Protágoras estabelece uma conclusão negativa do fenômeno: não há efetivamente akrasia dado que o fenômeno é apenas um tipo de ignorância (357c-e). Ao final, a posição socrática do Protágoras chega a uma tese paradoxal, 'ninguém age pelas coisas que considera serem más' (358d-e). Na República, Platão apresenta uma posição diferente acerca do conflito interno da alma, mas vincula o conflito moral típico da akrasia ao caráter do vício moral. Dessa vez, o personagem Sócrates introduz a teoria tripartite da alma no livro IV e revela o papel fundamental da educação moral das paixões irracionais no caráter moral. Além disso, o filósofo apresenta uma série de casos de conflito moral no exame dos livros VIII-IX caracterizados pela condição instável de ignorância dos tipos de alma injusta. Diante desses diálogos clássicos, Platão mantém a mesma posição a respeito do conhecimento moral frente a akrasia mesmo reconhecendo o conflito interno da alma.

A Ética a Nicômaco de Aristóteles mantém a mesma preservação do conhecimento moral contra a akrasia tradicional. De alguma forma, a Ética reflete a tradição platônica do Protágoras e da República. De um lado, ele reconhece o conflito interno da alma e o papel da educação moral dos apetites irracionais no caráter moral (1102b13-1103a5). De outro lado, Aristóteles entra em uma polêmica direta contra a posição socrática da impossibilidade da akrasia no livro VII. Com efeito, Aristóteles acredita que a posição socrática contradiz os 'fatos aparentes' 
(phainómena) (1145b25-30). Ao final, contudo, Aristóteles concede, de certa maneira, à posição socrática de que o 'conhecimento propriamente dito' não pode ser arrastado pela paixão irracional (1147b15-19). Como veremos, Aristóteles não está se referindo ao mesmo tipo de conhecimento moral do que a posição socrática. De qualquer forma, Aristóteles faz parte da mesma tradição antiga da defesa do conhecimento moral contra a akrasia.

Ao contrário da akrasia antiga, o problema contemporâneo não se dirige ao conhecimento moral e nem a um tipo de conflito de desejos. Na realidade, a fraqueza de vontade contemporânea está exclusivamente voltada à consistência lógica da razão prática. Nessa medida, o problema do conhecimento moral se transfere para a consistência lógica do 'melhor juízo' do agente. Assim, o problema da fraqueza de vontade contemporânea tem origem em uma nova plataforma filosófica.

O problema contemporâneo emerge do conflito entre o 'melhor juízo' do agente e a ação irracional da fraqueza. Dessa forma, o problema se constitui a partir da crença intuitiva na eficácia prática do 'melhor juízo', isto é, o reflexo da ação intencional no 'melhor juízo' do agente. A fraqueza de vontade é um fenômeno que representa o conflito prático interno do agente. Por isso, a fraqueza de vontade contemporânea surge essencialmente de um problema interno da racionalidade ou irracionalidade da razão prática. Dessa maneira, a fraqueza de vontade contemporânea dá origem às seguintes questões filosóficas: Será que é realmente possível agir contra o 'melhor juízo' na fraqueza de vontade? Qual o estatuto do ‘melhor juízo’ na razão prática do agente? Seria o ‘melhor juízo’ mais fundamental que outros tipos de juízos avaliativos na esfera prática? Será que o 'melhor juízo' seria correspondente ao juízo moral para orientar ou prescrever a ação intencional? Ou teria o 'melhor juízo' outro estatuto lógico superior independente das considerações morais? Ora, mas será que o agente tem realmente consciência do ‘melhor juízo' no momento da ação irracional? Será que o agente não está sob efeito de outro fenômeno irracional? Talvez ele não está completamente consciente do melhor juízo ou está sob efeitos de fortes impulsos irracionais? O que efetivamente constitui a irracionalidade prática do agente na fraqueza de vontade? Diante dessa série de questões filosóficas, Hare e Davidson apresentam suas resoluções fundamentais à fraqueza de vontade contemporânea. 
A preservação da consistência lógica do 'melhor juízo' constitui um ponto de convergência de Hare e Davidson. De um lado, a negação da fraqueza de vontade de Hare assegura a preservação da consistência do juízo moral prescritivo e a ação moral. De outro lado, a possibilidade da fraqueza de vontade de Davidson garante a desvinculação do juízo de 'todos os fatores' da ação irracional. Todavia, a fraqueza de vontade se constitui incialmente como um problema moral diante da doutrina do prescritivismo moral de Hare.

A negação da fraqueza moral de Hare estabelece a impossibilidade da fraqueza de vontade. Desde o início, Hare mantém a consistência de seu prescritivismo moral, isto é, a doutrina de que todos os juízos morais prescritivos guiam as ações morais. Diante disso, a fraqueza moral só pode ser o resultado de um uso derivativo não genuíno ‘entre aspas' (inverted-commas) dos juízos morais. Com base no prescritivismo moral, o fenômeno não é genuíno mas reflete, na realidade, outros tipos de fenômenos irracionais: a hipocrisia, o autoengano, a impossibilidade física ou a impossibilidade psicológica, dentre outros tipos de fenômenos. Em especial, Hare associa explicitamente a akrasia grega à um tipo de compulsão psicológica, a submissão absoluta do agente aos impulsos irracionais. Dessa forma, a fraqueza moral descaracteriza completamente a fraqueza de vontade e, inclusive, a akrasia antiga.

Em verdade, a defesa intransigente dos rígidos princípios morais do prescritivismo moral de Hare o leva à negação absoluta da fraqueza moral. Em virtude disso, Davidson abandona as categorias morais tipicamente associadas ao fenômeno, preferindo mostrar uma caracterização mais ampla da possibilidade da fraqueza de vontade. Mesmo assim, Davidson mantém a preservação do 'melhor juízo', ou melhor, do juízo de 'todos os fatores considerados' (all things considered) diante da possibilidade da fraqueza de vontade.

Em 'How is Weakness of Will Possible? (1969) Davidson inaugura a formulação clássica do problema contemporâneo da possibilidade da fraqueza de vontade. Nesse artigo, Davidson sustenta que há uma incompatibilidade lógica entre o 'melhor juízo' do agente e a ação irracional da fraqueza. A sua estratégia central reside na distinção lógica de dois tipos de juízo avaliativos, os juízos prima facie condicionais e os juízos sans phrase absolutos. Na realidade, o juízo de 'todos os fatores' constitui um juízo prima facie condicional do agente desvinculado logicamente do juízo absoluto da ação intencional da fraqueza. A partir de 
'Paradoxes of Irrationality' (1982), o exame amplo da irracionalidade prática da fraqueza reforça a consistência lógica do 'melhor juízo' do agente. Dessa vez, Davidson sustenta que a fraqueza consiste na violação do princípio prático do 'melhor juízo' da ação intencional. Como veremos, essa descrição da fraqueza gera outras dificuldades em relação à própria concepção da irracionalidade prática. Independente disso, a defesa de Davidson da consistência lógica do 'melhor juízo' prático do agente se mantém ao longo de suas obras.

O ‘melhor juízo' ou o juízo de 'todos os fatores' do agente reflete o cálculo lógico de todos os fatores relevantes independente das considerações avaliativas dos juízos ordinários prima facie. Com isso, o problema da fraqueza de vontade é destacado do problema moral estrito da fraqueza moral. Mesmo assim, a eficiência prática do 'melhor juízo' do agente na ação reflete, de alguma forma, a potência prática do conhecimento moral. A fraqueza de vontade contemporânea está intrinsecamente relacionada à recepção analítica da akrasia antiga.

A fraqueza de vontade contemporânea marca integralmente a recepção analítica da akrasia antiga. Dessa forma, o debate contemporâneo da fraqueza de vontade obscurece a natureza original do fenômeno e do problema da akrasia antiga. Em geral, podemos destacar essas dificuldades interpretativas em dois campos: (1) a confusão da akrasia antiga com outros tipos de fenômenos irracionais contemporâneos; (2) a natureza da razão prática e do conhecimento moral no debate antigo de Platão e Aristóteles. A partir disso, poderemos reestabelecer o problema original da akrasia antiga e a natureza da razão prática na filosofia antiga.

Em primeiro lugar, a akrasia antiga é relacionada a outros tipos de fenômenos irracionais modernos. Como vimos, o problema da fraqueza de vontade contemporânea envolve a distinção do fenômeno de outros fenômenos irracionais correlatos, como a hipocrisia, o autoengano e até a compulsão psicológica. Dentro da tradição interpretativa tradicional, a descrição da ignorância de Platão e Aristóteles da akrasia antiga também tem sido associada a esses fenômenos modernos. No entanto, é imprescindível destacar a akrasia antiga de outros fenômenos irracionais derivados da psicologia moderna da vontade. Dessa forma, teremos melhor compreensão da descrição filosófica da akrasia antiga tendo em vista as categorias mentais da psicologia antiga.

Em segundo lugar, a natureza da razão prática e do conhecimento moral está relacionada à formação do caráter moral do agente na filosofia antiga. Diante da 
akrasia, Platão e Aristóteles revelam a descoordenação da razão prática e dos desejos irracionais do agente. Na filosofia contemporânea, a interação desses dois elementos desaparece e o problema da fraqueza recai na consistência interna da razão prática do agente. Sobretudo, isso afeta inclusiva a recepção analítica do silogismo prático de Aristóteles e do conhecimento moral antigo. Em particular, a doutrina do silogismo prático de Aristóteles é assimilada ao debate lógico analítico da inferência prática moderna. Na Ética de Aristóteles, a descoordenação da razão prática e os desejos irracionais se reflete na ineficácia do silogismo prático durante a akrasia. O papel do silogismo prático na akrasia não é adequadamente compreendido na filosofia analítica contemporânea.

Esse equívoco crucial se transfere à uma incompreensão mais profunda sobre a natureza do conhecimento moral na filosofia antiga. Para Platão e Aristóteles, o conhecimento moral envolve inevitavelmente a educação moral dos apetites irracionais. Por isso, a akrasia reflete justamente a ausência desse distinto conhecimento moral. De outro lado, o 'melhor juízo' mantém sua consistência lógica independente da condição dos desejos irracionais na fraqueza de vontade contemporânea. A eficácia prática do conhecimento moral diante da akrasia nem sempre é bem compreendida por conta das categorias lógicas modernas da razão prática. Ao restaurarmos a concepção antiga do conhecimento moral, teremos a oportunidade de compreender o papel dos desejos irracionais na eficácia da razão prática sobre a ação intencional. Dessa maneira, poderemos esclarecer a recepção analítica da akrasia antiga na formulação original da fraqueza de vontade contemporânea.

\section{5}

\section{Desenvolvimento da tese}

A estrutura dos capítulos estabelece o plano de investigação desta tese de doutorado. Na sequência, descrevermos brevemente a ordem de tópicos abordados em cada um dos capítulos.

No segundo capítulo, trataremos das raízes etimológicas do termo da akrasia e os antecedentes do fenômeno na literatura grega. Desde o Protágoras de

Platão e na Ética de Aristóteles, testemunhamos a presença de uma descrição tradicional popular da akrasia na opinião dominante grega. Com base nesses 
indícios, investigaremos os antecedentes do conflito interno característico do fenômeno na tradição da literatura grega antiga.

No terceiro capítulo, analisaremos a controversa negação da akrasia antiga de Sócrates no Protágoras de Platão. Durante o exame socrático da opinião dominante, se estabelecem duas posições fundamentais sobre o fenômeno, a conclusão epistemológica negativa acerca da inconsistência absoluta da akrasia tradicional e a descrição socrática positiva do efeito ilusório da ignorância do bem. A partir disso, o controverso paradoxo socrático constitui o eudaimonismo psicológico, isto é, o princípio de que há uma inclinação humana natural ao bem. Ao longo da República, Platão não abandona essencialmente as posições socráticas do Protágoras.

No quarto capítulo, analisaremos a teoria tripartite da alma e o conflito interno da alma na República. A teoria tripartite da alma na República inaugura a divisão psicológica da parte racional e da parte irracional da alma sem ainda a separação moderna estrita da cognição, desejo e motivação humana. A partir da psicologia tripartite, Sócrates persiste em caracterizar o conflito interno da alma com um tipo de ignorância moral, particularmente, a submissão da parte racional às partes inferiores da alma. Dessa forma, Platão traz à tona o papel da educação moral dos apetites irracionais na formação do caráter moral.

No quinto capítulo, trataremos da análise clássica da akrasia na Ética de Aristóteles. Na Ética, temos a primeira definição clássica do que constitui especificamente o caráter moral voluntário do acrático. Dessa forma, Aristóteles reconhece a divisão da parte racional e da parte irracional da alma, mas se coloca contra o paradoxo socrático do Protágoras. Na verdade, os aspectos fundamentais do caráter moral acrático se refletem na possibilidade da akrasia e a controversa doutrina do silogismo prático de ENVII.3. Com isso, mostraremos que o conflito da akrasia representa essencialmente a descoordenação da razão prática e os maus apetites irracionais. Em particular, a akrasia reflete a falta fundamental do conhecimento moral da prudência (prhónesis) e da virtude moral. Dessa forma, passamos então à recepção analítica da akrasia antiga na fraqueza de vontade contemporânea.

No sexto capítulo, abordaremos a negação da fraqueza moral de Hare. Diante do prescritivismo moral, Hare alega que não há casos efetivos de fraqueza moral. Na verdade, o próprio precritivismo moral está fundamentado em uma 
apropriação analítica do silogismo prático de Aristóteles. Invariavelmente, a negação da fraqueza moral de Hare acaba reduzindo o fenômeno a um mero conflito de princípios morais na razão prática. Diante disso, Davidson adota outra posição em relação à possibilidade genuína da fraqueza de vontade.

No sétimo capítulo, investigaremos a possibilidade da fraqueza de vontade em Davidson. Em seu clássico artigo de 1969, Davidson elabora uma reestruturação do silogismo prático e da descrição aristotélica da akrasia. Dessa forma, a fraqueza consiste na incompatibilidade do juízo de 'todos os fatores considerados' e a ação irracional da fraqueza. Em 'Paradoxes of Irrationality' (1982), Davidson aborda a irracionalidade prática diante das descrições tradicionais da akrasia da pura racionalidade e da pura irracionalidade humana. Diante disso, a concepção da irracionalidade prática de Davidson se revela incoerente em vista da ignorância do princípio da continência e controversa partilha da mente. De certa forma, mostraremos que a concepção antiga da coordenação da razão prática e os apetites irracionais ainda é fundamental para compreender a fraqueza de vontade na filosofia contemporânea. 


\section{2 \\ Antecedentes da Akrasia Antiga}

O problema filosófico da akrasia antiga recebe sua denominação clássica apenas com a Ética a Nicômaco de Aristóteles. O fenômeno denominado de 'akrasia', isto é, a escolha do que é pior mesmo sabendo o que é melhor, emerge de uma tradição filosófica antiga grega. Apesar da formulação clássica do problema remeter a Aristóteles, outras referências filosóficas ao fenômeno também aparecem na República e no Protágoras de Platão. Ainda assim, estudiosos helenistas têm apontado que descrições dessa experiência já estariam presentes na literatura grega, possivelmente nas tragédias de Eurípides.

Em geral, diversas obras sobre a psicologia no pensamento grego atribuem a emergência da descrição clássica da akrasia a fontes pré-filosóficas. Por tal razão, somos levados a supor que a akrasia não é uma invenção propriamente filosófica, mas um fenômeno presente nos antecedentes da literatura grega. A partir dessa linha interpretativa, a akrasia seria um conflito psicológico moral em que o desejo racional pelo bem é submetido pelos desejos irracionais (como emoções ou apetites). A princípio, os antecedentes do fenômeno seriam mais claramente reconhecidos nas tragédias Medéia e Hipólito de Eurípides por um suposto debate indireto com o Protágoras de Platão. Mesmo se buscarmos sua emergência em fontes anteriores, contudo, é válido indagarmos primeiro sobre a presença de uma teoria psicológica grega em obras dramáticas da literatura grega, como as tragédias de Eurípides.

O problema seria, portanto, o seguinte: será que é preciso ir em busca das raízes da akrasia na poesia ou na tragédia grega ou seria isso apenas uma projeção filosófica tardia sobre a literatura grega? Para responder essa questão, é preciso investigar o que motiva propriamente a atribuição da descrição da akrasia à literatura grega. Se essa associação estiver desvirtuada por princípios filosóficos externos à literatura grega devemos abrir mão dessa investigação. Todavia, se essa associação for, em alguma medida, pertinente, é cabível questionar porque o conflito psicológico da akrasia se encontra em Eurípides e não, talvez, em fontes anteriores da literatura grega. 
Como veremos, há uma descrição tradicional da akrasia vinculando a filosofia grega às tragédias de Eurípedes. Entretanto, pretendo mostrar que uma parte da tradição que se ocupou com essa relação de Eurípides com o pensamento filosófico o fez a partir de princípios psicológicos equivocados. Ao estabelecermos princípios psicológicos condizentes com a psicologia grega antiga, comuns à literatura e a filosofia antigas, poderemos apreender melhor a relação entre Eurípides e o Protágoras de Platão. Sendo assim, é preciso seguir uma clara orientação metodológica para ultrapassar as dificuldades que ora se apresentam.

Em virtude do problema apresentado, devemos investigar o conflito psicológico moral representado dramaticamente na poesia e nas tragédias gregas. Para realizar esse empreendimento, é preciso estabelecer parâmetros para determinar o que diferencia a akrasia de outros exemplos de conflitos psicológicos vividos pelos personagens dessas obras literárias.

Dessa forma, estabelecemos a seguinte estrutura de investigação: em uma primeira seção, pretendemos analisar a origem etimológica do termo grego akrasia evidenciando a distinção de seu significado original de outros termos modernos correspondentes; em uma segunda seção, confrontaremos os textos épicos e as tragédias em busca de indicações dos antecedentes da descrição tradicional da akrasia. Em especial, devemos estabelecer um critério comparativo a partir da descrição tradicional da akrasia claramente apresentada no Protágoras e na Ética a Nicômaco. Com efeito, observaremos que os conflitos psicológico-morais são representados frequentemente por personagens da literatura épica e trágica, desde Homero a Eurípides, mas apenas no último autor encontramos claras indicações da descrição tradicional do fenômeno. Para aprofundar nossa análise de Eurípides, confrontaremos as falas emblemáticas de Fedra no Hipólito e Medeia na tragédia homônima a fim de determinar se elas representam, em algum sentido, o conflito interno da akrasia. Antes de tudo isso, porém, é necessário nos voltarmos primeiramente à etimologia da akrasia a fim de determinar como o significado original do termo é obscurecido por pressupostos filosóficos contemporâneos e como isso prejudica nosso entendimento da experiência original grega. 


\section{1}

\section{A etimologia da akrasia e os pressupostos psicológicos modernos}

A introdução do termo akrasia na tradição filosófica é claramente vinculada a Aristóteles, mas suas raízes etimológicas remontam a Homero. Segundo o dicionário etimológico Dictionnaire étymologique de la langue grecque de Pierre Chantraine (1968, p. 578), a palavra akrasia deriva do termo grego krátos que significa propriamente 'força'. A palavra krátos, por sua vez, não remete a qualquer tipo de força, mas particularmente à força física necessária para vencer um combate ou triunfar sobre um inimigo da qual provém também 'vitória', 'poder' ou 'soberania' com claras conotações bélicas ${ }^{18}$. A presença do prefixo ' $a$ ' antes de 'krátos' em 'akrasia' determina a negação do sentido original da raiz 'krátos'. O termo 'akrasia' estabelece uma impotência ou derrota da qual provém a noção de 'não ter poder' ou 'não se conter', ou seja, não possuir a força física necessária para vencer ou dominar.

$\mathrm{O}$ adjetivo correspondente 'akratés' é normalmente contraposto à 'enkratés', que significa propriamente 'ser mestre de si'. A clássica oposição dos substantivos correspondentes, 'akrasia' e 'enkrateia', é cristalizada tardiamente na Ética a Nicômaco ${ }^{19}$ de Aristóteles. Como Aristóteles especifica brevemente em EN III.4, o 'enkratés' age em vista do propósito racional (prohaíresis), enquanto o 'akratés' age em vista do apetite (epithymía) contra o propósito racional (1111b416). Nesses termos, podemos dizer que o 'enkratés' mantém o domínio de sua escolha racional e o 'akratés' perde o controle da razão deixando ser influenciado pelos apetites irracionais. A própria expressão 'ser mestre de si' nos remete ao ‘domínio de si mesmo' em contraponto à ‘falta de domínio' relacionada à akrasia. Por conta desses traços etimológicos, recomendou-se que a enkrateia fosse

\footnotetext{
18 Além das raízes homéricas de krátos, é especialmente pertinente que o verbo kratéo apareça justamente com tais conotações beligerantes nas tragédias de Ésquilo e Sófocles. Dentre as várias expressões indicando mudança de opinião em Ésquilo e Édipo elencadas por Knox (1979, p. 233), encontramos os verbos kratéo e nikéo no sentido de 'vencer' ou 'conquistar' em diversas sentenças com claros nuances do mesmo vocabulário bélico. No entanto, Knox também salienta que a mudança de opinião dos personagens em Ésquilo e Sófocles são sempre impostas por fatores externos e apenas nos personagens de Eurípides teríamos genuínas mudanças de opinião por motivações internas. É interessante notar que essas palavras aparecem vinculadas à descrição do conflito psicológico remetido à akrasia, especialmente, nas tragédias de Eurípides e também nas discussões filosóficas do Protágoras e da Ética a Nicômaco.

${ }^{19}$ De agora em diante, iremos nos referir a Ética a Nicômaco sob a sigla EN acompanhado do número do livro, do capítulo e da passagem stephanus respectivamente.
} 
traduzida como 'autocontrole' enquanto a akrasia corresponderia a uma 'falta de controle'. Ainda que seja uma alternativa viável de tradução, a expressão não elimina os problemas relacionados a nossos pressupostos psicológicos modernos ${ }^{20}$.

As traduções modernas correntes de 'akrasia' são afetadas pelos mesmos pressupostos psicológicos modernos. Apesar da expressão 'falta de controle' ser adequada, seu significado moderno implica a submissão absoluta do agente aos impulsos irracionais, o que normalmente associamos à compulsão psicológica ${ }^{21}$. Sob o efeito desse fenômeno, impulsos completamente irracionais, externos à razão prática, determinam a ação moral do agente mesmo contra o desejo racional pelo que é melhor. De acordo com a definição aristotélica da akrasia, no entanto, o apetite exerce influência na ação moral contra o propósito racional, mas não constitui uma força motivacional absolutamente irracional.

Devido a essas dificuldades, alguns autores sugeriram outro par correspondente à enkrateia e akrasia: a 'continência' e 'incontinência', respectivamente. Entretanto, a 'incontinência', por vezes, está estreitamente relacionada à luxúria sexual pela tradição cristã ${ }^{22} \mathrm{e}$, em outros casos, até uma disfunção urinária. Em face dessas dificuldades, poderíamos talvez recorrer a palavra portuguesa 'acrasia' que nada mais é do que uma transliteração literal do próprio termo grego akrasia. Mesmo assim, a controvérsia de tradução persistiria visto que a 'acrasia' abrange um significado semântico muito próximo da expressão moderna 'fraqueza de vontade' 23.

\footnotetext{
${ }^{20}$ Nos estudos filosóficos sobre o tema da akrasia, o problema de tradução do termo grego é um tópico imprescindível e incontornável. Cf. BOSTOCK, 2000, p. 123-124; GAUTHIER \& JOLIF, 2002, p. 579; PRICE, 2009, p. 231 n. 1; PAKALUK, 2005, p. 233-234; CHARLES, 2011, p. 207; CHARLTON, 1988, p. 4-9; GOSLING, 1990, p. 97-101.

${ }^{21}$ A 'falta de controle' apenas contempla um dos dois tipos de akrasia abordados em EN VII. Como veremos, Aristóteles apresenta dois tipos de akrasia: a 'fraqueza' (astheneia) e a 'impuslividade' (propeteia) (EN VII.7 1150b 20-30).

${ }^{22}$ Cf. GAUTHIER-JOLIF, 2002, p. 579: 'L'usage qu'en fait Aristote apparait comme une paranthèse dans l'évolution du terme, et, lorsque les théologiens chrétiens des premiers siècles intégrèrent à l'enkratéia l'ideal évangélique de la virginité, ils pouvaient se réclamer de toute la tradition stoïcienne. Ce n'est que dans la second moitié du XIII siècle que la signification aristotélicienne fut remise en honeur. Mais l' authorité de la continence-virginité était si grande que cette restauration ne devait pas aller sans redoutables equivoques (...)."

${ }^{23}$ No Dicionário Houaiss de Língua Portuguesa, nos deparamos efetivamente com a palavra 'acrasia' que deriva da mesma raiz grega. No dicionário, encontramos as seguintes acepções: "1. ausência de regra, de ordenação, de comedimento, desregramento; 2 . fraqueza de vontade, condição de quem, apesar de saber o melhor a ser feito, faz outra coisa." Como podemos ver, o termo português, por mais que seja etimologicamente apropriado, ainda supõe a experiência moderna atual da 'fraqueza de vontade' e a psicologia da vontade ao qual está associada.
} 
Dentre os termos modernos correntes, a 'fraqueza de vontade' foi promovida à tradução oficial do termo grego 'akrasia' no contexto contemporâneo. O fenômeno específico ao qual essa expressão se refere, assim como a akrasia no contexto antigo, representa um problema filosófico moderno influente até a filosofia analítica contemporânea. É um fato notável que obras dedicadas à história do problema filosófico, do contexto antigo ao contexto contemporâneo, apareçam sempre com o mesmo título: 'fraqueza de vontade'. Mesmo que os autores reconheçam a distinção entre 'akrasia' e 'fraqueza de vontade', eles preferem assumir de antemão (talvez, por economia) que esses termos possuem uma mesma referência. Entretanto, essa estratégia encobre dificuldades inerentes às categorias psicológicas relativamente distintas.

Em qualquer tradução moderna de 'akrasia', acabamos pressupondo a noção moderna de 'vontade' e projetamos sobre os gregos a 'fraqueza de vontade'. De um lado, um extenso conjunto de estudos helenísticos tem ressaltado a manifesta ausência de palavra ou concepção psicológica remotamente associada à 'vontade' no vocabulário grego de Homero à Aristóteles ${ }^{24}$. Como salienta Gill (1996), por exemplo, a psicologia grega não estabelece uma separação absoluta entre a razão e os impulsos irracionais pela intermediação de uma vontade moral ${ }^{25}$. De fato, mostraremos a seguir que isso constitui uma vantagem da psicologia grega sobre a filosofia analítica contemporânea. De outro lado, a própria 'fraqueza de vontade' resulta em uma experiência distinta da akrasia antiga. Por mais que se reconheça

\footnotetext{
${ }^{24}$ Cf. VERNANT, 1990, p. 34: "Uma tal lacuna [do conceito de vontade] marca a distância que separa as concepções grega e moderna do agente. (...) ela sublinha as orientações diferentes da ética grega e da consciência moral de hoje; mas traduz também e mais profundamente a ausência, no plano psicológico, de uma categoria elaborada da vontade, ausência que já denuncia, ao nível da linguagem, a falta de uma terminologia apropriada da ação voluntária." Como veremos, no entanto, Vernant, assim como outros helenistas, foi levado a crer que a ausência do 'termo' implica ao menos uma concepção rudimentar do agente humano. Segundo Williams (1993, p. 41-43), qualquer estratégia adotada para salvar os gregos dessa 'falta' acaba incorrendo em uma leitura fadada ao fracasso: por um lado, insistem em projetar a 'vontade' sobre as categorias mentais gregas; por outro lado, lhes atribuem uma concepção de psicologia moral que eles não reconhecem. Ver também CHARLTON, 1988, p. 5-8.

${ }^{25}$ Cf. GILL, 1996, p. 178: “(...) psyhological division is explained, typically, in Greek philosophy by reference to the tension between two beliefs (or rather, two sets of belief-cum-reasoning) and the emotions and desires correlated with these beliefs, rather than to the conflict between rational will and (non-rational) passion. (Thus, akrasia, a term used by Aristotle to denote a specific type of psychological conflict, should not be taken to signify 'weakness of will' in the sense identified earlier though it is often translated in this way)." De fato, Gill assume que a concepção grega da akrasia deriva estritamente da filosofia antiga, mas pretendo evidenciar adiante que o conflito interno da razão e dos impulsos irracionais pode ser encontrada nos conflitos psicológicos representados em algumas passagens de Homero e dos tragediógrafos.
} 
uma efetiva analogia entre as expressões grega e moderna, não parece haver razões suficientes para atribuir ambas ao mesmo fenômeno psicológico.

Assim como a akrasia antiga, a 'fraqueza de vontade' também implica no seu oposto, a 'força de vontade', ou melhor, a obediência à vontade moral na ação. Por essa acepção, a ‘fraqueza' seria, portanto, uma incapacidade ou falha em seguir a determinação da vontade moral. Conforme já salientamos, a experiência da akrasia não contempla qualquer faculdade da 'vontade' no pano de fundo psicológico antigo. Além disso, a 'fraqueza de vontade' abrange exemplos atuais que não são contemplados na akrasia antiga: morosidade, procrastinação, falta de coragem moral e falha em seguir planos predeterminados ${ }^{26}$. Em todos esses diversos casos, nos deparamos com a forma passiva da fraqueza em que o agente simplesmente cede aos seus impulsos em contraposição à forma ativa em que há pleno domínio da ação. Apesar dos textos gregos estarem repletos de casos de 'passividade', observaremos adiante que nenhum deles contempla claramente a submissão a impulsos completamente irracionais ${ }^{27}$. De fato, tal descrição do fenômeno advém de uma psicologia da vontade baseada em uma separação radical entre razão e impulsos irracionais. Em virtude disso, reiteramos que a fraqueza de vontade e a akrasia antiga dizem respeito a categorias psicológicas distintas e, consequentemente, a fenômenos psicológicos distintos.

A akrasia antiga, tal como concebida pelos gregos, representa um conflito psicológico moral. Como vimos anteriormente, a experiência emerge da presença de um conflito interno do agente em que as forças motivacionais opostas buscam prevalecer na determinação da ação moral. Nada implica que tais impulsos irracionais não tenham valor cognitivo ou que não estejam vinculados às crenças do agente. Assim como outros conflitos psicológicos presentes nos textos gregos, a akrasia decorre de um confronto entre diferentes forças motivacionais, relativas à sua própria categoria de crenças e desejos. A particularidade da akrasia reside em sua descrição psicológica específica: a tensão entre o desejo racional pela melhor

\footnotetext{
${ }^{26}$ De acordo com Gosling (1990, p. 97), esses exemplos modernos de ação irracional passiva contra o 'melhor juízo' do agente não são contemplados pela experiência ativa da akrasia antiga.

${ }^{27}$ Em verdade, nos referimos aqui aos impulsos irracionais absolutamente não cognitivos tal como concebidos dentro da psicologia da 'vontade'. Como veremos adiante, essa teoria psicológica tradicional gerou uma série de equívocos sobre a akrasía antiga ao projetar um conflito absoluto entre razão e paixão. Como veremos a seguir, essa distinção só se verificará primeiramente no campo filosófico, com Platão e Aristóteles, mas em nenhum momento eles deixarão de caracterizar os ‘impulsos irracionais' em termos intrinsecamente cognitivos e motivacionais.
} 
ação e as motivações irracionais pela ação contrária. Para entender o que torna a akrasia antiga um conflito psicológico especial, precisamos localizar sua emergência no contexto antigo.

Em seguida, buscaremos pelos antecedentes da akrasia antiga antes de Platão e Aristóteles. Particularmente, a presença de uma descrição tradicional comum da akrasia antiga é indicada no Protágoras de Platão e na Ética de Aristóteles. Sem dúvida, Platão e Aristóteles nos fornecem indicações contundentes da emergência préfilosófica da akrasia antiga. A partir disso, pretendemos analisar os conflitos morais-psicológicos presentes em certas passagens de Homero e dos tragediógrafos. Primeiramente, devemos mostrar como Platão e Aristóteles indicam que uma descrição tradicional da akrasia já circulava entre os gregos antes mesmo da sua constituição como um problema filosófico.

\section{2 \\ A descrição tradicional da akrasia da opinião dominante grega}

A akrasia antiga é reconhecida sobretudo como um problema filosófico. Entretanto, a descrição tradicional do fenômeno não está precisamente circunscrita ao campo filosófico. De fato, a própria filosofia grega parece indicar que a akrasia tem profundas raízes na cultura grega ${ }^{28}$. Mesmo em Platão e Aristóteles, encontramos fortes indícios de um debate prévio da akrasia antiga. Apesar da repercussão da formulação clássica do problema filosófico, é legítimo buscarmos por uma descrição preliminar do fenômeno em fontes externas ao campo da filosofia. Para isso, nos voltaremos primeiramente aos textos de Platão e Aristóteles.

Os indícios das origens de uma descrição preliminar da akrasia já podem ser constatados a partir dos textos de Platão e Aristóteles. Ambos os filósofos fornecem indicações de que uma descrição preliminar estava em circulação, por

\footnotetext{
${ }^{28}$ Quando nos referimos à 'filosofia grega', reconhecemos também o período posterior a Aristóteles, notavelmente a filosofia estoica. No entanto, não teremos oportunidade de abordar a filosofia estoica no escopo dessa Tese de Doutarado. A razão dessa exclusão se deve ao fato de que a recepção analítica da akrasia antiga foi marcada pelo debate filosófico em torno dos textos de Platão e Aristóteles. Segundo Gill (1996, p. 226-233), os estoicos teriam sido os primeiros a relacionar explicitamente o problema filosófico da akrasia com o emblemático conflito psicológico representado na Medéia de Eurípides. Todavia, buscaremos mostrar adiante que os textos de Platão e Aristóteles remetem claramente as falas de Medéia e Fedra e que não precisaremos recorrer aos estóicos para encontrar o elo perdido entre literatura grega e filosofia.
} 
assim dizer, na opinião popular ateniense. No diálogo Protágoras, Platão nos apresenta, por meio do personagem Sócrates, a descrição tradicional da akrasia dando voz à 'opinião dominante' (hoi polloî) $)^{29}$ de sua época. Em Ética a Nicômaco ${ }^{30}$, por sua vez, Aristóteles contrasta a visão de 'Sócrates' (em alusão indireta ao Protágoras) com a opinião corrente da akrasia fornecida pelos 'fatos aparentes' (phainómena) ${ }^{31}$. Em ambos os contextos, a formulação do problema filosófico gira em torno do mesmo conjunto de questões: como é possível agir contra o que se considera melhor? Será que a opinião comum está correta ou equivocada a respeito desse fenômeno? Se a opinião comum estiver equivocada, como podemos explicar esse fenômeno? Seria o conhecimento moral realmente submetido pelos impulsos, como julga a opinião dominante? Ou será que somente a crença, sendo mais instável do que o conhecimento, estaria à mercê da akrasia?

Como veremos adiante, tanto Aristóteles quanto Platão estarão dispostos a preservar o conhecimento moral reformulando a descrição tradicional da akrasia. Com base nessas indicações, acreditamos que seja viável reconstruir uma visão popular da akrasia e buscar as raízes de sua emergência em fontes literárias externas à filosofia antiga. Sendo assim, vamos analisar de forma mais detalhada as passagens filosóficas mencionadas acima.

A introdução da descrição tradicional da akrasia no Protágoras de Platão está envolvida na discussão de Sócrates e Protágoras sobre a natureza da virtude. Por grande parte do diálogo, o sofista tem defendido a pluralidade das virtudes se desvencilhando dos argumentos de Sócrates em favor da unidade da virtude. Quando Protágoras defende explicitamente que "a coragem (andreía) provém da natureza (apò phýseos)" (351b), Sócrates investe em uma longa discussão sobre o hedonismo e akrasia em 351b-358d a fim de esclarecer a posição de Protágoras perante o conhecimento. Apesar de não podermos analisar os pormenores dessa

\footnotetext{
29 Sigo prioritariamente a tradução de Daniel Lopes (2017), porém adoto algumas adaptações ocasionais a fim de ressaltar aspectos relevantes do texto original. A tradução de 'hoi polloî' para 'opinião dominante', por exemplo, me parece justificada diante da 'personalidade' que a expressão adquire ao longo da passagem $351 \mathrm{~b}-358 \mathrm{~d}$.

${ }^{30}$ Para a Ética a Nicômaco, seguimos a tradução de Gerd Bornheim que infelizmente é derivada da tradução inglesa de W. D. Ross. Como essa tradução portuguesa se afasta demasiadamente do texto original grego, tivemos de confrontá-la eventualmente com outras traduções a fim de oferecer alternativas viáveis que contemplem a edição grega.

${ }^{31}$ Como esclareceremos adiante, o termo 'phainómena' em Aristóteles abrange tanto as evidências empíricas quanto os testemunhos da opinião corrente. No capítulo dedicado a Aristóteles, pretendemos mostrar mais claramente que Aristóteles adota um método de escrutínio dos phainómena e que essa investigação é crucial em sua própria abordagem do problema da akrasia.
} 
discussão no momento, podemos antecipar que ela advém da implicação de que a virtude é composta de elementos não cognitivos. Ao vincular a posição de Protágoras sobre o prazer com a ‘opinião dominante' (hoi polloî) (351c-d), Sócrates leva o sofista a confrontar a descrição tradicional da akrasia. Dada a relação do sofista com a maioria, o filósofo julga necessário realizar um exame da 'opinião dominante' acerca do prazer e da akrasia.

O exame meticuloso das crenças da 'opinião dominante' traz à tona a descrição tradicional da akrasia. De agora em diante, Sócrates trava um diálogo direto com a ‘opinião dominante' personalizada enquanto Protágoras é relegado ao segundo plano da discussão ${ }^{32}$. Com efeito, o fato de que Platão confere voz à sociedade de sua época é um efeito dramático significativo para nossa investigação. De fato, Sócrates se dirige à 'opinião dominante' como potencias vítimas da akrasia $^{33}$. Durante a passagem 352 b-e, Sócrates relata a descrição tradicional da akrasia pela visão da opinião dominante:

[...] muitos (polloús) afirmam, mesmo sabendo o que é melhor (gignóskontas ta béltista), não desejam contudo, praticá-lo (ouk ethélein práttein), ainda que lhes seja possível fazê-lo (exòn autois), e acabam praticando alguma outra coisa. E todos aqueles a quem perguntei qual é, afinal, a causa (aítión) disso, afirmam que quem age assim o faz porque é vencido (kratouménos) pelo prazer ou pela dor, ou é dominado (hettoménous) por alguma outra coisa dentre aquelas a que há pouco me referi. (352d-e)

Mesmo diante da ausência do termo técnico 'akrasia', já podemos notar claramente a descrição tradicional do fenômeno. A partir do relato de Sócrates, Platão nos fornece claras indicações de como a sociedade grega de sua época encarava essa experiência particular. Na visão da opinião dominante, é possível que um agente tenha o desejo racional pela melhor alternativa e acabe fazendo o que é pior por conta dos mais variados impulsos.

\footnotetext{
${ }^{32}$ As implicações da relação entre o sofista e a opinião dominante serão analisadas no capítulo 3 sobre o diálogo Protágoras de Platão. Por ora, é importante ressaltar que o exame da opinião dominante nada mais representa do que o exame de crenças com as quais o próprio sofista está comprometido.

${ }^{33}$ Cf. CALLARD, 2014, p. 38-39: "In order to approach Socrates' argument as critically as possible, it is best to avoid the Protagorean temptation to tie the views of hoi polloi to the uneducated, the unsophisticated, or more generally to any group of people characterized in such a way that we can distance ourselves from them. When one is arguing against an absent interlocutor, as Socrates is doing here, one must guard actively against turning him into a straw man. (...) If Socrates' interlocutors are espousing the standard view of akrasia, reading the argument as ad hominem means reading it as directed to proponents of the standard view in their capacity as akratics." (itálicos da autora)
} 
Para fins de esclarecimento, podemos destacar os seguintes aspectos fenomenológicos dessa experiência: (1) em uma dada situação, um agente precisa optar entre duas alternativas de escolha, uma 'melhor' (béltion) e outra 'pior' (kákion), e ambas estão à sua disposição, ou seja, ‘é possível fazê-las' (exòn autoîs). Diante da falta de exemplos nessa passagem, podemos supor de antemão que o 'melhor' ou 'pior' é avaliado em função do que é 'bom' ou 'mau' para si mesmo embora não se descarte necessariamente considerações morais pelos outros ${ }^{34}$; (2) tendo plena consciência (seja crença ou conhecimento) da melhor alternativa, o homem delibera em função do que é melhor, porém, 'não desejam praticá-la' (ouk ethélein práttein) e acabam realizando a ação errada. Pela linguagem grega, o ato é realizado de 'bom grado' (hékon), isto é, ele não age de 'mau grado' (ákon) ${ }^{35}$, forçado ou coagido por forças externas à sua deliberação. Como indica Aristóteles em EN III.1-3, há diversos fatores que contribuem para a ação de 'mau grado' (ákon): a pressão da coerção (bíai) externa determinando a ação moral ou a necessidade (anankaía), a desconsideração de fatos particulares e a ignorância. Em contraponto, os atos de akrasia são realizados de bom grado (hékon), isto é, a deliberação racional não é comprometida e há plena responsabilidade do agente sobre sua ação moral. Além disso, a descrição tradicional enfatiza que a 'crença' ou o 'conhecimento' não determina necessariamente a ação humana. Como ressalta Sócrates, a opinião dominante julga que o 'conhecimento' não exerce qualquer “domínio (archikòn)" no agente sendo frequentemente "arrastado (perielkoménes)" por outros impulsos "como um escravo (hósper perì andrapódou)" (352b-c); (3) a causa (aitía) da ação é atribuída a variados impulsos, a ira (thymón), o prazer

\footnotetext{
34 Cf. TAYLOR, 1991, p. 203; KAHN, 1996, 234-243. Apesar de concordarmos com os comentadores que as considerações morais do que é nobre (tò kalón) são temporariamente excluídas de toda a discussão dos interlocutores sobre a akrasia e o prazer na passagem 351c-358d, não concordamos com o egoísmo ético pressuposto nessa linha interpretativa. De fato, os valores morais relativos à oposição entre o nobre (tò kalón) e o vergonhoso (tò aischrón) só retornam no último argumento da unidade entre sabedoria e coragem., apenas em 359e-360a. De fato, isso não precisa implicar em um egoísmo ético, doutrina ética em que o agente toma qualquer atitude moral em prol de seu benefício pessoal, mesmo se prejudicar a outrem. Ora, o argumento hedonista pode estar em plena harmonia com considerações morais pelos outros. Como Sócrates salienta no argumento hedonista, a opinião dominante valoriza as 'coisas boas' em função do 'domínio sobre os outros' mas também da 'salvação das cidades' $(354 b-c)$. No próximo capítulo, elucidaremos melhor alguns aspectos da discussão da akrasia e do hedonismo no Protágoras de Platão. Ver também PENNER, 1992, p. 123.

35 Dispensamos aqui a tradução corrente de hékon e ákon como 'voltuntário' e 'involuntário' respectivamente. As categorias do voluntário e involuntário remetem a uma faculdade da 'vontade' que está completamente ausente da psicologia grega antiga. Por essa razão, optamos por utilizar a tradução francesa de 'bom grado' e mau grado' ao nos referir respectivamente a hékon e ákon.
} 
(hedonén), a dor (lúpen), desejo sexual (érota) ${ }^{36}$ e o medo (phóbon) (352b). Em nenhum desses casos, porém, se menciona qualquer restrição a impulsos absolutamente irracionais ou motivações não cognitivas. De fato, a menção de que o agente é ‘vencido' (kratouménos) ou 'dominado' (hettoménous), um vocabulário estreitamente vinculado à etimologia da akrasia como mostramos anteriormente, sugere fortemente um conflito de forças psicológicas. No entanto, associar a akrasia a um conflito absoluto entre razão e paixão irracional, como muitos intérpretes têm sustentado $^{37}$, não nos parece legítimo. Como veremos a seguir, os impulsos irracionais mencionados aqui são estreitamente associados a razões nos conflitos psicológicos morais presentes na poesia e na tragédia grega. Por ora, é importante salientar que encontramos nessa passagem elementos suficientes que nos permitem reconstituir uma descrição tradicional da akrasia.

É exatamente contra essa visão da opinião dominante que Sócrates, com o apoio de Protágoras, irá se contrapor em favor do conhecimento (352c). Na sequência do diálogo, o filósofo não só vai estabelecer que a akrasia é ignorância (amathía) (357d) como irá estabelecer uma conclusão paradoxal contra a opinião corrente, a tese de que o mal não é de bom grado (358c-d). Por ora, não vamos nos deter agora nas implicações filosóficas desse paradoxo socrático, é suficiente salientar aqui que essa tese estabelece a negação da descrição tradicional. Aparentemente em oposição a tal conclusão, Aristóteles retoma indiretamente o debate da akrasía antiga presente em Protágoras buscando favorecer, em parte, a descrição tradicional do fenômeno.

${ }^{36}$ Cf. LIDDEL-SCOTT, 1990. A maioria das traduções consultadas propõe a palavra 'amor' como tradução para o termo grego 'érota'. Acreditamos que a tradução por amor pode incorrer em equívocos e optamos por uma tradução que corresponda melhor ao que os gregos designavam por 'éros'. Érota se aproxima de 'paixão' ou 'desejo sexual' e implica desejos relativos ao 'sexo' (estreitamente ligado a 'aphrodision' em 353c). A sugestão de Taylor (1991) por 'luxúria' é mais próxima do que o que está sendo designado pela palavra 'érota'.

${ }^{37}$ Cf. TAYLOR, 1991, p. 173: "The common-sense view see no incompatibility between the description of someone having been overcome by some appetitive force and the judgment that he is responsible for having acted under the influence of that force. (...) At the same time we, like the Greeks, feel that there are some irresistible desires, and finds serious moral and legal problems in the attempt to demarcate that restricted class." (itálicos do autor) Ver também SNELL, 1964, p. 182; IRWIN, 1983, p. 189-192; KAHN, 1996, p. 226-233. Como veremos adiante, essa passagem tem sido usada como principal evidência de uma polêmica entre Sócrates e Eurípides. Essa interpretação é calcada, no entanto, em uma concepção da akrasia como um conflito absoluto entre razão e paixão. Apesar de concordamos em termos com uma provável relação entre o Sócrates (do Protágoras) e personagens de Eurípides, não aceitamos a representação da akrasia sustentada por tais intérpretes. De qualquer maneira, a representação do conflito de forças presente nessa passagem não só comprova os antecedentes da akrasia como também tem extrema relevância para a discussão subsequente do Protágoras. 
Em sua clássica análise da akrasia da Ética a Nicômaco VII ${ }^{38}$, Aristóteles defende a possibilidade do fenômeno contra a posição socrática anterior. Mesmo sem mencionar diretamente o Protágoras, a reprodução literal dos argumentos, e até mesmo das palavras do personagem Sócrates, é notável. Em sua visão, há uma evidente contradição entre a tese socrática e os 'fatos aparentes' (tô̂s phainoménois):

Como é possível que um homem que julga com retidão agir com akrasia? Alguns afirmam que tal conduta é incompatível com o conhecimento; pois seria estranho - assim pensava Sócrates, que, existindo o conhecimento num homem, alguma coisa pudesse vencê-lo (krateîn) e 'arrastá-lo como um escravo' (periélkein hósper andrápodon). Com efeito, Sócrates combatia inteiramente esse argumento, sustentando que não há (ouk oúses) akrasía, pois ninguém quando julga, ele dizia, age contrariamente ao que é melhor, os homens só assim procedem por efeito de ignorância (tês ágnoias). Ora, este argumento [de Sócrates] contradiz nitidamente os fatos aparentes (tô̂s phainómenois) [...] pois é evidente que o homem que age com akrasía não acredita (ouk oíetai), antes de chegar a esse estado (en tô páthei), que deva agir assim. (1145b20-32)

Embora o alvo de Aristóteles seja o suposto Sócrates histórico (figura da qual nada de concreto sabemos ${ }^{39}$ ), o vocabulário utilizado nos remete indiretamente ao personagem homônimo do Protágoras. Dentre os argumentos mencionados aqui, existem três teses que podem ser vinculadas ao personagem platônico: (I) ninguém age contra 'o que considera ser melhor', isto é, o paradoxo socrático; (II) a akrasia não existe pois é somente ignorância; (III) o conhecimento não pode ser 'vencido' e nem 'arrastado como um escravo' ${ }^{40}$. Como observamos anteriormente, todas essas teses figuram nos argumentos levantados por Sócrates no Protágoras de Platão. Diante da ausência de qualquer outra referência mais direta a respeito de

\footnotetext{
${ }^{38}$ É importante ressaltar que a Ética a Nicômaco não é o único livro de Aristóteles a abordar o tema. Encontramos tratamentos similares do tema na Ética a Eudemo e mesmo na Magna Moralia, embora este último tenha a autoria disputada. Cf. IRWIN, 2008, p. 26.

${ }^{39}$ Cf. KAHN, 1996, p. 71- 100. Segundo Kahn, não temos indicações absolutamente incontestáveis de quais teses ou teorias o Sócrates histórico realmente teria defendido durante sua vida. Embora os diálogos platônicos realmente possam dar algumas pistas acerca da influência do mestre sobre Platão, nenhuma delas é absolutamente conclusiva.

${ }^{40}$ Cf. IRWIN, 2008, p. 32-35. Segundo Irwin, há fortes indícios de que a tese (III) tenha sido adicionada em ENVII justamente porque Aristóteles teria feito uma 'releitura' do Protágoras e constatou que Sócrates estava certo a respeito do conhecimento. No capítulo sobre Aristóteles, pretendemos demonstrar se Aristóteles realmente conseguiu superar as teses socráticas. Contra DENYER, 2008, p. 182-183.
} 
tais teses, podemos seguramente atribuí-las ao personagem platônico ${ }^{41}$. Em especial, é particularmente notável que a formulação da tese (III) contenha o mesmo vocabulário utilizado por Sócrates para marcar a descrição tradicional da akrasia contra a qual se contrapõe (352b-e). Naquela passagem, o personagem também expressa a submissão do conhecimento na visão da opinião dominante.

Tanto em Protágoras quanto em ENVII, os verbos 'kratéo' e 'periélko' a expressão 'hósper andrápodon ${ }^{42}$, sublinham a precedência de um conflito interno e a derrota do conhecimento moral. Com base nessas indicações, a oposição entre os 'fatos aparentes' (tô̂s phainoménois) e Sócrates torna-se ainda mais significativa em ENVII. Na visão de Aristóteles, a descrição tradicional da akrasia está vinculada aos phainómena. Como ressalta Nussbaum (2009, p. 211), os phainómena, correspondem a evidências empíricas e as opiniões gerais da sociedade ou de sábios eminentes na filosofia aristotélica. Nesse sentido, a visão tradicional da akrasia atende indistintamente às impressões empíricas e opiniões correntes da sociedade grega. Em outras palavras, a impotência do conhecimento da descrição tradicional parece persistir ainda na sociedade grega da época de Aristóteles. Assim, a referência de ENVII reforça mais uma vez as crenças da 'opinião dominante' veiculadas no Protágoras de Platão. A reprodução do vocabulário e a representação da 'opinião dominante' em ambos os contextos indicam que a descrição tradicional da akrasia não é uma mera invenção filosófica, mas sim uma reconstrução do ponto de vista popular enraizado na cultura grega. Apesar de se manifestar a favor dos phainómena, Aristóteles não admite simplesmente a impotência do conhecimento moral expressa pela opinião corrente.

Ao longo de ENVII, Aristóteles acaba se aproximando mais da tese socrática do que efetivamente da opinião corrente. Quando Aristóteles apresenta sua própria formulação da akrasia em ENVII.3, observamos que sua discordância com a posição socrática está mais ligada à (I) do que propriamente a (II) e (III). De um lado, ele assume que a akrasia consiste em uma espécie de ignorância de um tipo

\footnotetext{
${ }^{41}$ Cf. IRWIN, 2008, p. 25: “(...) we have nothing besides Plato's Socratic dialogues to test Aristotle's claims about Socrates, and we have to rely on Aristotle's testimony if we are to believe that these dialogues tell us about the historical Socrates (...) If we believe that Aristotle is right to suppose that some Platonic dialogues tell us about Socrates; for what he tell us fits the relevant Platonic dialogues."

${ }^{42}$ Cf. LIDDEL-SCOTT, 1990. Com efeito, andrápodon significa literalmente um indivíduo tomado em cativeiro da guerra e vendido como um escravo. Como ressaltamos anteriormente, o termo se enquadra no que estamos designando de 'vocabulário da guerra' ligado à etimologia original do termo grego akrasia.
} 
de 'conhecimento' em sentido forte que não é submetido pelos impulsos (1147a251147b15). De outro lado, seu objetivo primordial permanece sendo garantir a possibilidade da akrasia em favor dos phainómena contra o paradoxo socrático. Por essa razão, Aristóteles concede que outro tipo de 'conhecimento', ligado à sensação (tês aisthetikês), acaba sendo submetido pelos apetites irracionais (1147b19). Com efeito, a difícil posição de Aristóteles sobre a akrasia envolve a controversa doutrina do silogismo prático e a suposta superação da posição socrática ${ }^{43}$. Como essa investigação nos levaria a aprofundar nossa análise de ENVII, devemos deixar essa discussão para outro capítulo. Por ora, é suficiente ressaltar que Aristóteles, tal como Platão no Protágoras, precisam confrontar a mesma posição popular comum sobre a impotência do conhecimento diante do conflito interno da akrasia.

O problema filosófico da akrasia antiga é formulado da mesma forma no Protágoras e na Ética a Nicômaco, em termos de conhecimento moral. A manifestação da akrasia impõe um problema à superioridade do conhecimento prático moral. Em ambos os casos, Platão e Aristóteles visam preservar o conhecimento moral contra a descrição tradicional da akrasia $^{44}$. Nesse sentido, eles se referem à mesma visão da 'opinião dominante' veiculando ideias que estavam supostamente em circulação na sociedade grega ${ }^{45}$. Como observamos, o vocabulário reproduzido e a descrição do conflito psicológico representam ideias correntes da experiência da akrasia. Com base nessas evidências, podemos concluir que a descrição tradicional do fenômeno não é apenas uma criação filosófica mas uma representação de um ponto de vista popular: o ponto de vista da sociedade

\footnotetext{
${ }^{43}$ Como veremos adiante, muitos intérpretes não acreditam que Aristóteles tenha conseguido efetivamente se desvencilhar da formulação socrática da ignorância e demonstrar a possiblidade da akrasia. De fato, as propostas de elucidação do fenômeno presentes em $E N$ VII.3 reincidem de uma ou outra forma em uma versão da ignorância socrática.

${ }^{44}$ Diante do plano deste capítulo, evitamos abordar ainda o suposto caso de akrasia de Leôncio da República de Platão e a polêmica interpretativa com a negação socrática da akrasia do Protágoras. Ao longo dos capítulos 3 e 4, defenderemos que não há uma descontinuidade radical entre a posição 'socrática' do Protágoras e a posição 'platônica' República, como supõem os adeptos do 'desenvolvimentismo' platônico.

${ }^{45}$ Com certeza, é possível objetar que Platão e Aristóteles se referem somente a suas respectivas sociedades, limitadas por seu próprio contexto sociolinguístico. De acordo com tal objeção, não há qualquer implicação que eles se referem a mesma sociedade grega, isto é, as mesmas crenças compartilhadas por sociedades tão dispares. Ora, as referências citadas, no entanto, indicam a continuidade da certa descrição tradicional da akrasia antiga. Mesmo se concedermos as particularidades do contexto político-social de cada época, o fato é que uma representação específica da akrasia foi transmitida através dos tempos e dispomos de evidências textuais que permitem reconstruir esse ponto de vista. Com efeito, o objetor poderia ainda alegar que estamos lidando apenas com fontes filosóficas e que não há nenhuma comprovação desse ponto de vista fora do campo filosófico. Na sequência, pretendemos mostrar que mesmo em fontes 'não filosóficas' encontramos fortes indícios dessa continuidade.
} 
grega. De fato, isso nos estimula a buscar por descrições correlatas do fenômeno em fontes externas à filosofia grega. Para tal, precisaremos buscar pela descrição tradicional do fenômeno sem nos restringirmos as ocorrências técnicas do termo 'akrasia'. Como evidencia Platão e Aristóteles, a descrição tradicional da akrasia da opinião dominante independe da existência ou não do termo grego correlato.

A pretensão de investigar os antecedentes da akrasia antiga restringindo-se ao próprio termo grego está fadada ao fracasso. Deixar de reconhecer qualquer descrição do fenômeno com base apenas na ausência da 'akrasia' ou de um termo correlato no sentido clássico aristotélico está intrinsecamente vinculado a um princípio léxico. Com efeito, helenistas, como Snell e Dodds, efetivamente adotam esse princípio metodológico para analisar o desenvolvimento do pensamento grego $^{46}$. Em linhas gerais, o princípio léxico assume que não devemos atribuir uma concepção de um contexto linguístico $X$ a um contexto linguístico $Y$ quando não dispomos de uma palavra ou termo correlato do mesmo campo semântico. Embora o princípio léxico seja útil na delimitação do sentido etimológico de 'akrasia', se tomado com rigor ele elimina a própria existência do fenômeno nos termos da descrição tradicional. Como lembra Gaskin (Ibid., p. 4-5), o princípio léxico nos leva, por vezes, a confundir uma diferença etimológica com uma diferença ontológica. Nesse sentido, se distinguirmos claramente a diferença linguística de uma diferença etimológica seremos capazes de distinguir a concepção geral do fenômeno em meio a suas diferentes definições filosóficas. A partir disso, buscaremos por antecedentes da descrição tradicional da akrasia em vez de buscar uma definição filosófica propriamente fechada.

A descrição tradicional da akrasia antiga está mais vinculada ao seu sentido etimológico original do que a uma definição filosófica categórica. Notavelmente, a literatura grega está repleta de casos de conflito psicológico moral que remetem ao vocabulário bélico da akrasia. Na medida em que Homero e os tragediógrafos gregos representam a própria cultura grega, devemos buscar as ideias correntes sobre a akrasia antiga nos exemplos fornecidos dentro da literatura grega. Dessa forma, nos voltaremos para essa investigação na próxima seção.

\footnotetext{
${ }^{46}$ Já no capítulo 1 de A Descoberta do Espirito, Snell (2001, p. 1) adota tal princípio ao empreender sua análise da língua homérica: "Se interpretarmos Homero atendo-nos puramente a sua língua, poderemos também dar uma interpretação mais viva e original de sua poesia e permitir que, entendidas no seu verdadeiro significado, as palavras homéricas recuperem o antigo esplendor." Ver também DODDS, 1956, p. 5-7; p. 20 n. 31.
} 


\section{3 \\ Antecedentes da akrasia tradicional na literatura grega: a psicologia grega antiga e a psicologia da vontade}

$\mathrm{Na}$ seção anterior, buscamos salientar como uma mesma descrição tradicional da akrasia está presente no Protágoras e na Ética a Nicômaco. Conforme evidenciamos, as crenças sociais veiculadas em nome da 'opinião dominante' adquirem personalidade própria e representam ideias correntes da sociedade grega. As similaridades entre a passagem 352b-d do Protágoras e duas passagens das tragédias Medéia e Hipólito de Eurípides ${ }^{47}$ corroboraram a ideia de uma polêmica entre Sócrates (remetido ao Protágoras) e Eurípides. À medida que essa relação está fundada na emergência de um suposto conflito absoluto entre razão e paixão irracional externo à concepção grega da akrasia antiga, devemos buscar por ocorrências anteriores da descrição tradicional.

Como vimos anteriormente, a descrição tradicional da akrasia apresenta suas raízes etimológicas já em Homero. Dessa forma, estamos autorizados a buscar por traços do conflito psicológico moral da akrasia antes mesmo de Eurípides. Com isso, não pretendemos rejeitar, a princípio, a relação entre o diálogo Protágoras e Eurípides mas, ao contrário, reforçaremos ainda mais o elo entre a descrição tradicional do fenômeno e as passagens das tragédias de Eurípides. Antes disso, no entanto, devemos nos voltar primeiramente para as fontes poéticas de Homero anteriores às tragédias de Eurípides a fim de delinear as condições que possibilitam o conflito psicológico da akrasia.

A descrição tradicional da akrasia faz parte do que classificamos como conflito psicológico moral. Em obras fundamentais da cultura grega, Homero e outros tragediógrafos nos apresentam casos emblemáticos de conflitos internos representados de forma dramática por seus personagens. Os personagens encaram

\footnotetext{
${ }^{47}$ Da mesma forma, devemos interpretar a 'posição' de Eurípides em relação a akrasia sob qualificação. À medida que possuímos apenas as tragédias de Eurípides para encontrar uma reflexão sobre o fenômeno, devemos nos limitar a encontrar tais ideias enquanto restritas as falas das personagens Fedra no Hipólito e Medéia na tragédia homônima. Mesmo dentro desses limites estreitos, ainda temos de nos referir com qualificação a certas passagens onde encontramos essas referências e não a uma 'posição' filosófica e, muito menos, a uma 'teoria' da akrasia em Eurípides veiculada através de suas personagens.
} 
situações éticas decisivas, deliberam entre as alternativas de ação e relatam um confronto entre diferentes motivações internas. A princípio, esse parece ser um terreno propício ao conflito interno da akrasia.

No entanto, helenistas tem sustentado que personagens homéricos e trágicos antes de Eurípides não representam deliberações em termos puramente intelectuais. Em uma visão progressista do pensamento grego $^{48}$, eles acreditam que os gregos foram gradativamente desenvolvendo uma concepção depurada da deliberação racional frente a outras motivações irracionais particularmente a partir de Eurípides. Novamente, o que esses helenistas querem encontrar aqui é o conflito absoluto entre razão e paixão irracional que configura, na concepção moderna, a psicologia moderna da vontade e a fraqueza da vontade. Em contraponto a tal visão, mostraremos que casos emblemáticos de conflito psicológico da poesia homérica e das tragédias gregas apresentam uma relação intrínseca entre razão, emoção e motivação. Nesse sentido, os indícios atestam um modelo misto cognitivomotivacional da psicologia humana. Dessa forma, é fundamental encararmos os pressupostos dessa corrente intelectualista moderna sobre o desenvolvimento do pensamento grego.

Para darmos início a tal investigação, precisamos analisar fundamentalmente quais os efeitos dessa visão intelectualista no pensamento grego. Sobretudo, esse empreendimento será fundamental especialmente em relação a Homero, uma vez que tal corrente sustenta que os personagens homéricos sequer fazem uma deliberação racional.

Ao longo de estudos helenísticos da psicologia grega antiga, helenistas tem alegado que personagens homéricos não deliberam em sentido estrito. Desde os clássicos A Descoberta do Espírito (1960) de Bruno Snell e The Greeks and the Irrational (1956) de E. R. Dodds, uma corrente de helenistas estabeleceu que tais personagens não são agentes autênticos pois não apresentam uma deliberação

\footnotetext{
${ }^{48}$ Cf. WILLIAMS, 1993, p. 5: "According to the progressivist account, the Greeks had primitive ideas of action, responsibility, ethical motivation and justice. (...) It is agreed, on this account, that devolpment took a long time; it is also agreed that some improvements occurred in the lifetime of Greek antiquity itself, while others were reserved for a later time. (...) These stories are deeply misleading, both historically and ethically. Many of the questions they generate, of when this, that, or the other element of a developed moral consciousness is supposed to have arisen, are unanswerable, because the notion of a developed moral consciousness that gives rise to these questions is basically a myth."
} 
puramente intelectual. Ora, mas como explicar as diversas referências de Homero a personagens que parecem justamente fazer isso, isto é, deliberar?

Em vista dessa evidência, tal corrente sustenta que as deliberações homéricas não são autênticas por causa de duas 'faltas' primordiais: (1) o homem homérico não tem controle sobre si mesmo e, por isso, está à mercê de seus próprios impulsos irracionais, forças externas ou extraordinárias; (2) a sociedade homérica (e a cultura grega de forma geral ${ }^{49}$ não apresenta consciência moral interna consistente porque, dentre outras razões, não possui a concepção moderna de 'vontade' ou é dominada por uma cultura da vergonha. Em virtude da abrangência da tese (2), teremos de avaliá-la posteriormente. Para nossos interesses imediatos, será necessário apenas avaliarmos o fator (1) por enquanto averiguando se o homem homérico é um sujeito passivo às forças externas ou se ele pode ser considerado um agente ativo capaz de deliberar e sofrer um conflito psicológico interno sem outras interferências externas.

A representação do homem homérico como um feixe descentralizado submetido a forças externas foi propagada por Snell. Com efeito, já podemos constatar em seus textos uma preocupação premente em distinguir a psicologia grega das concepções modernas do agente. Em A Descoberta do Espírito, Snell (2001, p. 22) já demarcava a condição peculiar do homem homérico frente ao homem moderno:

Os homens homéricos, que ainda não sentem a alma como lugar de origem das próprias forças, não atraem para si, contudo, essa força com práticas mágicas, e sim recebem-na - dom natural - dos deuses. (...) os órgãos da alma como nóos e thymós, destituídos que são da faculdade de pensar e mover-se por si, devem forçosamente estar à mercê do poder mágico, e homens que têm uma tal concepção de sua vida interior devem naturalmente sentir-se expostos ao poder de forças arbitrárias e tenebrosas.

A 'ausência' fundamental do homem homérico frente ao homem moderno, já indicada nessa passagem, é a do 'lugar de origem' da alma. O que Snell (Ibid., p.

\footnotetext{
${ }^{49}$ Somente Dodds generaliza esse aspecto para toda cultura grega enquanto Snell encontra a ideia de uma autonomia moral já na tragédia grega. Ao contrário de Dodds, Snell visualiza um claro progresso do desenvolvimento do pensamento grego. Sobre a perspectiva 'hegeliana' de Snell, ver GILL, 1996, p. 36: "Above all, Snell presupposes the Hegelian view of the history of civilization as the dialectical evolution of the spirit or mind (Geist) towards ever heightened self-awareness. He refers to Hegel's schema for this dialectical evolution (thesis-anthitesis-synthesis) in his characterization of the dominant genres in early Greek culture."
} 
53-54) constata como uma 'falta' é a falta de 'centralidade' da alma humana diante das forças 'externas' que tomam conta da deliberação racional dos personagens homéricos.

Nesse sentido, podemos averiguar dois efeitos dessa 'falta' no homem homérico. De um lado, ao invés de constituir um agente 'único' ele apresenta ao menos três entes distintos, 'psyché', 'nóos' e 'thymós' (Ibid., p. 16). Na época de Homero, esses termos têm conotações mais ligadas a órgãos vitais do propriamente a faculdades mentais pois não havia a distinção clara entre 'corpo' e 'alma'. Por isso, a 'psyché' não atende ainda pela 'alma', mas pelo 'sopro vital' que possibilita a vida humana ${ }^{50}$. Enquanto isso, 'nóos' e o 'thymós' são órgãos responsáveis respectivamente pelo raciocínio, percepção sensorial e controle das emoções. De outro lado, a 'ausência' de um 'eu' centralizado ainda submete o homem homérico à interferência abrupta de forças divinas em sua deliberação racional. Em diversas ocasiões, os deuses intervêm direta ou indiretamente nas ações dos personagens homéricos ${ }^{51}$. A partir disso, Dodds reforça as conclusões de Snell dando maior ênfase à interferência de forças divinas.

Assim como Snell, Dodds retoma algumas das conclusões da Descoberta do Espírito aprofundando outras 'diferenças' da cultura grega e da cultura moderna. Em The Greeks and the Irrational, Dodds reitera a falta de unidade da 'alma' homérica $^{52}$ e salienta sua vulnerabilidade às forças divinas, sob a concepção grega do irracional. Por vezes, personagens homéricos reconhecem que certas ações extraordinárias, inesperadas ou além dos limites humanos, não são derivadas da deliberação racional mas de intervenção divina (Cf. Ibid., p. 13). Tal cegueira divina

\footnotetext{
${ }^{50}$ Cf. SNELL, 2001, p. 9: “A palavra tem afinidade com psýchein, "expirar”, e significa o hálito de vida, e, portanto, psyché sai pela boca (a saída através do ferimento e, ao que parece, uma forma secundaria). Esse hálito vital e quase um órgão físico que, até que o homem esteja vivo, nele vive. Mas sobre onde essa psyché se situa e como age, Homero nada diz, e assim tampouco a nós e dado sabê-lo."

${ }^{51}$ Cf. Ibid., p. 20-21: "Nós interpretamos esse fato imaginando que um homem supere seu estado por suas próprias forças, com um ato de vontade, mas quando Homero quer explicar-nos a proveniência dessa nova massa de forças, só sabe dizer que foi um Deus que as concedeu. (...) E é o verdadeiro e autêntico ato da decisão humana que Homero ignora; daí porque, mesmo nas cenas em que o homem reflete, a intervenção dos deuses sempre tem uma parte importante."

${ }^{52}$ Cf. DODDS, 1956, p. 15-16: “(...) Homeric man has no unified concept of what we call "soul" or "personality". (...) This habit of (as we should say) "objectfying emotional drives", treating them as not-self, must have opened the door wide to religious idea osf psychic intervention wich is often said to operate, not directly on the man himself but on his thumos or in its physical seat, his chest or midriff."
} 
é representada particularmente pelo fenômeno designado de áte $e^{53}$ e sua influência se estende a termos correlatos encontrados nas tragédias gregas. Como a intervenção divina não é nosso interesse primordial aqui, devemos tentar buscar em Homero casos de conflito estritamente psicológico. Com efeito, helenistas tem indicado casos de conflito psicológico nos poemas homéricos que contestam francamente essa suposta condição passiva do homem homérico.

A ideia de que o homem homérico é um mero sujeito passivo e não um agente autêntico, capaz de deliberar por si mesmo, foi amplamente questionada. $\mathrm{Na}$ visão de Snell e Dodds, o homem homérico é apenas uma marionete das forças 'externas' sujeito a paixões abruptas ou à interferência divina. Em grosso modo, essa posição ortodoxa se baseia em dois pilares: (a) sob o princípio léxico mencionado acima, determinou-se que Homero não possui nenhuma palavra para designar o 'eu' ou a 'autoconsciência' e, portanto, essa concepção a rigor não existe em Homero ${ }^{54}$. (b) devido a sua condição passiva, a ação do homem homérico sempre é determinada pela interferência divina. Em particular, Sharples (1983) e Gaskin (1990) apresentaram críticas a tal visão cristalizada do homem homérico alegando que a referida 'unidade da alma' é um pressuposto moderno que não precisa se aplicar aos personagens homéricos. Por um lado, Sharples indica que a concepção de sujeito em Homero é 'dinâmica', isto é, sem os limites fixados subentendidos na concepção de subjetividade moderna ${ }^{55}$. De outro lado, Gaskin alega, contra o princípio léxico, que o fato de Homero não possuir palavras exatamente correlatas a 'sujeito', 'personalidade', 'consciência', não implica na

\footnotetext{
53 Dodds toma como exemplo a apologia de Agamêmnon em Ilíada XIX. 75-95. A áte não é uma força que provém do próprio agente mas algo que vem 'de fora' da sua deliberação e que o força a realizar uma ação que não condiz com seu caráter habitual, algo extraordinário para sua condição. Segundo Dodds (Ibid., p. 5): "Always, or pratically always, ate is a state of mind - a temporary cloudering or bewildering of the normal consciousness. It is, in fact, a temporary insanity; and, like all insanity, it is ascribed, not to physiological or pscyhological causes, but to an external "daemonic' agency." Nessa perspectiva, os personagens homéricos se referem a áte quando reconhecem que suas ações não podem ser atribuídas a causas diretamente perceptíveis. Eles julgam que são orientadas pela interferência de uma divindade (daímon) ou qualquer tipo de potência sobrenatural. ${ }^{54}$ Cf. SNELL, 2001, p. 1-2: "Já de há muito se descobriu que numa língua relativamente primitiva as formas de abstração ainda não estão desenvolvidas, mas que em compensação existe uma abundância de definições de coisas concretas, experimentáveis pelos sentidos que pareceriam estranhas numa língua mais evoluída." Ver também DODDS, 1956, p. 5-7; p. 20 n. 31.

${ }^{55}$ Cf. SHARPLES, 1983, p. 4: "Homeric man can so easily distinguish from his 'self' or contrast with it the sources of impulses which he rejects, that that 'self' can remain simple. (...) And, it must be stressed, the situation is always a dynamic one; the boundaries of the self are not fixed, but fluctuate, even within the course of a single decision-making process."
} 
inexistência ontológica dessas concepções no registro linguístico homérico ${ }^{56}$. Sem tais preconceitos, somos capazes de compreender o processo deliberativo homérico mais positivamente. Todavia, a extensão dos preconceitos de Snell e Dodds são mais explicitamente revelados na crítica de Bernard Williams em Shame and Necessity.

A condição passiva do homem homérico constitui uma das principais representações equivocadas dos gregos analisadas em Shame and Necessity. As críticas a tal representação equivocada são concentradas no capítulo "Centres of Agency". Nesse contexto, Williams sustenta que as teses equivocadas de Snell (reiteradas por Dodds) estão fundadas em pressupostos filosóficos modernos. De fato, a representação passiva do homem homérico se apoia fortemente sobre o pressuposto de que há três entes 'psicofísicos' no homem homérico e nenhuma representa a unidade do sujeito. Segundo Williams (1993, p. 25), a necessidade da 'unidade' psicológica está carregada de pressupostos filosóficos:

But none of this would have enough power to distort Homeric image so drastically if it were not backed up by something more important - the assumption that not only in later Greek thought, but truly, a distinction between soul and body describes what we are.

A separação entre uma 'alma' unitária distinta de um 'corpo' atende à demanda filosófica do dualismo corpo e alma. Quando Snell não encontra essa separação claramente demarcada no vocabulário homérico, ele assume de antemão que somente o dualismo corpo alma exprime o que constitui verdadeiramente o ser humano em termos ontológicos. De acordo com Williams, não precisamos restringir o homem homérico ao dualismo do corpo e alma e nem mesmo à ‘unidade’ necessária da alma.

É necessário preservar a concepção psicofísica da alma salientada por Snell, mas também reconhecer uma forma de deliberação no homem homérico. Ao contrário do que supõe Snell (e Dodds), os personagens homéricos não estão

\footnotetext{
${ }^{56}$ Cf. GASKIN, 1990, p. 5: "That Homer now has no word which corresponds to our word 'self' does not deprive him of the concept of selfhood, since what is presented by these words in the contexts which concern us (such as: he spoke to his thymós) is precisely the integrated, unitary item which the word 'self' also (and always as opposed to sometimes) refers to. The semantic difference between 'self' and thymós (in its relevant usage) must accordingly be located in the different modes under which these terms present the same concept (namely selfhood); in other words, the difference is a linguistic and not an ontological difference.” Ver também WILLIAMS, 1993, p. 27
} 
simplesmente à mercê de forças 'externas' arbitrárias que comandam suas decisões. Como indica Williams, os textos homéricos refletem uma teoria da ação extremamente simplificada: os personagens atribuem suas ações à intenções, crenças, desejos e fundamentalmente a razões, tal como os agentes humanos ${ }^{57}$. Além disso, as próprias divindades tomam decisões com base em deliberações prévias. A influência dos deuses sobre as ações humanas ocorre frequentemente por uma cegueira momentânea, mas por vezes também por persuasão na deliberação humana (cf. Ibid., p. 29-33). A partir dessas indicações, temos indícios suficientes para encontrar conflitos psicológicos concretos em Homero e menos dependentes da condição passiva retratada anteriormente.

Apesar da consistência de sua crítica à interpretação ortodoxa, Williams não está isento de suas próprias preferências filosóficas. Com efeito, tem se indicado que a frequente comparação do homem grego com 'nós' (us) em Shame and Necessity é seletiva e carregada de pressupostos filosóficos modernos ${ }^{58}$. Como veremos em outro capítulo, suas preferências filosóficas ficam mais explícitas nas críticas dirigidas à psicologia moral platônica. De qualquer forma, isso não afeta substancialmente a sua crítica ao suposto estado passivo do agente homérico. Em vista disso, estamos inclinados a reconhecer nos personagens homéricos conflitos psicológicos morais mesmo em face de sua interação constante com os deuses.

Desse modo, devemos buscar por exemplos de conflitos psicológicos em Homero que favoreçam essa nova abordagem do homem homérico. Nesse intuito, pretendemos destacar passagens da Ilíada e da Odisséia envolvidas apenas com o estrito conflito psicológico moral. Com isso, acreditamos poder esclarecer os antecedentes da akrasia antiga dentro do universo homérico.

Nos poemas homéricos, nos deparamos com diferentes representações de conflitos psicológicos. A princípio, alguns casos confirmam a interferência divina na deliberação humana: como no caso de Aquiles em Ilíada I persuadido por Afrodite a conter sua "cólera (chólon)" contra Agamenon por prêmios futuros

\footnotetext{
${ }^{57}$ Cf. Ibid., p. 33: "Indeed, it is hard to see how we could understand the Homeric poems as speaking of human action at all unless we could find in their words the presence of such a notion, and of beliefs, desires and purposes."

${ }^{58}$ Cf. IRWIN, 1993, p. 48: "Williams's conception of 'us' is no less selective than his conception of the 'Greeks' (...). 'We' agree with Williams in so far as we believe that a set of views common to Plato, Aristotle, Christianity and Kant are false, and 'we' find common ground with the 'Greeks' in so far as 'our' ethical views freed from these these views 'we' rejected, become clearer to us when we compare them with 'Greek' views that are still untouched by Platonic and late erros."
} 
(Il.I.188-218) ou a apologia de Agamemnon na passagem já mencionada, em que ele alega ter realizados seus atos por influência da áte (Il.XIX.75-95). Além disso, temos a clássica cena do canto III em que Afrodite persuade Helena a ceder à sua paixão por Páris (Il.III.390-460). No entanto, há cenas centrais dos poemas homéricos que apresentam apenas um simples conflito psicológico entre diferentes motivações. Dessa forma, abordaremos apenas duas cenas emblemáticas de conflito psicológico, uma da Ilíada e uma da Odisseía, que nos levam a contestar a passividade do homem homérico.

No canto IX da Ilíada, ${ }^{59}$ presenciamos uma longa reunião dos guerreiros destinada a convencer Aquiles a retornar a guerra de Tróia. A cena retrata um encontro entre os guerreiros e Aquiles a fim de exortá-lo a aceitar os presentes de Agamêmnon, desistir de sua cólera contra o Atrida e retornar a guerra. Com longos discursos, Odisseu, Fênix e Ájax se revezam apelando ao seu thymós diversas vezes $^{60}$. Com efeito, Aquiles não parece ceder a quase nenhum dos discursos de seus companheiros. Entretanto, o derradeiro discurso, o de Ájax, leva Aquiles a expressar um claro conflito em sua alma:

Com quase todas as tuas palavras meu peito concorda (katà thymòn mythésasthai $)^{61}$.

$\mathrm{O}$ coração, porém, enche com cólera ${ }^{62}$ (allá oidánetai kradíe chóloi) ao lembrar-me do insulto que me atirou Agamêmnon em face do exército aquivo como se eu fosse um errante sem qualquer honra (atímeson metanásten). (Il.XIX.645-8)

Nessa ocasião, Aquiles relata um conflito interno entre seu thymós e seu kradie 'cheio de cólera'. O conflito emerge do peso das considerações de sua cólera perante as novas considerações trazidas por Ájax. De um lado, Aquiles já havia mencionado anteriormente as razões que fundamentam sua cólera, a humilhação sofrida pelo rapto da consorte por Agamêmnon mesmo com seu empenho na guerra (310-430). Na perspectiva de Aquiles, esse tratamento não é digno mas apenas de um homem "sem qualquer honra (atímeson)". De outro lado, Ájax critica a intransigência de Aquiles, lhe chamando de "cruel", 'impiedoso', e sobretudo the fazendo tomar consciência de sua ingratidão aos companheiros, "não preza pela

\footnotetext{
${ }^{59}$ Para a Ilíada, sigo a tradução de Carlos Alberto Nunes com pequenas alterações a fim de melhor contemplar o significado dos termos e das expressões originais em grego.

${ }^{60}$ Cf. Il.IX. 254-260; 434-436; 496-499; 630-640.

${ }^{61}$ Em sentido literal, 'tuas palavras falam de acordo com meu thymós'.

${ }^{62}$ Esse é sentido mais literal da expressão grega oidánetai chóloi.
} 
amizade dos companheiros (philótetos hetaíron)" (630). Em seu discurso, o guerreiro reitera de forma mais incisiva o apelo à amizade feito nos discursos anteriores de seus outros companheiros ${ }^{63}$, mas seu tom de distanciamento tem maior gravidade pois reforça o isolamento pessoal do Pelida ${ }^{64}$. O apelo à amizade, então, representa o 'outro' dentro de Aquiles, o 'outro' interior que integra sua personalidade. Por essa razão, seu conflito interior representa o confronto de suas razões da cólera de seu kradíe e as razões de suas relações de amizade 'de acordo com seu thymós' (katà thymón) ${ }^{65}$.

Como nenhuma dessas considerações é ligada explicitamente à 'melhor razão', não há como identificar aqui um caso claro de akrasia, nos termos tradicionais. Há apenas um conflito psicológico entre duas considerações morais relevantes. Certamente, não encontramos aqui de que lado se encontram as 'melhores considerações' e nem um conflito claro entre razão e uma paixão colérica irracional $^{66}$. Dentro dos limites do texto, os impulsos, representados respectivamente, por kradíe e thymós, não são forças externas, mas são embasados nas razões do agente. Dessa forma, o conflito de Aquiles é um legítimo conflito psicológico moral embora ainda não seja um caso de akrasia. Nesse sentido, é pertinente trazermos aqui um outro caso de conflito psicológico da Odisséia que também desafia a interpretação ortodoxa do homem homérico passivo.

No início do canto XX da Odisseía ${ }^{67}$, encontramos outro conflito característico ligado ao thymós. O episódio narra a resistência de Odisseu ao ímpeto de matar imediatamente suas servas traidoras estragando, assim, seu disfarce de ancião e seus planos de vingança contra os pretendentes de sua noiva. Quando servas passam em seu caminho, seu thymós agita no peito e "cogita no juízo e no

\footnotetext{
${ }^{63}$ Cf. Il.IX 300-306; 582-589; 630-635.

${ }^{64}$ Cf. GILL, 1996, p. 194-195: "The third-personal form seems designed to suggest, woundingly, that Achilles is no longer one of their number and is beyond the reach of properly grounded ethical argument, a suggestion to which Achilles is likely to be highly sensitive (...)."

${ }^{65}$ Cf. CLAUS, 1981, p. 42: "If we recognize the idiomatic qualitiy of thymô $i$ and the apparent use of katà thymón and other expressions to satisfy a fairly mechanical need for personified exchange, it can be seen that 'affection' is the only really important category added by thymós to the 'life' uses of other words." . De acordo com Claus, portanto, a expressão katà thymón expressa claramente uma 'troca de personalidades'.

${ }^{66}$ Para Gaskin (1990, p. 11-13) e Sharples (1983, p. 5), seria possível enxergar casos de akrasia em Homero, principalmente, no exemplo de Helena ou de Aquiles. Como salientamos, diversos traços fenomenológicos do conflito psicológico já podem ser vistos nesses exemplos, mas eles não representam explicitamente o conflito entre deliberação racional pelo bem e os impulsos irracionais que constitui a descrição tradicional da akrasia.

${ }^{67}$ Para a Odisséia, sigo a tradução portuguesa de Christian Werner.
} 
ânimo (mermérize kata phréna kaì katá thymón)" se deve assassiná-las imediatamente (Od.XX.8-10). Ao mesmo tempo, Odisseu reconhece que outro impulso lhe retém:

\begin{abstract}
seu coração, dentro, latia (kradie dé hoi éndon huláktei). Como a cadela (hòs dè kíon), envolvendo os frágeis filhotes ao estranhar um varão, late, sôfrega por brigar (máchesthai), assim, em seu íntimo, latia, indignado com as vis ações. Após golpear o peito, reprovou o coração com o discurso (kradíe henípate múthoi):

"Suporta, coração (kradíe): suportaste outro feito mais canalha no dia em que o Ciclope, de potência incontida, comeu os altivos companheiros; tu resististe até a astúcia a ti conduzir para fora do antro, pensando que morrerias". Assim falou, abordando o caro (phílon) coração no peito; e seu coração, obediente de todo (tôi mal'en peíse kradie), aguentou e resistiu sem cessar (Od.XX.12-21)
\end{abstract}

Em relação ao caso anterior da Ilíada, o conflito relatado aqui em Odisséia XX envolve mais uma 'animalidade' do que propriamente a 'personalidade' de Odisseu. A representação do 'outro' é claramente demarcada pela metáfora do comportamento canino. Tal "como a cadela (hòs kíon)" protegendo a cria, o 'coração' (kradíe) de Odisseu urge por justiça imediata frente às 'ações vis' de suas servas traidoras. No entanto, o herói se dispõe a travar um 'diálogo' com seu 'coração' através de seu thymós relembrando da resistência às adversidades passadas contra o Ciclope. O coração está disposto a 'brigar' (máchestai) por seu impulso imediato de retaliação e também a ouvir e ser 'obediente de todo' (mal'en peise) ao thymós. Sobretudo, o kradie caracteriza um 'outro' animal e adquire simultaneamente 'personalidade' quando é tratado de forma 'amigável' (phílon), em um processo de autodistanciamento e autoaproximação de si mesmo ${ }^{68}$. Como já podemos constatar, o típico conflito psicológico-moral que dá origem a akrasia está profundamente arraigado na cultura grega desde Homero.

Diante dos episódios narrados em Ilíada IX e Odisséia XX, encontramos indícios suficientes para colocar em xeque a representação do homem homérico como mero feixe de 'forças externas'. Não apenas existem claros conflitos psicológicos sem interferências externas como também aparecem vinculadas às

\footnotetext{
68 Para essa concepção antiga de autodisatanciamento e autoaproximação psicológica ver GILL,
} 1996, p. 188-190; SHARPLES, 1983, p. 3-4. 
crenças e motivações internas do homem homérico. Apesar de não encontrarmos um caso explícito de akrasia, já observamos elementos psicológicos imprescindíveis para a emergência da akrasia antiga.

Em geral, podemos salientar dois aspectos correlatos dos conflitos psicológicos em Homero: (1) uma psicologia moral interativa relacionada a um 'eu' e a um 'outro' na alma; e (2) a presença de um diálogo interno entre as forças motivacionais. Ambos os aspectos foram salientados recentemente na literatura crítica e pretendemos explorá-las como paradigmas do conflito psicológico grego. Dessa forma, analisemos cada um desses aspectos fundamentais a seguir.

Em primeiro lugar, os personagens homéricos apresentam uma psicologia moral interativa em que as motivações conflitantes são representadas por um 'eu' e um 'outro'. A ideia de um 'outro' psicológico remete ao que Williams classifica de 'outro' internalizado. Segundo Williams (1993, p. 84), o 'outro internalizado' constitui uma representação psíquica de uma pessoa "cujas reações eu respeitaria" ou que "respeitaria aquelas mesmas reações se elas fossem apropriadamente dirigidas a ele.”. A concepção do ‘outro internalizado' está claramente presente nos conflitos psicológicos anteriores. Tanto Aquiles quanto Odisseu se referem às motivações impulsivas como um 'outro' explicitando seus aspectos cognitivos e possibilitando uma interação com o 'eu', em ambos os casos o thymós. Embora Williams (Ibid., 41) rejeite a presença de uma psicologia moral antes de Platão, observamos que há claras referências a motivações morais internas já em Homero ${ }^{69}$.

Em segundo lugar, a representação interativa do 'eu' e do 'outro' permite aos personagens homéricos engajarem um diálogo interno consigo mesmos. Em Personality in Greek Epic, Tragedy and Philosophy, Gill (1996) sustenta que a concepção do 'eu' (self) em diálogo é extremamente difundida em todo o pensamento grego, de Homero à filosofia antiga. Como mostra Gill (Ibid., p. 1517), a noção grega de um diálogo interno distingue profundamente a psicologia moral grega da psicologia moral moderna. Ao invés de uma concepção do sujeito

\footnotetext{
${ }^{69}$ Sobre as resenhas críticas mais abrangentes a Shame and Necessity, ver STRIKER, 1993; IRWIN, 1994, p. 53-56. Em diversas resenhas críticas, comentadores colocaram sob suspeita a tese de Williams de que os gregos, de Homero aos tragediógrafos, não possuíam uma psicologia descrita em termos morais. De fato, Williams pretende eliminar a distinção entre 'moral' e 'não moral' remanescente da psicologia moral da filosofia antiga e, particularmente, consagrada em Kant. Em que pesem as preferências filosóficas de Williams, acreditamos que a psicologia moral grega certamente é incompatível com a psicologia da 'vontade' de Kant mas, simultaneamente, também acreditamos que a psicologia moral antiga está intrinsecamente ligada aos valores morais da sociedade grega.
} 
isolado e privado em si mesmo, a 'subjetividade' grega é intrinsecamente fundada na relação com os outros e na vida ética dentro de uma comunidade social. A própria constituição 'subjetiva' grega é inseparável das atitudes reativas do 'outro' internalizado. A dimensão dialógica da subjetividade está presente nos conflitos psicológicos anteriores. Por um lado, Aquiles reflete claramente que os apelos de seus companheiros pela philía atendem aos anseios de seu thymós. Por outro lado, Odisseu tenta trazer seu coração à razão relembrando as adversidades passadas e exortando a abandonar a cólera. Dessa forma, esses casos de conflito psicológico ilustram aspectos da psicologia grega que serão enfatizados também na tragédia grega.

Antes de nos voltarmos propriamente às tragédias gregas, cumpre nos atentar para dois problemas relacionados à akrasia antiga. A emergência da concepção da akrasia antiga tem sido constantemente associada a um progressivo esclarecimento do conflito absoluto entre a razão e paixão irracional explicitado em Eurípides e no Protágoras de Platão. Na sequência, mostraremos que a distinção absoluta entre razão e paixão não se encontra claramente no pensamento grego e provém, na realidade, de uma antecipação da psicologia da vontade. Para vermos isso, precisaremos investigar primeiro a ideia da emergência de um suposto intelectualismo grego.

Anteriormente, salientamos que os personagens homéricos são autênticos agentes humanos que passam por conflitos psicológicos internos. A partir daqui, passamos a um pressuposto mais geral da cultura grega de Homero aos tragediógrafos. Para uma série de helenistas, a emergência do debate da akrasia antiga marca o progressivo intelectualismo do pensamento grego rumo a uma clara distinção entre a razão e os impulsos irracionais. Essa linha interpretativa se baseia em dois pressupostos fundamentais: (1) uma tendência grega ao 'intelectualismo', isto é, atribuir significado puramente intelectual às palavras gregas ligadas ao 'conhecimento racional'; (2) a partir de (1), o pensamento grego apresenta o conflito explícito entre razão e paixão irracional da akrasia antiga. Como veremos a seguir, o conflito absoluto entre razão e paixão irracional não exprime por si só a akrasia mas antecipa uma psicologia moderna da vontade. A partir disso, certos autores alegam ainda que a cultura grega não apresenta uma consciência moral 
autônoma justamente pela ausência da concepção moderna de "vontade'70 . Na ausência da 'vontade', o conflito entre razão e paixão representaria assim os primeiros indícios de uma consciência moral grega. Para averiguarmos esses pressupostos, precisamos nos voltar primeiramente para o intelectualismo grego.

A teoria do 'intelectualismo' grego tem atraído um grupo seleto de helenistas. Apesar das divergências internas, a corrente 'intelectualista' tem uma preocupação comum com o contraste entre a cultura grega antiga e o 'intelectualismo' socrático, particularmente, as teses socráticas de que 'virtude é conhecimento' e o paradoxo socrático 'ninguém faz o mal de bom grado' expostas no Protágoras de Platão. O problema central seria o seguinte: como poderiam essas teses socráticas paradoxais terem surgido dentro da cultura grega ateniense? Como Platão (e Sócrates) viviam em Atenas, certas condições culturais podem ter favorecido a emergência de um 'intelectualismo' grego. Tal corrente ‘intelectualista' buscou a origem do 'intelectualismo' na própria cultura grega.

Em particular, podemos encontrar uma defesa influente do 'intelectualismo' grego em GI. Para Dodds (1956, p. 16-17), o nascimento do intelectualismo grego já se encontra em Homero por duas condições específicas: (1) o "hábito arraigado de pensamento" de explicar o comportamento humano em termos de 'conhecimento'; (2) a referida condição passiva do homem homérico diante de forças 'externas'. O 'intelectualismo' grego estabelece que tudo que não é diretamente conhecido no intelecto, como impulsos irracionais ou intervenção psíquica, está fora do caráter moral e deriva de causas 'externas ${ }^{71}$. Nesse sentido, Dodds (Ibid., p. 185) indica que o 'intelectualismo' socrático não seria assim tão paradoxal ao homem comum grego embora reconheça um contraste posterior entre as ideias socráticas e do homem grego. De qualquer modo, a implicação central de

\footnotetext{
${ }^{70}$ De fato, somente Dodds (1956) generaliza tal fator para toda cultura grega enquanto Snell encontra a ideia de uma autonomia moral já na tragédia grega. Ao contrário de Dodds, Snell (2001) visualiza um claro progresso no desenvolvimento do pensamento grego. Sobre a perspectiva hegeliana de Snell, cf. GILL, 1996, p. 36: "Above all, Snell presupposes the Hegelian view of the history of civilization as the dialectical Evolution of the spirit or mind (Geist) towards ever heightened selfawareness. He refers to Hegel's schema for this dialectical evolution (thesis-anthitesis-synthesis) in his characterization of the dominant genres in early Greek culture."

${ }^{71}$ É importante observar que Snell não compartilha da hipótese da presença do 'intelectualismo' grego em Homero. Embora ambos concordem com a passividade do homem homérico, Snell não acredita que os termos homéricos relativos a 'faculdades' mentais adquirem a especificidade que viriam a ter em uma época tardia. Como veremos adiante, Snell, em todo caso, acredita que o 'intelectualismo' tem origem em Eurípides e acaba reforçando a relação entre Eurípides e Sócrates quanto ao problema da akrasia.
} 
encontrar o ‘intelectualismo’ em Homero significa encontrar também uma distinção preliminar entre deliberação racional e impulsos irracionais.

A teoria do 'intelectualismo' grego é endossada, entre outros helenistas influentes, por Vernant (1990, p. 35). Todavia, sua presença efetiva em Homero já foi sistematicamente contestada. De qualquer forma, os defensores do 'intelectualismo grego' estão claramente comprometidos com a visão progressista do pensamento grego cujo ápice seria o tardio 'intelectualismo’ socrático. Por essa razão, alguns adeptos esperam encontrar um intelectualismo preliminar justamente nas obras de Eurípides. $\mathrm{Na}$ realidade, o objetivo desses helenistas concerne justamente o conflito interno da akrasia: a emergência de um claro confronto entre intelecto e a paixão irracional que faz emergir a influente polêmica entre Eurípides e Sócrates. Para compreendermos melhor tal polêmica, será preciso antes analisarmos as críticas dirigidas ao suposto 'intelectualismo' dos termos gregos de 'conhecimento'.

Um dos problemas centrais do intelectualismo grego é a admissão velada de que não há nada de paradoxal nas teses socráticas pois elas não se originam contra mas a partir das crenças comuns da sociedade grega. Em The Socratic Paradoxes and the Greek Mind, O'Brien (1967, p. 25-50) alega que o suposto 'intelectualismo' grego não se verifica na literatura grega anterior às teses 'intelectualistas' socráticas. Os termos gregos relativos a 'conhecimento', como oîda, sophía, gnóme, phrénes, noûs, sophrosyne e seus derivados, possuem conotações igualmente intelectuais e morais. Em uma extensa catalogação de Homero aos tragediógrafos, O’Brien (Ibid., p. 42) registra um mesmo padrão comum: "The intellect, the will, the character, and the emotions seem to have no clear boundaries for the Greeks.". Com isso, o autor indica que a literatura grega reflete a mesma psicologia complexa: uma psicologia que não isola o 'intelecto', o ‘caráter' e as 'emoções' em faculdades mentais separadas mas integra tais elementos psicológicos no agente humano ${ }^{72}$.

\footnotetext{
72 Assim como O’Brien, Irwin (1983, p. 182-187), rejeita a visão 'intelectualista' de Dodds sobre Homero e reconhece que o homem homérico adota uma visão indiferenciada da deliberação humana (mesclando elementos cognitivos e emocionais). No entanto, Irwin acaba interpretando isso como uma deficiência da psicologia homérica sobre a psicologia dos trágicos. Por um lado, Irwin (Ibid., p. 186) sustenta que os personagens homéricos não deliberam propriamente ou seguem simplesmente seus impulsos, refletindo a representação passiva de Snell e Dodds: "This sort of person is not likely to have the beliefs and desires of an incontinent. He will often have a strong desire and act on it (...) he will not pause to make an "all things considered" judgment. Hence incontinence is possible, but not likely on important matters, which are settled by impulse anyhow." Por outro lado, ele acaba assumindo o progresso 'intelectualista' (ou, em seus próprios termos, 'cognitivista') que culmina na polêmica de Eurípides e Sócrates sobre a akrasia (Ibid., p. 189-192).
} 
Da mesma forma, Williams (1993, p. 28) compartilha do ceticismo em atribuir um significado 'intelectualista' generalizado aos termos gregos originais de 'conhecimento'. Mesmo assim, O’Brien reincide no 'intelectualismo' grego ao atribuir uma 'especialização' cognitiva do ‘conhecimento' na influente polêmica de Eurípides e Sócrates sobre a akrasia antiga ${ }^{73}$. Quanto a essa polêmica, teremos de deixá-la para a próxima seção. Nessa ocasião, devemos ressaltar uma categoria mental controversa que O'Brien não hesita em atribuir aos gregos, a 'vontade' $(\text { will })^{74}$.

A hipótese do intelectualismo grego parece ser compatível com a oposição entre razão e paixão irracional da psicologia da vontade. Com o intelectualismo das palavras gregas do 'conhecimento', os intelectualistas esperam encontrar o terreno apropriado ao esboço de um claro conflito entre intelecto e paixão irracional em Eurípides contra a qual seria apresentado o puro ‘intelectualismo’ socrático. Nesses termos, no entanto, eles acabam encontrando a 'fraqueza de vontade' ao invés da akrasia grega. Como veremos a seguir, esse problema está relacionado a ausência da 'vontade' na psicologia grega.

Como já foi ressaltado, a categoria moderna da 'vontade' não é claramente refletida em nenhum termo mental grego. Dentre os termos gregos mencionados relativos à 'alma' grega, como psyché, thymós, nóos e seus derivados, não encontramos qualquer termo aproximado da 'vontade'. Na verdade, essa ausência não é meramente terminológica ou semântica, mas anuncia um problema filosófico mais profundo: a falta de uma psicologia da vontade. A ausência da 'vontade' independe do princípio léxico exposto acima já que essa categoria mental é inerente aos princípios da psicologia moral moderna. Como a ausência da 'vontade' implica a própria diferença entre akrasia e fraqueza de vontade, precisamos nos concentrar sobre esse problema na sequência.

A maioria dos helenistas reconhece que a falta da 'vontade' na psicologia grega não é um fator que pode ser simplesmente ignorado. Invariavelmente, o

\footnotetext{
${ }^{73}$ Cf. O'BRIEN, 1967, p. 44: "As the Greek language developed, the note of perception in eîdonidón came to exclude that of attitude or emotion. The same kind of development took place in oîda. By the late fifth century, Euripides can use it to denote knowledge rendered ineffectual by emotion." ${ }^{74}$ Cf. Ibid., p. 53 n. 74. Para O'Brien, seria possível incluirmos a 'vontade' na psicologia grega se simplesmente passarmos a nos referir ao noûs ao invés de nos referirmos ao 'intelecto' como faz Dodds. O 'intelecto' exclui a 'vontade' enquanto o noûs integra diversas categorias mentais modernas. Na sequência, pretendemos mostrar que essa estratégia não elimina propriamente $o$ problema que está ligado à estrutura psicológica atrelada a noção de 'vontade' moral totalmente externa à psicologia grega.
} 
problema da falta de 'vontade' envolve a relação entre a moral grega e a moral moderna ${ }^{75}$. Dentre os estudiosos que se ocupam com tal problema, há alguns que encaram a ausência da 'vontade' como uma deficiência moral grega e outros a encaram como uma vantagem sobre a moral moderna. Com efeito, uma longa tradição relaciona a privação da 'vontade' na psicologia moral grega à uma falta de uma autonomia moral ou, em outras palavras, à ausência de consciência moral no homem grego. De fato, essa visão dá continuidade a representação passiva do homem grego e o desqualifica com base em uma moral do dever. Um ponto de partida fundamental é o influente capítulo "Da cultura da vergonha à cultura da culpa" de GI.

No capítulo 2 de GI, Dodds defende que a cultura grega sofreu uma mudança significativa da Grécia arcaica homérica do século VIII a. C. à Grécia clássica do século V a. C: a transformação progressiva de uma cultura da 'vergonha' para uma cultura da 'culpa'. De um lado, a cultura da 'vergonha' se caracteriza pela exortação externa da moralidade, da comunidade social ou da intervenção divina, que leva a ação moral em conformidade com os valores morais estabelecidos. Por sua vez, a cultura da 'culpa' dá lugar a exortação 'interna' da moralidade marcada, principalmente, pela punição das ofensas cometidas. Essas condições fornecem o terreno ideal ao desenvolvimento da cultura da 'culpa'. No entanto, a verdadeira inovação é principalmente na concepção da autonomia moral do agente.

A certa altura do capítulo 2, Dodds (1956, p. 36-37) salienta que a distinção entre a “culpa” primitiva da 'poluição' (míasma) da linhagem familiar e a culpa da moral cristã reside justamente na ausência de uma 'consciência interna' moral:

The distinction between the two situations is of course that $\sin$ is a condition of the will, a disease of man's inner consciouness, whereas pollution is the automatic consequence of an action, belongs to the world of external events, and operates with the same ruthless indifference to motive as a typhoid germ. Strictly speaking, the archaic sense of guilt becomes a sense of sin only as a result of (...) the "intenalising" of conscience (...).

\footnotetext{
${ }^{75}$ Eu utilizo os termos 'moral grega' e 'moral moderna' para relacioná-los de forma geral a qualquer reflexão moral no âmbito 'literário' ou 'filosófico'. Quando menciono a 'ética grega', 'ética moderna' ou 'ética contemporânea' estou restringindo o escopo dessas expressões à reflexão teórica sistemática da filosofia moral. A distinção esboçada aqui não indica nenhum juízo de valor ou critério de superioridade entre 'moral' e 'ética'.
} 
A ênfase de Dodds na falta da "internalização' da consciência” da cultura grega implica ainda a carência de uma 'moral da culpa' calcada na 'vontade moral'. Ao contrário dos modernos, os gregos seguem "o mundo dos eventos externos" justamente por não terem amadurecido ainda sua 'consciência moral'. Essa caracterização evoca novamente a condição passiva do homem homérico de Snell. Antes de Dodds, Snell também já havia defendido que os personagens homéricos delegam suas decisões deliberativas à intervenção divina ou aos indivíduos de seu entorno sem propriamente deliberarem por si mesmos ${ }^{76}$. Na visão de Dodds, a moral grega da vergonha está fundada no olhar alheio externo (seja humano ou divino) regulando as normas sociais do comportamento. $\mathrm{O}$ homem grego adotaria decisões em vista de sua imagem pública perante o olhar alheio e desconsidera inteiramente a 'intenção' do agente na ação. Na moral da culpa tardia, no entanto, a consciência moral estabelece suas próprias leis morais universais, independentemente de expectativas sociais ou do olhar alheio. Isso permite que o homem moderno adquira a autonomia moral, isto é, a capacidade de deliberar e tomar decisões morais por si mesmo e não por causa dos outros. A passagem da cultura da vergonha para a cultura da culpa significa, portanto, a "internalização" ou a “conscientização" progressiva da moral diante da moral 'externa' dos gregos ${ }^{77}$. A transformação marca o desenvolvimento da moralidade, uma moralidade da culpa marcada pela 'condição da vontade'.

\footnotetext{
${ }^{76}$ Cf. SNELL, 2001, p. 108: "Em Homero, as cenas em que o homem deve refletir e tomar uma decisão têm uma forma típica; (....) às vezes, Homero diz: "Pareceu- lhe que seria melhor fazer esta ou então aquela outra coisa"; às vezes, ao contrário, fala da intervenção de um deus que determina a decisão do homem (como acontece na Ilíada), ou então (como às vezes na Odisséia) é a aparição de uma segunda pessoa que provoca a decisão. (...). Não existe aqui, portanto, uma escolha subjetiva e muito menos uma luta para a decisão: é, pelo contrário, um dos objetos que se apresenta como mais vantajoso.". É importante ressaltar aqui a oposição sutil entre "escolha subjetiva" e "o que se apresenta como mais vantajoso". Sob essa distinção, subtende-se que os personagens homéricos são egoístas éticos que buscam realizar apenas "o que lhes parece vantajoso" em contraponto ao que seria uma decisão propriamente moral, isto é, "uma escolha subjetiva" levando em conta o bem alheio. Em face dos exemplos de conflitos psicológicos que vimos anteriormente, observamos que tal distinção é arbitrária e equivocada pois os personagens abordados levam em considerações tanto o melhor para si próprio quanto o bem estar alheio. Isso constitui o conflito ético por excelência dos personagens homéricos e trágicos.
}

${ }^{77}$ Cf. DODDS, 1956, p. 34: "It was a misfortune for the Greeks that the idea of cosmic justice, which represented and advance on the old notion of purely arbitrary divine Powers, and provided a sanction for the new civic morality, should have been thus associated with the primitive conception of the family. For it meant that the weight of religious feeling and religious law was thrown against the emergence of a true view of the individual as a person, with personal rights and personal responsibilities." 
As observações de Dodds da moral da culpa expõe os pressupostos em torno da visão negativa da carência grega da noção de 'vontade'. Assim como Dodds e Snell chamaram atenção para tal 'deficiência' moral nos gregos ${ }^{78}$, outros helenistas seguiram passos semelhantes. Em 'Esboços sobre a Vontade na Tragédia Grega', Vernant (1990, p. 51) ressalta que o cidadão ateniense do século V, destituído da 'vontade', pode até possuir a noção de responsabilidade moral mas não de autonomia moral: "nem o indivíduo, nem sua vida interior adquiriram bastante consciência e autonomia para constituir o sujeito como centro de decisão de onde emanariam seus atos.". A ausência da 'vontade' representa a ausência de uma psicologia moral madura com um espaço central na formação da autonomia moral. Como vimos, a 'vontade' apenas é desenvolvida plenamente na moral interna da culpa mas não tem lugar na moral 'externa' da vergonha. Em uma crítica à moral 'externa' dos gregos, Williams dá nova perspectiva ao valor moral da 'vergonha' grega revelando os pressupostos kantianos da psicologia moderna da vontade.

Além das críticas pertinentes à passividade do homem homérico em Shame and Necessity, Williams oferece um novo olhar sobre a 'vergonha' grega no capítulo 'Shame and Autonomy'. Partindo do princípio da cultura da 'vergonha' grega, Williams critica a concepção exclusivamente 'externa' da moral da vergonha. Contra Dodds, Williams (1993, p. 82-84) defende que a vergonha grega não é apenas mediada pelo 'outro' externo pois depende também de um 'outro' interno indispensável. Como vimos anteriormente, o 'outro' internalizado constitui a representação interna do olhar de uma pessoa respeitada sobre minhas próprias atitudes morais. A vergonha 'internalizada' integra o olhar alheio na constituição ética da minha autoimagem pessoal sem apenas reproduzir o comportamento social 'externo' da sociedade grega. A partir disso, Williams salienta que a psicologia moral grega da vergonha é incompatível com a psicologia moderna da culpa.

De acordo com Williams (1993, p. 94-95), a constituição do 'eu' moral da culpa reside em uma psicologia moral da 'vontade':

In this picture, I am provided by reason (...) with a knowledge of moral law, and I need only the will to obey it. The structures most

\footnotetext{
${ }^{78}$ Para a ausência da moralidade moderna na moralidade grega antiga, ver SNELL, 2001, p. 20-21; DODDS, 1956, p. 20 n. 31
} 
typical of shame then fall away: what I am, so far as it affects the moral, is already given, and there is only the matter of discerning among temptations and distractions what I ought to do.

A crítica de Williams à moral da culpa é também uma crítica geral à própria psicologia da 'vontade' moral. Em tal estrutura psicológica, a vontade constitui um elemento intermediário entre a razão, as paixões e os desejos humanos. Por sua afinidade natural com a moral moderna, a 'vontade' realiza a ação moral indicada pelo 'conhecimento' da lei moral universal. Para Williams (Ibid., p. 93), a 'irracionalidade' da culpa está mais ligada à desobediência da norma moral da 'razão' do que a reparação de um erro moral relativo ao 'outro'.

Por trás disso, existe uma oposição absoluta entre 'razão' (moral) e as tentações 'irracionais', sejam elas desejos ou emoções. Enquanto a moral da 'culpa' promove uma constituição moral baseada em leis morais abstratas e imparciais, a moral da 'vergonha' integra o 'outro' personalizado no caráter moral do 'eu'. Segundo Williams, a 'vergonha' grega, associada ao termo aidós, abrange uma noção mais abrangente do que associamos a culpa moral moderna. Dessa forma, a psicologia moral da 'vergonha' é superior à psicologia moral culpa, isto é, a psicologia moderna da vontade.

O problema central da psicologia da 'vontade' reside em uma psicologia moral individualizada. Para Williams, a psicologia moderna da vontade é reconhecida a partir de Kant, mas já teria suas primeiras raízes desde a psicologia moral platônica. Sobre a crítica de Williams dirigida à Platão, precisamos analisála melhor no capítulo dedicado à psicologia moral da República. Nessa ocasião, o que importa sublinhar é o valor imprescindível do 'outro' internalizado na psicologia moral grega. A propósito disso, Gilll (1996, p. 39-40) ressalta que a única "deficiência" dos gregos é a manifesta ausência de uma consciência moral 'individual' e 'subjetiva'. De qualquer forma, ambos mostram que a ausência da psicologia da vontade resulta mais em uma vantagem do que uma desvantagem para os gregos. Mesmo assim, os 'intelectualistas' persistem em enxergar na akrasia antiga um conflito moral absoluto entre paixão irracional e a razão prática a partir de uma psicologia da vontade.

A tendência intelectualista de enxergar nos gregos uma clara distinção entre razão e paixão reside na projeção da psicologia moderna da vontade. O conflito da razão e paixão irracional que tanto se associa à akrasia antiga nada mais é do que a 
própria fraqueza de vontade moral. De certo modo, essa distinção psicológica se deve à progressiva conscientização moral interna dos gregos que culmina na época das tragédias, particularmente nas obras de Eurípides ${ }^{79}$.

Como observamos, essa conscientização moral seria mais precisamente o reflexo da separação de ordem moral entre o intelecto ou a razão e os impulsos absolutamente 'irracionais'. Sendo assim, o progresso do intelectualismo grego e a conscientização moral teriam contribuído para a emergência do conflito entre razão e paixão irracional. De um lado, o intelectualismo teria promovido a especialização 'intelectual' das palavras gregas de conhecimento. De outro lado, a conscientização moral estabeleceu uma hierarquia moral entre intelecto e os outros impulsos irracionais. Ambas as condições contribuíram para a emergência da akrasia antiga como um problema moral envolvendo o conflito entre razão e os impulsos irracionais. Entretanto, mostramos anteriormente que o fenômeno da akrasia antiga supõe uma psicologia 'mista' cognitivo-motivacional.

A akrasia antiga não admite uma separação absoluta entre razão e impulsos irracionais. Os pressupostos progressistas do intelectualismo grego e da consciência moral estão ambos equivocados.

Em primeiro lugar, temos evidências que colocam em xeque o suposto significado 'intelectualista' das palavras gregas de conhecimento. Como vimos anteriormente, os termos de conhecimento assumem, por vezes, conotações morais, emocionas e desiderativas associadas amplamente a motivações humanas.

Em segundo lugar, a conscientização moral dos gregos não se expressa em uma distinção moral absoluta entre razão e paixão irracional. A necessidade da distinção psicológica absoluta advém de uma psicologia da vontade projetada sobre os gregos do que propriamente das categorias mentais gregas. Como observamos, as motivações humanas em Homero já apresentam características reconhecidamente motivacionais e morais sem precisar das categorias mentais explicitamente delimitadas. Dessa forma, precisamos dissociar claramente a akrasia antiga de categorias mentais da fraqueza de vontade. Apenas nessas condições, teremos a possibilidade de compreender a akrasia antiga em sua própria emergência original. Em vista dessas indicações, nos voltaremos agora para a

\footnotetext{
${ }^{79}$ Cf. SNELL, 2001, p. 132: "Eurípides leva a consciência moral a uma nova crise, colocando como base da moral o sentimento individual, ele a faz partícipe da instabilidade do indivíduo.”
} 
tragédia grega onde os conflitos psicológicos que vislumbramos em Homero adquirem uma nova dimensão.

A tragédia grega dá nova dimensão aos dilemas morais vivenciados pelos personagens homéricos. Embora a tragédia retome elementos que marcavam o universo divino de Homero, a estrutura de seu mundo reserva um espaço fundamental ao campo da responsabilidade humana. No entanto, o homem trágico, ao menos das tragédias de Ésquilo e Sófocles, encontra-se em uma situação dramática que exige a necessidade urgente de deliberação racional em circunstâncias extremas da ação moral. Na sequência, observaremos que as circunstâncias extremas de ação moral eliminam a possibilidade de encontrarmos um caso especifico de akrasia nas obras de Ésquilo e Sófocles. Para isso, devemos analisar alguns elementos fundamentais do universo trágico.

O universo trágico apresenta o ambiente ideal para uma reflexão profunda sobre o papel da deliberação racional na vida humana. Alguns dos mais importantes elementos da 'situação' trágica fornecem fatores fundamentais para avaliarmos as condições da ação moral. No entanto, a tragédia ainda aparece ligada a um pano de fundo religioso voltado dessa vez à emergência das instituições jurídicas. Por essa perspectiva, vamos abordar três fatores fundamentais do universo trágico: (1) a influência das forças divinas punitivas sobre a deliberação do agente; (2) o papel da fortuna ou acaso (týche) e o campo destinado à responsabilidade moral do agente; (3) os conflitos internos e a inexorabilidade trágica, especialmente em Ésquilo e Sófocles. Sendo assim, devemos analisar primeiramente qual o papel das forças divinas no universo trágico.

A tragédia grega não era um espetáculo de teatro, mas uma cerimônia cívico-religiosa profundamente marcada pelas instituições sociais da cidade-estado grega. Nesse contexto, a tragédia reflete tanto as instituições jurídicas quanto a nova configuração religiosa das divindades. De um lado, o fortalecimento das instituições jurídicas promove um intenso debate acerca da responsabilidade do agente perante seus crimes. Como sustenta Vernant (1990, p. 50), as tragédias gregas se encontram no limite dessa mudança social: "a culpabilidade trágica constitui-se assim num constante confronto entre a antiga concepção religiosa da falta (...) e a concepção nova, posta em ação no direito". De outro lado, helenistas, ressaltam os reflexos do desenvolvimento jurídico sobre uma nova forma de religiosidade punitiva no período de Ésquilo e Sófocles. Como mostram Dodds e 
Vernant, essa modificação mental está ligada à mudança de vocabulário da época homérica para a época social da tragédia ${ }^{80}$ : a áte, antes relacionada à cegueira momentânea do agente, passa a designar um engano divino induzindo ao erro (hamartía); a figura das divindades Erínias, ligadas à vingança familiar; a poluição (míasma) ligada ao crime de membros familiares e a influência da divindade maléfica (alástor). O agente trágico se encontra assim na encruzilhada entre o peso de sua responsabilidade moral e as forças divinas que revelam a necessidade inexorável da ação moral.

Os personagens da tragédia se deparam com situações de 'conflito' de difícil escolha em uma condição de extrema vulnerabilidade. Conforme enfatiza Nussbaum (2009, p. 3) em A fragilidade da bondade, a týche, o acaso ou, melhor dizendo, a 'fortuna', desempenha um papel fundamental na deliberação prática dos agentes trágicos. A týche designa o que está fora do controle humano, o que simplesmente ocorre, do qual não é possível identificar a causa ou o modo como veio a ocorrer. Nessa condição, o agente se encontra é exortado à deliberação moral por conta do 'conflito' trágico com o qual se depara (cf. Ibid., p. 21). Diante de circunstâncias adversas, o agente se encontra em difícil conflito moral em que a necessidade da decisão moral se impõe mesmo diante de graves danos a si mesmo ou aos entes mais próximos. Por vezes, tais situações 'trágicas' são geradas por fatores externos: a ignorância dos fatores envolvidos na ação moral, circunstâncias fora de seu controle, coação física ou divina.

Mesmo assim, os personagens atribuem responsabilidade moral a si mesmos e aos outros, por termos causais como aitía ${ }^{81}$. Como os agentes homéricos, eles fundamentam sua escolha moral em razões ligada à sua prévia deliberação. Dessa forma, o agente trágico está no limite entre sua própria responsabilidade moral e fatores externos que não estão inteiramente sob seu controle. Os fatores mencionados anteriormente se verificam especialmente nos conflitos internos dos personagens trágicos de Ésquilo e Sófocles.

\footnotetext{
${ }^{80}$ Para essa modificação na mentalidade grega acerca da responsabilidade moral do agente no contexto social grego, ver DODDS, 1956, p. 37-39; VERNANT, 1990, p. 35-36.

${ }^{81}$ Segundo Williams (1993, p. 55-56), os gregos não ignoraram as 'intenções' humanas porque eles efetivamente contemplam as condições mais básicas da responsabilidade moral: (1) a causa da ação; (2) a intenção ou falta de intenção em uma ação moral; (3) o estado psicológico do agente; (4) a exigência da responsabilidade moral diante da ação realizada.
} 
A tragédia grega enfatiza assim a conexão causal entre o agente e sua deliberação racional apresentada no dilema de seus personagens trágicos. Diante disso, a deliberação dos agentes trágicos se encontra no limite com fatores externos além do domínio humano. Esses fatores acabam influenciando, em especial, a deliberação dos personagens das tragédias de Ésquilo e Sófocles.

Os personagens de Ésquilo e Sófocles representam seus dilemas morais em geral por 'conflitos deliberativos' e não exatamente pelo 'conflito entre diferentes tipos de motivação'. Mesmo diante de deliberações complexas, os agentes se mantêm firmes em suas resoluções finais. A decisão final acompanha a resignação do agente em vista da necessidade de escolha e do dano inevitável da ação moral. De acordo com Knox (1979), os personagens de Ésquilo e Sófocles, ao contrário dos de Eurípides, somente mudam de opinião por influências 'externas', sejam pessoas ou circunstâncias adversas, mas nunca por si mesmos' ${ }^{82}$. De fato, essa 'influência externa' é marcada sobretudo pelo que já foi notado como a condição peculiar do homem trágico, sua situação entre as limitações da ação humano e o desígnio inexorável 'sobrenatural' ${ }^{83}$. Dessa forma, não é de se impressionar que as 'motivações' ou 'impulsos' internos nas obras de Ésquilo e Sófocles refletem a própria inexorabilidade da decisão moral do agente.

Um breve olhar sobre certas tragédias de Ésquilo e de Sófocles evidencia as raras referências ao que designamos de 'motivações psicológicas'. Nessas passagens, as motivações não resultam de um conflito interno mas geralmente reforçam decisões cruciais já tomadas pelos personagens. As forças psicológicas são atribuídas a dois fatores da ação, por vezes, interligados: (a) limitações da deliberação humana (ignorância, limitações físicas ou psicológicas, fortuna (týche); (b) estados alterados da mente provocados por interferência divina (manía, míasma e outras causas 'sobrenaturais' já mencionadas). Os casos do tipo (b) parecem ocorrer com mais frequência que os casos do tipo (a).

\footnotetext{
${ }^{82}$ Cf. KNOX, 1979, p. 232-233: "In Aeschylus and Sophocles, then, a change of mind is a rare phenomenon; when it does occur, it is either attributed to a secondary character or affects a secondary issue. The two older poets apparently found a change of mind either difficult to manage or downright undesirable on their tragic stage: it did not fit the tragic situations which they created and explored. (...) Instead, the idea is expressed by phrases which present a change of mind not as a personal decision but as something imposed from outside or else in pejorative metaphors which suggest that it is a thing to be avoided, above all by heroes."

${ }^{83}$ Sobre o tênue limite entre a necessidade da ação humana e a inexorabilidade do desígnio divino sobre o destino humano, ver VERNANT, 1990, p. 47; SNELL, 2001, 106-117.
} 
O desejo erótico (éros) figura como um poder divino associado à loucura e ao engano nas tragédias de Sófocles em contextos ligados a (b). Em Antígona, por exemplo, o Coro diz que os desejos eróticos provocam engano (apáte) e áte, e elogia, ao mesmo tempo, o "imbatível (aníkate)" Éros divino que traz manía a mortais e imortais (780-790; 615-625) ${ }^{84}$. A mesma invencibilidade e poder ilusório de Éros é exaltado pelo Coro em Traquínias e no momento que a personagem Dejanira concede perdão a seu esposo Héracles (e a qualquer um) acometido pela "doença (têi nósoi)" gerada por tal divindade (440-500). Com efeito, a potência divina de Éros nesses exemplos relembra o caso de Helena em Iliad. III. Em todos esses casos, encontramos o mesmo tipo de potência compulsória. No entanto, há casos complexos nas tragédias de Ésquilo que refletem a influência de forças sobrenaturais nos conflitos internos dos agentes.

Os aparentes conflitos motivacionais presentes em duas tragédias de Ésquilo, Sete contra Tebas e Agamêmnon, ilustram a interação das fontes da ação (a) e (b). Em Sete contra Tebas, por exemplo, Etéocles trava um breve diálogo deliberativo com o Coro sobre o dilema da iminente batalha com seu próprio irmão (665-715). De um lado, Etéocles demonstra resignação em enfrentá-lo mencionando razões que justificariam sua decisão, como a justiça, honra e glória. De outro, o Coro o exorta a resignar sua "cólera (orgèn)" e seu "desejo (hímeros)" (685-695). Ainda assim, ambos também evocam causas sobrenaturais para explicar o iminente combate com o irmão: as pragas do pai Édipo, a 'poluição' da linhagem, a determinação dos deuses, e a vingança das Erínias. Em última instância, Etéocles acaba indo de encontro ao seu irmão como ao encontro de seu próprio destino. Diante dessas influências externas, seria a ação de Etéocles gerada por sua própria deliberação ou por forças sobrenaturais? O caso de Etéocles ilustra bem a condição trágica do agente, em face da necessidade inexorável da ação moral exigida pelas circunstâncias adversas e a necessidade da deliberação racional pela decisão final ${ }^{85}$.

\footnotetext{
${ }^{84} \mathrm{Na}$ Antígona de Sófocles, há diversas passagens em que os desejos eróticos são associados ao engano e à loucura divina : "Éros invencível no combate (aníkate máchan) (...) quem te possuis enlouquece (ho échon mémenen)" (780-790); "Para muitos é vantagem a esperança errante, para outros desengano de loucos desejos (apáta kouphónoon eróton). (...) Era sábio quem descobriu o famoso provérbio; parecer bem o que é mal, é só a quem o deus leva à ruína (theós agei pròs átan)" (615-625). Seguimos aqui a tradução de Maria Helena da Rocha Pereira.

85 Os conflitos emblemáticos dos personagens Etéocles e Agamêmnon são objeto de uma controvérsia interpretativa entre Nussbaum e Williams. Ambos os intérpretes concordam sobre a necessidade que os leva à deliberação, mas Nussbaum extrai uma lição moral sobre a culpa dos personagens enquanto Williams salienta a inexorabilidade de suas deliberações. Quanto ao caso de Etéocles, por exemplo, Nussbaum (2009, p. 32-34) julga que ele não reflete seriamente sobre o
} 
De toda forma, no caso de Etéocles não há nenhum conflito claro entre sua motivação interna, suas razões e sua decisão final.

Um outro caso dessa condição trágica envolvendo um conflito interno mais claro aparece em Agamêmnon de Ésquilo. Em certa altura da obra, o personagemtítulo precisa escolher entre sacrificar a própria a filha, Ifigênia, em nome de Ártemis ou arruinar a sua própria frota de guerreiros. Em uma breve deliberação relatada pelo Coro, Agamêmnon exprime consternação pela 'poluição' do crime mas logo expressa desejo pelo sacrifício: "O sacrifício de cessar-vento e o virgíneo sangue, deseja-los com superfurioso furor (periorgôi sph' epithymeîn), é lícito (thémis), pois bem que seja!"86 (215-220). A despeito da controvérsia em torno da culpa de Agamêmnon ${ }^{87}$, podemos afirmar aqui que seu 'desejo' (epithymeîn) se conforma à 'lei divina' (thémis). Além disso, o próprio Coro anuncia em seguida que a ação é realizada sob o 'jugo da necessidade' (anánkas). Mesmo diante das circunstâncias externas envolvidas, a decisão de Agamemnon jamais é encarada como um produto exclusivo da necessidade divina. $\mathrm{O}$ 'conflito' do personagem, no entanto, não é uma akrasia pois sua epithymía está em pleno acordo com a resolução necessária do assassinato. Assim como no caso de Etéocles, a decisão de Agamêmnon está inevitavelmente situada entre a deliberação racional do agente e a necessidade inexorável da escolha moral.

Mesmo nos casos mais complexos de Etéocles e Agamenon, não encontramos um conflito psicológico explícito que seria classificado de akrasia. Por mais que os personagens trágicos sejam exortados à deliberação, a necessidade divina impõe a ação moral em conformidade à deliberação racional e os outros impulsos irracionais. Diante dessas condições, o conflito psicológico da akrasia simplesmente não é claramente explicitado nas obras de Ésquilo e Sófocles. É preciso enfim nos voltarmos às tragédias de Eurípides em busca de uma representação dramática mais próxima da descrição tradicional da akrasia.

dilema de batalhar com o próprio irmão e Williams (1993, 136-139) crê que sua decisão reflete a ineficácia de sua deliberação. Em face da situação trágica de Etéocles, acreditamos que sua decisão exprime mais a inexorabilidade do confronto com o irmão do que uma decisão apressada ou displicente.

${ }^{86}$ Seguimos aqui a tradução de Jaa Torrano.

${ }^{87}$ A mesma controvérsia entre Williams e Nussbaum se aplica ao caso de Agamêmnon. No caso de Agamêmnon, Nussbaum (2009, p. 29-30) sugere que o personagem deveria ter uma reação mais negativa a possiblidade do sacrifício, enquanto Williams (1993, p. 134-136) acredita que ele foi levado por insanidade ou por exigência de Ártemis a realizar o crime. Novamente, nos inclinamos mais para a segunda leitura do que para a primeira leitura. 


\section{4}

\section{A descrição tradicional da akrasia em Eurípides}

A ideia de uma polêmica entre Eurípides e o Sócrates platônico acerca da akrasia é antiga. Em Scenes of Greek Drama, Snell (1964, p. 60-64) já sustentava que as falas das personagens Medéia e Fedra das obras de Eurípides e o debate da akrasia no Protágoras de Platão atestam uma evidente polêmica em curso ${ }^{88}$. Desde Snell, outros intérpretes, helenistas e até filósofos, também endossam essa posição, mesmo tratando a 'polêmica' entre Eurípides e o Sócrates platônico de forma mais indireta $^{89}$. No entanto, há uma corrente crescente de estudiosos da literatura grega, voltado ao contexto dramático original das falas das personagens de Medéia e Hipólito, tem contestado a polêmica com o Sócrates do Protágoras. Em nossa visão, defenderemos que é possível reconhecer a origem da descrição tradicional da akrasia do Protágoras nas obras de Eurípides sem caracterizá-lo dentro do quadro de uma evolução do ‘intelectualismo’ grego.

A tese ortodoxa da 'polêmica' se baseia na evolução do 'intelectualismo' grego à filosofia socrático-platônica. Em virtude da proximidade histórica de Platão, alguns helenistas chegaram até a se referir a Eurípides por termos paradoxais, um 'irracionalista' e um 'racionalista' ao mesmo tempo ${ }^{90}$. De um lado, a alcunha 'racionalista' se baseia no fato notável de que os deuses têm significativamente menor espaço nos dramas de Eurípides do que nas tragédias de Ésquilo e Sófocles. De outro lado, o título de 'irracionalista' se baseia no reconhecimento positivo das paixões irracionais humanas sem a interferência ostensiva da esfera divina. Ambos os fatores contribuiriam para o suposto

\footnotetext{
${ }^{88} \mathrm{Na}$ verdade, Snell explora uma hipótese mais ousada. Com base na evidência de que existem duas versões do Hipólito de Eurípides, Snell defende que o foco da psicologia passional de Fedra na segunda versão é, na realidade, uma provocação ao próprio Sócrates histórico do Protágoras. De fato, não possuímos nenhuma evidência concreta de uma 'polêmica' tão direta entre Sócrates e Eurípides acerca da akrasia. Sobre as duas versões do Hipólito, ver também BARRET, 2001, p. 1115.

89 Ver também IRWIN, 1983; DODDS, 1973; Idem, 1956, p. 185-187; MUNIZ, 2011, p. 46; KAMTEKAR, 2017, p. 44-45. De fato, muitos intérpretes apenas atestam as evidentes similaridades das passagens do Hipólito e da Medéia com a descrição tradicional da akrasia do Protágoras, sem se comprometer explicitamente com a teoria do 'intelectualismo' grego.

${ }^{90}$ Dentre os helenistas, Verral é um dos defensores mais célebres do 'racionalismo' de Eurípides (cf. VERRAL apud DODDS, 1973, p. 78).
} 
‘intelectualismo' grego de Eurípides: em suas obras, as paixões irracionais humanas aparecem de forma mais positiva em oposição ao 'conhecimento' racional do bem. Como vimos anteriormente, isso endossa a polêmica da akrasia entre Eurípides e o personagem Sócrates do Protágoras. Além disso, tal visão abre pretexto a um contraste ainda mais radical: enquanto Eurípides reconhece o poder das motivações irracionais contra o conhecimento, Sócrates rejeita as motivações irracionais em defesa do poder do conhecimento do bem. Novamente, vemos os reflexos da oposição absoluta entre razão e paixões irracionais que marca o 'intelectualismo' grego. Ao abrirmos mão do 'intelectualismo', temos a oportunidade de investigar a verdadeira relação entre Eurípides e Platão. A seguir, vamos explorar algumas evidências externas que justificam uma relação de proximidade entre o tragediógrafo e o filósofo.

A proximidade de Platão e Eurípides é significativa para ser simplesmente ignorada. É um fato reconhecido que ambos viveram na Atenas do século V (em datas pouco distantes) e tomaram contato com as teorias sofísticas da época acerca da virtude e do poder do conhecimento ${ }^{91}$. No entanto, existem dois indícios que dão maior ênfase à nossa hipótese: (1) existem claras referências e alusões às obras de Eurípides dentro dos próprios diálogos platônicos; (2) a proximidade das datas da representação dramática de Medéia e Hipólito em Atenas e o surgimento do diálogo platônico Protágoras.

Em primeiro lugar, alusões diretas e indiretas às obras de Eurípides são abundantes nos diálogos platônicos. Em Plato and Euripides, Sansone (1996, 3561) nos oferece um longo catálogo das referências dispersas nos diálogos platônicos e especula sobre a possível influência de Eurípides sobre Platão. A partir disso, Sansone (Ibid., p. 39-40) conclui que "it is unimaginable that the young Plato can have been indifferent to the dramas of Euripides"92. Dentre as referências aos dramas de Eurípides, é pertinente salientar que encontramos referências do Hipólito

\footnotetext{
${ }^{91}$ Sobre o provável contato de Platão e Eurípides com as teorias sofísticas sobre o ensino da virtude moral, ver DODDS, 1973, p. 78-83.

${ }^{92}$ Além de levantar essas referências nos diálogos platônicos, Sansone é especialmente crítico aos historiadores das ideias que, em larga escala, negligenciaram o papel de Eurípides nos diálogos e na filosofia platônica (com a notável exceção de Wilamovitz e, mais recentemente, em um artigo de Jacqueline Romilly). Como ele próprio reconhece, até mesmo Nussbaum, que pretende explorar a relação entre tragédia e filosofia em A Fragilidade da Bondade, dedica apenas um último capítulo à Eurípides. De fato, essa exclusão afeta sobretudo seu Interlúdio 1 dedicado a analisar especialmente a relação entre a forma do drama da tragédia e do diálogo platônico já que ela dispensa qualquer referência a Eurípides.
} 
no Teeteto (153d4-6) e alusões gerais às suas obras em outros diálogos platônicos (cf. Hipólito, 612; Symp. 199a5-6). Assim como outras tragédias de Eurípides, Platão e o público de sua época certamente tinham conhecimento das tramas de Hipólito e Medéia.

Em segundo lugar, um tempo relativamente curto separa a representação dramática dessas duas tragédias e o surgimento do Protágoras de Platão. De acordo com os registros disponíveis, o Hipólito e a Medéia teriam sido representadas, respectivamente, por volta de 429 a. C. e 431 a. C., enquanto o Protágoras de Platão teria vindo ao público em 433a.C ${ }^{93}$. Conforme salienta ainda Kahn (1996, p. $227-$ 228), é natural inserir o diálogo platônico no contexto de um debate corrente sobre o poder da deliberação racional e das paixões humanas em que as falas de Medéia e Fedra tem um papel central ${ }^{94}$. Dessa forma, é bem provável que Platão esteja veiculando, através da voz da opinião dominante no Protágoras, uma experiência que seu próprio público tinha familiaridade a partir das emblemáticas passagens do Hipólito e da Medéia.

Na falta de uma referência explícita da passagem Prot. 352b-e as obras do tragediógrafo, seria imprudente endossar uma 'polêmica' direta de Eurípides com Platão (muito menos, com o obscuro Sócrates histórico mencionado anteriormente). Como bem já havia mencionado Moline (1975, p. 65-66), é problemático e infrutífero atribuir uma polêmica direta a tragediógrafos que se expressam na forma dramática como Eurípides. O principal problema da 'polêmica', nesse caso, seria discernir a visão do dramaturgo destacada por um porta-voz específico ${ }^{95}$. De fato,

\footnotetext{
93 A divulgação pública ou a representação dramática das obras de Eurípides e do Protágoras de Platão chegaram ao público ateniense ocorre em períodos relativamente próximos. De um lado, as datas aproximadas da representação dramática das duas tragédias são reconhecidas respectivamente nas edições críticas do texto grego, em particular, na introdução do Hipólito de Barret (2001) e na introdução da Medéia de Page (2001). De outro lado, Guthrie (1974, p. 214) atribui a divulgação do Protágoras de Platão ao público ateniense por volta de 433 a. C.

94 Conforme sustenta Kahn (1996, p. 232): "a great dramatist like Plato was as acutely aware as Euripides was of the role played by strong feeling and temperament in the lives of ordinary human beings.". No entanto, justamente por admitir que Platão reconhece a influência dos desejos irracionais na maioria dos diálogos, Kahn não admite que a refutação da akrasía seja uma tese defendida em própria pessoa por Sócrates. De fato, Kahn (Ibid., p. 232) também alega que "the author of the Protagoras does not himself mean to endorse the omnipotent rationalism of the passage in question." No próximo capítulo, sustentaremos que a tese da refutação da akrasía não significa uma negação do poder dos desejos irracionais. Em nossa hipótese, portanto, as teses de Sócrates no Protágoras não visam comprovar a 'onipotência' da razão humana frente aos impulsos irracionais.

${ }^{95}$ Cf. MOLINE, 1975, p. 46: "Plainly the point of engaging in a polemic against someone's view would be convince the audience to which the polemic is addressed that view in question is incorrect. And when it is alleged that a writer of Euripides acknowledge intelligence and expertise engaged in a polemic, this allegation cannot be independent of the claim that he engaged in it intelligently and
} 
uma dificuldade análoga se verifica nos diálogos de Platão a medida que nem mesmo Sócrates deve ser encarado como porta-voz absoluto da filosofia platônica.

Mesmo diante dessas dificuldades, podemos sustentar ao menos, em linhas gerais, que a "opinião dominante" de Protágoras veicula a descrição tradicional da akrasia que já era conhecida do grande público ateniense. Como não encontramos nenhuma representação desse fenômeno em obras dramáticas anteriores, cabe nos indagarmos se podemos encontrá-la em Eurípides. Ora, mas isso nos leva a encarar Fedra ou Medéia como personagens acráticas? A princípio, mostraremos que o exame analítico da descrição tradicional da akrasia não exige o reconhecimento do caráter acrático das personagens no contexto das tragédias.

As personagens Medéia e Fedra são amplamente reconhecidos como exemplos emblemáticos da akrasia. Nesse sentido, elas são conhecidas como figuras acráticas pelos seus impulsos irracionais contra a razão, a ira avassaladora de Medéia e o desejo erótico de Fedra. Por vezes, elas são apresentadas como portavozes do 'irracionalismo' de Eurípides. Dessa forma, os discursos de Medéia e Fedra são destacados do seu próprio contexto dramático em confronto com as teses socráticas do Protágoras de Platão.

No entanto, isso é uma injustiça com Eurípides e Platão. Por mais que encontremos similaridades com a passagem Prot. 352b-e, não podemos nos precipitar em caracterizar o caso de Fedra ou de Medéia como akrasía. Além disso, promover Medeia ou Fedra a porta-vozes de uma 'teoria' da akrasia de Eurípides seria desconsiderar o conflito psicológico das personagens no contexto dramático das próprias tragédias. $\mathrm{O}$ caso de Fedra é ainda mais contestável visto que sua participação no drama Hipólito é relativamente menor do que a de Medéia na tragédia homônima (cf. KNOX, 2015, p. 168).

Dessa forma, precisaremos avaliar os seguintes fatores ao confrontarmos os discursos de Fedra e Medéia em seus contextos dramáticos: (1) se os discursos das personagens efetivamente correspondem com a descrição tradicional da akrasía

with reasonable hope of success." Na perspectiva de Moline, Eurípides jamais quis contestar a tese socrática de que a sabedoria é suficiente para a virtude. De fato, ele chega à conclusão paradoxal de que Eurípides seria mais socrático do que anti-socrático, a partir do caráter moral de ambos os personagens. Ver também BARRET, 2001, p. 229. De outro lado, Knox (1983, p. 288) também salienta o papel de Eurípides como dramaturgo: "For dramatists, especially the greatest dramatist are not philosophers, not original thinkers; they reflect and use, dramatize and intensify the thought and feeling of their time." 
atribuída à opinião dominante no Protágoras de Platão; e (2) se o contexto das respectivas tragédias nos autoriza a declarar se elas possuem o caráter moral ou mesmo realizam uma ação sob efeito da akrasia. A partir desse ponto de vista, pretendemos analisar as tragédias Medeia e Hipólito na sequência.

As tragédias Medéia e Hipólito se tornaram paradigmas da potência das paixões irracionais em Eurípides. Como vimos, essa imagem perpassa Snell mas também alcança outros célebres helenistas, como Kitto, Dodds, Romilly, entre outros $^{96}$. A partir disso, os helenistas demarcam o contexto intelectual que separa as tragédias de Eurípides das obras de Ésquilo ou Sófocles: um relativo distanciamento do vocabulário religioso em vista de uma visão mais positiva das motivações humanas.

Mesmo assim, os personagens de Medéia e Hipólito permanecem se referindo a causas sobrenaturais para explicarem os eventos do drama. Em Medéia, por exemplo, o Coro atribui o crime da personagem título à 'poluição' do sangue (1265), enquanto Jasão reitera a mesma impressão $(1370 ; 1405)$ além de atribuir sua própria ruína a um alástor (1335). Da mesma forma, em Hipólito, Afrodite relata a fuga de Fedra para Cecrópidas por conta de uma 'poluição' (34) e Teseu atribui a morte de Fedra a um alástor (820). Não são apenas esses personagens que apelam a explicação sobrenatural dos eventos do drama. De fato, as próprias personagens Medéia e Fedra usam do mesmo vocabulário religioso. Se Medéia atribui seu infortúnio à áte (275-280), Fedra atribui sua 'loucura' (manía) à mesma causa (240), além de narrar a 'poluição' de sua família (315-320). Mesmo que os elementos religiosos ainda exerçam influência na cultura grega da época, seu papel na explicação da ação humana é notavelmente menor nas obras de Eurípides.

Em sua maioria, essas imagens religiosas têm um papel mais dramático, isto é, relativo aos eventos do próprio drama, do que propriamente psicológico, ou seja, como fatores motivacionais que influenciam as ações humanas. Nessa esfera, Eurípides demarca mais claramente o que denominamos de "motivações irracionais" do que seus predecessores. A princípio, isso parece mais verdadeiro no caso da ira de Medéia do que na paixão de Fedra promovida pela deusa Afrodite. De fato, já tem sido recorrentemente salientado que Afrodite e Ártemis funcionam

\footnotetext{
96 Ver KITTO, 1972, p.11-46; DODDS, 1973; ROMILLY, 2011, p. 114-151; IRWIN, 1983, p. 193 -
} 197; NORTH, 1966, p. 68-84. 
como forças opostas da natureza de um universo cíclico na trama de Hipólito ${ }^{97}$. Mesmo com tal contexto divino, as similaridades entre a passagem de Protágoras 352b-e e o discurso de Fedra em Hipólito (375-430) tem sido constantemente reconhecidas ao longo do tempo. Em vista disso, precisaremos analisar os eventos do Hipólito que levam Fedra a enunciar tal discurso e avaliar se sua relação com a descrição tradicional da akrasia no Protágoras é realmente plausível.

Desde o prólogo do Hipólito, Afrodite declara sua responsabilidade na geração da "paixão avassaladora" de Fedra pelo enteado Hipólito ${ }^{98}$ (25-50). Em tom fatídico, a deusa anuncia que seu objetivo final é arruinar Hipólito em retaliação à sua devoção exclusiva à Ártemis. Ao longo do drama, acompanhamos a grande luta interna de Fedra para esconder sua paixão dos outros personagens enquanto Teseu, seu marido, está fora do palácio real. Com efeito, todos os personagens em volta reconhecem nela um tipo de "doença (nósos)". Em uma sequência de delírio, Fedra faz alusões a práticas típicas de Ártemis (remetendo veladamente a Hipólito) enquanto alega estar sob o efeito da "loucura (manía)" e áte (200-250). A princípio, Fedra parece estar em um estado compulsório de paixão e não sofrendo propriamente akrasia. Em um longo discurso geral sobre a condição humana, ela demonstra clara lucidez ao invés de alucinação.

Quando Fedra é levada a confessar sua paixão por Hipólito em virtude do exímio escrutínio da Nutriz $^{99}$, ela desata em um longo discurso sobre a condição humana perante os impulsos irracionais. Com acerto, helenistas reconheceram uma similaridade patente entre tal discurso e a descrição tradicional da akrasia no Protágoras. No entanto, o monólogo de Fedra não só está sujeito à controvérsia interpretativa como também é extremamente contestável como testemunho pessoal

\footnotetext{
${ }^{97}$ Sobre a presença de potências opostas no desenvolvimento do drama de Hipólito ver KNOX, 2015, p. 196-197; KITTO, 1972, p. 35-36; DODDS, 1973, p. 87; SNELL, 1964, p. 68.

98 A tradução usada aqui é de Frederico Lourenço. Algumas modificações tiveram de ser realizadas na tradução para tornar mais clara a correspondência de alguns termos dessa passagem e a descrição da akrasía da opinião dominante no Protágoras. Para realizar as modificações, confrontei a tradução portuguesa com a tradução de David Kovacs.

${ }^{99}$ Cf. KNOX, 2015, p. 188. A Nutriz possui uma habilidade com o lógos digna dos sofistas. A certa altura, Fedra reconhece essa habilidade ao declarar que tem medo de sua 'sabedoria' (sophé) (515520). Nesse contexto, a palavra sophé caracteriza um extenso conjunto de técnicas que estava associada sobretudo a figura do 'sofista' na Grécia (cf. Prot. 320d). Dessa forma, é mais consistente com o texto atribuir a revelação da paixão por Hipólito a sua habilidade engenhosa do que atribuíla à fraqueza de Fedra diante de sua paixão. Apesar da condição 'doentia' de paixão, observaremos que Fedra mantém uma firme resolução com base em seus valores.
} 
de akrasia. Dessa forma, abordaremos a seguir o controverso discurso de Fedra com especial atenção às suas similaridades com o Protágoras de Platão.

Em 375-380, Fedra se dirige ao Coro das mulheres Trezênias com um discurso reflexivo sobre um fenômeno típico da condição humana:

\begin{abstract}
tenho refletido, na duração arrastada da noite, sobre aquilo que destrói a vida dos mortais. E o que me parece é que não é devido à natureza de sua compreensão (ou katà gnómes phýsin) que praticam o mal (prássein kakión); muitos tem bom senso (ésti gàr tó g'ê̂ phroneîn polloîsin). Mas devemos considerar o seguinte: nós conhecemos e compreendemos o que é bom (tà chrést' epistámestha kaì gignòskomen), só que não o pomos em prática; uns, por inércia (argías); outros, porque põem à frente do que é nobre outra coisa, um prazer qualquer (hoi d'hedonèn prothéntes antì tô̂ kaloûa állen tin'). Há muitos prazeres (eisì hedonaì pollaî) na vida: grandes conversas (mákrai léskai), o lazer (scholé) (um mal prazeroso (térpnon kakón) e o pudor (aidós), de que há duas espécies. Um não é mau (oû kakòn), o outro é a ruína das casas. (375-380)
\end{abstract}

Desde o início, Fedra elabora uma reflexão generalizada sobre a condição humana da 'maioria' (pollô̂sin) em que supostamente ela própria está incluída ${ }^{100}$. De fato, a condição da 'maioria' descrita por Fedra evoca os próprios termos com que Sócrates relata a descrição tradicional da akrasia da opinião dominante (hoi polloí) no Protágoras.

Em linhas gerias, podemos notar as seguintes correspondências sem nos determos nas divergências interpretativas: (1) não é 'por causa da natureza da compreensão' (ou katà gnómes phýsin) que os homens acabam por 'praticar o mal'. Fedra reconhece claramente que há um conflito entre a deliberação racional e a ação moral. Como vimos, podemos atribuir a 'falha' humana, por vezes, a forças externas ou mesmo à ignorância. Contudo, a descrição do fenômeno enfatiza a boa condição da gnóme e sequer menciona outros fatores. Como na descrição tradicional do Protágoras, a ação é realizada de bom grado (hékon), isto é, com plena consciência do agente; (2) mesmo 'conhecendo e compreendendo o que é bom' ou tendo 'bom senso' (ê̂ phroneîn) não agimos conforme o conhecimento moral. Ao que tudo indica, isso reflete um conhecimento moral relativo ao que é

${ }^{100} \mathrm{O}$ caráter geral do discurso de Fedra tem sido reiteradamente indicado pelos intérpretes. Segundo Snell (1964, p. 56-57), o discurso de Fedra é dirigido ao público em geral da qual ela também faz parte, como fica mais claro na sequência dos eventos da tragédia. 
bom e mal caracterizado na excelência da boa deliberação (ê̂ phroneîn). Mesmo tendo a posse da virtude, ainda assim trocamos o que é 'nobre' (tò kalón) pelo 'prazer' (hedoné) na ação moral. Segundo a opinião dominante do Protágoras, o conhecimento ou compreensão do bem de nada vale pois podemos sempre agir por outros impulsos imediatos; (3) a enumeração das causas do fenômeno está ligada a uma variedade de motivações internas. Como expõe a personagem, alguns são levados por 'inércia' (argías), outros são vítimas de 'prazeres variados' (hedonaì pollaí): 'grandes conversas' (mákrai léskai), 'lazer' (scholé) e o 'pudor' (aidós) (bom ou mau ${ }^{101}$. Apesar de tratar de uma lista abrangente de motivações, a opinião dominante claramente reconhece a causa da akrasia na variedade dos prazeres maus.

Em vista desse conjunto de fatores, é plausível reconhecer nessa passagem uma clara correspondência com a descrição tradicional da akrasia no Protágoras. Entretanto, essa passagem é mais conhecida por caracterizar uma polêmica entre Eurípides e Platão acerca do conflito entre razão e paixão.

Por longo tempo, a tradição enxergou no discurso de Fedra uma clara reação à tese socrática da superioridade do conhecimento moral no Protágoras de Platão. Essa visão foi difundida sobretudo com base em duas premissas fundamentais: (a) a passagem 375-380 apresenta palavras de 'conhecimento', como gnóme, êu phroneîn, epistásmestha e gignóskomen, pela primeira vez com sentido estritamente 'intelectual'. Assim, Eurípides teria revelado o poder da paixão irracional estabelecendo um conflito essencial entre razão e paixão; (b) o discurso de Fedra é uma confissão da personagem em relação à sua própria condição de akrasia, ou melhor, uma certa concepção de impotência diante da força de seu "éros avassalador" (26). A seguir, avaliaremos primeiramente os problemas relativos a (a) e depois analisaremos os aspectos dramáticos que inviabilizam a interpretação (b).

\footnotetext{
${ }^{101}$ Há uma polêmica em torno do duplo sentido de aidós, mas alguns comentadores acham que o termo ambíguo não é propriamente aidós mas hedoné. Cf. KOVACS, 1980, p. 287-303; CLAUS, 1972, p. 228-238; WILLIAMS, 1993, p. 225-230. Para Kovacs e Claus, por exemplo, a ambiguidade reside apenas em hedone, enquanto Williams, e outros autores, acreditam que há efetivamente um bom aidos e um mau aidós. Certamente, Fedra afirma claramente que o 'prazer' pode estar tanto vinculado ao que é 'nobre' (tò kalón) quanto ao seu oposto, o vergonhoso. No Protágoras, observamos que Platão explora essa ambiguidade na discussão sobre a akrasia. Todavia, Fedra também salienta a ambiguidade de aidós, reiterado depois ao associar a 'ruína das casas' (relativo ao aidós mau) aos belos discursos (486). Da mesma maneira, acreditamos que a ambiguidade não é exclusiva à hedoné ou ao aidós mas contempla os dois termos.
} 
A interpretação intelectualista dos termos de conhecimento está diretamente ligada a 'polêmica' com Sócrates. Notadamente, Snell endossou a hipótese de uma polêmica entre o Sócrates histórico e Eurípides ressaltando que as palavras de Fedra perdem todo sentido se "não forem tomadas eticamente no sentido estrito" (1964, p. 63) ${ }^{102}$. Na mesma linha de Snell, Dodds (1973, p. 82) enxerga no discurso de Fedra a "impotência moral da razão" contra o racionalismo socrático. Ao sustentar uma polêmica mais indireta entre o Protágoras de Platão e Eurípides, Irwin oferece uma leitura mais plausível. Segundo Irwin (1983, p. 190-191), a intenção de Eurípides no discurso de Fedra é evidenciar o que não se verifica em nenhum texto grego anterior: a presença de termos 'intelectuais' que fundamentam um claro conflito entre razão e paixão ou, em outras palavras, a akrasia $^{103}$. De fato, nem os termos de 'conhecimento' da passagem devem ser encarados como termos estritamente intelectuais nem a akrasia pode ser reduzida a um conflito absoluto entre razão e paixão.

Como diversos autores já salientaram, os termos gnóme, epistásmestha e gignóskomen preservam um significado mais inerentemente cognitivomotivacional do que um significado puramente intelectual ${ }^{104}$. De fato, os intérpretes anteriores, levados pela semelhança dos textos de Platão e Eurípides, conferiram um significado estritamente intelectual aos termos de 'conhecimento'. No entanto, não precisamos concluir assim que não há como estabelecer qualquer relação entre o discurso de Fedra e a descrição tradicional da akrasia. Como vimos, a descrição tradicional da akrasia abrange um conflito intelectual-motivacional que não pode ser reduzida a termos absolutos de 'racionalidade' e 'irracionalidade'. O discurso de Fedra apresenta um dado novo que não se verifica nos casos anteriores de conflito psicológico, uma clara conexão entre razão prática e valores morais, como 'melhor' (chrestá) e 'pior' (kákion). Ao contrário de um conflito entre razão e

\footnotetext{
102 Para Snell (Ibid., p.56-69), a referência da polêmica com Eurípides abrange o Sócrates histórico e não apenas o Sócrates platônico do Protágoras. Como observamos anteriormente, é praticamente impossível reconstruir uma doutrina positiva de um personagem histórico tão obscuro, principalmente, em relação a suas supostas doutrinas filosóficas. Por isso, devemos nos referir apenas as teses socráticas efetivamente encontradas e filosoficamente sustentadas pelo personagem platônico 'Sócrates' do Protágoras.

${ }^{103} \mathrm{Na}$ realidade, Irwin adota o termo inapropriado 'incontinência', mas já salientamos os problemas implicados na utilização desse termo moderno para se referir à akrasia antiga.

${ }^{104}$ Para essa leitura cognitivo-motivacional ver BARRET, 2001, p. 228-229; CLAUS, 1972, p. 231 232; NORTH, 1966, p. 74-75. Em relação a Barret e Claus, eles tendem a rejeitar a referência socrática da passagem, mas acreditamos que isso não seja necessário se nos atermos somente às similaridades entre o Hipólito e ao Protágoras.
} 
paixão irracional, teríamos aqui ao menos um claro conflito entre deliberação racional e outros impulsos irracionais ou, em outras palavras, uma descrição genuína da akrasia. No entanto, isso não mostra que a própria Fedra tenha um caráter acrático.

Dentro da tradição interpretativa ortodoxa, Fedra é representada como uma personagem problemática do ponto de vista moral. Para a maioria dos intérpretes, a personagem incorpora o poder da paixão irracional sobre a razão humana na forma da akrasia. Para outros, sua 'resolução moral' é fraca e, por isso, ela é suscetível ao poder de seus impulsos (cf. BARRET, 2001, p. 227). De qualquer forma, ambas as interpretações lhe atribuem uma forma ou outra de falta de caráter.

Em primeiro lugar, encará-la como uma 'vítima' de sua paixão implica muito mais em uma forma de compulsão do que propriamente de akrasia. Por várias ocasiões, Fedra, a Nutriz e o Coro das Trezênias reconhecem a impossibilidade de resistir a éros. Como mostramos anteriormente, o 'desejo sexual' (éros) de Fedra é gerado pela deusa Afrodite desde a cena de abertura (25-50). Nessa perspectiva, a Ama declara que "É impossível resistir a Cípris quando jorra num grande caudal" (444) e Fedra admite que "sua alma está completamente arada no desejo" (505). Sob essa perspectiva, poderia se esperar que Fedra se renda à sua paixão contra seu senso moral de vergonha ${ }^{105}$. Ao invés disso, é a Nutriz quem revela a Hipólito a paixão de Fedra sem seu consentimento (600-615). Dessa forma, a imagem de uma Fedra impulsiva que age apenas por paixão não se sustenta.

Em segundo lugar, atribuir uma falta de resolução moral a Fedra é totalmente incompatível com seus traços de caráter dentro da trama da tragédia. Após o início de seu discurso sobre a condição humana, ela descreve o "percurso de sua gnóme" em três momentos (390-400): (I) sua primeira reação, foi o "silêncio (sigân)" da paixão ao qual ela exorta constantemente à Nutriz em vão (cf. 309-354); (II) em seguida, ela buscou vencer a 'demência (anoia)' pelo 'bom senso (ê̂ tôi sophroneîn)" sem sucesso; (III) por fim, sem conseguir "dominar Cípris (Kýprin kratêsai)", ela resolve sua angústia da forma mais radical, isto é, pelo próprio suicídio. Em nenhum momento, Fedra se arrepende dessa decisão final. Diante da humilhação pela revelação de sua paixão a Hipólito (a seu contragosto), ela não só comete suicídio como deixa um bilhete incriminando o enteado por estuprá-la, tudo

${ }^{105}$ Cf. IRWIN, 1983, p. 191: "In the second version [of Hyppolitus] she displays shame, but is too weak for her desires.” Ver também SNELL, 1964, p. 56-59. 
para manter a integridade de sua reputação. Em diversas ocasiões, Fedra enaltece o valor da "honra (timé)" e da "boa fama (eukleés)" na vida humana (325-330; 485; 680-730) ${ }^{106}$. Sendo assim, as atitudes de Fedra refletem sua resolução firme na preservação absoluta de sua reputação. Com efeito, uma linha interpretativa mais recente tem reconhecido a força de sua resolução moral ao contrário da imagem impulsiva tradicional ${ }^{107}$. Sob esse ponto de vista, podemos encarar sua reflexão anterior acerca da condição humana como um autodistanciamento da paixão impulsiva.

Ao reconhecer a condição humana sujeita a akrasia, Fedra promove uma meditação sobre a impotência do conhecimento moral da virtude frente aos mais variados impulsos. Diante do risco da humilhação, Fedra jamais se coloca em uma situação que pudesse saciar sua paixão destrutiva contra a preservação de sua reputação. Mesmo assim, ela própria declara antes de se matar que a "paixão a submeteu (érotos hethésomai)" (725). Na realidade, essa sentença acaba sendo um reconhecimento do poder de Afrodite sobre seu destino final do que propriamente uma 'confissão' de akrasia. Dessa forma, temos aqui uma descrição geral do fenômeno compatível com o relato da opinião dominante de Prot. 352b-e, embora ainda não tenhamos um caso explícito de akrasia em Fedra.

$\mathrm{Na}$ ausência de um caso de akrasia em Hipólito, devemos nos voltar para a tragédia Medéia uma vez que a própria deliberação da personagem-título é tomada como um conflito mais claro de akrasia.

Em Medéia, fica claro desde o início que a personagem-título é movida por sua "cólera (chólos)"108 contra Jasão, seu ex-marido. A sua ira é plenamente justificada em razões passadas: em nome de sua paixão por Jasão, ela sai de sua cidade natal para Corinto, mas logo foi traída pelo ex-marido, que pretende se casar com a filha do rei Creonte, sendo abandonada à própria sorte com os filhos em terra estrangeira (5-20). No desenrolar da trama, descobrirmos que seus planos de revanche contra Jasão envolvem não apenas lhe atingir, mas também atingir sua nova esposa e o rei Creonte (370-385). A vingança contra o ex-marido não estará completa sem o assassinato de sua linhagem, ou seja, os próprios filhos (790-800).

\footnotetext{
106 Ver também. KNOX, 2015, p. 186-187.

${ }^{107}$ Nessa perspectiva, Claus (1972, p. 231) ressalta que o tom da personagem em seu discurso se torna "quase didático e assertivo ao invés de confessional".

108 Seguimos a tradução de J. A. A. Torrano. Na sequência, algumas alterações serão sugeridas mais enfaticamente na problemática passagem Med. 1075-1080.
} 
Tudo se segue como planejado: o rei Creonte e sua filha são envenenados com drogas pelos presentes dos filhos de Medéia; e, logo em seguida, a própria personagem assassina suas crianças. Com efeito, a ira e linguagem de Medéia já foram associadas à personalidade dos personagens heroicos de Homero, notadamente o caráter típico de Aquiles ${ }^{109}$. Assim como no caso anterior de Aquiles, a cólera da personagem emerge da indignação com seu estado de "desonra (atimásas)" causada por Jasão. No entanto, o assassinato de seus filhos parece indicar que a ira de Medéia ultrapassa o caráter dos heróis da época homérica.

A princípio, a tragédia parece mais um conto de perversidade moral de Medéia do que o relato de um caso tradicional de akrasia. Antes do assassinato propriamente dito dos filhos, a personagem explicita seu conflito psicológico interno em um longo monólogo, tomado como um caso clássico do fenômeno. Para entendermos esse conflito interno, precisamos analisar os eventos anteriores do drama que culminam no clímax do monólogo de Medéia.

Os planos de vingança de Medéia se dirigem prioritariamente aos seus inimigos e só depois envolvem seus filhos. O convencimento de Creonte para que fique mais um dia em Corinto com os filhos é crucial para colocar em execução seus primeiros planos: matar o rei e a filha evenenados com drogas (370-385). As intenções de Medéia com relação ao ex-marido, sua atual esposa e o rei são claramente perversas. A morte deles é cuidadosamente planejada pela personagem. No entanto, seus planos se modificam ao longo do caminho.

A visita repentina de Egeu e seu anseio por herdeiros não só lhe garante um pacto e um refúgio em Atenas, mas também revela o valor dos filhos para a vida de um homem (660-775). De fato, o próprio Jasão já havia ressaltado anteriormente sua intenção em multiplicar sua prole a partir do novo casamento (550-595). A partir disso, Medéia modifica seus planos: após enviar os presentes envenenados por seus filhos, deverá assassiná-los para arruinar definitivamente o ex-marido.

Em todas essas ocasiões, Medéia se refere a seus planos vingativos constantemente pelo termo grego 'bouleúmata', relacionado tanto a 'deliberações' quanto a 'decisões' (765-770). Mesmo o Coro de Mulheres, que até então havia aprovado seus planos, protesta agora alegando que tal crime traria mais males a ela mesma, por sua condição materna (810-860). Embora Medéia se mantenha firme

\footnotetext{
${ }^{109}$ Sobre a linguagem heroica de Medéia, ver KNOX, 1983, p. 274-277; FOLEY, 1989, p. 66;
} GILL, 1996 p. 219-220. 
com seus planos na maior parte do tempo, ela começa a dar sinais de vacilação a respeito do assassinato dos filhos. Quando convence maliciosamente Jasão a manter os filhos na cidade para a entrega os presentes a sua nova esposa, ela desata em um choro incontido (920-970). Quando o Preceptor informa que as crianças já chegaram ao palácio real, Medeia volta a cair em pranto e confessa com mais clareza seu conflito psicológico ao Coro.

Assim como o discurso de Fedra, o monólogo de Medéia também é encarado tradicionalmente como um conflito absoluto entre razão e ira irracional. No entanto, a própria trama da tragédia inviabiliza essa linha interpretativa. Como veremos, o discurso representa um caso de akrasia com um conflito cognitivo-motivacional dos impulsos humanos. Por conta da extensão do monólogo em 1020-1080, nos limitaremos apenas a captar algumas das transições desse complexo discurso:

[1] A coragem some, ó mulheres, quando vi o olhar límpido das crianças. Eu não poderia. Digo adeus às decisões anteriores (chaíreto bouleúmata tà prósthen), levarei meus filhos desta terra. Por que ferir o pai destes com estes males e obter eu mesma duas vezes tantos males (autèn dìs tósa kaká)? Eu não mesmo! Digo adeus às decisões (bouleúmata). [2] Contudo, que sofro? Quero causar riso deixando impunes meus inimigos? Há de ousar isto. Mas que vileza a minha de ainda ter meigas palavras no espírito (malthakoús lógous phrenî)! (...) [3] Nunca, ò animo (thymé), tu nunca (mè sú) farás isto! Deixa-os, ó mísera, poupa os filhos! (...) nunca será de modo que eu permita aos inimigos ultrajar os meus filhos! É de todo necessário (anánke) que morram, assim, nós os massacraremos, que os criamos. É de todo um fato, e não há escapatória. (...) [4] Eu irei por misérrima via, eu os enviarei por via mais mísera ainda. (...) Não posso contemplar-vos mais, mas sou vencida por males (nikômai kakoîs). Sim, compreendo quais males farei (mantháno drân méllo kaká). $\mathrm{O}$ furor é superior ${ }^{110}$ às minhas decisões (thymòs kreísson tôn emôn bouleumáton), ele causa os maiores males aos mortais (megíston aítios kakôn brotô̂s). (1040-1080)

Nessa passagem, tentamos registrar mais claramente algumas das transições de sua longa deliberação. Assim, deveremos analisar sobretudo a transição (1)-(3) pois a transição (4) marca exatamente o problema interpretativo da akrasia $^{111}$.

\footnotetext{
${ }^{110}$ Com efeito, 'superior' aqui traduz kreísson que significa literalmente 'mais forte' ou 'mais poderoso'.

111 A estrutura da divisão foi inspirada em Irwin (1983, p. 192), mas observarei que minha interpretação da passagem difere da sua própria principalmente com relação a transição [5] onde ele vê a akrasia de Medeia em termos de uma submissão irracional de suas 'melhores deliberações'. perante seu thymós.
} 
Durante o monólogo, observamos claramente a flutuação da deliberação de Medéia quanto ao fato de levar a cabo o assassinato de seus filhos. Para analisarmos esse conflito, seguiremos as transições marcadas: (1) Tendo em vista os anseios maternos no futuro dos filhos, a personagem contempla sua dedicação em criá-los e a miséria de sua própria vida ao lhes matar. Diante disso, Medéia declara abandonar as 'decisões anteriores' (bouleúmata tà prósthen), isto é, os planos de matar os filhos (cf. 769, 772). Nessa ocasião, ela reconhece que o assassinato dos filhos afeta mais a ela mesma do que ao seu inimigo: não só acarreta dores ao pai, mas ela mesma sofrerá ‘duas vezes tantos males' (dìs tósa kaká); (2) A indignação em ser ridicularizada por seus inimigos traz sua cólera novamente à tona. Anteriormente, Medeia já havia exaltado um ideal tradicional da justiça grega: 'fazer bem aos amigos e mal aos inimigos' (805-810). Como ressaltamos, a linguagem de Medéia reflete assim o código de conduta heroica da época homérica. O desprezo pelas 'meigas palavras' (malthakoús lógous) anteriores reflete um distanciamento pessoal de seu lado materno; (3) A presença da segunda pessoa do singular 'tu' (sú) salienta um diálogo interno mais privado com seu thymós (cf. FOLEY, 1989, p. 66-71). Em um tom mais pessoal, Medéia cogita deixá-los viver mas logo descarta a hipótese ao refletir que seus inimigos poderão ainda ultrajá-los. A partir disso, a morte dos filhos se impõe como uma 'necessidade' (anánke) iminente. A natureza da necessidade fica mais clara após analisarmos a última transição (4) que culmina na controversa passagem da akrasia.

A interpretação tradicional costuma ver em Medéia um exemplo autêntico de submissão da razão pela ira irracional. Em geral, isso se deve a interpretação tradicional das linhas finais de seu monólogo (1075-1080): a ira irracional ligada ao thymós seria superior ao conhecimento moral expresso em 'mantháno' e 'bouleumáton'. A propósito dessa passagem, Snell (1964, p. 56) declara que vemos aqui o primeiro registro de que o "homem está tão completamente por si mesmo que o único motivo conhecido para sua ação é sua paixão e reflexão", enquanto Irwin (1983, p. 192) alega que "ela ainda pensa que essas [deliberações] são as deliberações corretas, mas possui um desejo contrário mais forte" ${ }^{112}$. Nesses

\footnotetext{
${ }^{112}$ Apesar de insistir que o conflito de Fedra e Medéia não implica conotações morais, no sentido de uma moralidade que 'se preocupa com o outro', é especialmente difícil não interpretar 'boas ou corretas deliberações' em sentido moral. Ao que tudo indica, Irwin está se referindo a um sentido bastante restritivo de uma moral de valores absolutos. Com isso, ele perde o sentido moral dos
} 
termos, o conflito de Medéia resulta da submissão de suas 'boas deliberações' por salvar os filhos contra a ira avassaladora por Jasão. Como já indicamos anteriormente, o simples conflito entre razão e paixão irracional não se sustenta à luz das evidências textuais da tragédia.

Tal como no discurso de Fedra, existe uma forte tendência moralista por trás da interpretação tradicional. Por uma análise contextualizada, alguns intérpretes têm sugerido uma tradução alternativa dos termos mencionados anteriormente ${ }^{113}$. Por um lado, mantháno e bouleumáton não possui qualquer conotação de conhecimento moral em sentido forte. Particularmente, o termo 'bouleúmata' se refere consistentemente aos 'planos de vingança' em falas anteriores de Medéia e é improvável que seu significado seja alterado justamente no monólogo. Novamente, o sentido forte de conhecimento moral deriva provavelmente da suposta polemica de Eurípides e Sócrates. Por outro lado, o thymós é muito menos uma força irracional irrefreável do que uma motivação justificada por seus 'planos de vingança'. Como vimos anteriormente, Medéia adota um autodistanciamento de seu thymós para "convencê-lo" a abrir mão dos planos. Tudo indica que o thymós tem o controle dos bouleumáton ao invés de estar contrário as resoluções de vingança. Dentro desse contexto, Foley (1989, p. p. 67-68) sustenta que é mais consistente traduzir 'kreísson' como 'ser mestre de' ou 'ter controle de' do que 'ser superior que ${ }^{114}$. Embora kreísson seja um adjetivo comparativo, o seu verbo original kratéo quando acompanhado de genitivo efetivamente adquire tal significado (cf. SMYTH, 1984, p. 324-325). Ao invés de uma oposição entre thymós e bouleumáton, uma tradução mais consistente seria "o thymós tem o controle sobre as minhas deliberações [de vingança]". Em vista disso, abrimos uma nova linha interpretativa para o conflito interno expresso no monólogo de Medéia.

A tradução sugerida de 1075-1080 implica que há um conflito psicológico mais significativo no monólogo do que apenas uma oposição absoluta entre razão e ira irracional. Como indica Kovacs (1986, p. 346), o conflito de Medéia é menos um processo decisório do que uma reflexão tardia sobre o custo de uma decisão já tomada. Nesse viés, essa corrente buscou evitar a suposta polêmica com Sócrates

próprios códigos morais específicos de Fedra ou Medéia ao lhes atribuir curiosamente uma moral egoísta na ausência de uma moral de valores absolutos.

${ }^{113}$ Para uma análise contextual do monólogo de Medéia, ver FOLEY, 1989, p. 67-73; KOVACS, 1986, p. 351; RICKERT, 1987, p. 100-101.

114 Ver também GILL, 1996, p. 224-225. 
ao analisar o thymós de Medeia dentro do contexto original da tragédia. Por um lado, Rickert (1987, p. 116) rejeita tratar thymós como 'paixão' e sugere conectá-lo ao próprio código moral heroico de Medéia. No entanto, ele persiste na tradução tradicional de 1075-1080 encarando o conflito da personagem como a submissão das deliberações dos 'sentimentos maternos' pelo thymós ${ }^{115}$. Por outro lado, Foley (1989, p. 72-73) e Gill (1996, p. 223-225) apresentam uma interpretação mais consistente do monólogo de Medéia apoiando-se na tradução alternativa de 10751080. Na perspectiva de ambos, o conflito de Medéia resulta no domínio das deliberações de vingança sobre seus sentimentos maternos. Ao se afastar da referência filosófica de um conflito moral entre razão e paixão, essa tendência interpretativa visa abandonar qualquer referência moral ao fenômeno da akrasia $^{116}$. Entretanto, mostraremos a seguir que o monólogo de Medéia envolve uma forma de akrasia.

O monólogo culmina no conflito de dois valores morais que precedem a iminência do infanticídio de Medéia. Em Medea's Divided Self, Foley (1989, p. 6673) mostra que Medéia é uma personagem dividida entre dois gêneros de personalidades: a parte masculina heroica e a parte materna feminina. Para Foley, o monólogo marcaria assim a supressão definitiva do código materno feminino pelo código heroico masculino. O monólogo marca assim um processo simultâneo de desumanização/endeusamento de Medéia encaminhando para seu final apoteótico na fuga nos carros de Sol. A partir dessas indicações, vizualisamos mais claramente como o conflito de sua motivação heroica masculina e sua motivação maternal feminina caracteriza um tipo de akrasia. De forma geral, a própria personalidade de Medéia lhe encaminha ao derradeiro conflito do monólogo.

Durante toda a tragédia, encontramos sinais e reflexos da crise psicológica do monólogo de Medéia. Por um lado, as más intenções de Medéia são marcadas repetidas vezes pela figuração animalesca de sua personalidade. Antes do infanticídio, a Nutriz mostra duas vezes preocupação com a expressão de leoa e touro de Medéia, uma delas dirigindo o olhar aos próprios fillhos $(92 ; 186)$. Após o

\footnotetext{
115 De fato, Rickert (1987, p. 101-116) já havia salientado esse aspecto, mas acaba adotando a interpretação tradicional 'meu thymós é mais forte que minhas deliberações [maternas]'.

116 Para evitar qualquer pressuposto moral sobre a interpretação do fenômeno, Gill e Foley dissociam, por exemplo, os 'males' de Medeia de qualquer conotação moral. Com razão, eles pretendem dissociar o conflito de Medéia de uma moral absoluta do dever moral. No entanto, revelaremos que é possível interpretar o conflito de Medéia dentro de seu próprio código moral e, dessa forma, encará-lo como uma forma de akrasia.
} 
infanticídio, a mesma impressão de Medéia é reforçada no horror de Jasão: leoa, Cila e sobretudo uma "não mulher (ou gunaîka)" (1340-1355). Nesse sentido, temos indicações que a alteração da personalidade de Medéia com o infanticídio se reflete em sua figuração animal. Por outro lado, a parte materna de Medéia acaba se revelando à medida que o momento do assassinato se aproxima. Em seu protesto contra o infanticídio, o Coro lhe alerta sobre sua miséria na condição de mãe (810850). Por duas vezes, Medéia cai em prantos de forma inadvertida em frente a Jasão e ao Preceptor na iminência de seu monólogo deliberativo (Cf. 920-940; 10051010). Quando desata em choro na frente a Jasão, Medéia relaciona seu pranto à sua condição feminina: "mulher é feminina ainda por lágrimas" (925). O domínio de seu lado heroico sobre seu lado materno é antecipado quando Medéia declara ainda: "eu preferia lutar com escudo três vezes a parir uma vez." (250). Em vista desses aspectos, o monólogo marcaria assim a submissão da parte feminina mais branda pela parte masculina mais selvagem. Nesses termos, seria possível contemplar aqui sua condição de akrasia

O conflito psicológico de Medéia representa um caso claro da descrição tradicional da akrasia. Sem dúvida, o conflito revela a progressiva consciência do custo de uma decisão de cometer o infanticídio, mas vemos aqui um processo deliberativo para convencer seu lado heróico a desistir da empreitada. Como no caso de Odisseu em $O d$. 22, observamos aqui um processo similar de autoaproximaçao e autodistanciamento de seu thymós ${ }^{117}$. Durante o monólogo, Medéia vacila constantemente entre sua personalidade materna e sua personalidade heroica em uma complexa alternância entre ambos os lados.

Para visualizarmos como isso ocorre, retomemos brevemente a complexa oscilação do monólogo. No estágio (1), o lado materno emerge da interiorização das preocupações maternas do Coro. O lado materno adquire a forma de um 'eu' interior em Medéia para lhe convencer dos 'maiores males' (megistôn kakôn) que o infanticídio acarretará para si mesma. Em (2), observamos o desprezo de seu lado heroico em relação às 'meigas palavras' do lado materno e a relembrança de seu código de justiça contra os inimigos. Durante (3), Medéia adota um breve distanciamento de seu lado heroico em uma interlocução com seu thymós personalizado. Como vimos, a hipótese da fuga com os filhos é logo descartada pela

${ }^{117}$ Como vimos, a inspiração dessa interpretação é apresentada em Gill (1996, p. 223-226), mas ele não explora as implicações interpretativas dessa correspondência. 
'necessidade' do infanticídio. Muitos intérpretes têm questionado o caráter ilógico da 'necessidade'118, mas é plausível associá-la a imposição do próprio thymós. De fato, é nessa ocasião que o thymós determina sua decisão final sobre o lado materno; em (4), constatamos os derradeiros momentos de seu lado materno frente a decisão de seu thyóos heroico. O conflito da akrasia é ressaltado pelo caraterístico vocabulário de guerra: "sou vencida por males (nikômai kakô̂s)". Nesse contexto que devemos interpretar a passagem "o thymós tem o controle sobre as minhas deliberações". Para concebermos melhor o conflito psicológico, precisamos nos afastar do simples conflito absoluto entre razão e paixão irracional.

A contextualização da passagem 1075-1080 nos afasta do conflito moral absoluto da razão e paixão. O principal erro da interpretação tradicional era caracterizar o thymós como uma força irracional e encarar o bouleumáton como 'deliberações corretas' (em vista do que é bom). Como observamos, essa interpretação não se sustenta. No entanto, retirar simplesmente as implicações morais dos 'males' (kaká) mencionados no monólogo não parece contribuir para o esclarecimento do conflito da personagem. Afinal, contemplamos um confronto entre dois códigos morais diferentes no monólogo, como vimos anteriormente. Dentro dessa perspectiva, seria possível caracterizarmos a decisão de Medéia 'contra sua deliberação dos males' ao invés de 'contra sua deliberação pelo que é bom'. Ora, mas isso caracterizaria um caso de akrasia propriamente dito? Seguindo a descrição tradicional, a ação em favor do que se considera pior é tanto um caso de akrasia quanto a ação contrária ao que se considera bom. Durante o monólogo, é efetivamente o lado materno de Medéia que constata os 'males' relativos aos bouleúmata que, nesse momento, está vinculado ao assassinato dos filhos. Quando o thymós exorta Medéia a colocar em prática seus planos, o impulso o faz em favor dos 'males' que ela consistentemente reconhece como 'males'. Sob essa condição, temos um conflito de akrasia em que o thymós promove os planos de vingança mesmo diante do que é pior para si mesma, isto é, Medéia.

O conflito trágico de Medéia perde força dramática se simplesmente abstrairmos o valor moral dos 'males' no monólogo. A sua condição como mãe está intrinsecamente ligada a preocupação com um ‘outro' específico, em seu caso, seus filhos. Nessas condições, o lado materno de Medéia representa claramente seus

${ }^{118}$ Para a controvérsia em torno da necessidade do infanticídio, ver KOVACS, 1986, p. 344-346; REEVE, 1972, p. 59-60. 
valores morais pelo outro. Por essa razão, o monólogo marca assim a crise de seus valores morais maternos e sua desumanização a uma personalidade mais bruta e selvagem ${ }^{119}$. Como vimos, as indicações dessa animalidade são representadas sutilmente nas impressões dos personagens da tragédia sobre Medéia. A fuga de Medéia com os filhos mortos em um veículo de Hélios como uma força divina salienta ainda mais seu processo de desumanização. A essa altura, Jasão evoca novamente a impressão animal e selvagem de Medéia e a personagem assume a representação de bom grado (1340-1355). Dessa forma, acreditamos que representar o monólogo como um longo conflito de akrasia reforça a dramaticidade da crise moral e materna de Medéia. Ao contrário de Fedra, Medéia representa um caso claro de akrasia nos termos tradicionais.

As personagens Fedra e Medéia estão longe de serem personagens impulsivas como são normalmente retratadas na tradição. Ambas planejam com cautela seus atos, Fedra em função de sua 'boa reputação' (euklées) e Medéia em nome de sua justiça convencional (cf. Hip. 329, 485-490; 685-689; 715-719). Em Hipólito, Fedra reflete sobre todos os meios possíveis para evitar ceder ao apetite sexual violento de Afrodite, chegando ao ponto de se suicidar e acusar Hipólito de estupro para deixar a reputação intocada. Em Medéia, o thymós da personagemtítulo representa uma motivação cognitiva que lhe leva a pensar pensa cuidadosamente em cada passo de seus planos de vingança. Além disso, a personagem tem clara reputação por sua 'sabedoria' (sophé) diante dos outros personagens (cf. KNOX, 1983, p. 290). Ao invés de personalidades impulsivas, contemplamos duas personagens obstinadas em seguir seus valores pessoais.

Diante da astúcia de Fedra e Medéia, é natural que não encontremos um conflito entre razão e paixão nem no discurso de Fedra e nem no monólogo de Medéia. Entretanto, constatamos que essas famosas passagens de Hipólito e Medéia claramente representam a descrição tradicional da akrasia do Protágoras.

Em primeiro lugar, o discurso de Fedra estabelece a vulnerabilidade humana à akrasia reproduzindo fidedignamente as palavras da opinião dominante do diálogo platônico. A meditação de Fedra sobre a condição humana contempla três condições básicas da descrição tradicional da akrasia: (1) a desvinculação entre a deliberação prática pelo melhor e a ação humana; (2) a realização da má ação

\footnotetext{
${ }^{119}$ Para a nova personalidade bruta e selvagem de Medéia, ver FOLEY, 1989, p. 83.
} 
contra a deliberação correta; (3) a causa desse fenômeno vinculada a uma variedade de impulsos internos. Apesar dessas similaridades entre as passagens, concluímos que a própria Fedra não está na condição da akrasia.

Em segundo lugar, Fedra não apresenta um caso claro do fenômeno, mas Medéia expressa um conflito psicológico de akrasia em seu influente monólogo. Com plena consciência da condição humana sujeita a akrasia, Fedra jamais deixa que seu impulso sexual ameace sua reputação perante os outros. Durante o Hipólito, ela demonstra plena consciência da força de seu impulso sexual e toma providências extremas para que sua doença não seja exposta ao público. De outro lado, Medéia expressa um claro conflito psicológico em seu monólogo que lhe deixa vacilar nas suas firmes resoluções de vingança. A decisão de Medéia pelo assassinato dos filhos é tomada contra a clara constatação que o ato lhe trará os 'maiores males'. O caso de Medéia, portanto, contempla a descrição tradicional da akrasia no Protágoras. Nessa perspectiva, temos claras evidências de que Eurípides teria sido o primeiro tragediógrafo a expressar mais claramente o conflito interno característico da akrasia ao qual a 'opinião dominante' faz referência no Protágoras.

\section{5 \\ Os antecedentes da akrasia antiga e a descrição tradicional no Protágoras de Platão}

Os antecedentes da akrasia antiga registram as origens culturais de um fenômeno absorvido como um clássico problema filosófico por Platão e Aristóteles. Os indícios desses antecedentes culturais da akrasia são expostos claramente no Protágoras de Platão e reforçados na Ética a Nicomaco de Aristóteles.

Em ambas as obras, somos apresentados a mesma descrição tradicional do fenômeno veiculada em nome da opinião dominante da sociedade grega. No Protágoras, em especial, Platão dá voz personalizada a descrição da akrasia que estava em circulação em sua época. Segundo a opinião dominante, um agente pode escolher a pior alternativa, mesmo deliberando pela melhor alternativa, por submissão a impulsos variados. O conflito psicológico relatado pela opinião dominante corrobora o vocabulário bélico das raízes etimológicas do termo akrasia que remontam a Homero. Com base nisso, encontramos indícios que nos levaram a buscar as origens do conflito psicológico da akrasia na literatura de Homero e dos 
tragediógrafos, a base cultural da sociedade grega. Entretanto, a tendência de confundir a akrasia com outros fenômenos tem gerado uma série de equívocos interpretativos. Notavelmente, o engano mais permanente tem sido reduzir a akrasia a um conflito entre razão e paixão. Em nossa investigação, mostramos que isso equivale a confundir a akrasia antiga com a fraqueza de vontade.

A confusão entre akrasia e fraqueza de vontade deriva do que denominamos de uma antecipação da psicologia da vontade. Nessa linha, a interpretação ortodoxa costuma atribuir a origem do conflito entre razão e paixão à polêmica de Platão e Eurípides. Como vimos anteriormente, a ideia de uma clara distinção entre razão, paixão e desejos reflete categorias mentais externas à psicologia tradicional grega. Em geral, a oposição entre razão e motivações irracionais está fundada em dois pressupostos sobre os gregos: (1) o intelectualismo grego e (2) a ausência da 'vontade' moral. A seguir, vamos considerar brevemente os problemas que verificamos nesses pressupostos.

O intelectualismo grego se baseia na ideia de que o pensamento grego evoluiu gradativamente para a intelectualização de termos gregos de conhecimento. Como observamos, os termos gregos de conhecimento possuem tanto conotações intelectuais quanto morais. Nos exemplos de conflitos psicológicos mencionados, não verificamos qualquer especialização do significado 'intelectual' destacado de outras conotações emocionais e desiderativas dos termos gregos de 'conhecimento'. Diante da ausência de uma 'razão' puramente cognitiva, também não encontramos paixões e desejos absolutamente 'irracionais'. De igual modo, a ausência da 'vontade' não parece ser um fator negativo.

A ausência de uma 'vontade' moral também tem sido apontado como um fator negativo na psicologia grega. Sem a 'vontade' moral, os gregos não teriam desenvolvido a autonomia moral necessária para reconhecer o conflito entre razão e paixão. No entanto, salientamos que a psicologia grega não precisa da noção de 'vontade' para expressar uma consciência moral autônoma. Na verdade, a psicologia grega está até melhor do que a psicologia da 'vontade' justamente por dispensar a noção de uma culpa individualizada. Como vimos, a psicologia grega é mais interativa e centrada na noção de vergonha e na internalização do outro. Assim, as categorias mentais da psicologia da vontade estão ausentes da psicologia grega. Por isso, não encontramos qualquer indício do conflito entre razão e paixão 
presente na fraqueza de vontade. Examinamos, então, os antecedentes da akrasia antiga nas obras literárias fundamentais da cultura grega.

A descrição tradicional da akrasia emerge do conjunto de conflitos psicológicos que são atestados em exemplos emblemáticos da cultura grega. Em uma breve análise, mostramos que esses traços psicológicos já se encontram em Homero. Para mostramos como isso se verifica em Homero, exploramos dois casos de conflitos psicológicos: a ira de Aquiles em Ilíada IX e o thymós de Odisseu em Odisséia XX. A partir disso, observamos traços psicológicos paradigmáticos da cultura grega como a estratégia de autoaproximação e autodistancimento das motivações mas, sobretudo, sua natureza intrinsecamente cognitiva. No entanto, não encontramos nos conflitos psicológicos abordados em Homero qualquer indício claro da akrasia nos termos tradicionais. Em seguida, nos debruçamos sobre as tragédias gregas que contemplam uma série de elementos culturais fundamentais para uma reflexão madura da deliberação humana. Como os personagens das tragédias de Ésquilo e Sófocles são motivados à deliberação por forças externas, encontramos consequentemente poucos casos de conflitos psicológicos e nenhum deles representa claramente um caso de akrasia. Enfim, voltamos a atenção para Eurípides em busca das origens da descrição tradicional da akrasia.

As similaridades entre as falas das personagens Fedra e Medéia de Eurípides e a passagem 352b-e do Protágoras de Platão endossam a existência de uma polêmica acerca da akrasia tradicional. Entretanto, mostramos que a suposta polêmica dependia demasiadamente do intelectualismo grego e o conflito entre razão e paixão. Ao nos afastar da leitura intelectualista, percebemos que as falas de Fedra e Medéia devem ser analisadas em seus respectivos contextos dramáticos. Em Hipólito, mostramos que o discurso de Fedra sobre a condição humana remete a 'maioria' dos homens tal como a descrição tradicional da akrasia, do Protágoras. No entanto, a própria personagem não chega ao ponto de realizar a akrasia tal como a outra personagem de Eurípides. Em Medéia, a personagem-título reafirma a aspiração de justiça vingativa de seu thymós contra a constatação de seus próprios 'males', consideração levantada por seu lado materno. Em nenhum dos dois casos temos um conflito entre razão e paixão, mas sim descrições de conflitos psicológicos que remetem a descrição tradicional da akrasia. Desse modo, Platão demonstra ter plena consciência no Protágoras tanto das raízes culturais do fenômeno quanto da força do problema filosófico que está inaugurando. 
O desafio filosófico da akrasia antiga é formulado primeiramente no Protágoras de Platão. Como observamos, o conflito absoluto entre razão e paixões irracionais não aparece claramente nem em Eurípides e nem na descrição tradicional da akrasia do Protágoras. Diante desse fato, temos uma nova possiblidade de compreender como o fenômeno da akrasia se configura como um problema filosófico no diálogo platônico. Ao contrário da intepretação intelectualista ortodoxa, cremos que a refutação da descrição tradicional do fenômeno no Protágoras leva as crenças da opinião dominante ao absurdo dentro de seus próprios termos. 


\section{3. A refutação da descrição tradicional da akrasia no
Protágoras de Platão}

\section{1 \\ O problema da akrasia antiga e a psicologia moral nos Diálogos: parâmetros interpretativos e contexto dialógico}

O problema filosófico da akrasia surge primeiramente dos Diálogos de Platão. Notadamente, a primeira formulação do problema filosófico da akrasia antiga surge reconhecidamente nos Diálogos ${ }^{120}$. No entanto, dois diálogos platônicos marcantes, o Protágoras e a República, ilustram duas posições aparentemente antagônicas de Platão acerca da existência desse fenômeno. A controvérsia dos Diálogos reflete o difícil desafio de dar conta do conflito interno da akrasia e da irracionalidade na alma humana.

O Protágoras é a primeira obra filosófica a apresentar o problema. No entanto, este diálogo apresenta uma posição aparentemente paradoxal sobre o fenômeno: a tese de que a akrasia tradicional, isto é, a possiblidade de agir contra o conhecimento pelos impulsos irracionais, não existe. Por outro lado, a República apresenta uma teoria tripartite da alma que admite o conflito interno das motivações humanas e, em especial, a akrasia. As posições divergentes desses diálogos ilustram dois paradigmas da 'psicologia moral' desenvolvida na obra de Platão: a 'psicologia' socrática e a 'psicologia' platônica. A partir dessa divisão, há uma ordem cronológica tradicional atribuída aos diálogos, segundo a qual o Protágoras seria anterior à República ${ }^{121}$.

\footnotetext{
${ }^{120}$ Sobre isso, a história do problema filosófico é relativamente unânime, ver CHARLTON, 1988, ch. 2; GOSLING, 1990, cap. I-II. Como vimos anteriormente, o próprio Aristóteles reconhece em ENVII.2 que a tese socrática do Protágoras é uma posição filosófica influente a respeito da akrasia antiga.

121 Devemos ressaltar que assumimos a cronologia tradicional estabelecida por Cornford que insere o Protágoras dentro do grupo dos primeiros diálogos denominados de 'socráticos': Apologia, Críton, Cármides, Laques, Lísias, Eutifron, Hípias Menor e Maior, Protágoras, Alcibíades I, Górgias, Eutidemo, Ín, Mênon, Fédon, Menexeno, Crátilo, República, Banquete, Fedro, Parmênides, Teeteto, Sofista, Político, Timeu, Crítias, Filebo, Leis.
} 
O antagonismo da psicologia 'socrática' e da psicologia 'platônica' nos Diálogos mostra a dificuldade em definir claramente a posição definitiva de Platão acerca da akrasia. Afinal, Platão teria mudado sua posição filosófica ou estaria ainda comprometido com a posição anterior à luz de uma nova teoria psicológica? Se considerarmos que Platão abandonou a psicologia 'socrática' em vista de uma psicologia 'platônica', por que o fez? Em última instância, seria a posição da República superior à posição do Protágoras? Ou, ainda, estaria Platão comprometido com a mesma posição acerca da akrasia em ambos os diálogos? Será mesmo que sequer temos uma explícita formulação do problema da akrasia nesses diálogos, ou seria isso uma mera projeção filosófica posterior sobre o diálogo travado pelos personagens platônicos? Para averiguar isso, é preciso lidar com dois problemas inerentes à filosofia de Platão: a ordem das obras platônicas e a própria expressão dramática da filosofia no diálogo entre diferentes personagens.

É preciso analisar, em linhas gerais, o que significa a divisão de uma 'psicologia' socrática e uma 'psicologia' platônica a partir da ordem dos Diálogos. O estudo deste corpus recorre a certos recursos hermenêuticos relativamente unânimes de análise do texto grego platônico: (I) o surgimento de temas filosóficas comuns nos Diálogos e, principalmente, (II) a 'estilometria', o estudo da mudança do estilo na escrita de Platão ao longo dos Diálogos ${ }^{122}$. De qualquer forma, os métodos de interpretação de Platão estão abertos a muitas divergências.

Existem duas tendências interpretativas majoritárias dos Diálogos: o desenvolvimentismo e o unitarismo ${ }^{123}$. Na esteira da estilometria, uma corrente tradicional apela ao desenvolvimentismo dos Diálogos, ou seja, a teoria de que a ordem dos Diálogos reflete não só diferentes estilos de escrita mas expõe o progresso do pensamento platônico em três fases distintas: juventude, maturidade e velhice. Para essa vertente, as mudanças de posição filosófica sobre o mesmo tema

\footnotetext{
122 Para referências sobre à 'estilometria' e as diferentes abordagens interpretativas dos Diálogos, ver KAHN, 1996, cap. 2; IRWIN, 1995, cap. 1; ANNAS, 2003, cap. 3; ROWE, 2006.

${ }^{123}$ Como salienta Rowe (2006, p. 13-17), as correntes do unitarismo e o do desenvolvimentismo se espelham em tradições antigas de leitura dos Diálogos platônicos. De um lado, os céticos exaltam o caráter aporético do grupo dos primeiros diálogos de Platão, salientando o que viria a integrar a perspectiva desenvolvimentista. De outro lado, os neoplatônicos exaltam propriamente o caráter mais doutrinário dos diálogos típicos da fase madura, o que viria a integrar a perspectiva do unitarismo. Segundo o próprio Rowe, ambas as tradições interpretativas radicalizadas apresentam suas próprias inconsistências inerentes. Para uma abordagem desenvolvimentista de Platão, ver GUTHRIE, 1975; IRWIN, 1995, ch.1; VLASTOS, 1991; REEVE, 1988; BRICKHOUSE \& SMITH, 2010. Com efeito, uma abordagem unitarista mais complexa tem revitalizado a unidade do pensamento platônico. Sobre essa nova tendência unitarista, ver KAHN, 1996; ANNAS, 2003.
} 
em diálogos diferentes refletem o amadurecimento intelectual de Platão. Contra essa tendência interpretativa, uma corrente mais antiga, o unitarismo sustenta que os Diálogos expressam a mesma visão única e sistemática da filosofia platônica. Nesta perspectiva, as aparentes incongruências dos Diálogos desaparecem em nome da consistência relativamente unificada de um 'sistema' filosófico. Todavia, o contraste entre os temas e os métodos filosóficos presentes em diálogos como o Protágoras e a República são tão evidentes que fica difícil ignorar a pertinência premente do desenvolvimentismo dos Diálogos. No entanto, isso também ilustra o problema da incompatibilidade dos princípios e métodos filosóficos apresentados em diálogos de fases distintas.

A corrente desenvolvimentista se ampara nas inovações estilométricas para mostrar um 'progresso' dentro da filosofia platônica. De acordo com essa visão, os diferentes estilos de diálogos corresponderiam à 'evolução' da filosofia platônica em diferentes fases de pensamento. A mudança dramática e filosófica do personagem Sócrates, como, por exemplo, do Protágoras à República, seria explicada com base nas inovações filosóficas presentes na fase madura de Platão.

Em Plato and the Socratic Dialogue, Charles Kahn (1996) critica sistematicamente os pressupostos da visão desenvolvimentista e defende a continuidade intrínseca dos Diálogos. De acordo com Kahn, os dados objetivos do desenvolvimento estilístico do texto platônico não permitem atestar, de forma incontestável, a presença de uma rígida ordem cronológica de composição dos diálogos platônicos ${ }^{124}$. Por esse ângulo, a divisão dos diálogos em três grupos representa nada mais do que mudanças no estilo de escrita, e não mudanças filosóficas significativas.

O projeto de Kahn enfatiza os elementos de continuidade dos diálogos sem ignorar, no entanto, as notáveis descontinuidades dos Diálogos. Particularmente,

${ }^{124}$ Cf. Ibid., p. 45-46: "The attempt to establish a complete linear ordering for the dialogues on stylometric grounds has produces no reliable results, no agreement after a century of work. And this is what we might expect, since the attempt is based upon the fallacious assumption that chronological order will in every case be reflected in stylistic change. (...) This prolonged and continuing endeavor has serve only to obscure, and hence undermine confidence in, the one solid, objective (or at least, reliably intersubjective) result of the chronological studies that began with Campbell. This is the modest but decisive achievement of dividing the dialogues into three groups.". Como salienta Kahn (1996, cap. 2), a 'estilometria' é um método fundamental da mudança do estilo de escrita platônica, no entanto, isso não nos leva a assumir a ideia de uma mudança do pensamento platônico ao longo dos Diálogos. Para Kahn, podemos reconhecer três estilos de escrita sem incorrer na ideia do desenvolmimentismo estrito de fases de pensamento de Platão, reconhecendo assim um unitarismo intrínseco do pensamento platônico em convergência às teses platônicas da República. 
Kahn (Ibid., p. 39-42) sustenta um tipo de unitarismo em que as teses dos diálogos 'socráticos' estariam voltadas para o eixo temático central da República. Em todo caso, os detalhes da visão de Kahn sobre a 'psicologia' de Platão ficarão para uma ocasião posterior. Por ora, é importante notar que as críticas de Kahn aos pressupostos do desenvolvimentismo permitem observar uma continuidade subentendida dos Diálogos, um sistema de referência cruzada entre diálogos que compõe uma unidade complexa da filosofia platônica.

A seguir, esboçaremos uma posição 'moderada' do desenvolvimentismo dos Diálogos. Para isso, devemos analisar as diferenças entre o Protágoras e a República que ilustram a divisão entre a primeira fase e a segunda fase do pensamento platônico.

Dentro da cronologia tradicional, o Protágoras é um típico diálogo da primeira fase de Platão ou a fase 'socrática', enquanto a República é um diálogo claramente vinculado à fase média ou a fase 'platônica'. Na sequência, vamos abordar dois tópicos em que há diferenças notáveis entre o Protágoras e a República: a mudança de posição filosófica e a mudança no contexto dramático dos Diálogos.

Em primeiro lugar, as teses do hedonismo e da negação da akrasia no Protágoras são claramente incompatíveis com a crítica ao $\operatorname{prazer}^{125}$ e a divisão interna da alma em típicos diálogos maduros, como a República, assim como o Górgias e o Fédon. De um lado, a análise negativa do prazer geralmente vem associada a uma investigação da natureza do desejo: no Górgias, a turbulência dos apetites corporais leva à rejeição da identidade entre 'bem' e 'prazer' (497d), sustentada na teoria hedonista do Protágoras (351c) $)^{126}$; no Fédon, os apetites corporais surgem como um grave obstáculo à aquisição do conhecimento (65a67b), e há uma rejeição explícita ao cálculo de prazer e dor (69a), imprescindível na defesa da técnica da medida no Protágoras. De outro lado, o conflito interno da

\footnotetext{
${ }^{125}$ Em The Greeks on Pleasure, Gosling \& Taylor elaboram uma grande análise da influência e, em parte, da rejeição de Platão às doutrinas correntes do prazer de sua época. Para Gosling \& Taylor (1982, p. 9), o tema do prazer adquire um estatuto central justamente a partir da filosofia de Platão: "With the possible exception of Democritus, no greek writer before Plato seems to have made pleasure a central topic for discussion."

${ }^{126}$ Para alguns comentadores, como Rudebusch (1999a), Gosling e Taylor (1982), o hedonismo exposto no Protágoras não é negado no Górgias. No entanto, outros comentadores, como Irwin (1995) e Zeyl (1980), acreditam que o Sócrates do Górgias refuta a tese hedonista apresentada no Protágoras. Como mostraremos adiante, o hedonismo do Protágoras só é controverso enquanto confrontado com diálogos da maturidade tipicamente conhecidos devido à sua crítica sistemática do prazer e da vida prazerosa.
} 
akrasia não ganha claro destaque como um problema filosófico explícito em mais nenhum outro diálogo platônico além do Protágoras (cf. KAHN, 1996, p. 253$257)^{127}$. Apesar disso, a teoria tripartite da alma na República é especialmente elaborada para dar conta do conflito interno da alma, sobretudo no caso do impulso irracional de Leôncio por cadáveres (439e-440b), um suposto caso de akrasia. Sob qualquer ângulo, as teses defendidas no Protágoras estão em franca oposição às posições defendidas nos diálogos maduros. Além das diferenças teóricas que separam o Protágoras e a República, existe também outro ponto de extrema controvérsia: os elementos dramáticos e metodológicos inerentes à expressão do diálogo platônico em geral.

O que nos leva ao nosso segundo tópico: a presença ostensiva de personagens, que orientam os debates filosóficos, coloca um problema interpretativo singular, principalmente diante da ausência de uma posição explícita do autor dos Diálogos.

Nesse caso, é imprescindível adotar parâmetros hermenêuticos claros de interpretação do texto platônico, independente dos interlocutores do diálogo. É um procedimento tradicional tomar Sócrates como o porta-voz das teses de Platão justamente por seu papel de protagonismo em grande parte dos Diálogos. No entanto, o suposto 'porta-voz' nem sempre desempenha um papel significativo no diálogo e, por vezes, nem mesmo enuncia nenhuma tese ou teoria em nome próprio. Mesmo tendo um papel proeminente na condução do debate filosófico, a sua personalidade e expressão filosófica claramente se altera ao longo dos Diálogos. Nos últimos diálogos, há outros protagonistas, como o Estrangeiro de Eléia no Sofista e o Parmênides no diálogo homônimo, que tomam seu lugar. De todo modo, a estrutura dinâmica do diálogo platônico exige ir além da posição particular de seus protagonistas ou interlocutores.

A estrutura do diálogo orienta a condução argumentativa das teses e dos problemas filosóficos dentro do amplo contexto dialógico da obra platônica. Ao longo dos Diálogos, o encadeamento dos argumentos vinculado à expressão discursiva dos interlocutores e artifícios literários, que incluem: a) diferentes

\footnotetext{
127 Com a possível exceção das Leis, onde notavelmente o termo akrasia ocorre com maior frequência, embora sem seu sentido técnico clássico conferido na Ética de Aristóteles. Contudo, Kahn salienta que o interesse premente de Platão na akrasia repousa mais sobre o paradoxo socrático 'ninguém faz o mal de bom grado' e o 'mal involuntário' do que especificamente ao fenômeno da akrasia em si mesmo.
} 
modos de expressão filosófica, como digressões, interjeições, personificação de interlocutores, monólogo e diálogo; e b) elementos literários, como ironia, riso, metáfora, analogia, comédia, silêncio e até detalhes da cena dramática. Com essas indicações textuais, o texto platônico exige um papel ativo do leitor na seleção de possibilidades interpretativas e na reconstrução dramática dos problemas e argumentos filosóficos, independentemente da posição singular dos personagens. Desse modo, salientaremos elementos da estrutura geral dos diálogos socráticos e dos diálogos médios que marcam, respectivamente, o Protágoras e a República.

A estrutura dramática dos Diálogos esclarece o que distingue o Protágoras e a República. Nos primeiros diálogos, Sócrates apenas apresenta argumentos a partir do exame das crenças de seus interlocutores sem, no entanto, enunciar uma posição própria explicitamente. Em grande medida, esses diálogos são marcados por determinadas características comuns: 1) a proposição de uma questão da definição sobre uma coisa, "o que é $x$ ?”, geralmente se referindo a uma virtude específica ou a virtude em geral; 2) o método socrático do elenchus, termo que significa 'investigação' ou 'refutação', levando à condução de um exame crítico para a análise da consistência ou inconsistência dos argumentos em vista da definição adequada de ' $x$ '; 3) o estabelecimento de uma aporia, isto é, o 'impasse' diante da insuficiência das teses apresentadas na definição adequada de ' $x$ '. Além do Protágoras, encontramos ainda outros diálogos socráticos, como, por exemplo, Cármides, Laques, Críton, Eutífron e Hípias Maior e suas investigações de virtudes específicas ${ }^{128}$. As diferenças das 'fases' socrática e a médio-platônica já se anunciam na mudança de personalidade e atitude filosófica do próprio personagem Sócrates.

Nos diálogos médios, Sócrates enuncia teses e doutrinas mais positivas, de forma explícita e em nome próprio, incorrendo em discursos mais longos e explorando, por vezes, outras formas de expressão filosófica. Nesse conjunto de diálogos, encontramos as mais influentes doutrinas platônicas, como a Teoria das Formas, a teoria da reminiscência, as distinções clássicas entre o plano sensível e o plano inteligível, conhecimento e crença, além da clara separação do corpo e da

\footnotetext{
${ }^{128}$ Dentro dessa lista mais reduzida de diálogos, não incluímos a Apologia e o Críton simplesmente por não se enquadrarem no típico formato dos diálogos socráticos de definição da virtude. Em matéria estilística, no entanto, não resta a menor dúvida que esses diálogos pertencem à classe dos diálogos socráticos (cf. KAHN, 1996, p. 42-48).
} 
alma (psyche). Além disso, o método do elenchus socrático dá espaço agora a um novo método filosófico, a dialética, isto é, a investigação das verdades últimas puramente inteligíveis do 'que é em si mesmo', as Formas, desvinculadas da opinião e do campo sensível (cf. Rep. 532a-534e). A partir disso, encontramos diálogos como Górgias, Mênon ${ }^{129}$, Fédon, Banquete e, principalmente, a obra magna República. Diante dessas características, podemos reconhecer os elementos que inserem o Protágoras e a República nesses dois grupos diferentes de diálogos.

O Protágoras e a República representam exemplares respectivos das fases socrática e platônica dos diálogos de Platão e ilustram os problemas que resultam de sua incompatibilidade. De um lado, há provas contundentes para inserir o Protágoras dentro da fase socrática do pensamento de Platão. Primeiramente, essa obra claramente aborda a natureza da virtude e sua identidade com o conhecimento. Ademais, as discussões desenvolvidas são semelhantes às presentes nos primeiros diálogos. Como observamos, o Protágoras se diferencia dos diálogos supracitados à medida que não contém nenhuma teoria sobre a natureza da alma (cf. GOSLING; TAYLOR, 1982, p. 61), a teoria das Formas, nem os dualismos corpo/alma e sensível/inteligível dos diálogos da maturidade (cf. MUNIZ, 2011, p. 49). Assim como Guthrie (1975, p. 214), reconhecemos que o diálogo pode ser classificado, de maneira razoável, como "o último dos diálogos socráticos". Essa classificação permite relacionarmos as teses socráticas do Protágoras a outras teses socráticas expostas no grupo dos primeiros diálogos de Platão. Desse ponto de vista, a República se distingue claramente do Protágoras.

A República aborda teorias epistemológicas e metafísicas a partir da distinção clássica sensível/inteligível ausente dos diálogos socráticos. Nesse cenário, Sócrates apresenta teses positivas em nome próprio: a Teoria clássica das Formas, a crítica aos prazeres corporais, a imortalidade da alma, o mito escatológico pós-morte e até a expulsão dos poetas da Cidade Ideal governada pelo filósofo-rei (cf. GUTHRIE, 1975, p. 434-436). Sobretudo, as diferenças se estendem à suposta divergência entre a psicologia socrática e a psicologia 'platônica'. No entanto, as incompatibilidades indicadas pelo desenvolvimentismo se refletem em problemas fundamentais na própria estrutura dialógica interna do Protágoras e da República.

\footnotetext{
${ }^{129}$ Os diálogos Górgias e Mênon costumam ser classificados dentro de um grupo específico de diálogos 'transicionais', justamente porque apresentam elementos característicos dos diálogos socráticos e diálogos maduros.
} 
Em primeiro lugar, o argumento hedonista apresentado por Sócrates no Protágoras tem uma singularidade dentro do corpus platônico. Com efeito, existem motivos internos e externos ao Protágoras para colocar sob suspeita o debate do prazer e a akrasia. De um lado, a discussão sobre o prazer e a akrasia na passagem 351b-358d surge de maneira abrupta e um tanto deslocada do tópico central do diálogo, a unidade entre virtude e conhecimento. De outro lado, o argumento hedonista do Protágoras claramente entra em confronto com a crítica de Sócrates ao prazer nos diálogos maduros tardios, como Górgias, Fédon e República. Por conta disso, há uma permanente suspeita sobre o comprometimento de Sócrates com o argumento hedonista do Protágoras.

A tradição interpretativa do Protágoras se divide acerca da posição de Sócrates diante do argumento hedonista contra a akrasia em duas correntes divergentes, a 'hedonista' e a 'anti-hedonista'. Para a corrente 'hedonista', o argumento hedonista é defendido efetivamente pelo próprio Sócrates na refutação da descrição tradicional da akrasia da opinião dominante. Para a corrente antihedonista, Sócrates jamais se compromete claramente com a tese hedonista em própria pessoa, tendo apenas interesse em dirigir o argumento hedonista de forma ad hominem, isto é, contra as crenças de seus interlocutores, sejam os sofistas em conjunto, o próprio Protágoras ou apenas o interlocutor personalizado denominado de 'opinião dominante' (hoi polloí). Nesse cenário, o objetivo final de Sócrates seria, na realidade, sustentar apenas a unidade entre virtude e conhecimento no argumento final. Em função dos complexos detalhes dramáticos da cena do Protágoras, a tendência majoritária atual tem sido a leitura anti-hedonista.

Sem dúvida, a polêmica é extensa e parece estar longe de um desfecho satisfatório. Ambas as correntes recorrem a detalhes dramático específicos da passagem ou do diálogo como um todo de forma igualmente persuasiva, mostrando a plausibilidade de sua leitura ${ }^{130}$. Em nossa postura interpretativa, indicaremos que

130 Segundo a tradição interpretativa do diálogo, é controverso se Sócrates realmente defendeu o hedonismo apresentado ou se ele o defendeu como um argumento ad hominem, isto é, apenas para refutar as posições defendidas por Protágoras, os sofistas ou a opinião dominante. No primeiro grupo, denominado de 'hedonistas', encontramos Gosling \& Taylor (1982), Rudebusch (1999), Nussbaum (1992), Irwin (1995) e Muniz (2011). No segundo grupo, denominado de 'antihedonistas', os intérpretes se dividem quanto ao comportamento de Sócrates em relação a seus interlocutores, se ele é irônico ou simplesmente insincero. Como defensores dessa corrente, podemos citar Vlastos (1969), Guthrie (1975), Ferrari (1990), Kahn (1996), Zeyl (1980), Annas (1999), Woolf (2002), Weiss (2006), o próprio Taylor (2008) que revisou seu ponto de vista e agora critica sua própria posição hedonista. Morris (2006), Lopes (2017), Wolfsdorf (2006), Callard (2014). A controvérsia dramática é tão extensa e aparentemente insolúvel aos estudos platônicos que 
não é preciso recair em uma posição absoluta acerca do posicionamento filosófico de Sócrates. Como veremos adiante, o próprio elenchus socrático no Protágoras exorta a uma postura mais imparcial sobre o exame do argumento hedonista.

Por ora, devemos chamar atenção, em segundo lugar, para uma outra polêmica derivada do desenvolvimentismo: a incompatibilidade interna do livro I com os outros livros da República.

O personagem Sócrates da Rep. II-X parece adotar uma postura filosófica incompatível com sua posição anterior em Rep. $\mathrm{I}^{131}$. O problema da justiça é seguramente um tema central de toda a República, mas há uma mudança significativa do livro I em relação aos demais livros da obra. Nos parâmetros do desenvolvimentismo, a Rep. I assume o formato típico dos diálogos socráticos, enquanto a Rep. II-X exibe as doutrinas clássicas da fase madura de Platão. Em Rep. I, o problema da justiça é formulado nos termos socráticos da definição, 'o que é $x$ ?', e Sócrates adota o elenchus para avaliar as diferentes concepções da justiça de seus interlocutores, chegando a uma aporia no fim do diálogo (354b-c). A partir de Rep. II, os irmãos Gláucon e Adimanto reformulam o problema original da justiça em novos termos, e Sócrates, antes um mero questionador, agora passa a assumir uma postura mais propositiva com a construção teórica de uma Cidade Ideal e uma ampla investigação epistemológica, metafísica e psicológica da natureza da justiça.

Em face dessa incongruência, a tradição interpretativa alega que a própria República representa um rompimento de Platão com sua fase socrática: a Rep. II-X estaria disposta a renegar os resultados negativos do método socrático da Rep. I em prol da posição original platônica definida por doutrinas positivas e o novo método da dialética ${ }^{132}$. No entanto, devemos indicar que a República, como o Protágoras,

interpretações recentes sobre o problema da akrasia no Protágoras tem se isentado de assumir qualquer postura definitiva.

${ }^{131}$ A partir daqui, o termo 'República' designará toda obra incluindo o conjunto de seus 10 livros e recorreremos a forma abreviada 'Rep.' em referência a um ou mais livros específicos.

${ }^{132}$ Cf. REEVE, 1988, p. 23: "Book 1 emerges as a brilliant critique of Socrates, every aspect of which is designed to reveal a flaw in his theories.". Para Reeve (Ibidem, p. 22-24), a Rep. I expõe as falhas inerentes ao próprio método do elenchus como exame investigativo destinado a mudar as crenças dos interlocutores. Ver também ANNAS, 1981, p. 56-57; IRWIN, 1995, p. 198-200. Em geral, essa corrente interpretativa costuma reconhecer as falhas dos argumentos de Rep. I mas insistem em salientar a continuidade entre a Rep. I e os demais livros. Em uma interpretação mais antiga, alguns intérpretes chegam a sustentar que a Rep. I teria sido escrita antes de outros livros da República, justamente devido a suas características típicas da fase socrática (cf. GUTHRIE, 1975, p. 437-438). Todavia, acreditamos que a classificação de Rep. I dentro da fase socrática é válida enquanto relacionada a aplicação do método investigativo do elenchus, mas não deve fazer 
sofre os mesmos efeitos derivados dos pressupostos de descontinuidade do desenvolvimentismo.

A continuidade temática subentendida no nível hermenêutico mais profundo perpassa as descontinuidades expostas nas posições divergentes dos diálogos em seu nível superficial. Como salienta Muniz (2011), há um complexo sistema de 'ecos e reenvios' nos textos platônicos em que as indicações textuais nos remanejam a uma leitura mais ampla do conjunto dos Diálogos, ainda que preservando a autonomia de cada obra dentro de seu próprio contexto dialógico ${ }^{133}$. Por isso, encontramos nos Diálogos tanto referências internas às teses e argumentos dos personagens em cada obra e, simultaneamente, referências externas veladas a posições divergentes entre diferentes diálogos.

Com base nessas indicações hermenêuticas, devemos estabelecer dois níveis interpretativos nos Diálogos: o nível primário interno dialógico de cada obra, inserindo os problemas filosóficos, as teses e argumentos apresentados dentro de um amplo debate filosófico com diferentes personagens em torno de um tema central; e o nível secundário externo 'interdialógico', a continuidade e a descontinuidade dos argumentos e teorias presentes em diferentes obras em um sistema dinâmico abrangente de mútuas referências cruzando posições filosóficas diferentes dentro da unidade complexa do pensamento platônico.

Dessa forma, assumimos que o nível interpretativo primário prevalece sobre o nível interpretativo secundário. A autonomia interna de cada diálogo determina os limites interpretativos do texto dentro de um universo coerente de problemas e teses específicas. As referências externas interdiálogicas não podem comprometer ou complementar a coerência interna de cada diálogo. No limite, as referências externas exibem elementos de continuidade e ruptura diante de novas demandas dos problemas ou argumentos filosóficos apresentados em cada obra platônica. A divisão dos diálogos socráticos/platônicos transparece nas divergências de estilo e até mesmo de princípios filosóficos. No entanto, há uma continuidade mais

conjecturas abrangentes sobre 'fases de pensamento' de Platão ou sobre o 'progresso teórico' dos diálogos socráticos aos diálogos médios.

133 Cf. MUNIZ, 2011, p. 72-73: "não é nada desprezível a tentativa de seguir a trilha das indicações que os textos oferecem para recuperar as conexões entre passagens, e entrar no jogo discursivo dos Diálogos, que, dentre outros meios, possui esse sistema de ecos, esse circuito de reenvios que forma um subnível acessível de conexões. Não se quer dizer com isso, no entanto, que os Diálogos devem ser lidos apenas em seu conjunto, ou muito menos que eles se fecham em um sistema totalizável, mas que dentro da unidade relativamente autônoma de cada diálogo algumas frestas permitem perceber retomadas de temas, preenchimento de lacunas, presença de referências elucidativas." 
profunda em curso no nível 'interdialógico' indicando a manifestação de uma posição platônica consistente mais complexa por baixo da aparente divergência dos Diálogos.

Em defesa dessa postura interpretativa, abordaremos a incompatibilidade do método socrático do elenchus no Protágoras e o exame da natureza da justiça na República. Nesse cenário, os problemas interpretativos do hedonismo e da divisão interna da República desaparecem em face da continuidade implícita de cada diálogo. Na sequência, pretendemos indicar que Platão preserva a mesma posição sobre a akrasia mesmo diante da mudança de sua psicologia moral. Sendo assim, vamos nos concentrar adiante no método do elenchus socrático e a controversa discussão sobre o prazer e a akrasia do Protágoras.

\section{2 \\ O problema da akrasia antiga no contexto do Protágoras de Platão}

A controversa passagem $351 \mathrm{~b}-358 \mathrm{~d}$ sobre o prazer e a akrasia alcança o ápice de uma ampla discussão central de Sócrates e Protágoras sobre a natureza da virtude (329e-330b). De um lado, Protágoras defende a pluralidade das virtudes, alegando que virtudes tradicionais, como 'justiça' (dikaiosýne), 'piedade' (hósion), ‘temperança' (sophrosýne), 'coragem' (andreía) e 'sabedoria' (sophía) exibem diferentes capacidades (dynámeis) humanas, sendo 'partes' diferentes da virtude. Contra essa pluralidade das virtudes, Sócrates defende a reciprocidade das virtudes, isto é, a tese de que as virtudes se implicam mutuamente, sendo impossível possuir uma delas sem possuir automaticamente todas as outras (cf. IRWIN, 1995, p. 7980). A partir disso, Sócrates defende a reciprocidade da justiça e da piedade: "a justiça e piedade são a mesma coisa (tautón estin) ou coisas muitíssimo semelhantes (homóiotaton)" (331b). No entanto, Protágoras exprime resistência a esses e outros argumentos socráticos contra a pluralidade das virtudes.

Diante da insistência do sofista na defesa da pluralidade, Sócrates apresentará uma série de argumentos contra a pluralidade das virtudes: a) a unidade entre a justiça e a piedade (330c-331e); b) a unidade entre a temperança e a sabedoria (332a-333b); c) a unidade entre temperança e justiça (333d-333e); d) 
unidade entre sabedoria e justiça $\left(345 \mathrm{~d}-346 \mathrm{e}^{134}\right)$; e) a unidade entre a coragem e a sabedoria (349d-351b; 358d-360e). Em última instância, a reciprocidade das virtudes deve implicar na unidade final da virtude e sabedoria ou conhecimento (361a-b). Na realidade, o objetivo final de Sócrates com esses argumentos contra a pluralidade só fica claro quando compreendemos o papel do elenchus e o exame das crenças da opinião dominante.

É preciso averiguar o significado profundo do exame da opinião dominante dentro do contexto do diálogo como um todo. Em especial, nos preocupamos em analisar o papel do elenchus na condução sobre a natureza da virtude culminando no ápice do exame da opinião dominante grega. Nesse sentido, defenderemos que o exame da opinião dominante resulta de dois elementos centrais intercalados no diálogo: (a) os princípios metodológicos do elenchus de Sócrates em face das inconsistências da posição do sofista; (b) a crescente incompatibilidade dramática de dois modos de discurso antitéticos, a makrología ou discurso longo de Protágoras e a brakhulogía ou discurso breve de Sócrates. Diante de ambos os fatores, o exame da opinião dominante expressa um artifício metodológico e dramático para eliminar as inconsistências de Protágoras sobre a natureza e o ensino da virtude.

Durante a discussão sobre o hedonismo e a akrasia, Sócrates exige uma posição mais enfática de Protágoras perante as posições professadas em nome da opinião dominante. Durante o diálogo, o sofista já havia mencionado duas teses que estão vinculadas à opinião dominante: (1) a virtude é composta de elementos extra cognitivos; (2) há "prazeres maus (hedéa kaká)" e "dores boas (aniará agathà)" (351c). Em seu Grande Discurso, ele havia enfatizado que a educação da virtude provém não só do "ensino (didachês)" mas também do "exercício (askéseos)", do "empenho (epimeleías)" e, até mesmo, a "melhor natureza (euphyéstatos)" (cf. 323d-e; 327a-d). Ao longo do diálogo, ele insiste em afirmar que as virtudes são diferentes entre si e alega enfim que a "coragem (andreía) provém da natureza (apò physeos) e da boa nutrição da alma” (351b). Entretanto, o exame socrático da opinião dominante obriga Protágoras a ser mais claro a respeito do poder do conhecimento moral.

\footnotetext{
${ }^{134}$ Consideramos, com Weiss (2006, pp. 41-43), que o argumento da unidade entre a temperança e a justiça inicia na passagem anterior, mas só é concluído através do paradoxo estabelecido em $345 \mathrm{~d}$ e.
} 
Após trazer à tona a descrição tradicional da akrasia, Sócrates ganha o apoio explícito de Protágoras na defesa do conhecimento moral:

seria vergonhoso para mim [...] afirmar que a sabedoria (sophían) e conhecimento (epistémen) não são, entre todas as coisas humanas (pantón tôn antropeíon pragmáton), as que exercem maior domínio (krátiston). (352d)

A partir disso, o objetivo de Sócrates é examinar as crenças da opinião dominante na akrasia tradicional colocando em xeque, indiretamente, a concepção não cognitiva da virtude do $\operatorname{sofista}^{135}$. A proposição (2) vinculada à opinião dominante emerge da discordância do sofista com as premissas hedonistas iniciais de Sócrates. Em face da tese de que existem apenas 'prazeres bons e dores más', Protágoras toma uma posição mais cautelosa: "contanto que se viva comprazendose com coisas nobres (tô̂s kaloîs) ${ }^{136}$ (351c). A essa altura, Sócrates atribui tal tese à crença da maioria em 'prazeres maus' e 'dores más' sem que Protágoras ofereça qualquer resistência. Assim, o exame da opinião dominante de Sócrates acaba implicando em uma revisão profunda das teses do próprio sofista (351c-d). Durante o diálogo, as inconsistências de Protágoras levam Sócrates a reiterar os princípios fundamentais do elenchus.

Para compreender o que está em jogo aqui, é necessário ter em mente a postura socrática, marcada pelo método denominado de elenchus, e o episódio emblemático da 'crise' do diálogo entre o filósofo e o sofista (334c-338e).

Em duas ocasiões, Sócrates explicita as bases de seu método em face das inconsistências da posição de Protágoras. No primeiro episódio, a hesitação do sofista em assumir a tese da unidade das virtudes envolve justamente uma relação mais explícita entre sua posição e a da 'maioria' (hoi polloí). Por 'vergonha' (aischynoímen) Protágoras se recusa a admitir que é possível 'ser sensato e injusto' (333c). Ao delegar a seu interlocutor a investigação da posição da maioria, Sócrates curiosamente expressa indiferença quanto a quem será o inquirido:

\footnotetext{
135 É interessante notar que o sofista, em momento algum, reconhece explicitamente que a crença tradicional na akrasia é incompatível com a natureza não cognitiva da virtude defendida anteriormente.

${ }^{136} \mathrm{O}$ termo grego kalós possui, simultaneamente, conotações morais e estéticas. De forma geral, kalós caracteriza ações consideradas louváveis e honradas na sociedade grega. Deve ser contrastada com aischrós que significa vergonhoso, indigno, desonroso (cf. TAYLOR, 1991, p. 165).
} 
Mas, para mim, é indiferente (oudén moi diaphérei), contato que seja apenas você a me responder, a despeito da sua opinião sobre o assunto; pois é a tese que eu examino (tón lógon eksetádzo), embora decorra disso, talvez que tanto eu que formulo as perguntas, quanto quem as responde, sejamos, ambos, examinados (ísos eksetádzesthai). (333c)

A atitude filosófica socrática remete diretamente aos princípios metodológicos do elenchus. Nessa ocasião, Sócrates estabelece a prioridade da tese ou argumento (lógon) sobre as crenças pessoais do interlocutor. Com isso, Sócrates promove um autodistanciamento das impressões e crenças pessoais de seu interlocutor em favor do estrito exame dos argumentos filosóficos. Anteriormente, entretanto, ele parece adotar outra postura com relação a Protágoras. Enquanto o sofista concede que a justiça e piedade são similares, Sócrates rejeita justamente o exame do que "se lhe parece (ê̂ soi dokê̂)" ou "se você quiser (ei boúlei)" por uma análise mais precisa"refiro-me a esse "a você e a mim" (emé te kaì sé) presumindo que seja esta a melhor maneira de investigar o argumento (tòn lógon béltist' elénchestai): quando se abandona o "se"” (331c). Afinal, o que o exame do elenchus nos exorta a fazer, adotar uma postura de autodistanciamento ou investigar nossas próprias crenças pessoais mais profundas?

Ambas as passagens, na realidade, sinalizam que Sócrates está disposto a isolar o exame filosófico argumentativo do elenchus do mero debate pessoal da posição particular dos interlocutores. De fato, a resistência do sofista em reconhecer as inconsistências de suas teses reside justamente na difuldade em abrir mão de suas posições originais. Na passagem acima, Protágoras faz uma concessão controversa em favor da 'maioria' reiterando novamente a expressão condicional 'se lhe aprouver' (ei boúlei) (333c-d). Nessa ocasião, Sócrates não encontra motivo para examinar a 'opinião dominante'. No entanto, o agravamento dramático das modalidades discursivas dos interlocutores e a insistente concepção não cognitiva da virtude irá tornar o exame da opinião dominante incontornável. Em todo caso, precisamos compreender os princípios básicos do elenchus socrático.

Em seu artigo pioneiro The Socratic Elenchus, Vlastos (1994, p. 1-4) salienta que o método do elenchus socrático atende mais pelo sentido original do verbo 'elénchein' (exame crítico, refutação) e termos gregos associados a 


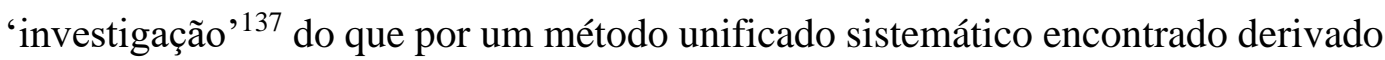
dos primeiros diálogos. Em função de seu caráter diversificado, o método do elenchus está aberto a controvérsias interpretativas. Apesar dessas controvérsias, acreditamos que podemos destacar os seguintes elementos formais do elenchus socrático em linhas gerais ${ }^{138}$ : (1) o estabelecimento de um problema filosófico nos moldes da questão 'o que é $x$ ?' que concerne a realidade ou a natureza da coisa ' $\mathrm{x}$ ', no caso, 'o que é a virtude?'; (2) o exame de uma tese T correspondente a uma tese tradicional dos interlocutores presentes em resposta à natureza do que é ' $\mathrm{x}$ ', como ' a virtude é ensinável', a 'virtude é conhecimento' ou 'as virtudes são diferentes entre si', destinada a responder a natureza do que é ' $x$ '; (3) a avaliação da consistência da tese $\mathrm{T}$ através de suas implicações com outras premissas subordinadas, sendo a, b e c, assumidas anteriormente pelos interlocutores (como 'as virtudes têm qualidades diferentes', 'a coragem provém da natureza'); (4) a eliminação de premissas incompatíveis e a assimilação de premissas compatíveis a $\mathrm{T}$.

Em diversos diálogos platônicos, vislumbramos uma estrutura argumentativa semelhante adotada por Sócrates. No Protágoras, o elenchus socrático assume um papel explícito na revelação das inconsistências da posição do sofista. O exame da opinião dominante também parece depender dos princípios metodológicos do elenchus.

O método socrático assume diversas características singulares em cada um dos diálogos e a pretensão de unificá-los pode resultar em uma generalização grosseira. Mesmo assim, diversos intérpretes destacam que o método do elenchus assume um papel crucial no exame da opinião dominante no Protágoras ${ }^{139}$. Dessa

137 Os termos gregos típicos de 'investigação' correspondem a skopô, diasképsasthai, sundiasképsasthai, episképsasthai, sképsis, dzetéô, eurískô. Em especial, no Protágoras, encontramos abundantes ocorrências desses termos: skopô (9), sképsis (6), dzetéô (7) seguidas, por fim, do verbo elénchein (3).

${ }^{138}$ Sobre as diferentes formulações do método socrático do elenchus, ver VLASTOS, 1994, p. 4-11; KAMTEKAR, 2017, p. 8-12; WOODRUFF, 1986. Mesmo em vista das notáveis divergências interpretativas em torno dos princípios do elenchus socrático, encontramos uma estrutura argumentativa relativamente geral nos Diálogos. Nesse sentido, é notável que as premissas subordinadas problemáticas sejam levantadas pelo próprio Sócrates. Dessa forma, há uma polêmica central sobre a suposta ignorância de Sócrates em torno do 'que é $x$ '. No Protágoras, veremos que Sócrates rejeita sistematicamente impressões pessoais em seu elenchus, o que provavelmente inclui suas próprias impressões pessoais.

139 A estrutura do elenchus do exame da opinião dominante é amplamente reconhecida pelos comenadores. De um lado, Kahn (1996, p. 240) ressalta que a estratégia de Sócrates "has the overall structure of an elenchus, refuting the thesis of the many from premisses they accept"139. De outro lado, Irwin (1995, p. 94) indica que o autor do Protágoras "reassure a critic who is dissatisfied with 
forma, o exame da opinião dominante está inserindo em uma estratégia argumentativa ampla diante da resistência do sofista em reconhecer as inconsistências de sua posição. No entanto, a função específica do elenchus está intimamente ligada à incompatibilidade das modalidades discursivas do filósofo e do sofista.

O exame da opinião dominante acompanha um movimento geral de desgaste e, em última instância, uma "crise" do diálogo entre seus interlocutores ${ }^{140}$. Como observamos anteriormente, a "crise" das modalidades discursivas de Sócrates e Protágoras ocorre especialmente em 334c-338e: por um lado, Sócrates exorta seu interlocutor a adotar a brakhulogía, isto é, a modalidade dos discursos breves marcados por perguntas e respostas pontuais (cf. 329a-c; 334d; 335b-336b), contra a tendência de Protágoras à makrología, a modalidade dos longos discursos cobertos de figuras de linguagem e efeitos retóricos, marcado em seu Grande Discurso, e reiterado ao longo diálogo (334a-c). Durante a "crise" do diálogo, os interlocutores e as figuras presentes, Hípias, Pródico e mesmo Alcibíades, se reúnem a fim de decidir os melhores termos de continuidade do diálogo. A essa altura, Protágoras defende abertamente a 'contenda verbal' (agôna lógon): "se eu acatasse suas exigências - tal como se o contendor (antilégon) exigisse de mim o diálogo (...) não seria melhor do que ninguém.” (335a). Mesmo após estabelecidos os termos da continuidade do debate, o clima hostil permanece até o fim do diálogo. Na realidade, a resistência constante de Protágoras à reciprocidade das virtudes já denuncia a atitude sofística que culminará, em última instância, no exame da opinião dominante.

O desgaste do diálogo entre os interlocutores principais pode ser observado em diversas ocasiões do Protágoras. De um lado, a resistência de Protágoras à tese da reciprocidade está profundamente vinculada à sua defesa intransigente da pluralidade das virtudes. Em seu ponto de vista competitivo, o sofista chega ao

\footnotetext{
the use of the elenchos in the shorter dialogues." e, particularmente, no exame da opinião dominante, "Plato wants to show that the conclusions rest on a fair examination of the merits of the case, as they appear to someone who is not initially disposed to agree with Socrates.".

${ }^{140}$ Cf. LOPES, 2017, p. 170: “(...) Platão está salientando, mediante a voz de outros personagens que observam e avaliam o andamento da discussão, a inclinação agonística assumida pelo diálogo (...) Em resumo, o contexto polifônico peculiar da "crise" do diálogo reafirma de maneiras diferentes a percepção de Protágoras: não se trata de um diálogo qualquer, e sim de um agon logon (...), em que as condições ideias para um diálogo (...) não se verificam.”
} 
ponto de acusar ao fim Sócrates de 'almejar a vitória' (philonikeîn) (360e-361e $)^{141}$. De outro lado, a resistência de Sócrates à makrología o leva a fazer uma crítica à exegese poética sofistica (347b-348a). Nessa ocasião, Sócrates exorta o sofista a abandonar o exame inconclusivo de poetas ausentes ao um exame mais cooperativo: “estabeleçamos uma discussão entre nós por nossa própria conta, aproveitando a oportunidade para testar a verdade e a nós mesmos (tês aletheias kai hemôn autôn)" (348a). Em virtude dos princípios do elenchus, Sócrates mostra que seu interesse no diálogo é apenas em estabelecer uma cooperação conjunta na investigação da virtude, independentemente das opiniões pessoais dos interlocutores. Nesse contexto, o exame da opinião dominante é especialmente emblemático.

Em sentido estrito, a análise da descrição tradicional da akrasia dispensa o diálogo direto com Protágoras e compõe um monólogo de Sócrates em debate com a opinião dominante personalizada. Ora, mas por que Sócrates, que tanto exaltava o diálogo direto investe em um monólogo tão extenso com a 'opinião dominante" grega? Por que dispensar seu interlocutor quando seria mais plausível, por seus próprios princípios do elenchus, interrogá-lo diretamente?

É interessante notar que o próprio Protágoras apresenta certo desprezo em rebaixar o debate ao nível da opinião comum: "devemos examinar a opinião da maioria dos homens, que diz aquilo que vier à cabeça (túchosi)?” (353a). O desprezo do sofista pela opinião dominante é bastante conveniente ao autodistanciamento necessário do elenchus socrático. Mesmo assim, a concepção não cognitiva de virtude do sofista o compromete diretamente com a akrasia tradicional. A partir disso, é necessário esclarecer o significado dramático do papel de espectador de Protágoras diante do exame da opinião dominante.

A introdução da 'opinião dominante' promove dificuldades interpretativas perante o tema central da natureza da virtude. O exame da opinião dominante permite atenuar o ambiente de hostilidade discursiva entre os interlocutores em vista de um combate com um suposto inimigo comum ${ }^{142}$. Ao longo dos Diálogos,

${ }^{141}$ Cf. FREDE, 1992a, p. xvi: "The Protagoras gives us a vivid picture of the practice of dialectic, of how the respondent can be fair or unfair, cooperative or uncooperative, of how the questioner can conceal the aim of his questioning, of the role the audience plays (...)."

${ }^{142}$ Cf. LOPES, 2017, p. 313: "a estratégia argumentativa de Sócrates é bastante arguta e eficiente, visto que consegue criar a impressão de que o alvo de toda a investigação sobre o problema da akrasia é uma terceira parte da discussão, i. e., o interlocutor fictício na figura da "maioria dos homens", criando assim um certo grau de empatia entre eles e apaziguando momentaneamente a resistência de Protágoras às investidas de Sócrates.” 
Sócrates levanta objeções a um interlocutor personalizado e, simultaneamente, estabelece uma simpatia provisória com o interlocutor real na investigação profunda da implicação de suas próprias teses (cf. 330c-331b; 355a-e) ${ }^{143}$. Nessas circunstâncias, Sócrates exorta a um distanciamento crítico de suas próprias teses. Como observamos anteriormente, o próprio elenchus socrático no Protágoras recomenda a adoção de um autodistanciamento dos interlocutores perante suas próprias convicções pessoais para a investigação conjunta do argumento.

O exame da 'opinião dominante' expõe a contradição interna das teses defendidas pelo próprio sofista. Como mostramos, o exame da opinião dominante deriva do tópico central da unidade das virtudes, em especial sobre a unidade entre coragem e sabedoria (353b). Por um lado, a separação da coragem das outras virtudes por conta da necessidade da 'melhor natureza' do agente inviabiliza seu ensino efetivo. Por outro lado, a concepção não cognitiva da coragem entra em claro conflito com a defesa do conhecimento $(352 \mathrm{c}-\mathrm{d})^{144}$. Para todos os efeitos, o argumento contra a opinião dominante demonstra que o ensino da virtude depende da unidade da virtude e conhecimento. Dessa forma, Sócrates exorta Protágoras à defesa do conhecimento contra as posições anteriores do sofista. A partir do elenchus socrático e a hostilidade do diálogo, podemos delinear uma proposta interpretativa mais imparcial do exame da opinião dominante independente da polêmica hedonista/anti-hedonista da posição pessoal de Sócrates ${ }^{145}$.

A controvérsia em torno do hedonismo/anti-hedonismo de Sócrates parece longe de estar encerrada. Sem levar em conta a postura de Sócrates em outros diálogos, o Protágoras nos fornece diversos elementos internos que favorecem ambas as propostas interpretativas. De um lado, todos os interlocutores parecem igualmente comprometidos com o hedonismo e a refutação da akrasia apresentada na passagem 351b-358d. Em especial, é difícil ignorar a insistência de Sócrates em relembrar constantemente o compromisso com os princípios hedonistas até o argumento final da unidade da coragem e sabedoria (cf. 358b; 359e-360a). Ao mesmo tempo, Sócrates claramente se dirige às crenças de Protágoras, da opinião

\footnotetext{
${ }^{143}$ Ver também LOPES, 2017, p. 122-128.

${ }^{144}$ Ver também ZEYL, 1980, p. 267; TAYLOR, 1991, p. 172-173.

${ }^{145}$ Cf. IRWIN, 1995, p. 93: 'Protagoras' misunderstanding of Socrates' methods and aims prevents him from understanding the implications of his own claims about virtue and about himself as a teacher of virtue. (...) Socrates might argue that if Protagoras really claims to teach virtue, and not simply to teach a skill that can be used well or badly, then he must agree with Socrates' view that knowledge is sufficient for virtue."
} 
dominante ou dos demais sofistas, por pronomes e verbos na $2^{\mathrm{a}}$ pessoa (singular e plural), sem aparentemente se comprometer em própria pessoa com os argumentos hedonistas. Além disso, a ironia socrática está dispersa em diversos momentos do diálogo, inclusive na controversa passagem quando Sócrates zomba da divisão de nomes de Pródico (358a-b) e elogia o suspeito ensino sofístico da virtude (357d$358 a)$.

O exame das crenças dos interlocutores não significa necessariamente que o hedonismo e a refutação da akrasia constituam argumentos acessórios e sem validade intrínseca ao tópico central da unidade entre a coragem e a sabedoria. Como vimos anteriormente, os princípios do elenchus de Sócrates no Protágoras nos levam a traçar uma distinção entre a posição teórica e as convicções pessoais dos interlocutores.

A passagem 351b-358d se insere dentro do plano maior da incompatibilidade das modalidades discursivas da atitude filosófica de Sócrates e a atitude sofística de Protágoras. Como observamos, quem está seriamente comprometido em 'vencer o argumento' a qualquer custo é Protágoras. Enquanto isso, Sócrates busca recorrentemente exortar seu interlocutor a fazer uma investigação cooperativa do argumento (lógos) independentemente de suas crenças ou impressões pessoais, com base nos princípios do elenchus (331c-d; 333c-d). A própria polêmica em torno da posição hedonista ou anti-hedonista de Sócrates isoladamente recai mais sobre a perspectiva sofística do ponto de vista particular do interlocutor do que na perspectiva socrática do diálogo filosófico.

Por conta disso, acreditamos que a própria defesa do elenchus socrático no Protágoras independe da determinação da postura pessoal de Sócrates. Ao invés disso, o próprio filósofo indica que o exame da opinião dominante tem o efeito de desvendar as relações entre as teses do sofista e as crenças populares acerca do prazer e do conhecimento.

A vinculação entre a posição de Protágoras e a opinião dominante é adequadamente esclarecida por Sócrates. Como base em uma analogia com o exame médico, Sócrates revela que a conexão das teses do sofista com a opinião dominante perpassa a relação entre o conhecimento o prazer: 
phès), preciso lhe perguntar o seguinte: "Vamos lá Protágoras, descubra-me também esta parte do teu pensamento (tês dianoías apokálupson): qual é a sua posição a respeito do conhecimento (pròs epistémen)? Por acaso a sua opinião (sô̂ dokeî) se assemelha à da maioria dos homens (hósper tô̂s pollô̂s anthrópois) ou se difere dela? (...)". (352a-b)

A analogia com o exame médico esclarece o objetivo central de Sócrates ao empreender o exame da opinião dominante como estratégia de investigação das teses do sofista. Conforme sustenta Taylor (1991, p. 171), a analogia indica que a primeira análise do bem e prazer corresponde ao exame das mãos e da face, enquanto a investigação acerca do conhecimento segue o exame completo do corpo. De outro modo, podemos afirmar que o exame do prazer corresponde à superfície e o exame do conhecimento envolve uma investigação aprofundada sobre os pressupostos em que as teses defendidas por Protágoras se baseiam. Dessa forma, a primeira investigação está subordinada à segunda sob o invólucro do exame das crenças da opinião dominante. Entretanto, a relação entre virtude e conhecimento é mais fundamental pois envolve o tópico central da unidade das virtudes.

O exame da descrição tradicional da akrasia é uma estratégia socrática destinada a exortar Protágoras à defesa do conhecimento contra sua concepção extra cognitiva de coragem (andreía). Por conta de sua vergonha (aischrón), Protágoras concorda enfaticamente com Sócrates a respeito da superioridade absoluta do conhecimento (352c-d). Por diversas ocasiões do diálogo, acompanhamos sua franca derrota na brakhulogia com Sócrates. Em geral, o sofista só aceita prosseguir no debate pelo constrangimento diante de sua distinta audiência de sofistas e seu desejo de assistir ao confronto dialógico (cf. 331e, 333c, 338e, 348b-c) ${ }^{146}$. Novamente, o que move Protágoras a continuar no debate é a possibilidade de 'vencer o argumento' por sua reputação sofística e não a defesa do poder do conhecimento por si mesmo.

Em todo caso, Sócrates consegue enfim uma aliança provisória com Protágoras a fim de realizar o exame das crenças da opinião dominante sobre o

146 Ver também LOPES, 2017, p. 254-255: “O sentimento de vergonha de Protágoras está diretamente associado ao contexto dramático figurado no diálogo, mais especificamente à presença de uma audiência que assiste à performance de ambas as personagens e avalia o desempenho de cada uma. Como o sucesso do "sofista" depende de sua doxa, ele acaba se tornando refém de seu próprio público, a ponto de ser constrangido a continuar dialogando com um interlocutor extremamente hábil, cuja consequência tem sido o desvelamento progressivo de uma inconsistência em suas opiniões relativa à própria matéria que ele se propõe a ensinar aos jovens mediante pagamento, ou seja, a virtude." 
prazer e a akrasia. A concepção da coragem do sofista efetivamente o compromete com a crença tradicional na akrasía (cf. WEISS, 2006, p. 47). Para todos os efeitos, as crenças da opinião dominante estão por detrás das teses fundamentais do sofista durante todo o diálogo.

O exame da 'opinião dominante' configura um momento crucial do debate com Protágoras sobre a unidade das virtudes. De um lado, o argumento contra a descrição tradicional da akrasia revela as implicações radicais dos elementos não cognitivos na virtude e constitui um argumento definitivo em favor da unidade da virtude e conhecimento. De outro lado, a personalização da opinião dominante por Sócrates configura um episódio dramático singular permitindo a união dos interlocutores em torno de um objetivo comum: o exame conjunto da opinião dominante. O problema da akrasia surge da necessidade de defesa do conhecimento contra as convicções populares no poder dos impulsos irracionais sobre a razão.

O exame da descrição tradicional da akrasia no Protágoras constitui a primeira formulação do problema filosófico. Ao invés de constituir um mero argumento auxiliar apenas contra a posição de seus interlocutores (isto é, de forma ad hominem $)^{147}$, a passagem configura uma objeção fundamental sobre a vulnerabilidade do conhecimento moral aos impulsos humanos. Da mesma forma, a 'opinião dominante' não expressa uma visão grosseira da natureza humana, mas integra o homem comum que pode ser submetido, em potência, à experiência da akrasia $^{148}$. De fato, o argumento seria dispensável caso se destinasse apenas a uma visão grosseira da natureza humana, pois está em jogo algo mais fundamental do que apenas um mero artifício ad hominem. Em virtude disso, precisamos compreender melhor como o problema da akrasia é formulado dentro do contexto do Protágoras de Platão. Como veremos a seguir, a refutação da akrasia não

\footnotetext{
${ }^{147}$ Para uma visão mais simples e rudimentar das crenças tradicionais da opinião dominante, ver KAHN, 1996, p. 240; WEISS, 2006, p. 47-63.

${ }^{148}$ Cf. WOOLF, 2002, p. 230: "So it is reasonable to suppose that Socrates (and ultimately Plato) is trying especially hard to construct a position whose refutation will not be liable to the charge of mere ad hoc eristic. Yet there is no reason in principle why a "real" interlocutor should not credibly have established such a position, in conjunction with Socrates, with equal care. It is, after all, the kind of position that many real people are likely actually to have held, or been sympathetic with the presence of the many at least surely indicates that." Ver também CALLARD, 2014, p. 38-40; KAMTEKAR, 2017, p. 44-45. Como vimos, o próprio diálogo Protágoras nos fornece indicações de que o conflito moral típico da akrasia pode ser encontrado em fontes literárias anteriores à Platão, em especial nas tragédias Medéia e Hipólito de Eurípides. Dessa forma, é a própria 'opinião dominante' apresentada no Protágoras inevitavelmente representa uma visão difundida dentro da sociedade ateniense da experiência da akrasia.
} 
envolve a negação do fenômeno, pois Sócrates efetivamente reconhece a 'experiência' ou 'afecção' (páthos/páthema) da akrasia (cf. 352e-353a; 357c). Durante o exame da opinião dominante, a refutação da akrasia envolve inevitavelmente a descrição tradicional ou o relato (lógos) do fenômeno (355c). Em nome do conhecimento, Sócrates se comprometerá a comprovar que a descrição tradicional da akrasia se trata apenas de um engano ou equívoco (pseudés) (353a; 358c). O problema da akrasia no Protágoras formulado no exame das crenças da opinião dominante integra, simultaneamente, uma explícita defesa conjunta de Sócrates e Protágoras em favor do conhecimento moral.

O exame da opinião dominante fornece o contexto dramático-argumentativo em que o problema da akrasia é apresentado no Protágoras. Dessa forma, a análise das crenças da maioria representa pela primeira vez a adesão conjunta dos interlocutores em função do autodistanciamento e do exame dialógico do problema da akrasia. Enfim, devemos ressaltar dois aspectos fundamentais da relevância fundamental do exame da opinião dominante no amlo contexto do debate de Sócrates e Protágoras acerca da natureza da virtude.

Em primeiro lugar, a introdução da 'opinião dominante' permite a Sócrates exortar o sofista a um autodistanciamento perante a sua posição da pluralidade tradicional das virtudes. Como observamos, Protágoras já mostrava hesitação em reconhecer a consistência da reciprocidade das virtudes por conta de teses relacionadas à visão da maioria. A irredutibilidade do sofista em observar as inconsistências de sua posição está fundamentalmente ligada à sua modalidade combativa de discurso e sua incompatibilidade com a modalidade cooperativa defendida por Sócrates. O exame da opinião dominante oferece uma oportunidade singular ao filósofo pois permite convencer Protágoras a aderir ao elenchus socrático contra um suposto inimigo comum, a opinião dominante e a akrasia tradicional. O clima de hostilidade discursiva dá espaço, então, a um clima explícito de mútua cooperação, algo inédito entre os interlocutores. Por isso, a passagem 351b-358d apresenta as condições ideais para uma análise estritamente filosófica do problema da akrasia.

Além disso, a estratégia socrática em vincular a posição de Protágoras à opinião dominante estabelece a relação necessária do problema da akrasia com o tópico central da unidade entre conhecimento e virtude. Desde seu Grande Discurso, Protágoras defendia uma concepção tradicional de educação da virtude 
inevitavelmente dependente de fatores extra cognitivos como o exercício, o empenho e até a melhor natureza (euphyéstatos) (cf. 323d; 327b-c). Por sua insistente resistência à reciprocidade das virtudes, constatamos que sua defesa da educação tradicional da virtude se ampara nas crenças da opinião dominante. Quando Protágoras novamente reitera sua concepção não cognitiva da virtude em função da coragem (351b), Sócrates explora mais profundamente a conexão implícita entre o sofista e a opinião dominante. Em primeiro lugar, o filósofo leva o sofista a reiterar sua posição sobre a 'relatividade do bem' conectando-a em seguida à crença da opinião dominante em 'prazeres maus e dores boas' (333d334c). Em segundo lugar, Sócrates introduz a descrição tradicional da akrasia da opinião dominante levando Protágoras a adotar um autodistanciamento de suas teses anteriores e, pela primeira vez, aderir explicitamente ao elenchus socrático na defesa do conhecimento. Por fim, a estratégia socrática demonstra a negação da descrição tradicional da akrasia e leva, consequentemente, a rejeição da posição anterior do sofista sobre elementos não cognitivos na virtude.

O problema da akrasia antiga inaugurado no Protágoras de Platão constitui um problema filosófico intrinsecamente ligado ao argumento da unidade entre conhecimento e virtude. Na sequência, analisaremos em maiores detalhes o problema do hedonismo e da akrasia tradicional dentro do exame da opinião dominante no diálogo.

\section{3 0 argumento hedonista e 0 absurdo da descrição tradicional da akrasia antiga}

$\mathrm{O}$ argumento hedonista contra a descrição tradicional da akrasia deriva de um debate preliminar entre Sócrates e Protágoras acerca das premissas hedonistas. Em linhas gerais, o argumento compreende três etapas: (1) uma discussão inicial entre Sócrates e Protágoras estabelecendo certas premissas hedonistas e, simultaneamente, esclarecendo a posição do sofista (351b-e); (2) o desenvolvimento do argumento hedonista a partir das crenças da opinião dominante (353c-354d); (3) a redução ao absurdo da descrição tradicional da akrasia (354e356c). As etapas 1-2 abrangem um tipo de hedonismo ético ligado a relação 
intrínseca entre Protágoras e a opinião dominante. A etapa 3 procede do hedonismo ético e revela a inconsistência da akrasia tradicional.

Como essas três etapas são estreitamente interligadas, devemos nos concentrar primeiramente sobre o hedonismo das etapas 1-2 nessa seção. Sendo assim, seguiremos a discussão inicial de Sócrates e Protágoras de modo a vislumbrar o caminho que leva em direção à necessidade do exame da opinião dominante.

Na sequência original do diálogo, a alegação do sofista de que a coragem depende da natureza humana instaura uma brusca mudança ao debate em torno do prazer. A breve discussão preliminar de Sócrates e Protágoras permite vislumbrar o caminho por onde seguem os argumentos socráticos. Em 351b-c, Protágoras concorda enfaticamente com as três primeiras premissas mas diverge quanto à conclusão derivada:

(1) Socr. - Você afirma, Protágoras, que certos homens vivem bem (eu dzeîn), e outros mal (toús kakôs)? Ele disse que sim; (2) Sócr. - Porventura, parece-lhe que um homem viveria bem, se levasse uma vida aflitiva e dolorosa (ề anióménos te kaì odunómenos)? Ele respondeu que não. (3) Sócr. - E se tivesse vivido aprazivelmente (ê̂ hedéos bioùs) ao chegar ao termo da vida (tôn bíon teleutésein)? Não lhe parece que ele teria vivido bem? Prot. - Pelo menos a mim parece - disse ele. (4) Sócr. Portanto, viver de modo aprazível é bom (agathón) enquanto viver de forma não aprazível é mau (kakôn). (351b-c) $)^{149}$

Nessa passagem, Sócrates demonstra a Protágoras que a admissão das premissas 1-3 leva a assumir, por necessidade lógica, a premissa 4 . O conjunto dessas 4 premissas já constitui por si só um tipo de hedonismo. Como indica Zeyl (1980, p. 252-253), o argumento estabelece que o prazer não é só um critério necessário mas também um critério suficiente na classificação da vida boa e da vida má. As premissas 2-3 constituem sentenças condicionais com base na conjunção "se (ei)" $" 150$. Enquanto a premissa 2 estabelece que ter dor e sofrimento na maior parte da vida é um critério suficiente para distinguir uma vida má da vida boa,

\footnotetext{
${ }^{149}$ É importante notar a presença dos verbos na segunda pessoa do singular (légeis, kaleîs) fortalecem a impressão de que as perguntas visam unicamente esclarecer as posições de Protágoras. ${ }^{150}$ A presença da conjunção ei no modo optativo marca o caráter condicional das premissas socráticas.
} 
simultaneamente, a premissa 3 assume que o prazer é um critério suficiente na classificação de uma vida realmente boa em sua completude ${ }^{151}$.

O assentimento de Protágoras com o argumento 1-4 parece lhe comprometer com crenças supostamente comuns na cultura grega acerca da eudaimonia, isto é, o sucesso pleno de durante toda a vida. A expressão 'ê̂ zên' (viver bem) possui uma clara relação semântica com a palavra eudaimonía. Por esses parâmetros, o argumento em si envolve um tipo de teoria hedonista eudaimonica segundo a qual o prazer é suficiente para determinar, com objetividade, se uma vida é inteiramente boa ou má. A interdição de Protágoras, no entanto, indica que a conclusão 4 está longe de ser uma posição unanimemente aceita pelos interlocutores.

A sequência do diálogo entre Sócrates e Protágoras revela uma explícita divergência. Contra Sócrates, Protágoras impõe uma restrição às premissas 1-4: "contato que (eíper) se viva comprazendo-se de coisas nobres (tô̂s kaloîs)" (351c). Como observamos, o filósofo vincula essa proposição na sequência à opinião dominante que classifica de "más certas coisas aprazíveis, e de boas, certas coisas dolorosas (hedéa kakà kaì aniarà agathá)" (351c-d). De fato, o sofista julga que a posição de Sócrates é "simples (haplôs)", assumindo uma posição alinhada às crenças da maioria (351c). Mesmo assim, Sócrates insiste que Protágoras deve assumir a tese hedonista: "indago-lhe se o próprio prazer não é bom (tèn hedonèn autèn ei ouk agathón estin).” (351e). Tudo indica que o argumento hedonista levaria o sofista a manter a consistência com as premissas $1-4^{152}$, mas ele acaba tratando a proposição como uma posição do próprio Sócrates sem analisá-la por si mesma. Como vimos, a atitude de Protágoras está em sintonia aqui com seu modo discursivo

\footnotetext{
151 Taylor (1991, p. 164) não acredita que as proposições 1,2 e 3 se comprometem com o hedonismo em estrito senso. Apesar de conceder que o conjunto 1 a 3 possibilite a avaliação de uma vida por um critério independente do prazer, este critério 'não permite uma vida prazerosa ser julgada pior que uma vida dolorosa por qualquer outro critério'. Como é muito difícil imaginar uma vida sem prazeres ou dores, poderíamos supor que uma vida em que os prazeres e dores sejam equivalentes pode ser considerada boa por alguma outra razão. No entanto, 1, 2 e 3 não admitem essa possibilidade (ZEYL, 1980, p. 265). De outro lado, 1, 2 e 3 são apresentadas por Sócrates e admitidas por Protágoras sem qualquer questionamento. Além de Zeyl, Weiss (2006, p. 48-49) e Annas (1999, p. 169) também reconhecem que tais premissas já constituem uma forma de hedonismo.

${ }^{52}$ É necessário salientar, no entanto, que não acreditamos na perspectiva anti-hedonista do comentador. Segundo Zeyl (1980, p. 254-260), Sócrates está tentando 'tomar vantagem' da teoria hedonista para fazer com que Protágoras reconheça a unidade entre conhecimento e virtude. Nós realmente concordamos que Sócrates vê no hedonismo uma forma de sustentar a unidade entre conhecimento e virtude. Na perspectiva socrática, a única forma de garantir o ensino das virtudes defendido por Protágoras é admitir a unidade entre o conhecimento e a virtude. Como o próprio sofista insiste em não reconhecer a consistência desse argumento, o filósofo recorre à uma tese hedonista por supor que um tipo de hedonismo é compatível com o argumento da unidade entre conhecimento e virtude.
} 
do embate agonístico no diálogo. Por essa razão, o exame da opinião dominante torna-se uma estratégia fundamental de Sócrates que leva ao distanciamento necessário perante o argumento hedonista.

A despeito da relação velada das teses do sofista e as crenças da maioria, encontramos claros indícios de que ambos os interlocutores rejeitam o hedonismo eudaimonista apresentado por Sócrates. O hedonismo eudaimonico não é propriamente intuitivo ou universalmente aceito pela sociedade ateniense. Diante dessas circunstâncias, o hedonismo não pode ser assumido de antemão por Sócrates mas deve ser adequadamente desenvolvido como um argumento hedonista ${ }^{153}$. Assim, o argumento hedonista compreende uma revisão das próprias crenças comuns em 'prazeres maus e dores boas'. Como observamos anteriormente, Protágoras já havia expressado uma posição similar na tese sobre a 'relatividade do bem' (333e-334c). Desse modo, Sócrates explora a relação entre o sofista e a maioria para extrair de Protágoras conclusões mais definitivas de sua posição sobre o conhecimento. A apresentação da descrição tradicional da akrasia convence o sofista, pela primeira vez, a ficar ao lado de Sócrates e demonstrar a superioridade do conhecimento contra sua própria posição anterior sobre os elementos não cognitivos da coragem. Em todo caso, o exame da descrição tradicional da akrasia depende do hedonismo implícito nas crenças da opinião dominante. Dessa forma, retornaremos em seguida ao exame das crenças de prazer e dor da opinião dominante.

O monólogo investigativo de Sócrates com a opinião dominante segue do acordo firmado entre o filósofo e o sofista na defesa do conhecimento (352b-e). Como indicamos anteriormente, o exame da opinião dominante exprime o dilema de Protágoras diante da contradição inerente às suas próprias teses: conceder a "submissão do prazer (hedonês hettâsthai)" da akrasia ou revisar crença em 'prazeres bons e dores más' relativas às crenças tradicionais? Em nome da defesa

\footnotetext{
${ }^{153} \mathrm{O}$ que classificamos aqui de 'argumento hedonista' basicamente abrange a análise das crenças da opinião dominante relativas à descrição tradicional do fenômeno: o exame sobre as concepções de prazer e dor (I) e a redução ao absurdo da akrasia (II). Como mostraremos em seguida, o primeiro estágio do argumento acaba atribuindo um tipo de hedonismo à opinião dominante em um formato estritamente ad hominem, isto é, dirigido apenas às suas crenças mais fundamentais. No segundo estágio, todavia, o argumento ultrapassa as crenças da maioria e se volta especificamente ao fenômeno em si mesmo.
} 
do conhecimento, os interlocutores se unem contra um inimigo comum, a descrição tradicional da akrasia.

A partir disso, Sócrates toma a dianteira do exame enquanto Protágoras fica em segundo plano acompanhando e verificando a consistência do argumento hedonista contra a akrasia. Como vimos, o filósofo constrói a personalidade da opinião dominante ao elaborar um argumento hedonista alinhado à sua tese hedonista anterior. Durante o diálogo com a maioria, ele irá mostrar que as crenças comuns de 'prazer' (hedoné) e 'dor' (lúpe) estão equivocadas (353-354e). O exame socrático tem o propósito de demonstrar os pressupostos hedonistas sob os quais se fundamentam as crenças tradicionais em 'prazeres maus' e 'dores boas'.

A investigação acerca dos 'prazeres maus' deriva diretamente de um caso específico de akrasia, a 'submissão ao prazer' (353c). Para a maioria, os homens agem contra sua deliberação racional justamente por causa do que se consideram ser 'prazeres maus' (hedéa kaká). Ora, se esses prazeres se referem à coisas tais como "bebida (póton)", "comida (síton)" e "sexo (aphrodisíon)"154, então a classificação de 'maus' não se deve propriamente aos seus prazeres intrínsecos, mas às "doenças (nósous)" e "miséria (penía)" que podem ocasionar posteriormente (353c-d). Por isso, o juízo comum da maioria, na realidade, leva em conta os efeitos resultantes dessas coisas ao invés dos "prazeres imediatos (hedonês parachrêma)" (353e). Segundo os termos da maioria, o critério por debaixo da classificação de certos prazeres 'maus' prova, na realidade, que tais prazeres são simplesmente dores. Em vista disso, Sócrates propõe uma nova classificação dos prazeres visando corrigir os juízos da maioria:

afirmam que, por vezes, o próprio prazer é mau (autò tò chaíren kakòn eînai), quando ele impede (aposterêi) a fruição de prazeres maiores do quantos eles contém (autò échei), ou quando proporciona dores maiores do que os prazeres encerrados nele (tôn ên autô hedonôn). (354c)

Os termos 'dor' (lúpe) e 'mau' (kakón) são apenas nomes diferentes para as mesmas coisas. O erro da crença comum em 'prazeres maus' está efetivamente

\footnotetext{
${ }^{154}$ Cf. LIDDEL-SCOTT, 1996. A palavra 'aphrodision' se refere, literalmente, às 'coisas sexuais'. Como mencionamos anteriormente, a termo português 'amor', adotado na tradução de Carlos Alberto Nunes, não contempla as conotações sexuais do sentido original do termo grego. Nas traduções de língua inglesa se sugere o termo 'sexo' que julgamos ser mais apropriado para o que está sendo designado pela palavra em grego.
} 
fundado sob um critério comparativo entre prazeres e dores segundo a "imediatez (parachrêma)" e suas 'consequências', ou melhor, à sua "finalidade (télos)". Sob a crença comum, existem pressupostos relacionados aos termos parachrêma e télos que expressam uma relação temporal dos prazeres e dores. Por um lado, o termo parachrêma designa literalmente o que 'está a mão' ou ao nosso alcance iminente ${ }^{155}$. Por outro lado, o termo télos indica o acabamento ou finalidade pela qual efeitos são produzidos ou realizados a partir de certas coisas. Sem dúvida, a dimensão da experiência humana deve ser pressuposta aqui para estabelecer a relação temporal dos prazeres e dores ${ }^{156}$.

A partir desse critério comparativo, constatamos que o juízo comum designa certas coisas de 'prazeres maus' apenas por causa das dores maiores que advém de seus prazeres intrínsecos. Na realidade, a relação temporal do prazer esconde um outro critério comparativo de classificação das coisas: o critério quantitativo de prazer $e$ dor. Em função do critério quantitativo, essas mesmas coisas são consideradas 'más' (kaká) efetivamente em vista de dores a longo prazo. Seguindo esses pressupostos hedonistas, as 'coisas más' (kaká) não são nada mais que 'dor' (aniará). Na sequência, Sócrates aplica o mesmo parâmetro de análise na crença em 'dores boas'.

Dando prosseguimento ao exame, Sócrates aplica o parâmetro comparativo à crença comum em 'dores boas'. Em ambos os casos, verificamos os mesmos pressupostos hedonistas. A opinião dominante considera que "exercícios físicos (gymnásia)", "expedições militares (strateías)" e "tratamentos médicos (tôn iatrôn therapeías)" são exemplos típicos de “dores boas’ (354a). Segundo Sócrates, o motivo dessas coisas serem consideradas boas não se deve a suas dores intrínsecas, mas aos seus efeitos posteriores: "saúde (hugíeaî)", "bem-estar físico (euexíai tôn somatôn)", "salvação da cidade (tôn póleon sotería)", "domínio sobre os outros (allôn archaì)" e "riqueza' (ploûtoi)" (354b) $)^{157}$. Por isso, a opinião dominante leva

${ }^{155}$ Cf. LIDDEL-SCOTT, 1996. Em especial, é importante lembrar que Sócrates em Rep. VIII-IX se refere à inclinação natural do elemento apetitivo por 'philochrématon' (amor ao dinheiro ou, de forma geral e, mais literalmente, aos bens materiais) (553c; 581a). De qualquer forma, o termo chremata se refere invariavelmente às posses materiais ou os objetos de desejo que costumamos alcançar com nossas próprias mãos.

${ }^{156}$ Cf. MUNIZ, 2011, p. 69: "O horizonte da expectativa que tensiona o presente da deliberação deve ser determinado, como supomos, pelo passado da experiência dos prazeres e dores." Ver também SINGPURWALLA, 2006, p. 253-254.

157 Taylor (1991, p.175) observa que o homem comum, na visão de Platão, não traça nenhuma distinção entre um hedonismo egoísta, voltado para o bem de interesse próprio, e um hedonismo moral voltado para o bem dos outros. Exemplos de prazeres que proporcionam 'saúde e boa condição 
em conta os resultados de prazer na classificação das 'dores boas' e não propriamente a dor imediata. Segundo o juízo comum, portanto, 'dores boas' são efetivamente prazeres. Em vista disso, Sócrates estabelece uma nova reavaliação do juízo comum dessa vez em relação à 'dor':

Vocês não chamam de bom, por vezes, o próprio sofrimento (tò lupeîsthai agathòn), quando ele liberta (apallátte) de dores maiores do que quantas ele contém (tôn en autôn ousôn), ou proporciona (paraskeuádze) prazeres maiores do que dores? $(354 \mathrm{~d})$

Assim como na passagem anterior, Sócrates recorre novamente ao parâmetro comparativo colocando em xeque a crença em 'dores boas'. De acordo com a opinião dominante, o 'bem' (agathón) das dores envolve as dores sofridas no momento e os prazeres subsequentes. Segundo o critério quantitativo, as 'dores boas' não seriam nada mais do que os prazeres maiores ou as dores menores colaterais. Por coerência lógica, a opinião dominante precisa assumir que as coisas boas nada mais são do que prazeres. O juízo comum concorda, então, que as 'dores boas' são simplesmente prazeres. Com a reavaliação das crenças da opinião dominante, Sócrates não só revela que o juízo comum de 'prazeres maus' e ‘dores boas' é equivocado mas também que, paradoxalmente, se caracteriza por um tipo de hedonismo. Em linhas gerais, o argumento hedonista, até esse estágio ao menos, toma a clara forma de um elenchus socrático.

A revelação dos pressupostos hedonistas implícitos da opinião dominante permite a Sócrates retomar a tese hedonista esboçada anteriormente. Dessa forma, existe uma linha de continuidade da tese hedonista socrática anterior ao argumento hedonista da opinião dominante. Para entendermos melhor tal continuidade, devemos retomar as premissas hedonistas de 351b-e:

Eu me refiro (egò gàr légo) $)^{158}$ ao seguinte: enquanto aprazíveis (kath' hò hedéa estín), elas não são, enquanto tais, boas,

física' são apresentados conjuntamente com os que proporcionam 'salvação da cidade e riqueza' (354a-b), sem supor qualquer tipo de conflito entre ambos. De fato, o argumento não parece prever o conflito moral entre o bem de interesse próprio e o bem proporcionado aos outros de tal forma que o hedonismo apresentado aqui não parece ser compatível com o utilitarismo moderno.

${ }^{158}$ A presença do pronome egó em grego tem um uso enfático. Os intérpretes hedonistas e anti hedonistas tem disputado veementemente a intenção de Sócrates ao enunciar egó. Dessa forma, Taylor (1991, p. 166), por exemplo, afirma que a sentença é uma pergunta retórica e pode ser utilizada como uma confirmação de que Sócrates está defendendo uma tese em própria pessoa. De 
desconsiderando futuras consequências que lhes sejam diversas (mè eí ti ap' autôn apóbesetai)? E inversamente, as coisas dolorosas não são, por sua vez, da mesma forma más, na medida em que são dolorosas (kath' hóson aniará, kakà)? (351c)

A partir do argumento hedonista, podemos esclarecer as premissas hedonistas anteriores de Sócrates. O argumento hedonista fornece os alicerces fundamentais para explicar a tese hedonista de Sócrates. De fato, as premissas socráticas abrem espaço a controvérsia interpretativa, principalmente, em relação à sentença "desconsiderando futuras consequências que lhes sejam diversas". Ora, estaria Sócrates endossando um hedonismo moderado, admitindo que outras qualidades além de prazer e dor contribuem na avaliação do que é bom ou mau, ou um hedonismo forte, segundo o qual 'prazer' e 'dor' determinam o que é bom ou mau em sentido absoluto? ${ }^{159}$. Ao mantermos o fio condutor do argumento hedonista não corremos o risco de seguir hipóteses interpretativas inviáveis. Como observamos, as crenças comuns em 'prazeres maus' e 'dores boas' estão equivocadas pois escondem implicitamente uma relação temporal de prazer. Em oposição a isso, a tese hedonista socrática assegura que o 'prazer' e a 'dor' sejam encarados por si mesmos abstraindo de quaisquer outras características.

Em linhas gerais, há duas teses fundamentais que se encontram presentes no hedonismo esboçado aqui: (a) a tese valorativa do prazer - segundo o qual o prazer e a dor por si mesmos são valorizados, respectivamente, como o bem e o mal; (b) a tese de identidade de referência - 'prazer' (hedoné) e 'bom' (agathón) se referem às mesmas coisas tal como 'dor' (lúpel aniará) e 'mau' (kakón). A seguir, pretendemos explorar sucintamente algumas propostas interpretativas que esclarecem os pressupostos desse tipo de hedonismo.

outro lado, Zeyl (1980, p. 266) acredita que a sentença apenas introduz uma questão direta e não é uma proposição indireta. Como mostramos anteriormente, somente Protágoras concebe que a tese hedonista é uma posição do próprio filósofo por falhar em compreender a forma dialógica de argumentação defendida por Sócrates. Dessa forma, sustentamos com Julia Annas (1999, p. 169170) que a presença do egó enfático apenas demonstra que o filósofo é o único a discutir a tese quando, na realidade, quem deveria estar mais interessado em discuti-la deveria ser o próprio sofista. ${ }^{159}$ Para atenuar a força do argumento de Sócrates, Vlastos (1969, p. 76) sugere que o filósofo defende um hedonismo moderado: 'todos os prazeres são bons e todas as dores são más' (ver também KAHN, 2006, p. 50-51). De acordo com Vlastos, Sócrates ainda poderia conceder que nem todas as coisas boas são prazeres e nem todas as coisas más são dores. No entanto, como mostra Taylor (1991, p. 168-169), esse tipo de hedonismo pode implicar na própria crença em 'prazeres maus' e 'dores boas', o que tornaria a posição de Sócrates muito semelhante à posição da opinião dominante (Cf. GOSLING e TAYLOR, 1982, p. 47-48). Como essa proposta interpretativa enfraquece os argumentos apresentados pelo filósofo, na medida em que atribuí a ele uma confusão em seus propósitos, concordamos com Taylor que o melhor seja descartá-la. 
Em primeiro lugar, a tese hedonista estabelece a identidade ontológica entre prazer e o bem. Como vimos anteriormente, 'bem' e 'prazer' e, por outro lado, 'dor' e 'mal' possuem a mesma referência. Em nenhuma ocasião, a tese hedonista estípula uma tese moderna de identidade semântica segundo a qual o 'prazer' e a 'dor' atendem pelo mesmo significado. A força da tese hedonista reside na identidade absoluta entre prazer e bem, isto é, a referência a uma única e mesma 'coisa'. De fato, o próprio Sócrates exorta o sofista a refletir se "o próprio prazer não é bom (hedéa estín ei ouk agathá)" (351e) ${ }^{160}$. A tese hedonista socrática estabelece assim a permutabilidade dos termos 'bem' e 'prazer' e também de 'dor' e 'mal', tratando-os como termos intercambiáveis. Além disso, a tese hedonista também se ampara na relação fundamental com a eudaímonia grega como vimos nas três premissas hedonistas iniciais da discussão entre Sócrates e o sofista.

Em segundo lugar, a tese hedonista se apoia na aspiração grega à eudaimonia, isto é, na satisfação plena da vida como um todo. Como vimos, a tese hedonista determina que os únicos critérios de classificação de uma vida boa ou uma vida má são, respectivamente, prazer e dor. Seguindo esses parâmetros, os mesmos critérios válidos na classificação da vida humana são transferidos também às coisas humanas, isto é, as ações deliberadas. Com efeito, Sócrates estabelece a seguinte conclusão pelo exame da opinião dominante: "vocês não perseguem (diókete) o prazer como sendo bom (hos agathòn), ao passo que evitam (pheúgete) a dor, como sendo má (hos kakón)?” (354c). O hedonismo assume um caráter valorativo, isto é, o 'prazer é $o$ bem' e a dor é $o$ mal' segundo o qual o 'prazer' e a 'dor' constituem o que é valorizado, respectivamente, como bom e mau na própria deliberação racional humana. As premissas hedonistas de Sócrates constituem um hedonismo ético em que 'prazer' e a 'dor' são os valores fundamentais que orientam toda a ação humana. Alguns intérpretes enxergam aqui um hedonismo psicológico, mas mostraremos adiante as implicações controversas dessa interpretação psicológica do hedonismo ${ }^{161}$. A partir de (a) e (b), Sócrates já pode estabelecer a conexão entre a eudaimonia e o juízo bom e mau.

\footnotetext{
${ }^{160}$ Cf. 355b: "Que esse argumento é ridículo, ficará evidente, se não empregarmos vários nomes ao mesmo tempo - aprazível e doloroso, bom e mau - e referirmos a eles mediante dois nomes, visto que concernem manifestamente a duas coisas apenas: no primeiro momento, mediante bom e mau, e no segundo momento, por sua vez, mediante aprazível e doloroso."

${ }^{161}$ Em verdade, a maioria dos comentadores defende que o hedonismo exposto por Sócrates nessa passagem abrange tanto uma tese ética quanto uma tese psicológica. Embora concordemos com a classificação do hedonismo ético, veremos adiante que o 'hedonismo psicológico' constitui uma tese
} 
A tese hedonista de Sócrates contribui para estabelecer uma relação intrínseca entre a eudaimonia e a deliberação racional pelo bem. De acordo com a correspondência entre 'bem' e 'prazer', poderíamos endossar as seguintes conclusões sobre a deliberação humana: (a) todas as ações deliberadas visam o prazer como um bem; (b) todas as ações deliberadas evitam a dor como um mal (c) toda ação deliberada é realizada em função das crenças pelo bem, isto é, a melhor alternativa de ação. Para diversos comentadores, o conjunto dessas premissas constitui o princípio do eudaimonismo psicológico ${ }^{162}$. A partir do eudaimonismo psicológico, portanto, seria possível derivar o paradoxo expresso em (c) contra a crença de que é possível agir contra o que se julga melhor a fazer, isto é, a akrasia.

Entretanto, Protágoras não deixa que Sócrates prossiga além das três premissas iniciais impedindo a derivação do hedonismo e, consequentemente, do eudaimonismo psicológico. Nessa medida, o filósofo acaba introduzindo a opinião dominante que rejeita integralmente o eudaimonismo psicológico por conta da descrição tradicional da akrasia. Por essa razão, Sócrates não pode assumir de antemão nem o hedonismo ético e nem o eudaimonismo psicológico. A posição intransigente do sofista lhe obriga a fazer uma demonstração de ambas as teses no exame das crenças da opinião dominante.

$\mathrm{O}$ argumento hedonista tem elementos típicos de um elenchus socrático. Até esse estágio, Sócrates se concentrou em examinar estritamente as crenças da opinião dominante sobre prazer e dor constatando que suas crenças em 'prazeres maus' e 'dores boas' se fundamentam em princípios hedonistas.

Dessa forma, temos aqui apenas a atribuição de um hedonismo ético à opinião dominante sem estipular nenhuma conclusão contundente sobre a plausibilidade do argumento hedonista em si mesmo ou sobre o que ocorre na akrasia. Entretanto, o argumento de redução ao absurdo da descrição tradicional da akrasia pretende ir mais longe. A redução ao absurdo da descrição tradicional vai além da mera análise acerca da consistência interna entre as crenças do interlocutor,

muito forte que comprometeria o argumento socrático contra a akrasia. Ao invés disso, mostraremos adiante que Sócrates constata apenas um fato sobre a motivação humana universal ao bem sem explorar propriamente a psicologia humana, tal como vemos, por exemplo, na República IV. Para a polêmica em torno do hedonismo psicológico, ver SANTAS, 1979, p. 206- 207; GOSLING \& TAYLOR, 1982, p. 48-50; RUDEBUSCH, 1999a, p. 22; PRICE, 1995, p. 15; NUSSBAUM, 2009, p. 100-101; WEISS, 2006, p. 47-63.

162 Para a formulação do eudaimonismo psicológico, ver IRWIN, 1995, p. 83; 52-53; SANTAS, 1979, p. 209. Ver também PENNER, 1997, p. 128-129. 
típica do elenchus, para uma investigação mais peculiar sobre a consistência das crenças e a ação. Nesse sentido, o argumento de redução ao absurdo pretende demonstrar que a descrição tradicional do fenômeno não corresponde ao fenômeno da akrasia em si mesmo. Para vislumbrarmos isso, precisaremos analisar então a redução ao absurdo da descrição tradicional da akrasia.

A redução ao absurdo da descrição tradicional da akrasia está intrinsecamente ligada ao hedonismo implícito da opinião dominante. Como observamos, esse hedonismo se sustenta em dois princípios básicos: (a) 'prazer' e 'bom' se referem às mesmas coisas assim como 'dor' e 'mau', constituindo apenas nomes diferentes da mesma referência; (b) a deliberação humana busca o prazer como o bem e repele a dor como o mal; (c) em uma dada situação, se $P$ considera que $x$ é mais prazeroso (ou melhor) do que $y, P$ escolhe $x$ em vez de $y^{163}$. No entanto, essas conclusões são válidas apenas enquanto dirigidas às crenças de prazer e dor da opinião dominante. $\mathrm{O}$ argumento de redução ao absurdo dá um passo adiante revelando a inconsistência da descrição tradicional e o fenômeno da akrasia tradicional.

A princípio, o argumento de redução ao absurdo parece relativamente simples mas está aberto à uma extensa controvérsia interpretativa. Na sequência, Sócrates retorna novamente à 'submissão ao prazer' da akrasia tradicional, analisando duas versões alternativas do fenômeno a partir dos princípios hedonistas anteriores. Por meio da substituição de nomes, Sócrates irá oferecer três formulações diferentes do fenômeno:

[F1] o homem, mesmo sabendo (gignóskon) que as coisas más são más (kakà estin), ainda assim o pratica porque é submetido pelo prazer (hypò tôn hedonôn) ${ }^{164}$ (355a-b) (...) [F2] o homem,

\footnotetext{
${ }^{163}$ Aparentemente, Davidson (2001a, p. 23) subscreve a um princípio semelhante em 'How is Weakness of Will Possible?'. No entanto, mostraremos que há uma sutil diferença na formulação de Davidson: Sócrates assume que as alterativas de ação estão efetivamente disponíveis ao agente na akrasia, enquanto Davidson alega que apenas a crença da disponibilidade das alternativas de ação é suficiente na fraqueza de vontade. Novamente, essa distinção crucial demarca as diferenças entre a perspectiva interna da fraqueza de vontade contemporânea em oposição à perspectiva objetiva da akrasia antiga presente em Platão e Aristóteles.

${ }^{164} \mathrm{Na}$ realidade, Sócrates passa nessa primeira formulação do plural tôn hedonôn para o singular hedonês. Em vista disso, certos intérpretes, como Vlastos (1969, p. 81-82) e Gosling \& Taylor (1982, p. 56-57), alegaram que a substituição de Sócrates aqui é ilegítima. Contudo, se recordamos dos princípios admitidos do hedonismo, como Sócrates reconhece em $355 \mathrm{~b}$, a substituição de nomes permite que 'submissão aos prazeres' e 'submissão ao prazer' correspondam exatamente a mesma formulação do fenômeno. Por isso, optamos por manter o singular 'prazer' para efeitos de formulação lógica.
} 
mesmo sabendo que as coisas más são más, ainda assim as pratica (...) porque é submetido pelo bem (hettómenos ${ }^{165}$ hypò tôn agathôn) (355c) (...) [F3] o homem, mesmo sabendo que as coisas dolorosas são dolorosas (aniará estin), ainda assim o pratica submetido pelo prazer (hettómenos hypò tôn hedéon) $(355 \mathrm{e}-356 \mathrm{a})$

Dessa forma, Sócrates toma como parâmetro a formulação comum [F1] e, com a substituição de nomes, faz uma análise detalhada das crenças da maioria em [F2] e [F3]. O argumento de redução ao absurdo prosseguirá, portanto, em dois estágios: no primeiro estágio, o argumento coloca em xeque a descrição da akrasia em termos de 'bem' e 'mal' (354e-355e), enquanto no segundo estágio, os interlocutores tratam da descrição alternativa do fenômeno em termos de 'prazer' e ‘dor' (355e-356a). A princípio, o argumento apresenta efetivamente a estrutura lógica clássica de uma redução ao absurdo das crenças da opinião dominante. Em termos dramáticos, no entanto, Sócrates classifica o 'argumento' ou 'relato' (lógos) da opinião dominante de géloion que significa, mais propriamente, 'ridículo' do que 'absurdo'166. De qualquer forma, o argumento como um todo visa mais fundamentalmente persuadir a opinião dominante e Protágoras do que apenas estabelecer uma mera inconsistência lógica.

A redução ao absurdo da akrasia compreende assim ambos os estágios do argumento e não podem ser tratados de forma isolada (cf. TAYLOR, 1991, p. 85). Todavia, é necessário não perder de vista que nenhum dos estágios toma a redução ao absurdo como uma obviedade. Cada um dos estágios apresenta um esclarecimento específico sobre o que exatamente é o absurdo em [F2] e [F3 ${ }^{167}$ : no primeiro estágio, Sócrates introduz a figura de um interlocutor "insolente (hybristès)" declarando sobre [F2] que "o argumento de vocês é ridículo (geloîon tòn lógon)"; no segundo estágio, Sócrates aplica os mesmos princípios dessa vez a

\footnotetext{
${ }^{165}$ Como mostramos anteriormente, termos como 'hettómenos' e 'kratoúmenos' compõem o típico vocabulário do conflito interno da akrasia grega registrado em referências anteriores a Platão.

${ }^{166}$ Cf. LIDDEL-SCOTT, 1996. Provavelmente, a exposição pública ao ridículo da crença da maioria na akrasía é uma exigência dramática do argumento dado que a opinião dominante precisa reconhecer que a descrição tradicional é inconsistente e, ao mesmo tempo, deve buscar com o auxílio de Sócrates outra descrição para o fenômeno. Ver também DENYER, 2008, p. 189: "Laughter can be a mark of hýbris (...) because the essence of that offence, as any bodily harm, is the gratuitious belittlement of the victim." É notável que o próprio Sócrates relembra a opinião dominante que ela está comprometida em reconhecer a descrição alternativa do fenômeno em função da constatação anterior da ridicularidade de sua própria descrição da akrasia (357d).

${ }^{167}$ Devo o esclarecimento da complexidade do argumento sobretudo ao artigo The Ridicoulessness of Being Overcome by Pleasure (2006) de Wolfsdorf que constitui a mais exaustiva análise da estrutura lógica da redução ao absurdo da akrasia tradicional.
} 
[F3], mas visa esclarecer a inconsistência ao eliminar uma objeção em vista da distinção temporal de prazeres. Como observaremos adiante, a explicação de [F3] já abre o caminho para a própria formulação socrática da akrasia. A fim de analisarmos ambos os estágios do argumento (354e-356c), devemos observar brevemente algumas das propostas interpretativas oferecidas a essa passagem.

É frequente intérpretes recorrerem a argumentos externos ou elementos posteriores no intuito de preencher 'lacunas' do argumento do absurdo da akrasia. Em geral, tais propostas costumam isolar os estágios do argumento original e classificá-los de acordo com os princípios que supostamente expõem a inconsistência fundamental do relato da maioria. Dessa forma, nem todos os intérpretes reconhecem um argumento estritamente lógico de redução ao absurdo, optando por localizar a inconsistência fundamental em etapas posteriores. Vejamos, então, algumas formulações do argumento do absurdo adiante:

Vlastos (1969) /Penner (1997): 'ninguém escolhe o que é pior com conhecimento $^{\prime 168}$

Taylor (1991): 'o acrático não tem conhecimento de que sua ação é má’; (autocontradição) $^{169}$

Nussbaum (2009) /Zeyl (1980): 'escolher a menor quantidade ao invés da maior quantidade de bem' porque é 'submetido pela menor quantidade de bem' (autocontradição) $)^{170}$

\footnotetext{
${ }^{168}$ É importante salientar que há notáveis discordâncias entre Penner (1997) e Vlastos (1969). Para Vlastos (1969, p. 80-84), a redução ao absurdo está concluída já no primeiro estágio com a autocontradição expressa na sentença 'tendo conhecimento (knowingly) de que Y é pior, o agente o escolhe por seu desejo do (bem)'. Para Penner (1997, p. 126-127), no entanto, o argumento só fica concluído quando Sócrates postula a instabilidade da crença e a estabilidade do conhecimento com base na passagem posterior 356c-357e. Apesar das formulações similares em função do conhecimento, o próprio Penner (Ibid., p. 117-126) indica que a interpretação de Vlastos depende do princípio estabelecido no paradoxo posterior (358b-d), favorecendo assim o poder da crença em detrimento da tese original socrática do poder do conhecimento. Como veremos a seguir, essa leitura derivada do paradoxo socrático foi influenciada pela interpretação de Santas (1979). Entretanto, Penner antecipa a formulação socrática do fenômeno no argumento em que Sócrates precisa apresentar uma redução ao absurdo de acordo com os princípios do hedonismo ético estabelecidos anteriormente. Como veremos a seguir, a redução ao absurdo não deriva propriamente do fato de que o acrático possui conhecimento mas sim da relação entre o conhecimento do agente e o fato de que um erro foi cometido.

${ }^{169}$ De certa maneira, Taylor (1991, p. 182-186) reproduz uma interpretação mais antiga que explica o absurdo em termos de ignorância ou, mais precisamente, um erro intelectual. Como mencionamos anteriormente, isso corresponde a uma antecipação da explicação socrática posterior, o que não configura, em estrito senso, um argumento de redução ao absurdo derivado apenas das próprias crenças da opinião dominante.

${ }^{170}$ De acordo com Nussbaum (2009, p. 100-101) e Zeyl (1980, p. 257-260), o absurdo deriva da incompatibilidade da avaliação e da escolha do agente segundo um parâmetro único de medida. Em termos mensuráveis, o absurdo seria exemplificado da seguinte forma: $A$ sabendo que 200 é maior
} 
Weiss (2006): 'o bem/prazer causa (produz) o mal/dor' (princípio psicológico causal) ${ }^{171}$

Santas (1979) /Woolf (2002): 'o agente (todos/eu) sempre escolhe o que é mais prazeroso' (hedonismo psicológico) ${ }^{172}$

Irwin (1995): 'A acredita (believes) que $x$ é melhor que $y$, considerando todos os fatores (all things considered), mas escolhe $y$ ao invés de $x^{173}$. (autocontradição/ hedonismo psicológico)

Wolfsdorf (2006): 'ser submetido’, por definição, é ‘ter mais maldade na ação acrática do que bondade no balanço geral' - [F1] estabelece uma autocontradição enquanto [F2] depende do hedonismo psicológico ${ }^{174}$

que 50 escolhe 50 sendo submetido pela quantidade de 50 . Como o absurdo não fica claro a partir dessa única passagem, Nussbaum recorre à formulação socrática do fenômeno para preencher as 'lacunas'. No entanto, Zeyl (Ibid., p. 260) encontra nessa inconsistência um vício de explicação da ação da akrasia: "The "logic of explanation" is vitiated if the explanation offered to make an action intelligible conflicts with the description of the action it is supposed to explain.". Em todo caso, nenhuma dessas interpretações consegue efetivamente localizar ou explicar em cada um dos estágios do argumento. Ver também RUDEBSUCH, 1999a, p. 21-22

${ }^{171}$ Dentre as propostas interpretativas, a interpretação de Weiss (2006, p. 51-55) se destaca das demais por incluir um princípio psicológico de causalidade no argumento: o 'bem/prazer causa apenas o bem/prazer' e 'o mal/dor causa apenas o mal/dor'. Além disso, Weiss ainda adota uma leitura ad hominem que restringe o argumento demasiadamente à psicologia da opinião dominante. Apesar de ser difícil localizar um princípio de causalidade expressamente formulado no hedonismo ético anterior (com exceção do termo aitión mencionado na akrasia tradicional (352d), a formulação lógica do absurdo no primeiro estágio é efetivamente esclarecedora.

${ }^{172}$ De acordo com essa linha interpretativa, o argumento socrático depende de um hedonismo psicológico formulado no segundo estágio explicando a inconsistência do primeiro estágio. Em todo caso, os autores divergem quanto ao tipo de hedonismo psicológico assumido por Sócrates. Por um lado, Santas $(1979,206-207)$ alega que o hedonismo psicológico estabelece um princípio psicológico geral: 'todo homem sempre escolhe o que é mais prazeroso'. Por outro lado, Woolf (2002, p. 239-240) alega que o hedonismo se restringe a um princípio subjetivo em função das admissões da maioria: 'eu/nós (a maioria) sempre escolho(emos) o que é mais prazeroso'. Ambas as formulações correspondem a um princípio psicológico forte, o que leva muitos adeptos dessa interpretação a considerar que o argumento socrático seja somente dirigido a seus interlocutores, isto é, de forma ad hominem. Ver também MORRIS, 2006, p. 197-205. Como veremos a seguir, no entanto, Wolf chama atenção para um elemento fundamental que faz toda a diferença na compreensão do argumento socrático: a relação entre as crenças da maioria e o fato do erro cometido na akrasia.

${ }^{173}$ Assim como Santas, Vlastos e Penner, a leitura de Irwin (1995, p. 83-84) parece ser influenciada pela abordagem contemporânea da fraqueza de vontade de Davidson (Ver também VLASTOS, 1969, p. 83 n. 41; SANTAS, 1979, p. 318 n. 3; PENNER, 1990, p. 62-72). Por isso, tal como seus antecessores, essa abordagem interpretativa subjetiva acaba deixando de lado um fator objetivo fundamental da perspectiva socrática sobre a akrasia: o fato de que o agente comete um erro objetivo sobre o que é melhor ou pior segundo valores morais objetivos. Não é estranho, portanto, que tais intérpretes recorram a um princípio psicológico forte, como o eudaimonismo psicológico ou o hedonismo psicológico, com o objetivo de eliminar as supostas 'deficiências' do argumento socrático.

${ }^{174}$ Como veremos adiante, nossa abordagem segue, em linhas gerais, os parâmetros fundamentais de sua interpretação. Entretanto, Wolfsdorf (2006, p. 117-123) comete dois equívocos em sua interpretação: 1) não mostra onde exatamente se encontra a impossibilidade psicológica no segundo estágio do argumento e acaba adotando uma classificação mais normativa do que psicológica do hedonismo socrático; 2) assume que não há qualquer distinção entre crença e conhecimento no 
Kamtekar (2017): "uma força menor de prazer submete uma força maior de prazer' (autocontradição) ${ }^{175}$

Callard (2014): 'o simulacro reconhecido (acknowledge) é incapaz de motivar a ação, 176

A maioria dos intérpretes assume que a base lógica da redução ao absurdo ocorre em [F2] mas reconhecem com frequência que a inconsistência é esclarecida em [F3]. De forma geral, as interpretações de Penner, Vlastos ${ }^{177}$ e Callard dependem demasiadamente dos argumentos da passagem posterior 356c-358d que nem sequer foram abordados ainda e muito menos assumidos pela opinião dominante. Por um lado, Taylor e Irwin se concentram em esclarecer a formulação lógica de [F2] mas sem esclarecer a especificidade de [F3]. Por outro lado, as interpretações de Santas e Woolf supõem que o absurdo está ligado ao hedonismo psicológico supostamente localizado em [F3]. Na realidade, a maioria dos intérpretes, com exceção de Wolfsdorf, Kamtekar e Callard, acreditam que o

\footnotetext{
argumento socrático, quando Sócrates estabelece logo depois estabelece o poder do conhecimento contra os efeitos da potência da aparência. (356c-357c; cf. Ibidem, p. 121-131)

${ }^{175}$ Em linhas gerais, Kamtekar (2017, p. 45-47) segue as conclusões fundamentais da interpretação de Wolfsdorf sobre a estrutura do argumento. Todavia, ela rejeita que o argumento dependa de qualquer tipo de hedonismo psicológico e busca assegurar a conclusão socrática posterior do poder do conhecimento. Para Kamtekar, o fator crucial do absurdo em [F2] é que o 'conhecimento' na akrasia, segundo o relato da maioria, é 'factível', isto é, representa o que efetivamente mais prazeiroso. Em nossa interpretação, o fator fundamental do argumento recai na relação intrínseca entre 'conhecimento (do prazer e dor) - fato (erro factual)' presente no absurdo da descrição tradicional.

176 De acordo com Callard (2014, p. 40-46), o argumento socrático jamais terá sucesso contra a descrição tradicional da akrasia apenas estabelecendo uma auto contradição pois é preciso explicar o que está errado nas crenças da maioria. Em função disso, ela rejeita a abordagem dos intérpretes que se limitam a constatar uma mera autocontradição das crenças da maioria, o 'anticontradicionistas' (anti-contradicionists), seja por uma incoerência lógica em [F2] ou o suposto hedonismo psicológico de [F3]. Ao invés disso, Callard sustenta que a inconsistência das crenças da maioria depende da explicação socrática posterior sobre a potência da aparência. No entanto, essa proposta interpretativa desconsidera totalmente a fórmula lógica do argumento de [F2] estritamente voltado ao hedonismo ético da maioria. De acordo com nossa abordagem, a inconsistência lógica de [F2] reproduzida também em [F3] estabelece a conclusão negativa sobre a descrição tradicional e, simultaneamente, demanda a explicação positiva de Sócrates no argumento posterior.

177 Segundo Vlastos (1969, p. 81-82), a formulação da akrasía não implica autocontradição se for traduzida por 'submissão aos prazeres' em vez de 'submissão ao prazer'. Para Vlastos, a autocontradição se realiza no primeiro caso se utilizamos o princípio da substituição de nomes de 'prazer' por 'bem' e formos levados a afirmar que uma pessoa é 'submetida pelo (desejo do) bem'. No segundo caso, a 'submissão pelo (desejo de) coisas boas' requer uma explicação do absurdo tal como é retratado no texto (seguindo o plural tàs hedonás). Todavia, como observa Taylor (1991, p. 183-185), Vlastos está errado por 2 razões: (1) o substantivo hedoné é utilizado de forma indiferenciada no singular e no plural, evidenciando que o texto não prevê qualquer distinção entre 'prazer' e 'prazeres'. De fato, quando a substituição de termos é operada (em 355c), Sócrates trata 'prazer' e 'bem' no singular. (2) a 'submissão a um desejo por coisas boas' não é mais autocontraditória do que uma 'submissão a um desejo pelo bem'. Na verdade, Platão trata o desejo por prazer como equivalente ao desejo por prazeres.
} 
absurdo da akrasia recai em algum tipo de impossibilidade psicológica ${ }^{178}$. Dentre as interpretações mencionadas, a de Weiss e Callard são peculiares pois supõem princípios que dificilmente se encontram no argumento central da passagem 354e356b. Apenas Wolfsdorf e Kamtekar buscam compreender as especificidades dos argumentos de [F2] e [F3] sem recorrer a princípios externos ao hedonismo ético explicitamente assumido pela opinião dominante. Como vimos anteriormente, o hedonismo ético e, consequentemente, a redução ao absurdo em [F2] e [F3] não exige qualquer princípio psicológico hedonista externo. Na sequência, pretendo determinar alguns parâmetros para analisarmos o argumento do absurdo da akrasia em seus dois estágios.

É necessário lembrar que o argumento do absurdo da akrasia tradicional procede do exame das crenças da opinião dominante. Dessa forma, Sócrates não terá sucesso contra a descrição tradicional da akrasia se simplesmente recorrer a princípios externos não admitidos explicitamente por seu interlocutor personalizado ${ }^{179}$. Até o presente momento, observamos que a opinião dominante reconheceu somente o próprio hedonismo ético com a qual está inevitavelmente comprometida. Por isso, o filósofo não pode pressupor, mesmo implicitamente, teses posteriores, como o poder do conhecimento contra os impulsos irracionais (357b-e) ou o paradoxo socrático de que ninguém escolhe o mal de bom grado (358b-d), que não foram explicitamente aceitos pela opinião dominante. De fato, o princípio do hedonismo psicológico constitui um caso peculiar mas demonstraremos a seguir que [F3] independe de uma forte teoria psicológica ${ }^{180}$. Para o argumento funcionar, no entanto, é imprescindível nos atermos estritamente sobre as crenças da opinião dominante.

\footnotetext{
178 Além disso, alguns intérpretes costumam derivar o eudaimonismo psicológico do suposto hedonismo psicológico presente no argumento socrático (em geral, a leitura ad hominem adota essa interpretação para mostrar que o hedonismo é dispensável na redução ao absurdo da akrasia). De fato, o eudaimonismo psicológico pode ser efetivamente derivado do paradoxo socrático (358d), como veremos posteriormente. Porém, o paradoxo somente é estabelecido na conclusão de todo o exame da opinião dominante, como resultado da descrição socrática alternativa do fenômeno. Dessa forma, a redução ao absurdo enquanto dirigida às crenças da opinião dominante não pode assumir quaisquer princípios que não sejam diretamente derivados de seu hedonismo ético.

${ }_{179}$ Para essa exigência do elenchus da opinião dominante, ver KAMTEKAR, 2017, p. $40-43$ e CALLARD, 2014, p. 43-46.

${ }^{180}$ Segundo Wolfsdorf (2006, p. 117), os intérpretes que adotam um princípio hedonista psicológico acabam explicando o argumento de [F2] em termos de redução ao impossível e não, como deveria ser, como uma redução ao absurdo. De qualquer forma, julgamos que [F2] deve ser preservado como um autêntico argumento de redução ao absurdo enquanto [F3] reestabelece o absurdo por outros termos mas se estende para explicar o absurdo em função de uma negação da relação temporal dos prazeres.
} 
O principal alvo de Sócrates é a descrição tradicional da akrasia da opinião dominante. Como observamos, a akrasia consiste fundamentalmente na impotência do conhecimento, ou seja, a vulnerabilidade absoluta da deliberação racional aos impulsos humanos. Nesses termos, o 'relato' ou 'descrição' (lógos) da maioria estabelece que o conhecimento não possui força motivacional prática suficiente na ação humana. Desde o início, Sócrates se comprometeu a mostrar que tal lógos está equivocado (352b-353a). O hedonismo ético vai constituir a peça chave da demonstração da inconsistência nas crenças tradicionais da opinião dominante.

O hedonismo assumido é crucial no argumento de redução ao absurdo. Por diversas vezes, Sócrates oferece a opinião dominante a oportunidade de "recuar (anathéstai)" em suas admissões ao hedonismo (cf. 354e-355a). De fato, isso já indica que a redução ao absurdo da akrasia depende dos princípios hedonistas anteriores. Diante da extensão do argumento hedonista, Sócrates explicita claramente seu objetivo:

Pois, em primeiro lugar, não é fácil demonstrar (apódeîxai) em que consiste (tí estìn) o que chamam 'ser vencido pelos prazeres'; em segundo lugar, todas as demonstrações dependem disso (pásai hai apodeíxeis). (354e)

A principal motivação de Sócrates é fazer uma 'demonstração' (apódeixis) geral da inconsistência da akrasia tradicional sobre "o que é (tí estín)" o fenômeno. Em todo caso, o argumento não se destina apenas ao caso de 'ser vencido pelos prazeres', mas também será válido a outros casos do fenômeno, como 'pelo medo', 'pelo sexo', 'pela ira', etc. (352b). Por isso, a força da redução ao absurdo da akrasia advém de fatos objetivos e não, como antes, apenas das crenças subjetivas da opinião dominante. Para esclarecermos melhor no que consiste o absurdo da akrasia, precisamos retornar a [F1] e analisar a estrutura lógica do argumento socrático.

Em função do hedonismo assumido da opinião dominante, Sócrates analisa primeiramente [F2]. Com base no princípio de substituição de nomes, a formulação de [F1] é substituída por [F2], isto é, a formulação de "submissão pelo bem (hettómenos tôิ agathô̂)" (355a-c). Desde o início, Sócrates declara de antemão que a descrição tradicional é "ridícula (gelô̂on)" e expõe as razões de sua declaração. É importante ressaltar que Sócrates não menciona explicitamente a 
relação temporal dos prazeres e dores nesse primeiro estágio do argumento. Durante o argumento, ele se refere a 'prazer' e 'dor' sem qualificação dando ao argumento a forma lógica adequada de uma redução ao absurdo. Para esclarecer isso, devemos elaborar uma fórmula lógica de [F2] a fim de apreciar a estrutura do argumento como um todo ${ }^{181}$ :

1. $P$ escolhe $y$ em vez de $x$, sabendo que $y$ é pior que $x$, porque é submetido pelo bem de $y$. (355c).

Sendo assim, obtemos a sentença lógica correspondente à [F2] que será o alvo de Sócrates no exame da opinião dominante. Como vimos, a descrição tradicional estabelece que o acrático age contra o que considera melhor em vista de outros impulsos internos. Com base no hedonismo, no entanto, o juízo comum naturalmente se inclina a buscar na deliberação racional o que é melhor, que consiste em suma, no maior prazer. Assim, é possível esclarecer os elementos que levam Sócrates à redução ao absurdo da akrasia tradicional. Na sequência, Sócrates se concentra em explicar no que consiste exatamente o absurdo de [F2].

À primeira vista, a sentença 1 parece conter uma contradição patente. Ora, como um homem em plena consciência escolhe o que é pior em detrimento do que é melhor sem ser coagido por outras forças externas? A formulação é meramente uma constatação da estranha manifestação da akrasia, mas está longe de constituir por si só uma autocontradição evidente.

Para expor a contradição, Sócrates introduz um interlocutor 'insolente' (hybristès) dentro do diálogo com a opinião dominante. Mesmo com sua aparição repentina, a sua função específica nesse estágio do argumento se expressa em sua "risada (gelásetai)" diante da formulação da 'submissão ao bem' (355c). A personalidade despudorada e ousada de sua hýbris, isto é, a insolência, pressiona o relato da opinião dominante às últimas consequências. Em certa ocasião, o insolente traz um problema fundamental às convicções da opinião dominante:

181 Devo essa formulação a Irwin (1995) e Weiss (2006). De qualquer maneira, reconheço que a formulação lógica de Irwin tem suas limitações na medida em que depende fundamentalmente de uma distinção qualitativa de prazeres que não corresponde ao hedonismo apresentado por Sócrates (trataremos desse problema logo em seguida). Por outro lado, a estrutura lógica do argumento apresentada por Roslyn Weiss tenta seguir o texto original com mais fidelidade. Por essa razão, minha própria formulação do argumento segue mais estritamente a formulação lógica proposta por Weiss. 
Porventura, indagará ele, 'as coisas boas que há em vossa estima (en hýmin $)^{182}$ não estão à altura de vencer (ouk axíon nikân) as más, ou estão? É evidente que, como resposta, diríamos que "não estão à altura delas (ouk axíon ônton), pois, caso contrário, não incorreria em erro (exemártanen) aquele homem que afirmamos ser vencido pelos prazeres. (355d) [F2]

O problema central salientado pelo interlocutor insolente reside no critério comparativo de 'axíon' (valor). Por conta de seu hedonismo ético salientado em en hýmin ('em vossa estima'), a opinião dominante deve avaliar 'as coisas boas' e 'as coisas más' sob o mesmo parâmetro de medida de prazer e dor. Sendo 'prazer' e 'bem' as mesmas coisas, o juízo comum delibera naturalmente pelo maior bem e a menor dor. Ora, em que medida os males são escolhidos em detrimento dos bens e os bens em detrimento dos males na akrasia? Para responder isso, será preciso levar em conta a descrição tradicional com base no hedonismo ético da opinião dominante.

É importante notar aqui que o insolente se refere justamente ao vocabulário bélico da akrasia tradicional: os termos 'nikân' (vencer), 'hettô' (submissão) e seus derivados (355d-e). A princípio, a presença desses termos nos indica que a concepção popular da akrasia não parece ser simplesmente ignorada dentro do argumento do absurdo. Com efeito, uma corrente de intérpretes defende que a redução ao absurdo em [F2] consistiria na simples substituição do paradigma da 'força relativa' dos desejos pela avaliação hedonista do agente a partir de um hedonismo psicológico. Dentre os adeptos dessa corrente influente, Gerasimos Santas é o principal expoente da leitura psicológica.

Em Socrates: The argument of the philosophers, Santas (1979, p. 206-207) sustenta que o hedonismo psicológico de Sócrates estabelece uma conexão fundamental entre o juízo avaliativo e 'o que se busca ou o que se escolhe fazer' (seeks or chooses to do $)^{183}$. O absurdo da akrasia estaria justamente na contradição entre a concepção popular de 'submissão ao prazer' e o princípio do hedonismo

\footnotetext{
182 Para essa tradução de en hýmin ver VLASTOS, 1969, p. 80.

${ }^{183}$ Cf. Ibid., p. 206: "the hedonistic principle elaborated by Socrates does not assert a connection between a man's evaluations or ranking of the alternatives before him (the immediate results of the "weighing" that Socrates is talking about) and his behavior (the execution of a particular action), but rather a connection between his evaluations and what (presumably as a result of the evaluations) he seeks or chooses to do." Ver também VLASTOS, 1969, p. 76-78. Nesse sentido, Santas estabelece a oposição absoluta entre a avaliação valorativa e a força relativa dos desejos. Em função dessa oposição absoluta, abre-se espaço para impulsos absolutamente irracionais, ou paixões cegas.
} 
psicológico, segundo o qual 'todos sempre buscam o maior prazer/evitam a maior dor'. No entanto, Santas alega que o hedonismo socrático é limitado aos pressupostos hedonistas justamente por ignorar a 'força relativa dos desejos' da concepção popular da akrasia. Ao invés do hedonismo, Sócrates poderia recorrer ao eudaimonismo psicológico dos primeiros diálogos, segundo o qual "every man desires or seeks (pursues) to get good things (...)" contra a akrasia tradicional (Ibidem, p. 209).

Mesmo assim, Santas (Ibid., p. 211) reconhece que o argumento socrático permanece vulnerável à incompatibilidade inerente do juízo valorativo e da 'força relativa dos desejos', ou melhor, a independência da força relativa dos desejos diante do juízo valorativo do agente. Com efeito, a ideia de que o argumento socrático depende exclusivamente apenas do juízo avaliativo do agente em substituição (ou negligência) da força relativa dos desejos é uma leitura extremamente influente do absurdo da akrasia.

$\mathrm{Na}$ visão de Santas, o hedonismo psicológico serve de base ao eudaimonismo psicológico socrático. O argumento hedonista, na realidade, é elaborado justamente contra a opinião dominante que nega o eudaimonismo psicológico por causa da crença na akrasia, isto é, na possibilidade de agir contra o que é bom. Dessa forma, o hedonismo psicológico constituiria um mero argumento auxiliar (dirigido somente à opinião dominante) na fundamentação da tese mais forte do eudaimonismo psicológico. Seguindo os passos de Santas, Irwin (1995, p. 83-84) reconhece no argumento hedonista duas teses diferentes, uma ética e outra psicológica, que resulta em uma autocontradição de crenças conflitantes: ' $y$ é mais prazeroso ou melhor (por todos os fatores) do que $\mathrm{x}$ ' e a 'a escolha de $y$ é pior do que $x$ '. Nessa mesma linha, Woolf (2002) indica que o absurdo envolve uma inconsistência mais profunda entre o que a opinião dominante diz (assumindo o seu hedonismo) e o que ela $f a z$ (em relação ao fenômeno da akrasia) ${ }^{184}$. Apesar de chamar atenção à inconsistência do relato do agente e a ação acrática, tal linha interpretativa restringe o absurdo da akrasia tradicional apenas ao hedonismo admitido pela opinião dominante.

\footnotetext{
${ }^{184}$ Cf. WOOLF, 2002, p. 247: "I want to suggest that in the specific case of his argument against akrasia Socrates has special grounds for opting the way he does, grounds that are emphasised in the text and are related to the particular psychological character of the (putative) akratic actions at issue."
} 
De forma geral, a corrente anti-hedonista alega que o hedonismo e todo o exame da opinião dominante se restringem apenas às crenças dos interlocutores de Sócrates sem que o argumento hedonista tenha qualquer validade intrínseca ${ }^{185}$. O problema central do hedonismo psicológico reside na suposta incompatibilidade de duas explicações antagônicas da ação humana, o cálculo deliberativo do juízo avaliativo e a força relativa dos desejos.

A separação do juízo avaliativo e a força relativa dos desejos corresponde ao abismo que separa o hedonismo ético e a concepção popular da akrasia. Por vezes, se alega que há uma sutil substituição de vocabulário: os termos do conflito interno da 'submissão' (hettómenos), 'vencer' ou 'sobrepujar' (nikân) dão lugar ao registro do valor 'ter valor', 'merecer' (axíon) ou 'não ter valor' e 'não merecer' (anaxíon) demarca a passagem da força relativa dos desejos para o juízo avaliativo do agente (Cf. 355a-356c). Com razão, os intérpretes têm indicado que a negligência da força relativa dos desejos colocaria sob suspeita toda a redução ao absurdo da akrasia. A partir disso, eles alegam que o que compromete a tese hedonista é o princípio psicológico forte que toda a escolha humana se inclina, de forma absoluta, ao juízo da alternativa mais aprazível/melhor.

Ora, nem o hedonismo psicológico e nem o eudaimonismo psicológico asseguram, por si mesmos, o absurdo da akrasia. De um lado, o juízo avaliativo do agente parece não corresponder necessariamente à força relativa dos desejos. De outro lado, como tem sido indicado recentemente, esses princípios psicológicos não foram claramente estabelecidos antes no exame da opinião dominante dando a impressão de que Sócrates não está fazendo a demonstração do absurdo da posição da maioria mas tentando convencê-los a aceitar uma nova tese independente ${ }^{186}$. Na realidade, o argumento hedonista depende fundamentalmente do hedonismo ético e não de uma forte tese psicológica.

O máximo que Sócrates faz no argumento hedonista é atribuir o hedonismo ético à opinião dominante. Grosso modo, isso equivale apenas a um fato psicológico

\footnotetext{
${ }^{185}$ Para uma leitura anti-hedonista similar, ver. KAHN, 1996, p. 237-242; WEISS, 2006, p. 62-63. $\mathrm{Na}$ realidade, o mesmo argumento é utilizado por ambos os autores na classificação do eudaimonismo psicológico como uma tese ad hominem sem validade intrínseca.

${ }^{186}$ Cf. KAMTEKAR, 2017, p. 43: "But if Socrates' refutation relies on this psychological principle on the grounds that Socrates has argued for it elsewhere [...] he isn't showing the Many that their position is absurd, only that it disagrees with his own position. Further the assumption of this principle makes the ethical hedonism for which Socrates has argued at such length redundant (...)." No sentido oposto, Callard (2014, p. 44-46) alega que o argumento hedonista, por si só, não revela a inconsistência intrínseca das crenças da maioria sobre a akrasia.
} 
da motivação humana: 'busca-se o prazer como bem e evita-se a dor como mal' (354c). Na realidade, o hedonismo ético não pode ser descartado do argumento socrático pois funciona como parte integrante da redução ao absurdo da akrasia. Antes mesmo desse argumento, Sócrates enfatiza que o compromisso da opinião dominante com o hedonismo é suficiente para inviabilizar o seu próprio relato (lógos) do fenômeno (354e-355a). De qualquer modo, Sócrates também parece assumir que o hedonismo ético é compatível com o vocabulário do conflito interno da akrasia. Por conta disso, somos obrigados a suspeitar que o argumento socrático assume que o juízo avaliativo e a força relativa dos desejos correspondem ao mesmo princípio explicativo da ação humana.

Sem o hedonismo psicológico ou o eudaimonismo psicológico, o argumento hedonista se livra assim do princípio psicológico de que a ação deliberada humana sempre depende das crenças do que é o maior bem/mais aprazível fazer. Nessas circunstâncias, o juízo avaliativo pode ser tratado nos mesmos termos que a força relativa dos desejos, ou melhor, a força relativa das motivações humanas. Como ressalta Kamtekar (2017, p. 46-47), o argumento socrático não pretende substituir a concepção popular da força motivacional pelo princípio do juízo avaliativo mas enfatiza, na realidade, que a avaliação hedonista correta está necessariamente alinhada à 'força relativa' das motivações do agente. Na sequência, veremos que o cálculo hedonista esclarece o absurdo do conflito motivacional da akrasia.

É imprescindível que o argumento de [F2] tenha o formato estrito de uma autocontradição inerente às crenças da opinião dominante. Na realidade, trata-se de uma confrontação entre duas crenças opostas da opinião dominante, o hedonismo ético e a relato tradicional da akrasia. Como observamos, o hedonismo psicológico é um princípio externo ao argumento hedonista e, ao mesmo tempo, Sócrates não pode ignorar os termos da akrasia tradicional. Assim, uma interpretação mais plausível do argumento socrático precisa levar em conta a força relativa dos desejos da concepção popular da akrasia.

O parâmetro de 'valor' do hedonismo deve revelar sob que circunstâncias uma força de $x$ é capaz de 'vencer' ou 'submeter' outra força de $y^{187}$. Não há outro parâmetro senão avaliar segundo o que é ‘maior' ou 'menor' (355d).

\footnotetext{
${ }^{187}$ É necessário salientar ainda que a akrasia antiga legitima a sutil substituição intercambiável entre 'estimativa de prazer' e 'força relativa dos desejos'. Como mostramos anteriormente, a psicologia grega aborda impulsos humanos ou motivações humanas levando em conta aspectos intrinsecamente
} 
Seguindo o hedonismo, se os bens forem maiores que os males, os bens serão escolhidos ao invés dos males, ou seja, a os bens 'vencem' os males. Isso ocorreria se o agente tivesse realizado a ação correta. No entanto, sabemos que ele “incorre em erro (exemártanen)", o que nos levaria a assumir que os bens, na realidade, não possuem o mesmo valor que os males. Como dissemos, o ponto crucial do argumento socrático reside na relação entre as crenças da maioria e o fato do erro moral. Para esclarecer os passos do argumento, retomemos sua estrutura lógica ${ }^{188}$ :

2. 'Ser vencido pelos prazeres' $=P$ sabendo (gignóskon) que $y$ é pior que $\mathrm{x}$, escolhe $y$ em vez de $x$, porque é submetido pelo bem de $y$. (355c). (substituição de nomes)

3. Os bens 'sobrepujam o valor' (axion) dos males, se e somente se, os bens forem mais/maiores que os males. (segundo o hedonismo) (355d)

4. $y$ 'vence' $x$, se e somente se, os bens de $y$ são maiores que o males de $x$.

5. Se a ação é correta, os bens em y valem mais ('vencem') / são maiores do que os males em $x$. (hipótese - suposição)

6. y não é a escolha correta (caso contrário, o agente não teria errado) (fato)

7. Os bens em y 'não valem' (anaxía) seus males.

8. Os bens em $y$ são menores/valem menos que seus males.

9. 'Ser vencido pelos prazeres' = 'tomar (conscientemente) maiores males por bens menores' - tomar maiores males e bens menores de y (355e)

10. É absurdo dizer que $P$ escolhe $y$ em vez de $x$, sabendo (de fato) que $y$ tem maiores males que $x$, porque é submetido (de fato) pelos bens menores de $y$.

A partir desses passos, o argumento socrático leva a descrição tradicional da akrasia ao absurdo. Na sequência, tentaremos esclarecer alguns princípios teóricos que são estabelecidos com base no argumento do absurdo da akrasia tradicional.

cognitivos de emoções e desejos humanos. Desse modo, a substituição de Sócrates, apesar de parecer estranha a olhos modernos, é legítima sob a perspectiva da psicologia grega pois não se exclui peremptoriamente aspectos cognitivos de impulsos irracionais. Com base nisso, é possível explicar a substituição do vocabulário do conflito interno pelo vocabulário do 'valor' no argumento hedonista.

188 Devo essa formulação do argumento do absurdo a Roslyn Weiss (2006, p. 52-53). 
Em primeiro lugar, é significativo lembrar a impotência do conhecimento da akrasia. Para a opinião dominante, o ‘conhecimento' não tem qualquer valor intrínseco de superioridade em relação à 'crença' do que é melhor. Durante a akrasia, não importa se o agente tem 'conhecimento' ou 'crença', pois na visão empobrecida da maioria, em ambos os casos o agente é submetido pelos impulsos. Todavia, é imprescindível, nos termos comuns, que o agente não esteja iludido ou em confusão mental na experiência da akrasia. Por isso, o termo 'gignósko' da akrasia tradicional representa o juízo avaliativo do agente sobre o que é melhor mas sua referência na passagem só pode ser “as coisas más que são más (tà kakà hóti kaká estin)" (355c). A akrasia tradicional envolve o pressuposto epistemológico de que o agente tem plena consciência de quais são as coisas realmente más. Invariavelmente, todos os outros passos do argumento se seguem desse fato psicológico controverso.

Em segundo lugar, o argumento socrático depende da incompatibilidade crucial entre crenças e fatos exposto no passo 6 reforçando o absurdo dos passos 910. Com efeito, o hedonismo compromete a opinião dominante com a escolha consciente do maior bem/menor dor. Se $y$ fosse realmente a escolha correta, o agente teria efetivamente realizado uma ação correta. Contudo, o fato é que $y$ não é a escolha correta justamente porque o agente incorreu em erro, talvez sem o propósito de o fazer, mas acabou realizando a ação errada ${ }^{189}$. Por essa razão, o insolente declara "o que (pragma) vocês dizem é ridículo" (355d). De fato, ele expõe uma incompatibilidade entre um "feito (prâgma)" e o que a maioria alega fazer ou seja, o que "dizeis (légete)". A partir disso, o argumento passa do mero exame da opinião dominante para uma análise mais profunda: a relação entre a descrição tradicional e o próprio fenômeno da akrasia.

Em Consistency and Akrasia in Plato's Protagoras, Woolf (2002) sustenta que a passagem da akrasia apresenta um argumento do tipo 'inconsistência palavrafeito' (word-deed inconsistency). Com efeito, esse tipo de argumento não aparece geralmente no típico elenchus socrático do exame das crenças dos interlocutores. Em linhas gerais, a 'inconsistência palavra-feito' de caráter indicativo revela a incompatibilidade entre as sentenças do interlocutor e suas ações atuais ou

\footnotetext{
${ }^{189}$ Com efeito, o erro (exemártanen) aqui não parece implicar um erro consciente ou deliberado por parte do agente. Ao contrário, parece partir da constatação do próprio erro efetivo, em si mesmo.
} 
factuais $^{190}$. Assim, Sócrates dá um passo decisivo de um exame restrito às crenças da opinião dominante em direção ao esclarecimento sobre $o$ que é efetivamente o fenômeno da akrasia. Por essa razão, tem se reconhecido que a análise socrática sobre a akrasia advém de um ponto de vista externo, isto é, a constatação da existência do fenômeno objetivo, e não de um ponto de vista interno subjetivo, como observaremos posteriormente, na fraqueza e vontade contemporânea.

A partir desse passo decisivo, é possível constatar então que o agente não escolhe concretamente os maiores bens. A conclusão final do interlocutor insolente deixa claro o absurdo: “é evidente que 'ser vencido' (tò hettâstai), como referido por vocês, consiste em contrair (lambánein) maiores males em troca de (antì) ${ }^{191}$ bens menores." (355e). Por conta do hedonismo ético e dos fatos apurados, é totalmente implausível que o acrático tenha a intenção de, em plena consciência, escolher (de fato) males maiores ou bens menores.

Segundo o hedonismo, os bens menores de $y$ não podem 'vencer'/'valer mais 'que os males menores de forma factual. Se ocorre um erro na akrasia, esse erro não se deve ao fato em si, isto é, às circunstâncias externas, mas à própria deliberação racional interna do agente. Nesse sentido, o absurdo da descrição tradicional nos leva a supor que o agente, na realidade, não apenas comete um erro mas um equívoco cognitivo. Nesse sentido, o segundo estágio do argumento relativo a [F3] pretende esclarecer as inconsistências da descrição tradicional por outro ângulo.

Dando prosseguimento à sua análise, Sócrates substitui então [F2] por [F3] e oferece uma análise da akrasia a partir da 'submissão ao prazer'. Ora, ele poderia

\footnotetext{
${ }^{190}$ Cf. Ibid., p. 240: "In short, the absurdity of the many's position for Socrates lies in the fact that it embodies an indicative word-deed inconsistency. The many set out a principle which asserts that they act in a certain way. The truth of this assertion is inconsistent with the taking place of certain acts, namely the putatively weak-willed acts in question. If the principle is correctly stated, then the acts in question cannot be taking place." De fato, Woolf (Ibid., p. 233-235) traça uma distinção entre a palavra-feito indicativo (indicative), segundo o qual uma sentença descritiva da ação corresponde com uma ação efetiva ou atual, e a palavra-feito normativo (ought), segundo o qual uma sentença normativa da ação corresponde a uma ação que deve ser realizada segundo uma moral do dever. Em sua perspectiva, o relato da opinião dominante sobre a akrasia assume a forma lógica específica da palavra-feito indicativa o que estabelece uma relação necessária entre as crenças e a ação do agente. Mesmo reconhecendo a plausibilidade da palavra-feito indicativo e a inconsistência constatada no argumento socrático, acreditamos que a redução ao absurdo não se restringe exclusivamente às crenças da opinião dominante. De fato, não concordamos com sua leitura $a d$ hominem do argumento e nem com o hedonismo psicológico subjetivo derivado da própria noção de 'inconsistência palavra-feito' indicativa.

191 Para essa tradução de antí ver SANTAS, 1979, p. 204-205; TAYLOR, 1991, p. 186-187.
} 
muito bem aplicar o mesmo tipo de argumento de [F2]. No entanto, a explicação aqui vai mais além de uma reprodução do argumento de redução ao absurdo.

Para ver rapidamente, o que é reiterado do argumento de [F2], retomemos a formulação lógica de [F3] com a substituição de nomes:

2. $P$ escolhe $y$ em vez de $x$, sabendo que $y$ é mais doloroso que $x$, porque é submetido pelo prazer de $y$. (355e-356a)

Na sequência, Sócrates reitera alguns pontos estabelecidos no primeiro estágio ao segundo estágio (355e356a): 1) o homem em akrasia erra (fato); 2) as coisas aprazíveis 'não valem' efetivamente mais que as coisas dolorosas; 3) as coisas aprazíveis sobrepujam (axíon) as dolorosas, se e somente se, as aprazíveis forem mais/maiores do que as dolorosas (segundo o hedonismo). Dessa forma, as mesmas conclusões válidas no argumento anterior também seriam válidas no caso de 'submissão ao prazer'. Contudo, Sócrates introduz uma objeção que demanda uma explicação mais contundente.

No esforço de esclarecer a relação entre prazer e dor, Sócrates insere uma objeção baseada na relação temporal dos prazeres:

Se alguém dissesse: 'Porém, é muito diferente, Sócrates, o aprazível imediato (tó parachrêma) do aprazível e doloroso ulteriores (tón hýsteron)', eu lhe retorquiria: ‘em razão de alguma outra coisa que não ao prazer e à dor? Pois não há como ser diferente disso (ou gàr esth' hótoi álloi). (356b) [F3]

A objeção do interlocutor hipotético traz novamente a dimensão temporal do prazer e da dor como um elemento que impede o absurdo da conclusão final. Ao invés de 'submissão ao prazer', a formulação tradicional da akrasia poderia ser substituída por 'submissão aos prazeres imediatos" ${ }^{\text {'192 }}$. Com isso, a akrasia ainda pode ocorrer se levarmos em conta a relação temporal dos prazeres. Contudo, Sócrates afirma que tal relação temporal dos prazeres não interfere essencialmente na derivação do absurdo da descrição tradicional. Ora, mas por que ele estaria tão seguro sobre isso? $\mathrm{Na}$ realidade, sua confiança advém do hedonismo ético já admitido pela opinião dominante.

\footnotetext{
${ }^{192}$ Segundo Gosling \& Taylor (1982, p. 56-57), a substituição de Sócrates seria ilegítima porque não se coaduna com o hedonismo socrático do prazer de longo prazo. No entanto, mostraremos adiante que a ilegitimidade reside na própria distinção temporal de prazeres sob a qual sua classificação se sustenta. Em especial, Rudebusch (1999a) revela as inconsistências dessa distinção temporal, como mostraremos adiante. Ver também IRWIN, 1995, p. 83-84.
} 
$\mathrm{O}$ argumento hedonista demonstra que as crenças em 'prazeres maus' e 'dores boas' está intimamente relacionada à relação temporal dos prazeres. A dimensão temporal demonstra que tais crenças emergem de uma visão extremamente restritiva dos prazeres e dores. A partir do hedonismo, Sócrates exorta seu interlocutor a olhar além da distinção das categorias de 'imediato' e 'posterior'. A objeção do interlocutor hipotético evoca assim a impressão popular da opinião dominante. Da mesma maneira, Sócrates está aqui rejeitando uma visão popular demasiado subjetiva do prazer e dor dependente da distinção temporal dos prazeres e resguardando um ponto de vista objetivo do prazer e dor pelos princípios hedonistas ${ }^{193}$.

Por isso, o que importa aqui é a estimativa quantitativa de prazer e dor. O argumento assim não se dirige mais exclusivamente à opinião dominante, mas abrange resultados teóricos concretos sobre o que consiste a akrasia grega. Novamente, o segundo estágio reitera com maior ênfase que o problema da akrasia perpassa definitivamente a deliberação prática sujeita à dimensão temporal dos prazeres e não apenas o que 'prazer' e 'dor' são em si mesmos.

A descrição socrática do fenômeno irá investir em uma análise epistemológica do que ocorre no agente em vista das proporções reais de prazer e dor. Sob o ponto de vista objetivo do hedonismo, o prazer e a dor são determinados segundo a estimativa quantitativa de prazer. Dessa forma, já vislumbramos aqui uma aspiração natural da deliberação prática à exatidão e objetividade. Como ressalta Nussbaum (2009), o Protágoras resgata um ideal grego de 'comensurabilidade' grego, isto é, a ideia de tornar todos os valores humanos universalmente comensuráveis ou comparáveis sob um mesmo padrão de medida $^{194}$. O hedonismo ético admitido pela opinião dominante parece se adequar a tal aspiração quantitativa. Contudo, o fato incontornável que o argumento

\footnotetext{
${ }^{193}$ Cf. WOLFSDORF, 2006, p. 123: "I emphasize that Socrates' is not simply a dogmatic assertion that the agent's temporal relation to the pleasures and pains does not affect the value of those pleasures and pains. His point implies the distinction between the objective and the subjective values of things. In other words, he will grant an objector that a proximate pleasure may seem more attractive to an agent than a remote pleasure. But, again, the actual values of the proximate and remote pleasures are independent of their temporal relations to the agent." Ver também nota anterior 194 Cf. NUSSBAUM, 2009, p. 95: "Um exame dos usos das palavras associadas à medida e comensurabilidade quantitativa no século $\mathrm{V}$ e início do século IV demonstra que elas vinham carregadas de fortes associações cognitivas e éticas: o que pode ser medido ou comensurado pode ser compreendido, conhecido, é ordendado e bom; o que não tem medida é ilimitado enganoso, caótico, ameaçador e mau." Ver também RUDEBUSCH, 1999, p. 25.
} 
hedonista mostra é que, tal como evidencia a akrasia, erramos frequentemente com relação à real dimensão dos bens da ação humana.

Diante da inconsistência da akrasia, o argumento socrático indica a necessidade de estabelecer uma distinção da aparência e da realidade dos prazeres. $\mathrm{O}$ argumento do absurdo mostra que o juízo subjetivo do agente não corresponde à realidade objetiva dos prazeres. A partir disso, Sócrates precisa mostrar o que constitui o erro factual da akrasia uma vez que não é o conhecimento objetivo dos prazeres reais. Na sequência, a explicação positiva do fenômeno é epistemológica: o erro factual do fenômeno se funda na ilusão da 'potência da aparência' enquanto o conhecimento efetivo das ações morais corretas está vinculado à técnica da medida de prazeres. A distinção da aparência e realidade de prazeres depende de uma analogia crucial dos objetos espaciais e da temporalidade dos prazeres. Antes disso, precisamos primeiro relembrar os termos da formulação do problema da akrasia antiga no Protágoras de Platão.

\section{4 \\ A refutação da akrasia tradicional: a analogia da percepção sensorial (aísthesis) e o hedonismo}

Ao longo da passagem 356c-357e, Sócrates fornece sua própria formulação do fenômeno denominado de akrasia diante do absurdo da descrição tradicional. Como vimos, a redução ao absurdo da descrição tradicional deriva da incompatibilidade entre o fato do erro de escolha do agente e o relato de sua experiência da akrasia (355b-e). Pelo hedonismo, constatamos que o juízo comum do agente acerca do fenômeno está equivocado. Por isso, a conclusão da redução ao absurdo da akrasia é claramente negativa: 1) o agente erra (exemártanen) (fato); 2) o agente erra em relação à escolha dos maiores prazeres reais; 3) o equívoco está relacionado às crenças tradicionais de prazer e dor e ao relato tradicional da akrasia. Por conta disso, Sócrates busca uma formulação mais positiva do fenômemo a partir das premissas hedonistas estabelecidas.

O problema da descrição tradicional da akrasia acompanha a defesa do conhecimento. Como vimos, a descrição tradicional estabelece a impotência do conhecimento, isto é, a sua completa subjugação diante da 'submissão ao prazer'. 
Antes de iniciar o exame da opinião dominante, Sócrates e Protágoras já haviam se comprometido com a defesa do conhecimento contra a akrasia (352c-d).

A partir do hedonismo e do absurdo da descrição tradicional, são alcançadas conclusões mais efetivas. Para Sócrates, o erro da akrasia nada mais é do que "ignorância (amathía)" que consiste basicamente na "falta de conhecimento (epistémes endeía)" (357d-e). Dessa forma, são estabelecidas duas conclusões: (1) o erro da akrasia está ligado às crenças do agente e não ao conhecimento em si mesmo; e (2) o fenômeno é desvinculado do conhecimento assegurando assim o poder do conhecimento.

A partir disso, Sócrates reitera então o compromisso estabelecido com Protágoras anteriormente pela defesa do conhecimento: "nós concordamos que nada é superior (medèn eînai krêttton) ao conhecimento e que ele, quando presente, domina invariavelmente (aê̂ krateîn) o prazer e todas as outras coisas.” (357c). Como observamos anteriormente, Sócrates está se contrapondo aqui à impotência do conhecimento pela akrasia. Em termos mais diretos, isso constitui uma negação absoluta do conhecimento-akrasia. No entanto, Sócrates indica que pretende ir mais além em suas conclusões, estendendo os resultados à tese paradoxal de que ‘ninguém faz o mal de bom grado' (358b-c).

Há uma longa polêmica interpretativa em torno da tese paradoxal socrática que abordaremos posteriormente. Diante do que dispomos agora, podemos assegurar que a formulação socrática da 'ignorância' está intrinsecamente ligada ao poder do conhecimento. A akrasia tradicional como amathía implica, em seu sentido original, a própria ausência de aprendizado ou conhecimento ${ }^{195}$. Ora, se o fenômeno for apenas um erro cognitivo, o conhecimento pode corrigir as crenças equivocadas do agente e determinar assim definitivamente a ação moral virtuosa.

Além disso, nota-se também a preocupação de Sócrates em reestabelecer a superioridade epistemológica do conhecimento sobre outras motivações humanas. Como vimos anteriormente, o argumento de redução ao absurdo da akrasia tratou de desvincular o conhecimento das crenças do acrático. Dessa maneira, é possível

\footnotetext{
${ }^{195}$ Cf. LIDDEL-SCOTT, 1990. O alfa privativo do termo amathía implica a negação da 'máthesis', isto é, do 'aprendizado' e do 'conhecimento'. Como veremos a seguir, a classificação da 'falta de conhecimento' está diretamente relacionada a ausência do parâmetro objetivo das dimensões reais de prazer e dor na deliberação prática.
} 
preservar o conhecimento contra a 'submissão ao prazer'. A formulação socrática da ignorância é essencial para estabelecer o poder do conhecimento.

Embora as teses socráticas sejam relativamente intuitivas, os argumentos de Sócrates são extremamente controversos. Ao que tudo indica, isso se deve ao fato de que os argumentos socráticos são demasiadamente abstratos e especulativos sem referências mais concretas a casos ou exemplos patentes de akrasia além de 352be.

A refutação da akrasia tradicional de Sócrates tem originado tanto problemas interpretativos quanto dúvidas acerca de sua validade intrínseca. Em linhas gerais, a refutação da descrição tradicional recorre ao argumento hedonista, a redução ao absurdo da akrasia e, em última análise, a reformulação socrática do fenômeno. Cada um desses estágios do argumento é colocado em xeque pelos intérpretes platônicos, mas a mais fundamental recai sobretudo sobre seus pontos mais cruciais, o hedonismo e a solução socrática final ao problema da akrasia.

Após constatar a inconsistência da akrasia tradicional, Sócrates recorre ao hedonismo para explorar o que constitui realmente o fenômeno. Como vimos, o hedonismo explica a deliberação humana a partir dos valores reais de prazer e dor. Após o exame da opinião dominante, fica estabelecido que a deliberação humana possui duas inclinações naturais, a busca do prazer e a repulsa da dor por um parâmetro comparativo único. No entanto, o acrático erra pois escolhe, efetivamente, 'menores prazeres e maiores dores'. Levando em conta o erro factual do agente, é necessário esclarecer então o que leva o agente a efetivamente cair nesse erro moral.

Para Sócrates, o fenômeno consiste em um "erro na escolha dos prazeres e dores (examártenein perì tèn tôn hedonôn aíresin kaì lypôn)", ou seja, 'ignorância' (357d-e), causada pela influência da "potência da aparência (tô̂ phainoménou dýnamis)"196 (356d). Contra essa ilusão, se recomenda o conhecimento da "técnica da medida (metretiké téchne)" capaz de determinar a escolha das proporções reais de prazeres e dores (356c-d). Com ressalta Muniz (2011), o Protágoras inaugura a primeira abordagem dos temas do prazer e da existência da ilusão do sensível no

\footnotetext{
${ }^{196}$ Para essa tradução de dýnamis, ver MUNIZ, 2011, p. 43-69. É importante salientar que o termo dýnamis no Protágoras se refere constantemente à 'capacidade' em amplo sentido, tanto relativa à constituição das virtudes humanas, mas também às capacidades singulares dos animais e dos homens no mito do sofista.
} 
plano dos Diálogos platônicos ${ }^{197}$. Sobretudo, a proposta socrática advém da conclusão negativa do argumento de redução ao absurdo da akrasia tradicional.

A analogia da disposição dos objetos no espaço e a disposição temporal dos prazeres é fundamental na descrição socrática do fenômeno. Diante disso, a analogia traça um plano comparativo entre o campo espacial e o campo temporal dos prazeres na ação humana (356c-357b). Dessa maneira, Sócrates sugere que a ilusão de ótica no espaço é semelhante à ilusão temporal dos prazeres na ação. Sendo assim, o 'perspectivismo' espacial ajuda a compreender o 'perspectivismo' temporal da ação. Todavia, a analogia de espaço e tempo por si só causa diversas dificuldades interpretativas que mencionaremos a seguir.

Ora, mas como a analogia pode esclarecer exatamente o plano temporal da ação? Seria o mesmo efeito provocado pela ilusão de ótica dos objetos à nossa volta? Seria um engano meramente cognitivo ou as motivações irracionais desempenham algum papel singular na ilusão dos prazeres? O que efetivamente causa a 'potência da aparência' e que influência exerce sobre o agente durante o fenômeno da akrasia?

Os problemas interpretativos da passagem são cruciais para se compreender o que realmente representa a ignorância da ilusão da aparência dos prazeres. Sem a demonstração da ignorância da aparência, a superioridade do conhecimento se tornaria inviável. Sendo assim, é fundamental analisarmos algumas propostas interpretativas para determinarmos a plausibilidade da refutação da descrição tradicional da akrasia.

A controvérsia interpretativa em torno da akrasia tradicional perpassa a classificação do hedonismo socrático e a 'potência da aparência'. Em particular, pretendemos analisar os problemas diretamente envolvidos na descrição socrática da ignorância aparente e apenas, de forma derivada, a polêmica em torno da classificação do hedonismo.

No Protágoras, o hedonismo está intrinsecamente ligado à potência da aparência e a técnica da medida. No entanto, a natureza do prazer em si não é propriamente explorada no diálogo. Assim, a classificação do hedonismo socrático é imprescindível apenas no esclarecimento da teoria socrática da potência da

197 Cf. MUNIZ, 2011, p. 71: "Essa passagem [da acrasia], crucial para a compreensão do desenvolvimento desses temas nos diálogos posteriores, indica a forma primeira do tratamento dos temas da imperfeição do mundo sensível e o cuidado com os prazeres (...).” 
aparência. Em última instância, teremos de avaliar os problemas levantados em face das diferentes propostas interpretativas da passagem 356c-357a de modo a averiguar a consistência da refutação socrática da akrasia no Protágoras. Com isso, poderemos comprovar o sucesso ou o fracasso da redescrição socrática do fenômeno enquanto ignorância e, portanto, a refutação da akrasia tradicional. Desse modo, retornaremos sucintamente a analogia entre espaço e tempo de modo a compreender a sua relação intrínseca ao hedonismo socrático.

Antes de prosseguiremos propriamente à classificação do hedonismo, devemos analisar a analogia espaço-temporal. A analogia tem um papel fundamental no processo da dýnamis da aparência e a ilusão dos prazeres. Para Sócrates, a percepção espacial constitui um parâmetro essencial para compreender os efeitos da percepção dos prazeres no tempo: "as mesmas grandezas não se vos afiguram (phaínetai) à vista (tê ópsei) maiores, quando mais próximas e menores, quando mais afastadas?" (356c). Por isso, devemos averiguar como a analogia esclarece a ilusão temporal dos prazeres levando em conta o hedonismo exposto anteriormente.

A analogia espaço-temporal está ligado ao termo grego aísthesis que significa propriamente 'percepção sensorial' em sentido amplo ${ }^{198}$. De fato, Sócrates usa como parâmetro a 'percepção' visual do espaço, mas um fenômeno similar é encontrado também na 'percepção' do tato, com relação à intensidade dos sons, e a 'percepção' da audição, quanto a espessura dos objetos (356c). O mote central da analogia consiste na possibilidade de transferência do plano da percepção espacial para outro plano de percepção temporal já que todos esses campos perceptivos compõem a experiência abrangente da aísthesis. Com efeito, o que permite aos gregos tratar a percepção de prazer como a percepção sensorial engloba uma experiência mais abrangente e 'objetiva' do que costumamos restringir a uma experiência subjetiva interna de uma faculdade da sensação. Por isso, Sócrates pode se referir ao prazer em seu valor objetivo para além de sua percepção aparente

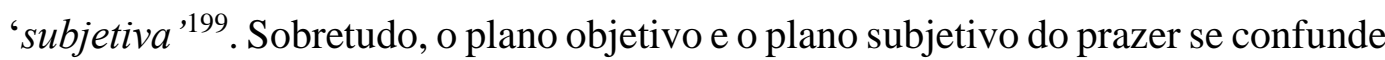
na aísthesis grega.

\footnotetext{
198 Sobre o amplo significado do termo aísthesis, ver LIDDEL-SCOTT, 1990. No sentido grego original, não há uma distinção explícita do plano objetivo e o plano subjetivo da experiência da aísthesis humana como há no significado moderno da 'percepção' interna do sujeito.

${ }^{199}$ É importante salientar aqui que não estamos nos referindo propriamente ao 'sujeito' no sentido moderno, relativamente cartesiano, separado estritamente do 'mundo exterior'. De acordo com o
} 
De acordo com Muniz (2011), a substituição dos termos hedoné e aísthesis marca um hábito tão comum entre os gregos que é natural classificar a 'sensação' em termos de prazer e dor ${ }^{200}$. Em outras palavras, há uma relação profunda entre a aísthesis e os desejos de forma geral. Dentro do contexto grego, a transferência da experiência sensória 'externa' dos objetos para a experiência 'interna' de prazer é legítima e justificada. Em todas essas experiências particulares de aísthesis, notamos uma inclinação humana espontânea: a atribuição de maior valor ao que está mais próximo e menor valor ao que está mais distante. Devido ao caráter intuitivo da percepção espacial, Sócrates transfere o parâmetro espacial para esclarecer a temporalidade obscura dos prazeres.

Na experiência visual, temos consciência de que o que é percebido costuma não condizer com o que é a realidade das coisas. Sob o aspecto perceptivo ${ }^{201}$, os objetos apresentam uma pluralidade de formas visíveis diferentes. Sob o aspecto objetivo, porém, podem ter exatamente as mesmas dimensões. A partir de nossa experiência prévia, sabemos que isso está intrinsecamente ligado ao ponto de vista definindo pelas condições de 'percepção' dos objetos visíveis. Em função da perspectiva humana, a aparência nos leva ao juízo comum de que os objetos sensíveis mais próximos têm dimensões maiores do que os objetos distantes menores. No entanto, a avaliação objetiva das medidas dos objetos visíveis nos revela, com frequência, que o juízo comum da percepção visível das dimensões aparentes não condiz com as dimensões reais. A percepção visual promove a ilusão da 'perspectiva' dos objetos espaciais e, principalmente, explica o comportamento humano ordinário de tomar as dimensões reais pelas dimensões aparentes.

que sabemos, havia uma separação tão demarcada entre o 'sujeito' e o 'mundo externo' até a Idade Média tal como se configurou para o mundo moderno. Nesse sentido, a experiência da 'sensação' era concebida normalmente como algo que ocorre entre o sujeito e o objeto exterior e não algo que restrito à uma 'faculdade da mente' humana (Ver também SNELL, 2001, ch. 1 e MUNIZ, 2011, p. 29-35). Com efeito, é isso que permite, por exemplo, Sócrates se referir ao prazer como uma 'coisa' com existência própria e não simplesmente, como nós, a uma sensação meramente subjetiva.

${ }^{200}$ Cf. MUNIZ, 2011, p. 38: “Ainda é preciso tirar algumas consequências do fato de a hedoné poder substituir o termo aísthesis, pois essa substituição, em diversos contextos, pode justificar, pelo menos idiomaticamente, o hábito bem estabelecido, no pensamento grego, de se caracterizar a sensação em termos hedonísticos, i. e., de tomar cada sensação como agradável ou desagradável, excluindo a possibilidade de haver sensação que não fosse, mesmo que minimamente, sensação de prazer ou sensação de dor. (...) Como a hedoné é uma aísthesis, a sugestão é de que há uma relação implícita entre a percepção de um modo geral e os apetites."

${ }^{201}$ Em função da dubiedade do termo 'subjetivo' no campo moderno, devemos evitar esse termo em favor do termo mais abrangente 'percepção' supondo assim a relação direta com um 'objeto exterior' que não fica tão clara assim com o termo anterior. Como mencionamos anteriormente, a aisthesis para os gregos sempre tem referência com um 'objeto exterior' e não contempla adequadamente a ideia moderna de 'impressões subjetivas internas'. 
Dessa forma, a percepção visual espontânea não nos fornece parâmetros epistemológicos seguros para determinar as magnitudes reais das coisas. Por suposto, um fenômeno análogo ocorreria na deliberação humana através da percepção temporal dos prazeres levando em conta a relação intrínseca entre aísthesis e aparência (phainómenon).

A conexão da aisthesis com a aparência (phainómenon) é essencial para o argumento socrático. No entanto, a transferência da percepção visual à percepção temporal dos prazeres não é tão imediata. Para entendermos a analogia, devemos retomar brevemente algumas conclusões do argumento hedonista de Sócrates sobre a inclinação humana natural ao prazer.

$\mathrm{O}$ argumento hedonista já havia constatado que a realidade do prazer e da dor não condiz com sua percepção aparente (356b-c). O exame da opinião dominante demonstra que as crenças em 'prazeres maus' e 'dores boas' são derivadas da relação temporal de prazeres e não condiz efetivamente com o que o 'prazer' e a 'dor' são em si mesmos, isto é, 'bem' e 'mal'. Nesse estágio, já se configura uma distinção preliminar da impressão equivocada das crenças tradicionais e o hedonismo ético objetivo de prazer e dor. Na perspectiva temporal, o prazer e a dor se caracterizam pela oposição temporal de parachrêma e télos. O reconhecimento do prazer 'imediato' e o prazer final do agente supõe a experiência prévia da deliberação humana espontânea. No entanto, o argumento hedonista comprova que a deliberação espontânea da akrasia não se inclina ao maior prazer em suas dimensões reais. Em face disso, Sócrates indica que o erro factual da akrasia não está ligado às dimensões reais de prazer e dor, mas às suas dimensões aparentes envolvidas na relação temporal de prazeres.

Ao que tudo indica, essa impressão ilusória espontânea nos leva a tomar os prazeres reais pelos prazeres aparentes. Por isso, a analogia com a percepção espacial visa esclarecer a impressão ilusória que se verifica na akrasia tradicional. Assim como a ilusão visual dos objetos afeta a percepção espacial, uma ilusão similar afeta a percepção temporal dos prazeres. Em A potência da aparência, Fernando Muniz (2011) tece observações pertinentes sobre o paradigma visual e o papel da analogia no argumento hedonista ${ }^{202}$.

\footnotetext{
202 Para a analogia da aísthesis, a minha referência fundamental foi A Potência da Aparência de Fernando Muniz. Segundo Muniz (Ibid., p. 78-80), a analogia nesse caso tem a função de esclarecer um domínio obscuro, a deliberação e a temporalidade dos prazeres, a partir de um campo
} 
Na seção O paradigma da percepção sensível e o prazer, Muniz enfatiza a relevância do paradigma visual na produção da ilusão da percepção temporal dos prazeres. Segundo Muniz (2011, p. 75), a distância dos objetos visíveis configura o plano relacional essencial na produção da ilusão que marca a percepção temporal dos prazeres: "não é possível que a ilusão possa se dar a partir de um objeto isolado, mas sim entre os objetos dispostos no espaço e os prazeres e dores no tempo". A partir disso, Muniz (Ibid., p. 79) estabelece que a analogia indica a reprodução de uma deformidade comum entre a percepção espacial visível e a percepção temporal da deliberação humana:

A transferência operada nessa comparação torna transparente a deformidade comum aos dois sistemas, estabelecendo nessa homologia uma semelhança no plano da deformidade, semelhança esta que os integra num mesmo domínio, o domínio regido pela mesma potência da aparência.

O plano relacional tem uma importância fundamental no argumento analógico de Sócrates. Assim como a ilusão de ótica só pode ser compreendida em função de sua distribuição na relação espacial, a ilusão dos prazeres precisa ser compreendida em função de sua relação temporal. Da mesma forma que a impressão ilusória visível depende do ponto de vista do observador, a ilusão dos prazeres depende da perspectiva temporal do agente. A deliberação espontânea se inclina à aparência 'maior' de prazer imediato e evita a aparência 'menor' do prazer futuro assim como o observador julga pela aparência espacial dos objetos visíveis. Em ambos os casos, a deformidade da aparência impede o acesso às dimensões reais das coisas. Ora, isso ocorre porque ambos compõem o mesmo registro amplo da 'aparência sensorial' da aísthesis. A seguir, mostraremos que esse fenômeno não é meramente cognitivo pois tem um aspecto intrinsecamente psicológico. De qualquer forma, devemos indicar quais as conclusões de Sócrates sobre o hedonismo ético e a ilusão da aparência dos prazeres.

Tendo em vista o hedonismo ético, Sócrates indica que a solução contra a ilusão da aparência estaria em uma forma de cálculo objetivo dos prazeres. Em 356b-c, Sócrates oferece uma série de orientações que parecem abrir preceito para

diretamente conhecido, a percepção sensível e a espacialidade dos objetos. Sendo assim, o mecanismo da ilusão da aparência só pode ser apreendido dentro desse contexto relacional da temporalidade e da espacialidade. 
uma leitura mais factual do que normativa do hedonismo ético no texto original grego:

\begin{abstract}
Se pesar coisas aprazíveis com coisas dolorosas, caso as dolorosas forem suplantadas pelas aprazíveis, quer as mais próximas pelas mais longínquas, quer as mais longínquas pelas mais próximas, você deverá empreender a ação (tèn prâxin praktéon) em que as aprazíveis dominarem. Contudo, caso as aprazíveis forem suplantadas não deverá empreendê-las (ou práktea). (356b-c)
\end{abstract}

Diante dessa passagem, observamos mais claramente a divisão do plano real objetivo e o plano temporal aparente de prazer. Com efeito, Sócrates orienta para nos comportarmos ou mesmo que sejamos tal "como um homem hábil em pesagem (hósper agathòs histánai)" (356b-c) para determinar as dimensões reais de prazer. No entanto, a linguagem adotada por Sócrates parece ambígua entre um fato da motivação humana ou uma exortação moral para a adoção do hedonismo.

O problema interpretativo recai fundamentalmente nos adjetivos verbais utilizados: ‘deverá optar’ (leptéa), ‘deverá empreender' (praktéon) ou 'não deverá empreender' (ou praktea) (356b-c). De forma geral, esses adjetivos verbais gregos expressam 'necessidade' e, especificamente, na construção impessoal presente no texto do Protágoras, a ênfase recai primordialmente sobre a ação verbal ${ }^{203}$. No contexto dessa passagem, o significado ambíguo da 'necessidade' da ação, abre-se o pretexto para duas leituras divergentes: uma 'descritiva psicológica' (é necessário, é preciso, não é possível fazer $x$ ) e outra 'normativa prudencial' (deve-se, ter de, é melhor fazer $x$ ). Em outras palavras, estaria Sócrates recomendando ou exortando à adoção de um tipo de hedonismo ético ou estaria ele apenas constando um fato necessário da motivação humana? Diante desse impasse, há uma controvérsia interpretativa em torno dessa passagem.

A controvérsia interpretativa se divide entre a leitura psicológica e a leitura normativa. De acordo com a primeira proposta 'psicológica', os termos leptea e praktea devem ser compreendidos como forças ou impulsos da natureza humana, derivados em última instância da admissão de um hedonismo psicológico. Como

\footnotetext{
${ }^{203}$ Cf. SMYTH, 1984, p. 479-480. Segundo Smyth, a construção impessoal dos adjetivos verbais em -teón/-téa é mais comum que a construção pessoal em -téos/-téa/téon. A ênfase da construção impessoal sobre a ação realizada confere um significado (praticamente) ativo ao adjetivo verbal e o torna equivalente à expressão 'dề' (é preciso, é necessário) (sec. 2149-2152, ver também, sec. 358.2, 471-473).
} 
vimos anteriormente, Santas (1979, p. 206-207) sustenta que o argumento de redução ao absurdo da akrasia depende de um forte hedonismo psicológico.

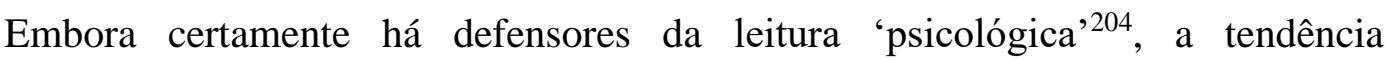
interpretativa geral tem sido assumir que o hedonismo psicológico não é tão decisivo no argumento hedonista, dando mais espaço à leitura 'normativa'. De acordo com essa segunda proposta, os adjetivos verbais têm a função de exortar 'o interlocutor', isto é, a opinião dominante a assumir um hedonismo ético. A partir disso, Taylor (1991) salienta que Sócrates apenas mostra aos seus interlocutores como agir corretamente de acordo com as premissas hedonistas ${ }^{205}$. Mais recentemente, tal leitura 'normativa' tem sido mais adotada ${ }^{206}$ para esclarecer o papel crucial do hedonismo ético no argumento hedonista. Apesar do caráter persuasivo dessa hipótese interpretativa, devemos indicar que o hedonismo socrático é indissociável do próprio exame das crenças da opinião dominante.

O hedonismo ético de 356b-c segue a inconsistência da akrasia tradicional (354e-356b). Como observamos, o argumento da redução ao absurdo da akrasia havia constatado o fato objetivo do erro (exemártanen) na escolha dos prazeres e sua incompatibilidade com o relato (lógos) da opinião dominante (355b-e). A objeção do interlocutor insolente revela que a relação temporal de prazer e dor não interfere nas dimensões reais de prazer e dor do hedonismo ético (355e-356c). Durante o exame da opinião dominante, Sócrates relembra constantemente o compromisso com os princípios do hedonismo ético. Por isso, a questão crucial da redução ao absurdo da akrasia concerne o parâmetro avaliativo da própria opinião dominante: o bem possui o mesmo valor do mal "em vós (en hýmin)"? (355d). Sem dúvida, Sócrates está se referindo à 'estimativa' de prazer e dor do hedonismo ético da opinião dominante. Diante disso, a redução ao absurdo da akrasia tradicional

\footnotetext{
${ }^{204}$ Para a leitura psicológica da passagem, ver VLASTOS, 1969, p. 85 n. 49; RUDEBUSCH, 1999a, p. 21-22.

205 Cf. TAYLOR, 1991, p. 190: "we should understand the function of the passage to be the application of the evaluatively hedonistic assumption of the common man to the notion of an aggregate of pleasures. Socrates (...) he induces the common man to accept his account of how one chooses correctly, in order to pave the way for his account, which follows at once, of how incorrect choices come to be made."

206 Dentro dessa linha interpretativa, Wolfsdorf (2006, p. 121-125) concede uma leitura normativa mas alega que a oposição normativa/psicológica não se aplica adequadamente ao argumento socrático do Protágoras (ou em outros diálogos, em que esses adjetivos verbais reaparecem e a leitura psicológica supostamente prevalece sobre a leitura normativa). No entanto, outras interpretações mais recentes têm relativizado essa oposição absoluta normativa/psicológica. Na sequência, adotaremos justamente essa nova proposta interpretativa.
} 
revela que a estimativa acurada do hedonismo é incompatível com o erro cometido pelo acrático. A separação do hedonismo e da ação incorreta da akrasia permite a Sócrates elaborar um argumento hipotético para mostrar de que modo o hedonismo acarreta a ação moral correta ${ }^{207}$. O hedonismo ético atribuído à maioria assume, então, o caráter do hedonismo socrático acurado. Por conta do caráter hipotético de 356b-c, o hedonismo socrático é seguramente normativo mas, de tal forma, que não exclui inteiramente uma leitura psicológica.

O hedonismo socrático, cujos princípios são expostos em 356b-c, apresentase como um hedonismo ético amparado no fato da inclinação humana natural ao prazer. Recentemente, alguns comentadores têm contestado a oposição normativa/psicológica levando em conta que o argumento hedonista socrático está mais voltado para a natureza da deliberação prática humana em geral do que ao exame de uma teoria ética ou psicológica singular ${ }^{208}$. Com efeito, os únicos princípios hedonistas admitidos por Sócrates estão expostos no exame das crenças da opinião dominante. Como vimos, o hedonismo da opinião dominante contempla duas teses simplificadas: (a) o princípio valorativo do hedonismo ético, isto é, o 'prazer' é $o$ 'bem' e a 'dor' é $o$ 'mal' (353e-354e); (b) o principio hedonista da motivação humana, ou seja, o homem busca o 'prazer' como 'bem' e foge da 'dor' como 'mal' (354c). O exame das crenças da opinião dominante é eminentemente negativo e não nos compromete com nada além de princípios hedonistas que expõe um hedonismo ético com base na inclinação hedonista natural da deliberação prática humana.

\footnotetext{
${ }^{207}$ O caráter hipotético da passagem é marcado sobretudo pela presença ostensiva das partículas eán e án e também pela preposição condicional 'ei' (se). Devido a construção do argumento socrático de 356b-357b, Kamtekar (2017, p. 50) classifica o argumento de 'protréptico': "Just as there is a schema for refutation, there is one for protreptic: show how wisdom and/or virtue is the best means to the goods already recognized." No entanto, a sua classificação, como ela mesmo reconhece, acaba transferindo o valor explicativo da 'potência da aparência' e da 'ignorância' (356b-357e) para o paradoxo socrático final (358a-d). De acordo com minha interpretação, o paradoxo final deriva de uma conclusão da descrição correta do fenômeno da akrasia enquanto 'ignorância' promovida pela potência da aparência.

${ }^{208}$ Cf. SEGVIC, 2009, p. 74: "The reflection he [Socrates] is interested in is practical reflection: one that changes preferences, and goes all the way down, to influence the very valuations in which we act. The more we add the notion of better judgment in terms of one's identification with it, the closer we get to the grounds on which Socrates refused to admit that one can ever act against one's knowledge of what is bettter." De fato, a reflexão sobre a deliberação prática abrange o aspecto ético e o aspecto motivacional mas não pode ser isolado em uma teoria ética ou uma teoria psicológica de forma independente. Na realidade, o exame negativo de Sócrates sequer contempla uma 'psicologia' humana em sentido forte mas somente constata um fato sobre a motivação humana ligado às crenças tradicionais da opinião dominante. Para uma análise da deliberação prática no argumento hedonista. Ver também CALLARD, 2014, p. 57; KAMTEKAR, 2017, p. 48-49.
} 
Após a redução ao absurdo da akrasia, o argumento hedonista esclarece o que ocorre realmente no fenômeno. Nesse estágio, a constatação do erro da akrasia demonstra que o fenômeno é incompatível com o hedonismo. Novamente, o exame negativo de Sócrates demonstra que o 'prazer' e a 'dor' em si mesmos, isto é, em sua dimensão real, não podem ser afetados pela relação temporal de prazeres com base no hedonismo (356a-b). Diante disso, o argumento lança a seguinte hipótese: se a dimensão real de prazer e dor não é afetada pela relação temporal, então a dimensão aparente deve sofrer os efeitos ilusórios da percepção temporal. A dimensão aparente de prazer e dor que explicaria o que ocorre efetivamente no erro da akrasia.

O hedonismo socrático, portanto, tem um papel decisivo na própria descrição correta do fenômeno como ‘ignorância’ (amathía). Que o argumento hedonista é imprescindível na refutação da akrasia, é algo relembrado no final do exame da opinião dominante: "Se naquela ocasião tivéssemos prontamente respondido 'Ignorância' (amathía), vocês teriam rido da nossa cara; todavia, se agora rirem de nós, rirão de si próprios" (357d). O argumento hedonista da opinião dominante constitui parte integral do hedonismo socrático e a descrição correta da ignorância do fenômeno. Da mesma forma, a descrição socrática da ignorância depende da consistência do hedonismo socrático. Nessas circunstâncias, precisamos compreender o que constitui propriamente o hedonismo socrático já que sua consistência envolve o sucesso ou fracasso decisivo da refutação da akrasia tradicional.

A controvérsia interpretativa da refutação da akrasia tradicional perpassa o hedonismo socrático e a 'potência da aparência'. Dessa forma, pretendemos verificar os problemas envolvidos na descrição socrática da ignorância.

Para isso, analisaremos dois temas intrinsecamente relacionados: a classificação do hedonismo socrático e a refutação da akrasia tradicional. Em primeiro lugar, nos preocuparemos com a classificação do hedonismo e sua consistência no argumento socrático do Protágoras. Em segundo lugar, analisaremos especificamente a refutação da akrasia tradicional através do hedonismo socrático. Para tanto, devemos trazer à tona as interpretações conflitantes da passagem de forma a avaliar os problemas levantados sobre a classificação do hedonismo e a consistência da refutação socrática da akrasia. Com isso, poderemos comprovar o sucesso ou o fracasso de Sócrates na refutação da 
descrição tradicional da akrasia. Desse modo, retornaremos sucintamente a analogia do espaço e tempo de modo a compreender qual sua relação com a classificação do hedonismo.

\section{5 \\ A divergência interpretativa: a classificação do hedonismo e a akrasia tradicional}

A tradição interpretativa do diálogo confere ao hedonismo um papel primordial na refutação da akrasia tradicional. Nessa linha interpretativa, Gosling \& Taylor, seguidos por Irwin, postularam que o hedonismo socrático se ampara em uma distinção temporal de prazeres. Com isso, esses autores alegam que a refutação socrática não funciona porque o hedonista ainda estaria sujeito aos seus impulsos irracionais. No entanto, mostraremos que isso é um problema relativo ao hedonismo contrafactual dos prazeres de longa duração e não se sustenta nos próprios argumentos socráticos. Assim, vejamos alguns dos pressupostos desse tipo de hedonismo.

A distinção temporal dos prazeres fundamenta o hedonismo dessa corrente interpretativa. Os autores de The Greeks on Pleasure, Gosling \& Taylor (1982), indicam que a identidade entre o prazer de longa duração e o bem é fundamental ao hedonismo socrático. Com efeito, a distinção entre prazer de curto e longo prazo parece ser antecipada quando Sócrates classifica as coisas aprazíveis como "as coisas que compartem (metéchonta) ou produzem (poioûnta) prazer" (351d).

Para Gosling \& Taylor (Ibid., p. 56-57), Sócrates compreende então que o prazer pode ser tanto uma qualidade inerente a objetos ou ações - uso padrão quanto pode ser produzido posteriormente por tais coisas - uso extensivo. Nesse caso, o uso padrão de classificação do prazer corresponde aos prazeres de curta duração do juízo comum da opinião dominante, enquanto o uso extensivo corresponderia ao prazer de longa duração. Nessa perspectiva, os autores (Ibid., p. 53) atribuem a Sócrates um hedonismo esclarecido em que o agente dispõe do conhecimento adequado para a escolha, com precisão, dos prazeres de longa duração, que o conduzirão, com precisão, à predominância de prazer durante toda sua vida. 
Em Plato's Ethics, Irwin (1995, p. 88-91) adota uma linha interpretativa semelhante assumindo uma distinção temporal dos prazeres. De acordo com Irwin (Ibid., p. 114-115), o problema da akrasia constitui uma objeção forte ao eudaimonismo psicológico de Sócrates, a teoria segundo a qual todos os homens visam universalmente a plena realização humana (eudaimonía) na ação humana. Ora, o eudaimonismo não é universalmente aceito, mas o prazer constitui um critério mais objetivo da vida humana. O eudaimonismo é extremamente controverso se levarmos em conta variedade e particularidade que a concepção de 'eudaimonía' tem para cada um - pois cada um se refere a um conjunto diferente de valores necessários para alcançar a felicidade - ao passo que é mais fácil e objetivo determinar se um indivíduo está aproveitando sua vida com prazer. Assim, o hedonismo apresenta o prazer como um fundamento e não como um mero substituto da eudaimonía, um critério objetivo para definir o bem que é o fim último de todas as nossas ações. Dessa forma, Irwin (Ibid., p. 83) classifica o hedonismo socrático de hedonismo epistemológico, isto é, "taking judgments about pleasure to be epistemologically prior to judgments about goodness." ${ }^{209}$. Mesmo assim, tanto Irwin quanto Gosling \& Taylor levantam substancialmente a mesma objeção orientada a demonstrar que o hedonismo socrático não inviabiliza a akasia tradicional.

A partir dessa linha interpretativa, o agente, mesmo assumindo o hedonismo, ainda estaria sujeito a akrasia ${ }^{210}$. É possível ter plena consciência dos efeitos de suas ações e, ainda assim, ser influenciado por prazeres imediatos ou pela satisfação imediata dos desejos. Plausivelmente, ele pode achar que determinada conduta pode ser pior ou mais dolorosa a longo prazo e, ainda assim, ser atraído de forma imediata à conduta errada. Por ventura, o indivíduo estaria sujeito à preguiça, à impaciência, ou mesmo a um forte impulso. O homem acrático acabaria negando não só o hedonismo como também, principalmente, o princípio derivado de que 'sempre agimos de acordo com o que cremos ser melhor' ou, em outros termos, 'ninguém faz o mal de bom grado' que constitui o eudaimonismo psicológico. Em

\footnotetext{
${ }^{209} \mathrm{Na}$ realidade, o hedonismo epistemológico de Irwin (Ibid., p. 53-54) abrange duas teses sobre a eudaimonía: o eudarimonismo racional, a tese segundo a qual a eudaimonía fornece a justificação última de nossas ações, como também o eudaimonismo psicológico, segundo a qual ela constitui a razão última de nossas ações. Como mencionamos anteriormente, o eudaimonismo psicológico se encontra claramente formulado na passagem 358b-d.

${ }^{210}$ Cf. IRWIN, 1995, p. 115; GOSLING \& TAYLOR, 1982, p. 57-58. Ver também objeções similares em TAYLOR, 1991, p. 203-204; PRICE, 1995, p. 21-22; SANTAS, 1979, p. 213-217.
} 
todo caso, o problema fundamental não está no hedonismo socrático, mas na distinção temporal pressuposta por esse tipo de hedonismo.

O hedonista esclarecido é o único capaz de medir os prazeres de longa duração em função de uma vida predominantemente prazerosa. Assim como a opinião dominante, o homem acrático, por sua vez, realiza o cálculo errado por estimar mais a curta duração do que a longa duração, já que não possui o conhecimento adequado do esclarecido, a técnica da medida. Em todo caso, o hedonismo não apela aos desejos atuais do prazer de curta duração do ignorante, mas apenas aos desejos contrafactuais, isto é, desejos que teria caso tivesse o conhecimento da distinção qualitativa de prazeres do homem esclarecido ${ }^{211}$. A conexão implícita do hedonismo entre crenças e desejos impossibilita que o sujeito ignorante sinta qualquer prazer na satisfação dos desejos que só podem ser experimentados pelo homem esclarecido durante sua ação errada. Nessa perspectiva, o hedonismo temporal dos prazeres supõe que o conhecimento dos prazeres de longa duração possa promover desejos que o ignorante, efetivamente, não possui.

Apesar dos problemas envolvendo a distinção temporal dos prazeres, a classificação do hedonismo de Irwin possui algumas vantagens sobre o hedonismo de Gosling e Taylor. Ao contrário desses autores, Irwin compreende que o prazer fornece a Sócrates um critério quantitativo objetivo para determinar o fim último da eudaimonía e, sobretudo, com o objetivo de fundar o hedonismo sob o conhecimento (epistéme).

A distinção temporal dos prazeres, contudo, inviabiliza esse projeto socrático. De um lado, isso abre precedente para que a akrasia seja o resultado da submissão a um conjunto variado de 'sensações'. Como mostra Rudebusch (1999a, p. 24), a distinção temporal inviabiliza o argumento socrático contra akrasia porque constitui uma distinção qualitativa que realça a diversidade dos impulsos imediatos do agente. Com isso, o hedonismo recairia na crença da incomensurabilidade, isto

\footnotetext{
${ }^{211}$ Podemos associar a classificação do hedonismo sugerida por Gosling, Taylor e Irwin com o hedonismo de satisfação cognitivamente contrafactual apresentada por Rudebusch em seu artigo $O$ Hedonismo de Cálicles. De acordo com Rudebusch (1999b, p. 167-168), esta teoria sustenta que 'o bem de uma pessoa consiste na satisfação dos desejos que ela teria quando fosse cognitivamente esclarecida, ou seja, tivesse informação factual completa e acurada e habilidade lógica e conceitual'. De fato, as críticas de Rudebusch a essa teoria são bastante similares as críticas dirigidas pelos próprios autores ao hedonismo de Sócrates (Ibid., p. 168-169). Para outra crítica ao hedonismo esclarecido ver também PRICE, 1995, p. 18-20.
} 
é, de que não há um parâmetro único de comparação das alternativas de ação. Não conseguimos julgar objetivamente qual delas tem maior valor. Ao contrário, o que Sócrates visa assegurar é a comensurabilidade, isto é, que há um parâmetro mensurável de comparação das diversas alternativas de ação. De outro lado, o próprio exame da opinião dominante mesmo reconhecendo a distinção temporal dos prazeres apresenta um hedonismo estritamente restrito à um parâmetro quantitativo de prazer.

Como observamos anteriormente, o argumento hedonista da opinião dominante efetivamente salienta a relação temporal dos prazeres (353e-354e). Todavia, o argumento originalmente pretende mostrar as inconsistências da opinião dominante sobre a crença em 'prazeres maus' e 'dores boas' (351c-e). O argumento hedonista revela que essa crença está fundada sob a relação temporal dos prazeres, enquanto o 'prazer' e 'dor' "em si (en autôi)" são determinados apenas na relação quantitativa, por serem 'maiores' ou 'menores' (354c-e). A partir disso, Sócrates abandona qualquer distinção de nomes entre 'prazer', 'dor', 'bom' e 'mau' tratando 'prazer' e 'bem' assim como 'dor' e 'mau' como “as mesmas coisas (autá)” (355b). Na própria demonstração do absurdo da akrasia tradicional, Sócrates claramente elimina qualquer distinção temporal dos prazeres com base em uma objeção hipotética. De fato, tudo leva a crer que o objetor representa ainda as crenças da opinião dominante que persistem na avaliação dos prazeres pela relação temporal.

O hedonismo socrático abandona não só as crenças em 'prazeres bons' e 'dores boas' como também a relação temporal sob a qual tais crenças tradicionais estão fundadas. $\mathrm{O}$ hedonismo socrático definitivamente rejeita a distinção temporal dos prazeres advinda das crenças comuns subjetivas da maioria. Nesse sentido, Sócrates reitera que é preciso distinguir o prazer e a dor em si (autá), isto é, em sua realidade objetiva, e o prazer e dor temporais do juízo comum da opinião dominante, em sua aparência subjetiva. Portanto, é preciso encontrar uma classificação do hedonismo que contemple o critério objetivo de prazer.

Em seguida, abordaremos outra proposta interpretativa oferecida por Rudebusch e Nussbaum que estão mais próximos da distinção quantitativa dos prazeres do hedonismo socrático. Como veremos, os critérios quantitativos definidos permitem preservar o que dessigamos anteriormente de comensurabilidade, ou seja, um parâmetro singular que promove a possibilidade de comparação entre as alternativas de escolha do agente. 
A proposta interpretativa de Rudebusch e Nussbaum enfatiza o interesse primordial de Sócrates em fundar o hedonismo na comensurabilidade. A partir desse hedonismo comensurável, o argumento hedonista visa eliminar a ameaça da akrasia que reside principalmente na incomensurabilidade da diversidade incomparável dos impulsos humanos. Em linhas gerais, o hedonismo socrático depende definitivamente da comensurabilidade. Contudo, devemos ressaltar que o hedonismo é um argumento auxiliar no diálogo destinado a desvendar a verdadeira natureza a natureza do poder do conhecimento e o efeito da 'potência da aparência' dos prazeres. A partir disso, abordaremos a seguir a proposta interpretativa de Rudebusch e Nussbaum.

Nessa outra linha interpretativa, a força da descrição tradicional da akrasia corresponde ao poder da incomensurabilidade. Como vimos anteriormente, Rudebusch sustenta que a distinção qualitativa entre prazeres de curta e longa duração inviabiliza o argumento socrático antiakrasia pois apela à crença em uma pluralidade heterogênea de motivações humanas.

Segundo Rudebuch (1999a, p. 22-24), o efeito da akrasia reside justamente na convicção da incomensurabilidade, ou seja, na impossibilidade de comparar as diferentes alternativas de escolha através de um critério objetivo. Nesse sentido, a opinião dominante iria continuar atribuindo o erro da akrasia a diversos desejos imediatos - como medo, sexo, comida, bebida, ira (352c-d) -, mesmo aderindo a um padrão quantitativo e determinando com objetividade qual a melhor alternativa. Ao contrário do que parece, nenhum desses casos de akrasia corresponde a uma simples opção de mais ou menos, maior ou menor. Na verdade, os diversos impulsos representam apenas razões que justificam de alguma forma a escolha da pior alternativa de ação (Ibid., p. 22). A convicção em um conjunto variado de motivações instaura a incomensurabilidade no processo deliberativo e elimina assim a perspectiva de um parâmetro comensurável da ação. Assim como Rudebusch, Nussbaum reconhece e reforça em mais detalhes a relação intrínseca entre incomensurabilidade e a akrasia.

Em A fragilidade da bondade, Nussbaum (2009, p. 95-104) explora com mais profundidade o poder da incomensurabilidade da akrasia. Em sua perspectiva, não é apenas uma mera crença na qualidade que provoca a alteração no juízo do agente, mas fundamentalmente um tipo de especialidade que torna sua escolha 
única e insubstituível. De acordo com Nussbaum (Ibid., p. 103), o poder da akrasia reside exatamente nesta característica:

A akrasia, como a conhecemos e vivemos, parece depender da crença que os bens são incomensuráveis e especiais: que (...) essa pessoa, essa atividade, embora em certo sentido não tão boa em geral quanto sua rival, tem, entretanto, um gênero especial de bondade que nos impulsiona a ela (...). (itálicos da autora)

A incomensurabilidade, portanto, deve explicar como o acrático avalia com objetividade as alternativas de ação e acaba agindo contra sua razão prática. De acordo com Nussbaum, isso se deve à crença na especialidade dos objetos ou das atividades à nossa disposição no momento da ação. Essa incomensurabilidade dos objetos de desejo abre espaço ao desenvolvimento de motivações irracionais justificando o desejo pela satisfação imediata e a ação contrária ao melhor juízo. Por isso, a crença na qualidade especial peculiar de uma variedade de coisas - do amante, alimento ou atividade - nos leva a considerar que qualquer ação imediata tem um valor singular incomparável a outras alternativas de ação. Dessa forma, a incomensurabilidade estaria na base da 'potência da aparência' no Protágoras.

Como observamos, Sócrates demonstrou que o acrático, enquanto hedonista, tem uma inclinação natural pelo maior bem/ maior prazer, mas acaba sendo impedido de alcançá-lo por causa da ilusão temporal de prazeres. Dessa maneira, ele tem a impressão de que avalia o que é bom/mau por um critério objetivo, quando, na realidade, está utilizando um critério qualitativo de escolha pelo prazer imediato. Com efeito, essa impressão aparente de objetividade do juízo comum espontâneo do agente em sua deliberação prática constitui um efeito ilusório fundamental da akrasia. Como ressalta Sócrates, a potência da aparência promove um estado constante de "errância' e "vacilação (metalambánein)" na ação (356d). A partir dessa nova proposta interpretativa, o poder da incomensurabilidade não oferece qualquer parâmetro objetivo de comparação das alternativas de escolha. Contudo a incomensurabilidade transmite também a impressão aparente ilusória de objetividade da deliberação prática imediata. Por isso, estabelecer que a opinião dominante é hedonista é insuficiente ao argumento socrático pois é preciso ir além e assegurar a escolha correta das dimensões reais de prazer.

Em oposição à incomensurabilidade, a aspiração socrática da comensurabilidade, isto é, tornar as alternativas de escolhas comparáveis por um 
mesmo padrão singular, é plenamente justificada. Somente nesse contexto, é possível compreender melhor porque o prazer fornece a Sócrates um critério objetivo de escolha. De acordo com Nussbaum (2009, p. 97), a tese hedonista não surge pelo interesse isolado no prazer, mas com o objetivo de selecionar um fim singular para sua nova técnica prática: "Sócrates o adota [prazer], antes, por causa da ciência que ele promete, e não por sua própria plausibilidade intrínseca". Nessa perspectiva, o hedonismo surge como uma tese experimental elaborada para viabilizar uma técnica prática que forneça à deliberação humana a precisão das técnicas de contagem ou mensuração de objetos no espaço (cf. Ibid., p. 95-96).

No Protágoras, a "técnica da medida (metretiké téchne)" tem o propósito fundamental de assegurar a deliberação racional correta com base no hedonismo. Com efeito, Sócrates demonstra confiança no modelo matemático da técnica da medida para "a salvação de nossas vidas (hemîn he sotería tô̂ bíou)":

\begin{abstract}
Uma vez que salvação de nossas vidas depende manifestamente da escolha (en orthêi têi airései) referente ao prazer e à dor, ao mais e menos numeroso, ao maior e ao menor, ao mais longínquo e ao mais próximo, porventura não é claro que, em primeiro lugar, que diz respeito à medida (metretikè), visto que consiste no exame do excesso, da falta e da equivalência de um com relação ao outro? (357a-b)
\end{abstract}

As técnicas de mensuração e a aritmética servem de inspiração à técnica deliberativa de Sócrates. Nessa passagem, observamos que a técnica socrática visa colocar as alternativas de ação em uma escala quantitativa única. Como vimos, isso garante a comensurabilidade do prazer segundo um padrão de medida singular. Ao mesmo tempo, a comensurabilidade da técnica da medida teria a possibilidade de abolir a ilusão da aparência do 'mais longínquo ao mais próximo' que se configura na relação temporal de prazer. A ameaça da crença na incomensurabilidade da diversidade de impulsos imediatos também seria eliminada. A técnica da medida está efetivamente comprometida com a comensurabilidade quantitativa do prazer.

Com base na comensurabilidade, Rudebusch (1999a, p. 24-25) apresenta uma classificação mais apropriada do hedonismo socrático. Pela comparação com quantidade mensurável de dinheiro, ele demonstra que o hedonismo socrático permite explicar a akrasia com base na distinção entre aparência e realidade de prazeres. Para Rudebusch, o dinheiro, assim como o prazer, é uma quantidade abstrata cuja magnitude real só pode ser identificada através da aparência. O prazer, 
no entanto, tem a capacidade de aparecer de maneira muito mais variada que o dinheiro. Assim, a vulnerabilidade do agente, diante do prazer, faz com que seu juízo acerca das proporções de suas alternativas seja alterado por conta da presença de um prazer imediato (Ibid., p. 26). De qualquer maneira, não precisamos recorrer à incomensurabilidade dos variados impulsos imediatos se nos mantivermos hedonistas. É apenas o imediatismo da aparência de prazer que pode justificar a crença equivocada do homem acrático e impedir a avaliação correta do maior prazer. Segundo Rudebusch, a distinção dos prazeres que Sócrates postula no Protágoras é a diferença das magnitudes reais e aparentes de prazer.

A preservação da comensurabilidade é um claro objetivo da técnica da medida, porém o foco principal do hedonismo recai mais fundamentalmente na natureza da akrasia. Como assinala Price (1995, p. 23-24), a comensurabilidade de um hedonismo calcado na homogeneidade qualitativa do prazer não condiz com os argumentos abstratos de Sócrates. O hedonismo não parece estar substancialmente comprometido nem com a 'precisão' da técnica e nem mesmo com a exclusão absoluta da akrasia $^{212}$. Com relação à potência da aparência, a passagem do hedonismo e da akrasia sequer explora a natureza do sensível ou estabelece uma conclusão mais definida sobre a deficiência ontológica do sensível, claramente explicitada em diálogos posteriores de Platão ${ }^{213}$. Na realidade, o exame da opinião dominante assume a forma típica do elenchus socrático, estabelecendo conclusões negativas acerca das crenças tradicionais de seu interlocutor personalizado (a própria opinião dominante) do que conclusões positivas acerca da natureza do prazer ou do campo sensível.

O exame da opinião dominante está comprometido com a descrição correta do fenômeno em vista das crenças tradicionais equivocadas na akrasia. Em nenhum momento, Sócrates pretende traçar conclusões definitivas sobre a potência da aparência ou a técnica da medida. Particularmente, a vagueza de Sócrates sobre a técnica da medida é notável: "o que é essa arte e conhecimento investiguemos em outro momento. (...) que é conhecimento, basta para a demonstração (prós tèn

\footnotetext{
${ }^{212}$ Ver também KAMTEKAR, 2017, p. 39: "in the Protagoras, [the socratic paradox] is made plausible by Socrates' refutation of the Many's account of how knowledge can be overcome by pleasure, rather than (...) being required for the refutation."

${ }^{213}$ Cf. MUNIZ, 2011, p. 75: "O texto não nos permite supor a desqualificação da experiência sensória por alguma falha ontológica ou qualquer outra razão metafísica que fundamente a atribuição de uma deficiência à natureza do sensível."
} 
apódeixin) (...).” (357b-c). Desde o início, o mote central do exame continua sendo a demonstração (apódeixis) do equívoco da opinião dominante sobre a 'experiência' (páthos/páthema) da akrasia. Mesmo assim, a preservação da comensurabilidade da deliberação prática e as proporções reais do prazer permanecem sendo fundamentais na demonstração do erro factual da 'ignorância' do fenômeno.

A distinção da aparência e realidade dos prazeres viabiliza o parâmetro quantitativo e objetivo do argumento socrático. Por isso, a proposta interpretativa de Rudebusch e Nussbaum tem méritos sobre as interpretações precedentes. De um lado, tal distinção assegura a comensurabilidade do parâmetro objetivo de avaliação das alternativas de ação pela quantidade de prazer. De outro lado, a distinção também contempla a diferença crucial das magnitudes reais e aparentes de prazer.

No entanto, há também certos aspectos do texto não contemplados nessa perspectiva interpretativa: (a) Sócrates não menciona efetivamente nada definitivo acerca da natureza dos prazeres e nem sobre qualquer hedonismo homogêneo qualitativo; (b) a incomensurabilidade da aparência reflete o efeito do 'ignorância' em contraposição à comensurabilidade da dimensão real de prazer, mas não esclarece a causa da ilusão da 'aparência' em si mesma, isto é, a irracionalidade do fenômeno por si mesma não explica o que lhe ocasiona efetivamente; (c) o argumento socrático é propositalmente negativo sem estabelecer nenhuma conclusão definitiva acerca da técnica da medida ou da potência da aparência independente da própria descrição correta do fenômeno. De fato, o argumento socrático trata de desvincular o erro ilusório da 'ignorância' do conhecimento objetivo da técnica da medida.

O interesse primordial do argumento é a demonstração do erro da akrasia e a clara distinção do fenômeno do conhecimento moral. Com a redução ao absurdo da descrição tradicional, Sócrates consegue estabelecer essa conclusão negativa, ou seja, que o fenômeno não constitui o conhecimento do bem real.

Com base no hedonismo, a potência da aparência surge como um fenômeno fundamental destinado a esclarecer o que é o erro factual da akrasia levando em conta a relação temporal equivocada dos prazeres. A partir disso, Sócrates estabelece uma distinção negativa entre o domínio real e o domínio aparente de prazer. O fenômeno da akrasia é esclarecido a partir do efeito ilusório da potência 
da aparência dos prazeres. $\mathrm{O}$ argumento hedonista está voltado exclusivamente à demonstração do erro da akrasia.

\title{
3. 6
}

\section{A errância da aparência: a estado de ignorância e a ilusão do prazer}

A refutação da descrição tradicional da akrasia resulta na demonstração de que o fenômeno é ignorância. Apesar da consistência da defesa do conhecimento, a formulação socrática do fenômeno é extremamente controversa. A dificuldade em se compreender a natureza da ignorância perpassa o processo da 'potência da aparência'. Em 357d-e, Sócrates compara o estado interno do agente sob a "potência da aparência (toû phainoménou dýnamis)" e sob a "técnica da medida (metretiké téchne)":

\begin{abstract}
Ou este último [a potência da aparência], por vezes não fazia com que vacilássemos (eplána kaì epoíei áno te kaì káto) recorrentemente e trocássemos de lugar (metalambánein) as mesmas coisas, e nos arrepedêssemos (metamélein) de nossas ações e escolhas referentes as coisas grandes e pequenas? A técnica da medida, por seu turno, não destituria a autoridade desta aparência (ákuron epoíese toûto tò phántasma) e, ao lhe mostrar o que é verdadeiro, não tranquilizaria a alma (hesuchían échein tèn psychèn) que passaria a se calcar nele (ménousan epì tôi alethê̂), salvando-lhe a vida? (356d-e)
\end{abstract}

A descrição da ignorância está intrinsecamente ligada à dyamis da aparência. Diante disso, a oposição entre potência da aparência e técnica da medida deixa em evidência dois estados internos diferentes da alma. De um lado, a potência da aparência coloca em jogo um vocabulário marcado pela condição de errância: metalambánein, metamélein, mas, principalmente, o verbo eplána junto à expressão áno te kaì káto. De outro lado, a técnica da medida envolve um conjunto de atributos opostos que salientam a ausência de perturbação do estado interno da alma, "a destituição da aparência (ákuron toûto tò phántasma)", a "tranquilidade da alma (hesuchían tèn psychèn)" e a "permanência na verdade (ménousan epì tôi alethê̂)". Em ambos os casos, o que emerge do poder da aparência é a própria condição errática e o conflito interno da alma humana.

$\mathrm{Na}$ passagem mencionada anteriormente, o vocabulário da errância manifesta o efeito da potência da aparência na condição interna do agente. 
Sobretudo, a condição errática do indivíduo é marcada na expressão eplána kaì epoíei áno te kaì káto. Por si mesmo, o verbo 'planáo' expressa o ato de colocar o outro em 'engano', 'ilusão', no sentido de 'desencaminhar-se', 'estar incerto', 'desviar-se' [do caminho correto]. Na voz médio-passiva, o verbo designa o movimento irregular dos astros, como 'vaguear' ou mesmo 'perambular' ${ }^{214}$. Como salienta Muniz (2011), o verbo 'planáo' acompanhado da expressão 'áno te kaì káto' (literalmente, de cima para baixo) intensifica o movimento errático do pensamento e da ação do agente, expresso no estado vacilante permanente da alma perante sua vulnerabilidade constante à ilusão da aparência ${ }^{215}$.

A condição errática do agente é reforçada pelos verbos metalambánein e metamélein: em ambos os casos, a preposição 'metá' e o infinitivo de 'lambánein' e 'mélein' acentuam a ideia de uma mudança constante da alma do agente. Enquanto metalambánein significa literalmente 'substituir, tomar em troca de ou tomar no lugar de', metamélein significa, por sua vez, 'arrepender-se', 'lamentar-se' das ações realizadas. Em especial, o verbo 'méllo', como indica Chantraine (1968, p. 682-683), significa uma 'quase-intenção', ou melhor, 'estar ao ponto de ter uma intenção' pela proximidade iminente do futuro, do porvir, do que provavelmente irá ocorrer em breve. Em si mesmo, o termo 'méllo' designa apenas uma 'hesitação' ou 'indecisão' enquanto a palavra composta 'metamélein' enfatiza a condição recorrente de indecisão das resoluções do agente. Nesse sentido, 'metamélein' expressa, o efeito ilusório do prazer parachrêma, isto é, o prazer iminente ligado à expectativa do futuro próximo. Como observamos, essa expectativa temporal iminente dos prazeres é ilusória, já que mantém a impressão aparente espontânea de que o prazer imediato é sempre mais valoroso do que o prazer futuro. Assim, o vocabulário da errância intensifica o estado errático do agente sujeito à influência das aparências.

Diante dessas condições, Sócrates reconhece aqui todos os elementos essenciais da representação fenomenológica da experiência da akrasia. Como

\footnotetext{
${ }^{214}$ Sobre a etimologia de planáomai ver CHANTRAINE, 1968, p. 909-910.

215 Cf. MUNIZ, 2011, p. 84-85: “a dýnamis da aparência, por seu modo de atuação, produziria a errância como um estilo de vida. Daí que esses dois termos týkhe e pláne são indissociáveis, já que são complementares, pois, enquanto a týkhe é o que comanda, digamos, espontaneamente, o agir e o pensar humano, o resultado de uma ação e de um pensamento comandado pela týkhe é sempre pláne, pensamento da errância. (...), o movimento errático e ilusório que esse verbo [planao] designa, quando associado à expressão adverbial áno kaì káto, ganha ênfase tanto no seu aspecto topográfico, o da errância num espaço, quanto no aspecto cognitivo, quando está associado à ilusão, à sedução ilusória promotora da perpetuidade do movimento."
} 
ressaltamos, a negação socrática da akrasia não é uma rejeição do próprio fenômeno mas uma descrição correta de sua verdadeira natureza. Em oposição ao estado interno provocado pelo efeito das aparências, Sócrates representa o estado interno do agente sob domínio da 'técnica da medida' (metretiké téchne).

A posse da técnica da medida assegura um estado de equilíbrio da alma contrário ao conflito interno e instável da alma sob o efeito das aparências. Principalmente, a oposição estabelece uma relação correspondente entre o nível epistemológico do agente e o estado interno de sua alma. Dessa forma, cabe aqui ressaltarmos três características internas fundamentais do agente em posse da técnica da medida:

a) 'a destituição da aparência' (ákuron toûto tò phántasma) ou seja, o desvelamento da ilusão da aparência em sua condição de aparência perante a própria realidade. Por um lado, o termo akuron designa simplesmente 'tornar ineficaz, obsoleto' mas pode também adquirir conotações legais, no sentido de 'destituição' ou 'deslegitimação' de uma autoridade. Ao que tudo indica, Sócrates não quer dizer que a aparência é simplesmente eliminada, mas apenas que, revelada sua condição efetiva de aparência, ela não exerce mais influência sobre a deliberação do agente. A destituição epistemológica da aparência é marcada na substituição do termo positivo phainoménou ao termo negativo phántasma ${ }^{216}$. Com efeito, a tradução indistinta de 'aparência' não capta a transfiguração do phainómena em phántasma, isto é, da aparência positiva ao 'simulacro' ou 'fantasma' da realidade. Com isso, Sócrates pretende salientar ainda mais que a aparência perde sua dynamis ilusória quando demarcada a distinção aparência/realidade.

b) 'permanência na verdade' (ménousan epì tôi alethê̂). Em função da distinção entre aparência e realidade da técnica da medida, o agente estabelece a 'permanência' ou 'preservação' de sua resolução pela verdade. Ao contrário da instabilidade e errância do juízo comum sob ilusão da aparência, a técnica da medida assegura a estabilidade da deliberação correta. Como vimos anteriormente, a comensurabilidade é um traço distintivo do conhecimento moral da técnica da medida. Apenas a comensurabilidade fornece o critério quantitativo das dimensões

\footnotetext{
${ }^{216}$ Cf. LIDDEL-SCOTT, 1990. O termo 'phántasma' constitui o sentido negativo da 'aparência', enquanto reconhecida como 'mera imagem' ou cópia imperfeita em contraste com a coisa efetivamente real, e 'phainómema' implica em seu sentido positivo enquanto manifestação da 'aparência' da realidade da coisa.
} 
reais do prazer através da aparência ilusória da relação temporal de prazer. Assim, a técnica da medida assegura a estabilidade epistemológica do conhecimento moral da verdade. Enquanto isso, a ilusão da aparência transmite apenas a instabilidade epistemológica, sem um parâmetro objetivo de distinção da crença verdadeira ou falsa. Além disso, Sócrates reconhece ainda a transferência do nível epistemológico para os efeitos na condição interna da alma.

c) 'tranquilidade da alma' (hesuchían tèn psychèn). Com essa ênfase sobre o estado interno do agente, Sócrates indica que a condição epistemológica do agente tem reflexos sobre a condição interna da alma. A expressão hesuchían significa 'tranquilidade' ou, propriamente, um estado permanente de 'imperturbabilidade' da alma. Ora, se a alma permanece 'imperturbável' e em 'tranquilidade' com a técnica da medida, o agente sob efeito ilusório das aparências manifesta as qualidades opostas, um estado permanente de 'perturbação' e 'intranquilidade' da alma. Como vimos, isso expressa apropriadamente o estado errático, inconstante e o arrependimento do próprio agente diante da ilusão da aparência. No entanto, vemos mais claramente que a errância do agente não tem um aspecto meramente cognitivo mas revela um aspecto fundamental do estado psicológico de sua alma.

Há um claro contraste entre o conflito interno do agente sob o efeito das aparências e a condição imperturbável do agente com o conhecimento da técnica da medida. A partir disso, Sócrates indica que o 'conflito' interno do agente reflete a presença de motivações irracionais contra a deliberação racional pelo bem ${ }^{217}$. Em oposição a isso, o conhecimento da técnica da medida promove, de alguma maneira, a eliminação do 'conflito' interno do agente. O que isso significa exatamente, só poderemos descobrir posteriormente com a análise do controverso paradoxo socrático. Por ora, o que podemos concluir dessa passagem controversa é que Sócrates definitivamente estabelece uma oposição fundamental entre duas condições epistemológicas distintas na conduta do agente, o estado do conhecimento e o estado da ignorância. Em seguida, devemos analisar a descrição socrática da 'ignorância' do efeito ilusório das aparências.

217 Para a possível influência de desejos irracionais no argumento socrático antiakrasia ver BRICKHOUSE \& SMITH, 2010, p. 70-88; DEVEREUX, 1995, p. 387-396; SINGPURWALLA, 2006, p. 249-254. Na sequência, devemos abordar melhor o problema do 'intelectualismo' socrático e o papel obscuro das motivações irracionais no argumento socrático. 
Por conta do caráter abstrato do argumento, temos de transferi-lo a um plano mais concreto em que podemos compreender melhor a descrição socrática da ignorância. Dessa forma, podemos avaliar melhor a consistência da descrição socrática do fenômeno através da interpretação 'intelectualista' influente de Terry Penner. Com isso, pretendemos mostrar que a leitura intelectualista de Penner é naturalmente controversa justamente por se basear em uma reconstrução tardia da descrição aristotélica da akrasia, isto é, que o fenômeno consiste em um estado transitório de ignorância. $\mathrm{Na}$ realidade, o argumento socrático insiste em estabelecer que a akrasia é, na realidade, um estado permanente de ignorância. Para isso, teremos de analisar primeiramente a interpretação 'intelectualista' do argumento hedonista socrático.

A interpretação tradicional de Penner da descrição socrática da akrasia tem influência, de uma forma ou de outra, em diversos comentários do Protágoras. A interpretação tradicional enxerga o problema da akrasia no diálogo a partir de uma perspectiva temporal dos prazeres presente no exame da opinião dominante. Nesse sentido, uma tradição interpretativa influente da descrição socrática da akrasia é formada a partir de Terry Penner.

Dentro da perspectiva de Penner (1990) $)^{218}$, a relação temporal simultânea entre o processo deliberativo e a ação do agente é central para esclarecer a descrição socrática da akrasia. Em primeiro lugar, devemos assumir duas categorias epistemológicas de akrasia: o conhecimento-akrasia, sob o qual agimos contra o conhecimento do que é bom ou mau; e a crença-akrasía, sob o qual agimos contra a crença do que é bom ou mau. Em segundo lugar, há duas perspectivas temporais do processo deliberativo simultâneo entre juízos avaliativos e ação na akrasia, a sincrônica e a diacrônica. De um lado, podemos agir contra o que acreditamos no momento da ação, isto é, sincronicamente. De outro lado, podemos encarar a situação de uma perspectiva diacrônica considerando que agimos contra o que pensamos antes e depois da ação, mas não especificamente contra o que julgamos no momento da ação. A partir disso, Penner (1997, p. 118-119) alega que o

\footnotetext{
${ }^{218}$ A leitura de Penner (1990) é apresentada em dois artigos influentes levando em conta o controverso 'intelectualismo' socrático do desejo. Dentre os adeptos dessa interpretação tradicional, estão RUDEBUSCH, 1999a; NUSSBAUM, 2009, cap. 4; DEVEREUX, 1995; SINGPURWALLA, 2006; BRICKHOUSE \& SMITH, 2010, cap. 2-3. Na seção segunite sobre o paradoxo socrático, devemos abordar brevemente o controverso papel das motivações irracionais na descrição socrática da akrasia.
} 
argumento socrático está comprometido apenas com a negação absoluta do conhecimento-akrasía, enquanto a negação da crença-akrasia sincrônica é uma clara obviedade, impossível em si mesma.

Em The Strength of Knowledge, Penner (Ibid., p. 133-134) sustenta que o argumento socrático visa demonstrar a possibilidade da crença-akrasia diacrônica, pois é a única possibilidade de akrasia que assegura o 'poder do conhecimento'. Nessa perspectiva, Penner argumenta que a tese socrática visa estabelecer a 'força do conhecimento' contra a akrasia tradicional ${ }^{219}$. O poder do conhecimento garante a 'estabilidade epistemológica' preservando a correspondência entre a deliberação racional e a ação diacronicamente, isto é, durante todo o período da ação. Por sua vez, a crença é 'instável' e se altera constantemente ao longo de cada momento da ação, em especial, em relação ao que é deliberado antes e depois da ação (Ibid., p. 132-33). De qualquer modo, Sócrates não parece traçar uma distinção explícita entre crença-akrasia sincrônica ou diacrônica na refutação da akrasia tradicional.

$\mathrm{Na}$ realidade, a negação da crença-akrasia sincrônica, ou seja, a impossibilidade de agir contra o que se julga melhor no momento da ação, também está no horizonte do argumento socrático da 'potência da aparência'. Em última instância, a descrição do erro do 'poder da aparência' contempla as crenças falsas do agente sem qualificação e rejeita, portanto, a submissão aos impulsos da akrasia tradicional.

A estabilidade epistemológica do conhecimento é certamente um dos objetivos centrais do argumento socrático. Da mesma maneira, a instabilidade da 'crença' se ampara no vocabulário de errância da potência da aparência. Ora, mas será que o texto do Protágoras nos fornece indicações suficientes sobre o que ocorre exatamente durante a ilusão da aparência? Como veremos a interpretação tradicional incorre em diversas dificuldades interpretativas. Para visualizarmos melhor os problemas dessa intepretação tradicional, introduziremos um exemplo hipotético do diabético acrático.

Para efeitos de esclarecimento, devemos abordar a interpretação tradicional da ignorância socrática pelo caso hipotético de um diabético acrático. Nesse caso,

\footnotetext{
${ }^{219}$ Cf. Ibid., p. 124: "The strength of knowledge resides not (...) in the impossibility of synchronic knowledge-akrasia; rather, the strength of knowledge resides (...) in the impossibility of diachronic knowledge-akrasia - in the stability of knowledge throughout the temporal context of the action, while under assault from the many different impressions the situation before one may give off, this stability of knowledge being opposed to the instability of belief."
} 
devemos assumir a adesão do diabético acrático ao argumento hedonista socrático do Protágoras. Desse modo, o diabético reconhece sua inclinação natural ao maior bem/prazer e sua deliberação racional em vista do maior prazer por um critério objetivo. Sendo assim, estamos diante de um caso típico de akrasia que pode ser reformulado a partir do hedonismo socrático.

Em t1, o homem assume a prescrição médica de que 'não deve comer doces' porque precisa preservar sua saúde, ou seja, o maior prazer, sem colocar sua vida em risco. Em t2, no momento da ação, observamos ele comendo a torta vorazmente não apenas pondo em risco sua saúde, mas aparentemente contrariando sua deliberação anterior em função de seu próprio benefício. Em t3, percebemos seu arrependimento expresso na reafirmação do juízo avaliativo de t1, 'eu sabia o tempo todo que não devia comer esse doce'.

Como vimos, Sócrates reconhece o estado errático característico do homem acrático. Ora, mas se o que ocorreu não foi uma submissão completa ao impulso em t2, como alega a opinião dominante, o que seria então? Pela intepretação tradicional, o erro de $\mathrm{t} 2$ tem como causa a alteração das crenças do agente no derradeiro momento da decisão. Sem dúvida, isso seria o efeito ilusório da 'potência da aparência' dos prazeres em sua relação temporal. Provavelmente, o agente mantém o mesmo juízo do cálculo deliberativo nos instantes t1 e t3, porém sofre um 'esquecimento temporário' no momento t2 por conta da crença ilusória no prazer imediato.

Ora, mas o que espécie de efeito ilusório causaria esse esquecimento em t2? Como observamos, a descrição socrática da ignorância é explicada a partir da potência da aparência. Contudo, há diversas hipóteses interpretativas sobre o que ocorre no efeito das aparências. Para Penner (1997, p. 127-135), o efeito ilusório seria causado pelas diferentes perspectivas do tempo em cada momento da ação (cf. Idem, 1990, p. 45-49). De acordo com Rudebusch e Nussbaum, isso seria causado pela crença na incomensurabilidade que impede a avaliação objetiva das alternativas de ação segundo um critério quantitativo de prazer (cf. NUSSBAUM, 2009, p. 97-103; RUDEBUSCH, 1999a, p.23-27). Em uma linha interpretativa mais recente, a potência da aparência seria plenamente explicada com base na influência 
desejos irracionais ${ }^{220}$. Nesse caso, o efeito das aparências não se limitaria apenas à alteração das crenças do agente, mas envolveria, principalmente, a relação entre crenças e motivações irracionais. Em todo caso, o problema do caso descrito segundo a interpretação tradicional reside na própria formulação problemática do fenômeno. Em última análise, a principal controvérsia perpassa o que Sócrates designa de 'ignorância' (amathía).

Diante da interpretação intelectualista da descrição socrática, diversos tipos diferentes de ignorância têm sido apresentadas pelos comentadores platônicos. Como já observamos, uma corrente influente julga que a ignorância ocorre pela ilusão temporária provocada pela aparência dos prazeres. Sob essa perspectiva, a descrição socrática seria assimilada a dois tipos de fenômenos irracionais contemporâneos diferentes, como (a) o autoengano inconsciente ou (b) a compulsão psicológica. De um lado, o autoengano ocorre sem a consciência plena do agente sobre o conflito interno de seus desejos. De outro lado, a ausência implícita das motivações irracionais independentes da deliberação racional no argumento socrático inviabiliza a classificação da compulsão psicológica. A seguir, indicaremos alguns dos problemas de ambas as propostas interpretativas.

As falhas da interpretação tradicional são expostas claramente na tentativa de classificar a ignorância em termos de autoengano (self-deception). Em Plato on Akrasia and Knowing Your Own Mind, Bobonich (2007, p. 50-53) dirige certas críticas à descrição socrática da akrasia do Protágoras. Para Bobonich, o relato tradicional deixa algumas inconsistências em aberto. Ora, se o efeito das aparências promove a crença falsa no prazer imediato em t2, como o mesmo 'efeito' provoca um 'esquecimento temporário' da crença falsa em t3? Diante dessas inconsistências, o relato tradicional precisa ser preenchido para contemplar a complexidade do fenômeno original.

Seria plausível admitir que o diabético apresenta, por exemplo, uma cisão interna entre duas crenças incompatíveis: a preservação de sua saúde e o desejo abrupto de comer a torta em $\mathrm{t} 2$. Como o agente alega que pretendia preservar sua saúde durante toda a ação, estamos comprometidos a admitir que a crença em t2 não era totalmente consciente ao agente. De acordo com Bobonich (2007, p. 54),

220 Para uma leitura tradicional compatível com a presença de desejos irracionais, ver BRICKHOUSE \& SMITH, 2010, p. 70-81; DEVEREUX, 1995, p. 390-396; SINGPURWALLA, 2006, p. 249-254. 
isso envolveria um tipo de autoengano inconsciente do agente diante de seu conflito interno mental ${ }^{221}$. Nesses termos, a ignorância socrática parece contemplar uma psicologia mais complexa do que a fornecida no Protágoras.

Entretanto, podemos resistir a essa conclusão quando tomamos consciência de que o caso relatado corresponde mais a perspectiva aristotélica do fenômeno do que propriamente a ao argumento hedonista socrático. De resto, ainda precisamos considerar a suspeita de que Sócrates poderia isolar casos que não se adequem à ‘ignorância’ à casos de compulsão psicológica.

A refutação socrática da akrasía é acusada também de não apresentar adequadamente o fenômeno que pretende explicar. Por um lado, alguns críticos do argumento hedonista têm apontado que a descrição socrática corre sério risco de assimilar casos do fenômeno à compulsão psicológica. De acordo com Irwin (1995, p. 209-208), a descrição da akrasía como ignorância oferece a Sócrates oportunidade de associar ações que não são motivadas pelo desejo racional à compulsão psicológica. Com isso, um grande conjunto de ações humanas se tornaria efetivamente ininteligível para nós. Do mesmo modo, Santas $(1979$, p. $215-$ 217) alega que é plenamente plausível que o erro da akrasía seja vinculado à força relativa dos desejos independentemente do cálculo de prazer do agente e, com isso, ação resulte de compulsão psicológica. No entanto, um problema comum ao fenômeno do autoengano e da compulsão psicológica reside propriamente em desejos absolutamente não cognitivos.

Em nenhum momento, Sócrates contempla propriamente a noção de motivações irracionais inconscientes quando menciona os diversos impulsos imediatos na descrição tradicional da akrasia. Como vimos, Sócrates assume a concepção psicológica cognitivo-motivacional antiga difundida na comunidade grega. A eficácia do argumento de redução ao absurdo da akrasia tradicional reside justamente na psicologia cognitivo-motivacional antiga assumida no argumento socrático. Nesse sentido, devemos abandonar essas classificações modernas da irracionalidade prática e busca compreender a ignorância socrática em um contexto mais abrangente.

\footnotetext{
${ }^{221}$ Cf. Ibid., p. 54: “(...) what the apparent akratic of the Protagoras really fails to believe is that pleasure is the good which is a putative fact about the world and not his own mind. But this misdescribes the case. It is essential to Plato's solution that at $\mathrm{t} 2$ the agent's desire is directed at the good as such or is under the guise of the good. The agent's conscious unawareness of this is a failure to understand her own mind."
} 
Ao contrário da interpretação ortodoxa, Aristóteles reconhece a peculiaridade da tese socrática contra a akrasia. Em Ética a Nicômaco VII, ele efetivamente salienta, como mostramos anteriormente, a diferença entre sua própria posição e a posição de Sócrates acerca da akrasia: "é evidente que o acrático não crê (ouk oietaí), antes de estar nesse estado, que deva agir assim.” (1145b20-32). Assim, Aristóteles reconhece, como a interpretação tradicional, que a akrasia consiste em uma mudança das crenças do agente e, ao mesmo tempo, admite também que Sócrates era contrário a tal concepção do fenômeno ${ }^{222}$. Ao invés disso, Aristóteles sustenta plausivelmente que a ignorância para Sócrates não é apenas um estado provisório, mas um estado permanente do agente. De fato, ele assume, em parte, a força e a plausibilidade da tese socrática: "qual é o tipo (trópos) de ignorância [do fenômeno]?” (1145b20-25). Nessas circunstâncias, o argumento socrático envolve essa mesma questão fundamental e exibe uma resposta diametralmente oposta à posição aristotélica.

A partir de ENVII, podemos concluir que o argumento socrático do Protágoras visa estabelecer que a ignorância é um estado permanente do agente. $\mathrm{O}$ problema principal dessa abordagem parece residir na 'ignorância temporária' que acomete o agente ao longo da ação. Com isso, não pretendemos mostrar que a interpretação tradicional está necessariamente incorreta mas que o próprio Sócrates tem menos interesse no processo descritivo da experiência do que pela causa de sua manifestação, a dýnamis da aparência. Recentemente, uma corrente interpretativa alternativa tem buscado preservar a consistência das conclusões socráticas sobre a natureza da ignorância e da falta de conhecimento da potência da aparência.

Desde o início do exame da opinião dominante, o problema da akrasia foi introduzido no Protágoras em termos de conhecimento (352a-e). Como vimos, a força da descrição tradicional da akrasia reside propriamente na impotência do conhecimento perante os impulsos imediatos. Ao fim do exame da opinião

\footnotetext{
${ }^{222}$ Como Callard (2014, p. 67 n 50) salienta, a corrente interpretativa tradicional 'intelectualista' costuma analisar a crítica de Aristóteles à negação socrática da akrasia por uma perspectiva equivocada (cf. DEVEREUX, 1995, p. 390-396; SINGPURWALLA, 2006, p. 245-254; BRICKHOUSE \& SMITH, 2010, p. 70-88). Com efeito, acredita-se que Aristóteles atribui a Sócrates a concepção de que a akrasia é, na realidade, um estado provisório de ignorância quando, na realidade, isso apenas reflete a própria definição aristotélica da akrasia. Em oposição a essa interpretação, Penner (1997, p. 119-120, n. 7) reconhece que o próprio Aristóteles claramente distingue sua própria perspectiva temporária da 'ignorância' do estado de ignorância permanente da visão socrática.
} 
dominante, Sócrates conclui que tal experiência, na verdade, não envolve conhecimento da melhor ação e, em decorrência, passa a definir o fenômeno em termos de ignorância.

Com base nisso, uma corrente interpretativa alternativa reconhece a relevância da classificação do fenômeno como um estado permanente de ignorância do agente. Por um lado, Ferrari (1990, p. 132-134) indica que Sócrates visa revelar à opinião dominante que sua crença na akrasia decorre da ignorância de sua própria visão empobrecida do conhecimento ${ }^{223}$. Por outro lado, Callard (2014) também ressalta que a descrição socrática relaciona a ignorância do agente a seu próprio relato integral da experiência, sem notar a confusão e a indistinção epistemológica entre conhecimento, crença e aparência ${ }^{224}$. Nessa linha interpretativa, os comentadores concordam que o argumento socrático antiakrasia destina-se a combater principalmente a concepção errônea da impotência do conhecimento da akrasia tradicional. Com esse propósito, a refutação da akrasia tradicional contesta o relato habitual da opinião dominante sobre o que ocorre durante essa experiencia.

A partir disso, Sócrates recorre à potência da aparência para justificar a descrição correta do fenômeno como ignorância. Para a substituição do relato tradicional da akrasia, o filósofo precisa explicar positivamente o que ocorre na akrasia a partir dos pressupostos hedonistas. $\mathrm{O}$ argumento da potência da aparência dos prazeres permite explicar a descrição fenomenológica correta da ignorância. Nesse sentido, o estado permanente de ignorância reflete a instabilidade e a errância

\footnotetext{
${ }^{223}$ Em uma linha interpretativa divergente, Kamtekar (2017, p. 52-54) também salienta que o argumento socrático reconhece a visão empobrecida da maioria sobre motivações humanas, mas insiste que a explicação socrática definitiva reside no princípio do eudaimonismo psicológico: "ninguém se dirige de bom grado às coisas más" (358d-e). Como mostraremos a seguir, acreditamos que esse paradoxo socrático contra a akrasia é derivado de uma conclusão e não propriamente da descrição da potência da aparência no argumento socrático. De qualquer forma, a pobreza do conflito de motivações humanas é compatível com a impotência do conhecimento.

${ }^{224}$ Cf. CALLARD, 2014, p. 59: " My suggestion, then, is that the simulacrum of which Socrates speaks in his praise of knowledge refers, quite generally, to the item that the akratic wrongly insists that he knows (or believes), and the power of that simulacrum consists-in ways that are to be detailed below - precisely in its ability to get itself confused for knowledge or belief." (itálicos da autora). Com efeito, a interpretação de Callard é demasiado complexa para abordar de forma sucinta mas um problema fundamental de sua abordagem reside no 'poder do simulacrum', termo derivado de phántasma. O problema reside em atribuir ao acrático uma distinção entre simulacro e realidade que Sócrates jamais reconhece da redução ao absurdo da akrasia tradicional. Como vimos, Sócrates distingue claramente o poder do phainómenon da técnica da medida que revela o phántasma deixando a aparência sem eficácia (ákuron). Em sua exemplificação do argumento socrático, a autora invoca reiteradamente tal distinção entre aparência e realidade de prazer durante sua análise interpretativa quando Sócrates mostra que o relato tradicional do acrático não depende dessa distinção. De fato, minhas críticas se refletem aqui nas próprias indicações de Kamtekar (2017, n. 27, p. 64-65).
} 
do acrático durante toda sua ação. Para mostrarmos isso, vamos analisar brevemente a conclusão final de Sócrates sobre o que é efetivamente o fenômeno da ilusão da aparência.

Em 358c-d, Sócrates estabelece algumas conclusões finais controversas acerca do fenômeno agora designado efetivamente de ignorância (amathía): "Por acaso vocês não afirmam que ignorância é algo do gênero, como ter opinião falsa e estar enganado (tò pseudê échein dóxan kaì epseûsthai) a respeito de assuntos de grande valia?" (358c). Em retrospectiva, essa conclusão evoca claramente o cumprimento da tarefa estabelecida anteriormente entre o filósofo e o sofista na demonstração do que está "incorreto (ouk orthôs)" no relato da opinião dominante a respeito da "experiência (tò páthos)" da akrasia (353a).

Durante o exame da opinião dominante, Sócrates se referia consistentemente ao fenômeno por um 'erro' (exemártanen) e agora, em sua conclusão final, passa a designá-lo por 'equívoco' ou 'engano' (pseudés). A passagem marca mais claramente a constatação do erro factual cometido pelo agente, da demonstração do absurdo da akrasia para a constatação decisiva de que o erro tem origem na deliberação espontânea pelo prazer imediato. Sob essa perspectiva, o argumento socrático parece reconhecer dois planos descritivos da ação, o ponto de vista objetivo da realidade e o ponto de vista subjetivo da aparência.

$\mathrm{O}$ ponto de vista objetivo e o ponto de vista subjetivo expressam perspectivas diferentes da ação da akrasia no argumento socrático. Segundo o ponto de vista objetivo da realidade, Sócrates constata o erro factual do agente que coloca sob suspeita todo o relato tradicional da akrasia. A partir disso, o ponto de vista interno com base na potência da aparência visa esclarecer a causa efetiva do conflito interno do agente. Dentro da filosofia antiga, a akrasia antiga parte do ponto de vista objetivo do erro moral do agente para explicar o ponto de vista subjetivo do agente do fenômeno. Antes de analisarmos propriamente o efeito da aparência, precisamos nos deter sobre a referência da "opinião falsa (tò pseudê dóxan)".

A referência ao fenômeno como 'opinião falsa' (pseudê dóxan) está intrinsecamente ligada à classificação da 'ignorância' e da "falta de conhecimento (espistémes endeíai)" do acrático (357d-e). Ora, mas estaria Sócrates falando aqui da crença falsa no momento da ação ou a todo o relato (integral) da experiência? 
Como vimos, os adeptos da interpretação tradicional suspeitam que há uma referência aqui ao surgimento de uma crença falsa no momento do erro do agente.

Nessa perspectiva, o agente passaria por um tipo de 'ignorância' provisória. Durante a ação, ele sustenta uma crença falsa no momento da ação, mesmo que mantenha a crença verdadeira antes e após a ação. No caso do diabético, por exemplo, ele possui a crença falsa em t2 de que o prazer da torta é maior, tendo um esquecimento provisório de que não devia comê-la por conta de sua saúde antes e depois da ação. É notável que Sócrates jamais entra em detalhes sobre o processo deliberativo da ação no Protágoras, nem mesmo se refira a crença falsa ou verdadeira em qualquer momento da ação acrática.

O caráter abstrato do argumento de Sócrates nos leva a suspeitar, então, que 'tô pseudê dóxan' se refere propriamente à 'opinião' ou ao relato tradicional da experiência como um todo. Em sua tese paradoxal, Sócrates parece reconhecer que não é possível agir contra o conhecimento ou crença (358d) indistintamente, mas mesmo aqui não parece interessado em especificar se seria a crença verdadeira ou falsa. Novamente, essas indicações reforçam a ideia de que a tese socrática depende de um estado permanente de ignorância expresso no próprio relato tradicional da akrasia.

O estado permanente de ignorância, em última instância, está relacionado à constante errância e instabilidade da potência da aparência. Como vimos, a potência da aparência se perpetua pela influência da relação temporal dos prazeres na deliberação humana. A deliberação espontânea fica sujeita, assim, à distorção temporal ocasionada pelo prazer imediato. A ilusão epistemológica do fenômeno decorre da indistinção da aparência e realidade. Além disso, o efeito cognitivo da 'ignorância' se segue de um efeito psicológico, a errância e a turbulência interna na alma. Sob a potência da aparência, o estado interno do agente está relacionado a um conflito incessante de errância. Com base na analogia, devemos considerar que o conflito interno decorre da inconstância e incessante mudança nas crenças do agente.

A confusão do agente reflete um conflito interno da alma de crenças incompatíveis, uma crença pelo melhor curso de ação e outra crença pelo pior curso de ação. No nível da aparência, não há critérios epistemológicos adequados para distinguir a crença verdadeira da crença falsa e, assim, determinar qual é (realmente) a melhor alternativa de ação. Por isso, Sócrates não apenas se limita a 
estabelecer que a akrasia é ignorância, porém salienta o tipo da ignorância: "não apenas por falta de conhecimento (ou mónon epistémes), mas por falta daquilo que (...) concordaram que era conhecimento referente à medida (metretikes)" (357d). Com efeito, ele é mais específico sobre o tipo de ignorância do que sobre o conhecimento de técnica da medida. Ao que tudo indica, a ênfase recai mais uma vez no conhecimento das dimensões reais de prazer.

Por suposto, a falta de conhecimento implica mais profundamente a ausência do parâmetro objetivo na definição das dimensões reais de prazer. $\mathrm{Na}$ ausência do plano da realidade objetiva, o plano da aparência se instaura como ponto de referência fundamental abolindo a distinção realidade/aparência dos prazeres na deliberação prática. Em ambos os casos, Sócrates deriva uma conclusão paradoxal contra as convicções tradicionais da maioria: 'nenhum mal é realizado de bom grado'. Nesse sentido, é necessário investigar a profundidade e as implicações do influente e controverso paradoxo socrático em seu contexto original.

\section{7 \\ O paradoxo socrático (358c-d): o 'intelectualismo' motivacional e os desejos irracionais}

O exame da opinião dominante leva Sócrates a estabelecer uma tese paradoxal contra a descrição comum da akrasia. Em linhas gerais, o argumento segue a seguinte estrutura: em primeiro lugar, a constatação do absurdo e do equívoco da akrasia tradicional (354e-356a); em segundo lugar, a apresentação da descrição correta do fenômeno com o objetivo de eliminar as inconsistências do relato tradicional da maioria e revelar o que o fenômeno realmente é (356c-357e). Enfim, Sócrates estabelece que tal experiência se trata, na realidade, de ignorância e deriva sua conclusão paradoxal de que 'todo mal é involuntário' (357d-358e).

Como vimos anteriormente, o hedonismo estabelece que: (a) prazer e bem assim como dor e mal são a mesma coisa e (b) a deliberação prática invariavelmente busca o prazer e evita o mal. Dessa forma, a ignorância designada erroneamente de akrasia nada mais é do que um erro factual na escolha de magnitudes maiores de prazer, isto é, 'falta de conhecimento' (epistemes endeias) acerca das dimensões reais do prazer (357d). Em última instância, o homem ignorante e o homem com 
conhecimento estão comprometidos com o mesmo parâmetro objetivo de prazer, a aspiração ao prazer ou o bem efetivamente maior.

Diante dessas premissas, Sócrates estabelece uma conclusão paradoxal contra a descrição comum da akrasía:

(i) ninguém, sabendo (eidòs) ou presumindo (oiómenos) que há outras coisas a seu alcance melhores (beltío) do que aquelas que põe em prática e é capaz de fazê-las (dynatá), realiza-as mesmo assim, quando lhe é possível realizar as que são melhores. (...) (ii) ninguém se dirige de bom grado (hekòn) às coisas más ou àquelas que presume serem más (oíetai kaká), tampouco pertence à natureza humana (en anthrópou phýsei), como é plausível, desejar se dirigir às coisas consideradas más, preterindo as boas (oíetai kaká antì tôn agathôn). (358b-d) ${ }^{225}$

Diante da referida passagem, constatamos que o paradoxo socrático contempla duas teses radicais contra as convicções da maioria, uma tese epistemológica do bem e outra tese psicológica do bem envolvendo a "natureza humana (en athrópou phýsei)". Em outras palavras, a tese socrática se constitui aparentemente da negação absoluta da akrasia tradicional.

Para efeitos de esclarecimentos, devemos distinguir as duas teses radicais nos seguintes termos: (i) a negação da akrasia constitui a negação do conhecimento-akrasia e a negação da crença-akrasia. Como observamos, a descrição tradicional da akrasia decorre na impotência do conhecimento. Entretanto, o paradoxo socrático afirma claramente que nem o conhecimento nem a crença podem ser submetidos pelos impulsos humanos. A passagem estabelece que ninguém se inclina às coisas más, ainda que esteja 'sabendo' (eidós) e 'tenha conhecimento' ou até 'considerando' e "presumindo (oiómenos)" que as coisas más

\footnotetext{
${ }^{225}$ Há efetivamente outra formulação do paradoxo durante a discussão sobre o poema de Simônides (345d-e), mas é importante ressaltar que a formulação da passagem 358c-d é uma conclusão do exame direto das posições de Protágoras através da análise das crenças da opinião dominante. Conforme esclarece Kahn (1996, p. 247-248), o paradoxo aparece nos diálogos de Platão em duas formas diferentes, em uma formulação prudencial e em uma formulação moral. Na primeira formulação, temos o paradoxo de que ninguém faz o que é mau de bom grado, isto é, agir contra o que é bom não é do próprio interesse. Na segunda formulação, o paradoxo estabelece que ninguém faz o que é injusto de bom grado. Segundo o autor (Ibid., p. 247), a segunda formulação pode ser derivada da primeira se acrescentarmos a premissa socrática S: 'Nunca é do próprio interesse agir injustamente (adikein)'. Nos diálogos, é frequente que um dos interlocutores de Sócrates rejeite a proposição moral e leve o filósofo a recorrer a proposição prudencial para demonstrar a consistência da primeira proposição. No Protágoras, identificamos essa estratégia, particularmente, uma vez que a formulação prudencial em 358c-d sustenta a identificação entre 'bem' (agathon), 'prazer' (hedone) e 'nobre (kalon), o que implica na formulação moral. Sobre o paradoxo socrático, ver também SANTAS, 1979, p. 183-194.
} 
são realmente más. (ii) o paradoxo de que 'ninguém faz o mal de bom grado' estabelece um princípio psicológico da motivação natural humana ao bem. De forma geral, esse princípio dá origem ao que é tradicionalmente reconhecido como eudaimonismo psicológico, isto é, a tese de que a natureza humana está naturalmente inclinada à eudaimonia, a plena realização humana.

Em conjunto, as teses (i) e (ii) integram o controverso paradoxo socrático originando diversas controvérsias interpretativas não só entre os comentadores platônicos mas também em toda a filosofia ocidental posterior, de Aristóteles à filosofia contemporânea.

É imprescindível lembrar que o paradoxo socrático deriva das conclusões estabelecidas com base no hedonismo e a inconsistência da akrasia tradicional. Como mostramos anteriormente, nenhum dos estágios anteriores do argumento socrático com a opinião dominante pressupõe, de alguma maneira, o paradoxo socrático. Ao contrário, o paradoxo socrático parece ser efetivamente uma conclusão genuína de todo o argumento socrático antiakrasia.

A conclusão fundamental necessária do paradoxo socrático estabelece que o agente não pode jamais ser 'subjugado' ou 'vencido' por seus impulsos, o que constitui uma negação tout court da akrasia tradicional. Como observamos anteriormente, Sócrates não está somente empenhado na negação do conhecimentoakrasia mas também na negação da crença-akrasia de forma absoluta, diacrônica e sincrônica. Por isso, o paradoxo socrático é extremamente controverso e contrário às impressões intuitivas da opinião dominante. Com base nisso, devemos analisar os problemas interpretativos atuais envolvendo as teses (i) e (ii) que compõem a dimensão do paradoxo socrático.

O paradoxo socrático possui uma dimensão intrinsecamente epistemológica e psicológica. Dentre as possibilidades interpretativas, alguns comentadores platônicos dão maior ênfase aos desdobramentos epistemológicos da tese (i) na negação da akrasia. Outros comentadores julgam que a tese (ii) da natureza humana é mais decisiva. Em nossa análise, buscaremos compatibilizar ambas as teses (i) e (ii) em uma proposta interpretativa unificada e coerente levando em conta a dimensão integral do paradoxo socrático. Por conta disso, nos concentraremos primeiramente sobre os problemas interpretativos da tese (i) envolvidos mais diretamente nas evidências textuais do Protágoras. 
O principal problema interpretativo da tese (i) envolve as implicações do paradoxo socrático sobre o problema epistemológico do poder do conhecimento ou da crença diante dos impulsos humanos. Para contornar essa dificuldade, foram elaboradas algumas alternativas interpretativas diferentes e diametralmente opostas.

De acordo com a primeira proposta, o paradoxo socrático é uma posição radical acerca da akrasia e, por isso, é uma tese dirigida apenas contra os interlocutores de Sócrates. Nessa perspectiva, Charles Kahn (1996, p. 228-243) e Roslyn Weiss (2006, p. 60-61) sugerem que a tese paradoxal somente é válida enquanto dirigida aos interlocutores de Sócrates, isto é, de forma ad hominem. O paradoxo socrático como um todo não teria qualquer validade intrínseca fora de seu contexto dialógico porque Sócrates não defende tal posição em sua própria pessoa $^{226}$. Em especial, Kahn (1996) alega, com base em (ii), que o paradoxo é uma negação absoluta da akrasia, em termos de crença ou conhecimento, revelando o poder decisivo do 'racionalismo onipotente', isto é, o controle absoluto da 'razão' sobre quaisquer outras motivações irracionais ${ }^{227}$. Nessa perspectiva, o paradoxo envolveria não apenas a invencibilidade da crença mas também uma negação absoluta das motivações irracionais. Para ambos os autores, a onipotência da razão sobre as motivações irracionais é contestada amplamente nos diálogos maduros de Platão.

Teremos de analisar o problema das motivações irracionais da tese (ii) posteriormente já que não se trata de um tema explicitamente destacado no Protágoras além de depender do confronto com outros diálogos socráticos. Por ora, devemos indicar que a negação da akrasia constitui o objetivo central do paradoxo socrático sem implicar qualquer tipo de invencibilidade da crença sobre outros impulsos humanos. Com vimos, a leitura ad hominem simplesmente não condiz com a postura do autodistanciamento crítico do elenchus de Sócrates. Desse modo,

\footnotetext{
${ }^{226}$ Com frequência, muitos dos adeptos dessa leitura anti-hedonista acreditam que toda ou parte da passagem 351b-358d, incluindo o exame da opinião dominante e o hedonismo, é inteiramente $a d$ hominem. É interessante notar que diversos adeptos dessa leitura seguem a influente sugestão de Vlastos (1969, p. 76-78) de que Sócrates adota um hedonismo moderado sem se comprometer com $\mathrm{o}$ argumento hedonista posterior.

${ }^{227}$ Cf. KAHN, 1996, p. 240: "the argument against akrasia and in support of omnipotent rationalism, depending as it does on the hedonist assumption, is throughout an argument ad populum."
} 
estamos dispostos a buscar outras propostas interpretativas que levam em conta a força e seriedade do argumento socrático antiakrasia.

Em uma segunda proposta interpretativa, o paradoxo socrático subentende implicitamente a superioridade epistemológica do conhecimento. Nessa perspectiva, Vlastos $(1969$, p. 72) sustenta que o paradoxo da impossibilidade da ação contrária a crença do que é melhor deve incluir um elemento adicional: "when we do have knowledge" (itálicos do autor). Apesar dessa leitura reforçar o poder do conhecimento, a sentença condicional não condiz com o que efetivamente está no texto platônico. Numa linha interpretativa semelhante, Taylor (1991, p. 202-203) indica que a referência à 'crença', na passagem, deve ser associada à 'crença verdadeira', na ausência de uma explícita distinção entre conhecimento e crença verdadeira presente nos diálogos posteriores ao Protágoras. Sob esse ângulo, a crença verdadeira poderia, por vezes, prevalecer sobre os impulsos embora sem a mesma regularidade que o conhecimento. Ambas as interpretações de Vlastos e Taylor inserem alterações artificiais para assimilar o que é dito textualmente na passagem com a tese do poder do conhecimento defendida no Protágoras e também em outros diálogos socráticos. De qualquer forma, a tese (i) contempla de forma indiscutível a força do 'poder do conhecimento' e a negação absoluta do conhecimento-akrasia.

Como vimos anteriormente, Penner (1997) alega que qualquer tipo de crença - verdadeira ou falsa - está sujeita à ignorância ilusória. Desse modo, a crença não pode estar, de modo algum, no mesmo nível epistemológico do conhecimento no argumento socrático. A passagem 358c-d apresenta efetivamente o termo 'oiómenos', que designa propriamente uma 'presunção ou consideração' em sentido fraco, sem qualquer qualificação implícita de 'verdade' ou 'falsidade'. De fato, não encontramos nenhum argumento da invencibilidade da crença no Protágoras. Como salienta Penner (Ibid., p 123-125), a mera impossibilidade de agir contra a crença do bem não garante nenhuma 'potência superior' epistemológica da crença. De fato, essa proposta interpretativa parece compatível com a tese socrática de que não há efetivamente a submissão dos impulsos da akrasia, mas a admissão de que a crença é vulnerável à influência dos impulsos irracionais.

Em uma versão mais recente dessa linha interpretativa, alguns comentadores alegam que o 'poder do conhecimento' implica no absoluto controle cognitivo- 
motivacional sobre os impulsos irracionais ${ }^{228}$. A tese da potência epistemológica do conhecimento visa reestabelecer a autoridade do conhecimento contra a akrasia tradicional. Sob esse ângulo, a posse do 'conhecimento' não só envolve aspectos cognitivos mas também tem desdobramentos sobre o estado desiderativo e motivacional do agente (incluindo desejos e emoções irracionais). Mesmo a tese da superioridade do conhecimento em si mesma não é suficiente para a derivação do paradoxo socrático de 358b-e. Além disso, o paradoxo socrático também depende da descrição socrática da ignorância. Em última instância, o erro da ignorância só é plenamente compreendido após as conclusões da tese da 'potência da aparência'.

Em uma terceira proposta interpretativa, o 'poder do conhecimento' se contrapõe à própria visão empobrecida do conhecimento da opinião dominante, ou seja, a impotência do conhecimento. Diante da inconsistência da akrasia tradicional, o argumento socrático comprova que o relato tradicional envolve o próprio equívoco do que é o conhecimento moral objetivo. Nessa perspectiva, o argumento socrático apresenta o autoengano ilusório do agente sobre suas próprias crenças e motivações internas no efeito da 'potência da aparência' ${ }^{229}$. Seria preciso, então, esclarecer qual o papel das motivações irracionais no efeito ilusório que leva ao erro moral do agente. De qualquer forma, o paradoxo socrático, expresso nas teses (i) e (ii), não parecem enfatizar mais a ignorância do que o conhecimento do agente. Na realidade, o paradoxo socrático estabelece uma conclusão contundente sobre a universalidade de uma inclinação humana natural comum tanto ao que detém quanto ao que está destituído do conhecimento moral.

\footnotetext{
${ }^{228}$ Para uma proposta interpretativa influente alinhando o poder do 'conhecimento ao domínio cognitivo das motivações irracionais no Protágoras ver SEGVIC, 2009, p. 75-77: "In denying akrasia, Socrates is denying a certain picture of how human motivation operates. Thus he would be likely to deny weakness of the will as thought of by those who subscribe to the wrong picture of human motivation. (...) What he rejects is a picture according to which passions or feelings are psychic states independent of reason. Against this, he believes that in every passion reason is in some way exercised." Para outras propostas na mesma linha interpretativa, ver também DEVEREUX, 1995, p. 387-396; BRICKHOUSE \& SMITH, 2010, p.81-88; SINGPURWALLA, 2006, p. 249-254. Como veremos adiante, essa proposta interpretativa envolve o controverso 'intelectualismo' socrático e o problemático estatuto dos 'desejos irracionais' dentro dessa teoria motivacional.

${ }^{229}$ Apesar de sua leitura anti-hedonista, Ferrari (1990) claramente observa a visão empobrecida do conhecimento. Cf. FERRARI, 1990, p. 132: "I am suggesting that the apparent outrageousness of Socrates' conclusion - the fact that it seems to ignore the phenomenology of akrasia — is intended to prompt just this sort of puzzlement and reflection in them. (...) Ideally, with the insight that what led them into their quandary, what enabled Socrates to argue them into hedonism, was their false and impoverished understanding of the role of reason or wisdom." Para uma leitura similar da visão empobrecida do conhecimento, ver BOBONICH, 2007, p. 50-59; CALLARD, 2014, p. 57-63.
} 
A tese epistemológica (i) parece efetivamente sustentar a negação absoluta da crença-akrasia, independentemente da veracidade das crenças ou a temporalidade dos prazeres do agente. Ora, mas se Sócrates estiver comprometido com a negação da crença-akrasia sincrônica estaria ele disposto a negar, ou mesmo até ignorar, o poder dos impulsos irracionais sobre a ação humana? De fato, esse problema compromete substancialmente a leitura 'intelectualista' de Penner sobre as implicações do paradoxo socrático do Protágoras. Para responder satisfatoriamente ao problema, devemos nos voltar para a controvérsia envolvendo a tese da natureza humana (ii).

A controvérsia interpretativa envolvendo a tese (ii) se baseia na ideia difundida de que Sócrates, no Protágoras e em outros diálogos 'socráticos', está comprometido com a negação absoluta dos desejos irracionais. Em termos gerais, a tradição interpretativa costuma atribuir isso a uma 'teoria intelectualista do desejo' do Sócrates dos primeiros diálogos.

Os princípios fundamentais desse 'intelectualismo' socrático dos desejos são dispostos por Terry Penner e Christopher Rowe. No entanto, existe uma influente corrente atual que coloca em xeque a definição rígida do 'intelectualismo' motivacional e, principalmente, a pressuposta unidade 'socrática' dos 'primeiros' diálogos platônicos. Para compreendermos melhor tal controvérsia, precisaremos compreender o que exatamente constitui a 'teoria intelectualista do desejo' dos diálogos socráticos.

Dentre os comentadores platônicos, as bases do intelectualismo socrático são apresentadas principalmente nos textos de Penner e Rowe. Em Sócrates e os primeiros diálogos, Penner (2013, p. 163-165) apresenta uma definição geral da teoria do intelectualismo socrático do desejo:

Nos diálogos socráticos, encontramos uma teoria intelectualista do desejo, de acordo com a qual todos os desejos, não só os desejos dos virtuosos, são desejos pelo bem - isto é, pelo que quer que seja melhor para mim nas circunstâncias em que me encontro. (...) De acordo com essa teoria, todos os desejos de fazer alguma coisa são desejos racionais, à medida que sempre automaticamente se ajustam às crenças do agente (...). (itálicos do autor) ${ }^{230}$

${ }^{230}$ Em seu artigo Strength of Knowledge, Penner (1997, p. 129) volta a assumir seu compromisso com esses princípios do 'intelectualismo' socrático do desejo. 
Além de Penner, outra formulação da teoria intelectualista do desejo, em termos similares, é defendida também por Rowe. No artigo A problem in the Gorgias, Rowe (2007, p. 23) define nos seguintes termos a teoria intelectualista da motivação:

\begin{abstract}
What is this 'intellectualist' theory of motivation (or, perhaps better, theory of action; it is not just a theory of desire)? Briefly, and at bottom, it consists in the claims (a) that all human agents always and only desire the good; (b) that what they desire is the real good, not the apparent good; and (c) that what we do on any occasion is determined by this desire together with whatever beliefs we have about what will in fact contribute to our real good. (itálicos do autor)
\end{abstract}

Apesar das divergências, observamos assim os princípios básicos comuns que norteiam o intelectualismo do desejo socrático influente entre os comentadores platônicos ${ }^{231}$. Em grosso modo, podemos destacar três princípios básicos comuns do 'intelectualismo do desejo' entre as diferentes formulações dessa teoria: (1) todos os desejos são desejos pelo bem expressos através de crenças pelo que é (realmente) melhor para mim; (2) apenas as crenças pelo bem orientam a deliberação prática em vista dos meios adequados para o fim último ou o bem real (o que se designa de eudaimonía - isto é - a plenitude humana); (3) se todos os desejos são desejos racionais pelo bem, todos os desejos humanos podem ser reduzidos à crenças pelo bem. Nessa medida, há apenas desejos racionais pelo bem e motivações irracionais simplesmente não existem.

Ambos os autores concordam com as teses (1) e (2), mas a tese (3) abre precedente à uma extensa controvérsia interpretativa. Em linhas gerais, as teses (1)(2) delimitam o que é denominado de eudaimonismo psicológico na tradição interpretativa ou, como vimos anteriormente, o princípio segundo o qual todos os homens buscam ou desejam o bem em suas ações e, sobretudo em função do bem maior, a eudaimonía ${ }^{232}$. No entanto, há controvérsia se a tese (3) abrange a

\footnotetext{
231 Para versões similares do 'intelectualismo' socrático do desejo ver IRWIN, 1995, p. 75-76; p. 209; DODDS, 1973, p. 78; TAYLOR, 1991, p. 203-204; Ibid., 1998, p. 74-75; VLASTOS, 1969, p. 83-84; SANTAS, 1979, p. 209; FREDE, 1992, p. xxx; FERRARI, 2007, p. 167-169; REEVE, 1988, p. 134-145; LESSES, 1987, p. 147-148; KAHN, 1987, p. 85; LORENZ, 2006, p. 29-30.

232 Para uma influente corrente interpretativa, o eudaimonismo psicológico estaria calcado no hedonismo psicológico desenvolvido no argumento hedonista de Sócrates e pode comprovar, por si só, a inconsistência da akrasia tradicional (cf. SANTAS, 1979, p. 199-209; IRWIN, 1995, p. 52-53, p. 81-91; MORRIS, 2006, p. 203-204; WOOLF, 2002, p. 237-249). No entanto, como mostramos anteriormente, o argumento socrático não parece pressupor em momento algum um princípio
} 
eliminação de todos os desejos irracionais ou somente de motivações irracionais enquanto 'desejos cegos' (blind desires), ou seja, absolutamente independentes de qualquer concepção de bem. A seguir, nos ocuparemos com essa polêmica explorando algumas possibilidades interpretativas.

O 'intelectualismo' motivacional de Sócrates parece consistir apenas de 'desejos racionais' expresso em crenças pelo bem. Nesses termos, o ‘intelectualismo' parece se calcar na distinção absoluta entre 'desejos racionais' e 'desejos irracionais'. Em certo sentido, a classificação de 'desejos racionais' claramente implica um critério negativo: 'desejos racionais' representam crenças cognitivas, ou seja, desejos puramente racionais sem quaisquer elementos extra $\operatorname{cognitivos}^{233}$. Por isso, o 'intelectualismo' socrático implica automaticamente na negação de desejos irracionais. Como veremos a seguir, é possível preservar o intelectualismo do desejo ao abrimos mão dessa categoria restritiva de desejos racionais. Recentemente, uma corrente interpretativa alternativa tem colocado em questão a consistência da rigidez desse intelectualismo do desejo.

Em larga medida, os comentadores platônicos questionaram sistematicamente os pressupostos dessa rígida teoria intelectualista do desejo. Em primeiro lugar, uma crítica contundente apresentada por Kahn, seguida por outros autores como Weiss ${ }^{234}$, foi dirigida à divisão absoluta entre a 'psicologia' socrática e a 'psicologia' platônica presente nos Diálogos de Platão. Em segundo lugar, uma série de referências internas ao próprio grupo dos diálogos 'socráticos' demonstra o reconhecimento de motivações irracionais. Em face dessas evidências, o ‘intelectualismo’ socrático não parece implicar, de forma alguma, na eliminação do papel das motivações irracionais na ação humana. De forma geral, esses dois elementos expõem os problemas inerentes a uma definição 'unificada' do 'intelectualismo socrático dos primeiros diálogos. Na sequência, abordaremos o questionamento sistemático desses pressupostos intelectualistas na crítica de Kahn

psicológico forte, seja hedonismo ou eudaimonismo psicológico. Como vimos, o eudaimonismo psicológico parece ser mais uma conclusão necessária do argumento hedonista do que propriamente um princípio invocado contra a opinião dominante que, obviamente, não o aceita antes da refutação da akrasia tradicional.

${ }^{233}$ Cf. PENNER, 1990, p. 39-49. p. Com certeza, o intelectualismo socrático formulado por Penner advém de sua própria rejeição radical de quaisquer motivações irracionais. Em sua própria visão, os desejos irracionais são equivalentes a desejos cegos (blind desires), ou seja, desejos puramente irracionais. Ver também ROWE, 2006, p. 165-166.

${ }^{234} \mathrm{~A}$ crítica também é seguida por Ferrari (1990) que compartilha das críticas de Kahn à divisão das teorias psicológicas presentes nos diálogos 'socráticos' e 'maduros'. 
em face das referências dos próprios diálogos socráticos ao reconhecimento do poder das motivações irracionais.

Em Plato and the Socratic Dialogue, Kahn (1996, p. 243-247) critica a rígida divisão tradicional da 'psicologia' socrática, ligada aos diálogos da juventude, e a psicologia platônica, derivada dos diálogos maduros de Platão. Na verdade, isso subentende uma separação artificial de uma psicologia 'socrática', restrita aparentemente nos primeiros diálogos, e uma doutrina propriamente 'platônica', presente nos diálogos maduros. Essa postura interpretativa enfatiza mais as descontinuidades do que as continuidades inerentes às teorias clássicas encontradas nos diálogos de diferentes fases filosóficas de Platão.

Nesse sentido, o 'intelectualismo' socrático reconhece exclusivamente os desejos racionais expressos em crenças cognitivas pelo bem, enquanto a 'psicologia platônica' traça a clássica distinção entre desejo racional e impulsos irracionais, como emoções ou apetites. No entanto, Kahn e uma corrente interpretativa influente $^{235}$ levantaram um conjunto de referências internas ao próprio grupo dos diálogos 'socráticos' que colocam em xeque a 'unidade' dessa rígida teoria intelectualista do desejo.

A rigidez do 'intelectualismo socrático' foi questionada em função de um conjunto de referências de diálogos 'socráticos' que estabelecem uma distinção dos tipos de desejos humanos. Em diversas passagens, observamos normalmente o próprio Sócrates realizar uma distinção entre palavras gregas relativas ao desejo de forma abrangente, como 'boúlesthai' e 'epithymeîn' e suas palavras correlatas: em Laques, Sócrates menciona que os corajosos adquirem a coragem em relação aos apetites (epithymíais), aos medos (phóbois), aos prazeres (hedonaîs) e dores (lýpais - 191e); no Cármides, o filósofo estabelece uma distinção similar entre apetite (epithymía), o querer (boúlesis), e o desejo sexual (éros) - (167e) e, no mesmo diálogo, ele próprio reconhece o poder das paixões ao perder o controle de si mesmo vislumbrando o dorso nu do personagem-título e 'arder' em desejo erótico' (155d). Desconsiderando o Protágoras, todos esses outros diálogos socráticos parecem

235 Cf. KAHN, 1996, p. 232; WEISS, 2007, p. 96-100; DEVEREUX, 1995, p. 396-403; BRICKHOUSE; SMITH, 2010, p. 50-62. Além disso, Muniz (2011, p. 54-64) também chama atenção para essas referências explícitas às motivações irracionais nos diálogos socráticos. Dessa forma, ele reconhece a inexistência de uma reflexão mais contundente e amadurecida sobre o funcionamento dessa categoria de desejos ou da própria natureza do prazer no grupo dos diálogos socráticos. 
atestar a existência de motivações irracionais representadas também na tradição cultural grega, como observado anteriormente.

$\mathrm{Na}$ própria linguagem grega, 'boúlesthai' e 'epithymía' se referem efetivamente a concepção de 'desejo' de forma ampla e indiferenciada, mas permitem também um sentido mais restritivo ${ }^{236}$. Em termos mais modernos, podemos adotar respetivamente as traduções correntes de 'querer' racional em vista do bem e de 'apetite' irracional, como a fome ou sede, ligado à satisfação imediata dos desejos corporais. Dentro do contexto dessa passagem, Sócrates está apenas assumindo uma distinção popular dos desejos do contexto grego sem qualquer análise mais profunda da psicologia humana. Em todo caso, o objetivo central de Sócrates nunca se desvia da definição do que é a 'virtude' em ambos os diálogos, sendo no Cármides a sophrosýne (temperança) e no Laques, a andreía (coragem).

Em nenhuma dessas ocasiões, Sócrates se alonga sobre a natureza psicológica dos desejos, sejam eles racionais ou irracionais. Sem adentrar em uma investigação mais detalhada desses diálogos, podemos apenas assegurar que Platão não contesta a visão tradicional sobre a motivações irracionais nesses diálogos socráticos. Diante dessas referências, o paradoxo socrático do Protágoras aparece de uma forma ainda mais controversa.

A presença das motivações irracionais nos diálogos socráticos cria um problema interpretativo envolvendo o restrito 'intelectualismo' do paradoxo socrático do Protágoras. Por conta da clara oposição entre tais referências e a clara negação da akrasia, Kahn (1996, p. 230-233) ${ }^{237}$ sustenta que não há qualquer evidência de uma psicologia 'socrática' contra uma psicologia 'platônica' nos diálogos de Platão. Na realidade, o ‘racionalismo' rígido do paradoxo socrático seria uma tese ad hominem isolada encontrada explicitamente somente no Protágoras. Na mesma linha, Weiss (2006, p. 60-68) também adere a leitura ad hominem do rígido paradoxo socrático desse diálogo sustentando que o

\footnotetext{
${ }^{236}$ Sobre essa distinção intercambiável dos termos de desejo, ver WEISS, 2007, p. 97; DEVEREUX, 1995, p. 400. Apesar disso, Sócrates não parece preocupado em traçar qualquer distinção mais técnica sobre tipos de desejos no Protágoras. Além disso, ele inclusive rejeita explicitamente a distinção de desejos apresentada por Pródico no diálogo (337a-c; 358a-b).

${ }^{237} \mathrm{De}$ fato, uma leitura ad hominem no mesmo espírito anti-hedonista é apresentada em FERRARI, 1990. Como evidenciamos anteriormente, a leitura anti-hedonista tende a relativizar a força dos desejos irracionais dentro do argumento hedonista socrático contra a akrasia. Para todos os efeitos seria como se o argumento hedonista desconsiderasse completamente o papel das motivações irracionais. Com vimos, o exame socrático coloca em xeque apenas a coerência entre as crenças da opinião dominante e o erro factual do agente na akrasia tradicional. Para isso, Sócrates não precisa adentrar em um exame mais profundo da psicologia humana.
} 
‘intelectualismo' socrático não se verifica em nenhum outro diálogo 'socrático'. Nessa perspectiva, o 'intelectualismo' socrático do Protágoras representa uma explícita negação das motivações irracionais que não possui qualquer plausibilidade nos fatos da natureza humana.

Essa leitura ad hominem é incompatível com os princípios socráticos de diálogo. Na realidade, o paradoxo socrático esclarece de forma contundente fatos sobre a motivação humana que são essenciais no argumento socrático antiakrasia. Todavia, ambos os autores presumem que o 'intelectualismo' socrático estabelece a exclusão absoluta das motivações irracionais humanas. Como vimos, eles endossam o 'intelectualismo' ortodoxo alegando que o paradoxo socrático do Protágoras constitui um 'racionalismo onipotente' calcada no implausível controle absoluto da razão sobre os impulsos e na negação de fatos óbvios da natureza humana. No entanto, o estado de conflito interno da alma na potência da aparência parece contemplar a existência de certas motivações irracionais. Ora, mas se as motivações irracionais existem, então qual seria seu papel no 'intelectualismo' expresso pelo paradoxo socrático?

Mesmo reconhecendo a existência de motivações irracionais, o Protágoras não parece nos oferecer indicações explícitas de seu espaço no 'intelectualismo’ do desejo. Em vista disso, uma corrente interpretativa influente tem oferecido diferentes explicações sobre o que é a motivação irracional no 'intelectualismo' socrático: (a) a pura motivação irracional independente de qualquer avaliação valorativa, ou, um desejo ‘cego'; (b) a crença pelo bem; (c) um impulso de atração ao objeto de desejo em vista da crença do bem. Em seguida, analisaremos se algumas dessas hipóteses interpretativas poderia contemplar a dimensão do ‘intelectualismo socrático’ do Protágoras.

A partir do 'intelectualismo' socrático original do Protágoras, é difícil definir o que poderia representar as motivações irracionais no fenômeno da ignorância. Em primeiro lugar, a própria existência de impulsos 'cegos' é automaticamente incompatível com o argumento hedonista e a descrição da potência da aparência. Os impulsos irracionais poderiam afetar diretamente a ação humana sem mediação do desejo racional, o que parece ser inviável segundo pelos princípios do intelectualismo. Em segundo lugar, a tese forte de que os desejos irracionais são apenas crenças avaliativas do bem implica em um tipo de reducionismo das motivações humanas ao estado cognitivo do agente sob efeito da 
aparência $^{238}$. Sob esse ângulo, o erro do agente é explicado inteiramente por uma falha intelectual sem explicar propriamente seu estado interno de conflito. Em terceiro lugar, a representação do desejo irracional como um 'impulso de atração' pelo bem parece ser mais coerente mas não deixa de ter suas inconsistências ${ }^{239}$. $\mathrm{O}$ 'intelectualismo' socrático não separa claramente os aspectos cognitivos e motivacionais das crenças pelo bem. É particularmente difícil definir o que é o ‘impulso de atração' humana pelo bem sem associá-lo à própria crença valorativa do que parece bom (cf. SINGPURWALLA, 2006, p. 250-251). De qualquer forma, o argumento socrático não parece interessado em definir claramente o que são as motivações irracionais.

O argumento socrático trata de forma indistinta a dimensão epistemológica e a psicológica do conflito interno da potência da aparência. Nesse sentido, Sócrates parece mais preocupado em descrever os efeitos internos do que propriamente à explicação das causas da potência da aparência. Mais propriamente, o objetivo central do argumento socrático é distinguir o estado interno estável da posse do conhecimento em face do estado instável da aparência ilusória. Sob essa perspectiva, os desejos irracionais só se manifestam claramente em sua dimensão cognitiva, subordinados às crenças pelo bem, e jamais enquanto desejos 'cegos' absolutamente independentes do bem. Afinal, as motivações humanas são observadas com base no parâmetro epistemológico e objetivo da aparência e a realidade.

No horizonte, as preocupações epistemológicas de Sócrates no Protágoras o levam a distinguir o conhecimento do erro ilusório sem, no entanto, investigar propriamente o que é esse fenômeno classificado equivocadamente de akrasia. Nesse contexto, a definição conclusiva de Sócrates enfatiza o diagnóstico da 'falta de conhecimento' (epistémes endeíai): “a ação incorrida em erro sem conhecimento (áneu epistémes) praticada por ignorância" (358d). Dessa forma, a perspectiva epistemológica negativa do argumento sobressai em detrimento de uma análise psicológica mais positiva.

\footnotetext{
${ }^{238}$ Para uma versão do reducionismo dos desejos irracionais ao estado cognitivo do agente, cf. SEGVIC, 2009, p. 73-77; SINGPURWALLA, 2006, p. 253-254.

239 Sobre a provável presença dos 'desejos irracionais' no argumento socrático antiakrasia, ver DEVEREUX, 1995, p. 393-396; BRICKHOUSE \& SMITH, 2010, p. 78-81.
} 
Na ausência da investigação psicológica, Sócrates não explica propriamente o que constitui a irracionalidade da akrasia na alma justamente porque não esclarece a origem das motivações irracionais humanas. Todavia, essa falta de interesse do Protágoras em investir em uma explicação psicológica do fenômeno irracional advém de um elemento marcante da psicologia encontrada nos diálogos socráticos de Platão, a concepção unitária da alma.

A unidade da alma presente nos diálogos 'socráticos' tem sido reiteradamente reconhecida nos estudos platônicos. Embora Sócrates jamais se refira exatamente à uma 'unidade' da alma nesses diálogos socráticos, a tese psicológica surge como um 'pressuposto necessário' da defesa da tese socrática da unidade entre conhecimento e virtude como visto, por exemplo, no Protágoras. A 'unidade' da alma tem a função específica nesses diálogos de assegurar a absoluta complementaridade entre saber e ação, contemplando o aspecto teórico e prático (ou ético) inerente da psicologia socrática ${ }^{240}$. Diante da concepção unitária da alma, não há muito espaço para uma reflexão mais profunda das motivações irracionais.

A psicologia socrática abrange uma uniformidade do plano teórico e prática da motivação humana em vista de uma concepção abrangente e universal de bem. De um lado, a simplicidade absoluta da alma socrática expressa a orientação universal do desejo racional pelo bem em amplo sentido, e, sobretudo, realizado no conhecimento do bem ${ }^{241}$. De outro lado, essa unidade da alma permite tratar as motivações irracionais em termos objetivos cognitivos e morais, excluindo impulsos 'cegos' absolutamente independentes da avaliação do bem. Em última instância, a ausência de uma reflexão psicológica aprofundada das motivações irracionais está ligada a condições teóricas específicas da psicologia 'socrática' dos primeiros diálogos.

A ausência da problematização da natureza dos prazeres e a obscuridade em torno da constituição da alma marcam a concepção unitária da psicologia 'socrática' típica do Protágoras.

\footnotetext{
${ }^{240}$ Cf. SEGVIC, 2009, p. 79: "the unity of the soul (...) it ties inextricably the practical side of our nature - the desiderative, the emotional, and the volitional - with the supposedly non-pratical side of us, namely the side that forms judgments and possess knowledge."

${ }^{241}$ Cf. IGLÉSIAS, 1998, p. 28: "A alma socrática é assim de uma unidade e simplicidade absoluta, um princípio ao mesmo tempo racional e desejante, e desejante de uma coisa única: aquilo que é tido pelo bem. Ela é sede das virtudes, ou das ações virtuosas, que não são remetidas a diferentes fontes dentro da alma, uma vez que são uma só, ciência, que é também desejo daquilo que sabe ser o bem."
} 
Segundo Muniz (2011, p. 46), o desenvolvimento de uma investigação sobre a natureza da alma e do prazer em Platão emerge de condições filosóficas específicas dos diálogos 'maduros':

o que torna necessária essa problematização [dos prazeres] é, no desdobramento teórico dos Diálogos, o aparecimento de uma dupla oposição (...) nos diálogos do dito período médio: corpo/alma e sensível/inteligível.

Dessa forma, observamos que a ausência de uma análise mais profunda da natureza da alma e a complexidade das motivações humanas está ligada a própria ausência das oposições fundamentais dos diálogos 'socráticos': corpo/alma, no campo psicológico, e sensível/inteligível, no campo epistemológico. Sobre os primeiros diálogos antes do Protágoras, observamos anteriormente que as motivações irracionais integram uma discussão mais abrangente da virtude sem jamais integra uma análise psicológica independente e aprofundada da alma humana.

Enquanto isso, o Protágoras propriamente suscita a primeira discussão em torno da distinção epistemológica da aparência e da realidade dos prazeres. No entanto, essa perspectiva epistemológica do problema da akrasia no diálogo não chega a explorar a natureza dos prazeres ou a natureza da alma humana. Nessas condições, o Protágoras comprova o que o fenômeno da akrasia absolutamente não é, ou seja, o domínio dos impulsos sobre o conhecimento e a virtude. Em um ambiente mais propício à divisão corpo/alma, Platão terá oportunidade de explorar o conflito interno das motivações humanas e definir em termos mais positivos o fenômeno da akrasia.

O Protágoras e a República marcam tradicionalmente posições divergentes de Platão sobre o problema da akrasia. O hedonismo e ampla concepção de bem do Protágoras dão lugar à diversidade dos 'bens' relativos à diferentes motivações da alma na República. Em paralelo, a unidade da alma dos primeiros diálogos definitivamente dá espaço à complexidade da alma na psicologia platônica dos diálogos 'maduros'.

Nesse cenário, a República apresenta a teoria tripartite da alma que possibilita uma análise psicológica mais detalhada do conflito interno psicológico. Dessa forma, a psicologia da República oferece parâmetros psicológicos para 
explicar as motivações irracionais da akrasia de um ângulo diferente da perspectiva epistemológica do Protágoras. A princípio, a psicologia platônica da República parece culminar no resultado diametralmente oposto ao Protágoras. Seria plausível admitir, como supõe a tradição interpretativa, que a República rejeita a negação da akrasia do Protágoras? Na sequência, devemos avaliar os elementos de continuidade e descontinuidade de ambos os diálogos no intuito de apresentar uma visão mais consistente e integrada da mudança de paradigma platônico em relação ao problema da akrasia. 
4.

\section{A teoria tripartite da alma e o conflito interno da akrasia na República}

\section{1}

\section{A psicologia moral platônica e a akrasia na República}

A transição do Protágoras à República de Platão demarca uma mudança significativa da psicologia moral platônica. Para a tradição interpretativa platônica, essa mudança se verifica em dois níveis diferentes: (a) a rejeição do paradoxo socrático do Protágoras, segundo o qual "ninguém faz o mal de bom grado (hekón)' (358d-e); (b) o reconhecimento da descrição da akrasia tradicional a partir de uma nova teoria tripartite da alma na República (435b-442b). Em vista dessa divergência, devemos analisar se isso configura uma absoluta descontinuidade dentro da filosofia de Platão. Entretanto, precisamos primeiramente determinar o que constitui a 'psicologia' de Platão em seu sentido original grego.

Ao contrário da 'psicologia' moderna, a 'psicologia' platônica advém diretamente de seu original grego psyché, correspondente ao 'sopro da vida' homérico ou, mais especificamente, à 'alma' ${ }^{242}$. A partir dessa tradição grega, as diferenças entre a psicologia moderna e a psicologia platônica são mais claramente demarcadas. De um lado, a psicologia platônica não se concentra em um 'eu' subjetivo, isolado de sua relação intersubjetiva com os outros e de outras influências externas, como a formação educacional e moral ${ }^{243}$. De outro lado, a psyche constitui um elemento central que reúne diferentes desejos e motivações humanas e, apenas de forma derivada, a sede da razão e da consciência moral ${ }^{244}$. Independente de

\footnotetext{
${ }^{242}$ Como observamos no capítulo 3.

243 A dimensão abrangente da 'psicologia' platônica em relação à psicologia moderna é particularmente analisada em GILL, 1996, cap. 4; LEAR, 2001. Ambos os autores mostram como o exame da psyché na República é intrinsecamente conectado à formação educacional, cultural e suas relações intersubjetivas. Sobretudo, Gilll (1996, p. 275-287) salienta como a própria psicologia platônica está vinculada a elementos fundamentais da psicologia grega antiga e como se destaca da filosofia da mente contemporânea.

${ }^{244}$ Cf. LOVIBOND, 1991, p. 36-37: "Many people presumably bring to their reading of Plato a conception of 'mind' informed by debates within analytical philosophy. For such readers, perhaps the most striking feature of Plato's doctrine will be his portrayal of psyche as primarily an organ of desire or striving, and only secondarily (and consequentially) as the seat of our reasoning powers or of our moral conscience."
} 
outras formulações da psicologia platônica, a República nos fornece indícios suficientes da dimensão característica da psicologia moral platônica do período médio ${ }^{245}$.

A República exibe um argumento que revela a dimensão abrangente da psicologia platônica. Em Rep. I, Sócrates classifica a função (érgon) e a virtude (areté) específicas da alma (psyché) (352-354a). Para o filósofo, todas as coisas apresentam um érgon específico de sua atividade própria e uma areté que desempenha bem, de forma virtuosa e excelente, ou mal, de modo disfuncional e precário a sua função (353a-b). Por exemplo, a faca é projetada para cortar, os olhos fornecem a visão, os ouvidos a audição, e todas as coisas exibem sua 'atividade' peculiar. A função específica ou o ‘trabalho' do érgon de cada objeto manifesta sua arete correspondente de acordo com seu bom ou mal desempenho de sua atividade.

$\mathrm{O}$ argumento da função depende da relação intrínseca de érgon e areté, compartilhada na língua e na sociedade gregas. A partir desse raciocínio, Sócrates afirma que a função característica da alma é viver (tò zên) pela qual é exercida a atividade de "cuidar, governar, deliberar (tò epimelê̂sthai kaì árchen kaì bouleúesthai) e todos os atos da mesma espécie" (353d-e). Em última instância, o argumento da função visa comprovar a tese que o justo é mais feliz que o injusto por conta da relação intrínseca dos efeitos da justiça e da virtude na alma humana (353e-354a). Em reiteradas ocasiões, Sócrates lembra efetivamente que o exame da República está comprometido com a determinação do melhor "curso da vida (bíou diagogén)" (cf. 344e; cf. 352d; 578c-d). Dessa forma, a investigação da República se orienta a investigar propriamente a vida do justo e a vida do injusto.

Dentro dessa ampla perspectiva, a psicologia platônica integra a relação fundamental do estado psicológico da alma e a vida ética humana ao invés de apresentar uma psicologia humana estrita centrada na mente humana. A psicologia platônica da República envolve tanto uma 'psicologia' no sentido estrito, isto é, uma teoria da alma, quanto um exame amplo dos tipos de caráter humano, isto é,

\footnotetext{
${ }^{245}$ Por conta do nosso foco primordial sobre o problema da akrasia antiga, devemos deixar outras teorias psicológicas dos diálogos médios platônicos fora do escopo desta pesquisa. Seguramente, o Górgias (492d-494c;496d-e; 503d, 506d), o Menôn (80e-82a) e o Fédon (73c-80c) já apresentam a distinção entre corpo e alma e a imortalidade da alma, mas não tratam especificamente do conflito interior da alma típico da akrasia. Dentre os outros diálogos, é necessário destacar o diálogo tardio As Leis, que exibe uma análise mais detalhada do termo akrasia. No entanto, o interesse filosófico pela discussão da akrasia presente nesse diálogo foi demasiado tardio para merecer atenção da discussão inicial da filosofia contemporânea sobre o problema da fraqueza de vontade.
} 
os modos de vida. Por isso, classificamos a teoria psicológica da República como um tipo de psicologia moral, isto é, intrinsecamente relacionada aos valores morais humanos. A partir disso, devemos tratar da polêmica interpretativa em torno do paradoxo socrático e da akrasia na República.

A polêmica do paradoxo socrático e da akrasia gira em torno da divergência entre a psicologia do Protágoras e da República. Em geral, há um contraste explícito entre a concepção da unidade da alma no Protágoras e a complexa teoria tripartite da alma da República. De fato, tais diálogos são considerados respectivos representantes de duas teorias psicológicas divergentes da filosofia de Platão: a psicologia socrática, relativa aos primeiros diálogos, e a psicologia platônica, relacionada aos diálogos médios. Como vimos, essa corrente interpretativa se caracteriza pelo desenvolvimentismo, pois considera que há uma 'mudança' teórica dos diálogos de fases distintas do pensamento platônico. No entanto, essa classificação das fases do pensamento platônico dá origem às controvérsias interpretativas que rondam o paradoxo socrático e a akrasia.

Para a interpretação ortodoxa, a inovação da psicologia platônica se verifica em dois pressupostos fundamentais: (a) a admissão de motivações irracionais contrárias ao desejo racional pelo bem; (b) o reconhecimento da possibilidade do conflito interno psicológico e, em especial, o conflito interno característico da akrasia. A seguir, veremos alguns dos pressupostos teóricos dessas diferentes linhas interpretativas.

A complexa psicologia platônica da República representa uma suposta ruptura com o paradoxo socrático do Protágoras. A própria demonstração da teoria tripartite da alma em Rep. IV contém teses que parecem dirigidas ao intelectualismo socrático do Protágoras.

A suspeita de uma contraposição entre ambos os diálogos e a inovação da psicologia platônica da República reside em dois aspectos primordiais: a própria teoria de três impulsos naturais da alma e a suposta objeção ao paradoxo socrático de 438a. Em primeiro lugar, a teoria tripartite da alma de Rep. IV estabelece a existência de três 'partes' da alma, correspondentes a três motivações diferentes (439d-441c): a parte apetitiva (epithymetikón), a parte impetuosa (thymoeidés) e a parte racional (logistikón). Em segundo lugar, Sócrates rebate uma objeção específica sobre o desejo pelo bem em Rep. IV que relembra o paradoxo socrático do Protágoras. Sobretudo, Sócrates ressalta uma clara oposição entre a 
"irracionalidade (tôi alogístos)" da parte apetitiva e a parte racional da alma (439d; 441c).

Seguindo essas indicações, a tradição interpretativa ortodoxa alega que a República apresenta desejos ou motivações 'independentes do bem' (goodindependent) em contraposição ao exclusivo desejo racional 'dependente do bem' (good-dependent) do Protágoras ${ }^{246}$. Novamente, observamos aqui a distinção absoluta entre racional e irracional derivada da psicologia moderna da vontade. Apesar dos fortes indícios textuais a favor de uma interlocução de ambos os diálogos, é preciso resistir à tendência interpretativa apressada de buscar elementos externos de uma 'mudança' na posição platônica sem antes esgotar as possiblidades interpretativas dos elementos internos no diálogo da República. Todavia, essa ideia da 'mudança' da posição de Platão ainda se apoia sobre outro fator fundamental, o suposto conflito interno da akrasia em Rep. IV.

Em contraposição à negação socrática da akrasia do Protágoras, a alma tripartite da República oferece uma teoria psicológica aparentemente compatível com a descrição tradicional. A princípio, a demonstração da teoria tripartite da alma de Rep. IV é designada para explicar o conflito interno da alma em geral. Durante essa demonstração, Sócrates apresenta o caso específico de Leôncio, que acaba cedendo ao impulso vergonhoso de ver cadáveres no momento decisivo, contra sua deliberação racional (439e-440b). Com base nisso, o filósofo estabelece que tais fatos comprovam que os impulsos irracionais se impõem "contra a razão" (para ton logismon), nos mesmos termos do vocabulário típico da akrasia.

A tradição interpretativa alega que a teoria tripartite da República reconhece a akrasia tradicional contra a negação socrática da akrasia no Protágoras. Supostamente, Platão teria abandonado assim o intelectualismo do desejo de Protágoras e a descrição intelectualista da ignorância. Em outros termos, Platão poderia assim apelar ao princípio da força relativa dos desejos e rejeitar o

\footnotetext{
${ }^{246}$ Acerca dessa distinção ortodoxa dos desejos do bem, ver KAHN, 1987, p. 85; Idem, 1996, p. 243-246; IRWIN, 1995, p. 75-76; Idem, p. 209; TAYLOR, 1991, p. 203-204; REEVE, 1988, p. 134145; ROWE, 2007, p. 23-25. Com frequência, adeptos dessa abordagem supõem fortes conotações cognitivas da distinção, implementando uma oposição absoluta entre o desejo racional e desejos completamente irracionais, isto é, desejos cegos. Para uma versão mais acentuada de desejos independentes do bem, ver PENNER, 1990 p. 49-61; WATSON, 1977, 320-321; CHARLTON, 1988, p. 26-27; FERRARI, 2007, p. 167-169. No entanto, existem aqueles que preferem uma visão mais moderada, alegando que a República preserva o paradoxo socrático em alguma medida: cf. LESSES, 1987, p. 152; BOBONICH, 2002, p. 240; LORENZ, 2006, p. 29; MORRIS, 2006, p. 223225.
} 
predomínio do desejo racional sobre os diversos impulsos irracionais ${ }^{247}$. A suposta 'mudança' da psicologia platônica abrange a teoria tripartite e o conflito interno da akrasia. No entanto, algumas dificuldades se colocam diante dessa leitura ortodoxa dos Diálogos.

As dificuldades da leitura ortodoxa tradicional são expostas quando notamos que a teoria tripartite de Rep. IV não exibe o quadro completo da psicologia moral da República. A partir do exame dos regimes e das almas injustas de Rep. VIII-IX, nos deparamos com novas subdivisões da alma. Com efeito, essas subdivisões ocorrem dentro da parte apetitiva da alma: primeiramente, os apetites são divididos entre os grupos de desejos necessários (anankaîon) e desejos não necessários (ouk anankaîon) (558d-559d); em seguida, os desejos não necessários são posteriormente subdivididos em legítimos (nómoi) e ilegítimos (paránomoi) (571a). Dessa forma, Sócrates não parece estar inteiramente comprometido com um modelo fixo de 'partes' da alma da teoria tripartite original. Na verdade, mostraremos que Sócrates realmente admite subdivisões internas da alma. Como veremos, o exame psicológico inaugurado em Rep. VIII-IX integra a teoria tripartite original da alma e a analogia cidade-alma apresentada em Rep. II. O desenvolvimento completo da psicologia moral platônica desafia a hipótese tradicional da 'mudança' da teoria tripartite da alma na República.

A partir da psicologia platônica completa da República, Platão nos fornece indicações que não está necessariamente envolvido com as implicações do modelo tripartite de Rep. IV. Como vimos, a extensão da psicologia de Rep. VIII-IX revela que o modelo tripartite admite subdivisões internas da parte apetitiva. Além disso, ainda podemos levar em conta que a psicologia platônica se restringe à 'alma encarnada'. Em Rep. X, Sócrates indica que "a natureza original (tèn archaían phýsin)" da alma é simples e imortal, e não complexa, como em seu estado

\footnotetext{
${ }^{247}$ Em última instância, a corrente desenvolminentista alega que a teoria tripartite da República é introduzida com o propósito de dar conta do conflito interno em geral e, em especial, o conflito da akrasia contra a negação socrática do fenômeno no Protágoras. Para essa interpretação ortodoxa dos Diálogos, ver LESSES, 1987, p. 157-158; COOPER, 1984, p. 3-4; IRWIN, 1995, p. 75-76; TAYLOR, 1991, p. 203-204; FREDE, 1992, p. xxx; REEVE, 1988, p. 134-145; BOBONICH, 2002, cap. 3; ROWE, 2007, p. 23-25. No entanto, há uma linha interpretativa alternativa mais recente em defesa da continuidade entre o Protágoras e a República, ressaltando a tese interpretativa que ambos os diálogos visam explicar o conflito interno da alma em termos de ignorância. Para essa leitura alternativa dos Diálogos, ver KAHN, 1996, p. 253-257; PRICE, 1995, p. 91-100; WILBURN, 2014, p. 77-87.
} 
deteriorado no corpo (611b-612a) ${ }^{248}$. Mesmo assim, isso não invalida as conclusões acerca da alma encarnada na cidade, já que a psicologia concerne à vida humana em geral: "o que dissemos sobre ela, é verdade, quanto sua aparência no estado presente (en tôi parónti phaínetai)." (611d). Em suma, as observações de Sócrates indicam que o modelo tripartite da alma admite subdivisões em função de seu contato deteriorado com o corpo ${ }^{249}$. O quadro completo da psicologia 'encarnada' nos permite reconsiderar, a partir de dois aspectos, o papel da teoria tripartite da alma e o estatuto do conflito interno da akrasia na República.

Em primeiro lugar, cada parte da alma acaba tendo seu próprio critério valorativo: o desejo pelo bem se manifesta, de forma específica, nos seus respectivos objetos naturais de desejo das partes da alma. Assim como a parte racional tem seu amor de aprender (philomathés) e saber (philósophos), a parte impetuosa exibe seu amor pela vitória (philónikon) e pela honra (philótimon), e a parte apetitiva, amor por lucro (philokerdés) e riqueza (philochrématon) (581a-c).

Na verdade, a inclinação natural ao bem constitui um atributo universal dos objetos de desejo em geral e não está propriamente restrita à parte racional da alma. Dentro dessa perspectiva, a distinção dos desejos bem-independentes e desejos dependentes do bem não faz mais sentido e a hipótese da objeção socrática de 438a fica sob suspeita. No entanto, restaria considerar ainda a presença da akrasia na República.

Em segundo lugar, a akrasia não adquire o estatuto de um problema filosófico distinto na República tal como no Protágoras. Dentre os diversos casos de conflito psicológico presentes na República, o caso de Leôncio surge isolado como um exemplo distinto de akrasia em Rep. IV. Com efeito, o vocabulário do 'conflito' da akrasia está disperso por toda a República. Entretanto, o vocabulário está constantemente subordinado ao foco principal da psicologia moral da República, o conflito interno da alma. Antes mesmo da demonstração da teoria tripartite, Sócrates vincula o vocabulário do conflito interno à oposição entre

\footnotetext{
${ }^{248}$ Em outra seção, abordaremos brevemente as dificuldades derivada da 'pura' atividade racional da alma sugerida em Rep. X mas já anunciada em outras passagens da República. Por ora, assumiremos apenas que essa concepção 'pura' da alma se restringe à alma imortal e não invalida propriamente as conclusões da psicologia tripartite 'encarnada' presente em Rep IV.

${ }^{249}$ Cf. REEVE, 1988, p. 162: "Indeed, the view that the psyche is really simple is an intelligible extension of the theory that it is temporarily complex. Thus viewed in secular psychological terms, Plato's brief portrait of the psyche's true nature is not such a radical departure from his vastly richer portrait of it as it is in this life."
} 
sensatez (sophrosýne) e intemperança (akolasía) (431e-432b). Dessa forma, a mudança do pensamento platônico do Protágoras à República não parece ser tão radical quanto supõe o desenvolvimentismo ortodoxo.

A suposta mudança radical da psicologia platônica entre Protágoras e a República deve ser colocada sob suspeita. Com certeza, não há como negar a incontestável evidência de que a República inaugura uma nova teoria psicológica em confronto com o intelectualismo motivacional do Protágoras.

Em nossa perspectiva, defenderemos que há elementos de continuidade e descontinuidade da posição de Platão sobre a psicologia moral e a akrasia. Em relação à continuidade, mostraremos que Platão mantém, em essência, as teses fundamentais do pressuposto motivacional do desejo natural do bem e a descrição do akrasia como ignorância. Em relação à descontinuidade, indicaremos que o contexto dialógico altera a paradigma psicológico da akrasia. Se o Protágoras estabelece uma definição negativa do conflito interno da akrasia em relação ao conhecimento, a psicologia moral da República fornece uma explicação positiva do conflito interno humano. Todavia, a psicologia moral e o conflito interno da alma estão inseridas no contexto mais amplo da estratégia da analogia cidade-alma em resposta ao Desafio da Justiça da República.

É preciso analisar a emergência do tema da psicologia moral a partir da analogia cidade-alma e do Desafio da Justiça da República. Dessa forma, devemos contextualizar o conflito interno da alma e a psicologia moral platônica em meio aos outros temas colaterais do diálogo. Para verificarmos essa conexão, precisaremos esclarecer primeiro o contexto amplo do Desafio da Justiça e a analogia cidade-alma.

Antes de abordar a analogia cidade-alma, precisamos investigar os termos do Desafio da Justiça dos irmãos Gláucon e Adimanto. No contexto da República, o exame psicológico da natureza da alma de Sócrates tem seu início desde a formulação do problema do Desafio da Justiça. Nesse cenário, poderemos esclarecer os traços de continuidade e descontinuidade do exame socrático do Protágoras e o exame socrático da República. Sobretudo, devemos retomar o problema fundamental da unidade do contexto dialógico da República. 


\section{2 \\ O exame da natureza da alma na República: o Desafio da Justiça e a analogia cidade-alma}

A unidade do contexto dialógico da República supera a aparente divisão

entre Rep. I e os demais livros Rep. II-X. Dentro desse escopo, é primordial compreendermos a gênese da psicologia tripartite e do conflito interno da alma dentro do debate central que perpassa toda a República. Para isso, teremos de nos voltar a dois tópicos que integram o fio condutor do exame da natureza da alma: o problema central da justiça e a analogia cidade-alma.

O exame da natureza da alma em Rep. IV decorre indiretamente de dois tópicos que perpassam a República: em primeiro lugar, o problema central da definição da justiça (dikaiosýne) inaugurado em Rep. I e reforçado no Desafio da Justiça dos irmãos Gláucon e Adimanto a partir de Rep; em segundo lugar, a resposta de Sócrates ao Desafio da Justiça de Rep. II com base controversa analogia cidade-alma. Dentro desse contexto, a teoria tripartite da alma esclarece a dimensão psicológica interna da justiça e da injustiça, promovendo critérios objetivos de avaliação para o Desafio da Justiça.

O 'Desafio da Justiça' constitui uma série de quatro objeções dos irmãos Gláucon e Adimanto à definição da justiça e à defesa da vida justa de Rep. II. De forma geral, o Desafio compreende dois problemas fundamentais amparados na visão da opinião dominante: 1) o que é a justiça e a injustiça, independentemente de sua aparência (dóxa)?; 2) qual das duas vidas é a melhor e qual é a pior, em termos de felicidade (eudaimonía), a do mais justo ou a do mais injusto? Aparentemente o Desafio inaugura novos parâmetros de discussão, mas, na realidade, o problema original da justiça continua sendo o foco principal desde Rep. I. Diante disso, Sócrates fornece, através da analogia cidade-alma, duas extensas estratégias argumentativas em busca de uma resposta definitiva à altura do Desafio da Justiça.

A partir da analogia cidade-alma, a psicologia tripartite estará diretamente associada a duas estratégias argumentativas fundamentais de resposta ao Desafio: (a) a fundação da Cidade Ideal e o exame interno da justiça e injustiça com base na teoria tripartite da alma em Rep. IV; (b) o exame da degradação moral dos regimes políticos e caracteres injustos a fim de determinar a comparação decisiva do 
'perfeito justo' e do 'perfeito injusto' sem suas aparências em Rep. VIII-IX. Em meio à ampla estratégia, uma outra frente de investigação leva à epistemologia, a metafísica da Linha Dividida, a Teoria das Formas e a dialética - que estarão fora do escopo deste capítulo. Diante dessa estratégia ambiciosa, a psicologia tripartite cumpre um papel primordial na resposta final de Sócrates ao Desafio da Justiça dos irmãos Gláucon e Adimanto.

O empreendimento central da República concerne à resposta de Sócrates ao Desafio da Justiça de Gláucon e Adimanto. Nesse cenário, pretendemos indicar que a psicologia tripartite cumpre duas funções primordiais na resposta definitiva da definição da justiça e da preferência da vida justa. De um certo ponto de vista, a complexa teoria tripartite da alma de Sócrates em Rep. IV está em contraste com uma visão simplificada da inclinação natural da alma à injustiça derivada do Desafio da Justiça. De outro, a psicologia tripartite e a analogia cidade-alma contribuem para estabelecer o argumento comparativo final de Rep. IX. Em última instância, as três demonstrações (apódeixis) finais de Sócrates em nome da vida justa em Rep. IX revelam definitivamente o exame interno do estado psicológico do injusto e do justo destituídos de suas aparências.

A seguir, analisaremos como o Desafio da Justiça e a teoria tripartite da alma tem sua gênese a partir do primeiro exame da natureza interna da justiça. Em seguida, nos deteremos sobre o papel da analogia cidade-alma e da psicologia tripartite na resposta definitiva de Sócrates ao Desafio da Justiça.

Iniciemos nossa investigação a partir da formulação do Desafio da Justiça de Gláucon e Adimanto na Rep. II. Os interlocutores estabelecem o desafio a partir de dois problemas relacionados ao "parecer da maioria (dokeî toîs pollô̂s)" (358a): 1) a defesa da justiça “em si e por si mesma (autò kath' autó)" ou, em outra palavras, a definição do que a justiça realmente é (cf. 358b; 367d) $)^{250}$; 2) a comparação

\footnotetext{
${ }^{250}$ Nesses termos, o problema da definição da justiça formulado na República se aproxima dos diálogos socráticos que geralmente abordam a definição da virtude (em geral ou em particular). De fato, a maioria dos intérpretes reconhece que apenas Rep. I se aproxima dos diálogos socráticos a ponto de, por vezes, constatar-se sua disparidade com os demais livros (cf. IRWIN, 1995, p. 198200; REEVE, 1988, p. 22-24). Todavia, a formulação do problema (1) em Rep. II revela que há continuidade entre o problema da justiça formulado e reformulado em Rep. I-II. De fato, o próprio Sócrates exprime insatisfação com a aporia final de Rep. I e Gláucon e Adimanto reforçam essa insatisfação na retomada da tese fundamental de Trasímaco em Rep. II. Dessa forma, isso indica que Platão permanece preocupado com a definição do que é $x$, mesmo exibindo uma preocupação mais premente com os métodos utilizados para alcançar $x$ (cf. KAMTEKAR, 2017, p. 14-15). Assim, projetar a divisão absoluta entre o pensamento 'socrático' e 'platônico' dentro da própria República não parece ser a melhor estratégia de leitura.
} 
objetiva das vidas do justo e do injusto a fim de determinar qual dessas duas vidas é a mais feliz (eudaímon) para além de sua 'aparência' diante da maioria (cf. 361e362c; 362e-368a). Sobretudo, a análise dos efeitos internos da justiça depurada de sua doxa orienta o exame da natureza e dos efeitos internos da justiça na alma.

O Desafio da Justiça tem raízes anteriores, especificamente na insatisfação de Gláucon e Adimanto com os argumentos socráticos contra a definição de justiça de Trasímaco em Rep. I. Ao recapitularmos brevemente a discussão de Rep. I, compreenderemos por que o Desafio da Justiça tem sua origem no problema da definição da justiça de Rep. I.

Assim como o Protágoras, a Rep. I assume o típico formato dos diálogos socráticos da primeira fase. O problema da justiça é formulado como um problema da definição da coisa em si: ‘o que é $x$ ?' (331c; 354b). Ao longo da discussão, os interlocutores se revezam em defesa de diferentes definições de justiça. Ao longo de Rep. I, os principais interlocutores são Céfalo, seu filho Polemarco e o sofista Trasímaco. Em linhas gerais, Céfalo e Polemarco apresentam definições de justiça compatíveis com as convenções sociais atenienses ${ }^{251}$ : “a restituição do que é devido" (331d-e) e "fazer bem aos amigos e mal aos inimigos" (332a-c). Entretanto, o sofista Trasímaco apresenta duas definições mais sofisticadas e polêmicas, amparadas em uma tese central: "a justiça é a vantagem do mais forte (tò tôu kreíttonos symphéron)" (338c). Durante essa discussão, Sócrates coloca em xeque todas as definições de justiça através do método do elenchus, chegando, ao fim de Rep. I, a uma aporia, isto é, a um impasse acerca do que "a justiça realmente é (tò dikaion hóti pot'estín)" (354b).

O Desafio da Justiça de Rep. II tem clara origem na insatisfatoriedade do último ato de Sócrates e Trasímaco. Todavia, é preciso analisar a dimensão interna do Desafio da Justiça antes de confrontar suas implicações indiretas na posição de Trasímaco de Rep. I. Com disso, seguiremos a formulação do problema da definição da justiça de Rep. II em vista da classificação preliminar de Gláucon dos tipos de bens.

O Desafio da Justiça decorre da divergência de Sócrates e da opinião dominante a respeito da classificação da justiça dentre os bens humanos. Para demarcar essa divergência, Gláucon apresenta três classes de bens (agathón) (357b-

${ }^{251}$ Sobre o caráter tradicional da definição de justiça das definições de justiça de Céfalo e Polemarco, ver ANNAS, 1981, p. 30; REEVE, 1988, p. 8-9. 
c): (1) os bens que buscamos "por si mesmos (autò autô̂)", sem levar em conta suas consequências, como, por exemplo, a "alegria (tò chaírein)" e os prazeres inofensivos ${ }^{252}$ (357b); (2) os bens que desejamos "por si mesmos e por suas consequências (autó autô̂ kaì tôn ap'autoû gignoménon)", como a visão, a saúde e "sensatez (tò phroneîn)" (357c); (3) os bens buscados exclusivamente "em vista das consequências (gígnetai ap'autôn)", como ginástica, tratamento médico na doença e diversas "práticas lucrativas (chreamatismós)" (357c). Nessa última classe, estão incluídas coisas boas que são "penosas, mas nos beneficiam (opheleîn hemâs)" por suas consequências.

Diante das três classes de bens, Sócrates e Gláucon apresentam diferentes classificações do bem da justiça. De um lado, Sócrates afirma que a justiça pertence à classe (2) sendo boa por si mesma e em vista da eudaímonia, a classe "mais bela (en tôi kallístoi)". Em seguida, Glaucon alerta que o 'parecer da maioria' (dokề en tô̂s pollô̂s) inclui a justiça dentro da classe (3) de bens. Para a maioria, a justiça é um bem difícil em si mesmo, mas compensatória pelos efeitos futuros, como a promoção do "bom nome (eudokiméseon)" e de vantagens financeiras "em vista da reputação (dià dóxan)" (358a). Na sequência, o Desafio da Justiça é formulado para expor a visão da opinião dominante e exortar Sócrates à defesa da justiça nos termos da classe (1).

O Desafio da Justiça é composto por quatro longas objeções dos irmãos Gláucon e Adimanto à justiça e à vida justa. A partir do Desafio, ambos os irmãos expressam a visão da opinião dominante e exortam Sócrates a apresentar uma defesa mais definitiva da justiça. As primeiras três objeções principais são de Gláucon, mas Adimanto inclui uma objeção adicional a fim de "deixar mais claro o que Gláucon parece querer dizer" $(363 \mathrm{e})^{253}$. Em linhas gerais, cada uma das objeções se apoia sobre uma tese fundamental, na seguinte sequência: 1) a origem e a natureza da justiça segundo a distinção grega clássica de phýsis x nómos (natureza x convenção) (358e-359b); 2) "ninguém é justo de bom grado (oudeìs hekòn díkaios)", apenas "por necessidade, mas não como algo bom” (360d),

\footnotetext{
${ }^{252}$ Ver também Rep IX, 584b-c. Dentro dessa classe de bens, poderíamos incluir ainda os prazeres do olfato que não são antecedidos de dor e nem mesmo proporcionam dor futura.

${ }^{253}$ Por vezes, os comentadores costumam isolar a objeção de Adimanto como uma objeção acessória e dispensável ao Desafio da Justiça apresentado nas 3 objeções fundamentais de Gláucon à justiça. No entanto, acreditamos que a objeção de Adimanto cumpre um papel importante no plano do Desafio da Justiça pois fundamenta as objeções contrafactuais de Glaucon nas crenças tradicionais da opinião domminante além de reforçar o Desafio da Justiça como um todo.
} 
levando em conta o paradigma do conto do anel de Giges e a possibilidade de impunidade perpétua (359b-d); 3) a vida do mais injusto é muito mais feliz do que a vida do mais justo (360e-361d), tendo-se em vista a comparação das vidas do 'perfeito justo' e do 'perfeito injusto'; 4) a objeção de Adimanto invoca "argumentos (lógon)" da justiça e da injustiça de "leigos e poetas (idíai kaì poietôn)", a fim de reforçar as objeções de Gláucon nas crenças convencionais da sociedade ateniense (362e-367e).

Devido ao presente escopo da investigação, analisaremos apenas as implicações psicológicas do Desafio da Justiça. Sobretudo, devemos nos concentrar sobre a tese da existência de um desejo humano natural da injustiça exposta na segunda objeção de Gláucon. Com isso, pretendemos indicar que a teoria tripartite da alma da República configura uma resposta fundamental à redução da natureza humana à inclinação natural da injustiça. Particularmente, é preciso analisar as implicações da teoria simplificada da natureza humana sobre o problema comparativo fundamental das vidas do 'perfeito justo' e do 'perfeito injusto' na terceira objeção. Em vista disso, prosseguiremos diretamente à segunda objeção de Gláucon derivada da inclusão da justiça no grupo das convenções humanas.

A partir da clássica distinção entre nómos ('leis', 'costumes humanos') e phýsis (natureza), Gláucon alega que a justiça advém das convenções humanas, por coação externa e contra os impulsos humanos naturais. Para ilustrar seu argumento, Gláucon recorre ao conto paradigmático do anel de invisibilidade de Giges. Segundo a narrativa, o anel mágico da invisibilidade permitiu ao humilde pastor Giges organizar um complô contra seu superior, o rei da Lídia, e ainda seduzir sua esposa e até mesmo usurpar o seu trono (359d-360b). A história do anel de Giges ilustra a inclinação do homem à injustiça diante da liberdade da repreensão social e do temor da punição de suas injustiças.

Diante do conto do anel, Gláucon sustenta que o mesmo fenômeno acometeria o homem justo e o injusto. Assim como Giges, o justo e o injusto cometeriam as mesmas injustiças diante da impunidade perpétua: confiscariam a propriedade alheia, invadiriam casas, violentariam, matariam e libertariam quem quisessem em seu alcance (360b-c). De acordo com Gláucon, concedendo a “permissão de fazer o que quiser (exousían hekatéroi poieîn hoti án boúletai)” a ambos os homens e observando por onde o "desejo (epithymía) lhes conduzirá (áxei)", constataremos o mesmo resultado: 
Apanhá-lo-emos, ao justo, a caminhar para a mesma meta que o injusto devido a ganância, coisa que toda natureza está disposta a buscar como um bem (dià tèn pleonexían ho pâsa phýsis diókein péphyken hos agathón); mas, por convenção, é forçada (nómoi dè bíai) a respeitar a igualdade. (359c)

Desse modo, o justo e o injusto caminham para 'a mesma meta' justamente porque são constituídos da mesma natureza humana. Ambos seguem o impulso fundamental da pleonexía, isto é, o desejo simples de 'sempre querer ter cada vez mais'. A pleonexía abrange invariavelmente a aspiração de 'levar vantagem' sobre os outros ou 'tomando' o que é alheio, sejam dinheiro, propriedade, etc ${ }^{254}$. Com base na distinção de phýsis e nómos, a pleonexía se insere no campo da phýsis humana enquanto o nómos nos exorta à justiça, em conformidade à equidade $\mathrm{e}$ igualdade (358e-359b). Nesses termos, Gláucon fornece um modelo simplificado da natureza pleonética humana ou, em outras palavras, o impulso natural humano em função da injustiça.

$\mathrm{O}$ argumento da pleonexía humana parte do princípio de que "ninguém é justo de bom grado. Uma nova dimensão é inserida então nas objeções anteriores contra a justiça: a perspectiva interna do agente. Segundo Gláucon, nenhum homem aspira efetivamente a ser justo porque todos possuem plena consciência de que a justiça "não é um bem por si, mas individualmente (hos ouk agathoû idíai óntos)": "todos os homens acreditam (oíetai) que lhes é muito mais proveitosa, individualmente (polù mâllon idíai), a injustiça do que a justiça."(360d). A natureza pleonética humana fundamenta ainda a tese forte do egoísmo psicológico segundo a qual todos os homens invariavelmente buscam a injustiça e evitam a justiça em seu próprio interesse mesmo em prejuízo dos outros ${ }^{255}$. Sendo assim, Gláucon procede de uma análise da justiça e injustiça segundo phýsis e nómos à uma tese psicológica mais forte da pleonexía humana em sua segunda objeção.

\footnotetext{
${ }^{254}$ Sobre a pleonexía, ver DOVER, 1994, p. 193: “Just as greed, aggression and fraud are all aspects of pleonexia, 'trying to get more', so an anxiety to avoid any imputation of plexonexia is a strong inducement to accept less than one's due.”. Segundo Muniz (2011, p.165-167), a aspiração humana à pleonexía é encarnada sobretudo na concepção da vida boa defendida pelo personagem Cálicles em termos da intensidade e o fluxo incessante de apetites e desejos no Górgias de Platão. De forma paradoxal, o ideal tirânico de Sócrates na altura de Rep. IX recorre ao mesmo ideal de pleonexia em referência à sua inerente condição de escravidão por seus desejos.

${ }^{255}$ Com efeito, seguimos algumas considerações sobre o egoísmo de Cálicles no Górgias sugeridas em RUDEBUSCH, 1999b, p. 155-156.
} 
A terceira objeção de Gláucon traça uma comparação das vidas do mais justo e do mais injusto, a partir das imagens do 'perfeito justo' (téleos díkaion) e do 'perfeito injusto' (téleos ádikon). Em linhas gerais, o argumento visa comprovar que a vida do mais injusto é melhor do que a vida do mais justo em termos de felicidade (eudaímania) (361d-362c).

A construção teórica do 'perfeito justo' e o 'perfeito injusto' é fundamental na formulação da terceira objeção. Para Gláucon, o 'perfeito injusto' e o 'perfeito justo' seguem tipos de vida antitéticas: “suponhamos que cada um deles é perfeito (téleon) em sua maneira de viver" (360e). A partir disso, ele sugere a troca da 'aparência' $(\text { dóxa })^{256}$, ou seja, a 'reputação' de ambos: o justo ficaria com a reputação do injusto enquanto o justo ficaria com a reputação do injusto. De um lado, o 'perfeito injusto' buscando viver em função da 'realidade' da injustiça e não de sua dóxa "não quer parecer injusto, mas sê-lo (ou dokeîn ádikon all'eînai ethélein)” (362a). O 'perfeito injusto' concretiza o ideal de injustiça do anel de Giges: “como os artífices habilidosos (hósper hoi deinoì demiourgoì)", é capaz de realizar as injustiças sem ser notado, angariando a "maior reputação para a justiça (tèn megísten dóxan eis dikaiosýnen)" (361b). De outro lado, o 'perfeito justo' terá de sofrer injustiças e “compreenderá que se deve querer, não ser justo, mas parecêlo (ouk eînai díkaion allà dokeîn dề ethélei)" (362a). Ao invés das honrarias (timaî) e dádivas (doreaî), o 'perfeito justo’ deve possuir a “reputação da máxima injustiça (dóxan tèn megísten adikías)" (361c). Em vista de ambos os modelos de justiça e injustiça, o contraste do 'perfeito justo' e o 'perfeito injusto' fornece os parâmetros do Desafio da Justiça.

O Desafio da Justiça, exposto nas três objeções de Gláucon, é reforçado com a objeção adicional de Adimanto em vista das crenças tradicionais da justiça. Em seu conjunto, as objeções de Gláucon oferecem razões suficientes para a escolha da injustiça, mas seus argumentos são contrafactuais, isto é, correspondem às condições ideias favoráveis à vida injusta embora não expressam as convicções

\footnotetext{
${ }^{256}$ Em geral, o termo dóxa se refere a aparência visível, mas também à reputação conferida pelos outros, de forma indistinguível, portanto, da opinião dominante. Em especial, é importante salientar também a relevância da dóxa ou, mais especificamente, da éndoxa dentro do método habitual de investigação aristotélico na Ética a Nicômaco. No entanto, se Aristóteles busca explicar os phainómena analisando suas contradições e visando esclarecer sua consistência, Platão costuma adotar o método oposto, colocando os phainómena e a opinião dominante sob suspeita. Para a incompatibilidade dos métodos filosóficos de Platão e Aristóteles, ver NUSSBAUM, 1986, cap. 5.
} 
factuais da sociedade ateniense sobre a vida injusta ${ }^{257}$. A objeção adicional de Adimanto revela de que modo as objeções de Glaucon são compatíveis com as convenções sociais da maioria. Com isso, Adimanto acaba reforçando as teses fundamentais em nome da maioria expostas nas objeções de Glaucon. De qualquer forma, ambos salientam novamente a pleonexia natural na figura do 'perfeito injusto'.

Anteriormente, Glaucon já havia salientado as habilidades impressionantes do 'perfeito injusto'. O 'perfeito injusto' consegue enriquecer, favorecer amigos, prejudicar inimigos e até agraciar os deuses com 'votos magníficos' porque pode "prevalecer e levar vantagem (pleonekteîn) sobre os adversários" (362b-c). Na sequência, Adimanto reforça esse mesmo ideal de injustiça "seguindo os passos dos argumentos (tôn lógon phérei)". Para Adimanto, cometer injustiças sem ser percebido é suficiente para alcançar a eudaímonia, porque a persuasão ou o poder contra os outros nos exime das punições futuras "de tal maneira que levaremos vantagem sem termos de pagar pena (hos pleonektoûntes díken mè didónai)" (365d). De um lado, o 'perfeito injusto', satisfaz plenamente sua pleonexía preservando a dóxa de justiça e alcançando a felicidade máxima. De outro lado, o 'perfeito justo' é frustrado e prejudicado constantemente em suas aspirações, mantendo a dóxa de injustiça e sendo extremamente infeliz. Assim, a defesa da justiça exige a eliminação absoluta da dóxa da opinião dominante.

Ambos os irmãos Gláucon e Adimanto reforçam as teses defendidas pelo sofista no livro anterior. Desde o início, Gláucon anuncia que está retomando o argumento (lógon) de Trasímaco (358b-c). Na sequência, Adimanto alerta que Sócrates corre o risco de concordar com as teses de Trasímaco, se defender a aparência (tò dokeîn) da justiça ao invés de sua natureza real (367b-d). Nesses termos, ambos os irmãos salientam a figura do 'puro injusto', que mantém a reputação da justiça mesmo sendo injusto. Ao retomarmos brevemente a discussão final de Sócrates e Trasímaco de Rep. I, verificamos a origem da figura do 'perfeito injusto’ do Desafio da Justiça.

\footnotetext{
${ }^{257}$ Cf. IRWIN, 1995, p. 185: "In saying that we do just action unwillingly, Glaucon emphasizes the fact that we recognize that we must give up something attractive in order to do just action; to this extent it is similar to undergoing surgery and different from some other instrumentally good action (...) Glaucon is right to say that such a view requires us to agree that in the counterfactual conditions he describes we would have good reason to act unjustly." Para uma distinção mais rigorosa das consequências naturais e artificiais de justiça, ver ANNAS, 1981, p. 66-70.
} 
Durante a discussão final com Trasímaco em Rep. I, o sofista apresenta dois argumentos aparentemente incompatíveis em nome da mesma definição da justiça: 'a vantagem do mais forte'. No primeiro argumento, Trasímaco define a justiça como a "vantagem dos governos constituídos (tês kathestekuías archês symphéron)" (338e-339a). Nessa perspectiva, ‘o mais forte' designa quem detém o poder político e estabelece a 'justiça' de acordo com as leis e punições que lhe sejam convenientes. No segundo argumento, Trasímaco defende uma nova concepção da 'vantagem do mais forte': a "justiça e o justo são um bem alheio (allótrion agathòn)", que na realidade consiste na vantagem do mais forte e de quem governa" (343c). A partir disso, a justiça se aplica exclusivamente à obediência dos súditos, enquanto 'o mais forte' agora é o mais injusto, o único que “tem capacidade de ter grande ganância (tòn megála dynámenon pleonekteîn)" (344a). Em que pesem as diferenças entre essas duas posições, os argumentos de Trasímaco são claramente refletidos no Desafio da Justiça.

A divergência das posições de Trasímaco em Rep. I é amplamente reconhecida a ponto de parecem, inclusive, irreconciliáveis ${ }^{258}$. Em todo caso, o diálogo final com Trasímaco em Rep. I claramente resulta em um aporia sem uma definição positiva sobre "o que é a justiça (tò díkaion pot'estín)" (354b-c). Apesar disso, Gláucon expressa insatisfação com os argumentos de Sócrates contra a defesa da injustiça: "queres aparentar que nos persuadiste (..) de que de toda maneira (pantì trópoi) é melhor ser justo do que injusto?" (357a-b). De qualquer modo, a figura central refletida no ideal máximo de injustiça de Trasímaco, o tirano, corresponde ao 'perfeito injusto' do Desafio da Justiça.

O ideal máximo da 'injustiça' de Trasímaco, o tirano, adquire proeminência ao longo da República. Para Trasímaco, o mais injusto é capaz da mais "completa

\footnotetext{
${ }^{258}$ De acordo com os intérpretes, há divergência quanto aos dois argumentos principais apresentados por Trasímaco em sua definição de justiça; o primeiro argumento é classificado de convencionalismo, enquanto o segundo argumento é designado de imoralismo (cf. ANNAS, 1981, p. 42-46). Desconsiderando eventuais divergências, cremos que ele se refere em ambas as ocasiões à mesma tese fundamental: "a justiça é a vantagem do mais forte" (338c). Sobretudo, é importante lembrar da intervenção de Clitofonte em meio à primeira discussão sobre a 'vantagem do (governo) do mais forte' (340a-c). Assim como a segunda objeção de Gláucon, Clitofonte introduz a perspectiva interna do homem mais forte sobre a justiça a fim de esclarecer a inconsistência de duas teses aparentemente incongruentes de Trasímaco: a tese da 'vantagem do mais forte' e a possibilidade do erro do governante com a 'instituição de leis prejudiciais a si mesmo'. Apesar de Trasímaco aparentemente dispensar a observação com seu segundo argumento, a tese de que a justiça é um bem alheio abrange tanto a perspectiva interna dos súditos quanto a perspectiva interna do mais forte (cf. REEVE, 1988, p. 16-19; ANNAS, 1981, p. 46). O desafio de Glaucon reforça ainda mais o ponto de vista de Trasímaco sobre as vantagens da injustiça sobre a justiça.
} 
injustiça (tèn hólen adikían)”, isto é, de cometer injustiças sem ser notado, sendo considerado o mais feliz enquanto os súditos submetidos à justiça são os mais infelizes (344a-c; 348d). O tirano é eleito como ideal de injustiça, e o sofista afirma que "a injustiça quando é suficiente, é mais forte, mais livre, e mais despótica do que a justiça" (344c). No exame dos tipos de almas injustas de Sócrates em Rep. IX, no entanto, essa figura ideal do 'perfeito injusto' emerge como um ideal de extrema impotência e subjugação diante de seus apetites insaciáveis de injustiça (574a; 586a). Sob esse ângulo, a resposta ao Desafio da Justiça jamais perde de vista a figura do 'perfeito injusto' encarnada no tirano de Trasímaco ${ }^{259}$.

O Desafio da Justiça evoca claramente as teses de Trasímaco, e permite integrar Rep. I aos demais livros da República. Na realidade, o Desafio não deixa de refletir a típica busca da definição socrática: a defesa da justiça em si e por si mesma, independente da dóxa. Todavia, o problema da definição justiça não atende mais aos termos puramente epistemológicos dos primeiros diálogos, pois envolve uma investigação mais marcadamente psicológica.

Durante a formulação do Desafio da Justiça, Gláucon expressa claramente a dimensão psicológica da nova busca de definição 'pura' da justiça e da injustiça: “Desejo ouvir o que é cada uma delas (tí t'éstin hekáteron), e que potência possui por si (tína échei dýnamin autò kath'autò), quando existe na alma (en têi psychêi), sem ligar importância a salários nem a consequências" (358b).

A defesa definitiva da justiça significa propriamente, a inclusão da justiça interna na classe (1) de bens por si mesmos contra sua classificação na classe (3) de bens pelas consequências. Por isso, Gláucon salienta os parâmetros da definição da justiça e da injustiça 'pura': (a) o que cada uma "realmente é (t'estin)"; (b) qual é a potência (dýnamis) de cada uma "na alma (en têi psychêi)", excluindo "recompensas e suas consequências (tà gignómena ap'autôn)" (358b). O Desafio da Justiça, portanto, elimina as consequências da justiça, de onde provém seu valor extrínseco, e determina a avaliação objetiva de seu valor real intrínseco. Nesse sentido, Adimanto também salienta o isolamento da aparência e da realidade da justiça e da injustiça: "não diremos que exaltas a justiça, mas a reputação (tò dokeîn), nem que censuras a injustiça, mas a reputação (tò dokeîn)” (367b-c). Em

\footnotetext{
259 As sucessivas referências a Trasímaco dispersas por toda a República apenas comprovam reiteradamente o reflexo da sua defesa da injustiça sobre o Desafio da Justiça. (cf. 358b, 367a; 450ab; 590d)
} 
última instância, os termos da defesa da justiça interna na República refletem a busca da definição da virtude típica dos primeiros diálogos socráticos, como o Protágoras.

O Desafio da Justiça na República e o problema da natureza da virtude no Protágoras ilustram os aspectos comuns e divergentes das diferentes 'fases' dos Diálogos. Sob esse ângulo, o Desafio da Justiça claramente reflete elementos importantes da busca de definição da virtude derivada do elenchus socrático. Ao mesmo tempo, a República introduz novos parâmetros psicológicos para a definição da justiça que extrapolam o exame epistemológico da virtude presente no Protágoras. Sobretudo, esses elementos contextuais esclarecem o papel da psicologia moral e do problema da akrasia dentro de cada um desses diálogos.

A seguir, salientaremos apenas alguns elementos de ambos os diálogos que comprovam a unidade complexa dos Diálogos.

Em primeiro lugar, o Desafio da Justiça envolve um problema primordial de definição 'pura' da justiça assim como o problema da natureza da virtude do Protágoras. Nesses termos, o problema definicional da República reproduz importantes elementos do elenchus socrático: (1) no Desafio da Justiça, o problema da definição é formulado em termos ontológicos: 'o que é realmente' (t'estín) a justiça e a injustiça 'puras' (358a-d), enquanto o problema da definição da virtude do Protágoras se exprime em termos semelhantes (329c-330b); (2) o Desafio da Justiça sucede a aporia das definições insatisfatórias da justiça ao fim de Rep. I (354a-c) e as definições malsucedidas da natureza da virtude do sofista levam a uma aporia no ato final do Protágoras (361c-d). Nesse contexto, notamos particularmente as semelhanças de ambos os diálogos no nível interdialógico. No entanto, as diferenças mais significativas surgem no nível interno dialógico nos critérios epistemológicos diversificados do Protágoras e da República.

Em segundo lugar, os critérios epistemológicos divergentes da busca da definição de Protágoras e da República delimitam o novo enfoque de Platão sobre a psicologia moral e o fenômeno da akrasia. No Protágoras, o problema da natureza da virtude resulta em um problema epistemológico de conhecimento: contra a pluralidade tradicional das virtudes não-cognitivas do sofista, Sócrates exorta a unidade necessária da virtude e conhecimento através do elenchus. Dentro desse contexto, o problema da akrasia leva às últimas consequências a natureza não cognitiva da virtude e a força dos impulsos irracionais na alma. Em contraposição, 
o Desafio da Justiça de República incorre em um exame interno psicológico da natureza da justiça: a definição 'pura' da justiça e da injustiça na alma independentemente de sua aparência (dóxa). Sob esse ângulo, o exame da justiça interna resulta em um exame da própria natureza complexa da alma tripartite e do conflito interno da alma. Dessa forma, as diferentes abordagens sobre a akrasia são claramente explicadas pelos critérios epistemológicos no nível interno dialógico.

Dessa forma, observamos elementos de continuidade e descontinuidade no Protágoras e na República. No entanto, o elemento central de descontinuidade do exame socrático da República aparece de forma mais decisiva na controversa analogia cidade-alma. Dessa forma, analisaremos em seguida a formulação da analogia cidade-alma diante do Desafio da Justiça de Glaúcon e Adimanto.

A analogia cidade-alma surge especialmente para dar conta das exigências do Desafio da Justiça. Em vista disso, é preciso contemplar dois problemas do Desafio da Justiça: 1) a natureza da justiça e da injustiça, e seu valor intrínseco na alma humana, independente dos valores extrínsecos da 'aparência' (dóxa); 2) examinar quem é mais feliz (eudaímon), o (perfeito) justo ou o (perfeito) injusto. A elaboração estratégica da analogia visa dar conta da complexidade do Desafio da Justiça.

Diante do complexo Desafio da Justiça, a analogia cidade-alma de Sócrates oferece uma resolução viável aos problemas anteriores. Em uma primeira resposta, Sócrates recorre à formação de uma Cidade Ideal e estabelece uma teoria tripartite da alma humana contra a simples pleonexía natural de Gláucon em Rep. IV. Na segunda resposta, a analogia cidade-alma e a psicologia tripartite são intrinsecamente conectadas na exposição final das três provas (apódeixis) decisivas de que o mais justo é mais feliz que o mais injusto em Rep. IX. Dessa forma, a analogia integra uma extensa estratégia argumentativa em resposta ao Desafio da Justiça. Em ambos os contextos argumentativos, a analogia cidade-alma está intrinsecamente ligada a um exame amplo da natureza da alma ou, em termos modernos, uma psicologia moral. Dessa forma, devemos salientar a formulação problemática da analogia e delimitar sua função primordial dentro do exame da psicologia moral da República.

Em toda a extensão de Rep. II-X, a analogia revela ser uma estratégia argumentativa claramente multifuncional. À primeira vista, a analogia cidade-alma parece ter implicações claramente políticas. Entretanto, a sua formulação original 
na República expõe seu amplo alcance diante do complexo Desafio da Justiça. Em geral, podemos destacar ao menos algumas funções diretas da analogia cidadealma: (1) a apresentação de um paradigma da Cidade Ideal onde encontraríamos a 'justiça' pura (472c-d); (2) a bi-implicação psicológica-política, a promissora analogia intercambiável da política à psicologia moral e inversamente da psicologia moral ao campo político; (3) a tipologia de caracteres morais e diferentes modos de vida; (4) o paradigma da teoria tripartite da alma encarnada ${ }^{260}$.

O princípio da analogia da cidade-alma é filosoficamente ambicioso, e a integração de suas diferentes funções é objeto de extensa divergência interpretativa. Ao mesmo tempo, não se pode tratar da teoria tripartite da alma sem antes abordar seu papel no plano da analogia cidade-alma em resposta ao Desafio da Justiça. Desse modo, devemos nos voltar para a emergência da analogia com a Cidade Ideal e suas implicações controversas sobre a psicologia moral da República.

A analogia cidade-alma surge com o simples propósito preliminar de estabelecer uma correspondência da justiça e da injustiça no nível da cidade e no nível individual da alma. Na falta de "acuidade de visão (oxù blépontos)", Sócrates apresenta um método adequado a "pessoas de vista fraca", tal como se apresentam as mesmas letras em dimensão maior para lhes vermos melhor do que quando as enxergávamos em tamanho menor (368c-d). Se a justiça está no indivíduo assim como está em "toda a cidade (hóles póleos)", podemos verificar "como ela é (poîón tí estin) nas cidades", no nível global, e nos voltarmos depois ao nível individual "observando a semelhança (homoióteta) com o maior na forma (idéai) ${ }^{261}$ do menor" (368e-369a). Apesar da convicção inicial de Sócrates no poder da analogia, a estratégia argumentativa aparentemente simples toma amplas proporções ao longo dos argumentos socráticos da República.

A amplitude da aplicação da analogia na resposta ao Desafio da Justiça gera uma extensa controversa interpretativa. A princípio, devemos evidenciar a polêmica interpretativa derivada dos dois princípios divergentes da analogia apresentados no clássico artigo The Analogy of City and Soul in Plato's Republic, de Bernard Williams. Em seguida, iremos indicar como esses dois princípios divergentes da

\footnotetext{
${ }^{260}$ Como indicamos anteriormente em Rep. X, a teoria tripartite da alma se restringe apenas à alma encarnada pois a alma em si mesma, em sua essência desencarnada, é simples e indivisa.

${ }^{261}$ Assim como ê̂dos, o termo idéa nessa passagem não tem o sentido clássico da Forma inteligível platônica. A clássica teoria da Formas é formulada explicitamente apenas em Rep. VI-VII.
} 
analogia contribuem para fornecer as duas respostas de Sócrates ao Desafio da Justiça. Dessa forma, pretendemos indicar qual o papel da analogia dentro da incursão psicológica da alma da República.

Williams (1999, p. 256-259) revela que a analogia cidade-indivíduo reflete uma "tensão incontornável” (“ineliminable tension”) de regras incompatíveis de analogia. Para Williams, essas duas regras se complementam ao longo do diálogo por conta do caráter intercambiável do princípio analógico da cidade-alma: a regra de parte-todo e a regra da seção predominante. De acordo com a regra parte-todo, a propriedade $F$ existe em uma cidade se, e somente se, seus cidadãos também são $F$. Pela regra da seção predominante, o princípio da analogia seria outro: a propriedade $F$ está na cidade se, e somente se, a classe predominante de seus cidadãos também é $F$. Com efeito, diferentes correntes interpretativas tem favorecido a primeira ou a segunda aplicação desses princípios analógicos atentos ao próprio texto da República. Em vista disso, cabe averiguarmos a formulação desses princípios e a tensão essencial inerente da analogia a partir da República.

Em 434d-435e, a analogia da Cidade Ideal é aplicada novamente ao indivíduo em termos que reforçam a regra parte-todo de Rep. II. A essa altura, Sócrates acredita encontrar na alma as mesmas características que vislumbramos na cidade Ideal:

entenderemos que o indivíduo, que tiver na alma estas mesmas qualidades (tà autà taûta eíde en têi autô̂ psychêi échonta), merece bem, devido a essas mesmas disposições (dià tà autà páthe), ser tratado pelos mesmos nomes que a cidade. (435b)

Nessa passagem, observamos claramente a correspondência entre as qualidades (eíde) e as disposições (pathe) da alma e da cidade. Como salienta Sócrates, "não é absolutamente forçoso que concordemos que em cada um de nós há as mesmas formas (eíde) e caracteres (éthe) que na cidade?" (435e). A regra contempla a analogia em termos de correspondência de propriedade, em vista da semelhança (hómoios): a cidade e a alma exibem o mesmo eídos e, por isso, possuem também um logos comum. Com efeito, essa leitura da analogia é adotada pela corrente interpretativa que enxerga na analogia um mero reflexo dos argumentos políticos sobre a composição tripartite da alma, levando em conta a 
correspondência entre as três classes da Cidade e as três partes da alma ${ }^{262}$. Em todo caso, Williams (1999, p. 256) salienta que a simples regra parte-todo leva a analogia à circularidade, caso se trate de um mero reflexo da propriedade $F$ na cidade e na alma individual. Em última instância, isso tornaria ambos os lados da analogia inexplicáveis, além de resultar em incongruências como a extensão da 'grandeza' da cidade aos seus próprios cidadãos. Seguramente, a regra parte-todo serve para refletir o paradigma da Cidade Ideal na alma ${ }^{263}$. Contudo, o exame dos regimes políticos e caracteres morais degenerados de Rep. VIII-IX envolve uma nova aplicação da analogia.

Em 544c-545a, Sócrates explora uma nova aplicação da analogia, dessa vez tendo em vista os regimes e caracteres morais degenerados. Na sequência, ele estabelece uma relação entre os 'regimes' ou "constituições (politeías)" e os “caracteres (éthon)" dos cidadãos:

Sabes então que é forçoso que haja tantas espécies de caracteres de homens (anthrópon eíde) como de tipos de regime (politeiôn)? Ou julgas que elas nasceram do carvalho e da rocha, e não dos caracteres dos cidadãos (ek tôn éthôn tôn en taîs pólesin) (...)? (544d-e)

Dessa forma, observamos aqui a relação intrínseca da classe predominante no regime (politeía) com os caracteres (éthon) dos cidadãos. A analogia retoma, então, o princípio do governo do 'mais forte' da primeira posição de Trasímaco com o objetivo de esclarecer as relações de poder típicas dos regimes políticos degenerados. O princípio abrange dois lados de relação de predomínio: a cidade é $F$ se a classe predominante é $F$, tal como a alma é $F$ se a parte dominante da alma também é $F$. De uma forma ou de outra, há uma incompatibilidade irreflexiva entre

\footnotetext{
${ }^{262}$ Para uma abordagem estritamente política da analogia, ver CHARLTON, 1988, p. 27; GOSLING, 1990, p. 20-23; WATSON, 1977, p. 319-320.

${ }^{263}$ Constatando as incongruências dessa regra parte-todo reflexiva, Smith (2001) alega que a analogia constitui apenas uma ferramenta necessária para indicar o que é efetivamente a justiça e a injustiça na alma. Para Smith (Ibid., p. 129), a teoria tripartite seria descartável na defesa da justiça: "In carefully distancing himself in this way from his earlier partitioning arguments, Plato's Socrates shows that we should not understand those earlier arguments as being in any way decisive as to how we are to conceive of "Plato's theory of the soul", if he has such a theory. Instead, we should remind ourselves what the purpose of the earlier arguments was: to try to discern the aspect of justice in a soul. (...)." Apesar da coerência da Defesa da Justiça com a teoria das Formas na República, Smith deixa de considerar dois aspectos importantes: (a) a defesa da justiça só é efetivamente concluída em Rep. IX quando Sócrates apresenta as três provas da superioridade da vida justa sobre a vida injusta; (b) a segunda prova, em especial, faz explícita referência à alma tripartite e o desenvolvimento posterior da psicologia presente em Rep. VIII-IX.
} 
as relações de poder 'estar sob domínio de' e 'ser governado por': o domínio da classe $x$ na cidade não pode ser explicada nos mesmos termos da condição da classe $x$ 'sendo governada' por outra classe $y^{264}$. O problema central envolve o paradoxo de abordar a psicologia em termos políticos e a política, por sua vez, em termos psicológicos.

As divergências entre o princípio parte-todo e o princípio da seção predominante são notáveis: 1) no plano global, a analogia envolve tanto a 'cidade como um todo' quanto a classe governante; 2) no plano individual, a analogia se aplica à alma individual e posteriormente se volta aos tipos de caráter moral ou, melhor, aos modos de vida dos cidadãos. Diante disso, Williams (1999, p. 260) constata o colapso dos dois princípios da analogia:

(...) Plato seems disposed to confound two very different things: a state in which there are various characters among the people, and a state in which most of the people have a various character, that is to say, a very shifting and unsteady character. (itálicos de minha autoria)

A análise de Williams é extremamente pertinente evidenciado diversos problemas da analogia cidade-alma. Ao mesmo tempo, a analogia é indispensável a todos os argumentos em resposta ao Desafio da Justiça, principalmente em referência à psicologia tripartite. No entanto, Williams parece ignorar outro aspecto fundamental da analogia cidade-alma.

A partir da regra parte-todo, uma outra corrente interpretativa alega que o princípio cidade-alma não é uma analogia, mas um isomorfismo: a correspondência causal entre a composição da cidade e a constituição da alma $^{265}$. Em Inside and Outside the Republic, Lear (2001) salienta o papel intercambiável da internalização

\footnotetext{
${ }^{264}$ Para o caráter irreflexivo da regra da predominância, ver WILLIAMS, p. 260-262. Em especial, Williams se preocupa com a condição da classe de artífices dominada pelos apetites. Seguindo a reflexão platônica, teríamos duas histórias incompatíveis: na primeira história, uma classe harmônica dos artífices se submete de bom grado ao domínio da classe superior racional, enquanto na segunda história uma classe violenta de artífices precisa ser reprimida e levada pela força à obediência da classe racional. Para objeções similares, ver ANNAS, 1981, p. 116-117 e IRWIN, 1995, p.229-230. Em especial, Irwin enfatiza as implicações problemáticas na educação avançada dos filósofos mencionada apenas em Rep. VII 520a-c.

${ }^{265}$ Por exemplo, Moline (1978, p. 6) adota a regra da seção predominante denominando 'governo' (rule) como o princípio causal da pólis e da psyché: "Talk of "rule" is plainly causal and explanatory in force, and given the isomorphism of polis and psyche that Plato posits and requires for his arguments, we are to take it as straightforward, not metaphorical." Para uma abordagem similar do suposto isomorfismo platônico, ver também LEAR, 2001, p. 186-187; GILL, 1996, ch. 4.
} 
e a externalização na dinâmica psico-política da relação da cidade-alma. Enquanto a internalização significa a introjeção de referências culturais exteriores na formação cultural da alma (educação, poesia, a música, etc.), a externalização significa o processo inverso, ou seja, a transmissão dos valores morais da alma de volta à comunidade da cidade. Ambos os processos integram a complexa relação dinâmica e intercambiável da cidade-alma e não podem ser isoladas entre si (Ibid., p. 176).

Com efeito, Williams deixa de analisar o importante papel das influências externas na formação moral da alma. Nesse sentido, é imprescindível retomar o papel crucial da formação educacional dentro da psicologia moral da República ${ }^{266}$. No entanto, o princípio do isomorfismo não abrange propriamente a complexidade da analogia cidade-alma. Em sentido estrito, o isomorfismo não se aplica ao princípio da seção predominante no exame posterior dos regimes e caracteres morais degenerados. Devemos levar em conta o funcionamento da analogia com base na psicologia moral e no contexto amplo da resposta de Sócrates ao Desafio da Justiça na República.

A analogia cidade-alma envolve dois modelos opostos da psicologia moral na República: em primeiro lugar, a analogia isomórfica da Cidade Ideal e a alma individual justa em Rep. IV; em segundo, a analogia do predomínio dos regimes e os caracteres das almas injustas de Rep. VIII-IX. Em ambos os contextos, o exame da natureza da alma fornece as respostas fundamentais ao Desafio da Justiça.

Sendo assim, precisaremos traçar um esboço geral de ambos os contextos argumentativos a fim de esclarecer o amplo alcance da analogia cidade-alma. Dessa forma, devemos nos voltar à primeira resposta de Sócrates com base na fundação da Cidade Ideal em Rep. II.

A fundação da Cidade Ideal surge do esforço socrático em encontrar uma resposta à altura do Desafio da Justiça. Desde sua origem, a fundação da Cidade Ideal envolve a satisfação dos desejos humanos básicos: as necessidades de

\footnotetext{
${ }^{266}$ Cf. LEAR, 2001, p. 181: "However, once we recognize internalization and externalization as basic psychological activities, we can see that the psychic parts can be shaped, and thus that the conditions under which we first identify them need not be the conditions under which they operate. (...). And once we see that psychic parts need not always be functioning in the conflictual ways in which they are first identified, we can then grant culture a greater role in psychic formation than would otherwise be thought possible." Da mesma forma, Schofield (2006, p. 271-275) indica que o cuidado com a educação e a cultura promove uma organização social bem diferente daquela sugerida por Williams: em vez de completa submissão da classe produtiva aos seus apetites, o que encontramos é uma obediência harmônica possibilitada pelo fator educativo.
} 
alimentação, vestuário, reprodução e dinheiro (369 b-c). A partir disso, Sócrates inaugura a construção teórica da Cidade Ideal: "Fundemos em palavras (tôi lógoi $)^{267}$ uma cidade desde o início" (369c). Nessa cidade inaugural, fica clara a necessidade de estabelecer um princípio de especialização diante da "diversidade da natureza humana (diaphéron tèn phýsin)": "cada um para a execução de sua tarefa (érgou prâxin)" (370a). No entanto, essa primeira cidade logo se comprova insuficiente para atender aos desejos humanos mais sofisticados.

Em um segundo momento, Sócrates precisa construir uma segunda cidade, uma "cidade inflamada (phlegmaínousan pólin)". Nessa cidade maior e mais populosa, serão necessários outros artífices, como artistas miméticos ${ }^{268}$, educadores, poetas, cozinheiros e cabelereiros (372e-373c). Na realidade, essa segunda "cidade de luxo (truphôsan pólin)" procede de um protesto de Gláucon contra a primeira cidade, classificada então como "cidade de porcos" $(372 \mathrm{c}-\mathrm{e})^{269}$. De qualquer modo, Sócrates julga que será mais adequado buscar a justiça e a injustiça nessa segunda cidade. A essa altura, a Cidade Ideal promoverá guerras e conflitos com a necessidade de formar um novo exército (373e-374a). A partir daqui, Sócrates se empenhará na formação educacional da nova classe de guardiões (tôn phylákon) (374e), abrindo o caminho para a conclusão do empreendimento da Cidade Ideal e a formulação da primeira resposta ao Desafio da Justiça.

\footnotetext{
${ }^{267}$ Em diversas ocasiões, Sócrates se refere explicitamente à criação da Cidade Ideal nos termos de uma fundação 'em discurso' ou 'em palavras' (têi en lógois) (cf. 473a-b; 501e; 592a-b). Com efeito, o termo lógos aqui é de difícil tradução e admite diversas hipóteses interpretativas. Contudo, devemos alertar aqui que não há definitivamente nenhum comprometimento com um projeto político sistemático em curso na fundação teórica da Cidade Ideal, como a República tem sido tradicionalmente compreendida dentro da filosofia política. Por diversos momentos, Sócrates expressa algum ceticismo acerca da implementação concreta da Cidade Ideal na realidade. Dessa forma, devemos adotar a mesma cautela ao tratar das propostas políticas voltadas para a Cidade Ideal. Como veremos, a Cidade Ideal serve especialmente como um paradigma designado a compreender a natureza adequada da justiça e injustiça.

${ }^{268}$ A classe denominada atualmente de 'artistas' estava incluída dentro do grupo abrangente dos produtores ou artífices na Grécia clássica do séc. V. Ao longo da República, acompanhamos o esforço platônico em isolar o metier típico dos 'artistas' dos outros artífices em vista de sua 'técnica' da mímesis (termo grego de difícil tradução, normalmente associado à 'imitação' ou, em outras palavras, à 'representação'). Sobretudo, a função dessa especificação particular é, como em outros diálogos platônicos, apresentar uma crítica contundente ao que classificamos atualmente como arte. ${ }^{269}$ Para Gláucon, falta à primeira cidade o costume (nomízetai) que abrange uma série de desejos mais sofisticados. Na prática, a intervenção de Gláucon implica no reconhecimento da inclinação humana ao excesso, além das necessidades básicas imediatas: "desejo da posse ilimitada de riquezas, ultrapassando a fronteira do necessário (tòn tôn anankaíon hóron)" (373d). Ao que tudo indica, a observação de Gláucon tem raízes na tendência humana à pleonexía, ou seja, o desejo de possuir cada vez mais.
} 
Ao longo de Rep. II-III, Sócrates descreve a rigorosa 'formação educacional' (paideía) dos guardiões, levando em conta a necessidade da 'ginástica' (gymnastiké) ao corpo e as 'artes da Musas' (mousiké) 270 à alma (376bd). Dentro desse escopo, a formação educacional permite a realização de uma nova purificação da Cidade Ideal: "purificamos (diakathaírontes) de novo a cidade que há pouco dizíamos estar luxuosa (truphân)" (399e). A Cidade Ideal fica expurgada dos desejos excessivos que ameaçavam sua fundação ideal perfeita e justa ${ }^{271}$. Tendo concluído a formação educacional dos guardiões, Sócrates apresenta os retoques finais da Cidade Ideal em Rep. IV

Em Rep. IV, o projeto de fundação da Cidade Ideal é finalmente concluído com sua formação "perfeitamente boa (teléos agathèn ê̂nai)" (428a). A composição ideal apresenta três classes distintas: os "Artífices (demiourgố)" e uma divisão mais precisa entre os "Guardiões Perfeitos (phúlakas pantelê̂s)", responsáveis legítimos do governo da cidade ${ }^{272}$, e os "Auxiliares (epikoúrous)", orientados à guerra e aos empreendimentos militares (414b). Em vista dessa composição ideal, Sócrates pretende descobrir a definição 'pura' da justiça e da injustiça na Cidade Ideal.

A conclusão da fundação da Cidade Ideal promove o retorno à busca socrática da definição das virtudes, com vimos no Protágoras. No entanto, o exame clássico de definição da virtude toma novas proporções em Rep. IV. O exame das virtudes assume uma dimensão externa na Cidade Ideal e uma dimensão interna na alma individual ${ }^{273}$. Dentro dessa investigação, o objetivo final de Sócrates é distinguir a natureza interna da justiça e da injustiça na alma dentre as demais virtudes.

A definição das virtudes externas da Cidade Ideal se reflete na definição das virtudes internas da alma. Na Cidade Ideal, a classificação das virtudes externas acompanha a relação funcional das três classes: a sophia consiste na 'boa

\footnotetext{
${ }^{270}$ Cf. LIDDDEL-SCOTT, 1996. O termo mousiké é de difícil tradução, pois é normalmente confundido com o que designamos atualmente pelo termo mais restrito 'música'. No entanto, mousiké abrange não só a música no sentido estrito, pois a música era intrinsecamente acompanhada da poesia cantada e da dança dentro da tradição grega. Por conta disso, optamos por traduzir o termo em seu sentido mais literal 'artes das Musas', contendo uma ampla gama de estudos culturais que eram presididos pelas Musas e compõem a base 'curricular' da formação cultural ateniense.

${ }^{271}$ Cf. REEVE, 1988, p. 178-179.

${ }^{272}$ Posteriormente, esses guardiões perfeitos serão designados de filósofos-reis (473d-e; 503b).

${ }^{273}$ Para essa distinção entre a dimensão interna e externa da cidade-alma, sigo os termos técnicos 'internalização’ e ‘externalização' apresentados em LEAR, 2001, p. 169-176.
} 
deliberação' (eubolía) e conhecimento (epistéme) da classe dos guardiões (428d429a); a andreía é a resistência aos prazeres, temores e apetites dos auxiliares (430a-b); a sophrosýne é a 'concórdia' (homónoia) e a "harmonia natural (katà phýsin sumphonían)" entre os diversos cidadãos (432a-b). Ao transferir o exame das virtudes externas da Cidade ao exame das virtudes internas da alma, Sócrates incorre em um exame da natureza da alma.

O exame das virtudes internas depende da natureza tripartite da alma humana. Segundo a teoria tripartite, a alma é dividida em três partes principais, a parte apetitiva (epithymetikón), a parte impetuosa (thymoeidés) e a parte racional (logistikón) (435b-441c). Com efeito, deixaremos os detalhes dessa teoria tripartite da alma para a seção sobre a psicologia moral da República. Por ora, devemos apenas ressaltar aqui que a teoria tripartite da alma é essencial para o exame interno das virtudes na alma.

Assim como as virtudes externas dependem da composição da Cidade Ideal, a definição das virtudes internas prossegue da relação funcional das partes da alma: a sabedoria interna é o "governo (árchein)" da parte racional (442c); a coragem interna reflete a "preservação (diasózei)" das determinações da razão pela parte impetuosa sob penas e prazeres (442b-c); a temperança interna estabelece a amizade e a harmonia das partes inferiores em reconhecimento do domínio da razão (442cd). A partir do exame das virtudes externas e internas, Sócrates chega enfim à definição da justiça e injustiça.

A definição da justiça e a injustiça integra o objetivo final da investigação de Sócrates em Rep. IV. Assim como as outras virtudes, a definição da justiça e da injustiça se espelha na analogia cidade-alma.

$\mathrm{Na}$ esfera da Cidade Ideal, a justiça externa se refere simplesmente ao próprio princípio de especialização, orientando cada um à tarefa "adequada à sua natureza (phýsis pephykyîa)", enquanto a injustiça externa constitui justamente a incapacidade em preservar uma tarefa única, a polypragmosýne, isto é, a intromissão incessante em múltiplos afazeres ou negócios (prâgma) alheios ${ }^{274}$ (433a). Na esfera da alma individual, o princípio de especialização externo

\footnotetext{
${ }^{274}$ Cf. DOVER, 1994, p. 188: “Polypragmosyne, interferring in other people's business (e. g. Lys i 16; in Ar. Frogs 749 it is used by a slave of doing what a slave has no business to do) and preventing them from doing what they wish to do has something in common with litigiousness; it is associated in Lys. xxiv 24 with bold relish of enmities, and the verb polypragmonein is applied in Ar. Wealth 913 to the man who claims always to be ready to prosecute in the city's interests"
} 
representa "uma imagem da justiça (eidolón ti tês dikaiosýnes)" na alma (443c). De um lado, a justiça interna não concerne tanto às ações externas quanto às "atividades internas (perì tèn entós)" do homem, ou seja, a harmonia interna das três partes da alma em suas respectivas funções apropriadas refletindo "aquilo que é ele e o que lhe é próprio (perì heatón kaì tà heautoû) verdadeiramente" (443c-e). De outro lado, a injustiça interna constitui o "conflito (stásin) dos elementos da alma" e a intromissão das partes da alma em atividades que são alheias à sua natureza (444b). Em virtude da analogia, Sócrates estabelece a definição 'pura' da justiça e injustiça interna da alma em termos de natureza humana.

Em 444d, Sócrates estabelece a definição da justiça e injustiça internas com o objetivo de contemplar o problema da definição da justiça:

a justiça consiste em dispor, de acordo com a natureza, os elementos da alma (tà en têi psychêi katà phýsin), para dominarem ou serem dominados (krateîn te kaì krateîsthai) uns pelos outros, a injustiça, em, contra natureza (parà phýsin), governar ou ser governado (árchein te kaì árchesthai) um pelo outro. (444d)

Com isso, Sócrates define a justiça e a injustiça internas da alma como modelos fundamentais da virtude e do vício (444c-d). A justiça interna determina a própria condição da posse de todas as outras qualidades virtuosas "numa perfeita unidade, temperante e harmoniosa" (443e). Por sua vez, a injustiça interna reúne todos os outros estados de vício (kakía): "estas perturbações e desvios que resultam na injustiça, na intemperança, covardia, ignorância e, de modo geral, toda a maldade (pâsan kakían)" (444b). Invariavelmente, a justiça e a injustiça internas representam diferentes relações funcionais das partes da alma na psicologia moral da República. Sendo assim, Sócrates conclui a primeira resposta ao Desafio da Justiça.

O final de Rep. IV apresenta a primeira resposta de Sócrates ao Desafio da Justiça, mas também indica suas limitações inerentes. Com efeito, o próprio Gláucon admite que a vida do injusto seria intolerável, apenas tendo em vista a definição da injustiça interna: "quando o tumulto e a ruína afetarem a natureza do próprio princípio pelo qual vivemos" (445a-b). Mesmo assim, Sócrates insiste em prosseguir a uma investigação mais abrangente das quatros espécies de regimes 
políticos (politeíon) e de almas (psychês) injustas (445c-449a). Na sequência, esse exame é interrompido e só é retomado efetivamente apenas em Rep. VIII-IX.

Ao que tudo indica, o próprio texto da República fornece indicações suficientes de que a primeira resposta de Sócrates em Rep. IV não contempla a extensão do Desafio da Justiça. Há uma constatação relativamente unânime entre os comentadores platônicos a respeito da insuficiência e das inconsistências da resposta de Rep. IV ${ }^{275}$. Com efeito, essa posição é claramente compartilhada entre os interlocutores do diálogo. Dessa forma, o exame de Rep. VIII-IX revela claramente que Sócrates ainda pretende usar a analogia para fornecer uma segunda resposta mais eficaz ao Desafio da Justiça.

A analogia cidade-alma constitui a principal estratégia de reposta ao Desafio da Justiça. Essa estratégia engloba não só a fundação da Cidade Ideal, mas também o exame dos regimes e almas injustas de Rep. VIII-IX.

Em meio a isso, o exame dos interlocutores toma rumos inesperados em Rep. V-VII, abordando temas diversos como o papel comum das mulheres e crianças, a incursão na epistemologia e metafísica da Linha Dividida e a Teoria das Formas, e até mesmo a possibilidade de efetivação da Cidade Ideal. Em virtude de nosso foco central sobre a psicologia moral, não abordaremos esses tópicos. Mesmo durante essa aparente digressão do tema central, Sócrates não deixa de salientar o papel crucial da analogia para o Desafio da Justiça. Em Rep. V, Sócrates salienta que a analogia consiste em um "paradigma (paradeígma)" da natureza da justiça e da oposição entre o 'perfeito' justo e o 'perfeito' injusto (472c-d). Sob esse ângulo, a analogia dos regimes e almas injustas permite a Sócrates encontrar uma resposta mais contundente ao problema comparativo sobre as vidas do 'perfeito' justo e do 'perfeito' injusto em termos de felicidade.

O exame dos regimes e almas injustas de Rep. VIII-IX recorre novamente à analogia cidade-alma. Desde o início do exame, Sócrates reitera seu objetivo central de "levar ao termo a pesquisa (teléa he sképsis)" acerca da justiça e injustiça em termos de felicidade (545a-b). Na realidade, o amplo exame da degeneração moral acaba refletido no aprofundamento dos múltiplos desejos da parte apetitiva da alma.

Ao longo de Rep. VIII-IX, Sócrates descreve a decadência moral de diversos tipos de regimes políticos e seus respectivos caracteres morais injustos: a

${ }^{275}$ Sobre a insuficiência da definição da justiça interna de Rep. IV, ver ANNAS, 1981, p. 153-170; IRWIN, 1995, p. 169-179. 
timocracia, a oligarquia, a democracia e, por fim, a tirania. Em outra seção, pretendemos abordar melhor a psicologia de cada um desses caracteres em uma análise mais abrangente sobre o conflito interno moral e a akrasia na República. Dentre os tipos de caracteres injustos, o tirano é o que ganha maior destaque, justamente porque constitui o 'perfeito' injusto e, portanto, integra a resolução final de Sócrates ao Desafio da Justiça.

A partir da psicologia do tirano, o exame socrático enfim estabelece um parâmetro objetivo de comparação das vidas do 'perfeito' justo e do 'perfeito' injusto. Ao final de Rep. IX, Sócrates recorre novamente à analogia cidade-alma para desvelar a condição real do tirano na cidade para além da aparência da opinião dominante (hoi polloí) (576c-e):

só deve avaliá-los quem, em pensamento (têi dianoíai), for capaz de penetrar no caráter de um homem (eis andròs êthos) e ver claro nele, e não ficar fascinado como uma criança, que só vê na aparência (éxothen) do luxo que exibem no mundo exterior (pròs toùs éxo) (...). (577a)

Dessa forma, Sócrates vai estabelecer uma distinção clara entre o parâmetro aparente da opinião dominante e o parâmetro objetivo do exame socrático. De um lado, o exame determina a eliminação da doxa da opinião dominante sob a qual se fundamenta o Desafio da Justiça e, simultaneamente, a defesa da injustiça de Trasímaco. De outro lado, o parâmetro objetivo deriva da psicologia moral e da metafísica desenvolvidas ao longo de toda a República. Dessa forma, Sócrates irá buscar comprovar que o 'perfeito' injusto, isto é, o tirano, é mais infeliz e desgraçado do que o 'perfeito' justo, em uma inversão da imagem ideal da vida do tirano de Trasímaco no livro I.

Em sua resposta final, Sócrates apresenta três provas (apódeixis) orientadas a revelar a verdadeira condição miserável do tirano diante de sua imagem aparente: (1) o tirano é, na verdade, um escravo, que não alcança o que realmente deseja (578b-580a); (2) o critério de satisfação dos desejos: os desejos do conhecimento do homem sábio e justo são superiores aos desejos de honra e dos apetites irracionais dos outros homens em matéria de experiência, inteligência e raciocínio (581a-583a); (3) a natureza do prazer: os prazeres do conhecimento verdadeiramente preenchem a alma, enquanto os prazeres dos apetites seriam apenas fantasmas dos prazeres reais, consistindo apenas em alívio da dor (583b- 
588a). A partir disso, Sócrates pretende então oferecer uma resposta mais definitiva ao Desafio da Justiça.

A despeito da segunda resposta final de Sócrates em Rep. IX, não há consenso sobre se as três provas contemplam as exigências do Desafio da Justiça. Para uma longa tradição interpretativa, a consistência das três provas, bem como a longa estratégia da analogia de Sócrates em resposta ao Desafio da Justiça, ainda são matéria de controvérsia permanente ${ }^{276}$. Para todos os efeitos, essa controvérsia está longe de nosso foco de investigação.

Em última instância, pretendemos apenas indicar que a segunda resposta de Sócrates salienta novamente a relação fundamental da analogia cidade-alma e da psicologia moral na resolução do Desafio da Justiça. Nesse sentido, é preciso levar em conta aqui principalmente a inversão socrática do ideal de felicidade da pleonexía, isto é, da máxima injustiça refletida na figura do tirano no Desafio da Justiça.

O argumento final de Sócrates claramente pretende responder não só ao Desafio da Justiça, mas, principalmente, ao seu reflexo indireto, a defesa da injustiça de Trasímaco (Cf. 545a-b; 590d-e). Como vimos, Trasímaco defendia a pleonexía e o ideal da máxima vida injusta, e Gláucon e Adimanto retomam a defesa da injustiça de Trasímaco no Desafio da Justiça. Em geral, podemos destacar três teses principais dos interlocutores em favor da pleonexía: (1) a pleonexía constitui um desejo natural humano pela injustiça; (2) a satisfação da pleonexía promove a máxima felicidade enquanto a vida justa é a mais infeliz; (3) o ideal da felicidade humana é expresso na vida do tirano, o grau máximo de injustiça. Dessa forma, os argumentos finais de Sócrates contra a injustiça mostram uma inversão completa da figura do ideal de felicidade do tirano.

$\mathrm{Na}$ imagem socrática do tirano, os desejos de sua alma o levam a 'levar vantagem' (pléon échein) sobre os outros, inclusive sobre parentes e amigos (574a). A pleonexía do tirano oculta sua completa submissão aos apetites e à parte inferior da alma (577d-578c). Nesse sentido, Sócrates equipara a pleonexia do tirano à compulsão animal: “devido a ganância (tês pleonexías), dilaceram-se uns aos outros (...) matando-se por causa de seu desejo insaciável (di'aplestían)" (586a-b). O ideal

\footnotetext{
${ }^{276}$ Sobre a longa controvérsia interpretativa que envolve as três provas finais de Sócrates demonstrando a superioridade da vida justa sobre a vida injusta em Rep. IX, ver ANNAS, 1981, p. 305-317; IRWIN, 1995, p. 290-297; REEVE, 1988, p. 235-264.
} 
da pleonexia despido de seu invólucro aparente nada mais é do que uma condição de absoluta submissão aos desejos irracionais. Em todo caso, a analogia cidadealma e a psicologia moral estão igualmente comprometidas com a revelação da condição real da infelicidade do tirano.

$\mathrm{O}$ argumento final de Sócrates contra a pleonexia e a tirania depende fundamentalmente da analogia cidade-alma e da psicologia moral da República. Desse modo, salientamos que a analogia e a psicologia moral estão intrinsecamente ligadas em dois recursos fundamentais da República: (a) na ampla estratégia argumentativa de Sócrates em vista das duas respostas contundentes ao Desafio da Justiça; (b) no exame comparativo da condição psicológica do 'perfeito' justo e do 'perfeito' injusto.

Em primeiro lugar, a analogia cidade-alma é crucial na longa investigação da República, e fornece duas respostas decisivas ao Desafio da Justiça, à definição da justiça interna e à comparação das vidas do justo e do injusto. Na primeira resposta de Rep. IV, a analogia promove a construção da Cidade Ideal e o reflexo da justiça externa da cidade sobre a justiça interna da alma. Na segunda resposta de Rep. IX, a analogia leva a um extenso exame sobre os regimes e caracteres morais injustos e demonstra, então, em que condições o 'perfeito' justo está em relação ao 'perfeito' injusto na cidade. No entanto, a própria analogia cidade-alma abre o caminho para a psicologia moral também envolvida nas respostas de Sócrates ao Desafio da Justiça.

Em segundo lugar, a psicologia moral está intrinsecamente ligada à analogia de modo a revelar qual a condição real das vidas do homem justo e do homem injusto. De um lado, a teoria tripartite da alma permite a Sócrates estabelecer as definições 'puras' da justiça e da injustiça interna da alma na primeira resposta ao Desafio da Justiça. De outro lado, o exame das almas injustas acaba demonstrando a verdadeira condição de completa submissão do tirano por seus próprios apetites. Em todo caso, buscamos apenas indicar aqui que a psicologia moral da República está intrinsecamente ligada à controversa analogia cidade-alma.

Devido ao nosso foco central, apenas indicamos a orientação do argumento final de Sócrates em vista do Desafio da Justiça. No entanto, toda essa discussão revela como a psicologia moral é imprescindível na resolução final do Desafio da Justiça. Dessa forma, nos voltaremos a seguir para a psicologia tripartite 
propriamente dita e a possibilidade do conflito interno da akrasia. Antes de mais nada, precisamos traçar um quadro completo da psicologia moral da República.

Na próxima seção, deveremos analisar os princípios fundamentais da teoria tripartite da alma e sua suposta rejeição do paradoxo socrático do Protágoras. A partir do quadro completo da teoria tripartite da alma, devemos verificar se o foco central sobre conflito interno da alma na República nos fornece parâmetros necessários de classificação da akrasia tradicional. Dessa forma, pretendemos mostrar as continuidades e descontinuidades do pensamento platônico sobre a psicologia moral e a akrasia.

\section{3}

\section{A teoria tripartite da alma na República e o paradoxo socrático}

A teoria tripartite da alma de República IV aborda casos comuns de conflito psicológico associados ao fenômeno da akrasia. De fato, existem dois elementos da teoria tripartite que parecem especialmente voltados contra a negação socrática da akrasia no Protágoras: o reconhecimento do conflito interno da alma e o caso específico de Leôncio de Rep. IV. Com efeito, ambos os elementos estão baseados no princípio do conflito de desejos humanos e na demonstração da teoria tripartite da alma. Nesse cenário, a concepção indivisa e simplificada da alma no Protágoras daria lugar a uma complexa psicologia tripartite da alma na República ${ }^{277}$.

Diante disso, a corrente interpretativa tradicional alega que Platão teria abandonado o paradoxo socrático e a negação da akrasia do Protágoras. Para essa corrente interpretativa, a teoria tripartite da alma e o reconhecimento do conflito interno da República marcam a rejeição da posição socrática anterior. Apesar da

\footnotetext{
277 Como já havíamos mencionado, estamos nos referindo à teoria tripartite derivada da alma encarnada sem nos comprometer com a forma simples (monoeidés) da alma desencarnada presente em Rep. X. Embora Sócrates indique que a "verdadeira natureza (tèn alethê phýsin)" da alma, sua "natureza primordial (tèn archaían phýsin)" deve ser avaliada sem interferência da união deteriorada com corpo, ele não deixa de reconhecer a validade das conclusões anteriores "quanto as afecções e formas que tem na vida humana (en tôi anthropínoi bíoi)" (612a). Ver também BURNEYAT, 2006, p. 6: "Granted immortality, which Socrates has just argued for, the conclusion we are left with is that the soul in its true nature must be either uniform or a wondrously well-wrought composite." (itálicos do autor). É necessário lembrar ainda que o Protágoras nem sequer apresenta propriamente uma análise psicológica da alma indivisa, pois Sócrates só se preocupa com o estado interno da alma enquanto relacionada aos seus efeitos na presença ou ausência do conhecimento. Nesse sentido, a própria 'unidade' da alma é mais um pressuposto do que uma teoria positiva exibida no diálogo precedente.
} 
marcante divergência da psicologia moral de ambos os diálogos, mostraremos que a tripartição da alma de República não rejeita as conclusões socráticas fundamentais do Protágoras.

A teoria tripartite da alma de República exibe elementos de continuidade com duas teses socráticas do Protágoras: (a) a inclinação natural humana pelo bem expressa no paradoxo socrático; (b) a akrasia é, na realidade, um tipo de ignorância. Em relação a (a), indicaremos que todas as partes da alma contêm crenças e desejos intrinsecamente voltados ao bem (mesmo diante da objeção de 438a). Quanto a (b), defenderemos que a perturbação interna da alma pela potência da aparência no Protágoras se reflete no exame da condição interna das almas injustas de República. Por mais que Rep. IV forneça a impressão contrária, precisamos esclarecer essa hipótese interpretativa com base na própria demonstração da teoria tripartite de Rep. IV.

Em sua gênese, a teoria tripartite da alma da República visa apenas esclarecer os fatos patentes do conflito interno dos impulsos na alma humana. O argumento da alma tripartite de Rep. IV deriva das claras evidências de conflitos morais psicológicos presentes na experiência humana. Em todo caso, a República carece ainda da precisão terminológica da definição técnica da akrasia presente na Ética de Aristóteles ${ }^{278}$. De fato, o foco central da teoria tripartite é, de modo mais geral, o conflito interno da alma, e aborda-se apenas de forma marginal o fenômeno da akrasia $^{279}$. Para compreender sua provável presença na República, precisamos localizá-la dentro da discussão central dos interlocutores do diálogo.

A composição da alma em três partes está aparentemente relacionada à composição da Cidade Ideal em três classes distintas. Como ressaltamos anteriormente, a fundação da Cidade Ideal iniciada em Rep. II compõe o extenso argumento de Sócrates designado a responder ao exigente Desafio da Justiça. Em Rep. IV, Sócrates enfim conclui a fundação da Cidade Ideal (427d-e), sendo dotada de "três classes naturais (géne phýseon)" (435b): a classe dos 'guardiões'

\footnotetext{
${ }^{278}$ Cf. PRICE, 1995, p. 91-92.

${ }^{279}$ Como mencionado anteriormente, há um consenso entre os comentadores platônicos de que a teoria tripartite não visa propriamente explicar a akrasia (Cf. KAHN, 1996, p. 253-257; BURNYEAT, 2006, p. 20; KAMTEKAR, 2008, p. 135-137.). Em Plato's Utopia Recast, por exemplo, Bobonich (2002, p. 217-218) dedica o capítulo 3 exclusivamente à relação entre a psicologia tripartite e a akrasia na República, embora admita que essa não é a preocupação central da teoria psicológica de Rep. IV. Antes do fenômeno específico da akrasia, o foco central da teoria da alma tripartite reside no conflito interno da alma e na evidência das diferentes motivações humanas.
} 
(phýlakoi), a dos auxiliares (epíkouroi) e os 'artífices' (demiourgoî) e 'negociantes' (chrematistikoî), estes dois últimos grupos integrados em uma única classe. Seguindo os princípios da analogia, as três classes da Cidade Ideal devem corresponder a três 'partes' correspondentes da alma. De fato, Sócrates indaga se a alma contém "as mesmas formas (tà autà eíde)" e "mesmas qualidades (tà autà páthe)" da Cidade Ideal (435a-e). A princípio, a dependência da analogia levaria à simples derivação política da composição tripartite da alma. No entanto, o que se segue não é uma derivação da composição da alma a partir da consituição da Cidade Ideal. De fato, há uma rigorosa demonstração da alma tripartite diante de evidências empíricas do comportamento humano ${ }^{280}$.

Dentro do plano geral da República, o argumento da alma tripartite está integrado ao Desafio da Justiça. A demonstração (apódeixis, 504b) da psicologia tripartite salienta o prenúncio de uma bifurcação de dois 'caminhos' divergentes de investigação: o 'caminho mais curto', conjuga a teoria tripartite da alma e as virtudes 'internas' correspondentes, e o "caminho mais longo e mais extenso (makrotéra kaì pleíon hodòs)" (435d), representa a epistemologia e metafísica de Rep. VI-VII (Cf. 435d; 504a-e) ${ }^{281}$. De um lado, Sócrates ressalta que o 'caminho mais curto' constitui “uma medida que deixa a desejar (...) da realidade (tô̂ óntos)", sendo também uma "medida imperfeita (atelès métron)" que "carece de precisão (erréthe tês akribeías)" (504b-c). De outro lado, ele indica que o "caminho mais longo" proporciona a "obra perfeita (tèn teleotáten apergasían)" já que "as coisas mais valiosas merecem a maior exatidão (megístas tàs akribeías)" (504d-e).

Tais observações de Sócrates demarcam as especificidades de dois métodos diametralmente opostos. Em todo caso, a divisão dos métodos salienta o caráter

\footnotetext{
${ }^{280}$ Cf. COOPER, 1984, p. 4: "In fact there is good reason, despite the order of exposition, the view that justice requires three distinct social classes rather derived support from than gave support to the theory that the soul has three independent parts. It is the psychological theory that Plato thought more firmly anchored in the facts." Alguns comentários mais antigos da República costumam supor que a composição tripartite da alma simplesmente reproduz a composição política das três classes na cidade derivada da analogia cidade-alma (Ver, por exemplo, CHARLTON, 1988, p. 27; GOSLING, 1990, p. 20-23; WATSON, 1977, p. 319-320). No entanto, a tendência interpretativa atual acompanha a rigorosa demonstração lógica da teoria tripartite da alma de Rep. IV destinada a comprovar a divisão estrita das três partes da alma e suas motivações psicológicas correspondentes. ${ }^{281}$ Como ressaltamos anteriormente, a epistemologia e a metafísica de Rep. VI-VII não se inserem no escopo da minha investigação da psicologia tripartite e a akrasia na República. Em 437a, Sócrates chega efetivamente a tomar o princípio do conflito dos desejos como uma hipótese (hypothémenoi), o que sinaliza o caráter hipotético da teoria tripartite para dar conta das diferentes motivações humanas. Para mais detalhes dos diferentes 'caminhos investigativos' da República, ver ADAM, 1902, p. 244-245; BOBONICH, 2002, p. 527-528, n. 11.
} 
experimental do caminho curto constituído pela demonstração tripartite da alma em contraste com a epistemologia e metafísica tardias de Rep. VI-VII e a analogia cidade-alma aplicada ainda em Rep. VIII-IX.

Por ora, nos concentraremos exclusivamente sobre a teoria tripartite da alma, deixando a aplicação da analogia cidade-alma ao exame da corrupção da alma injusta para a próxima seção voltada exclusivamente ao problema da akrasia na República. Em todo, é preciso primeiro esclarecer brevemente o que designa propriamente as 'partes' da alma.

A teoria tripartite da República depende obviamente da controversa concepção de 'partes' da alma. No entanto, o que significam exatamente essas 'partes' da alma? Durante Rep. IV, Sócrates se refere a um conjunto de termos intercambiáveis referentes aos 'elementos' da alma: eíde ('formas'), géne ('tipos' ou 'gêneros'), marginalmente, mérei (em sentido mais literal, 'partes'), mas também páthe ('afecções' ou 'qualidades') e héxeis ('disposições') ${ }^{282}$. Na maior parte da República, as referências às 'partes' da alma constituem uma ampla gama de termos que não se restringem a uma localização espacial específica.

Naturalmente, costumamos associar esses termos genéricos com o que designamos por 'faculdades' ou 'capacidades' da 'mente' humana. No entanto, essa nomenclatura moderna revela-se inapropriada para a psicologia cognitivomotivacional da República. Em primeiro lugar, a concepção indivisa e unitária da alma não encontra respaldo na teoria tripartite da alma e entra em conflito com a analogia cidade-alma ${ }^{283}$. Como vimos, a psicologia tripartite da República pressupõe a complexidade da alma humana, e, portanto, trata-se de uma psicologia moral ligada a componentes morais e sociais indissociáveis das inclinações humanas. Em segundo lugar, não há qualquer referência explícita às 'partes' da alma em sentido metafísico forte. A demonstração da teoria tripartite representa o

\footnotetext{
${ }^{282}$ Para maiores referências dos termos gregos das 'partes', ver ADAM, 1902, p. 244. Com efeito, o texto original grego pode carecer de consistência terminológica justamente porque Sócrates não parece interessado em manter uma absoluta precisão conceitual. Para todos os efeitos, buscaremos eliminar algumas dificuldades propondo as seguintes referências conceituais: 'motivações' ou 'desejos' (em sentido abrangente) referem-se aos desejos de quaisquer partes da alma; 'apetites' ou 'motivações irracionais' referem-se aos desejos da parte apetitiva; 'emoções' ou 'aspiração' referem-se aos desejos da parte impetuosa; 'desejo racional', aos desejos relativos à parte racional da alma.

${ }^{283}$ Cf. KAHN, 1987, p. 79-80: "Plato, at least in the Republic, has no place for a generic conception of desire, as opposed to some other psychic faculty. The tripartition of the Republic is not the division of a faculty of desire but a division of the psyche itself." Ver também MOLINE, 1978, p. $1-2$.
} 
'caminho curto' da resolução do problema da justiça interna e não está comprometida diretamente com a especulação metafísica do 'caminho longo' de Rep. VI-VII.

A rigorosa demonstração da alma tripartite também está longe de ser apenas um artifício de linguagem metafórica. Ao contrário, a referência às 'partes, ou aos 'tipos', 'princípios' ou 'elementos' da alma correspondem às motivações humanas que agrupam um conjunto de capacidades abrangentes da alma, como crenças, preferências e impulsos voltados a objetos de desejo específicos e, por vezes, divergentes entre $\mathrm{si}^{284}$. Como salienta Iglésias (1998), a teoria tripartite da alma, assim como a teoria das Ideias, segue o mesmo princípio da economia para 'salvar os fenômenos éticos': abrange um conjunto variado e complexo de ações humanas que não podiam ser contempladas antes na pressuposta unidade da alma socrática do Protágoras ${ }^{285}$.

Dessa forma, os 'elementos' ou 'partes' servem apenas como 'princípios' heurísticos, destinados a agrupar e classificar as origens das motivações humanas divergentes na alma. Para compreendemos melhor o que constitui a divisão das 'partes' da alma, precisaremos analisar a demonstração da teoria tripartite da alma na sequência.

A teoria da alma tripartite é estabelecida a partir de fatos empíricos comuns acerca do conflito entre as diferentes motivações humanas. Desse modo, a demonstração da alma tripartite se baseia principalmente em dois princípios básicos: (1) o Princípio dos Opostos (PO) e (2) o Princípio dos Relativos (PR). Em conjunto, ambos os princípios viabilizam o critério fundamental do Princípio do Conflito dos desejos (PC) da divisão das partes da alma. Nessa extensa passagem, particularmente, Sócrates rejeita uma objeção calcada na existência de um desejo uniforme do bem (438a), o que parece ecoar o paradoxo socrático do Protágoras.

\footnotetext{
${ }^{284}$ Como ressalta Kamtekar (2008, p. 132), as 'partes' da alma são elementos metafisicamente incompletos que constituem 'poderes' psicológicos ativos e passivos ao mesmo tempo: "This suggests that a part as such is metaphysically incomplete. (...) We may think of Plato's talk of 'parts' in a couple of different ways. First, a part is a capacity to affect and be affected by some range of objects, which ones in particular depending on the power it has developed. Second, when Plato speaks of a part being that by which we do or experience something, or that which does or experiences something, we need to supplement his account by saying what power it is that enables the part to do or experience this."

${ }^{285}$ Cf. Ibid., p. 28: "Platão parece ter se dado conta de que a alma socrática deixava sem explicação, e mesmo negava a possibilidade de phainomena amplamente observáveis relativos à ação humana. (...) Platão deve ter constatado esses fenômenos, e precisava salvá-los. Para isso vai ter de romper com a hipótese da alma indivisa, e criar diferentes fontes de motivação humana."
} 
É necessário, portanto, retomarmos os argumentos que sustentam o princípio do conflito de desejos e definirmos mais claramente qual o alvo real de Sócrates na objeção de 438 a.

Em 437d-439c, acompanhamos a análise das motivações irracionais 'mais básicas’, isto é, 'os apetites' (tàs epithymías). De início, os apetites da fome e sede são classificados de desejos "mais evidentes (enargestátas)"286 (437c-d). Na sequência, surge o seguinte problema (437d-e): são a fome e a sede, respectivamente, simples desejos de comida e bebida ou são classificados por suas 'qualidades' específicas, como bebida e comida quente ou fria, em grande quantidade ou pequena quantidade? Segundo Sócrates, a natureza desses desejos não admite qualificação: “o ter sede em si (autò) jamais será o desejo seja do que for, senão o da sua natureza (péphuken), a mera bebida, e, por sua vez, o ter fome é-o da comida." (437d-e). Assim, a classificação das partes da alma corresponde à distinção dos objetos naturais de desejo:

cada desejo em si (auté he epithymía hekáste) é apenas o desejo do que é seu próprio objeto natural (hekástou oû péphyken), e o desejo de uma coisa determinada (tô̂ toíou) depende desta ou daquela qualidade adicional (toíou tà prosgignómena). (437e)

A princípio, a natureza peculiar dos apetites de fome e sede manifesta claros exemplos de motivações irracionais na alma. Claramente, observamos o reconhecimento da existência de motivações irracionais pelo puro apetite de comida ou bebida. Temos a mesma impressão, quando o mesmo argumento é reformulado dessa vez tendo por causa de dois novos elementos: 1) a sede e a fome são impulsos que levam o homem a se comportar tal "como um animal selvagem (hósper theríou)" (439b); 2) o conflito entre os apetites e a razão deixa clara a “irracionalidade (alogistón)” inerente ao elemento apetitivo da alma (439d). Ao que parece, Platão parece estar reconhecendo apetites absolutamente irracionais, posição francamente contrária ao paradoxo socrático do Protágoras. Para verificarmos se é isso que está em curso, devemos esclarecer a classificação natural

\footnotetext{
${ }^{286}$ A princípio, a categoria de desejos 'mais evidentes' pode nos levar ao equívoco de que os desejos da parte apetitiva são restritos à categoria dos apetites corporais da fome e sede, sendo motivações absolutamente irracionais. Contudo, o reconhecimento posterior do desejo por dinheiro explicitamente vinculado à parte apetitiva sugere uma dimensão social mais destacada.
} 
dos desejos com base nos princípios PO e PR, que integram o Princípio do Conflito (PC) dos desejos da alma.

A seguir, buscaremos elucidar cada um desses princípios para revelar como eles se complementam na estrita divisão das partes da alma. Dessa forma, iremos determinar o que constitui primeiramente o Princípio dos Contrários e, logo depois, analisaremos o Princípio dos Relativos.

O Princípio dos Opostos (PO) da teoria triparte inspirou o que foi designado posteriormente de princípio lógico de não contradição (Cf. 4346-437a) ${ }^{287}$. Nesses termos, esse princípio é aplicado sobretudo à incompatibilidade de coexistência de opostos na mesma coisa e não se refere propriamente à incompatibilidade de proposições contraditórias. Para Sócrates, PO estabelece que "o mesmo sujeito (tò autò òn), não pode, ao mesmo tempo (háma), realizar e sofrer efeitos contrários na mesma de suas partes (katà tò autò) e relativamente à mesma coisa (pròs tò autò)." (436e-437a). Dentro da estrutura lógica sujeito-predicado, estipula-se então que a 'mesma coisa' (tò autò ón) não pode possuir dois opostos dentro das mesmas circunstâncias de tempo, espaço e segundo a mesma relação. Entretanto, Sócrates julga necessário testar PO antes de simplesmente assumir sua veracidade. Dessa forma, somos apresentados à duas objeções de um interlocutor hipotético orientadas a esclarecer o critério de divisão das 'partes' da alma.

As duas objeções à PO especificam o ‘critério lógico’ de demarcação das 'partes' das almas. De início, a primeira objeção aborda o caso de um homem parado que move, simultaneamente, as mãos e a cabeça (436c-d). Em seguida, a segunda objeção apresenta o caso de um pião imóvel em torno de seu eixo mas que se move em círculo em torno de sua circunferência (436d-e). A princípio, ambas as objeções têm o mesmo alvo, isto é, a presença de movimento e imobilidade na mesma coisa. De qualquer modo, a segunda objeção torna mais precisa a vaga noção de 'parte' ou 'elemento' presente na primeira objeção. A seguir, veremos qual é exatamente a especificidade que a segunda objeção adiciona sobre a primeira objeção.

A aparente contestação de PO desaparece sob a distinção da origem do 'movimento' e do 'repouso' no mesmo sujeito. Em relação à primeira objeção, Sócrates alega que o ‘movimento' e a 'imobilidade' estão em 'partes' diferentes do

287 Para outra formulação do influente princípio de não contradição em Platão e Aristóteles Ver também ADAM, 1902, p. 246-247. 
homem: "não deveria falar-se assim, mas dizer que uma parte de si mesmo (tò mén ti autoû) está imóvel, e outra se mexe" (436d). Diante da resolução proposta, podemos supor que Sócrates esteja lidando aqui com uma relação simples ou fraca de oposição, segundo a qual qualquer relação de oposição de contrários deve ser atribuída a 'sujeitos' diferentes. Nesses termos, PO seria apenas um princípio de qualificação designado a determinar, por exemplo, se o 'movimento' é aplicado às 'mãos e braços', enquanto a 'imobilidade' é aplicada à parte inferior do corpo.

No entanto, o que dizer sobre o 'homem inteiro' em relação às suas 'partes'? Será que devemos lhe atribuir 'movimento', 'imobilidade' ou ambos? Diante do conflito de desejos, uma simples oposição, como, por exemplo, entre o desejo de uma bebida quente e o desejo de uma bebida gelada, poderia instaurar uma divisão irrestrita sucessiva das 'partes' da alma ${ }^{288}$. Como essa solução provisória admite diversas exceções e casos problemáticos, a nova objeção é introduzida justamente para eliminar possíveis contraexemplos e oferecer uma solução independente de uma simples qualificação dos desejos.

A segunda objeção exibe um exemplo ainda mais complexo: o pião imóvel girando em torno do próprio eixo. Ao invés de se referir às 'partes' de onde se originam o 'movimento' e a 'imobilidade', a objeção enfatiza uma distinção 'relacional' (katá). Segundo Sócrates, o movimento e imobilidade se verificam assim em uma relação diferente: "diríamos que tem em si um eixo e uma circunferência, e que, em relação (katà) ao eixo, estão imóveis (...) e, em relação (katà) à circunferência, se movem em círculo.” (436e). A solução da segunda objeção, portanto, abandona a simples oposição anterior e adota uma relação restrita de oposição. A distinção relacional permite nos referirmos especificamente ao eixo por inteiro e a circunferência por inteiro sem envolver a relação controversa de parte-todo do exemplo antecedente.

Em função disso, a solução de Sócrates abandona assim a simples oposição anterior por uma relação absoluta de oposição. De acordo com essa nova relação, o mesmo 'sujeito' não pode conter opostos absolutos, eliminando, assim, casos

\footnotetext{
${ }^{288}$ Para essa hipótese interpretativa da simples oposição de desejos, ver PENNER, 1990, p. 56-59; PRICE, 1995, p. 39-42. Ambos reconhecem que o Princípio dos Opostos dessa hipótese interpretativa é inconsistente e problemática. No entanto, ao invés de confrontar essa hipótese interpretativa com as observações da segunda objeção, os autores preferem atribuir as inconsistências ao próprio PO.
} 
intermediários $^{289}$. Com essa definição final, PO determina que a mesma coisa não pode agir ou sofrer ação de opostos nas mesmas condições (de tempo, espaço e em respeito a mesma coisa).

Assim como o 'movimento' e a 'imobilidade' se originam em diferentes fontes no caso do pião, Sócrates recorre ao mesmo princípio para definir o conflito absoluto dos desejos nas 'partes' da alma. Mais uma vez, o princípio lógico e psicológico exibido aqui não permite tratarmos essas 'partes' psicológicas por um estrito sentido ontológico. Sobretudo, a distinção relacional (katá) antecipa outro princípio desenvolvido posteriormente, o Princípio dos Relativos (PR).

O Princípio dos Relativos (PR) envolve a clássica distinção filosófica entre o que é 'em si mesmo' (kath 'autó) e o que está ‘em relação com algo' (prós ti). Tal como $\mathrm{PO}$, o princípio lógico PR é aplicado à psicologia humana. Ao estabelecer PR, Sócrates estabelece um claro princípio de qualificação:

todas as coisas que são relativas a um objeto, aquelas que são relativas a um mesmo objeto são relacionados apenas consigo mesmas (autà mèn móna autôn mónon estín); se em relação a objetos determinados são relacionados a coisas determinadas (tôn dè poiôn tinon poià átta). $(438 \mathrm{~d}-\mathrm{e})^{290}$

A partir disso, Sócrates estabelece uma distinção geral sobre "o que é relacionado apenas consigo mesmo (autôn mónon estín)" e "o que é relacionado com certas coisas determinadas (tinon poià átta)". Em outros termos, poderíamos dizer que isso equivale à distinção correspondente do 'objeto' absoluto sem qualificação, isto é, o objeto em si mesmo de forma absoluta, e o 'objeto' qualificado, ou seja, em relação a uma ou mais qualidades de forma específica ${ }^{291}$.

Ao longo da exposição do princípio, são mencionados diversos exemplos comuns destinados a ilustrar a aplicação lógica correta dos pares de opostos. É extremamente comum, por exemplo, distinguimos o que é 'maior' do que é

\footnotetext{
${ }^{289}$ Para essa relação absoluta de opostos, ver IRWIN, 1995, p. 207-208; BOBONICH, 2002, p. 227 229; LORENZ, 2006, p. 21-24. De fato, essa relação absoluta de opostos é concebida especialmente em função da especificidade da $2^{\mathrm{a}}$ objeção de Sócrates e contornar as dificuldades geradas pela relação simples de oposição sugerida anteriormente.

${ }^{290}$ De fato, as traduções portuguesas do texto original nessa passagem são um tanto obscuras. Para contemplar melhor o texto, optamos por adaptar ao português a tradução francesa de Émile Chambry (Bellles Lettres), em virtude de sua fidelidade ao texto original e também por sua consistência com o argumento socrático presente nesse contexto.

${ }^{291}$ Para uma intepretação coincidente do princípio de qualificação, ver REEVE, 1988, p. 120-123.
} 
'menor', o 'dobro' do que é a 'metade', o 'quente' do 'frio', o 'pesado' do 'leve' sempre em referência a uma 'relação' com dois pares de opostos (438b-c).

Em função da ciência (epistéme), distinguimos as técnicas e conhecimentos por seus objetos relativos, como a ciência relativa a uma série de matérias diferentes, como a construção de casas, da saúde e doença, do que é bem e mal (438c-e). Nem por isso, confundimos a própria ciência com seus objetos de estudo, sendo ela mesma saudável ou doente ou mesmo boa ou má. Segundo Sócrates, a "ciência em si (autò) é ciência de conhecimento" enquanto "uma ciência determinada (tis) é ciência de um objeto específico (poiá tis poioû tinos kaì tínos)." (438c-d). Em ambos os exemplos, o objetivo primordial é distinguir a relação primordial da 'coisa em si' da relação qualificada derivada de qualidades opostas. Com isso, PR distingue dois tipos diferentes de relação: a relação de qualificação ligada aos objetos particulares e a relação absoluta da coisa 'em si mesma' sem qualificação. Assim, PO e PR integram o conflito de desejos.

Em conjunto, PO e PR estabelecem as bases fundamentais do conflito de desejos e a divisão das partes da alma. Como vimos, ambos os princípios endossam a incompatibilidade da relação de qualificação com a relação absoluta da coisa em si mesma. Segundo PO, a mesma coisa não pode ter, agir ou sofrer opostos absolutos simultaneamente, em si mesma e em relação a si mesma. A partir de PR, Sócrates exclui definitivamente qualquer qualificação dos opostos absolutos de PO. Sendo assim, PO e PR integram o Princípio de Conflito dos desejos (PC) segundo o qual - o 'sujeito' de opostos absolutos são compostos por fontes ou 'partes' distintas da alma. Dessa forma, podemos compreender melhor o que está por trás da suposta objeção socrática levantada em 438a em vista do impulso irracional dos apetites.

Quando retornamos à passagem 437d-438a, observamos Sócrates classificar os apetites da fome e da sede em vista do 'puro' apetite de comida ou bebida. Dessa forma, parece haver o reconhecimento da existência de apetites absolutamente irracionais contra o desejo natural do bem. Essa impressão é reforçada quando Sócrates bloqueia uma breve objeção de $438 \mathrm{a}$ em termos similares ao paradoxo socrático do Protágoras:

Que ninguém nos venha perturbar inadvertidamente, pretendendo que ninguém tem desejo de uma bebida que não seja 
boa (chrestô̂), nem de comida que não seja boa (chrestô̂). Porque, na verdade, toda gente tem desejo do que é bom (pantés tôn agathôn epithymoûsin). Se, pois, a sede é um desejo, sê-lo-á de uma bebida ou de qualquer outra coisa que seja boa (chrestô̂) (...). (438a)

Nessa passagem, Sócrates defende a existência de motivações irracionais contra a objeção de um interlocutor indefinido que alega existirem só desejos pelo bem. A tradição interpretativa costuma identificar o suposto interlocutor com o próprio Sócrates do Protágoras.

Uma expressiva corrente desenvolvimentista enxerga na passagem 438a a principal indicação de que a República reconhece a existência de desejos independentes do bem contra o ‘intelectualismo’ do desejo do Protágoras ${ }^{292}$. Como vimos, o intelectualismo do desejo sustenta que existe apenas o desejo racional pelo bem e as motivações irracionais são apenas expressões do mesmo desejo racional. A rejeição do intelectualismo do desejo implicaria automaticamente no reconhecimento de impulsos irracionais e o conflito interno da alma na akrasia. Como vimos, a manifestação animal dos 'puros' apetites da fome e sede representa a descrição da parte apetitiva como sede da "irracionalidade (alógiston)" (439d). Seguindo essas indicações, seria possível postular desejos completamente irracionais ou cegos, isto é, desejos inteiramente destituídos de cognição e incapazes de elaborar considerações racionais ${ }^{293}$. Nem todos os intérpretes dessa corrente reconhecem tal visão radical dos desejos irracionais na psicologia moral platônica, mas todos concordam que a República inaugura a concepção de motivações irracionais independentes do bem.

Em uma corrente interpretativa alternativa, outros intérpretes platônicos alegam que o objetor não pode ser o Sócrates do Protágoras. Como vimos, o paradoxo socrático do Protágoras se limita a estabelecer que há um desejo natural pelo bem, e não rejeita explicitamente a existência de motivações irracionais. Da mesma forma, a República reconhece a existência de uma inclinação natural ao bem. Sócrates afirma que o homem exibe uma inclinação natural ao bem mesmo

\footnotetext{
${ }^{292}$ Sobretudo, é importante conferir, por exemplo, a observação emblemática de Kahn (1987, p. 85): "In order to establish the distinction between reason and appetite Plato must here define, for the first time, the notion of a desire that is essentially independent of any judgment concerning what is good, beneficial, or advantageous (taking these three terms as synonimus)." (itálicos do autor). Para uma formulação similar de desejos independentes do bem, ver IRWIN, 1995, p. 208-209; REEVE, 1988, p. 134; LORENZ, 2006, p. 29-30; FERRARI, 2006, p. 168-169, GOSLING, 1990, p. 19-22.

${ }^{293}$ Para essa abordagem tradicional dos 'desejos cegos' platônicos, ver PENNER, 1990, p. 58-61; WATSON, 1977.
} 
sem ter conhecimento do que é o bem (505d). De outro lado, os desejos respectivos de cada uma das 'partes' da alma terão suas próprias concepções particulares do bem (581a-c). De acordo com essa corrente interpretativa moderada, a República preserva, em certa medida, o paradoxo socrático mas rejeita a negação socrática da akrasia do Protágoras ${ }^{294}$.

A partir dessa visão moderada, podemos suspeitar que algo mais está em jogo na objeção do interlocutor idealizado de 438a em Rep. IV. Dessa forma, a própria noção de desejos independentes do bem abre pretexto a uma série de equívocos que não se sustentam diante de uma interpretação mais meticulosa da República. No entanto, devemos deixar propriamente a polêmica da akrasia para a próxima seção. Retornemos ao contexto original de Rep. IV em busca de indicações textuais concretas sobre o que é defendido na objeção de 438a e quem é o interlocutor personalizado de Sócrates.

Ao nos defrontarmos novamente com a objeção de 438a, constatamos que a objeção não é uma tese isolada, mas uma inferência lógica pela qual Gláucon parece ter especial interesse.

Em primeiro lugar, o bloqueio da inferência lógica é crucial na estratégia argumentativa de Sócrates. Como ressalta Weiss (2007, 89-92), a intenção primordial de Sócrates se concentra na seguinte inferência lógica simplificada: (1) todo desejo é 'desejo pelo bem ou por coisas boas' (tôn agathôn epithymoûsin); (2) a sede 'é um desejo' (epithymía estî); (3) logo, a sede é um desejo por bebida 'boa ou benéfica' (chrestón). Na realidade, o alvo de Sócrates não é especificamente a tese 'todo desejo é pelo bem', mas a inferência lógica do 'puro' apetite ao desejo qualificado de 'bom' ou 'benéfico'. Nesse contexto, a substituição do termo agathón (bom, em sentido geral) ao termo chrestón (benéfico ou bom, em sentido específico) é extremamente eficaz pois exclui especificamente a qualificação do objeto natural de desejo, isto é, de bebida 'benéfica' ou de comida 'benéfica'.

Em outras palavras, o bloqueio da inferência lógica corresponde à aplicação de $P R$ ao 'puro' apetite em relação a si mesmo. A partir disso, Sócrates pode distinguir o desejo 'em si' do desejo qualificado 'bom', 'benéfico', 'quente', 'frio', etc. Por esse parâmetro, a fome e a sede constituem desejos simples voltados

\footnotetext{
294 Para essa interpretação moderada da 'mudança' da psicologia platônica nos Diálogos, ver LESSES, 1987. p. 157; PRICE, 1995, p. 49, p. 91-97; WEISS, 2006, p. 95; KAMTEKAR, 2017, p. 132; BOBONICH, 2002, p. 240; MORRIS, 2006, p. 224-228; LORENZ, 2006, p. 29-30.
} 
exclusivamente aos seus objetos naturais de desejo, isto é, comida e bebida sem qualificação. Todavia, isso não quer dizer que Sócrates pretende negar especificamente a tese que todo desejo é desejo pelo bem.

Em segundo lugar, há indicações textuais de que Sócrates aceita, em alguma medida, a tese (1) enquanto a inferência lógica (1)-(3) é designada para expressar o ponto de vista de Gláucon. Após formulada a objeção hipotética de Sócrates, Gláucon logo em seguida exprime adesão parcial ao objetor hipotético: "Parece-me que quem tal dissesse teria talvez certa razão." (438a). Devemos suspeitar que o interlocutor hipotético visa expressar um ponto de vista compartilhado com o próprio Gláucon e não um interlocutor externo ao diálogo da República.

Há fortes indícios de que o interlocutor hipotético de 438a seria, na realidade, o próprio Gláucon da República e não o Sócrates do Protágoras. Desde a classificação de bens de Rep. II, Gláucon já havia expressado sua preferência pelo bem em si no Desafio da Justiça (Cf. 357b; 358b-d). Entretanto, é plausível lembrar uma referência mais fundamental do desejo humano em sua tese da pleonexia natural exposta na segunda objeção à justiça ${ }^{295}$. Como vimos, Gláucon expressamente sustenta uma forte tese psicológica da pleonexía humana, isto é, o desejo natural pelo bem egoísta da injustiça (cf. 359c; 360c-d). Naquela ocasião, a pleonexía natural exprime uma inclinação humana da injustiça com base na crença de que a injustiça confere maior vantagem pessoal ou bem individual do que a justiça.

Tendo isso em vista, o interlocutor personalizado de 438a retoma a intrínseca relação de desejos e crenças com o bem derivada da pleonexía natural do Desafio da Justiça. Dessa forma, o bloqueio de Sócrates não se dirige propriamente ao intelectualismo do Protágoras mas à qualificação do objeto natural de desejo derivado da teoria pleonética de Gláucon. Nessas condições, a complexidade da alma tripartite de Sócrates é contraposta justamente à simplicidade da alma pleonética injusta de Gláucon.

\footnotetext{
295 Sobre a adesão de Gláucon ao interlocutor hipotético, ver WEISS, 2007, p. 96; KAMTEKAR, 2017, p. 131-132; SCHOFIELD, 2006, p. 264-270. A literatura crítica recente tem evidenciado as claras divergências entre o modelo da alma tripartite de Sócrates o modelo pleonético de Trasímaco e Gláucon. Em especial, Burnyeat (2006, p. 3) ressalta que a teoria tripartite da alma se dirige especialmente a interlocutores razoáveis como Gláucon: "Contrary to a common misconception, the Republic's moral arguments are not aimed at persuading an extremist like Thrasymachus, who was left subdued rather than convinced at 358b. As with the arguments in Aristotle's Nicomachean Ethics, their target is decent, well brought-up persons like Glaucon and Adeimantus, who accept without argument that justice is a virtue (427e), which Thrasymachus flatly denied (348cd)."
} 
Ao contrário do que parece, Sócrates não rejeita explicitamente a tese do desejo pelo bem expressa na premissa (2). Pelo menos na passagem acima, percebemos que o alvo de Sócrates não é a premissa (2) e muito menos o paradoxo socrático do Protágoras. Na realidade, o que tende a causar controvérsia interpretativa é justamente a distinção absoluta do desejo 'racional' pelo bem e o desejo irracional 'independente' do bem. Como vimos, a distinção absoluta da razão e das paixões irracionais provém da psicologia moderna da vontade e não é compatível com as categorias da psicologia grega antiga ou da psicologia tripartite da República. Todavia, a demonstração da teoria tripartite da alma parece realmente endossar a distinção 'racional' e 'irracional' do conflito de desejos.

Por ora, já temos indicações suficientes de que o bloqueio da objeção de 438a reforça PR e exclui a qualificação do desejo. O Princípio do Conflito de desejos (PC) delimita o desejo 'em si' exclusivamente em função de seu objeto natural de desejo, isolado de outras relações de qualificação. Ao contrário, a teoria pleonética de Gláucon decorre da qualificação irrestrita 'bom' a qualquer objeto de desejo humano em geral. Na sequência, veremos como a teoria tripartite da alma se constitui a partir dos conflitos psicológicos efetivos.

Com base no conflito absoluto de desejos, Sócrates consegue distinguir claramente o apetite 'puro' de outras motivações da alma derivadas. Desse modo, o desejo irracional genuíno constitui o modelo do apetite 'puro', isto é, a mera fome por comida ou a mera sede por bebida. A partir disso, Sócrates inicia um exame sobre as fontes originais das inclinações contrárias dentro da alma. Em face da sede, por exemplo, ocorre com frequência que os sedentos têm de refrear seu impulso de beber: "na alma deles não está presente o elemento que impele (tò keleûon) mas sim o que impede (tò kolûon) de beber (...)?” (439c) ? $^{296}$. Para Sócrates, o conflito de desejos mais básico é representado por impulsos contrários. A capacidade de sentir, simultaneamente, sede e repulsa por bebida demarca 'partes' distintas na alma. Ao aplicarmos os princípios PO e PR, constatamos que o impulso contrário ao apetite 'puro' da sede de bebida exige a existência de outro objeto natural oposto ao apetite em outra 'parte' distinta da alma, a parte racional (439b). Nesses termos, Sócrates distingue duas partes da alma:

\footnotetext{
${ }^{296}$ De certa maneira, essa oposição entre os termos keleúon e kolúon possui conotações políticas que antecipam a força da analogia cidade-alma no aprofundamento posterior da psicologia de Rep. VIIIIX.
} 
são dois elementos distintos, (...) o elemento racional (tò logistikòn) da alma, e aquele pelo qual ela ama, tem fome e sede (...), o elemento irracional e apetitivo ${ }^{297}$ (alogistón te kaì epithymetikón), companheiro de certas satisfações e prazeres (pleróseón tinon kaì hedonôn hetaîron). (439d)

Nessa passagem, Sócrates estabelece uma clara distinção entre a parte apetitiva e a parte racional da alma. A parte apetitiva é classificada como "irracional (alogistón)", em confronto com a "parte racional (logistikón)" da alma. A princípio, a oposição de logistikón e alógistos parece efetivamente corresponder à distinção moderna da 'racionalidade' e 'irracionalidade'. Entretanto, não precisamos chegar ao ponto de projetar a distinção absoluta entre 'racional' e 'irracional' na psicologia platônica, pressupondo categorias externas da psicologia moderna da vontade aos princípios da psicologia grega antiga.

Levando em conta apenas os apetites básicos, como sexo, fome e sede, a impressão de que estamos nos referindo a apetites 'cegos' é extremamente plausível. Entretanto, o termo grego 'logistikón' significa propriamente o elemento ‘calculativo' e admite um campo semântico mais abrangente do que a simples distinção moderna entre racional e irracional ${ }^{298}$. Por oposição, o que é 'irracional' na parte apetitiva é especificamente sua incapacidade 'calculativa', ou seja, de realizar um cálculo deliberativo sobre o que é ou não é benéfico em valores objetivos. Nesses termos, o objetivo primordial do conflito de desejos não é simplesmente determinar uma categoria de desejos independentes do bem. Como veremos adiante, os próximos conflitos de desejos da teoria tripartite da alma inviabilizam justamente a classificação categórica da racionalidade e

\footnotetext{
${ }^{297}$ Ao invés de adotar a tradução corrente portuguesa 'concupiscência', preferimos adotar uma tradução alternativa de epithymetikón por 'parte apetitiva' levando em conta que os 'apetites' são os desejos mais característicos dessa parte da alma.

${ }^{298}$ Com efeito, esse significativo detalhe de tradução é ressaltado por Ferrari, (2006, p. 192-193): "The term logistikon, translated as "calculative" in this chapter in order to highlight its merely instrumental aspect, here turns its other face to the light and is better translated as "apt for reasoning" or the more familiar "rational.". Cf. LIDDEL-SCOTT, 1990. O termo grego original logistikón tem um duplo significado: em um sentido geral, expressa apenas uma "habilidade ou prática em cálculo" ou, em um sentido mais específico, a própria 'capacidade' de raciocinar e pensar racionalmente ou a 'faculdade' da razão. Na teoria tripartite da alma, o logistikón parece atender a ambos os significados originais inicialmente. Todavia, a comparação posterior entre a alma justa e a alma injusta faz emergir uma diferença crucial. Na alma injusta, o logistikón tem uma função meramente instrumental e 'calculativa' sob o domínio do epithymetikón ou do thymoeidés. Na alma justa e filosófica, o aspecto 'intelectual' e 'racional' específico se acentua diante de seu domínio sobre as partes inferiores da alma.
} 
irracionalidade. Em todo caso, o conflito de desejos entre apetites e a razão fornece o paradigma central das próximas divisões da alma.

O paradigma central do conflito de desejos estabelece o parâmetro da divisão da alma. A partir disso, obtemos o critério primordial da divisão legítima dos impulsos contrários provenientes de 'partes' distintas da alma: o Princípio do Conflito absoluto de desejos (PC). Entretanto, a oposição do conflito de 'motivações' humanas abrange categorias psicológicas mais amplas do que as categorias modernas da psicologia humana. Nas palavras de Sócrates, os impulsos contrários abrangem uma série de elementos psicológicos diferentes:

estabelecerás que assentir com a cabeça (tò epineúein), ou abaná-la (tôi ananeúein), desejar receber alguma coisa (tò ephíestaí tinos labeîn) ou recusá-la (tôi aparneîsthai), trazer para perto de si (tò proságesthai) ou afastar (tôi apotheîstai), tudo isto é contrário entre si quer se trate de ações, quer de paixões (eíte poiemáton eíte pathemáton) (...)? (437b)

O modelo da teoria tripartite da alma de Rep. IV constitui uma ampla gama de atitudes motivacionais. Ao invés da psicologia moderna classificada em diferentes tipos de faculdades, a psicologia tripartite platônica fornece um modelo interativo e dinâmico de elementos motivacionais. De acordo com Sócrates, podemos destacar ao menos três tipos de elementos psicológicos manifestados nas ações e paixões (437b-c): (1) o comando, em função do "assentimento (tò epineúein)" ou "dissentimento (tôi ananeúein)"299 na orientação cognitiva da ação; (2) a função desiderativa, com o desejo "em vista de algo (tò ephíestaí tinos labeîn)" ou "sua recusa (tôi aparneîsthai)" dos objetos de desejo; (3) a atitude motivacional, o impulso de "trazer para si (tò proságesthai)" em atração ou "afastar de si (tôi apotheîstai)" em repulsão ao objeto de desejo.

Dentro desse quadro, vislumbramos uma complexa série de funções psicológicas em (1)-(3). A ordem sequencial (1)-(3) abrange uma série de elementos psicológicos característicos. Em primeiro lugar, os níveis (2) e (3) manifestam forças ou impulsos motivacionais internos que se expressam

\footnotetext{
${ }^{299}$ Ambas as expressões constituem uma referência literal a um aceno ou abano de cabeça em tom respectivo de aprovação ou reprovação. No dicionário Liddel-Scott (1990), os termos epineúein e ananeúein são naturalmente opostos: epineúein expressa 'acenar' em sinal de aprovação ou um aceno de assentimento, enquanto ananeúein significa o gesto grego de 'jogar a cabeça para trás' (como expressamos no gesto de balançar a cabeça) em tom de negação. Ver também ADAM, 1902, p. 249: "One part of the soul asks, and the other answers, the psychological process being compared with a kind of dialectic or queston and answer inside the soul (...)."
} 
diretamente nas ações morais externas. Em segundo lugar, o nível (1) envolve elementos internos da alma, a interação dinâmica entre as diferentes partes da alma. Como ressalta Bobonich (2002, p. 239), a representação do desejo em um comando fornece uma conexão fundamental do conteúdo proposicional do desejo e da ação humana $^{300}$. Nessa perspectiva, a determinação de um desejo por $p$, mesmo sem resultar em uma escolha em vista de $p$, confere ao agente uma inclinação para realização de $p$. Em outras palavras, a psicologia tripartite confere uma dimensão prescritiva à cada uma das motivações humanas.

Na República de Platão encontramos, então, a dimensão prescritiva das motivações das diferentes 'partes' da alma, isto é, a capacidade de orientar a realização das ações. Dessa forma, isso se verifica antes mesmo da teoria clássica da ação moral voluntária de Aristóteles. Como veremos, o prescritivismo moral de Hare se consolida, principalmente, na dimensão prescritiva da linguagem moral mesmo que sua explícita inspiração provenha da Ética de Aristóteles. Todavia, constatamos aqui que a dimensão prescritiva da psicologia humana já é reconhecida na teoria tripartite da República.

De qualquer modo, deixaremos as implicações da psicologia moral platônica sobre a filosofia da ação contemporânea para outra ocasião. Por ora, devemos traçar um quadro mais completo da divisão tripartite da alma e a complexa psicologia da República. Sobretudo, é necessário determinar o que são exatamente as três 'partes' ou 'elementos' da alma segundo o paradigma da psicologia tripartite. A partir disso, pretendemos indicar posteriormente que a complexa psicologia da República abrange a possibilidade do conflito interno da akrasia, embora não pareça comprometida a reconhecer diretamente a existência da akrasia tradicional.

Ao longo da demonstração da alma tripartite, Sócrates exibe diversos conflitos psicológicos para comprovar a divisão das três 'partes' da alma. No entanto, o caso de Leôncio aparece como um caso isolado dentre outros casos de conflito interno relatados em Rep. IV. Em sua exposição, Sócrates apresenta as seguintes distinções específicas da alma: (a) a separação entre a parte racional e apetitiva, com base no caso do homem sedento, resistente à sua própria sede (439a-

\footnotetext{
${ }^{300} \mathrm{Cf}$. Ibid., p. 239: "The representation of a desire as a command registers both that desire's link to action and its having a content. Desires, by their very nature, press for fulfillment or satisfaction. Less figuratively, the notion of a command involves the idea of an intimate link to action at least to the extent that having the desire that/ by itself, ceteris paribus, disposes its possessor to try to bring about p." (itálicos do autor)
} 
e): (b) a separação entre as partes apetitiva e impetuosa, com o caso emblemático de Leôncio em que o impulso por contemplar cadáveres submete a parte racional da alma (439e-441a); (c) a divisão da parte racional e impetuosa, mostrando a resistência racional de Odisseu contra seu impulso vingativo imediato em Od. XX (441b-c). Aparentemente, apenas o caso (b) representa um suposto caso de akrasia enquanto os outros casos, (a) e (c), relatam a superação da parte racional sobre o conflito contra os impulsos irracionais. Com efeito, todos esses casos colocam em evidência o modelo dinâmico e interativo da psicologia tripartite da República sem se ocupar diretamente com a akrasia $^{301}$. Entretanto, deixaremos a discussão da akrasia para outra ocasião. Nesse momento, nos preocuparemos em expor em maiores detalhes a natureza de cada uma das três partes da alma.

A parte racional (logistikón) se destaca claramente das demais partes devido à sua distinta capacidade epistemológica. Em Rep. IV, sua capacidade de visão global da alma é claramente evidenciada: "não compete à razão governar (árchein) (...) e tem o encargo de velar pela alma toda (hupèr apáses tês psychês prométheian) (...)?” (441e). A parte racional possui um ponto de vista privilegiado sobre o todo da alma, ou melhor, sobre o que é benéfico (apropriado) a cada uma das partes da alma. Dessa forma, sua capacidade de raciocínio crítico está em contraste com a limitação epistemológica inerente às outras partes da alma ${ }^{302}$. De forma alguma, isso significa afirmar que as outras partes da alma não possuam elementos cognitivos ou que sejam apenas desejos cegos. Por ora, o que podemos assegurar é que a parte racional possui uma capacidade intelectiva superior às outras partes da alma.

Diante desses aspectos, considerou-se que a parte racional teria a capacidade de formular um tipo de "cálculo de todos os fatores" ${ }^{303}$. De certa maneira, tal equivalência é pertinente mas não de todo exata. Dentro da filosofia analítica da ação, o cálculo de "todos os fatores considerados" (all things considered) corresponde ao ‘melhor juízo' do agente, como “ $x$ é melhor que $y$, em vista de todos

\footnotetext{
${ }^{301}$ Sobre a aparente ausência de casos explícitos de akrasia na República, ver WILBURN, 2014, p. 61-62; PRICE, 1995, p. 94.

302 Para as capacidades epistemológicas das três partes da alma, ver REEVE, 1988, p. 142-143; LESSES, 1987, p. 150-152; BOBONICH, 2002, p. 246-247; ANNAS, 1981, p. 130-131; PRICE, 1995 p. 60-61; IRWIN, 1995, 282. No entanto, é preciso alertar que essa hipótese interpretativa geralmente atribui à parte apetitiva um raciocínio instrumental de meio-fins. Na sequência, verificaremos que esse tipo de 'raciocínio' não se aplica expressamente à parte apetitiva da alma. ${ }^{303}$ Para essa hipótese interpretativa, ver LESSES, 1987, p. 155; IRWIN, 1995, p. 215; PRICE, 1995, p. 93.
} 
os fatores" ${ }^{304}$. Entretanto, é necessário salientar que a parte racional da alma exprime uma genuína aspiração ao saber que tem uma dimensão global de valores epistemológicos e morais objetivos. Com efeito, Sócrates classifica a parte racional em função de seu “amor de aprender e saber (philomathès kaì philósophon)” (581b). Para Sócrates, a capacidade distinta da parte racional se expressa sobretudo na alma filosófica: “aquele que é realmente amante do aprender (tôi ónti philomathê) deve (....) aspirar ao máximo à toda a verdade (páses aletheías)" (485d). De fato, a parte racional não se restringe a um estrito cálculo lógico condicional de "todos os fatores", abstraído de todo e quaisquer valores objetivos. Ao contrário, a genuína inclinação do saber confere uma motivação objetiva aos valores epistemológicos e morais verdadeiros. Por conta disso, cabe justamente à parte racional julgar objetivamente o prazer específico de cada uma das partes da alma (580d-583a).

A parte impetuosa (thymoeidés) da alma possui uma afinidade natural com a parte racional, mas sua legitimidade é, por vezes, colocada em xeque. Como vimos anteriormente, suspeitava-se que a divisão da alma em três partes, especialmente a separação da parte impetuosa, deriva simplesmente das três classes de indivíduos da analogia com a Cidade Ideal ${ }^{305}$. No entanto, a demonstração da teoria tripartite segue rigorosamente claras evidências empíricas das diferentes motivações da alma humana. $\mathrm{O}$ aspecto incomum da parte impetuosa advém da ausência de um elemento psicológico correspondente ao thymós nos parâmetros de psicologia moderna ${ }^{306}$. Todavia, o thymós corresponde efetivamente à sede das emoções humanas nos parâmetros da psicologia grega ${ }^{307}$.

Para esclarecer a natureza da parte impetuosa, Sócrates recorre a exemplos clássicos de conflito interno moral. Diante dos exemplos de Leôncio e Odisseu em

\footnotetext{
${ }^{304}$ Se consideramos apenas à formulação filosófica de Davidson (2001b), observamos que o cálculo de "todos os fatores" se destaca das considerações qualificadas de prazer e moralidade enquanto a psicologia tripartite não exclui nenhum desses tipos de juízos valorativos.

${ }^{305}$ Para tal interpretação política do thymoeidés, ver PENNER, 1990, p. 44; CHARLTON, 1988, p. 173-174; WILLIAMS, 1983, p. 263-164.

${ }^{306}$ Anteriormente, já havíamos ressaltado algumas incompatibilidades em torno da psicologia grega e a psicologia moderna da vontade. No entanto, verificaremos adiante se Platão ou mesmo Aristóteles abririam precedente para uma faculdade distinta da vontade moral.

${ }^{307}$ Diversos comentadores platônicos salientam o papel imprescindível do thymós grego dentro da psicologia moral grega. Sobre a contribuição da teoria tripartite da República na definição filosófica do thymós grego, ver PRICE, 1995, p. 63-70; BURNYEAT, 2006, p. 9-13; KAMTEKAR, 2017, cap. 5. Sobretudo, o estudo de Shame and Necessity constitui uma obra fundamental sobre a relevância do thymós dentro da psicologia grega da vergonha. No entanto, Williams julga que a psicologia tripartite platônica constitui uma deturpação negativa do papel do thymós na psicologia grega da vergonha. Na sequência, precisamos verificar mais detalhadamente sua crítica.
} 
Rep. IV, Sócrates ressalta qual a fonte dessa motivação distinta do comportamento humano. Com efeito, Sócrates reconhece que a parte impetuosa "toma armas pela razão (pròs tò logistikón), quando há luta interna da alma (en têi tês psychês stásei)". Por isso, essa parte da alma é "auxiliar do racional por natureza (epíkouroun òn tôi logístikôi phýsei)" (440e-441a). O controle de Odisseu sobre sua fúria ilustra de que modo a "parte impetuosa irracional (tôi alogístos thumouménoi)" está disposta à obediência da parte racional $(441 \mathrm{~b}-\mathrm{c})$. Como vimos no relato anterior de Od. XX.17, a resistência racional de Odisseu ao impulso de assassinar os pretendentes preserva seus futuros planos de vingança. Nessa assimilação platônica, o caso de Odisseu representa a dimensão dinâmica da psicologia tripartite, ilustrando a predominância do "raciocínio (tò analogisámenon)" do que é melhor sobre a raiva passional. Para a visão platônica, o caso da Odisseía comprova a existência do thymoeidés na alma. No entanto, o thymoeidés platônico, assim como o thymós grego, não se limita apenas à reação emocional da ira.

O foco na emoção da raiva constitui um traço distintivo do thymoeidés mas não é suficiente para classificá-lo de forma adequada. De fato, encontramos essa motivação primitiva de raiva já nas crianças e até os animais selvagens (441a-b). Todavia, como salienta Burnyeat (2006, p. 10-11), o thymoeidés responde aos valores morais do que é 'belo e vergonhoso' (kalón-aischrón) na cultura grega. Por isso, a psicologia tripartite delimita um campo moral específico ao estatuto da reputação, a honra e ao reconhecimento do que é nobre ou vergonhoso perante os outros $^{308}$. Sobretudo, a inclinação às nobres ações e repulsa às ações vergonhosas advém justamente de seu "amor da vitória e das honrarias (philónikon kaì philótimon)" (581a-b; cf. 549a).

A motivação da preservação da imagem pessoal está inevitavelmente ligada ao olhar alheio no ambiente social. Em Rep. X, essa dimensão social é particularmente retratada na reação emocional do homem decente pelo pesar dos entes falecidos: "quando ficar só (....) ousará dizer muitas coisas das quais se envergonharia se alguém as ouvisse e fará muitas outras, que não aceitaria que alguém o visse fazer" (604a). O thymoeidés expressa claramente a reação motivacional aos valores morais kalón-aischrón. A partir disso, Sócrates associa a inclinação da lamentação à irracionalidade da parte impetuosa contra a resistência

${ }^{308}$ Para os aspectos morais e sociais inerentes ao thymós grego na psicologia grega antiga, ver COOPER, 1984, p. 12-17; ANNAS, 1981, p. 128-129. 
da razão aos lamentos (604c-d). Nesses termos, o thymoeidés poderia caracterizar o ‘outro internalizado' de Williams. Em Shame and Necessity, Williams alega que a psicologia moral da República antecipa as categorias morais de uma psicologia da vontade em que não há mais lugar para o 'outro internalizado' da psicologia grega da vergonha. Antes de analisarmos essa objeção central de Williams, precisamos completar ainda o quadro geral da psicologia tripartite da República. Por ora, nos voltaremos à parte mais desproporcional da alma, a parte apetitiva.

A parte apetitiva (epithymetikón) se caracteriza inicialmente pelos apetites mais 'básicos' e, mais adiante, constitui a fonte de múltiplos desejos na alma. Como vimos, a teoria tripartite da alma estabelece a distinção preliminar do desejo racional e dos desejos irracionais com base nos claros exemplos da fome e da sede $^{309}$. Todavia, Sócrates só designa claramente essa parte de 'epithymetikón' ao fim do novo exame de Rep. VIII-IX:

\begin{abstract}
chamámos-lhe 'parte apetitiva' (epithymetikón), devido à violência dos desejos relativos à comida, à bebida, ao sexo e a tudo quanto o acompanha; e chamámos-lhe amiga do dinheiro (philochrématon), porque é sobretudo com dinheiro que se satisfazem os desejos dessa espécie. (580e-581a)
\end{abstract}

A demonstração da teoria tripartite da alma de Rep. IV apresenta uma classificação limitada da parte apetitiva da alma. A classificação preliminar da parte apetitiva da alma da teoria tripartite reflete o estado interno da alma justa em Rep. IV. Desde Rep. IV, Sócrates ressalta que a parte apetitiva constitui "a maior parte da alma" sendo suscetível à multiplicação de seus desejos. Nessa ocasião, o filósofo ainda reitera que a parte apetitiva pode "escravizar e dominar (katadoulósasthai kaì árchein) uma parte que não compete à sua classe e subverta toda a vida do conjunto." (442a-b). Na realidade, o desejo de dinheiro cumpre um papel fundamental na multiplicação dos desejos da parte apetitiva da alma. Para averiguarmos o desejo de dinheiro, precisaremos prosseguir à subdivisão da parte apetitiva de Rep. VIII-IX. A partir do modelo da alma injusta, Sócrates aprofunda a análise psicológica da alma tripartite.

\footnotetext{
309 Os desejos sexuais serão mencionados explicitamente no aprofundamento da psicologia moral em Rep. VIII-IX (559c; 580e-581a; 573a-e). Em Rep. IV, Sócrates só menciona os apetites da fome e da sede em oposição à razão. Supostamente, os apetites sexuais não são ainda mencionados nessa ocasião porque integram os desejos não-necessários da alma e não se enquadram na classe dos desejos necessários $(559 \mathrm{c})$.
} 
O exame dos tipos de regimes e almas injustas de Rep. VIII-IX aprofunda a psicologia da parte apetitiva da teoria da alma tripartite de Rep. IV. Durante esse extenso exame, a degeneração progressiva dos regimes e das almas injustas dá origem à duas subdivisões específicas dos desejos da parte apetitiva da alma.

A primeira subdivisão da parte apetitiva ocorre na distinção fundamental dos desejos "necessários (anankaíous)" e "não necessários (mè anankaîous)" (558d-559d). De um lado, os desejos necessários em si mesmos proporcionam "completo benefício a nós (apoteloúmenai opheloûsin)" de acordo com o que "a necessidade implantou na nossa natureza (hemôn têi phýsei anánke)" (558e). Nessa classe de desejos, Sócrates inclui os apetites básicos necessários da sobrevivência humana, como a sede e a fome dentro dos limites da saúde e do bem-estar físico ou da preservação de dinheiro (559a-c). De outro lado, os desejos não necessários se caracterizam por desejos excessivos que "não nos impele a nada de bom (pròs oudèn agathòn)" sendo um tipo de desejo que "é nocivo ao corpo e à alma, à inteligência e sensatez" (559a-d). Dentro desse grupo, estão os "desejos eróticos (aphrodisíon)", os "desejos dissipadores (epithymíai analotikás)", ligados a gastos dispendiosos de dinheiro, a até o desejo exótico de manjares ${ }^{310}$. A partir dessa subdivisão, o desejo de dinheiro surge comum um elemento comum em ambas as categorias.

O desejo de dinheiro tem despertado a hipótese interpretativa de que a parte apetitiva é capaz de fazer um tipo de raciocínio instrumental de meios-fins dos desejos necessários ${ }^{311}$. Todavia, isso entra em conflito com a divisão inicial da parte racional e da parte apetitiva irracional estabelecida pelo princípio de opostos (PO). O desejo de dinheiro integra a parte apetitiva justamente por não se configurar em um estrito raciocínio meios-fins. Como salienta Schofield (2006, p. 259-260), o desejo por dinheiro se manifesta em uma dupla inclinação tanto como meio para satisfação dos apetites básicos quanto como um fim em si mesmo ${ }^{312}$. Sendo um

\footnotetext{
${ }^{310}$ Sobre esses tipos de desejo, é interessante observar duas menções anteriores a esses tipos de desejos em ocasiões anteriores. Em primeiro lugar, o surgimento de dois tipos de desejos no homem oligárquico comparados ao zangão com ferrão e ao zangão sem ferrão dissipador de riquezas (552be). Em segundo lugar, a inserção de desejos sofisticados, como o desejo de manjar, na cidade inflama mencionada em Rep. II.

${ }^{311}$ Para a suposta presença do raciocínio instrumental na parte apetitiva ver ANNAS, 1981, p. 130131; IRWIN, 1995, p. 220-221; MOLINE, 1978, p. 10; BOBONICH, 2002, p. 246.

${ }^{312}$ Cf. SCHOFIELD, 2006, p. 259-260: "Here we need to observe a crucial distinction: (a) first, money will be desired by the elite as the means to secret satisfaction of more basic appetites, on a scale hugely more lavish than they themselves would have thought of attempting in the good city; (b) second, precisely because it is the key which unlocks so much else, it will be desired for itself
} 
desejo necessário, o desejo de lucro se constitui como um fim em si mesmo em vista da preservação econômica do dinheiro. Sendo um desejo não necessário, os desejos dissipadores estão orientados ao gasto desenfreado como um meio de satisfação dos apetites corporais. Dessa forma, o desejo de dinheiro se apresenta tanto como um desejo necessário quanto como um desejo não-necessário. Em nenhum momento, no entanto, Sócrates delega explicitamente qualquer capacidade de raciocínio instrumental à parte apetitiva da alma. Como mostraremos adiante, o desejo de dinheiro não inviabiliza a divisão estrita da parte racional e a parte apetitiva segundo PO. Ao menos, o desejo por lucro exige uma forma de autocontrole enquanto os desejos dissipadores implicam em descomedimento. Diante disso, a natureza dos desejos não necessários exige mais uma nova subdivisão da parte apetitiva.

Na segunda subdivisão da parte apetitiva, os desejos não-necessários são separados em outras duas classes de desejos em Rep. IX. Nessa ocasião, Sócrates distingue então outro subgrupo de desejos não-necessários, os "desejos legítimos (nómoi)" e os “desejos ilegítimos (paránomoi)" (571a-572b). A nova distinção dos apetites decorre dos limites estabelecidos pelo 'nómos', isto é, pelas leis ou costumes sociais. De acordo com Sócrates, os desejos legítimos são controlados na vigília: "castigados pelas leis e pelos desejos melhores, com o auxílio da razão (metà lógou)" (571b-c). Por sua vez, os desejos ilegítimos emergem principalmente durante o sono: "a parte animal e selvagem (tò theriodés te kaì ágrion) (...) ousa fazer tudo, como se estivesse livre e forra de toda a vergonha e reflexão (aischúnes kaì phronéseos)." (571c-d). Com efeito, os desejos ilegítimos se destacam pela violência e insaciabilidade em vista de seus objetos de desejos. Ao contrário dos desejos legítimos, esses desejos não obedecem e nem mesmo atendem aos anseios das outras partes da alma. O predomínio dos desejos ilegítimos na alma reflete a completa desconsideração dos valores morais objetivos do que é bom ou mau, belo ou vergonhoso. Em linhas gerais, a subdivisão interna da parte apetitiva corresponde ao exame caráter específico das almas injustas de Rep. VIII-IX.

Com base na tipologia das almas injustas de Rep. VIII-IX, constatamos que o predomínio dos tipos de apetites na alma corresponde a certos caracteres morais específicos. De um lado, o predomínio dos desejos necessários está relacionado ao caráter do homem oligárquico (550c-555b). De outro lado, o predomínio dos

('reverenced' or 'honoured') (....)." (itálicos do autor). Sobre a dupla capacidade do desejo por dinheiro, ver também PRICE, 1995, p. 60. 
desejos não necessários está ligado a dois outros tipos de caracteres morais: o democrático e o tirânico (555a-576a). Se o caráter democrático reflete o predomínio dos desejos legítimos, o caráter tirânico, por sua vez, representa o predomínio dos desejos ilegítimos na alma. O predomínio dos desejos não necessários na alma inviabiliza a reflexão objetiva dos valores e desejos da parte racional e impetuosa. Com efeito, deveremos analisar esses casos de conflito interno adiante na investigação da próxima seção sobre o conflito interno da alma e a akrasia. De qualquer forma, o quadro geral da psicologia tripartite da República já nos fornece elementos suficientes para classificarmos sua psicologia moral.

A psicologia tripartite da República é reconhecida como a precursora da psicologia moral ocidental. De certo modo, essa constatação aparentemente evidente envolve pressupostos que nem sempre são adequadamente explicitados ou demonstrados na filosofia ocidental. Sem dúvida, a divisão tripartite da alma e a relação natural hierárquica das três partes são estabelecidas em vista de claras categorias éticas ou morais. No entanto, essa constatação óbvia esconde uma hipótese moderna mais audaciosa: a tese de que a psicologia moral tripartite platônica, na realidade, antecipa de certa forma as categorias morais da psicologia moderna da vontade moral.

Em Shame and Necessity, Williams arrisca a hipótese moderna audaciosa de que a psicologia moderna da vontade tem sua origem na divisão tripartite da alma da República. Para Williams, como vimos anteriormente, a psicologia moderna da vontade contém categorias morais que excluem o 'outro internalizado' da formação psicológica do agente. Nessa perspectiva, a psicologia grega da vergonha anterior a Platão estaria supostamente isenta desse erro crucial. Mesmo reconhecendo que não há um correlato grego exato do termo 'vontade', Williams considera que a psicologia platônica da República, de certa forma, antecipa as categorias éticas inerentes da psicologia da vontade. Em 'Centres of Agency', Williams (1993, p. 42-43) deixa sua crítica à psicologia platônica mais explícita:

The idea is rather that the functions of the mind, above all with regard to action, are defined in terms of categories that get their significance from ethics. (...) It was left to later Greek thought to invent it, and is scarcely gone away from us since. It was invented, it seems, by Plato. (...) It is only in the light of ethical considerations, and certain ethically significant distinctions of character and motive, that Plato's schema is intelligible. 
A crítica de Williams não se dirige estritamente a mera aplicação de categorias éticas aos elementos psicológicos, ou o reconhecimento de motivações, crenças e desejos morais. De acordo com Williams (Ibid., p. 43), o problema central da psicologia platônica reside no uso de critérios éticos para caracterizar as próprias funções dos elementos internos da psicologia humana: "Reason operates as a distinctive part of the soul only to the extent that it controls, dominates, or rises above the desires.”. Com efeito, a teoria tripartite da alma não apenas reconhece a existência de diferentes motivações morais humanas. A psicologia tripartite estabelece uma relação hierárquica necessária da superioridade e do controle da parte racional sobre as partes inferiores da alma, a parte impetuosa e apetitiva. A partir disso, Williams classifica a teoria tripartite da República como uma 'psicologia eticizada' (ethicized psychology) ${ }^{313}$. Dentro da visão progressista, as categorias éticas da teoria tripartite da alma forneceriam as bases fundamentais da emergência da 'vontade moral' ausentes da psicologia grega da vergonha. Para Williams, no entanto, as categorias éticas internas da psicologia platônica antecipam, de certa maneira, as categorias morais da ética do dever e da 'autonomia moral' de Kant.

Ao atribuir a origem das categorias éticas fundamentais da 'vontade' à Platão, Williams endossa uma crítica mais contunde à 'moralidade descaracterizada' (characterless) da psicologia platônica da República. Para Williams, a psicologia moral platônica antecipa a noção kantiana de 'autonomia' moral marcada pela prioridade da razão moral crítica independente da influência de fatores externos sociais e culturais. No último capítulo, Williams (Ibid., p. 158-9) esclarece melhor sua associação da psicologia platônica com a psicologia moderna da vontade de Kant:

[The Kantian ideal] presupposes a Platonic idea of the moral self as characterless (...). If the aspiration makes sense, then the criticising self can be separated from everything that a person contingently is-in itself, the criticising self is simply the perspective of reason or morality.

\footnotetext{
${ }^{313}$ Com efeito, a crítica de Wiliams à psicologia eticizada de Platão contém diversos pressupostos nem sempre claramente explicitados. Para isso, ver IRWIN, 1994, p. 52: "To show that Plato's psychology is ethicized, Williams appeals to the fact that rational part of the soul is not concerned merely with instrumental reasoning about the satisfaction of non-rational desires. But this feature of the rational part is not enough to show that the rational part is to be defined in essentially ethical terms, in the minimally other-regarding sense."
} 
A psicologia platônica apresenta a capacidade de 'crítica total' (total critique) da razão moral. Nessa perspectiva, o 'eu' moral autêntico exibe a capacidade da razão moral crítica isolada de quaisquer outras influências externas de sua formação moral. O ideal platônico da 'crítica total' inspiraria, então, o ideal moderno kantiano de 'autonomia' moral. Segundo Williams, o paradigma do ideal platônico da razão crítica é ilustrado no Desafio da Justiça de Gláucon (Ibid., p. 98100). Diante do experimento comparativo do 'perfeito justo' e do 'perfeito injusto', Platão estipula a autoridade absoluta da determinação racional sobre a justiça independente das influências externas na formação moral. Por isso, o 'eu moral' platônico abre o caminho para a formação da autonomia moral de Kant. A concepção autonomia da razão moral exclui inteiramente a dimensão do 'outro internalizado' da formação moral do agente. Por isso, Williams afirma que Platão e Kant estão envolvidos com a mesma concepção do 'eu moral descaracterizado' (moral self characterless). Em linhas gerais, o 'eu moral descaracterizado' se expressa na eliminação do papel dos 'outros' e do meio social na formação do caráter moral ${ }^{314}$. A psicologia eticizada exclui inteiramente o papel do 'outro internalizado' em favor da autonomia absoluta da razão crítica (Ibid., p. 98-81). Por isso, a psicologia eticizada de Platão forma as categorias éticas indispensáveis da psicologia da vontade moral em oposição à psicologia grega antiga da vergonha.

As considerações de Williams da psicologia eticizada mostram que a psicologia tripartite platônica inaugura a aplicação das categorias morais aos elementos internos da psicologia humana. A partir disso, é possível esclarecer o ponto de vista negativo de Williams acerca da psicologia moral platônica. No entanto, a suposta antecipação da psicologia moderna da vontade e a crítica ao 'eu moral' descaracterizado da psicologia platônica são extremamente controversas. Com efeito, críticos posteriores têm indicado que Williams ignora o papel crucial da educação moral e da vergonha na formação da psicologia moral da República e em outros diálogos platônicos ${ }^{315}$. Independentemente das críticas de Williams, o

\footnotetext{
${ }^{314}$ Sobre o eu moral descaracterizado, ver WILLIAMS, 1993 p. 95: "The conception of the moral self as characterless leaves only a limited positive role to other people in one's moral life. Their reactions should not influence one's moral conclusions, except by assisting reason or illumination. If what others will think of me plays an essential role in my moral determinations, then morality is thought to have skidded into the heteronomy (...)."

315 Ver as resenhas críticas de IRWIN, 1994; STRIKER, 1993; WOODRUFF, 1996. Em especial, Woodruff chama atenção para o grande repertório de diálogos em que a vergonha moral cumpre um papel imprescindível na condução do exame argumentativo entre os interlocutores. Sobre os
} 
reconhecimento do pioneirismo de Platão no campo da psicologia moral é seguramente incontestável.

A teoria tripartite da alma de República apresenta efetivamente os elementos fundamentais da psicologia moral. A relação hierárquica das partes da alma envolve critérios morais indispensáveis. No entanto, a relação entre as categorias morais da psicologia da vontade e a psicologia moral platônica não é tão simples. Em Shame and Necessity, Williams lança essa hipótese ousada dentro de sua crítica geral aos princípios da psicologia moral derivada de Kant. Diante da inexistência da 'vontade' na linguagem grega, cabe indagarmos então: que tipo de parte da alma tripartite da República seria correspondente à categoria da 'vontade'? Seria o epithymetikón, o logistikón ou o thymoeidés? Para considerarmos essa hipótese, precisamos averiguar novamente a natureza das partes da alma e compará-las com a noção moderna da vontade.

A partir do quadro completo da psicologia platônica, é realmente difícil enquadrar a 'vontade' a qualquer das partes da alma. Em linhas gerais, a 'vontade' concerne uma faculdade intermediária entre a deliberação racional e outros impulsos irracionais, isto é, emoções e apetites, responsável pelo papel executivo da determinação racional. Por essa classificação, o epithymetikón claramente se apresenta do lado oposto da 'vontade' racional atendendo pelos apetites corporais e a inclinação à riqueza. Dessa forma, resta saber se o logistikón ou thymoeidés estariam aptos ao posto da 'vontade'. Ao esclarecermos isso, poderemos esclarecer provavelmente a relação entre a akrasia antiga e fraqueza de vontade.

Mesmo o logistikón e thymoeidés da psicologia tripartite não parecem atender aos requisitos necessários da 'vontade' moral moderna. Dentro desses parâmetros, seria condizente julgar que o thymoeidés estaria mais apto a cumprir o papel da 'vontade' do que o logistikón justamente por ser 'auxiliar da parte racional' (440e-441a).

Em uma proposta alternativa da psicologia platônica, Bobonich (2002, p. 273-282) sustenta que não há necessidade da presença de um elemento 'intermediário' da vontade na estrutura tripartite da alma. Dentro da psicologia moderna da vontade, a ausência da 'vontade' deixaria o agente totalmente passivo diante das diferentes forças motivacionais das partes da alma. No entanto, a 
psicologia tripartite platônica se expressa diretamente nas crenças e desejos do agente sem necessidade de qualquer elemento intermediário na explicação da ação humana. A partir disso, Bobonich (Ibid., p. 277) ressalta que a ausência de 'uma forte concepção da vontade' em Platão gera uma perplexidade filosófica diferente sobre o conflito da alma:

Plato's worry is not that we have not made room for the capacity to choose to act against our rational desire. His worry is, rather, that in certain cases my rational desire for what I judge overall best is weaker than one of my non-rational emotions or desires. If we accept that I shall try to do whatever I am most strongly motivated to do, it then seems inevitable that I shall act on the non-rational desire or emotion. (itálicos do autor)

Dessa forma, o conflito interno da alma em Platão não corresponde ao problema moderno da 'ação contrária ao nosso desejo racional'. Nesse aspecto, o problema da fraqueza da vontade recairia na incapacidade da 'vontade' de realizar a ação conforme o desejo racional. Na verdade, o que causa perplexidade a Platão é justamente a possibilidade do desejo racional ser mais fraco do que os outros desejos irracionais, sejam emoções ou apetites. Por si mesma, a ação conforme os desejos ou emoções irracionais não gera problema filosófico algum. Dessa forma, o problema filosófico platônico genuíno do conflito interno da alma depende intrinsecamente da força motivacional independente das partes da alma ${ }^{316}$. De fato, isso ressalta que a psicologia tripartite da República tal como a psicologia grega antiga dispensa integralmente o papel da 'vontade' moral. Além disso, a psicologia moderna da vontade (inspirada em Kant) está relacionado a capacidade interna do 'poder da pura escolha racional' enquanto a razão prática platônica é caracterizada pelo juízo do valor objetivo do bem humano ${ }^{317}$. Na realidade, a consistência da psicologia tripartite está na dupla capacidade inerente das partes da alma: (1) em seu papel no juízo avaliativo de seus objetos naturais do desejo no campo epistemológico e (2) em seu papel executivo no campo da ação moral.

\footnotetext{
${ }^{316}$ Em Plato's Utopia Recast, Bobonich dedica um capítulo inteiro de sua obra à relação da psicologia platônica e o problema da akrasia na República e nas Leis (cap. 4). Para Bobonich, fundamentalmente a psicologia moral das Leis é melhor do que a psicologia tripartite da República simplesmente porque não depende da concepção inconsistente de 'partes agente'. Na sequência, mostraremos que a psicologia tripartite da República não incorre nos problemas normalmente atribuídos às suas partes-agente.

${ }^{317}$ Com efeito, o próprio Bobonich (2002, p. 200-1) reconhece essa diferença fundamental entre a boa vontade de Kant e a psicologia tripartite. Nesse contexto, a psicologia platônica está plenamente interligada com a psicologia grega.
} 
Ao contrário do que alega Williams, a psicologia platônica está plenamente alinhada à psicologia grega da vergonha. $\mathrm{O}$ próprio thymoeidés representa uma aspiração genuína em relação ao 'olhar alheio' e oferece o paradigma fundamental do 'outro internalizado' no modelo da alma tripartite. A ausência da 'vontade' moral ou de uma 'intervenção' psíquica direta não transforma o agente em um mero receptor passivo das diferentes motivações da alma. Mais adiante, precisaremos analisar quais as implicações da teoria tripartite para o problema da unidade do agente. Por ora, é fundamental notar que a psicologia tripartite visa explicar o conflito interno da alma e não se constitui na formulação geral do problema da fraqueza de vontade moderna.

Em termos estritos, a akrasia antiga e fraqueza de vontade descrevem fenômenos psicologicamente distintos. De um lado, a akrasia antiga contempla o fenômeno em que 'a razão é mais fraca do que as motivações irracionais'. De outro, a fraqueza de vontade expressa a 'ação contrária à deliberação racional' diante da falha da vontade em cumprir a determinação moral da razão. Dessa forma, a divisão tripartite da alma na República surgiu justamente para explicar uma falha derivada de um conflito interno de motivações. A partir disso, a teoria tripartite apresenta uma psicologia interativa e dinâmica das distintas partes da alma. No entanto, precisamos então compreender como essa relação entre as partes da alma determina a inclinação 'natural' de cada uma de suas partes.

O quadro completo da teoria tripartite parece admitir que as partes da alma podem ser desviadas de sua inclinação 'natural'. Ao que tudo indica, isso se deve ao fato de há efetivamente dois modelos psicológicos distintos da alma que proporcionam diferentes relações entre as partes da alma. Em Rep. IX, Sócrates nos permite perceber que o exame psicológico da alma leva em conta dois gêneros psicológicos opostos:

Logo, quando toda a alma (apáses tês psýches) obedece à parte filosófica e não se revolta contra nenhum parte (mè stasiadzoúses hekástoi tôi mérei), é-lhe possível cumprir em tudo o que lhe cabe e ser justa, e colher cada uma os prazeres que lhe são próprios (tàs hedonàs tàs heatoû hékaston) (...) Mas quando uma das outras duas partes que domina (tôn hetéron ti kratései), não lhe é dado encontrar o prazer que lhe é próprio, e de mais a mais, força (anankázein) as outras partes a ir em busca de um prazer que lhe é alheio e não verdadeiro (tà alotrían kaì mè alethê hedonèn diókein). (586e-587a) 
Nessa passagem, Sócrates pode enfim demonstrar que o 'perfeito justo' e o 'perfeito injusto' correspondem a dois estados psicológicos divergentes, o modelo da alma justa e o modelo da alma injusta. Com efeito, notamos que a condição da alma influencia particularmente nas relações dinâmicas entre as partes da alma e suas respectivas inclinações aos objetos de desejos.

A psicologia platônica não se restringe às motivações 'naturais' da alma contempladas na melhor condição da alma, a da alma justa. Se fosse assim, bastaria o modelo fixo da alma baseado nos princípios da teoria tripartite da alma de Rep. IV. Em Rep. IX, Sócrates efetivamente se refere aos prazeres "específicos (idía)" de cada parte da alma (580d). De fato, os prazeres naturais específicos das três partes lhes conferem "o melhor e o mais apropriado (tò béltiston kaì oikeiótaton)" sob o comando da parte racional (586d-e). Nesse contexto, os prazeres da parte apetitiva e impetuosa devem estar "seguindo o conhecimento e a razão (têi epistéme kaì lógoi)" de acordo com a "condução do conhecimento moral (tôi phrónimon exêgetai)". No entanto, o exame dos regimes e almas injustas de Rep. VIII-IX nos oferece um quadro diferente da psicologia do homem injusto. Na alma injusta, o domínio ilegítimo de uma das partes sobre as outras instaura o 'conflito' (stásis) e o desvio de sua inclinação 'natural' pelos objetos de desejos. Por isso, as motivações humanas são desviadas de seu 'prazer próprio' de seu objeto natural de desejo ao 'prazer alheio' proveniente das outras partes da alma. Em vista disso, os dois modelos da alma derivam das diferentes relações entre as partes da alma.

Os modelos da alma justa e a alma injusta proporcionam diferentes relações interativas entre as partes da alma: (a) dentro da alma justa, as partes interagem "pela persuasão (peithô̂)" e "por meio do discurso (dià lógon)" com base na formação cultural e educativa adequada, isto é, na mousiké e na paideía (cf. 411d; 441e-442a). Nesse primeiro modelo, as partes da alma alcançam a "harmonia (symphôniai)" e entram em "concordância (homodoxôsi)" sobre o domínio legítimo da parte racional (cf. 442d; 411e-412a); (b) dentro da alma injusta, as partes interagem "pela força (bíai)" ou 'violência' promovendo um "comportamento rústico (agrióteti)" e animalesco marcado pela falta da formação educacional adequada da mousiké e paideía (Cf. 411d-e; 548b). Nesse segundo modelo, há uma “desarmonia (arruthumías)” entre as partes da alma marcada pelo 'conflito' (stásis) interno do homem injusto, cuja conduta é pautada "pela necessidade e medo 
(anánke kaì phóboi)" (cf. 411c-d; 554c-d). Com base nessas indicações, é possível determinar uma dinâmica interativa entre as partes da alma.

No plano da República, esses dois modelos representam estados psicológicos diferentes: o modelo da alma justa oferece a alma tripartite harmônica enquanto o modelo da alma injusta estabelece a corrupção moral e a subdivisão da alma tripartite. Com base no primeiro modelo, constatou-se que a 'persuasão’ pelo lógos estabelece uma comunicação cognitiva da parte racional com as outras partes 'irracionais' da alma, ou seja, a impetuosa e a apetitiva. Nessa perspectiva, Moline (1978, p. 22) indica que a parte racional é capaz de persuadir as outras partes por seu conhecimento privilegiado: "by possessing a potential for deep psychological understanding of the other parts and a persuasive power predicated upon that understanding (...)”. O conhecimento de cada parte da alma constitui a satisfação apropriada da inclinação de seus respectivos objetos naturais de desejo ${ }^{318}$. Com efeito, isso condiz com o modelo da alma justa, o modelo caracterizado pelo domínio da parte racional sobre as outras partes inferiores da alma. No entanto, o que ocorre com o modelo da alma injusta em que a parte racional não está mais sob controle das outras partes da alma?

Como observamos, a falta do domínio racional acarreta também a subversão das 'inclinações naturais' da alma (442a-b). Nessa segunda condição da alma, as motivações humanas não respondem à 'natureza' ou ao critério epistemológico da razão: (a) são reconduzidas ao prazer exclusivo de uma das partes da alma; (b) são desviadas de seu prazer 'natural' com base na falta de critério epistemológico característico do domínio absoluto da parte racional da alma. Sob o domínio da parte apetitiva, o conflito da alma acarretará uma nova configuração das diferentes motivações não mais orientadas pela razão à sua própria natureza mas restringidas pela compulsão aos objetos de desejo alheios.

A partir dessas indicações, tem se ressaltado reiteradamente que a própria República expande as limitações da teoria tripartite da alma presente em Rep. IV ${ }^{319}$. Seguindo os parâmetros estabelecidos anteriormente, buscamos mostrar que a psicologia platônica leva em conta sobretudo o estado psicológico moral da alma

\footnotetext{
${ }^{318}$ Para essa inclinação 'natural' dos desejos ver REEVE, 1988, p. 142-143; BOBOBNICH, 2002, p. 243-245.

319 Para uma interpretação mais restritiva da teoria tripartite ver KAMTAKEAR, 2008, p. 148-149; Idem, 2017, p. 150-152.
} 
humana, a condição da alma justa e a condição da alma injusta. Com isso, a teoria tripartite da alma inicial apresenta uma psicologia moral seguindo as inclinações 'naturais' do modelo da alma justa. Contudo, o exame do modelo da alma injusta nos permite observar que as inclinações naturais podem ser subvertidas com a subdivisão da parte apetitiva.

Sob esse ângulo, a psicologia platônica apresenta então estados psicológicos da alma segundo modelos divergentes. Por conta disso, podemos entender melhor qual o papel da psicologia tripartite diante dos casos de conflitos psicológicos da República. Sobretudo, isso nos fornecerá ferramentas para investigar apropriadamente qual o estatuto da akrasia na República.

Ao longo da República, somos apresentados a diversos casos de conflito psicológico e referências ao vocabulário típico da akrasia $^{320}$. Em Rep. IV, o conflito motivacional e o suposto caso de akrasia de Leôncio formam a peça fundamental na demonstração da teoria tripartite da alma. Em verdade, a teoria tripartite da alma de Platão visa dar conta, principalmente, do conflito interno da alma em geral e não do fenômeno específico da akrasia. Por causa desse enfoque abrangente, todavia, a teoria tripartite da alma desempenha um papel central na descrição do conflito interno da akrasia A presença ostensiva do vocabulário do conflito interno na República nos leva a reconhecer a uma discussão relevante para o esclarecimento da irracionalidade do fenômeno. Com base nisso, mostraremos que a complexa teoria tripartite da República fornece as bases fundamentais para fornecer uma explicação mais positiva e consistente do fenômeno.

\section{4}

\section{O conflito interno da alma e a akrasia na República}

O fenômeno da akrasia não é apresentado e nem retratado como um problema filosófico destacado na República tal como no Protágoras. Apesar disso, o vocabulário do conflito interno da alma está ostensivamente presente ao longo da

\footnotetext{
${ }^{320}$ Como mencionamos anteriormente, o único registro da palavra em seu sentido clássico preciso é encontrado na Ética a Nicômaco. Entretanto, isso não impede de encontrarmos o vocabulário bélico da akrasia em Platão e, muito menos, de já localizarmos uma discussão sobre a akrasia em seus diálogos. Em relação ao Protágoras, não resta dúvidas de que acompanhamos ali a primeira discussão filosófica sobre a akrasia. Em relação à República, como veremos, o fenômeno da akrasia jamais adquire o estatuto de um problema filosófico claramente destacado do tópico central do conflito interno da alma e a corrupção moral da alma injusta ao longo do diálogo.
} 
República. Mesmo assim, a corrente desenvolmimentista insiste em uma posição relativamente unânime: a teoria tripartite da alma em República é apresentada justamente para explicar o conflito interno da akrasia contra a negação socrática do fenômeno no Protágoras.

O foco primordial da psicologia tripartite sobre o conflito psicológico da alma abre um claro precedente ao conflito interno da akrasia. Em face disso, mostraremos que há exemplos típicos da akrasia dispersos na República, como o caso de Leôncio e os casos posteriores do homem timocrático e do homem oligárquico no exame das almas injustas de Rep. VIII-IX. Ao mesmo tempo, defenderemos não há sinais explícitos do abandono da tese socrática da 'ignorância' do Protágoras na República. Na verdade, Sócrates se apropria da noção popular do conflito interno de forças motivacionais da akrasia e a substitui por uma definição da ignorância inerente ao 'vício moral' (kakía). Com isso, a República rejeita a concepção simples do conflito de forças da akrasia tradicional em nome de um conflito interno expresso em termos de ignorância.

Dentro dessa nossa hipótese interpretativa, Platão não muda substancialmente de posição do Protágoras à República. Em ambos os diálogos, Sócrates defende a mesma tese de que a akrasia é ignorância. De fato, o que se altera entre ambos os diálogos é a descrição efetiva do tipo de ignorância do agente amparadas em teorias psicológicas diametralmente distintas. Para comprovarmos isso, precisamos nos voltar primeiramente para a apropriação socrática do vocabulário popular da akrasia na República.

A ausência de uma formulação clara do problema da akrasia na República causa um contraste com o Protágoras. Ao contrário do diálogo anterior, a República jamais aborda o fenômeno da akrasia em termos explícitos e claramente delimitados. De um lado, o vocabulário da akrasia da República está ainda distante do sentido clássico preciso conferido ao termo na Ética de Aristóteles ${ }^{321}$. Até mesmo nas Leis, um dos diálogos tardios do pensamento platônico, o termo akrasia surge mais claramente associado à resistência diante dos diversos impulsos irracionais ${ }^{322}$. Em todo caso, a noção popular da akrasia na República está

\footnotetext{
${ }^{321}$ Cf. PRICE, 1995, p. 91-92.

${ }^{322}$ Para maiores referências ao termo akrasia em Leis, ver BOBONICH, 2002, p. 541 n. 84 . Como indicamos anteriormente, Bobonich sustenta que o diálogo Leis apresenta uma teoria psicológica mais consistente que a República para lidar com o conflito psicológico da akrasia. Em virtude de nosso foco atual, não teremos como investigar o problema da akrasia nas Leis.
} 
intrinsecamente relacionada à discussão geral do conflito interno das variadas formas de vício moral $(k a k i ́ a)^{323}$. Diante disso, é oportuno retornamos à definição exterior da temperança (sophrosýne) de Rep. IV em que é colocado em xeque o vocabulário do conflito interno da alma.

A suspeita inerente ao vocabulário da akrasia tradicional surge justamente na busca da definição externa da temperança (sophrosýne) de Rep. IV (430e-432b). O exame socrático se dirige à definição tradicional da sophrosýne, de onde advém a expressão 'ser senhor de si' (kreítto autô̂), como um tipo de "autodomínio (enkráteia) de certos prazeres e desejos" (430e). Diante disso, Sócrates manifesta perplexidade em relação à noção tradicional de sophrosýne:

\begin{abstract}
Ora, a expressão 'ser senhor de si' não é ridícula? (...) Mas esta expressão parece-me significar que na alma do homem há como que uma parte melhor (tò béltion) e outra pior (tò cheîron); quando a melhor por natureza domina (enkratès) a pior, chamase isso a 'senhor de si' (tò kreítto autoû) (...) porém, quando devido a uma má educação ou companhia, a parte melhor (...) é dominada (kratethêi) pela superabundância da pior (...) chama ao homem que se encontra nessa situação escravo de si mesmo e intemperante (hétto heautô̂ kaì akólaston). (430e-431b)
\end{abstract}

Nessa passagem, observamos o uso ostensivo do vocabulário do conflito interno da alma na definição tradicional da sophrosýne. Em particular, devemos salientar os seguintes termos, as expressões tò kreítton autoû (senhor de si) e hétton autoû (escravo de si), os termos krátos (poder, domínio) e, principalmente, enkrateia, palavra assimilada posteriormente ao sentido clássico de 'autocontrole' em oposição à akrasia na Ética aristotélica.

A apropriação socrática do vocabulário da akrasia tradicional está relacionada ao par de opostos da virtude sophrosýne e o vício correlato akolasía (intemperança) $^{324}$. De um lado, o ‘domínio de si’ (kreítton autoû) expressa o domínio da melhor parte da alma sobre a parte inferior onde estão os apetites e os

\footnotetext{
${ }^{323}$ Conforme enfatiza Kahn (1996, 255), a akrasia na República está sempre subordinada à máxima da maldade involuntária: "Aside from the Leontius passage, Plato in the Republic avoids describing a situation where someone can judge correctly but act bad nevertheless. His concern is not with moral weakness but with alternative principles that can rule in the psyche. Perhaps he neglects cases of weakness because such cases might seem to tell against his claim that vice is never voluntary."

${ }^{324}$ Ao contrário do Protágoras, o termo sophrosýne na República surge muito mais em referência ao sentido clássico de resistência aos prazeres e dores do que em referência ao sentido menos usual de domínio intelectual. Por conta disso, optamos por manter seu sentido clássico nessa passagem apesar de estarmos cientes de que qualquer tradução implica em uma notável perda do escopo semântico do termo grego original.
} 
prazeres. De outro lado, a 'submissão de si' (hétton autô̂) reflete o controle da parte inferior sobre a parte racional superior da alma.

Em especial, há uma referência mais explícita ao termo 'akrasia' na República surge quando Sócrates alega que o tirano é "incapaz de dominar a si mesmo" (heautô̂ akrátor) porque se comporta "como uma pessoa doente e sem domínio sobre si mesmo (akrátori heautoû), forçada a passar a vida a competir em força física" (579c-d). Sob esse aspecto, a relação do descontrole interno da alma tirânica com a doença do corpo reflete mais o estado passivo do homem intemperante do que propriamente o conflito interno da akrasia tradicional. Como salienta Wilburn (2014), a apropriação platônica da noção popular da akrasia antecipa a noção posterior de predomínio psíquico da parte apetitiva na alma ${ }^{325}$. Sob outros parâmetros, a ressignificação do conflito interno da akrasia decorre do foco primordial da República sobre a classificação do caráter moral do agente antes mesmo de uma teoria psicológica da ação moral.

A ressignificação do vocabulário da akrasia tradicional estabelece três elementos primordiais: (1) a distinção da parte superior racional e a parte inferior irracional da alma; (2) a descrição do fenômeno da 'submissão a si mesmo' em função da analogia do predomínio da parte inferior apetitiva sobre a parte racional superior; (3) o estado de vício moral (kakía) da alma na classificação do fenômeno em vista do tipo de predomínio da parte inferior na alma. De certa maneira, essa reavaliação da akrasia tradicional antecipa a condição de corrupção da alma explorada no exame das almas injustas de Rep. VIII-IX. Em todo caso, Platão também mantém seu foco no exame da psicologia humana e a demonstração da teoria tripartite da alma. Ao longo da demonstração da teoria tripartite, o vocabulário da akasia reaparece no emblemático caso de Leôncio.

Como vimos anteriormente, a teoria tripartite da alma estabelece três partes da alma em Rep. IV, a parte racional (logistikón), a parte apetitiva (epithymetikón) e a parte impetuosa (thymoeidés). Durante a demonstração da alma tripartite, o foco de Sócrates recai sobre o paradigma do conflito interno (stásis) com o objetivo de

\footnotetext{
${ }^{325}$ Cf. WILBURN, 2014, p. 66: "In this way Plato does what he often does: he appropriates a popular notion and reworks it for his own philosophical purposes. Significantly, the phrases 'stronger' and 'weaker' than oneself disappear from the text following Socrates' analysis of them at 430e-431d. Having recast the popular language of akrasia in terms of psychic rule, it is the latter that becomes the focus of the text." Para a apropriação platônico da akrasia tradicional, ver também KAHN, 1996, p. 254-5; PRICE, 1995, p. 91-93; FERRARI, 2007, p. 119; SHIELDS, 2007, p. 78-79.
} 
distinguir cada uma das partes da alma (Cf. 440b; 440e; 442d). A divisão preliminar da parte apetitiva e a parte impetuosa ganha grande destaque por causa de seu conflito inerente com a parte racional da alma. Em 439e-440c, Sócrates relata o controverso caso de Leôncio que se depara de súbito com um carrasco ao lado de um amontoado de cadáveres:

teve um desejo de os ver (ideîn epithymô̂), ao mesmo tempo em que isso lhe era insuportável e se desviava; durante algum tempo lutou consigo mesmo (machoitó) e velou o rosto; por fim, dominado pelo desejo (kratoúmenos hypò tês epithymías), abriu muito os olhos e correu em direção aos cadáveres (...) Ora, já em muitas outras ocasiões sentimos que, quando os desejos forçam o homem contra sua razão (parà tòn logismòn), ele (...) se irrita com aquilo que dentro de si, o força (tôi biazoménoi), e que, como se houvesse dois contendores em luta (hósper duoîn stasiazóntoin), o ímpeto se torna aliado da sua razão (sýmmachon tôi lógoi). (439e-440b)

O destaque do caso de Leôncio em relação a outros casos de conflito interno de Rep. IV está estreitamente vinculado ao problema da akrasia. Para a corrente desenvolminentista, o caso de Leôncio representa uma prova contundente do reconhecimento da akrasia tradicional em vista da nova teoria tripartite da alma na República ${ }^{326}$.

A linguagem utilizada certamente nos dá a impressão de que estamos diante de um exemplar típico da akrasia tradicional. $\mathrm{Na}$ passagem mencionada, observamos alguns termos que evocam a akrasia tradicional: 1) as reiteradas referências à luta interna da alma (machoitó, polemeîn, stásis) e o paradigma da alma como centro de embate de dois contendores internos; 2) o domínio (kratoúmenos) e a força (biazontaí) dos desejos irracionais em sentido oposto à razão (parà tòn logismón), levando em conta que o thymós 'combate junto com' (sýmmachon) à razão. Diante da estrutura tripartite da alma, podemos considerar que a parte apetitiva se inclina à contemplação dos cadáveres enquanto a parte impetuosa e a parte racional se desviam, presumivelmente, pela vergonha da atitude repulsiva; 3) no caso específico de Leôncio, a escolha decisiva da contemplação vergonhosa dos cadáveres marca a submissão da razão aos apetites, ou melhor, a motivação superior da parte apetitiva sobre a parte racional da alma.

\footnotetext{
${ }^{326}$ Para esse pressuposto desenvolminentista do tema da akrasia em Platão, ver BRICKHOUSE \& SMITH, 2010, p. 16; COOPER, 1984, p. 128; GOSLING, 1990, p. 20-24; LESSES, 1984, p. 148; REEVE, 1988, p. 134; KAHN, 1996, p. 254-5; IRWIN, 1995, p. 192; BOBONICH, 2002, cap. 3.
} 
Há uma ampla controvérsia interpretativa sobre a anedota popular antiga da atração de Leôncio por cadáveres. A partir dessa sugestão tradicional, o impulso de Leôncio estaria ligado a um impulso sexual por cadáveres ${ }^{327}$. Nesses termos, o caso de Leôncio corre o risco de ser assimilado a um tipo de necrofilia por cadáveres, ou seja, uma forma de compulsão psicológica. No entanto, isso é incompatível com a análise de Sócrates sobre o combate interno dentro de Leôncio (se fosse um caso de necrofilia, o impulso presumivelmente seria apenas um desejo irresistível do agente sem constituir necessariamente um conflito interno dos desejos). Além disso, a referência da anedota é demasiado obscura para tirarmos conclusões definitivas do estranho impulso de Leôncio por cadáveres. Certamente, a classificação preliminar dos apetites 'básicos' em torno de desejos corporais contribui para uma caracterização impulsiva de seu caráter moral.

Em uma hipótese alternativa mais consistente, o impulso de Leôncio está relacionado a uma forma de adrenalina diante do risco da morte ou da violência da cena grotesca ${ }^{328}$. Para todos os efeitos, o caso de Leôncio é apresentado para exibir um claro caso de conflito interno em que a razão é vencida pelos impulsos irracionais. Nesses termos, portanto, estamos diante de um exemplo típico da akrasia tradicional.

De qualquer modo, reconhecer o caso de Leôncio como um exemplo de akrasia não significa afirmar que a teoria tripartite da alma oferece uma descrição explicativa da akrasia tradicional. Por um lado, é particularmente difícil ignorar a singularidade do caso de Leôncio diante dos outros conflitos internos mencionados na demonstração da alma tripartite de Rep. IV. A completa ausência de uma

\footnotetext{
${ }^{327}$ Para as referências obscuras da passagem de Leôncio ver ADAM, 1902, p. 255. Com efeito, Annas e Irwin relatam uma anedota antiga que associa o impulso de Leôncio a uma espécie de impulso sexual por 'jovens pálidos como cadáveres' (cf. ANNAS, 1981, p. 129; IRWIN, 1995, p. 382 n. 23). Seguindo essas indicações, seríamos levados a considerar o impulso de Leôncio como uma forma de necrofilia que, em última análise, acarretaria uma espécie de compulsão. No entanto, mesmo Irwin manifesta ceticismo sobre a possibilidade de determinarmos com certeza absoluta uma interpretação incontestável dessa anedota.

${ }^{328}$ Como salienta Cooper (1984, p. 11): "it seems certain (unless we are to understand Leontius' attrac tion as straightforwardly sexual) that whatever it is about dead bodies that so interests him has something to do with some way in which he is thinking of them - some thrill-inducing contrast between living, animated human beings and these limp and broken figures (...)." Ver também FERRARI, 2007, p. 182: "The transmitted text neither contains Leontius' name nor makes the accusation described, but must be extensively emended to do so; and even if the emendation were correct, the joke might make better sense as a consequence of his gawking at corpses than as an explanation of it." Por vezes, sentimos horror ao nos depararmos com cadáveres em nossa experiência cotidiana e, simultaneamente, sentimos um estranho impulso a continuar olhando em direção a eles.
} 
discussão mais específica do fenômeno reforça a suspeita de que o problema da akrasia não está no horizonte da teoria tripartite da alma. Por outro lado, a apropriação platônica do vocabulário do conflito interno da alma nos dá a impressão de que Sócrates está inclinado a reformular a concepção da akrasia tradicional. Nesse sentido, a Rep. IV isolada não fornece nenhuma evidência concreta para explicar o fenômeno da akrasia em si mesmo.

Diante dessas indicações isoladas, não podemos chegar a qualquer conclusão definitiva sobre a posição platônica da akrasia na República. Em busca de indicações mais concretas, é necessário primeiro definir mais claramente o que constitui um conflito interno da alma dentro dos parâmetros da psicologia tripartite. O interesse central no conflito interior da alma de Rep. IV era exclusivamente voltado à demonstração da teoria tripartite da alma levando em conta o modelo harmônico da alma justa. O aprofundamento da análise psicológica de Rep. VIIIIX coloca em pauta o conflito interno dentro das almas injustas. Durante essa nova análise, vislumbramos dois modelos descritivos do conflito interno da alma, o Modelo Hidráulico e o Modelo da Ignorância.

O Modelo Hidráulico e o Modelo da Ignorância exibem paradigmas descritivos aparentemente incompatíveis da alma injusta. De acordo com a tradição interpretativa, o primeiro modelo expressa o princípio da força relativa dos desejos, enquanto o segundo modelo reflete o princípio da avaliação valorativa ${ }^{329}$. Afinal, qual dos dois modelos Platão teria adotado definitivamente na descrição do conflito interno da alma? Tal controvérsia é essencial para determinar a posição platônica da akrasia na República diante da negação socrática da akrasia no Protágoras. Se adotar o Modelo Hidráulico, Platão estaria supostamente assumindo uma psicologia moral compatível com a akrasia tradicional. Se adotar o Modelo da Ignorância, isso lhe comprometeria com uma posição mais alinhada à negação da akrasia do Protágoras. Para definirmos melhor a posição platônica da República, devemos analisar o modelo Hidráulico apresentado em Rep. VI.

A imagem da torrente desviada de Rep.VI ilustra a força da inclinação dos desejos e inspira o Modelo Hidráulico. Em 485d-e, Sócrates expõe em detalhes a imagem do conflito da alma como uma torrente desviada:

\footnotetext{
${ }^{329}$ Para referências da presença dos dois modelos conflitantes em República, ver WILBURN, 2014,
} p. 72-73; BOBONICH, 2002, p. 236-237; PRICE, 1995, p. 52-5. 
quando os desejos se inclinam com violência para um só objeto (eis hén ti hai epithymíai sphódra répousin), sabemos de algum modo, se tornam mais fracos (asthenésterai) para o resto, como se fossem uma torrente desviada para aquele lado (hósper reûma ekeîse apocheteuménon) (...) Se a corrente for em direção às ciências ou atividades dessa espécie, julgo que não cuidará senão do prazer da alma em si (perì tèn tês psychês autês kath'autèn), e deixará o que vem através do corpo (dia toû sómatos), se for um filósofo não fingido, mas autêntico. (485d-e)

A partir dessa ilustração, vislumbramos uma analogia entre a inclinação dos desejos da alma e a imagem da torrente desviada. Em princípio, podemos destacar os seguintes aspectos relacionados ao conflito dos desejos. Em primeiro lugar, a inclinação dos desejos pode se deslocar de um objeto de desejo $x$ a um objeto de desejo y, "como uma torrente desviada". Com base no princípio do conflito (PC), podemos considerar o seguinte conflito interno: a parte racional considera que $x$ é melhor $y$, gerando a preferência racional de $x$, enquanto a parte apetitiva gera uma inclinação contrária por $y$. Nos termos do Modelo Hidráulico, o agente escolherá em função do desejo mais forte contra o desejo mais fraco independentemente de sua avaliação valorativa ${ }^{330}$. Em segundo lugar, a inclinação violenta do desejo a um objeto determinado torna, proporcionalmente, a inclinação aos outros objetos "mais fraca (asthenésterai)". O termo grego asthenés, relacionado posteriormente à um tipo clássico da akrasia aristotélica, salienta aqui o modelo da força relativa dos desejos. Nesse caso específico, a força superior do desejo racional sobrepõe os desejos fracos 'provenientes do corpo' (dià toû sómatos). Em terceiro lugar, assim como o desejo racional submete os desejos corporais, o inverso também pode ocorrer com o desejo racional. No caso inverso, o desejo racional é submetido pela força superior da parte apetitiva. Nesses termos, obteríamos aparentemente a descrição tradicional da akrasia, com base na psicologia tripartite da República.

A linguagem do Modelo Hidráulico perpassa diversas passagens da República, o que parece confirmar a adesão da psicologia platônica à força relativa dos desejos (Cf. 439b-d; 521d 533d; 550e). A presença do princípio da força relativa dos desejos na alma tripartite fornece legitimidade à akrasia tradicional.

\footnotetext{
${ }^{330}$ Para essa interpretação da força relativa dos desejos na psicologia da República, ver BOBONICH, 2002, p.240-242. Ver também SANTAS, 1979, p. 209-214; WATSON,1977, p. 326-329. Em Rep. VI, Sócrates se preocupa com a distinção da natureza e das inclinações distintas do filósofo em relação aos outros cidadãos da Cidade Ideal. Por isso, a investigação relaciona a distinção dos objetos de conhecimento de forma estreita aos objetos naturais de desejos humano. A certa altura, Sócrates inclusive se refere ao desejo universal humano ao bem e a opinião variada sobre o que é o bem (505d-e).
} 
Sob esse ângulo, a força superior do desejo pode determinar a ação independentemente da avaliação valorativa da parte racional dirigida à avaliação do melhor curso de ação moral. Pelos termos da akrasia tradicional, o desejo racional do melhor curso de ação pode ser submetido pelas inclinações da parte impetuosa ou da parte apetitiva da alma.

Como vimos anteriormente, a psicologia tripartite da República representa cada parte da alma de acordo com suas próprias crenças, motivações e desejos do bem. A psicologia tripartite da República permite explicar de forma mais consistente o conflito interno da akrasia sem recorrer a impulsos absolutamente cegos. No enanto, o Modelo Hidráulico da República entra em confronto com a posição socrática do Protágoras. Em face disso, a corrente desenvolvimentista declara o rompimento definitivo de Platão com a negação socrática da akrasia do Protágoras. A psicologia tripartite platônica precisa rejeitar, então, o princípio da avaliação valorativa, isto é, o princípio segundo a qual a ação humana decorre do melhor juízo avaliativo do agente independente da força relativa dos desejos.

Entretanto, a República também apresenta o Modelo da Ignorância em aparente contraponto ao Modelo Hidráulico anterior. Dessa forma, Platão não parece ter abandonado completamente a tese socrática da 'ignorância' do fenômeno. No exame dos modos de vida e caracteres morais das almas injustas de Rep. VIII, Sócrates enfatiza o poder absoluto da parte apetitiva sobre o cálculo da parte racional.

O Modelo da Ignorância apresentado em Rep. VIII reflete o conflito interno do homem oligárquico. Por sua peculiar inclinação à riqueza, o seu estado interno resulta da deposição do elemento "amante da honra e impetuoso (tô̂ philotimían te kaì tò thymoeidés)" da sua alma, derivado do homem timocrático (553c cf. 548b549a). Em 553b-d, Sócrates descreve seu conflito interno em termos claramente vinculados à ignorância:

Não achas que uma pessoa assim sentará então no trono da sua alma o elemento apetitivo e amante da riqueza (tò epithymetikón te kaì philochrématon), fará dele grande rei e o cingirá com a tiara, braceletes e cimitarras? (...) Quanto ao elemento racional e o impetuoso (tò logistikón te kaì thymoeidès), julgo eu, senta-os no chão ao lado daquele rei, de um lado e de outro, como escravos (katadoulosámenos), sem os deixar calcular nem examinar (tò oudèn állo eâi logízesthai oudè skopeîn) outra coisa que não seja a maneira de transformar pouca riqueza em muita, nem admirar 
e honrar nada que não seja a riqueza e os ricos, e a não ambicionar outra coisa (philotimeîsthai med' eph' henì állo) além da posse de riqueza e tudo que a ela conduz. (553b-d)

Nessa passagem, a descrição da condição psicológica do oligárquico expõe o absoluto predomínio da parte apetitiva na alma. Dentro dessa imagem, cabe destacar os seguintes aspectos: (a) o elemento apetitivo (epithymetikón) assume o 'trono da alma' ou, literalmente, o domínio completo da alma e orienta as ações humanas em vista da satisfação exclusiva de seus desejos de amor à riqueza (philochrématon); (b) as outras partes da alma, as partes racional e impetuosa, permanecem em plena submissão, tal como escravos (katadoulasámenos), seguindo as orientações da parte apetitiva. Nesse contexto, o vocabulário do conflito interno da alma tem a função de estabelecer uma relação de domínio absoluto da parte apetitiva; (c) o domínio da parte apetitiva impõe uma restrição sobre as motivações das outras partes da alma. Se a parte racional é impedida de calcular ou examinar pelo bem de toda a alma, a parte impetuosa deve admirar e honrar somente o dinheiro em detrimento da virtude. Por meio dessas restrições, a parte apetitiva determina a inclinação da alma em vista do cálculo exclusivo da economia de riqueza e a da admiração do estilo de vida rico. Mais adiante, abordaremos em maiores detalhes a gênese do homem oligárquico em Rep. VIII. Em todo caso, Sócrates passa então da terminologia da força dos desejos ao vocabulário do predomínio da parte inferior sobre a alma em termos de ignorância.

Em Rep. III, Sócrates já havia reconhecido a intrínseca relação da ignorância e do vício moral em confronto com o conhecimento da virtude: "o vício não pode conhecer-se a si e à virtude, ao passo que com o tempo, a virtude (...) atingirá o conhecimento de si mesma e do vício (autês te kaì ponerías epistémen)." (409d-e). Diante do Modelo da Ignorância mencionado acima, podemos considerar que a contraposição do conhecimento e da ignorância novamente demarca os traços de caráter distintivos da virtude diante do vício moral.

A psicologia tripartite da República adere à uma descrição do conflito interno da alma em termos de ignorância. A aparente divergência do Protágoras e da República, na realidade, converge a um resultado comum: a descrição geral do conflito interno da alma como ignorância e a rejeição da akrasia tradicional. Diante dos diferentes modelos psicológicos, uma corrente interpretativa 'compatibilista' alega que o Modelo Hidráulico e o Modelo da Ignorância são assimilados na 
descrição platônica do conflito interno da alma. Em última instância, a República converge à mesma posição socrática da akrasia no Protágoras ${ }^{331}$. A psicologia tripartite da República oferece a Platão a oportunidade de explicar o conflito interno de motivações na alma sem abrir mão, necessariamente, da negação socrática da akrasia tradicional.

Ainda que ambos os diálogos apresentem a mesma tese substancial da ignorância do vicio moral, os diferentes contextos dialógicos do Protágoras e da República promovem modelos psicológicos diametralmente divergentes do conflito interno da alma.

Em primeiro lugar, é difícil ignorar a complexidade da psicologia tripartite da República em contraponto à unidade indivisível da alma no Protágoras. Sendo assim, é possível sustentar que o Protágoras e a República concordam sobre a classificação do caráter permanente do conflito interno da alma em termos de vício moral e ignorância. No entanto, ambos os diálogos rejeitam igualmente a akrasia tradicional, especificamente na possibilidade do conhecimento-akrasia. De um lado, o Protágoras estabelece uma clara distinção entre o estado de conflito interno da ignorância e o estado equilibrado do conhecimento. De outro lado, a República oferece uma descrição geral da ignorância em vista do predomínio da parte irracional da alma sobre a parte racional.

Em segundo lugar, nenhum dos dois diálogos estabelece qualquer incompatibilidade explícita entre o Modelo Hidráulico e o Modelo da Ignorância. Como vimos anteriormente, o argumento do Protágoras contra a akrasia depende da assimilação do princípio da força de desejos ao princípio da avaliação valorativa. No capítulo anterior, mostramos que a consistência do absurdo da akrasia tradicional depende da transferência intercambiável de ambos os princípios. Do mesmo modo, os argumentos da República também pressupõem a coexistência de ambos os princípios, tendo em vista o caráter indissociável do Modelo Hidráulico e do Modelo da Ignorância. Dessa forma, é preciso ter em mente que ambos os modelos estão intrinsecamente ligados à psicologia tripartite e ao exame das almas injustas da República.

Seguindo essa hipótese interpretativa, podemos destacar aqui três elementos centrais: (1) o Modelo Hidráulico e o Modelo da Ignorância são indissociáveis da

${ }^{331}$ Para essa interpretação do Modelo da Ignorância, ver PRICE, 1995, p. 91-97; KAHN, 1996, p. 253-257; WILBURN, 2014, p. 67-87. 
descrição geral do conflito interno da alma; (2) ambos os modelos visam explicar o conflito interno da alma marcado pelo predomínio da parte apetitiva na alma ao longo de Rep. VIII-IX; (3) a maior parte dos casos de conflitos internos de República são relatados como casos de vício moral e ignorância de forma indissociável da akrasia tradicional. Com efeito, notamos um deslocamento central do interesse de Sócrates na República: o foco central na psicologia moral de Rep. IV é deslocado à psicologia dos caracteres e modos de vida das almas injustas em Rep. VIII-IX ${ }^{332}$. O problema da akrasia, o erro moral contra a deliberação racional do bem, jamais se destaca do problema amplo do estado psicológico interno da alma injusta e do caráter do vício moral (kakía). Mesmo com a ausência da formulação do problema da akrasia, ainda encontramos alguns casos de conflito interno com os traços marcantes do caráter moral da akrasia no exame das almas injustas de Rep. VIII-IX.

No exame das almas injustas de Rep. VIII-IX, são exibidos diversos casos de conflito interno da alma. Ao longo da degeneração moral dos regimes e almas injustas, Sócrates descreve a geração sucessiva de quatro regimes injustos: a timocracia, a oligarquia, a democracia e, por fim, a tirania, o paradigma final da 'pura' injustiça. Em relação a cada um desses regimes, há quatro caracteres morais injustos correspondentes: o timocrático, o oligárquico, o democrático e, por fim, o tirano, o mais injusto de todos. Dentre os complexos conflitos internos dos tipos de almas injustas, nenhum deles se apresenta nos termos da akrasia tradicional de uma forma distinta de um tipo de ignorância ${ }^{333}$.

Diante disso, indicaremos que o caso do timocrático e do oligárquico são exemplares mais próximos da akrasia do que os casos do democrático e do tirano.

332 Cf. FERRARI, 2007, p. 194-195: "If instead we take the shift between the two kinds of description - one where the inner man and one where the outer man controls the whole - as a way of marking the distinction between choices that determine particular actions and choices that embrace a pattern of life, a metaphorical scheme emerges."

${ }^{333}$ Nenhum desses casos é encarado como casos típicos de akrasia tal como o caso emblemático de Leôncio. Para uma interpretação tradicional nesse sentido, ver, por exemplo, IRWIN, 1995, p. 283 284. Em particular, Irwin se compromete o tratar a akrasia como um fenômeno de 'incontinência' o que aproxima o fenômeno de uma espécie de compulsão. Ao relacionar a incontinência ao elogio da tirania de Cálicles no Górgias, Irwin (Ibid., p. 284) nota proximidades com o caso do tirano na República mas logo descarta a hipótese: "The closest parallel to this sort of person in the Republic is the tyrannical person, with his dominating and demanding desires and aims. If Plato meant that this sort of person habitually acts against his rational plans, or fails to form rational plans altogether, then we could understand his view of domination by the non-rational parts. (...) On the contrary, his obsessive lust controls his rational plans too; and so he follows these plans in his actions. Like the other deviant people, he is guided by his rational plans and need not be prone to incontinence." Ver também REEVE, 1988, p. 43-48. 
Em todo caso, devemos ter em mente que o Modelo da Ignorância constitui o paradigma central do conflito interno das almas injustas. Com esse enfoque, nos voltaremos ao exame do processo de degeneração moral dos regimes e almas injustas de Rep. VIII-IX.

A análise psicológica das almas injustas de Rep. VIII-IX acompanha uma investigação ampla dos regimes e caracteres das almas injustas. Como vimos anteriormente, esse extenso exame decorre do exame anterior da 'pura' injustiça e, em última instância, a comparação final da felicidade do puro justo e do puro injusto no Desafio da Justiça (545a). Ao fim de Rep. IV, Sócrates já havia encontrado o que constitui a 'pura' justiça interna mas a investigação do 'puro' injusto a partir dos regimes degenerados é postergada desde o início de Rep. V (449a). Somente após o longo desvio de Rep. V-VII, o exame dos caracteres e almas injustas de Rep. VIII-IX é retomado na investigação final do ‘puro’ injusto.

O método de exame do 'puro injusto' em Rep. VIII-IX segue a correlação entre o regime político e os caracteres humanos: em primeiro lugar, uma análise da degradação sucessiva da 'constituição' ou 'regime' (tèn politeían) em regimes cada vez mais injustos; em segundo lugar, uma análise da condição psicológica dos tipos ou 'caracteres' (tà éthe) correspondentes dos regimes (545a-b). Nessas condições, Sócrates estabelece o princípio do 'conflito' ou 'dissensão' (stásis) dos regimes políticos: "toda constituição (pâsa politeía) muda por virtude daquele que detém o domínio (toû échontos tàs archás), quando o conflito (stásis) se origina em seu seio.” (545d). Com efeito, a origem do conflito externo na cidade remete ao próprio conflito interno da alma. Em Rep. IV, Sócrates já havia definido a injustiça interna em termos de ‘conflito' (stásis):

é forçoso que seja um conflito (stásis) das partes da alma, que são três, uma mistura e interferência no alheio (polypragmosýnen kaì allotriopragmosýnen), e uma sublevação de uma parte contra o todo, a fim de exercer nela o poder, sem lhe pertencer (árchei en autêi ou prosêkon), uma vez que possui uma natureza à qual convém a escravatura (...) (444b)

Como mostramos anteriormente, o princípio da seção predominante estabelece uma relação de domínio ilegítimo correspondente entre regimes e almas injustas. Assim como o a emergência do regime injusto atende pelo conflito entre classes, o caráter injusto igualmente reflete a "sublevação de uma parte contra o 
todo" da alma. Dessa forma, ocorrerá a 'mistura' das funções das diferentes partes da alma, o que permite que uma parte inferior da alma exerça "o domínio que não lhe pertence" no interior da alma. Na realidade, Sócrates indica que a degeneração moral é um resultado inevitável de todos os regimes e caracteres que não refletem o caráter filosófico e a Cidade Ideal (497b-c). Ao longo de Rep. VIII-IX, o exame dos regimes e almas injustas esclarece o processo de degeneração natural da Cidade Ideal perfeita.

De acordo com Sócrates, a degeneração da constituição decorre de um processo natural inevitável de corrupção geral: “como tudo que nasce está sujeito à corrupção" (546a). Afinal, haverá ocasiões em que os governantes sábios não conseguirão mais controlar a organização social da Cidade Ideal "por seu poder de raciocínio e percepção" (546b). O conflito instaurado na Cidade Ideal com a mistura das raças, então, faz surgir a "desigualdade e a anomalia desarmônica" além da "guerra e ódio" (547a) $)^{334}$. Na origem do conflito e da discórdia, há uma inclinação humana mais acentuada pelo dinheiro (547b-c). Em Rep. IV, Sócrates já havia atrelado a divisão interna da cidade à divisão social entre ricos e pobres: "são pelo menos duas, inimigas uma da outra, uma cidade dos pobres e outra dos ricos." $(422 \mathrm{e})^{335}$. Com efeito, a divisão de ricos e pobres no seio social da cidade instaura a corrupção moral e a divisão interna das almas injustas.

Dessa forma, a corrupção moral está intrinsecamente ligada aos diversos conflitos internos da alma de Rep. VIII-IX. Diante desse quadro, temos o cenário ideal para o desenvolvimento do conflito interno da akrasia. Em cada um dos regimes degenerados, acompanhamos o mesmo padrão de origem dos tipos de homens injustos: as referências externas divergentes do meio social entram em colapso na formação do caráter moral interno do agente. Como indica Gill (1996), o processo de corrupção das almas injustas enfatiza o importante papel do diálogo internalizado na formação psico-ética dos modos de vida dos homens injustos ${ }^{336}$.

\footnotetext{
${ }^{334}$ A classificação das raças havia sido introduzida em Rep. III com a nobre mentira dirigida aos jovens da Cidade Ideal (414a-d), porém a origem do mito remonta a Hesíodo.

${ }_{335} \mathrm{Em}$ Rep. IV, Sócrates havia alertado sobre os riscos da introdução da riqueza e da pobreza na Cidade Ideal (421d-422e).

${ }^{336}$ Cf. GILL, 1996, p. 257: "The descriptions [of lives] seem designed rather to analyse the process by which a person's psycho-ethical state and way of life takes on a certain character regardless of how conscious of this the person himself is. The analysis brings out the way in which the interplay between a given set of psycho-ethical state and set of social influences leads a given set of lifeshaping beliefs to become dominant, and so to shape the personal character and way of life." Ver também LEAR, 2001, p. 182-183.
} 
Devido a relevância do conflito interno na formação moral das almas injustas, cabe averiguar se algum dos casos anteriores constitui a akrasia tradicional.

Dentre os tipos de caráter injusto de Rep. VIII-IX, os casos do timocrático e o do oligárquico ainda exibem maior controle racional dos impulsos irracionais perante os casos impulsivos do democrático e do tirano. Por sua vez, os casos do democrático e do tirano se destacam justamente pela completa ausência de restrição racional e moral de seus caracteres morais injustos. Dessa forma, iremos primeiro traçar breves considerações sobre esses dois casos iniciais antes de passar propriamente aos casos mais fundamentais do timocrático e do oligárquico.

Em contraste com o timocrático e o oligárquico, os casos do homem democrático e do homem tirânico expressam o predomínio absoluto da parte apetitiva da alma. Ambos os caracteres morais marcam o domínio dos desejos não necessários, a condição interna em que a parte apetitiva não se detém diante de qualquer consideração da parte racional ou impetuosa. A ausência de restrição racional e moral, nos revela sua incompatibilidade com o erro moral típico da akrasia. O exame dos regimes e dos homens democrático e tirânico decorre do predomínio absoluto da parte apetitiva da alma.

A condição da democracia e do homem democrático manifesta a liberdade absoluta do domínio dos desejos não necessários. A democracia se dirige ao "prazer, anarquia, variedade e que reparte a sua igualdade, (...) pelo que é igual e pelo que é desigual" (559a). Nesse regime político, encontramos "todas as constituições' e 'todos os caracteres' reunidos sem qualquer critério de avaliação racional (557c-d). A mesma liberdade reaparece no interior do homem democrático: "uma espécie de igualdade entre os prazeres, entregará o comando de si ao primeiro que se lhe deparar" (561b). O homem democrático desfruta dos prazeres necessários e não necessários em pé de igualdade, se rendendo a desejos diversificados, como a sede, o sexo, a ginástica e até à filosofia. Por conta de seu caráter peculiar, podemos classificá-lo como um hedonista indiscriminado visando a satisfação irrestrita dos desejos imediatos ${ }^{337}$. Assim como o democrático, o

\footnotetext{
${ }^{337}$ Com efeito, essa classificação deriva de um tipo de hedonismo indiscriminado. Para uma definição contemporânea do hedonismo indiscriminado, ver RUDEBSUCH, 1999b, p. 157-158. Para uma classificação do hedonismo indiscriminado em termos de intemperança, ver IRWIN, 1995, p. 113-114.
} 
homem tirânico também se distancia do conflito interno da akrasia devido ao predomínio absoluto da parte apetitiva em sua alma.

A condição da tirania e do homem tirânico representa o predomínio da pleonexia humana e dos desejos ilegítimos. Ao invés da pleonexía humana de Gláucon, Sócrates salienta que a pleonexía do tirano lhe proporciona realmente uma condição de extrema sujeição e escravidão interna. Assim como o tirano precisa conviver e adular péssimas companhias (567b-d), o seu estado interno reflete uma condição de escravidão por seus desejos. Em seu interior, emerge "um amor (érotá tina) que preside aos desejos ociosos" ou, em outros termos, uma "espécie de zangão enorme e alado" (572e-573a). Assim, é eliminada de sua alma as opiniões sobre o que é justo, belo ou vergonhoso cedendo ao impulso violento de Éros: "numa total anarquia e anomia (...) conduzirá o homem (...) a toda espécie de audácias" (575a). Em virtude da natureza pleonética de seus desejos insaciáveis (579c-d; 586a-b), o tirano é incapaz de dominar a si mesmo. Diante dessas condições, o tirano tal como o homem democrático está distante da akrasia.

O predomínio absoluto da parte apetitiva no homem democrático e no tirano não permitem contemplar a akrasia tradicional. Ambos os tipos de almas injustas não passam por qualquer conflito interno com a parte racional da alma, o que não é compatível com o conflito interno da akrasia. Todavia, os casos do homem timocrático e oligárquico expressam um conflito interno em vista de suas considerações morais ou racionais. Em ambos os casos, observamos o conflito fundamental entre o impulso racional ou moral da virtude e uma inclinação contrária da riqueza em vista do vício moral.

O regime da timocracia e o caráter timocrático reestabelece a dupla inclinação divergente pela virtude e pelo dinheiro. Diante dessa dupla inclinação da alma, Sócrates irá descrever o conflito fundamental do regime e do caráter timocrático.

A timocracia emerge de dois regimes opostos, a aristocracia e a oligarquia. Em primeiro lugar, o regime é próprio da classe dos guerreiros pela veneração dos governantes, a exaltação da guerra e do combate e, em suma, o "amor pela competição e honrarias (philonikíai kai philotímiai)" (548b-d). Em segundo lugar, os homens manifestam seu desejo de riqueza de forma oculta (por ainda prezar sua honra, provavelmente) dispendendo grande gasto privado na satisfação dos apetites sexuais e corporais (548a). Sobretudo, a timocracia é marcada pela valorização da 
ginástica em detrimento da 'formação cultural' (mousiké) já que sua educação moral não é "por persuasão (hypò peithoûs)" mas "por violência (hypò bías)" (548b-c). Segundo Sócrates, os guerreiros deixam de ser "puros e inquebrantáveis" para terem "ânimos misturados (meiktoús) (...) nascidos mais para a guerra do que para a paz" (547e-548a). Diante disso, Gláucon reitera que a timocracia é uma "mistura completa, de bem e mal" (547a). A presença dessa dupla inclinação da honra e do dinheiro caracteriza o conflito interno típico do homem timocrático.

Assim como a timocracia deriva de regimes opostos, o homem timocrático terá sua origem em duas influências externas opostas. Diante de uma cidade mal governada, Sócrates descreve a origem do conflito interno do homem timocrático. O duplo caráter do timocrático se manifesta no amor pelo poder e honra ${ }^{338}$, mas também por sua repulsa à mousiké, aos discursos e o interesse amadurecido pelo dinheiro pois "participa na natureza do avarento (metéchein tês tô̂ philochremátou phýseos)" (549a-b).

A dupla referência familiar logo se reflete no conflito interno típico do timocrático. De um lado, ele se inclina ao seu pai, um homem bom (agathón) que não aprecia honrarias, processos ou envolvimento em negócios públicos ${ }^{339}$ (549c). De outro lado, a mãe e os parentes expõem diversas críticas às atitudes do pai: seu desinteresse por dinheiro, despreocupação com as dívidas ou injustiças sofridas, sua 'falta de virilidade' (ánandros), mas principalmente, sua indiferença à reputação da família (549c-550a). Desse modo, surge a imagem de um conflito interno no jovem timocrático, dividido entre a inclinação da 'parte racional' (tò logistikón) ligada ao pai e da inclinação da "parte apetitiva e impetuosa (tò epithymetikòn kaì tó thymoeidés)" estimulada pela mãe e os outros (550a). Segundo Sócrates, o timocrático entrega sua alma à parte intermediária:

Como não é mau homem por natureza (dià tò mè kakoû andròs ềnai tèn phýsin), mas teve más companhias e é puxado por ambas essas forças, vai para o meio delas, e entrega o domínio

\footnotetext{
338 É importante lembrar aqui a breve menção de Sócrates aos efeitos nefastos da formação de um guardião destituído de mousiké ou filosofia em Rep. III: "Uma pessoa assim torna-se inimigo da razão (misólogos) e sem cultura (ámousos), e já não serve de palavras para persuadir; leva a cabo todas as suas empresas pela violência e pela rudeza, como um animal selvagem, e vive na ignorância e na inaptidão, sem ritmo e graciosidade." (411e-412a)

${ }^{339}$ Segundo o relato, o pai não gosta de se envolver em philopragmosýne, isto é, em uma ampla variedade de negócios públicos e administrativos. Como vimos anteriormente, a expressão é derivada do termo original polypragmosýne que mencionamos anteriormente.
} 
da sua pessoa à parte intermédia (tèn em heautôi archèn parédoke tôi mésoi), que é amante da vitória e impetuosa (te kaì philoníkoi kaì thymoeideî), tornando-se um homem orgulhoso e amante de honrarias. (550a-b)

A geração do caráter timocrático através de sua dupla referência familiar expressa um claro conflito interno no agente em termos próximos da akasia. De fato, essas referências familiares assumem o papel do 'outro internalizado' que entram em inevitável conflito na personalidade do timocrático.

Para esclarecermos isso, é preciso analisar o conflito interno de forma mais detalhada: (a) há um processo de internalização das influências externas na formação de seu caráter moral exercidas pelas atitudes e palavras da família e o círculo de convivência social; (b) as influências externas antagônicas do pai e da mãe se expressam em inclinações internas opostas representadas, por um lado, pela parte racional e, por outro lado, pela parte impetuosa e apetitiva; (c) o domínio da parte impetuosa, intermediária entre os lados antagônicos, marca por fim seu caráter moral. Por correspondência, o domínio da parte impetuosa implica também na adoção correspondente do caráter e o modo de vida timocrático.

Nessa passagem, o conflito interno está claramente evidenciado mas não há aqui nenhuma descrição explícita de um caso de akrasia. Mesmo assim, a formação do caráter timocrático exprime o que estaria próximo de um caráter moral da akrasia. Sobretudo, o timocrático não tem um caráter genuinamente 'mau', próprio do vício moral, visto que "não é mau por natureza (dià tò mè kakoû andròs eînai tèn phýsin)". Nesses termos, o conflito interno do timocrático o aproxima das características típicas do caráter moral acrático 'meio-mau' apresentadas em ENVII. Em todo caso, Sócrates jamais chega a explicitar o caso do timocrático nos exatos termos da akrasia tradicional.

A assimilação entre o Modelo Hidraúlico e o Modelo da Ignorância levam Sócrates a classificar o caso do timocrático como um tipo de ignorância. Além disso, o exame das almas injustas insere o timocrático no grupo de caracteres do vício moral. Mesmo assim, observamos que o conflito interno do caráter timocrático não constitui o mesmo tipo de vício moral ou ignorância dos casos anteriores de almas injustas. Nesse cenário, consideramos que o exame das almas injustas busca estabelecer uma classificação mais precisa dos diversos caracteres de vício moral. Sob essa perspectiva, o caráter conflituoso do timocrático o aproxima da akrasia tradicional ainda que seu conflito interno esteja incluído na ampla 
categoria da corrupção moral da alma. De forma similar, a geração do caráter oligárquico segue em larga medida uma classificação similar de seu conflito interno da alma. Para isso, precisaremos antes estabelecer a origem da oligarquia e analisar posteriormente o homem oligárquico correspondente.

Assim como a timocracia, a oligarquia tem sua origem no conflito de duas inclinações opostas, a honra da virtude e dos bons homens e, simultaneamente, o apreço acentuado da riqueza. Desde Rep. IV, Sócrates atribui a origem da corrupção moral e a desintegração da unidade original da cidade à riqueza e a pobreza (422d423a). No exame de Rep. VIII, essas considerações são aprofundadas enfatizando a oposição entre virtude e riqueza: "é certo que a virtude difere da riqueza tal como se elas se inclinassem sempre em direções opostas" (551a). De certo modo, essa dupla inclinação divergente marca o regime oligárquico e, principalmente, o caráter oligárquico.

O regime oligárquico ilustrado em Rep. VIII é profundamente marcado pela corrupção moral e o desvirtuamento dos cidadãos. Nessa ocasião, Sócrates passa em revista os principais defeitos do regime oligárquico, alguns deles já previstos em Rep. IV: (1) o desvirtuamento da especialização dos cidadãos (551c-d); (2) a divisão da cidade e o conflito entre ricos e pobres (551d); (3) a inaptidão e o desestímulo à guerra e ao combate (551d-e); (4) o envolvimento em múltiplas atividades $(551 \mathrm{e}-552 \mathrm{a})^{340}$; (5) o risco iminente da indigência do afortunado resultando em sua inatividade na cidade (552a). Dentro desse quadro, Sócrates estipula ainda que o regime será marcado pela "falta de educação (apaideusían)" e "má criação (kakèn trophén)" (552e). Todos esses fatores contribuirão para o surgimento do homem oligárquico de um regime timocrático.

A geração do homem oligárquico deriva da contemplação da desgraça da figura paterna timocrática. Ao seguir os passos do pai, o filho contempla seu conflito contra a cidade, sua expulsão do cargo de general e sua destituição de suas posses e fortuna (553a). Como mencionamos anteriormente, o elemento apetitivo assume o comando deixando o elemento racional e impetuoso sob seu controle absoluto na alma oligárquica, tal como descrito no Modelo da Ignorância. Assim como o regime oligárquico, o homem oligárquico não desfruta da educação (paideía) e preza apenas por sua riqueza (554a-b). De qualquer forma, o caráter

340 Como mencionado anteriormente, isso se refere ao risco da polypragmosýne, isto é, ao desvirtuamento do princípio de especialização retomado em (1). 
oligarca se destaca "por ser poupador e operoso, somente satisfaz seus desejos necessários (tàs anankaíous epithymías) (...) escravizando (douloúmenos) os outros desejos como vaidades" (554a). Sob essa medida, o oligarca manifesta claramente um controle calculativo de sua fortuna em nome do seu "amor pela riqueza (philochrématon)", preservando ainda a satisfação dos desejos necessários. Como observamos anteriormente, os outros caracteres viciosos, o democrático e o tirânico, não mantinham o mesmo controle calculativo de seus apetites. Com efeito, esse controle calculativo do oligarca, por vezes, lhe aproxima de um caso típico de akrasia.

Em certas ocasiões, Sócrates descreve o conflito do oligárquico em termos próximos à akrasia. $\mathrm{O}$ conflito interno do oligárquico decorre da presença de um tipo particular de desejos: “desejos dos zangãos (kephenódeis), uns que levam a mendigar, outros a praticar o mal, dominados à força pelos restantes cuidados (bíai hypò tês álles epimeleías)" (554b-c). Tais desejos também são denominados de “dissipadores (analotikás)" pois estão ligados ao gasto desenfreado de dinheiro e à injustiça, sendo típicos de mendigos e malfeitores despossuídos (559 b-c; cf. 552cd; 553c-d). Segundo o critério anterior da necessidade dos desejos, os desejos dissipadores entram na classe de desejos não-necessários enquanto o desejo do lucro está vinculado à categoria de desejos necessários. Dessa forma, o desejo do lucro, sendo um desejo necessário, ainda exige uma forma de desejo racional pelo bem contra os desejos dissipadores não-necessários.

Assim como a oligarquia, o homem oligárquico é marcado por seu duplo caráter refletido em seu conflito de desejos: "uma vez que não é um só, mas duplo (...) a maior parte das vezes, os desejos melhores dominarão os piores.” (554d-e). Todavia, o seu caráter apenas 'parece ser justo' já que seu controle interno não se deve à persuasão ou discurso mas pela força: "por força em si mesmo (heatoû bíai), reprime outros desejos maus que tem (...) devido à necessidade e ao medo (anánke kaì phóboi)" (554d). Em vista desse domínio interno turbulento, Sócrates reconhece que o oligárquico por vezes se submete ao risco de fracassar em seu conflito interno:

Além disso, este homem poupado será um fraco antagonista da cidade (antagonistés en pólei), (...) com medo de despertar os desejos dissipadores (tàs epithymías tàs analotikàs) e de os chamar em seu auxílio (...). Como, à maneira oligárquica luta com poucas forças, é derrotado a maior parte das vezes (tà pollá hettâtai), mas mantém sua riqueza. (555a) 
Levando em conta o conflito entre os desejos necessários e não-necessários, o caráter oligárquico é intrinsecamente conflituoso. Apesar de seu caráter marcado pelo domínio do desejo do lucro, o seu controle interior forçado abre a possibilidade de uma eventual derrota pelos desejos dissipadores não-necessários. Pela força relativa dos desejos, a derrota dos desejos necessários nessa possibilidade corresponde a afirmar que os desejos dissipadores são mais fortes que o desejo de lucro. Nesses termos, teríamos um caso que contempla o conflito interno característico da akrasia. A possível derrota do oligarca por seus próprios desejos dissipadores significa mais precisamente sua transformação de econômico à indigente ou malfeitor. Em outras palavras, o conflito interno do oligarca antecipa o que Aristóteles designará de akrasia fraca (asthéneia) na ENVII.10, isto é, a submissão da deliberação racional aos apetites fracos. Tal como o caso do timocrático, o caso do oligarca também reflete os traços de caráter da akrasia.

Ao longo da República, Sócrates classifica o conflito interno da alma dentro das categorias do caráter moral, mais especificamente, na forma geral do vício moral ou da corrupção moral da injustiça. Dessa forma, o conflito interno do oligarca tal como o conflito do timocrático reflete os tipos de conflito interno característicos do caráter acrático, abrindo o caminho para a definição clássica da akrasia de ENVII. Ao mesmo tempo, Sócrates lança mão de uma definição de conflito interno da alma compatível com o Modelo da Ignorância, isto é, a submissão da parte racional às partes irracionais da alma. Assim como no Protágoras, Platão não abandona, no entanto, a sua classificação da ignorância do vício moral e nem mesmo dá indícios de abandono do paradoxo socrático. Por fim, o desenvolvimento da 'psicologia' platônica da República não leva Platão a abandonar as teses socráticas fundamentais do Protágoras.

Em seguida, devemos analisar problemas remanescentes da 'psicologia' moral e da akrasia na República. Em primeiro lugar, precisamos analisar a consistência da psicologia tripartite perante as objeções da unidade do agente e a regressão lógica da divisão das partes da alma. Em segundo lugar, é preciso recapitular a continuidade da posição de Platão sobre a akrasia na passagem do Protágoras à República. Em terceiro lugar, devemos avaliar enfim a contribuições da 'psicologia' platônica para o esclarecimento da irracionalidade humana e o conflito interno da akrasia. Na sequência, vamos analisar primeiro as objeções 
filosóficas mais influentes dirigidas à consistência da psicologia moral platônica da Republica.

\section{5 Os problemas da psicologia tripartite na República: as partes-agente e a negação socrática da akrasia no Protágoras}

A psicologia tripartite da República fornece um modelo psicológico promissor de amplo alcance para explicar os conflitos psicológicos, como a akrasia. Como vimos, a teoria tripartite da alma assimila o conflito de forças motivacionais à condição de vício moral e ignorância do agente. Ao mesmo tempo, a psicologia tripartite também abre o caminho a uma série de problemas filosóficos e divergências internas com outras teorias psicológicas da alma presentes nos Diálogos. Como já indicamos anteriormente, o problema mais patente diz respeito à psicologia 'socrática' do Protágoras. De fato, a psicologia tripartite da República é incompatível com o modelo da unidade da alma pressuposta no diálogo anterior. Apesar de termos reconhecido algumas posições convergentes, precisamos traçar conclusões mais definitivas da continuidade das teorias psicológicas de ambos os diálogos. Antes disso, porém, precisamos analisar primeiro alguns problemas drigidos à consistência filosófica da psicologia platônica tripartite da República.

Os principais problemas filosóficos atribuídos à alma tripartite e a akrasia na República envolve sua consistência como uma teoria 'psicológica' complexa da alma. Com efeito, a controversa relação analógica das partes da alma com agentes humanos dá origem à duas objeções filosóficas complementares: (a) o problema do homunculus, isto é, a tese de que as partes da alma refletem pequenos homens, isto é, paradigmas reduzidos do próprio agente humano; (b) o problema da unidade do agente, levando em conta que as partes isoladas jamais integram uma concepção unitária e autoconsciente do 'eu' em si mesmo (self). Em seu conjunto, ambas as objeções filosóficas ameaçam a consistência interna da psicologia tripartite platônica.

As inovações teóricas da teoria tripartite da alma ficam comprometidas diante da presença de miniagentes na alma e o rompimento da unidade fundamental do agente. De um lado, a objeção do homunculus leva à progressão de um regresso ao infinito: as 'partes' da alma acabam reproduzindo o próprio comportamento 
humano ao invés de explicar efetivamente a relação entre as diferentes motivações do agente e as ações humanas. De outro lado, as partes-agente também comprometem a unidade do agente moral. Embora cada uma das partes-agente constitua um centro particular de agência humana, com suas próprias crenças, valores e desejos específicos, a psicologia tripartite carece de princípios que assegurem a unidade do agente humano em vista de um centro de decisão e ação moral. Ambas as objeções atingem os princípios básicos da psicologia moral platônica, como o princípio do conflito de desejos (PC) e a delimitação precisa das três partes da alma. Dessa forma, iremos analisar primeiramente a primeira controvérsia.

A primeira objeção do homunculus estabelece que as partes da alma constituem paradigmas reduzidos do agente humano inteiro. Anteriormente, notamos que a teoria tripartite admite que as partes da alma tenham suas próprias crenças, desejos e motivações particulares, elementos refletidos no comportamento humano. Por conta disso, costuma-se atribuir à psicologia platônica uma concepção antropomórfica das 'partes-agente' sujeita a um regresso ao infinito ${ }^{341}$. Em particular, Moline (1978, p. 24) expressa de forma sintética a objecção central do homunculus e sua regressão ao infinito:

\begin{abstract}
A regress of parts-witihin-parts could make nonsense of Plato's theory (...) only if Plato were so engrossed in making the parts correspond to people that he made the parts subject to the same sorts of problems which motivated him to posit parts initially. (itálicos do autor)
\end{abstract}

Se as partes da alma correspondem integralmente a microagentes humanos a teoria tripartite perde inteiramente sua utilidade teórica. Desde sua introdução, a teoria tripartite da alma da República foi concebida originalmente para dar conta da origem das diferentes motivações humanas expressas nas ações do agente humano. Ora, se as três partes da alma reproduzem o próprio comportamento humano, teríamos uma mera reduplicação do problema uma vez que as próprias 'partes' deixariam a conduta humana totalmente inexplicável. Dentro dessa perspectiva, seria necessário introduzir uma segunda classe de 'partes-agente' cada vez menores destinada a explicar a primeira divisão original da alma, e assim sucessivamente em

\footnotetext{
${ }^{341}$ Para diversas formulações semelhantes da objeção central do homunculus, ver ANNAS, 1981, p. 142-146; IRWIN, 1995, p. 219-22; PRICE, 1995, p. 40-50 BOBONICH, 2002, p. 248-254.
} 
uma série infinita de 'partes-agente'. Ao fim, isso inviabilizaria o projeto original da teoria tripartite da alma.

A princípio, a própria psicologia tripartite efetivamente contempla uma série de subdivisões na parte apetitiva da alma ao longo de Rep. VIII-IX. As subdivisões da alma tripartite possibilitam novos conflitos entre desejos dentro da mesma parte da alma. Ademais, a parte apetitiva da alma contempla claramente o conflito interno de desejos a curto e longo prazo na condição da alma injusta ${ }^{342}$. Em última instância, a divisão sucessiva das partes da alma deriva do regresso ao infinito do próprio conflito de desejos. Por sua vez, a divisão infinita das partes da alma compromete então os princípios originais da teoria tripartite e a distinção fundamental das três partes da alma. Diante disso, são apresentadas algumas propostas interpretativas alternativas para salvar a psicologia tripartite da objeção do homunculus.

A concepção das partes-agente pode ser mais consistente do que parece sem assumirmos a correspondência reflexiva das 'partes' sobre o agente humano inteiro. Como já havia assinalado Annas (1981), a psicologia das partes-agente fornece um modelo psicológico eficiente justamente porque se ampara em certos aspectos fundamentais do comportamento humano sem, no entanto, reproduzir com isso o próprio agente humano ${ }^{343}$. Dentro dessa perspectiva, a psicologia tripartite constitui um modelo funcional da psicologia humana em que cada uma das partes da alma desempenha uma função específica dentro da alma. Como vimos, isso condiz com a atribuição de crenças, desejos e motivações específicas às diferentes partes da alma e suas relações interativas de persuasão e força (437b-c; 439a). Ora, as partes da alma operaram como o homem, isto é, em analogia, embora não sejam propriamente o agente humano de forma integrada e completa. A psicologia tripartite não está absolutamente comprometida com o antropomorfismo da alma.

${ }^{342}$ Cf. IRWIN, 1995, p. 220-21: "While the appetitive part is capable of recognizing conflicts between short-term and longer-term satisfactions, it lacks a system of values that takes account of something more than the comparative strength of different desires. (...) the appetitive part is capable of adopting some of the goals of the rational part; it adopts them not for the reasons that move the rational part, but because it sees their connexion with its own goals." Para as implicações do suposto raciocínio meios-fins da parte apetitiva sobre a teoria tripartite da alma, ver também BOBONICH, 2002, p. 250-253; PRICE, 1995, p. 58-60.

${ }^{343}$ Cf. Ibid., p. 145-146: "We do not have to choose between, on the one hand, thinking of the soul's parts as 'personified', reproducing the whole person in a regressive way (...). Rather the parts have some, but not all, of the features of the whole person whose behaviour they are introduced to explain. We find, then, a richly suggestive use of the 'top-down' kind of strategy for explaining puzzling facts about human behaviour." 
Sobretudo, os equívocos em relação as partes-agentes se refletem particularmente sobre a atribuição do raciocínio meios-fins à parte apetitiva da alma.

Anteriormente, mostramos que a ganância de dinheiro da parte apetitiva é fundamental na multiplicação dos desejos da parte apetitiva. A princípio, o desejo de dinheiro exerce assim um duplo papel funcional, tanto um meio instrumental para a satisfação dos apetites corporais como um fim em si mesmo. Com efeito, observamos que o modelo da alma injusta é inerentemente marcado pelo conflito interno de seus desejos. No entanto, isso não significa que a própria parte apetitiva, por si mesma, seria capaz de realizar um raciocínio meios-fins. Se assim o fosse, a parte apetitiva simplesmente cumpriria a função de realizar um cálculo deliberativo, tarefa delegada originalmente à parte racional da alma.

A subdivisão interna da parte apetitiva atinge os princípios da teoria tripartite da alma. Em The Brute Within, Lorenz (2006) sustenta que a psicologia platônica da República permanece consistente com o 'quadro simples' (simple picture) da divisão tripartite original da alma. De acordo com Lorenz (Ibid., p. 48), o raciocínio instrumental por dinheiro seria externo à parte apetitiva da alma:

Plato may well have thought that it goes without saying that the appetitive part, as he conceives of it, can (and usually does) develop a tendency to form desires for money as its patterns of attention and attachment are moulded from early childhood onward, in a way that does not depend on any use of practical reason on its part and that, in any case, precedes acquisition of the ability to reason.

De acordo com Lorenz, o 'quadro simples' da teoria tripartite é preservado quando consideramos que a inclinação por dinheiro é promovida por fatores externos, como a cultura e a sociedade, e não da própria natureza interna dos apetites. Nessa medida, o raciocínio instrumental do dinheiro deriva de sua fonte legítima e original, a parte racional da alma (Ibid., p. 50-52). Os princípios básicos da teoria tripartite são preservados contra o regresso ao infinito derivado da subdivisão posterior dos desejos da alma injusta. Mesmo que a parte apetitiva possua capacidade cognitiva, isso não significa que ela seja capaz de fazer um tipo de cálculo instrumental de meios-fins. Em última instância, a parte apetitiva apenas expressa a capacidade cognitiva relativa à satisfação exclusiva dos seus objetos de desejos naturais, independente de considerações epistemológicas sobre seu valor objetivo na realidade. 
A partir do Modelo da Ignorância, ressaltamos que o predomínio da parte apetitiva na alma representa efetivamente o desvio funcional das outras partes da alma à função primordial satisfação dos apetites humanos. Por isso, a parte apetitiva jamais cumpre propriamente a função específica da parte impetuosa ou da parte racional. Na realidade, o raciocínio meios-fins da parte racional é desviado aos objetivos e aos objetos naturais de desejo da parte apetitiva. Ao fim, nada compromete o modelo funcional básico das três partes da alma representado na psicologia moral platônica. No entanto, a divisão das 'partes-agente' implica em outra objeção fundamental à psicologia tripartite, a falta de unidade do agente.

A objeção da unidade do agente está intrinsecamente ligada à concepção das partes-agente. Assim como as partes da alma refletem miniagentes, a união desses elementos psicológicos deve fornecer igualmente o agente completo, autoconsciente de si mesmo e tendo autonomia sobre suas decisões. Ao invés disso, o que resulta da união das 'partes-agente' parece ser outra coisa: a imagem de diferentes partes-agente, com seus objetivos específicos e, por vezes, divergentes que jamais integram um agente humano completo. Em Plato's Utopia Recast, Bobonich (2002, p. 257) constata os efeitos do conflito interno da akrasia sobre a psicologia tripartite da República:

The lower parts are, to borrow some contemporary terminology, relatively 'informationally encapsulated'. (...) This permanent lack of integration along with the fact that the lower parts' beliefs, desires, and emotions do interact with a fair degree of minimal rationality makes it not unreasonable to think of the lower parts as subjects of psychic states and activities.

De acordo com Bobonich, o problema central da unidade do agente está ligado à falta de integração das partes inferiores com a alma inteira. De um lado, há claras limitações epistêmicas nas partes inferiores da alma que impossibilitam o acesso ao conhecimento objetivo próprio da parte racional (Ibid., p. 255-256) ${ }^{344}$. Sem tal parâmetro objetivo, as partes inferiores são incapazes de julgar adequadamente suas próprias crenças e motivações com base nos valores objetivos da realidade. De outro lado, Bobonich (2002, p. 257) alega também que o conflito

\footnotetext{
${ }^{344}$ Ao que parece, esse conhecimento objetivo seria plenamente promovido pelas Formas platônicas. Curiosamente, Rep. VI parece antever em diversas passagens uma relação entre a epistemologia e a psicologia moral, ou melhor, entre conhecimento e desejos. Ao que tudo indica, isso está relacionado à terceira prova contra a vida injusta em Rep. IX. Infelizmente, os temas da epistemologia, metafísica e do prazer não envolvem o escopo dessa pesquisa e não poderemos abordá-los nesse trabalho.
} 
das partes da alma reflete em uma condição passiva diante da akrasia: "[the person] seems to be left as a passive spectator of the competition of her own desires, and thus of her own actions.". O desalinhamento do melhor juízo da parte racional diante forças motivacionais irracionais resulta na predominância do desejo mais forte. Em última instância, Bobonich julga que faltaria às partes-agente da República um elemento intermediário de 'intervenção psíquica' das diferentes motivações da alma supostamente encontrado nas Leis. ${ }^{345}$ No entanto, indicamos anteriormente que a psicologia platônica da República não precisa de qualquer elemento intermediário independente das três partes da alma. Sobretudo, a psicologia moral da República se torna mais coerente quando abrimos mão de um modelo antropomórfico da psicologia tripartite.

O antropomorfismo das partes-agente não contempla o quadro completo da psicologia tripartite da República. Como indica Price (1995), a teoria tripartite platônica constitui 'campos' de crenças e desejos que estão em constante conflito interno. Todavia, esses 'campos' do agente não precisam estar totalmente conscientes de si mesmos da mesma forma que o sujeito ou o agente humano inteiro e autoconsciente ${ }^{346}$. Como vimos, os termos genéricos eíde, géne e mére representam 'elementos' sem constituírem propriamente 'partes' em um sentido ontológico forte. Da mesma forma, Shields (2007) rejeita qualquer atribuição do homunculus, isto é, dos miniagentes, à psicologia moral da República. As 'partes' da alma representam grupos interativos de agentes que não podem ser propriamente confundidos com os próprios agentes individuais ${ }^{347}$. Ao contrário, é mais provável supor que nenhuma das três partes da alma reflete as características das outras partes

\footnotetext{
345 Segundo Bobonich (Ibid., p. 260-274) as Leis apresentam uma psicologia platônica mais consistente e amadurecida do que a psicologia tripartite da República. Em particular, a concepção da intervenção psíquica sobre as partes da alma nas Leis promove uma psicologia mais ativa do que a psicologia tripartite passiva da República.

${ }^{346}$ Cf. PRICE, 1995, p. 52-53: "If the parts are not subjects, they are not agents either, though their contents are causes of action, constituting either forces (...) or conduits (...). It is a natural assumption that, in cases of conflict, action follows according to a play of forces and the relative strengths of opposing pulls (...)."

${ }^{347}$ Segundo Shields (2007, p. 79-86), a visão do homunculus não é particularmente atrativa por conta de seus problemas inerentes e sua incompatibilidade com a psicologia moral da República. Com efeito, ele apresenta dois motivos centrais para rejeição dessa proposta interpretativa: (1) a divisão da alma da República está prioritariamente voltada aos 'modos' de vida dos injustos e não para a akrasia propriamente ou para a falha de implementação da ação; (2) apesar das referências explícitas à elementos internos próprios de agentes, nada nos leva a concluir que Platão esteja pensando em agentes no sentido literal. Para Shields (Ibid., p. 85), "they are characterized as homunculi precisely to capture an important and easily overlooked datum of Plato's tri-partite moral psychology, namely that none of the three parts of Plato's soul is saturated by its dominant feature." (itálicos do autor)
} 
da alma nem exaure as características peculiares do agente inteiro. Sobretudo, a imagem decisiva da alma encarnada de Rep. IX revela não só aspectos humanos mas também elementos animais da psicologia tripartite.

A Rep. IX apresenta uma imagem da alma humana encarnada diametralmente oposta ao modelo da alma justa de Rep. IV. Diante do Desafio da Justiça, Sócrates reúne as reflexões da psicologia moral de República de forma conclusiva com uma "imagem da alma em palavras (tês psychês lógoi eidêi)" (588bc). A partir dessa imagem, cada parte da alma representa aspectos peculiares da personalidade humana, o ser humano (a parte racional), um leão (a parte impetuosa) e um monstro repleto de múltiplas cabeças, tanto domesticadas quanto selvagens (a parte apetitiva) (588b-d). Dessa forma, Sócrates apresenta uma imagem paradoxal da alma injusta em resposta aos defensores da injustiça:

o que [o defensor da injustiça] faz não é mais do que declarar que lhe é útil alimentar e fortalecer (euochoûnti poieîn ischuròn) o monstro de mil formas, o leão e seu séquito, matando à fome e enfraquecendo (limoktoneîn kaì poieîn asthenêi) o homem, de maneira que cada um dos outros o arraste para onde quiser, (...) deixa-os morder-se entre si e devorar-se reciprocamente na luta (machómena). (588e-589a)

A estratégia socrática é inspirada na analogia cidade-alma de Rep. II. Nessa passagem, Sócrates recorre a dicotomia interna-externa para revelar o que está "por dentro (tà entòs)" do "invólucro exterior (tò éxo)" da alma humana (588e). Nesse contexto, a relação externa-interna do homem representa a distinção clássica entre aparência e realidade. Diante disso, devemos analisar como essa imagem da alma reflete a relação das partes da alma e como isso explica o conflito interno da alma injusta.

A imagem da alma encarnada claramente evoca referências anteriores à dimensão animal e selvagem das partes irracionais da alma humana. Em primeiro lugar, a parte impetuosa já é reconhecida tanto em jovens imaturos destituídos de razão quanto em animais típicos, "como os cães (hósper kýon)" (440d; 441a-b). Em Rep. II, Sócrates já havia ressaltado a peculiaridade da parte impetuosa que inflige o temperamento 'dócil' aos concidadãos e 'impetuoso' aos inimigos, da mesma forma que cavalos ou cães bem criados "de raça (gennaíou)" (375a-376a). Em segundo lugar, a parte apetitiva responde pelo impulso absoluto e irrestrito pelo seu objeto de desejo, "como um animal selvagem (hósper theríou)" (439b). Como 
vimos, a degradação moral das almas injustas acompanha a multiplicação dos apetites da alma e a progressiva desconsideração pelos valores epistemológicos da razão e da estima social da parte impetuosa. O domínio dos desejos não necessários na alma injusta marca o absoluto desinteresse por qualquer avaliação objetiva dos objetos de desejo. Em terceiro lugar, a multiplicidade e violência dos desejos não necessários é reforçada justamente pela comparação com as abelhas zangãos (kephén)" (cf. 522c-d; 573a-b) ${ }^{348}$. Em todos esses casos, as figuras animais são mais crucias na caracterização das partes irracionais da alma do que propriamente sua 'personalização' humana. Ao contrário da animalidade das partes irracionais, a parte racional representa o elemento propriamente "divino (theiótaton)" do homem (cf. 518d-e; 589 d-e; 580c-d; 611e). Desse modo, vislumbramos a dupla natureza racional e animal do homem explica a falta de controle interno das almas injustas e o autocontrole interno da alma justa.

O vocabulário do conflito interno da alma perpassa a comparação final do perfeito justo e do perfeito injusto. Em termos psicológicos, o contraste das vidas de ambos coloca em evidência a condição psicológica de seus caracteres morais, o autocontrole (enkrateia) do mais justo e a escravidão interna do mais injusto.

O estado interno do homem injusto é marcado pelo fortalecimento das partes irracionais da alma e o correspondente enfraquecimento da parte racional. Dentro da alma injusta, a parte impetuosa se inclina à "riqueza e os desejos insaciáveis (tês aplestías)", o que torna a "melhor parte fraca por natureza (asthenès phýsei) não sendo capaz de comandar (mè dýnasthai árchein)" o monstro interno da alma (590b-c). Do outro lado, o homem justo expressa a condição oposta: com "maior autocontrole (enkratéstatos)", mantém sua criatura sob domínio, "alimenta e cultiva as espécies domésticas e impede de crescer as selvagens, fazendo da natureza do leão sua aliada (sýmmachon)" (589a-b). A partir disso, Sócrates expõe dois modelos antagônicos da alma levando em conta o estado imperturbável da alma justa contra o conflito interno incessante da alma injusta. Em nenhum momento, há uma referência explícita à 'ignorância' da alma injusta. Todavia, Sócrates recorre explicitamente a tese do 'mal involuntário' alinhada aos princípios do paradoxo socrático do Protágoras.

\footnotetext{
${ }^{348}$ Como observamos anteriormente, a figura do 'desejo zangão' ganha proeminência na condição psicológica do tirano, especialmente em sua forma mais desenvolvida da paixão violenta do Éros em Rep. IX.
} 
Em seu argumento final contra o defensor da injustiça, Sócrates alega que seu "erro não é voluntário (ou hekòn hamartánei)":

as normas legais entre o que é nobre e vergonhoso (tà kalà kaì aischrà nómima) tem sua origem nos seguintes factos: a nobreza submetea parte animalesca da nossa natureza à parte humana (tà hypò tôi anthrópoi),(...), ao passo que o que é vergonhoso escraviza a parte domesticada à selvagem (tà hypò tôi agríoi tò hémeron douloúmena)? (589c-d)

Nessa passagem, Sócrates estabelece os parâmetros objetivos das 'normas legais' (nómima) traçando um parâmetro objetivo dos modelos antagônicos da alma: os valores ligados a seus respectivos objetos de desejo. De um lado, as 'coisas nobres' (tà kalá) orientam a submissão da parte apetitiva sobre os desígnios da parte racional 'divina'. De outro lado, as 'coisas vergonhosas' (tà aischrá) determinam que a parte racional "seja escravizada (douloûntai)" pela parte selvagem "mais ímpia e miserável (tôi ateotátoi te kaì miarotátoi)" (589e-590a). Dessa forma, a condição 'normativa' da parte racional implica em um parâmetro epistêmico: a avaliação integral e superior da parte racional por 'toda a alma' fornece o parâmetro objetivo que deve prevalecer sobre a avaliação parcial e inferior das outras partes irracionais da alma. Com efeito, o argumento final recorre a um critério epistêmico objetivo para julgar a vida do perfeito justo e do perfeito injusto.

Em última instância, a opção por uma vida de vício em lugar de uma vida de virtude depende fundamentalmente do desconhecimento dos fatos objetivos derivados da psicologia moral da República. Por isso, Sócrates sustenta que o 'defensor' da injustiça comete um erro 'não voluntário' (ou hekón), isto é, em desconhecimento da condição interna instável da vida injusta. $\mathrm{O}$ argumento final da República supõe que a escolha da maldade, isto é, da pior vida nada mais é do que 'ignorância', em concordância com a posição socrática do Protágoras. No entanto, a psicologia moral tripartite não compromete ou fragmenta a unidade fundamental do agente da psicologia 'socrática' anterior.

Em primeiro lugar, a imagem final de Rep. IX jamais se restringe ao reflexo exato das 'partes' da alma na unidade do 'agente autoconsciente'. Como vimos, Sócrates confere uma dimensão animal inerente das partes irracionais da natureza humana. A própria constituição animal da parte impetuosa e da parte apetitiva nos fornece elementos para esclarecer a relação peculiar de proximidade e 
distanciamento com a parte racional da alma. Por um lado, a natureza emocional compartilhada com cães e jovens prematuros permite explicar a proximidade da parte impetuosa à capacidade inerente de resposta aos anseios da razão, promovidos pela boa educação (441a). Por outro lado, a natureza bestial multiforme da parte apetitiva ilustra seu distanciamento da razão e a necessidade de domesticá-la, lhe mantendo sob controle e vigília permanente. Além disso, a dimensão animal das partes irracionais demarca as suas limitações epistêmicas inerentes diante da parte racional da alma ${ }^{349}$. Em sua $2^{\text {a }}$ prova contra a vida injusta, Sócrates salienta ainda que as vidas dedicadas à satisfação dos prazeres da honra e da riqueza não desfrutam do mesmo nível de "experiência, inteligência e razão (empeiríai te kaì phronései kaì lógoi)" da vida do "filósofo e amigo da razão (philósophos kaì philólogos)" (582a-583a). Por seu parâmetro epistemológico, Sócrates distingue a perspectiva do bem geral da 'alma toda' da parte racional e a perspectiva limitada do bem particular das partes irracionais da alma. Com efeito, isso configura uma diferença crucial sobre a condição psicológica da alma justa e da alma injusta.

O exame das almas injustas expõe a condição verdadeira do domínio absoluto da parte apetitiva na alma em face da condição aparente do injusto aos olhos da opinião dominante. Sob o parâmetro ‘normativo' da razão, a constituição natural da alma humana representa o 'melhor estado da alma justa' em vista do valor objetivo superior da parte racional. As 'partes' da alma capturam 'aspectos' parciais do comportamento humano enquanto agente de dupla natureza, constituído de uma parte racional e outra parte animal, sem precisar necessariamente refletir a aparência idêntica de um agente autoconsciente. Com efeito, o argumento socrático exibe a real condição subserviente do homem injusto por detrás de sua 'aparência' perante a maioria.

Em segundo lugar, a psicologia tripartite exprime a condição 'ativa' do agente e não sua condição 'passiva' diante das diferentes motivações. A impressão da falta de autonomia do agente surge, principalmente, na primeira prova de Sócrates contra a perfeita injustiça: o tirano autêntico nada mais é do que um "autêntico escravo (tôi ónti doûlos)" (579d-e). Para Sócrates, a "alma tiranizada não fará de modo algum o que quer (hékista poiései à àn boulethêi)" uma vez que

\footnotetext{
${ }^{349}$ Para observações sobre a capacidades epistêmicas limitadas das partes irracionais da alma ver BOBONICH, 2002, p. 246-247; IRWIN, 1995, p. 215-219; KAMTEKAR, 2017, p. 147; GILL, 1996, p. 260-307.
} 
a parte apetitiva possui "autoridade (despózein)" sobre as demais e escraviza as melhores partes na alma injusta (577d-e). Nesses termos, a psicologia moral salienta a falta de autonomia do tirano perante o autocontrole do perfeito justo. A ausência da estrutura psicológica da vontade leva a crer que a psicologia moral platônica deixa o agente completamente à mercê da intervenção direta das diferentes motivações da alma na ação humana. No entanto, é preciso considerar os méritos positivos da psicologia tripartite independentemente dos parâmetros externos da psicologia moral moderna.

Independentemente da 'autonomia' moral, a teoria tripartite da alma certamente fornece as condições básicas de uma coerente psicologia moral. Ao contrário do que parece, a psicologia tripartite não estabelece simplesmente a existência de diferentes inclinações humanas, mas lhes atribui à uma origem comum, o próprio homem. Como vimos, a própria psicologia grega tradicional explicita de forma geral a dimensão cognitiva-motivacional dos impulsos humanos. Nesse aspecto, a psicologia tripartite dá um corpo filosófico às categorias psíquicas já presentes na psicologia grega antiga. Na República, observamos um esforço inovador de explicar filosoficamente as diferentes motivações humanas. Em particular, a psicologia tripartite introduz critérios claros de atribuição das diferentes motivações e define o campo da responsabilidade moral do agente independente de elementos externos da ação humana ${ }^{350}$. Como veremos adiante, Platão antecipa assim os preceitos fundamentais da própria psicologia moral da Ética de Aristóteles. Sobretudo, a teoria tripartite da alma revela que é possível ter uma psicologia moral sem a presença de uma 'vontade' moral.

A psicologia tripartite investe tanto na 'personificação' quanto na 'animalidade' caracterizando as relações interativas das partes da alma dentro da mesma natureza humana. Como vimos, Sócrates recorre a uma forma de autoaproximação e auto istanciamento de elementos da complexa natureza da alma humana. De fato, a subjugação do tirano depende de sua total submissão interna à parte apetitiva selvagem e insaciável. No entanto, a submissão interna do tirano não deve ser encarada como mera falta de autonomia, reflexo da ausência de uma 'vontade' moral independente. Diante da psicologia tripartite, o caráter bom e o

\footnotetext{
${ }^{350}$ Cf. KAMTEKAR, 2017, p. 154: “(...) it seems that by locating the origins of even our bad actions in our soul, and saying they are our desires, Plato is making the subject of such attitudes responsible for them more than their predecessors (...)."
} 
caráter mal estão intrinsecamente vinculados à relação natural apropriada das motivações internas de responsabilidade moral. Segundo Sócrates, a condição natural da alma leva a instauração de um "guarda e chefe semelhante a nós mesmos (par’hemîn phúlaka kaì hómoion kaì árchonta)" no interior da alma: "toda a alma, reconduzida à sua melhor natureza (....) atinge um estado (héxin) que tem um valor tanto acima do corpo (....) como o da alma é acima do corpo" (591a-b). A condição servil do tirano ao domínio da parte apetitiva na alma assinala, mais do que falta de autonomia, a plena dedicação da vida humana à máxima satisfação dos apetites irracionais em detrimento dos desígnios da razão.

A condição da servidão humana representa simplesmente o caráter do vício (kakía) e da ignorância em contraposição à virtude e ao conhecimento. Nesses termos, a akrasia aparece indissociável do vício moral. Em todo caso, a República apresenta uma psicologia moral que contempla e distingue mais positivamente as motivações irracionais humanas do que a psicologia 'socrática' do Protágoras.

A psicologia moral complexa da República revela um claro contraste com a teoria motivacional simplificada do Protágoras. A princípio, a República parece apresentar a teoria tripartite da alma e a possibilidade do conflito interno contra o paradoxo socrático e a negação da akrasia do primeiro diálogo. Por isso, a corrente desenvolmimentista alega que tais indícios demarcam a distinção da psicologia 'socrática' da psicologia 'platônica'. Em nossa perspectiva, defendemos que a psicologia tripartite constitui uma inegável inovação sobre a teoria motivacional do Protágoras, mas Platão não abandona substancialmente a tese socrática do eudaimonismo psicológico contra a akrasia tradicional.

Como observamos, as teses expostas nas obras platônicas dependem de seus respectivos contextos dialógicos. Dentro desse contexto, as teses e as posições defendidas na obra platônica devem ser remetidas, em geral, a dois fatores fundamentais ${ }^{351}$ : (a) personagens dramáticos defendendo convicções peculiares de um determinado caráter moral e (b) um contexto dialógico marcado por problemas filosóficos gerais e específicos. Dentro desses estreitos limites, é possível circunscrever as teses de Sócrates em ambos os diálogos ao contexto dialógico

\footnotetext{
${ }^{351}$ Cf. FREDE, 1992b, p. 216: "The Platonic dialogue quite conspicuously does not just present us with fictitious arguments in question-and-answer form. It also goes to great lengths to specify a fictitious context out of which the argument arises (...). By their artful characterization of the dramatic context of the arguments the dialogues show in an unsurpassable way how philosophy is tied to real life, to forms of life, to character and behaviour."
} 
interno com seus próprios interlocutores sem necessidade de introduzir referências externas de outros diálogos ou de forçar um 'sistema' único ou um 'rompimento' definitivo no interior do pensamento platônico presente nos Diálogos.

A aparente incompatibilidade do Protágoras e da República também está circunscrita às exigências do contexto dialógico de cada obra. No Protágoras, o paradoxo socrático e a negação da akrasia de Sócrates se coloca diante da posição implícita do sofista de que a posse da virtude depende de fatores extracognitivos (351a-b). Em República, por sua vez, a teoria tripartite da alma surge em contraponto ao modelo de natureza humana pleonética de Glaucon e não concerne diretamente às teses socráticas do Protágoras (438a). Ao contrário do que parece, a akrasia é assimilada a um estado de ignorância e de instabilidade constante da alma. Em face da descontinuidade mais explícita desses diálogos, notamos também seus elementos implícitos de continuidade.

Mesmo com a contextualização interna de cada diálogo, há uma continuidade inerente no pensamento platônico sobre a psicologia humana. Como salientamos anteriormente, a orientação filosófica platônica permite uma leitura transversal dos Diálogos em um sistema de referências 'interdialógico'. Com esse paradigma, é possível preservar as referências internas de cada diálogo e, simultaneamente, estabelecer conexões e desenvolvimentos de elementos, sejam eles temas, imagens ou argumentos, entre diálogos de diferentes 'fases' estilísticas. Nesse contexto, seria possível preservar uma mudança de 'paradigma' teórico de Platão em face às demandas argumentativas internas de cada diálogo.

Em especial, os Diálogos frequentemente recorrem a referências entre diálogos platônicos indicando uma mudança 'interdialógica' que não sinaliza necessariamente uma ruptura absoluta, mas antes demarca uma ressignificação dos princípios da psicologia platônica. Com efeito, isso ocorre devido a novas demandas argumentativas oriundas do contexto dialógico interno de cada diálogo. Dessa forma, a distinção entre uma psicologia 'socrática' e uma psicologia 'platônica' implica em uma 'mudança de posição' que não elimina necessariamente a presença de uma continuidade perpassando os Diálogos.

A psicologia tripartite da República subscreve claramente as teses socráticas do Protágoras tanto sobre a inclinação natural ao bem (505d-e) quanto à descrição do conflito interno do caráter injusto em termos de ignorância (409d-e). No entanto, existe uma continuidade mais significativa de uma controversa passagem de Rep. 
X. Em especial, isso nos permitirá mostrar uma diferença crucial da complexa psicologia tripartite da República em relação à teoria motivacional do Protágoras.

Em Rep. X, Sócrates investiga os efeitos negativos da ilusão da mimesis artística na alma recapitulando o tema da potência aparência do Protágoras. Nessa ocasião, a preocupação central gira em torno dos efeitos ilusórios específicos da pintura. Em 602c-d, Sócrates expõe claramente os efeitos internos da ilusão mimética e recorre aos mesmos termos da potência da aparência:

E os mesmos objetos parecem tortos ou direitos, (...) simples ou convexos, devido à uma ilusão de ótica (plánen tês ópseos) (...) e é evidente que aqui há toda espécie de perturbação na nossa alma (pâsá tis tarachè hemîn enoûsa aúte en têi psychêi). (...) Mas não se inventam a medição, o cálculo e a pesagem, como auxiliares preciosos (...), de tal modo que não prevalece em nós a aparência (mè árchein en hemîn tò phainómenon) de maior ou menor (...) mas o que se calculou (allà tò logisámenon), mediu ou pesou? (602c-d)

Nessa passagem, Sócrates estabelece que “opiniões contrárias (enantía doxázein) ${ }^{" 352}$ derivam de fontes diferentes da alma (602e). Pela medição e o cálculo, uma parte da alma nos inclina às magnitudes reais dos objetos de desejo: “o elemento que faz crer (pisteûon) na medida e no cálculo deverá ser a melhor parte" (603a). Pela ilusão da aparência, a outra parte irracional nos inclina às magnitudes aparentes através dos prazeres: “ao sexo, ao ímpeto e a todos os desejos (pánton tôn epithymetikôn) penosos ou aprazíveis da alma (...) não produz em nós os mesmos efeitos a mímesis poética (he poietikè mímesis)?”(606d). Nesse sentido, Sócrates parece apelar mais a opiniões ou crenças contrárias do que propriamente a desejos ou impulsos. De qualquer forma, as similaridades entre os efeitos internos da ilusão da aparência e da técnica da medida evocam os termos da discussão do Protágoras.

Em face das similaridades desses diálogos, costuma-se acreditar que a Rep. $\mathrm{X}$ instaura uma bipartição da parte racional incompatível com a tripartição da alma

\footnotetext{
${ }^{352}$ Em diversas ocasiões, Sócrates se refere indistamente às 'aparências e opiniões contrárias' (tanantía phaínetail enantía doxázein/ tò parà doxázon tês psychês) (602e-603a). Durante esse argumento, a mimesis está intrinsecamente relacionada ao domínio da aparência. Em virtude da controversa tradução de mimesis, optamos por manter o sentido abrangente original do termo grego tanto quanto possível, com suas reverberações na arte pictórica e na arte poética e teatral dentro do contexto grego.
} 
de Rep. IV $^{353}$. Ora, se seguirmos essas indicações caberia reconhecer então uma patente incongruência dessa nova divisão interna da parte racional em face da teoria tripartite da alma. No entanto, as frequentes referências a PO durante a passagem de Rep. X nos leva a suspeitar que Sócrates permanece coerente ao 'quadro simples' da psicologia tripartite (602e; 603d; 604a-b). Segundo Lorenz (2006), não há nenhuma psicologia diferente em Rep. X contra os princípios fundamentais da teoria tripartite de Rep. IV $^{354}$. Como observamos anteriormente, as três 'partes' da alma representam não só desejos e motivações da alma, mas também crenças intrinsecamente ligadas aos seus respectivos objetos naturais de desejo e seus prazeres peculiares.

A aparente bipartição da alma é, na realidade, um reflexo da oposição natural da parte racional e das partes irracionais da alma. De um lado, Sócrates claramente associa o cálculo e a medida à "função da parte racional na alma (tô logistikoû toû en pschêi érgon)" (602e). De outro lado, a parte impetuosa e a parte apetitiva integram juntamente o campo do "irracional (alogíston)", sendo a sede da ilusão dos sentidos e da perturbação na alma promovida pelas lamentações e sofrimentos da mímesis poética (604d-e). Em vista disso, podemos apreciar melhor a diferença mais substancial da psicologia moral da República à teoria motivacional do Protágoras.

As reflexões sobre o efeito ilusório da aparência presentes na República ilustram a simultânea continuidade e descontinuidade nos Diálogos platônicos. O Protágoras e a República exibem referências 'interdialógicas' comuns em relação à ameaça do perspectivismo da aparência. Por um lado, há continuidade diante da ilusão da restrita perspectiva da aparência e seus efeitos internos nocivos sobre a alma. Por outro lado, há descontinuidade por conta do contexto dialógico singular de cada diálogo e as claras diferenças da psicologia 'socrática' e a psicologia platônica. Na sequência, reuniremos de forma geral os elementos de continuidade e descontinuidade presentes nesses dois diálogos marcantes de Platão.

\footnotetext{
${ }^{353}$ Para a incompatibilidade da 'bipartição' da alma e a teoria tripartite, ver PRICE, 1995, p. 44; SINGPURWALLA, 2006, p. 254-257.

${ }^{354}$ Cf. LORENZ, 2006, p. 65: "while spirit and appetite frequently manifest their distinctness by pulling someone in opposite directions, it remains the case that they both are distinct from reason and jointly make up the worse part of a person's soul. It is a mistake, then, to suppose that book 10 offers bipartition of the soul as a rival theory to book 4's tripartition. It is the business of book 4 to distinguish reason, spirit, and appetite from one another, laying bare the structure of the embodied human soul. Nothing in book 10 contradicts or revises any of the distinctions made in book 4."
} 
Em relação à continuidade, o Protágoras e a República exibem uma preocupação comum com a ilusão perspectivista da aparência. Assim como no Protágoras, a República reconhece os mesmos efeitos internos da potência da aparência na alma. Em primeiro lugar, a ilusão da mimesis promove a mesma 'errância' (pláne) e 'perturbação' (taraché) interna na alma características da 'potência da aparência' (tô̂ phainomémou dýnamis) do Protágoras. Em segundo lugar, a orientação racional pela medida e pelo cálculo entram em conflito e inviabilizam a 'predominância em nós' (árchein en hemîn) da ilusão da aparência pelas partes irracionais da alma.

Porventura, ambos os diálogos assumem que a ilusão da aparência é típica da ignorância e em franca oposição ao conhecimento e à verdade. Em terceiro lugar, esse estado psicológico de inconstância e errância da ilusão mimética tem "boa reputação entre a maioria (eudokimésein en toîs polloîs)" (605a). De fato, a ilusão mimética é especialmente dirigida ao "caráter arrebatado e variado (aganaktetikón te kaì poikílon êthos)", enquanto o "caráter inteligente e calmo" é difícil de mimetizar (604e-605a). Ambos os diálogos reconhecem o conflito interno da ilusão da aparência e, consequentemente, a ignorância do bem antes apresentada nos termos da akrasia tradicional. No entanto, a descontinuidade intransponível do Protágoras à República concerne à nova psicologia tripartite do último diálogo.

\section{6}

\section{A unidade platônica do Protágoras e da República: a negação da akrasia e o conflito interno da alma}

A psicologia moral da República estabelece a descontinuidade essencial com a psicologia socrática do Protágoras.

Antes no Protágoras, a negação da akrasia de Sócrates envolvia um problema epistemológico: a dissociação entre o conhecimento da técnica da medida contra a ignorância reconhecida erroneamente nos termos da akrasia tradicional. Em especial, o diálogo socrático ressalta o estado de permanente equilíbrio do conhecimento da medida em oposição ao estado de constante desequilíbrio e conflito interno do domínio da aparência ilusória. Em última instância, Sócrates estava comprometido com uma conclusão negativa da akrasia: a experiência da potência da aparência dos prazeres não advém do conhecimento objetivo dos 
prazeres reais, mas de um estado permanente de estrita ignorância baseado na crença subjetiva dos prazeres aparentes. A conclusão negativa da akrasia resulta no paradoxo socrático 'ninguém faz o mal de bom grado'. Em termos gerais, o paradoxo constata a existência de uma inclinação natural ao bem com base em uma concepção unitária da alma humana. Dessa maneira, a imagem da força dos impulsos irracionais é substituída pelo conflito interno de crenças epistêmicas fracas do agente. Em República, Sócrates explora uma nova psicologia da alma sem, no entanto, abandonar expressamente as conclusões do Protágoras.

A psicologia tripartite da República permite analisar os efeitos internos da ilusão da aparência do Protágoras. Nesse sentido, a República oferece tanto uma inovação psicológica quanto uma explicação fundamental do conflito interno da alma.

Em primeiro lugar, a teoria tripartite da alma apresenta três partes, a parte racional, a parte impetuosa e a parte apetitiva que abrangem impulsos e crenças específicos da alma. Dentro dessa estrutura, as partes impetuosa e apetitiva são igualmente classificadas como partes irracionais da alma. A apresentação das partes irracionais da alma expressa claramente o campo da irracionalidade da alma humana e representa uma inovação em relação à unidade da alma pressuposta no Protágoras. Em especial, a parte apetitiva apresenta um impulso irracional absoluto voltado exclusivamente ao seu objeto natural de desejo. A princípio, essa classificação parece voltada contra o paradoxo socrático, mas observamos que, na verdade, seu objetivo é contestar o impulso simplificado da pleonexia de Gláucon. Dessa forma, a psicologia tripartite não implica na negação do paradoxo socrático mas reforça o reconhecimento de uma inclinação natural ao bem em todas as partes da alma. Além disso, psicologia tripartite acaba possibilitando uma análise mais profunda de diversos casos de conflito interno da alma na República.

Em segundo lugar, a psicologia tripartite permite explicar o conflito interno da alma em geral sem, no entanto, abandonar a conclusão negativa da distinção fundamental do conhecimento e da ignorância no Protágoras. Como vimos, a psicologia tripartite acompanha uma análise de diversos conflitos internos da alma na demonstração da teoria tripartite e no exame das almas injustas. Dentre esses casos relatados, o conflito interno de Leôncio e os conflitos do homem timocrático e o homem oligárquico parecem casos da akrasia tradicional. No entanto, salientamos que Sócrates recorre ao modelo das forças motivacionais e ao modelo 
da ignorância de forma intercambiável para explicar o conflito interno da alma. Nesse sentido, a psicologia tripartite trata o modelo das forças motivacionais como equivalente ao modelo da ignorância. No entanto, o conflito interno da alma jamais é relatado ou descrito nos termos explícitos do conhecimento moral. Dessa forma, a República reconhece assim a conclusão da negação da akrasia do Protágoras em termos de conhecimento. Ao mesmo tempo, a psicologia tripartite parece encontrar uma forma de explicar o fenômeno do conflito interno de maneira mais positiva sem, no entanto, recair na akrasia tradicional. Para todos os efeitos, a unidade complexa dos Diálogos apresenta a mesma negação da akrasia, mas Platão julga necessário apresentar uma nova psicologia para dar conta do conflito interno da alma.

Por nossos parâmetros interpretativos, Platão sustenta a negação da akrasia e apresenta a nova psicologia tripartite com objetivos diferentes. No Protágoras, a negação da akrasia tradicional promove a desvinculação epistemológica entre o fenômeno ilusório da potência da aparência e o conhecimento da virtude. $\mathrm{Na}$ República, a psicologia tripartite promove um esclarecimento do conflito interno da alma, mas não compromete a negação da akrasia tradicional em face do poder do conhecimento. Essa posição complexa de Platão sobre o fenômeno se reflete no estatuto da akrasia e do caráter moral acrático na Ética de Aristóteles.

Dentro da controvérsia da akrasia antiga, Aristóteles claramente se inclina a encontrar uma posição conciliatória da akrasia tradicional. Em Ética a Nicômaco, sua defesa dos 'fatos aparentes' (phainómena) o leva a uma posição paradoxal: constatar a existência da akrasia tradicional e, simultaneamente, desvincular o fenômeno do conhecimento prático. De um lado, o reconhecimento das partes irracionais da alma e do fenômeno como um ato voluntário claramente lhe comprometem com a akrasia tradicional. Sob esse ângulo, a psicologia aristotélica e sua teoria do ato voluntário em EN II-III convergem os fatos aparentes e a psicologia tripartite da República. De outro lado, a efetiva descrição aristotélica da akrasia em ENVII.3 claramente se apoia na desvinculação entre o fenômeno e o conhecimento. Como o próprio Aristóteles admite, a sua própria posição se inclina à posição socrática do Protágoras. Em grande medida, a posição aristotélica expressa a negação da akrasia enquanto conhecimento moral e, ao mesmo tempo, a necessidade de explicar o fenômeno de forma positiva. 


\section{5. \\ O problema da akrasia na Ética a Nicômaco de Aristóteles}

\section{1 O estatuto da akrasia antiga na Ética a Nicômaco}

A Ética a Nicômaco de Aristóteles apresenta uma descrição filosófica clássica influente da akrasia antiga. Como vimos anteriormente, a Ética apresenta uma classificação mais sofisticada do caráter moral acrático e do fenômeno correlato após os Diálogos de Platão. O problema filosófico da possibilidade da akrasia no livro VII da Ética ganha notável destaque desde a filosofia antiga até a filosofia analítica contemporânea. Ao mesmo tempo, a psicologia moral e a teoria da ação moral voluntária da Ética são fundamentais para caracterizar o conflito interno entre a razão e as paixões irracionais da akrasia, mas não ganham a mesma atenção da filosofia ocidental.

É preciso, então, compreender o estatuto geral da akrasia antiga na Ética de Aristóteles. Antes de analisar o problema da akrasia em si mesmo, devemos compreender a classificação aristotélica do conflito interno da alma e do caráter moral específicos do fenômeno. Nas categorias morais da Ética, o erro moral da akrasia se contrapõe à ação moral correta da enkrateia em relação ao domínio das paixões irracionais. Desse modo, devemos elucidar primeiramente o que constitui a oposição geral entre o caráter da akrasia e o caráter da enkrateia.

A akrasia e a enkrateia representam dois caracteres morais antagônicos na Ética relativos ao conflito interno da razão e das paixões irracionais. Como observamos, há uma clara distinção etimológica entre os dois termos: o termo 'akrasia' significa a negação do 'domínio' (kratos) dos apetites irracionais enquanto o termo 'enkrateia' descreve o controle interno dos apetites ${ }^{355}$. Em termos de caráter moral, a akrasia se inclui na categoria dos vícios morais, enquanto a

\footnotetext{
355 Cf. LIDDEL-SCOTT, 1996. Como salientamos anteriormente, o prefixo $a$ marca a negação do domínio (kratos) dos apetites irracionais. Naturalmente, o prefixo 'en' delimita o domínio interno (dentro) dos apetites. A partir desse significado etimológico, podemos descartar diversos termos modernos que têm sido usados em substituição aos termos gregos akrasia e enkrateia. No entanto, nossos termos modernos captam de forma imperfeita a experiência grega da akrasia.
} 
enkrateia faz parte da categoria das virtudes morais (1151b25-1152a5). De um lado, a enkrateia consiste no domínio da razão sobre os maus apetites corporais (hai epithýmiai phaûlai). De outro lado, a akrasia constitui a derrota da razão perante os apetites maus contrários (1145b10-15). A partir disso, devemos nos referir adiante à ação moral da akrasia e da enkrateia e, respectivamente, ao caráter moral acrático e encrático na falta de termos modernos mais apropriados. Como observamos anteriormente, os pares de opostos modernos correlatos, como incontinência e continência, fraqueza de vontade e força de vontade ou falta de controle e autodomínio, exigem categorias psicológicas morais modernas externas à psicologia grega ${ }^{356}$. Dessa forma, podemos então compreender o estatuto geral da akrasia antiga na Ética de Aristóteles.

Mesmo com o destaque central do livro VII, o tema da akrasia já é mencionado diversas vezes ao longo da Ética ${ }^{357}$. De fato, a akrasia e o caráter moral acrático tem um alcance mais amplo no contexto da obra. A psicologia moral, a teoria da ação moral voluntária e a teoria da virtude moral da Ética expõem os critérios da classificação do caráter acrático dentro da categoria do vício moral voluntário. Dessa forma, a akrasia não se restringe apenas a ENVII, mas se insere em um campo mais amplo dos princípios fundamentais da virtude moral da Ética. Em verdade, a extensa análise do caráter e do fenômeno da akrasia de ENVII não é plenamente compreendida sem as categorias básicas da virtude moral e da teoria da ação moral voluntária fundamentais da Ética.

A akrasia antiga abrange domínios diferentes da Ética. Para efeitos de esclarecimento, destacaremos o plano geral e o plano específico da Ética: a) no plano geral, a teoria da psicologia moral, a natureza da educação moral das paixões irracionais e a ação moral voluntária fornecem os parâmetros de definição do conflito interno da alma do caráter acrático; b) no plano específico, há um extenso exame peculiar do caráter moral e do fenômeno da akrasia antiga ao longo de

\footnotetext{
${ }^{356}$ Para recapitularmos, cada um desses pares opostos modernos apresenta um problema específico: (1) incontinência e continência evocam ideias da castidade cristão perante os desejos sexuais; (2) fraqueza de vontade e força de vontade apresentam a categoria moderna da 'vontade'; (3) 'autocontrole' e 'falta de controle' são os que mais se aproximam do sentido etimológico original da akrasia e enkrateia, mas mesmo esse par de opostos corre o risco de ser associada a outro fenômeno psicológico: a compulsão psicológica, que implica a intervenção de desejos cegos, isto é, desejos absolutamente irracionais.

${ }^{357}$ Daqui por diante, devemos nos referir a um sistema de referências específicos da obra Ética a Nicômaco. Para efeitos pragmáticos, devemos utilizar a sigla ' $E N$ ' em referência a Ética a Nicômaco seguida dos respectivos livros e capítulos específicos da obra, enquanto a obra completa da Ėtica de Aristóteles será designada apenas pelo termo singular Ética.
} 
grande parte da ENVII. Nesse exame mais específico, Aristóteles pretende classificar o caráter acrático e oferecer uma análise mais detalhada da possibilidade da akrasia. Em seguida, apresentaremos o esboço de um amplo projeto que integra o exame da akrasia antiga ao contexto geral da Ética.

No contexto geral da Ética, o conflito interno da alma e o caráter acrático são amparados em dados concretos da vida ética humana. De forma fundamental, o conflito interno entre razão e paixões irracionais comprova que o conhecimento racional em si mesmo é insuficiente no aprendizado efetivo da virtude moral. Para Aristóteles, é imprescindível se preocupar com a educação moral apropriada das paixões irracionais antes mesmo do amadurecimento da razão humana. De fato, o conflito interno do acrático coloca em evidência dois eixos investigativos da natureza da virtude e da ação moral na Ética: (a) a psicologia moral e os princípios da virtude moral (ENI.13-ENII); (b) a teoria da ação moral voluntária, os tipos de ignorância e a refutação do paradoxo 'ninguém é mal voluntariamente' (ENIII1-5).

Em ambos os eixos da Ética, há uma notável interlocução com a psicologia moral e a teoria da ação moral dos Diálogos de Platão. Por um lado, o conflito entre a razão e as paixões irracionais da alma e a necessidade educação moral das paixões são temas extensamente explorados na psicologia moral da República. Sobretudo, a divisão do elemento racional (tó lógon échon) e do elemento irracional (tó álogon) da alma (ENI.13) se reflete no princípio do conflito de desejos (PC) da teoria tripartite da alma. Por outro lado, a classificação do caráter acrático como um vício moral voluntário confronta o paradoxo socrático do Protágoras. Como vimos, o paradoxo socrático estabelecia todo o mal é involuntário, isto é, o vício moral é involuntário. A partir disso, Sócrates estabelece a negação da akrasia nesse diálogo uma vez que é impossível agir contra o desejo racional pelo bem. De forma indireta, Aristóteles se posiciona contra o paradoxo socrático ao sustentar que o vício moral é voluntário e, consequentemente, que a própria akrasia é voluntária. O conflito interno da alma e a teoria da ação moral voluntária são fundamentais na classificação da akrasia como um vício moral voluntário.

É necessário determinar os desdobramentos das teorias da ação moral dos Diálogos platônicos sobre a Ética de Aristóteles. Ao que parece, Aristóteles tem uma dupla reação aos Diálogos platônicos: o reconhecimento da consistência do princípio do conflito de desejos (PC) da teoria tripartite da alma da República mas, ao mesmo tempo, rejeição ao paradoxo socrático do Protágoras. Sobretudo, 
devemos investigar as implicações da posição de Aristóteles sobre sua classificação do vício moral voluntário da akrasia. Com base nisso, poderemos analisar melhor em seguida o exame específico da akrasia antiga de ENVII.

No contexto específico de ENVII, Aristóteles dedica 10 capítulos ao exame do caráter moral e da ação da akrasia. Sobre o caráter moral, a sua preocupação central é distinguir claramente o caráter acrático de outros caracteres morais correlatos a fim de delimitar os traços morais da akrasia. A partir disso, Aristóteles busca estabelecer o conflito interno específico do caráter acrático com base na distinção da akrasia absoluta (haplôs) e da akrasia 'por analogia' (1147b301148a5). Em sua essência, o caráter acrático representa um meio-termo entre a virtude e o vício moral: enquanto se destaca de outros vícios morais justamente por preservar a razão correta (orthós lógos), ao mesmo tempo, se distingue também das virtudes morais por seus apetites corporais pelo prazer imediato. Sobretudo, a maior controvérsia se concentra na possibilidade da akrasia em ENVII.3.

Em ENVII.3, Aristóteles adota uma posição aparentemente ambígua com relação ao Sócrates do Protágoras: mesmo reconhecendo a manifestação evidente da akrasia, ele acaba se inclinando à posição socrática do Protágoras, isto é, a tese de que o fenômeno não passa de ignorância. Ao longo de ENVII, o exame da akrasia absoluta acompanha o método investigativo dos phaínomena, isto é, os fenômenos aparentes relativo às impressões comuns. Ao mesmo tempo que reconhece as impressões da opinião dominante da akrasia, Aristóteles faz uma concessão à posição socrática em vista de duas teses distintas: a) a akrasia é um tipo de ignorância; b) não é o 'conhecimento propriamente dito' (kuríos epistémes) mas o conhecimento 'perceptivo' (tes aisthestikês) que é submetido na akrasia. De forma intrigante, Aristóteles está comprometido, de um lado, com a possibilidade da akrasia e, de outro lado, admite a tese socrática da ignorância do fenômeno.

Dentre as 4 propostas explicativas da akrasia de ENVII.3, todas parecem recair em um tipo de ignorância: (1) o acrático possui mas não exerce seu conhecimento (1146b30-34); (2) em seu silogismo prático, o acrático ignora, em certo sentido, a premissa particular embora possua a premissa universal. (1146b351147a9); (3) a akrasia se assemelha à condição do bêbado, adormecido ou louco que não exerce seu conhecimento pela influência de suas paixões (1147a10-24);(4) na descrição decisiva da akrasia, Aristóteles não abre mão da ignorância: o acrático 
ignora a 'proposição final' (teleutaía prótasis) do bom silogismo agindo de acordo com um silogismo de prazer por influência do apetite irracional (1147a25-1147b).

Ora, seria essa uma ignorância eminentemente cognitiva, tal como a que aparece no Protágoras, sem a influência das paixões humanas? Se levarmos em conta a psicologia moral e a teoria da ação moral anterior, devemos suspeitar que a ignorância temporária da akrasia se refere a um tipo de vício moral voluntário.

A partir disso, sustentarei que Aristóteles concorda com a posição socrática em seus próprios termos teóricos. Não há efetivamente referência à ignorância cognitiva e nem mesmo ao 'conhecimento racional' em ENVII.3. A ignorância temporária do acrático envolve o conflito das paixões irracionais contra a razão correta e não um equívoco estritamente intelectual das crenças do agente no momento da ação. Ao contrário, Aristóteles enfatiza reiteradamente que o acrático possui a razão correta mas não consegue agir efetivamente por causa das suas paixões irracionais. Nesses termos, o exame da akrasia em ENVII.3 é coerente com a psicologia moral e teoria da ação moral voluntária anterior. Em ambos os casos, Aristóteles defende que a akrasia é um vício moral voluntário em vista da desarmonia entre a razão correta e as paixões irracionais.

Com base nessas indicações, propomos um exame da akrasia na Ética em duas linhas de pesquisa diferentes: 1) na primeira parte, devemos examinar o papel do conflito interno da akrasia na definição dos princípios básicos da psicologia moral, da educação moral das paixões irracionais e da ação moral voluntária na Ética; 2) na segunda parte, devemos nos aprofundar sobre o exame específico do caráter e do fenômeno da akrasia em ENVII.3.

\section{2}

\section{O caráter e a ação moral voluntária da akrasia}

O fenômeno e o caráter da akrasia perpassa a Ética antes da discussão central de ENVII. Dessa forma, Aristóteles assume previamente a manifestação evidente da akrasia tradicional mesmo sem ter analisado ainda a possibilidade de existência do fenômeno. Em verdade, a teoria do caráter moral da Ética abre o caminho ao reconhecimento do conflito interno característico da akrasia. 
Os pressupostos da teoria do caráter moral da Ética lançam os fundamentos da classificação do caráter acrático. A teoria do caráter moral de Aristóteles envolve dois eixos fundamentais da Ética: 1) a psicologia moral e a teoria da virtude moral presente em ENI.13-II; 2) a teoria da ação moral voluntária apresentada em ENIIII5. A seguir, analisaremos as noções básicas da virtude moral e da ação moral voluntária. Em especial, devemos enfatizar a condição do conflito interno da akrasia diante das condições fundamentais da teoria do caráter e da ação moral.

Em ENI.3, Aristóteles assinala o tipo de educação moral ausente do caráter moral dos jovens e dos acráticos:

com efeito, ele [o jovem] não tem experiência nas ações da vida (ápeiros tôn katà tón bíon práxeon), e é em torno destes que giram nossas discussões; além disso, como tende a seguir as suas paixões (tô̂s páthesin), tal estudo será em vão e improfícuo, pois o fim (tò télos) que se tem em vista não é o conhecimento, mas a ação (ou gnôsis allà práxis). (...) A tais pessoas como aos acráticos (tô̂s akratésin), a ciência não traz proveito algum; mas aos que desejam e agem conforme um princípio racional (katà lógon) o conhecimento desses assuntos fará grande vantagem. $(1095 \mathrm{a} 1-12)^{358}$

Nessa passagem, uma comparação é traçada em torno do caráter moral do jovem e do acrático. Assim como o jovem, o acrático sofre da mesma falta de educação moral que o inclina a seguir suas paixões (toîs páthesin) ao invés da razão. De fato, o ensino geral da 'ciência política' (politiké) integra o campo individual da 'ética' (ethiké) em vista do 'bem humano' (tanthrópinon agathón) comum no campo prático da ação (1094a23-b12) ${ }^{359}$. A ausência da educação moral indica que há um tipo de conhecimento prático distinto do conhecimento estritamente teórico.

A educação moral das paixões precisa contemplar dois elementos fundamentais: (a) a experiência nas ações da vida prática que lhe permita ser 'bom

\footnotetext{
${ }^{358}$ Sigo prioritariamente a tradução portuguesa integral da Ética de Gerd Bornheim (1984) que infelizmente é derivada da tradução inglesa de W. D. Ross e não do texto original grego. Em virtude disso, será necessário fazer ligeiras adaptações com o cotejo ao texto original grego e outras traduções disponíveis da Ética. Principalmente, devemos consultar as traduções parciais da Ética de Zingano (2008) e de Angioni (2011a), a primeira relativa aos livros I.13-III8 e a segunda relativa ao livro VI respectivamente. Ambas as traduções são derivadas diretamente do grego ao português com devida atenção ao vocabulário filosófico próprio de Aristóteles.

${ }^{359}$ De acordo com Aristóteles, a 'política' (politiké) é superior a 'ética' (ethiké) justamente por abranger o 'bem humano' mais geral dos cidadãos da cidade-Estado (pólis) e não a esfera individual da relação moral interpessoal da vida boa (1094b5-10). De fato, Aristóteles reconhece a continuidade entre a ética e política que marca profundamente a tradição grega, como vimo antes no próprio Protágoras.
} 
ouvinte' das lições da ética ; (b) a educação moral das paixões (páthos) que assegura a harmonia entre os desejos e ação 'em conformidade ao princípio racional' (katá lógon). Nessa esfera, o homem bom virtuoso consegue tirar maior proveito das lições morais justamente porque dispõe da harmonia perfeita necessária entre suas paixões e a razão. Em contraponto, os jovens e acráticos estão sujeitos ao conflito interno entre suas paixões e a razão justamente por causa da imaturidade de suas paixões irracionais (1106b30-1107a5). O conflito interno da alma entre razão e paixões marca a ausência da educação moral apropriada das paixões.

A imaturidade ética das paixões irracionais indica que a educação moral é imprescindível na harmonia interna do agente. A educação moral envolve a cooperação interna entre as motivações internas e a ação moral: "as disposições (héxeis) originam-se de atividades similares (tôn homoíon energeiôn) (...) as disposições seguem as diferenças das atividades" (1103b20-25). Sobretudo, a virtude moral abrange a 'disposição' moral (héxis) do agente exercida através do hábito (éthos): "somos adaptados por natureza a receber [as virtudes] e nos aperfeiçoamos pelo hábito (dià tô̂ éthous)" (1103a20-25). O éthos, em seu sentido original grego, consiste no exercício permanente da virtude moral. Como o caráter acrático reflete a ausência da virtude moral, devemos analisar primeiramente os princípios básicos éticos que definem o caráter moral na Ética.

O caráter moral é pautado por condições éticas bem delimitadas. Nesse cenário, Aristóteles delimita as condições fundamentais do caráter moral e da ação moral voluntária. Os princípios básicos do caráter moral são imprescindíveis na classificação do caráter moral e da ação da akrasia. Diante disso, devemos determinar as condições básicas da ação moral voluntária e do caráter moral na Ética. O ponto de partida primordial da delimitação da ação voluntária é a distinção crucial do ‘voluntário/involuntário' (hekoúsion/akoúsion).

Como vimos, a akrasia antiga se destaca com a emergência da controvérsia teórica em torno dos limites da oposição arcaica hekón e ákon. Como vimos, os termos opostos 'voluntário/involuntário' não se aplicam de forma precisa às noções ordinárias arcaicas de hekón e ákon, designadas anteriormente de 'bom grado e mal grado'. Sobretudo, isso se deve justamente à noção moderna da 'vontade' implicada na dicotomia moderna 'voluntário/involuntário', inexistente nas categorias da psicologia moral grega. No entanto, a teoria da ação moral voluntária de Aristóteles 
representa um esforço notável em definir mais precisamente o campo filosófico do voluntário/involuntário.

A distinção preliminar de hekoúsion/akoúsion ilustra o problema da definição filosófica do campo da ação moral voluntária ao longo de ENIII1. Com efeito, Aristóteles atribui enfaticamente atos hekoúsion à animais e crianças prematuras (1111a20-25/1111b5-10). Na realidade, há uma extensão contínua inerente do exame natural do movimento humano 'voluntário' ao movimento animal geral 'voluntário'. Para Aristóteles, a natureza animal humana fundamenta, inclusive, a própria aspiração humana ao modo de vida ético. ${ }^{360}$ De fato, essa continuidade não fica tão explícita na Ética, mas ficará mais evidente quando tratarmos mais adiante da doutrina do silogismo prático. Em certa medida, Aristóteles confere um sentido mais técnico e preciso ao par de opostos hekoúsion/akoúsion, um sentido que o aproxima da distinção moderna 'voluntário/involuntário'. A teoria da ação moral pretende delimitar as condições da origem ou o princípio da ação voluntária do agente em contraposição às causas externas da ação. Por conta disso, adotaremos a tradução tradicional 'voluntário/involuntário' mas devemos averiguar em seguida qual o sentido filosófico específico atribuído aos respectivos termos hekoúsion/akoúsion em relação à ação moral.

Os parâmetros objetivos da definição de hekoúsion/ákousion são traçados em ENIIII. Em linhas gerais, Aristóteles parte de uma definição negativa da ação moral voluntária, com o objetivo de excluir casos que claramente não se enquadram nessa categoria de ações morais.

A classe de ações involuntárias inclui os casos por 'compulsão' (bía) e 'por ignorância' (di'ágnoian) (1109b1-1110a5). Em primeiro lugar, as ações compulsórias resultam de forças externas ao agente: "quando a causa (aitía) está fora do agente (en toîs ektòs) e ele em nada contribui." (1110b1-5). A partir disso, temos uma categoria externa da ação, algo que não está inteiramente sob domínio do agente, como as situações éticas sob forte ameaça, situações extraordinárias ligadas a catástrofes naturais ou condições adversas da ação (1109a30-1110a25).

\footnotetext{
${ }^{360}$ Cf. NUSSBAUM, 2009, p. 250: "as concepções éticas complexas de Aristóteles não precisam ser percebidas como em desacordo com sua explicação do movimento animal "voluntário" no $D e$ Motu, porque faz parte de sua concepção ética a ideia de que nossa natureza animal compartilhada é o fundamento de nosso desenvolvimento ético."
} 
Notavelmente, há casos compulsórios limítrofes que são classificados como ações parcialmente voluntárias, ou seja, ações 'mistas'361. No entanto, há ainda uma segunda classe de casos que são diferentes dos atos voluntários, as ações por ignorância. Em linhas gerais, os atos de ignorância envolvem desconhecimento total ou parcial do agente: "a ignorância pode relacionar-se com (...) todas as circunstâncias do ato (...)." (1111a15-17). Os atos de ignorância são mais controversos e exigem uma análise mais detalhada adiante. Diante da exclusão dos casos de ações involuntárias, temos uma definição filosófica do campo das ações voluntárias.

Após circunscrever os casos involuntários, Aristóteles delimita o campo do voluntário: “o voluntário parece ser aquilo cujo princípio (arché) reside no agente que tenha conhecimento das circunstâncias particulares (eidóti tà kath 'hékasta) da ação.” (1111a20). Nesses termos, podemos delimitar as seguintes condições básicas da ação moral voluntária: a) ter conhecimento das circunstâncias particulares da ação; b) ser o princípio (arché) eficiente da ação. Para Aristóteles, a ação humana voluntária concerne o que está “em nosso poder (eph'hemîn)": "os atos cujos princípios estão em nós devem também estar em nosso poder (eph'hemîn) e ser voluntários (hekoúsia)." (1113b20-23). A partir disso, Aristóteles fornece elementos fundamentais de sua teoria da ação moral voluntária.

A distinção hekoúsion/akoúsion da Ética não se enquadra perfeitamente em nossos termos modernos 'voluntário/involuntário'. Diante das noções modernas, a teoria da ação moral de Aristóteles representa, por vezes, a um esboço genérico do que é designado atualmente de teoria da 'ação intencional', 'reponsabilidade moral' ou simplesmente uma definição preliminar do voluntário e involuntário. Invariavelmente, os termos modernos arrastam consigo um significado moderno externo que não coincide propriamente com o sentido filosófico original de Aristóteles.

A expressão 'ação intencional' evoca automaticamente o par de opostos 'intencional'/'não-intencional'. Em Aristotle's Philosophy of Action, David Charles

\footnotetext{
${ }^{361}$ Há casos 'mistos' em que as ações morais parecem ser tanto voluntárias quanto involuntárias, embora Aristóteles reconheça que esses casos se aproximam mais de atos voluntários do que dos involuntários (1110a5-20). De fato, há situações tão extraordinárias que acabam levando o agente a realizar ações que não condizem com seu caráter moral, como assinala Pakaluk (2005, p. 126): "Properly speaking, it is an action in which someone does something which, in usual circumstances, would be characteristic of vice (...). And Aristotle's view is that whether or not an action of that sort in fact indicates bad character depends upon the ranking that is revealed."
} 
(1984) apresenta uma teoria da ação intencional aristotélica, relacionando o campo da 'intenção' ao domínio do hekoúsion ${ }^{362}$. Em particular, o conceito de 'intenção' restringe a controvérsia hekoúsion/akoúsion ao ponto de vista interno do agente apenas em vista de suas crenças e motivações para a ação. No entanto, esses termos não se enquadram adequadamente aos exemplos dos animais e crianças prematuras sem racionalidade constituída. Notavelmente, o exame de Aristóteles abrange mais do que 'crenças' ou 'motivações' do homem adulto maduro. De fato, o termo ‘intenção' não é mais apropriado do que o termo 'voluntário’ para classificar a distinção grega hekoúsion/akoúsion.

O exame de Aristóteles exige parâmetros mais objetivos de classificação da ação 'voluntária'. Como assinala Broadie (1991), a teoria da ação moral aristotélica enfatiza o ponto de vista externo ético, ou seja, baseado no comportamento moral observável do agente ${ }^{363}$. Nessa medida, a teoria da ação voluntária também se afasta de uma explicação puramente causal do 'livre arbítrio' ou da 'responsabilidade moral' no sentido moderno, ${ }^{364}$. Apesar da referência ao princípio ou origem (arché) da ação, o exame se dirige sobretudo a valores morais objetivos de aprovação ou repreensão moral. Antes da 'responsabilidade' moral da ação, a preocupação central de Aristóteles reside na ética e no modo de vida ético humano.

Desde o início de ENIIII, Aristóteles já havia estabelecido os parâmetros do exame da ação moral voluntária: “às paixões e ações voluntárias que dispensa, louvor e censura, enquanto as involuntárias merecem perdão e piedade" (1109a3032). Na realidade, nem a perspectiva interna da 'intenção' nem a 'reponsabilidade moral' moderna expressam a dimensão original de hekoúsion. Em termos gerais, o

\footnotetext{
${ }^{362}$ Para assimilar hekoúsion à 'intenção', Charles (1984, p. 61-62) é forçado a introduzir uma noção artificial de intenção, 'intencional em sentido derivado' para incluir uma classe de ações realizadas com conhecimento, mas sem a intenção do agente (Ver também BOSTOCK, 2000, p. 103-104). Entretanto, Broadie (1991, p. 174-175, n. 10) alerta para as dificuldades inerentes a adoção da tradução de 'intencionalidade' em vista da ampla gama de ações hekoúsion contempla, levando em conta as 'consequências previstas' das ações ou mesmo casos de negligência culpável. Da mesma forma, as ações animais e das crianças não se enquadram nos parâmetros racionais da intenção humana.

${ }^{363}$ Cf. Ibid., p. 137: "The fact is, however that his approach in NE III, focuses on agency as realised complete, out in the world for other to observe, and providing a palpable referent to the question 'Is it voluntary?'. (...) The agent is viewed from outside, figuring not only as 'he' or 'she', but also as 'you'."'

${ }^{364}$ De fato, alguns intérpretes costumam enxergar um debate preliminar do problema do livrearbítrio especialmente em ENIII.5. Para a presença do livre-arbítrio em Aristóteles, ver BROADIE, 1991, p. 159-174; BOSTOCK, 2000, p. 112-119. Todavia, mostraremos que a controvérsia desse capítulo da Ética se concentra sobretudo na refutação da tese do 'mal involuntário' e não em um tipo de discussão precursora sobre o livre-arbítrio moderno.
} 
exame da Ética define os limites legítimos de uma teoria da ação moral voluntária. Com efeito, a definição da ação moral voluntária nos encaminha novamente à educação moral das paixões irracionais e a teoria da virtude moral.

As condições fundamentais da ação moral voluntária implicam diretamente o caráter moral do agente. Como vimos, a ação voluntária se expressa nas condições efetivas da ação moral, particularmente, no conhecimento das circunstâncias particulares e sua origem a partir do próprio agente. No entanto, a ação moral voluntária, por si mesma, não é suficiente para a distinção do bom e do mau caráter moral. Desse modo, precisamos nos voltar então às condições fundamentais necessárias da virtude moral dispostas em ENII.

Em ENII4, Aristóteles enumera certas condições segundo as quais identificamos os traços distintivos do caráter virtuoso: (1) o agente "sabe" (eidós), ou seja, tem conhecimento do que faz; (2) forma-se o propósito (prohaíresis) "pelas coisas mesmas" (di'autá), ou seja, em vista da ação em si mesma; (3) a ação procede de um modo de agir habitual "firme e inalterável" (1105a25-30). Sobretudo, a ação virtuosa não se expressa apenas na ação particular do agente, mas também pelo modo de agir: "é justo e temperante não quem realiza ações [desse tipo], mas quem as realiza também tal como (hos) os justos e temperantes". (1105b5-10). De fato, o padrão normativo da virtude moral consiste na excelência racional do homem prudente (phrónimos): "a disposição do propósito (héxis proairetiké) (...) determinada pela razão (lógoi), isto é, como o prudente (hos phrónimos) determinaria." (1106b30-1107a3). Independentemente do paradigma virtuoso máximo do homem prudente, as condições essenciais da virtude moral envolvem invariavelmente a harmonia de três componentes essenciais: as ações morais, as crenças e as paixões irracionais do agente. A partir disso, podemos estabelecer uma definição mais precisa da natureza da virtude moral.

A virtude moral (areté) está relacionada a um estado habitual do caráter do homem bom virtuoso. A natureza da virtude moral não se restringe apenas às paixões (páthe) ${ }^{365}$, isto é, aos impulsos irracionais como apetites (epithymía) ou emoções, nem às capacidades (dynámeis) de realizar ou sofrer tais paixões na alma.

\footnotetext{
${ }^{365}$ Com efeito, o termo epithymía se aplica aos "desejos" de forma indistinta, tanto a curto como a longo prazo, mas no vocabulário psicológico de Aristóteles o termo tende a se aplicar mais aos "apetites corporais". De forma geral, epithymía engloba o gênero maior das paixões (páthe) na estrutura psicológica da alma de Aristóteles. Para uma abordagem similar da epithymía ver DA I.1 403a3-16
} 
Na realidade, a virtude é um estado habitual de 'disposição' (héxis) que abrange tanto as paixões quanto as capacidades da alma (1105b20-1106a10). O homem bom apresenta a plena coordenação entre a razão prática e a ação moral dentro do caráter moral. Ao contrário do caráter virtuoso, o homem acrático falha em sua ação moral justamente por falta da educação moral apropriada das paixões.

O caráter moral virtuoso deixa transparecer o tipo de deficiência moral que resulta no conflito interno acrático. No entanto, o erro moral do acrático não envolve a razão prática, mas sim o conflito fundamental da razão com as paixões contrárias. Em ENIII.2, Aristóteles assinala que o acrático, ao contrário do encrático, age contra o propósito (prohaíresis) em prol do apetite:

o acrático (akratès) age com apetite (epithymôn práttei), porém, não com propósito (prohairoúmenous ou), o encrático (enkratès) age com propósito, porém não com apetite. Ainda mais: há contrariedade (enantioûtai) entre apetite e propósito (...) o apetite relaciona-se com o prazer e a dor (hédeos kaì epilúpou), o propósito, nem com um nem com outro. (1111b10-17)

Nessa passagem, Aristóteles caracteriza o tipo de conflito interno que acomete o caráter acrático e o encrático. A diferença crucial está na oposição entre a prohaíresis e a epithymía. Antes de prosseguir, devemos detalhar a estrutura da razão prática no intuito de esclarecer o conflito interno do acrático. Para Aristóteles, a ação moral voluntária resulta de um processo elaborado da razão prática humana: (1) primeiramente, o fim (télos) da ação humana é fornecido por meio do querer (boúlesis), “o bem (tagathón) é o objeto do querer, mas para cada pessoa é o bem aparente (tò phainómenon)" (1113a15-20); (2) em seguida, há a deliberação (bouleusis) das alternativas de ação para alcançar o fim; (3) por fim, ocorre o propósito (prohaíresis) da preferência racional da ação em vista do fim (1113a10). Desse modo, pretendemos explicar cada parte do processo da razão prática levando em conta os termos técnicos de Aristóteles.

Cada um desses termos gregos, bouleúsis (ou boulé), boúlesis e prohaíresis, representa um desafio peculiar de tradução e precisão filosófica. Em primeiro lugar, a bouleúsis constitui um tipo de 'desejo racional' expresso na deliberação de coisas "que são realizadas por nós, mas nem sempre do mesmo modo", isto é, os objetos da ação humana (1113a15-20). Em segundo lugar, a boúlesis tem sido denominada pelos termos modernos 'vontade', 'anseio' ou 'querer', mas concerne basicamente 
ao fim objetivo ou aparente visado na ação humana (1113a15). No entanto, um dos termos mais controversos certamente é a prohaíresis que constitui uma autêntica inovação aristotélica em faca da psicologia grega antiga ${ }^{366}$.

A prohaíresis representa um termo técnico específico de Aristóteles dado a um elemento singular da razão prática. Dentre as traduções disponíveis, alguns arriscam caracterizá-lo como 'escolha', 'propósito' ‘decisão' ou ‘intenção'. De forma literal, o termo prohaíresis é composto da preposição 'pró' - antes - e 'haíresis' - escolha - o que significaria um tipo de escolha prévia da razão antes propriamente da escolha efetiva na ação ${ }^{367}$. Dentre as diversas traduções correntes, a mais usual atualmente tem sido o termo 'intenção' extremamente relacionada ao debate em torno da ação intencional na filosofia analítica contemporânea. Certamente, a prohaíresis, em seu sentido original, é mais ‘interna' do que 'externa' pois exprime o resultado final da 'decisão racional' do agente, anterior à 'escolha da ação propriamente dita'. No entanto, o termo moderno 'intenção' é um termo demasiado psicológico e dirigido às circunstâncias particulares da ação intencional. Ao contrário, a prohaíresis de Aristóteles tem a função de representar a 'resolução' racional genérica da deliberação racional em vista de um fim desejado independente ainda dos fatores circunstanciais da ação. Devido a esses fatores, a tradução mais próxima do sentido filosófico aristotélico seria o termo 'propósito' ${ }^{368}$. Em todo caso, Aristóteles enfatiza que o processo integral da razão prática da prohaíresis é contrário ao apetite do agente na akrasia. Dessa forma, o conflito interno do

\footnotetext{
${ }^{366}$ Cf. PAKALUK, 2005, p. 130: "Aristotle is self-consciously arguing for a significant change in the Platonic account of the soul." No entanto, Broadie (1991, p. 81) indica que a própria prohairesis envolve o caráter moral: "Aristotle's reference to the prohairetic state is by implication a reference to those very emotions, urges, pleasures and pains which seem to be left out of the definition - the relation being this: what characterises a prohairetic state (as distinct from, say, a skill) is that it shows itself in the agent's acting and failing to act because of his feelings." (itálicos da autora)

${ }^{367}$ LIDDEL-SCOTT, 1990. A prohairesis efetivamente significa a 'escolha de uma coisa perante outra', um 'propósito' ou uma 'resolução' ou, em outro significado, um 'plano' de ação. De qualquer modo, a prohaíresis acompanha o resultado da deliberação do agente e ocorre antes da ação propriamente dita. Cf. ENIII 2 1112a15-18.

${ }^{368}$ Com efeito, Angioni (2011b, p. 312) defende a tradução de prohaíresis por 'propósito' com argumentos convincentes especificando os motivos de rejeitar as outras opções de tradução correntes: "A prohaíresis, assim, envolve as seguintes características: (I) não designa um processo psicológico, mas uma resolução cujo prospecto é uma linha de ação constante; (II) é o mais importante para determinar a qualidade moral da ação; (III) não é um evento pontual a ocorrer no momento da ação; (IV) ocupa uma posição intermediária, que já envolve determinação preliminar sobre "meios", mas que funciona como "alvo" (fim) a ser especificado pela consideração sensata dos fatores singulares relevantes em cada ação. O conjunto de todas essas características parece ser mais bem captado por "propósito", pois (III) e (IV) são bem desfavoráveis às opções "decisão" e "escolha". Opção melhor seria "intenção", que ao menos captaria bem os pontos (II) e (IV)."
} 
acrático implica mais profundamente o apetite relacionado ao prazer e a dor do que propriamente à razão prática em si mesma.

A virtude moral consiste justamente na reação do agente perante o prazer e a dor mais do que propriamente o exercício isolado da prohaíresis. Nesse sentido, Aristóteles atribui o sinal distintivo da virtude moral ao prazer e a dor alinhando-se então a Platão:

\begin{abstract}
A virtude moral (ethikè areté) relaciona-se com prazeres e dores (perì hedonàs kaì lýpas) - por causa do prazer praticamos atos maus, por causa da dor nos abstemos das ações nobres. Por isso que deveríamos ter sido educados de certo modo desde a juventude, como diz Platão, a fim de nos alegrarmos e sofrermos com o que se deve (dê̂): esta é a educação correta (orthè paideía) $(1104 \mathrm{~b} 9-13)$
\end{abstract}

O prazer e a dor constituem reações emocionais distintivas do caráter moral do agente. Se o agente se satisfazer com ações nobres e boas ou sofrer com ações vis e vergonhosas, ele se inclina ou evita as coisas moralmente apropriadas ao caráter moral virtuoso. Se ele tiver prazer com ações vis e injustas e repudiar ações nobres e boas, ele se inclina ou evita coisas moralmente inapropriadas, exibindo um vício moral (1104b15-25). Em ambos os casos, as reações emocionais de prazer e dor antecedem a própria consciência moral do agente. $\mathrm{O}$ vício moral do acrático manifesta um conflito peculiar, o impulso de prazer pelas coisas vis e vergonhosas contra a orientação da razão correta ao bem. Por isso, o conhecimento racional é ineficaz sem a educação moral apropriada das paixões irracionais.

As diretrizes platônicas da República acerca da educação moral das paixões são seguidas na Ética de Aristóteles. Como observamos, o extenso projeto educacional da República enfatiza a relevância da educação moral das paixões na formação do caráter moral disposto à obediência dos impulsos irracionais à razão. As reações emocionais de prazer e dor apropriadas são estimuladas desde a juventude pela 'educação correta' (orthé paideía) antes mesmo do amadurecimento da razão ou da aquisição do conhecimento e da prática moral ${ }^{369}$. Dessa forma, o

\footnotetext{
${ }^{369}$ De acordo com Burnyeat (2010, p. 169), a doutrina aristotélica da educação moral das motivações irracionais tem profundas raízes platônicas: "Aristóteles deve a Platão, como reconhece em II 3, a ideia de que essas respostas avaliativas motivadoras não são racionais (...) e, porque não são racionais outros tipos de treinamento devem ser concebidos a fim de as dirigir aos tipos corretos de objetos sobretudo a prática guiada e a habituação (...)". Para maiores detalhes sobre a influência da educação moral platônica das motivações irracionais na teoria da virtude moral, ver também BROADIE, 1991, p. 103-108.
} 
ensino moral da Ética não é destinado a qualquer um, mas somente aqueles que já dispõem da educação moral necessária das paixões irracionais de prazer e dor.

A princípio, certos indivíduos, tais como os jovens e acráticos não conseguem tirar proveito das lições morais por causa da imaturidade de suas paixões. Por isso, Aristóteles assinala que suas lições não se dirigem ao conhecimento propriamente, mas ao exercício da virtude: "a presente disciplina não se dirige ao conhecimento teórico (...) pois inquirimos não para saber o que é (tí estin) a virtude, mas para tornar-nos bons (agathoì genómetha)." (1103b20-30). Dessa forma, a investigação sobre a aquisição da virtude moral precede o exame da natureza da virtude.

Como indica Burnyeat (2010, p. 158-162), o objetivo central da Ética não é proporcionar o saber do porque da excelência moral, isto é, a sabedoria prática do homem prudente (phrónimos) plenamente consciente do que precisa ser feito nas mais variadas circunstâncias da vida moral e adequadamente motivado a agir. Ao contrário, a principal finalidade da educação moral é proporcionar o saber do o que, do homem que ainda não possui a prudência (phrónesis) mas está disposto a prestar atenção e aplicar na prática os ensinamentos morais da Ética ${ }^{370}$. Notavelmente, o conflito interno entre razão e paixão do acrático manifesta o efeito psicológico da ausência da educação moral das paixões.

Para averiguarmos os efeitos psicológicos da falta da educação moral das paixões, precisamos nos voltar à psicologia moral por trás do conflito interno do acrático. Como veremos, a influência de Platão sobre a Ética não se verifica apenas na teoria da virtude moral, mas se reflete também na psicologia moral aristotélica. Diante disso, observaremos quais as semelhanças e as diferenças entre a psicologia moral da Ética e a psicologia tripartite platônica.

\section{3}

\section{A psicologia moral e o conflito interno da alma}

\footnotetext{
${ }^{370}$ Cf. Ibid., p. 162: “A pessoa plenamente desenvolvida e dotada de virtude prática entende o porque dessas convicções (...) ela tem conhecimento ou familiaridade no sentido não qualificado -, mas esse estado é precedido pelo conhecimento (no sentido qualificado - do que por parte do aprendiz, adquirido mediante habituação e tornado segunda natureza." Ver também, BROADIE, 1991, p. 109110 .
} 
O conflito interno da akrasia reflete a existência de um conflito fundamental entre a razão prática e o apetite irracional. Em ENI.13, a divisão do elemento racional (ton lógon échon) e irracional (álogon) da alma está claramente ligada à existência do conflito interno da alma. Nessa perspectiva, iremos explorar as raízes platônicas da divisão da alma aristotélica em De Anima. Antes disso, no entanto, precisamos analisar as condições específicas de divisão da alma na Ética a Nicômaco.

A psicologia moral da Ética está dentro dos limites do exame da virtude moral. Dessa forma, o exame da psicologia humana de EN I.13 está ligado à teoria da virtude moral. Efetivamente, a psicologia moral de $E N$ não tem a mesma dimensão que o exame mais detalhado da alma (psyche) dos seres vivos em geral de De Anima ${ }^{371}$. Dentro do amplo domínio político-moral da Ética, a psicologia humana também faz parte da política: "o homem político deve saber de certo modo o que concerne à alma (tà perì psychês)" (1102a15-20). No entanto, a psicologia humana só integra o campo político-moral porque envolve a 'virtude humana' da 'atividade da alma' (psychês enérgeian). De fato, o debate mais profundo sobre a natureza 'unitária' ou divisível da alma fica expressamente fora do escopo da presente investigação da Ética (Cf. 1102a25-30) ${ }^{372}$.

Durante esse exame, um dos campos do elemento irracional, a 'parte' vegetativa (phytikós) irracional, é logo excluída do exame da psicologia moral de ENI.13. Segundo Aristóteles, tal 'parte' psicológica não tem “nenhuma participação da razão" (oûdamos koinonê̂ lógou) e, portanto, não contribui no exercício da virtude moral (1102b29-30). A parte vegetativa abrange alimentação e crescimento, isto é, a função nutritiva do ser vivo, sendo comum (koinón) a homens, embriões e até mesmo homens bons e maus durante sono (1101a25-1102b10). A partir disso, Aristóteles abandona a passividade da parte nutritiva para analisar a área ativa da alma humana pertinente à ação moral.

\footnotetext{
${ }^{371}$ Cf. PRICE, 1995, p. 108: "In the Ethics, he can make use of partition for local purposes (...) without considering it critically as a contribution to a scientific psychology (...) Of course, this could be why he appears not too concerned in the Ethics about consistency. With or without being more careful, he evinces a very different attitude in the De anima when he is enquiring about 'what it is in the soul that causes motion." Ver também ZINGANO, 2008, p. 84-85

372 Com efeito, Aristóteles expressamente recomenda o estudo mais aprofundado dos "escritos exotéricos (toîs exoterikoîs lógois)" mas a sua posição sobre o tema pode ser analisada de forma mais desenvolvida em De Anima.
} 
O exame da alma de ENI.13 se restringe ao campo limitado da ação moral humana. Como vimos, Aristóteles adota à divisão popular fundamental do domínio racional e o domínio irracional da alma. No entanto, a psicologia moral se dirige à relação dinâmica entre o elemento racional e o irracional que "participa em certa medida da razão" (metéchousa pei lógou) (1102b12-14). Nesses termos, a natureza 'reativa' dessa parte irracional à razão prática inerente ao campo moral.

Há uma parte irracional 'responsiva' à razão de natureza dupla, isto é, que pode responder de forma positiva ou negativa à parte racional. De um lado, a parte irracional responde de forma positiva, quando é "acatadora e obediente" e "é persuadida de certo modo pela razão (peíthetai pos hypó lógou)" (1102b301103a1). De outro lado, a parte irracional pode reagir de forma negativa à razão, quando é "contrária à razão (parà tón lógon), contrapondo-se e resistindo a ela (enatioúmenon kaì antibaînon)" (1102b23-25). Particularmente, essas manifestações da irracionalidade são acentuadas na própria natureza do conflito interno do homem acrático e encrático.

O caráter acrático e o encrático manifestam diferentes conflitos internos da alma. Embora ambos sofram de conflito interno, o acrático e o encrático manifestam reações divergentes da parte irracional responsiva:

\footnotetext{
louvamos, no homem encrático e acrático, a razão e a parte racional da alma (lógon kaì tês psychês tò lógon), porquanto ela os impele corretamente às melhores ações, mas manifesta neles uma outra parte, por natureza contrária à razão (parà tón lógon pephukós), que combate e puxa em sentido contrário à razão. (...) no homem encrático, ele obedece à razão (peitharcheî tôi lógoi) (1102b12-28)
}

O erro do acrático e a ação moral correta do encrático expõem uma diferença significativa de comportamento moral. Do ponto de vista psicológico, ambos os casos são semelhantes: (1) os dois indivíduos sofrem um conflito interno entre a razão e a parte irracional responsiva, "contrária à razão" (pará tón lógon); (2) nenhum dos casos apresenta uma falha de raciocínio já que "a parte racional os impele corretamente às melhores ações". Entretanto, o que diferencia os dois casos é justamente na ação moral: enquanto o encrático consegue agir de acordo com a razão, o acrático simplesmente age contra a razão.

Como vimos anteriormente, o erro da akrasia não decorre efetivamente da prohaíresis da razão prática mas provém da influência do apetite irracional na ação 
moral. Ora, mas então porque o homem encrático consegue realizar a ação da prohaíresis em favor da razão? A diferença no comportamento moral de ambos os casos indica uma diferença substancial na natureza do seu conflito interno, a akrasia expressa a derrota da razão diante dos apetites enquanto a enkrateia envolve o domínio racional dos apetites. Com efeito, Aristóteles atribui elementos cognitivos ao domínio dos apetites: "a parte apetitiva e, em geral, desiderativa participa em certa medida da razão (epithymetikòn kaì hólos orektikòn metéchei pos)" (1102b3032). É necessário determinar, então, o que abrange o campo comum do epihtymetikon e orektikon e o tipo de interação dinâmica que promove o conflito interno do apetite com a razão prática.

Os termos orektikón e epithymetikón abarcam a terminologia conceitual do desejo na Ética. Ambos os termos órexis e epithymía atendem ao amplo significado semântico dos desejos humanos, mas Aristóteles confere um novo significado a esses termos no intuito de traçar uma distinção geral e específica de tipos de 'desejo'. Como vimos, o temo grego mais comum do ‘desejo' é epithymía ${ }^{373}$ ligado geralmente aos diversos 'apetites' de forma indistinta no sentido tradicional. Para Aristóteles, a epithymía costuma se restringir aos 'apetites corporais' estando ao lado de estados emocionais diversos, como cólera (orgé), medo (phóbos), ódio (mîsos), compaixão (eléos), prazer (hedoné) e dor (lýpe), dentro da ampla categoria das paixões (páthe) (11106b20-22). A princípio, o campo dos apetites corporais da epithymía se destaca do campo geral da órexis. Todavia, o termo órexis ${ }^{374}$ está absolutamente ausente da tradição grega e parece constituir uma autêntica inovação filosófica de Aristóteles.

De forma geral, a órexis expressa um termo técnico aristotélico que possui amplo alcance: contempla tanto os desejos corporais imediatos, como comida, bebida ou sexo, quanto desejos 'racionais' prolongados na saúde, virtude e

\footnotetext{
${ }^{373}$ Como mencionamos anteriormente, apenas Platão irá conferir uma noção mais precisa ao termo 'epithymía' com referência aos apetites irracionais de forma geral. Na Ética, Aristóteles reconhece a distinção tradicional básica entre apetites corporais e apetites da alma, bem como outras classificações de apetites (comuns e individuais ou naturais e excessivos, cf. 1117b25-1118119a20). Novamente, Aristóteles não exprime interesse em aprofundar a análise da natureza dos apetites pois seu interesse primordial é na psicologia moral e não no exame geral da psicologia humana.

${ }^{374}$ Cf. LIDDEL-SCOTT, 1996. Em sentido estrito, órexis é um termo amplo que significa 'desejo' ou 'impulso conativo' de forma geral, o que inclui desejos diferentes entre si como a boúlesis, o thymós e mesmo a epithymía. Não é por acaso que esse termo capta o desejo geral da ação por um fim no vocabulário psicológico de Aristóteles.
} 
felicidade ou o ímpeto (thymós) ligado à honra e à raiva ${ }^{375}$. Na realidade, o conceito singular órexis significa mais do que apenas um conglomerado de diversos desejos. Segundo Nussbaum (2009, p. 240-241), a órexis e suas formas derivadas conferem um duplo significado à terminologia aristotélica do desejo ${ }^{376}$ : (1) o foco do desejo orientado a um fim específico; (2) o predomínio da potência ativa em lugar da passividade do desejo. Desse modo, o impulso da órexis implica em uma tese teleológica do desejo humano, ou seja, a orientação natural do desejo humano a um fim (télos) específico da ação. A crítica aristotélica à divisão tripartite da alma em De Anima inevitavelmente pressupõe a unidade da órexis.

A crítica de Aristóteles à psicologia grega predecessora envolve a divisão das partes da alma. O seu alvo primordial é a noção tradicional das 'partes' da alma, mas não deixa de visar a psicologia tripartite da República. Em DA III.9, Aristóteles se dirige indistintamente aos adeptos da divisão da alma: "alguns dizem distinguir em calculativa, emotiva e apetitiva (logistikòn kaì thymikòn kaò epithymetikón), mas outros em racional e irracional." (432a22-30). Mesmo sem uma referência explícita, o seu alvo certamente inclui a psicologia platônica e o modelo tripartite da República. Ora, mas a crítica de Aristóteles é pertinente para esclarecer o conflito interno da alma? Para isso, devemos analisar a crítica aristotélica à noção de 'partes' da alma.

As múltiplas capacidades da alma não abarcam a divisão das partes da alma. Para Aristóteles, a alma humana exibe diferentes capacidades (dýnameis): a 'nutritiva' (threptikón), a 'perceptiva' (aisthetikón), a 'imaginativa' (phantastikón) e, enfim, a 'desiderativa' (orektikón) (432a29-b10). Nessa perspectiva, correríamos o risco de ter uma divisão ao infinito das partes da alma equivalente a cada uma das capacidades humanas. No entanto, a orektikón constitui uma unidade indivisível: “pois é na parte calculativa que nasce o querer (boúlesis), mas o apetite e a emoção (he epithymía kaì ho thymós), na parte irracional; e caso a alma seja tripartite, em

\footnotetext{
375. De fato, Aristóteles não destaca um espaço ao domínio das emoções em torno de uma capacidade mental específica, ao menos na psicologia moral da Ética. No entanto, o domínio das paixões (páthe) claramente engloba tanto os apetites quanto as emoções de forma geral. Ver também BOSTOCK, 2000, p. 34-35.

${ }^{376}$ Cf. Ibid., p. 240: "De qualquer modo, uma vez que recuperamos um sentido da novidade e a estranheza filosófica dessa palavra, podemos começar a ver, também, qual conteúdo pode haver para as afirmações de Aristóteles (..). Ele está dizendo, aparentemente, que são formas do estender-se ativo e interior, direcionado ao objeto; e que esse tipo de estender-se é comum tanto ao movimento dos humanos como de outros animais."
} 
cada parte haverá desejo (órexis)." (432b1-5). Nesse aspecto, a órexis constitui a unidade central do 'desejo' comum às diferentes 'partes' da alma.

A unidade do orektikón deixa transparecer a noção aristotélica das múltiplas capacidades (dýnameis) da alma. Em seu ataque às partes da alma, Aristóteles defende a unidade indivisível da órexis "de acordo com as potências" (katà tàs dýnameis): "é uma potência da alma deste tipo a que move (dýnamis kinê̂ tês psychês), o que é chamado de desejo (órexis)." (433a25-433b1). Dessa forma, Aristóteles defende o modelo das capacidades (dýnameis) psicológicas contra o modelo das 'partes' da alma. Particularmente, a órexis constitui a capacidade do movimento da alma para a ação. Ao mesmo tempo, as outras motivações da alma também envolvem órexis, como a boúlesis, o thymós e epithymía, o intelecto (noûs) e, o 'intelecto prático' (ho praktikós noûs) (433a9-20). De forma isolada, nenhum desses elementos da alma promove o movimento da alma por si mesmos sem estarem acompanhados da órexis.

O conflito interno da akrasia e da enkrateia exibe a limitação das motivações isoladas no domínio da ação (433a1-9): o acrático age pelo apetite contra as diretrizes do "intelecto e raciocínio (toû noû kaì tês dianoías)", enquanto o encrático age seguindo o intelecto (tô̂ noi), mesmo "tendo desejos e apetites (oregómenoi kaì epithymoûntes)" contrários. A órexis orienta as motivações da alma para ação em vista do fim desejado. Por isso, todo e qualquer conflito interno exige necessariamente o confronto da orientação prática da órexis com outras forças motivacionais na ação moral. No entanto, o modelo das dýnameis da alma não faz juz à teoria tripartite da alma platônica nem permite apreciar o grau de sua influência na psicologia moral aristotélica.

A crítica de Aristóteles às 'partes' da alma está comprometida com o modelo das dýnameis da alma. Ora, seria essa crítica pertinente à teoria tripartite da alma platônica? A capacidade da órexis capta a dimensão teleológica 'unificadora do desejo humano, enquanto a teoria tripartite da alma reflete o domínio teleológico particular de três domínios específicos do desejo humano ${ }^{377}$. A crítica particular do

\footnotetext{
377 Para Nussbaum (2009, p. 240-241), a capacidade unificadora da órexis é superior ao modelo tripartite de Platão: "Aristóteles, ao escolher essa palavra particular [orexis], está afirmando que o elemento singular ou comum que Platão deixa de reconhecer é esse elemento do buscar alcançar algo no mundo, procurar apreender algum objeto no intuito de toma-lo para si." No entanto, iremos mostrar que no modelo das dynameis de Aristóteles se aproxima do modelo tripartite da alma da República no reconhecimento da inclinação específica de cada desejo a seu elemento externo apropriado.
} 
modelo das dýnameis parece envolvida em uma confusão substancial sobre a psicologia tripartite platônica.

A divisão estrita do elemento racional e o elemento irracional da psicologia aristotélica é incompatível com a divisão tripartite da alma platônica. De acordo com Price (1995, p. 109-110), a crítica aristotélica falha ao destacar dois paradigmas psicológicos que estão intrinsecamente conectados na psicologia tripartite platônica, o modelo do domínio e o modelo de capacidades da alma Como observamos, a crítica de Aristóteles às partes da alma consiste em tratar o domínio em termos de capacidade psicológica, declarando que o modelo platônico do domínio inviável. Diante disso, Price assinala que a adesão aristotélica à concepção psicológica grega popular das capacidades não lhe permite enxergar as suas afinidades com o modelo do domínio das partes da alma da teoria tripartite platônica ${ }^{378}$. De fato, o próprio critério aristotélico de divisão racional/irracional segue os princípios fundamentais da teoria tripartite da alma.

Em DA III.10, Aristóteles subscreve a um princípio psicológico de separação dos desejos da alma que seria equivalente ao princípio platônico do conflito de desejos (PC):

Uma vez que ocorrem desejos que são contrários (oréxeis enantíai) uns aos outros, e isso acontece quando a razão e os apetites (lógos kaì epithymíai) forem contrários, (...) o intelecto (noûs), de um lado, ordena resistir por causa do futuro, mas o apetite (epithymía), de outro lado, ordena agir por causa do imediato (...) então, o que faz mover seria de uma única espécie: o elemento desiderativo (tò orektikón) enquanto tal (...) (433b511)

O conflito de desejos fornece um princípio suficiente para a distinção da natureza de dois tipos de desejo, a "razão e os apetites (lógos kaì epithymíai)". Nessa medida, Aristóteles reconhece na 'contrariedade' (enantíon) dos impulsos um critério de distinção dos diferentes tipos de desejos humanos. Em vista da contrariedade, o apetite (epithymía) orienta à ação pelo prazer imediato enquanto o intelecto (noûs), por sua vez, oferece resistência por causa das consequências

\footnotetext{
${ }^{378}$ Cf. Ibid., p. 110: "Instead, Plato's partition has to be rejected in favour of his own, and can be admitted within his Ethics only with the excuse that ethics does not demand the precision of psychology. Happily, indeed all too conveniently, he is willing to play along there with ways of thinking that he views aspopular. His injustice to Platonic partition in his philosophy of mind does not prevent him from making use of it (...)."
} 
futuras pela 'percepção temporal' dos prazeres. Assim como na teoria tripartite platônica, Aristóteles endossa, de certo modo, o princípio do conflito de desejos (PC), isto é, a oposição absoluta do objeto natural dos desejos. O conflito de desejos elimina, então, a simples contrariedade dos apetites particulares, como a oposição simples da fome e da sede (cf. BROADIE, 1991, p. 61-67). Todavia, Aristóteles não aplica o princípio de conflito de desejos (PC) à uma divisão estrita das partes da alma. Dentro da psicologia aristotélica, os desejos da alma só resultam na ação a partir da organização do desejo unificador da órexis. Mesmo assim, a adesão ao princípio do conflito de desejos (PC) revela as similaridades entre a psicologia aristotélica e a teoria tripartite platônica da alma.

Como observamos, o princípio de conflito de desejos (PC) está na base da demonstração da teoria tripartite da alma (436b-c). A divisão preliminar do elemento racional e do elemento irracional da alma de ENI.13 claramente decorre da natureza contrária dos apetites e do desejo racional. Nessa perspectiva, Aristóteles segue os parâmetros de PC da teoria tripartite da República.

Na República, a oposição absoluta dos apetites e do desejo racional assegura a separação da parte racional (logistikón) e da parte apetitiva (epithymetikón) na teoria tripartite da alma (439a-d). A partir disso, Sócrates também não deixa de reconhecer uma separação mais estrita da parte racional e a parte irracional da alma na República (439d-e). Ao final, a distinção platônica entre 'racional' e 'irracional' da República reflete a oposição fundamental da parte racional e as outras partes inferiores da alma, isto é, a parte impetuosa (thymoeidés) e o epithymetikón. Em todo caso, o princípio do conflito de desejos é fundamental para revelar a natureza irracional da parte apetitiva contrária a parte racional. Da mesma forma, o PC também contribui para a separação do elemento racional e do elemento irracional na psicologia moral de Aristóteles. No entanto, a unidade da órexis da psicologia aristotélica impede a divisão literal das 'partes' da alma. De qualquer modo, a Ética contém outras passagens que reforçam as afinidades da psicologia moral de Aristóteles com a psicologia tripartite platônica.

Ao longo da Ética, Aristóteles traça novas observações sobre a natureza dos apetites (epithymíai) e do ímpeto (thymós) que refletem a natureza do thymoeidés e o epithymetikón na teoria tripartite da alma da República. A seguir, devemos averiguar em que medida a interação do elemento irracional e o elemento racional 
da psicologia aristotélica e a interação dinâmica das partes da alma na psicologia platônica têm elementos comuns.

Em primeiro lugar, a contrariedade dos apetites em relação à razão reflete a natureza irracional do epithymetikón platônico. Em ENI.13, o conflito interno da alma manifesta uma dupla capacidade da 'parte irracional' da psicologia moral aristotélica: o elemento desiderativo "combate e puxa em sentido contrário à razão (máchetai kaì antiteínei tôi lógoi)" no acrático, enquanto no encrático o mesmo elemento "obedece à razão" (1102b15-30). Na sequência, a dupla capacidade do elemento desiderativo é reiterada. De acordo com Aristóteles, os apetites podem se tornar tão "fortes e violentos (megálai kaì sphodraì), que expelem o raciocínio" por conta de sua tendência natural (tò syngenés) à insaciedade (áplestos), mas, ao mesmo tempo, podem ser "poucos e moderados, sem oposição à razão", caso sejam disciplinados “conforme a razão (katà tòn lógon)" (1119b5-15). O impulso violento dos apetites pelo prazer é ainda mais forte na idade infantil devido à inclinação habitual das crianças às suas paixões. Desde cedo, a imaturidade das paixões dos jovens deve ser refreada com base no cultivo da virtude moral. Por isso, Aristóteles recorre ao paradigma educacional da "obediência à razão".

O paradigma educacional da 'obediência racional' salienta um aspecto adaptativo do elemento desiderativo. Como observamos, a parte desiderativa "participa de certo modo da razão" (metéchousa pei lógou) (1102b12-15) mantendo uma relação dinâmica com a parte racional da alma. O elemento irracional possui uma capacidade 'responsiva' da razão, o que abrange tanto uma reação positiva quanto uma reação negativa à regra racional ${ }^{379}$. De um lado, a parte irracional expressa uma reação positiva quando é "acatadora e obediente, do modo como dizemos levar em conta a razão (échein lógon) do pai e dos amigos"(1102b30). Em especial, a analogia destaca o paradigma da obediência paterna e da aprendizagem com o mestre representada na autoridade racional externa. De fato, o paradigma da autoridade externa determina a subordinação interna dos apetites irracionais à orientação da razão. De outro lado, a mesma parte irracional pode apresentar uma

\footnotetext{
${ }^{379}$ Cf. BROADIE, 1991, p. 66: "Much, then, hangs on being able to show that a relationship can exist between reason and something to which reason addresses its precepts that has the following features: (1) addresser and addressee are clearly other than each other; (2) they are clearly in harmony. This pair of conditions is seen to be fulfilled by the relationship between external authority and willingly obedient respondent."
} 
reação negativa à razão sem a formação da virtude moral e sem a educação moral necessária dos apetites em obediência à razão. Através da educação moral, as paixões imaturas são habituadas para acatarem as ordens da autoridade racional com o desenvolvimento da virtude moral. Desse modo, a parte irracional da alma se caracteriza não só por seus elementos não cognitivos mas também por seus elementos cognitivos.

A parte apetitiva (epithymetikón) da psicologia tripartite exibe a mesma plasticidade do elemento desiderativo de Aristóteles. Com efeito, Platão também confere à educação moral um papel decisivo na formação do caráter moral na República. Em ambos os casos, os apetites dependem da educação moral tanto na cooperação quanto no desvio dos preceitos da parte racional. No entanto, o thymoeidés constitui o intermediário fundamental entre a razão e os apetites na psicologia tripartite platônica. Mesmo sem dedicar uma análise destacada ao thymós em sua psicologia moral, Aristóteles esboça uma representação desse impulso na Ética que remonta à psicologia tripartite da alma.

Em segundo lugar, o thymós constitui um aliado natural da razão tal como o thymoeidés platônico. Na República, o thymoeidés representa um importante intermediário entre a parte apetitiva e a parte racional da alma sendo "auxiliar do racional por natureza" e sujeito à persuasão racional (441a). De um lado, a natureza do thymoeidés é fundamental na intermediação entre a razão global do logistikón e a irracionalidade absoluta do epithymetikón (439a-d). De outro lado, a natureza irracional do thymoeidés também o distancia da natureza da parte racional da alma: a raiva irracional é comum também em animais e crianças sem razão constituída, assim como o ódio à persuasão e ao argumento racional salienta a irracionalidade inerente das emoções humanas (Cf. 411b-412a;441b; 604d-e). No exame da akrasia de ENVII, Aristóteles reconhece traços irracionais semelhantes no thymós:

O ímpeto (ho thymòs) parece escutar a razão até acerto ponto (akuoúein ti toû logoû), mas ouvi-la mal (...) o ímpeto devido à sua natureza ardente e apressada (dià thermóteta kaì tachutêta tês phýseos), embora ela escute, não escuta uma ordem e precipitase para a vingança. (1149a29-32)

O thymós se alinha à razão mas, ao mesmo tempo, se precipita à ação antes de seguir as orientações da razão. Assim como na República, Aristóteles compara a ira irracional do thymós aos exemplos emblemáticos de servos apressados a 
cumprir ordens de seus mestres e animais domesticados, como cães, que, por vezes, não obedecem às ordens superiores. Como observamos anteriormente, a relação de autoridade racional reforça a imagem da 'obediência ao pai e ao preceptor' da 'parte irracional' capaz de 'escutar a razão'. Ao mesmo tempo, a desobediência da razão expõe a degradação moral da ausência da educação moral das paixões irracionais. Mesmo assim, Aristóteles ressalta também que o thymós tem maior afinidade natural com o raciocínio do que os apetites pela sua capacidade de 'escutar a razão' (1149a30-b4). De certa forma, as indicações de Aristóteles sobre o thymós acompanham as características do thymoeidés platônico aliado natural da razão. Sobretudo, a preocupação premente com a necessidade de educação moral dos apetites atravessa a psicologia moral de Platão e Aristóteles.

Em linhas gerais, a parte irracional da psicologia moral da Ética exibe elementos comuns à psicologia tripartite da República. Por mais que há diferenças notáveis nos modelos psicológicos de Platão e Aristóteles, verificamos também alguns elementos comuns. Sobretudo, notamos que Platão e Aristóteles estão alinhados ao modelo psicológico cognitivo-motivacional, isto é, uma teoria psicológica que atribui elementos cognitivos às paixões irracionais, inerente à psicologia grega antiga ${ }^{380}$. Nessa perspectiva, o conflito entre a razão e as paixões irracionais constitui um conflito inerente das motivações divergentes expressas em diferentes tipos de crenças e desejos humanos. Não é por acaso que ambos dedicam um espaço primordial ao papel da educação moral das paixões irracionais de prazer e dor no caráter moral independente do conhecimento racional. Assim, a psicologia tripartite da República antecipa de certa forma a preocupação premente da Ética com a educação moral dos apetites.

A divisão dos tipos de virtudes orienta a divisão da psicologia moral da Ética a Nicômaco. Desde a divisão da parte racional e irracional da alma de ENI.13, Aristóteles estabelece a separação preliminar das "virtudes intelectuais e de caráter moral (tàs mèn dianoetikás tàs dè ethikás)" (1103a4-10). A partir de ENVI.1, há uma nova divisão da alma dentro da parte racional da alma, uma parte "científica" (epistemonikón) e outra parte "calculativa" (logistikón). Nesse cenário, o objetivo

\footnotetext{
${ }^{380}$ Como mostramos anteriormente, a psicologia cognitivo-motivacional estabelece uma relação complementar entre o estado cognitivo e as motivações irracionais do agente. Nessa perspectiva, conflitos de motivações irracionais também pode envolver elementos cognitivos. Para algumas implicações dessa teoria cognitivo-motivacional em Aristóteles ver PRICE, 1995, p. 125-128; CHARLES, 1984, p. 161-168
} 
de Aristóteles é separar as virtudes intelectuais relativas ao conhecimento científico (das coisas necessárias) das virtudes práticas relativas à "deliberação e cálculo (tó bouleúesthai kai logízesthai)" (das coisas contingentes) (1139a5-15). Em última instância, a divisão das capacidades (dynámeis) humanas na psicologia moral acompanha o campo prático do exercício da virtude (areté) na Ética.

O conflito interno da akrasia constitui uma deficiência moral da parte irracional da alma relativa ao campo do caráter moral. De fato, Aristóteles classifica expressamente a akrasia como um tipo de vício moral. No entanto, o Sócrates do Protágoras alegava que a akrasia é apenas uma forma de ignorância involuntária. Por sua vez, Aristóteles sustenta que a akrasia é um vício moral decorrente de ações morais voluntárias. Na sequência, nos ocuparemos com os critérios de classificação dos tipos de ignorância e a refutação da tese do 'mal involuntário' presentes em ENIII. A partir disso, poderemos compreender os critérios de Aristóteles para a classificação da akrasia como um vício moral voluntário.

\section{4 \\ A ignorância e a akrasia voluntária}

De acordo com os princípios da ação moral, a akrasia e o homem acrático são claramente voluntários. Ao longo da Ética, Aristóteles assume com frequência que a akrasia é uma ação moral voluntária e o homem acrático possui um caráter voluntário $^{381}$. Em ENIII, há duas teses centrais que fundamentam sua classificação do vício voluntário da akrasia : a) a distinção entre a ignorância involuntária e a ignorância voluntária, na qual se incluiria a akrasia (1110b15-1111a); b) a refutação do paradoxo do 'mal involuntário' por conta da voluntariedade do vício moral, em geral, e, especificamente, do caráter acrático (1113b15-1114b25). Em todo caso, a tese socrática da ignorância e o paradoxo socrático do 'mal involuntário' conjugam a negação da possibilidade da akrasia e representam um desafio à defesa da akrasia voluntária.

A posição socrática do Protágoras compromete a ação moral voluntária da akrasia. Em ENVII.3, Aristóteles confronta a tese socrática da ignorância embora

\footnotetext{
${ }^{381}$ Sobre o aspecto voluntário da ação voluntária da akrasia e o caráter moral acrático ao longo da Ética, cf. 1141a5-18; 1136b1-5; 1142b15-20; 1152a14-20.
} 
admita, por fim, que o fenômeno consiste em um tipo de ignorância temporária (1147b15-20). Nessa medida, sua posição parece entrar em conflito com os princípios da ação moral voluntária de ENIII.1. A princípio, a classificação da akrasia como um tipo de ignorância enquadraria o fenômeno dentro da classe dos atos involuntários, isto é, atos realizados sem conhecimento do agente. É preciso lembrar que atos involuntários inspiram 'perdão' e 'piedade' enquanto os atos voluntários inspiram 'louvor' e 'censura' (1109b30-33). A akrasia estaria, então, fora do campo da ação moral caso envolva um ato involuntário de ignorância. Dentro dessa perspectiva, a akrasia não seria apenas um ato perdoável, mas um ato cometido pelo agente sem conhecimento de causa.

Ao mesmo tempo, a defesa da ignorância também compromete a refutação do paradoxo moral do 'mal involuntário' de ENIII.5. Na formulação de ENIII.5, o paradoxo geral do 'mal involuntário' não se dirige propriamente a Sócrates, mas claramente podemos incluí-lo entre seus prováveis defensores. Como observamos, o paradoxo socrático de que 'ninguém faz o mal de bom grado' constitui duas teses complementares do Protágoras, a negação absoluta do mal voluntário e o eudaimonismo psicológico, a tese de que há uma inclinação humana natural pelo bem. Ora, se Aristóteles descreve a akrasia em termos de ignorância, não estaria também comprometido implicitamente com o paradoxo socrático? Diante dessas inconsistências aparentes, é imprescindível explicitar antes mais claramente os princípios da teoria da ação moral vonluntária de ENIII.

Diante desses problemas, precisaremos nos voltar ao tema da ignorância e do paradoxo moral em ENIII. Dessa forma, devemos averiguar em que medida Aristóteles se aproxima ou se afasta da posição socrática do Protágoras. Com efeito, isso será fundamental quando nos voltarmos à descrição da natureza do fenômeno em ENVII. Nessa perspectiva, mostraremos que a teoria da ação moral voluntária de ENIII se contrapõe frontalmente às teses socráticas do Protágoras. Para isso, precisamos primeiro nos concentrar sobre o tema da ignorância na ação moral antes de prosseguirmos ao problema mais complexo do paradoxo moral. Desse modo, retornaremos adiante à relação entre a ação voluntária e a ignorância em ENIIII.

A princípio, os atos de ignorância parecem estar claramente incluídos na classe dos atos involuntários. Como observamos, os atos involuntários atendem à duas categorias específicas de ação: (1) podem ser compulsórios (bíai), isto é, tem 
a causa em uma interferência externa, natural ou humana, e, ao mesmo tempo, não há contribuição efetiva do agente na ação; (2) podem ser realizados por ignorância (di'ágnoian) sem que o agente possua pleno conhecimento de todos os fatores particulares da ação. A classificação da akrasia em termos de ignorância parece inserir o fenômeno dentro da classe dos atos involuntários, fora do campo da ação moral voluntária. No entanto, a controvérsia da ignorância em ENIII.1 mostra que é preciso definir as condições e os tipos de ignorância moralmente perdoáveis.

Ao longo de ENIII, Aristóteles esboça uma série de distinções sobre os tipos de ignorância. De acordo com a primeira distinção, os atos de ignorância se dividem entre atos não voluntários (ouk hekoúsion) e atos involuntários (akoúsion) (1110b15-25). De fato, ambos os casos parecem exibir ignorância da mesma maneira mas o que os diferencia realmente é a reação emocional posterior do agente: "as que se arrependem são consideradas agentes involuntários (akoúsion), e as que não se arrependem (....) de agentes não-voluntários (ouk hekoúsion)" (1110b20-24). No primeiro caso, a ignorância da ação moral não gera qualquer desconforto posterior no agente após o ato realizado, isto é, não causa aflição nem arrependimento (metaméleia). No segundo caso, a ignorância na ação moral gera claramente dor e arrependimento no agente mostrando seu incômodo com o ato realizado.

A distinção da ignorância não voluntária e involuntária fica mais clara quando analisamos um caso de ignorância sobre as circunstâncias particulares da ação. Em um caso hipotético, poderíamos considerar o exemplo de um homem que atira em uma árvore e, sem o pretender, acaba atingindo um transeunte nas imediações do local. Com efeito, o que distinguiria seu caráter moral seria sua reação emocional posterior ao ocorrido. Se o homem demonstrar frieza e insensibilidade, estaria agindo de forma 'não voluntária', mas se o homem exibir posteriormente aflição e preocupação com o transeunte estaria agindo de forma 'involuntária'. Em todo caso, o critério do voluntário e involuntário se aplica claramente ao caráter moral do agente.

A segunda distinção é mais crucial pois acentua ainda mais a atitude moral do agente. Para Aristóteles, há duas outras formas de ignorância da ação, o ato "por ignorância (tò di'ágnoian)" e o ato "em estado de ignorância (toû agnooûnta)" (1110b 25-27). A distinção grega subentende implicitamente uma categoria causal 
da ignorância e uma categoria ativa da ignorância ${ }^{382}$. No primeiro caso, a ação ocorre 'por causa da ignorância' sem a contribuição efetiva do agente, isto é, devido a uma causa específica da ignorância externa ao próprio ato realizado. No segundo caso, há uma categoria ativa da ignorância, isto é, em que a ignorância resulta da própria ação voluntária do agente.

Para Aristóteles, os casos do homem 'embriagado' e do homem 'enfurecido' são emblemáticos na definição da ignorância voluntária: "do homem embriagado e enfurecido diz-se que age não por ignorância (di'ágnoian), (...) e, contudo, não sabendo, mas estando na ignorância (agnoôn).” (1110b 25-27). De um lado, o ato 'em estado de ignorância' depende do agente, pois sua condição de ignorância está ligada à sua falha de caráter moral. De outro lado, o ato por ignorância independe do agente pois ocorre pela ignorância das circunstâncias da ação. Pelos critérios anteriores, o ato por ignorância é involuntário e o ato em estado de ignorância é voluntário. Em última instância, o foco de Aristóteles recai mais sobre a reação moral do agente perante sua ignorância do que sobre o conhecimento ou desconhecimento do agente na ação moral.

A condição da akrasia fica mais clara a partir da segunda classificação da ignorância. Ora, seria a akrasia uma ação 'por ignorância' ou 'em estado de ignorância'? Com efeito, os exemplos do bêbado e do enfurecido são paradigmáticos pois refletem o estado interno reiteradamente associado ao caráter moral acrático em $E N V I I^{383}$. De fato, a analogia com a condição do bêbado e do louco é crucial na descrição decisiva do fenômeno da akrasia de ENVII.3. Diante dessa analogia, Aristóteles parece comprometido a classificar a akrasia como um ato realizado “em estado de ignorância” e, portanto, uma ação moral voluntária. Na sequência, Aristóteles busca definir as condições da ignorância involuntária.

382 Cf. LIDDEL-SOTT, 1996. No texto grego, a oposição entre di'ágnoian e agnooûnta reflete melhor essa condição. De um lado, a primeira expressão di'agnoian constitui a conjunção da preposição diá e o substantivo acusativo ágnoian (ignorância) que resulta em uma construção causal 'por causa da ignorância' de acordo com o motivo ou razão definida da ação (cf. SMITH, 1984, 1685 , p. 374-375). De outro lado, o particípio presente do verbo agnooûnta implica uma condição ativa de ignorância causada pela ação do próprio agente, o que significaria então um 'erro ou equívoco feito de forma ignorante'. Dessa forma, o primeiro caso a ignorância é a causa efetiva da ação enquanto no segundo caso a ignorância provém da ação do agente. Como veremos, essa distinção será crucial para a distinção final da ignorância voluntária e involuntária.

${ }^{383}$ Principalmente, em uma das propostas descritivas da condição do acrático de ENVII.3 (1147a10$25 ; 1147 \mathrm{~b} 5-14)$, embora outras passagens reiterem a mesma correlação (cf. 1114a15-23; 1152a1317) 
Com base na distinção da ignorância voluntária e involuntária, são definidas as condições específicas da ignorância involuntária. Assim, Aristóteles lista uma série de aspectos envolvidos na ignorância dos fatos particulares da ação moral: (1) "quem age (tis)", isto é, o agente; (2) "o que faz (ti práttei)", ou seja, o ato em si mesmo; (3) "sobre o que ou em que age (perì tí e en tíni práttei)", o paciente da ação; (4) “com quem age (tini)", o instrumento utilizado na ação; (5) “com vistas a que (héneka tínos)", o objetivo final do ato; (6) e "como age (pôs)", o modo de agir (1110b30-1111a6). Diante disso, Aristóteles traça considerações gerais sobre quais aspectos podem ser realmente ignorados na ação moral involuntária.

Ao longo de ENIII.1, Aristóteles considera quais dos 6 aspectos ignoráveis efetivamente se refletem na ação moral involuntária. Apenas a condição (1) é efetivamente impossível de ignorar pois não há como 'ignorar a si mesmo' (heautón), ao menos se estiver numa condição extraordinária de "insanidade" (mainómenos). Todavia, todos os outros aspectos podem ser ignorados nas condições ordinárias da ação moral. Por exemplo, é possível ignorar as circunstâncias da ação (ato), confundir um aliado com um inimigo (paciente), usar uma arma sem saber que está carregada (instrumento), receitar um remédio a um doente sem saber de sua alergia à medicação (objetivo); lançar uma bola violentamente quando se pretendia jogar de forma suave (modo de agir). A partir desses 5 aspectos da ação, podemos incluir certos atos de ignorância na categoria de atos involuntários enquanto outros entrariam na classe dos atos voluntários.

As condições da ignorância involuntária são contrapostas à ignorância voluntária, a ignorância reprovável e censurável. Como observamos, a ignorância involuntária envolve o desconhecimento de fatos particulares da ação e a reação emocional de "dor e arrependimento". De fato, a ignorância voluntária exibe as características opostas da ignorância involuntária: a ignorância de fatos gerais de amplo conhecimento público e ausência de remorso ou arrependimento do agente. O homem mal claramente se enquadra nessa classificação pois "ignora o que deve fazer e de que deve abster-se" adquirindo seu caráter "por causa desse erro (dià tèn toiaúten hamartían)" (1110b25). A partir disso, Aristóteles traça uma diferença crucial entre a ignorância voluntária do homem mal e a ignorância involuntária: 
universal (he kathólou) (pela qual os homens são censurados), mas a ignorância dos particulares (kath'hékasta), isto é, das circunstâncias e dos objetos com os quais se relaciona a ação. (1110b25-1111a)

A ignorância do homem mal exibe todas as características próprias do caráter moral voluntário. Dentre os tipos de ignorância, há duas classes que não se enquadram no ato involuntário: (1) a ignorância na prohaíresis está ligada ao caráter moral do agente, reflete a ausência de um senso moral fundamental dos valores morais: "a maldade nos corrompe e nos engana (diapseúdesthai) a respeito dos princípios da ação (perì tàs praktikàs archás)" (1144a29-35); (2) a ignorância do universal (kathólou) também se reflete no ato voluntário, pois o agente não pode simplesmente ignorar fatos gerais de amplo conhecimento público, como os que ignoram as 'prescrições das leis' e agem "por causa de negligência" (di'améleian) (1114a1-5). De resto, a ignorância involuntária envolve apenas o último fator (3), o desconhecimento dos 'fatos particulares' (kath 'hékasta), isto é, as circunstâncias particulares descritas anteriormente. Apenas nesse caso, temos uma ação involuntária escusável e digna de perdão moral. Dentro desses parâmetros, o tipo de ignorância do vício moral, correspondente aos casos (1) e (2), resultam em ações morais voluntárias. Assim como o homem mal, o homem acrático também realiza ações morais voluntárias e está sujeito à repreensão moral.

A partir do exame da ignorância, Aristóteles pretende comprovar que o caráter do homem mau e do homem acrático são voluntários. No entanto, a falha de caráter moral de ambos é bem diferente e a akrasia, principalmente, é um fenômeno de difícil classificação. Certamente, o homem mal comete um erro moral voluntário por conta de sua ignorância negligente, mas a sua prohaíresis e seus apetites irracionais estão igualmente inclinados à má ação na maior parte das vezes ${ }^{384}$. Dessa forma, o homem mal está plenamente consciente e inteiramente disposto a realizar suas más ações. Nesses termos, a ignorância do homem mal se enquadra na ignorância voluntária do caso (1), isto é, a ignorância de sua prohaíresis pelo mal. Por sua vez, o erro do acrático também não consiste em uma ignorância involuntária

\footnotetext{
${ }^{384}$ Mesmo o homem mau pode estar sujeito ao conflito interno de seus desejos. Em 1166b8-25, Aristóteles efetivamente reconhece que o homem mau pode sofrer conflito interno devido a sua satisfação com coisas más: "porque sentiu prazer e desejaria que tais coisas não lhe fossem agradáveis; porque os maus têm a alma pelejada de arrependimento (en metaméleian)." Por isso, achamos melhor acrescentar que o homem mau não costuma sofrer com suas ações "na maioria das vezes".
} 
pois o acrático não desconhece nenhum dos fatos particulares da ação. Mesmo com relação ao homem mal, há uma diferença crucial no acrático, a sua prohaíresis está dirigida para o propósito correto, mas o seu erro moral advém da inclinação contrária de seus apetites irracionais pelo prazer (cf. 1111b15-20; 1148b5-12; 11152a14-20). Nesse caso, o homem acrático está plenamente consciente, mas não está disposto a realizar seu erro moral. Afinal, só resta atribuir ao acrático a ignorância do 'universal' do caso (2), de amplo conhecimento público. Nesse sentido, o acrático está agindo 'em estado de ignorância' em função da negligência temporária da ação e não 'por causa da ignorância'. Mesmo assim, a descrição da akrasia em ENVII.3 ainda parece entrar em conflito com a classificação da ignorância.

Ao longo de ENVII.3, Aristóteles fornece uma descrição da akrasia atribuindo sua causa a um tipo de ignorância (1145a30-32; 1147b5-17). Ao contrário de Sócrates, no entanto, Aristóteles classifica o fenômeno como um tipo de ignorância temporária e não um estado permanente de ignorância. Como veremos adiante, a natureza da akrasia envolve a controversa passagem ENVII.3. Com base no silogismo prático, Aristóteles parece alegar que a akrasia envolveria a ignorância temporária das "premissas particulares" (kath hékasta). Nesse caso, a akrasia estaria bem próxima da categoria da ignorância involuntária dos fatos particulares e não da ignorância voluntária do universal. Aparentemente, essa descrição do fenômeno se aproxima da posição socrática do Protágoras em que Sócrates também sustenta que o fenômeno é causado "por ignorância” (di'ágnoian) (360b) ${ }^{385}$. Desse modo, a descrição da akrasia de ENVII.3 seria causada 'por ignorância' dos fatos particulares e não no 'estado de ignorância' derivado da negligência voluntária do agente. Como veremos depois, a existência da akrasia voluntária não reflete a ignorância involuntária dos fatos particulares. $\mathrm{Na}$ verdade, a ignorância do acrático decorre da inclinação dos apetites irracionais e não a qualquer desconhecimento do agente. Em todo caso, a descrição definitiva da akrasia de ENVII.3 demonstrará como superar essa incompatibilidade aparente entre a 'ignorância' e a possibilidade do fenômeno.

\footnotetext{
${ }^{385}$ Cf. LIDDEL-SCOTT, 1996. O termo ágnoian significa literalmente 'falta de conhecimento perceptível' é um substantivo derivado do verbo grego gignósko, que constitui um ato de conhecer através da percepção dos sentidos. Dessa forma, o sentido original do substantivo coaduna com a ignorância dos fatos particulares da expressão aristotélica "por ignorância" (di 'ágnoian), isto é, a ignorância como fator causal da ação do agente.
} 
Como veremos adiante, essa controvérsia terá repercussões sobre a descrição decisiva da akrasia. A controvérsia envolve a ambígua relação de Aristóteles com a posição socrática do Protágoras. Ao longo da Ética, Aristóteles parece insistir na refutação do paradoxo moral de que o vício moral, como a akrasia, é fruto de ignorância involuntária ${ }^{386}$. Tendo isso em vista, cabe averiguarmos melhor a crítica de Aristóteles a outra tese socrática ainda mais forte, o paradoxo "ninguém é mal voluntariamente". A partir de ENIII.5, poderemos analisar melhor até que ponto Aristóteles está realmente disposto a levar adiante sua posição crítica com a negação socrática da akrasia.

\section{5 \\ O ‘mal voluntário' e o paradoxo socrático}

A teoria da ação moral voluntária é francamente incompatível com o paradoxo socrático do Protágoras. De acordo com a teoria da ação moral voluntária da Ética, tanto as boas ações quanto as más ações são ações morais voluntárias porque "estão em nosso poder" (1113b5-10). Por sua vez, o paradoxo socrático do Protágoras sustenta que "ninguém se dirige ao mal de bom grado" (hekón)' (358d). Com o paradoxo socrático, teríamos um tipo de assimetria das ações morais dado que as boas ações são voluntárias, mas as ações más são involuntárias. Por isso, o paradoxo socrático representa um desafio à Aristóteles, não só porque inviabiliza a possibilidade do mal voluntário como transforma a akrasia, consequentemente, em uma ação involuntária ${ }^{387}$.

Em ENIII.5, Aristóteles se detém na refutação do paradoxo do 'mal involuntário' que compromete sua teoria da ação moral. Nessa ocasião, Aristóteles se refere a um ditado proverbial "ninguém é miserável voluntariamente (oudeìs

\footnotetext{
${ }^{386}$ Como indica Bostock (2000, p. 120-121), o breve exame da ignorância exposto em ENV.8-9 levaria a reconhecer que ações acompanhadas de paixões tipicamente 'humanas', como a akrasia, são involuntárias. Em função das incompatibilidades de ENIII.1 e ENV.8-9, abordamos a teoria da ação moral que parece ser efetivamente adotada por Aristóteles. Notavelmente, o conflito entre sua teoria da ação moral voluntária de ENIII.1 e sua justificação da possibilidade da akrasia em ENVII.3 já nos revela o conflito interno de seus pressupostos teóricos. Em ENVII.3, teremos oportunidade de aprofundar essa discussão. Ver também 1136a30-b15.

387 Para o confronto de Aristóteles contra a assimetria moral, ver MEYER, 2009, p. 146: “A motivação de Aristóteles para rejeitar a tese da assimetria é clara. Uma vez que ele investiga a voluntariedade para capturar as condições causais do elogio e da censura, é uma exigência dessa abordagem que tanto ações boas quanto más seja voluntárias."
} 
hekòn poneròs)" (1113b14-15). Originalmente, o ditado proverbial do "mal involuntário' tem raízes arcaicas na tradição cultural e sofística grega anteriores à Platão. Todavia, o paradoxo socrático presente em diversos diálogos socráticos, como no Protágoras, efetivamente faz parte dessa longa tradição ${ }^{388}$. Independentemente, de quem seja o adversário de Aristóteles, a refutação da tese paradoxal do 'mal involuntário' deve garantir a possibilidade do mal voluntário.

O provérbio constitui um desafio primordial à teoria da ação moral de Aristóteles. Em linhas gerais, o desafio assume a forma de duas objeções centrais contra a ação moral voluntária. Segundo a primeira objeção, a ação moral não “depende de nós" pois está vinculada a formação do caráter moral. Ora, o caráter moral pode ser constituído de tal forma que não podemos agir de outro modo: "talvez um homem seja de tal tipo que não tome cuidado (mè epimelethênai)." (1114a4-5). Se a ação moral depende do caráter moral, não temos efetivamente controle da ação moral porque dependemos, em última instância, do que não está sob nosso alcance, a disposição moral do agente formada ao longo do tempo e por escolhas passadas (1114a5-25). Em seguida, a segunda objeção apresenta o seguinte raciocínio: se todo querer (boúlesis) tem por objeto um fim, isto é, o bem aparente (tô̂ phainoménou agathô̂), e não temos controle da aparência (tês phantasías) das coisas, então a ação moral simplesmente não 'depende de nós': “o fim aparece sobre uma forma correspondente a cada um (tò télos phaínetai autôi)" (1114a30-b2). Ambas as objeções expressam a tese central do 'mal involuntário' e, consequentemente, a inexistência do mal voluntário. Notavelmente, o mal involuntário reflete o paradoxo socrático do Protágoras de Platão.

O paradoxo socrático do Protágoras reforça as objeções do mal involuntário. Como vimos, o Sócrates do Protágoras estabelece uma tese paradoxal forte contra a akrasia tradicional "ninguém se dirige de bom grado (hekòn) às coisas más ou àquelas que presume serem más (oíetai kaká)" (358d-e). A partir disso, o

\footnotetext{
${ }^{388}$ De acordo com Zingano e Kamtekar o ditado proverbial possui profundas raízes na tradição grega. Como mostra Kamtekar (2017, p. 78-31), há um amplo contexto de debate em torno da 'mal involuntário' que confere o pano de fundo do Górgias de Platão e da passagem de ENIII.5 de Aristóteles. Dentro dessa ampla tradição grega, já encontramos os fatores essenciais que constituem a ação moral involuntária; (1) a compulsão no Elogio de Helena de Górgias; (2) a contrariedade à natureza abordada no texto $A$ Verdade de Antifonte e veiculada também pelos personagens Gláucon e Trasímaco; (3) a ignorância tratada em diversas tragédias gregas e retratada também no contexto jurídico por Antifonte. Além disso, Zingano (2008, 200-201) ainda nota que o provérbio aparece no diálogo platônico apócrifo Do Justo. Contra Bostock (2000, p. 113) que atribui uma tese mais forte ao provérbio a de que 'nenhuma ação é voluntária' e, com isso, abandona a hipótese das possíveis raízes socráticas do paradoxo.
} 
paradoxo estabelece duas teses complementares (358b-d): a) a negação do conhecimento do vício moral em vista da ignorância do bem real, o que torna o vício moral involuntário; b) o eudaimonismo psicológico, isto é, a tese de que há uma inclinação natural do homem em vista do bem. Dessa forma, a inclinação ao mal, tal como a akrasia, simplesmente não existe pois resulta apenas da ignorância do bem real.

Em última instância, as objeções anteriores refletem a mesma assimetria fundamental das ações morais, as ações boas são voluntárias e as ações más são involuntárias. De um lado, a primeira objeção atribui as más ações exclusivamente à disposição moral do vício moral, como o homem acrático ou intemperante, estabelecendo a impossibilidade do vício moral voluntário. De outro lado, a segunda objeção se refere à inexorabilidade do desejo natural do bem em termos aristotélicos, o 'querer' (boúlesis) do bem. Dessa forma, devemos analisar se as respostas de Aristóteles contemplam as objeções quanto ao desafio maior do paradoxo socrático.

As respostas de Aristóteles a ambas as objeções apelam a um aspecto comum, a relação causal entre a ação voluntária e o caráter moral. Nesse sentido, Aristóteles estabelece uma relação fundamental entre a vida ética e a ação moral voluntária da categoria do vício moral. Nesse sentido, tanto a vida do homem mau quanto do homem acrático refletem suas próprias ações voluntárias.

Em resposta à $1^{\text {a }}$ objeção, Aristóteles traça um paralelo entre o caso do doente voluntário e a vida conduzida em akrasia ou em maldade:

\footnotetext{
Podemos supor o caso de um homem que adoece voluntariamente (hekòn nosê̂) por levar uma vida acrática (akratôs bioteúon) a desobedecer aos seus médicos. Nesse caso, era-lhe, em um momento, possível não adoecer; mas agora, já não lhe é possível (...). O mesmo sucede com o injusto e o intemperante, era possível desde o início (ex archês) não se tornarem homens dessa espécie, e, por isso, o são voluntariamente (hekóntes eisín); e agora que se tornaram tais, não lhes é possível não o serem. (1114a15-20)
}

O doente voluntário que leva uma vida acrática, tal como os homens viciosos, não deve sua condição atual a seu estado de caráter propriamente dito, mas à origem (arché) de sua ação. Com efeito, o estado de caráter atual é uma disposição (héxis) elaborada ao longo da formação moral da vida que não se altera de forma imediata. Como assinala Aristóteles, o acrático não deixa de ser acrático, 
porque assim o deseja, e nem o bêbado deixa de ser bêbado porque assim o quer (1114a10-15). No entanto, isso também não é um simples dado inexorável da condição humana. Embora o caráter moral não esteja mais sob alcance do agente, foram as suas ações voluntárias que geraram seu caráter "desde o princípio" (ex archês).

De certa forma, o vício moral é análogo à doença e mesmo à embriaguez voluntária. A condição atual do doente ou do embriagado, como no caso acrático e injusto, refletem disposições (héxeis) que não estão sob domínio do agente, porém os atos voluntários que formaram tais disposições "estão em nosso poder". Sob esse ângulo, o vício moral é tão voluntário quanto as más ações do agente, dado que são suas ações morais que formam seu caráter moral. Assim como os vícios do corpo, os vícios da alma são objeto de censura quando decorrem "por falta de exercício e de cuidado (di'agmunasían kaì améleian)" e não "por natureza (dià phýsin)" (1114a23-26). Ao dispensar as causas externas naturais, resta atribuir as ações voluntárias do vício moral à negligência e à falta de cuidado do próprio agente. Nesse caso, as ações morais estão vinculadas ao que classificamos anteriormente de "estado de ignorância", isto é, a ignorância voluntária.

Assim como outros vícios morais, o caráter acrático é classificado como um tipo de ignorância voluntária. Dentro da classificação da ignorância, as más ações voluntárias constituem ações do agente em 'estado de ignorância' e não propriamente "por ignorância", isto é, tendo como causa a ignorância em si mesma. Como assinala Aristóteles, "ignorar (tó agnoeîn) que é pelo exercício dos atos particulares que se formam as disposições (hai héxeis) é marca do homem verdadeiramente insensível (anaisthétou).” (1114a10-13). A ignorância do vício moral não está ligada ao desconhecimento de fatos particulares, como no caso da ignorância involuntária, mas da ignorância de fatos de conhecimento geral comum. Nesse caso, o desconhecimento é voluntário dado que procede da negligência do agente e não da ignorância involuntária ${ }^{389}$. Do mesmo modo, a punição e o castigo dirigidos ao agente "responsável pela ignorância (aítios tês agnoías)", como no

\footnotetext{
${ }^{389}$ Cf. MEYER, 2009, p. 148: "ele [Aristóteles] está supondo a transitividade da responsabilidade: se você é responsável por uma disposição, você também é responsável pelo que decorre dessa disposição. Esse princípio de transitividade é muito mais fraco do que o princípio segundo o qual a responsabilidade por uma ação requer a responsabilidade pela disposição a partir da qual se está agindo. Não há evidência de que o último princípio seja suposto quer por Aristóteles, quer por seu oponente."
} 
caso do embriagado, comprovam que a "ignorância por negligência" está sob nosso controle e é voluntária (1113b26-30). Em última instancia, esse tipo de negligência está vinculada ao vício moral do acrático, do injusto ou do intemperante.

A partir disso, Aristóteles conclui seu primeiro argumento em favor do 'mal voluntário'. O caráter e a ação da akrasia são tão voluntários quanto o caráter do vício moral e das ações más. Como outros vícios morais, a akrasia é claramente desvinculada da ignorância involuntária, ou seja, do desconhecimento dos fatos particulares. Dessa forma, a alegação socrática de que o acrático não tem conhecimento do que está fazendo ou que ignora o bem real torna-se inconsistente. Em sentido fundamental, o agente tem plena consciência de que suas más ações promovem um vício moral. Com isso, a alegação de que o agente "não deseja (mè boúlesthai)", isto é, não quer efetivamente possuir um vício moral é simplesmente irracional (1114a10-13).

Dessa forma, tal conclusão de Aristóteles atinge o cerne do paradoxo moral do 'mal voluntário'. Não há ignorância involuntária uma vez que a negligência do agente é voluntária, nem há o desejo contrário ao caráter moral visto que as ações morais particulares do agente são voluntárias. Mesmo assim, a akrasia ainda representa um desafio a Aristóteles pois o acrático não deseja realmente cometer seu erro moral voluntário. Nessa medida, a $2^{\mathrm{a}}$ objeção apresenta um desafio adicional à teoria da ação moral pois parece efetivamente se dirigir à inclinação humana natural ao bem do paradoxo socrático.

A $2^{\text {a }}$ objeção concerne a capacidade aristotélica do 'querer' (boúlesis) ligado ao desejo pelo bem e com reflexos sobre o paradoxo socrático ${ }^{390}$. Para Aristóteles, a boúlesis é o desejo pelo fim da ação que não está propriamente sujeito à deliberação (1112b10-20). De acordo com a segunda objeção, se o bem aparente da boúlesis depende da aparência particular do fim, então o caráter moral também depende da aparência singular do bem relativa a cada indivíduo. Nesse sentido,

\footnotetext{
390 Alguns intérpretes têm indicado que a $2^{\mathrm{a}}$ objeção é concebida perante um hipotético adversário platônico indefinido. Para essa polêmica do adversário platônico, ver MEYER, 2009; ZINGANO, 2008; KAMTEKAR, 2017. Segundo Kamtekar (2017, p. 114-115), toda a $2^{\text {a }}$ objeção evoca a formulação do paradoxo socrático contida no diálogo posterior das Leis. Para Zingano (2008, p. 204206), a segunda objeção está voltada particularmente ao problema platônico do ensino da virtude, localizado sobretudo no Mênon. Assim como Meyer (2006, p. 142-146), acreditamos que o conjunto dos argumentos de ENIII.5 pode ser encarada como uma resposta dirigida a diversas formulações do paradoxo socrático encontrada nos Diálogos. Nesse sentido, a sugestão de que a formulação rígida do paradoxo socrático no Protágoras representa um desafio real à teoria da ação moral de Aristóteles torna-se plausível.
} 
Aristóteles estabelece o resultado paradoxal da objeção em uma formulação tipicamente socrática: "se ninguém é causa de seu próprio agir mal (...) todos praticam ações más pela ignorância do fim (di'ágnoian tô̂ télous)" (1114b1-4). Como vimos, o paradoxo socrático estabelece que o mal involuntário se ampara na ignorância do bem real e tendo em vista o desejo natural pelo bem. A seguir, Aristóteles novamente recorre à relação intrínseca entre o caráter moral e ação moral para construir sua resolução ao problema do bem aparente.

Para responder a $2^{\mathrm{a}}$ objeção, Aristóteles recorre a um argumento fundamental em face da inexorabilidade da boúlesis pelo fim:

A ambos os homens, ao bom e ao mal, o fim aparece e é fixado pela natureza (tò télos phýsei phaínetai kaì keîtai) ou de qualquer modo, mas o que quer que façam, referem o resto a este fim (tà loipà pròs toûto). (1114b10-16)

Tanto o homem mal quanto o homem bom dispõem do fim que "aparece e é fixado pela natureza ou de qualquer modo". Com base nisso, podemos considerar assim duas formulações diferentes da $2^{\mathrm{a}}$ objeção: 1) em relação ao fim aparente, à medida que o bem aparente é estabelecido de acordo com a aparência particular de cada agente; 2) em relação ao fim natural, tendo em vista que o bem aparente é fixado de forma inexorável pela própria natureza. Dessa forma, Aristóteles pretende inviabilizar ambas as formulações da objeção, alegando que o que realmente importa moralmente é a ação realizada antes do próprio desejo pelo fim.

Em relação ao fim aparente, Aristóteles se apoia sobre a necessidade da relação causal do agente sobre sua ação moral dado que "algo depende dele próprio" (par'autón). Seria absurdo assumir, simultaneamente, que o homem bom realiza ações voluntárias e o homem mal realiza ações involuntárias, quando ambos não possuem qualquer domínio sobre a própria aparência do bem (1114b1-6). Nessa medida, ou bem ambos realizam ações involuntárias ou bem ambos realizam ações voluntárias. De acordo com Aristóteles, é suficiente recorrer aqui ao princípio do caráter moral voluntário: "se alguém é causa de algum modo (estí pos aitíos) do caráter (tês hexeós), também será causa de certo modo pela aparência (tês phantasías)" (1114b1-4). Assim como o agente tem reponsabilidade sobre seu caráter moral, a mesma relação causal deve valer para o bem aparente pois a aparência do bem também depende do caráter moral do agente. No entanto, a hipótese do fim natural não admite o simples apelo à responsabilidade moral. De 
fato, essa segunda hipótese explora o cerne do paradoxo socrático e da capacidade distinta da boúlesis.

Em relação ao fim natural, Aristóteles critica a hipótese de que o fim depende da natureza humana. Seguindo esse argumento, poderia se alegar que "a tendência do fim não é autoescolhida (ouk authaíretos)" pois provém da natureza, de tal maneira que o juízo e a escolha do bem seria reservado apenas ao 'bem nascido' (euphyès), tal “como ter um olhar" apropriado ao bem (1114b5-10). Dentro dessa perspectiva, a virtude e as ações virtuosas não dependeriam do ensino moral ou da aprendizagem estando sujeito apenas à natureza apropriada do 'fim natural'. De toda forma, não é o 'fim natural' que determina a ação moral do agente, mas sim 'o que se "refere a este fim”, ou seja, os 'meios' de ação que são objeto da deliberação e da prohaíresis (1112b12-20). Para Aristóteles, o caráter mal é tão voluntário quanto o caráter do homem bom no que diz respeito aos meios da ação: "pois no homem mau está presente aquilo que depende de si mesmo nas suas ações (di'autòn en taîs práxesi), ainda que não no fim" (1114b15-21). Desse modo, a ação moral do agente está ligada aos 'meios da ação', o que depende de si mesmo e não especificamente em relação ao fim da ação. Nessa medida, toda a $2^{a}$ objeção evoca as características da boúlesis expressas originalmente em ENIII.4.

Anteriormente, a ENIII.4 já havia traçado as características fundamentais da boúlesis. A estrutura dialética do argumento de ENIII.4 analisa duas teses opostas tradicionais do desejo humano pelo fim: (i) uma delas alega que o desejo final é 'o bem' (tagathoû eînai), e (ii) a outra de que é o 'bem aparente' (tô̂ phainoménou agathoû) (1113a15-23). Ao que tudo indica, a primeira tese corresponderia a uma tese socrática, enquanto a segunda seria vinculada a visão sofística de Protágoras ${ }^{391}$. Diante do impasse, Aristóteles prefere conferir à boulesis do fim um duplo aspecto: “em absoluto (haplôs) (...) o bem é o objeto do querer (bouletòn eînai tagathón), enquanto o que aparece a cada um é o bem aparente (tò phainoménon)" (1113a2125). Nesse sentido, a boúlesis em sentido geral se dirige ao fim natural, isto é, o bem real, enquanto a boúlesis em sentido específico tem em vista o fim aparente 'de cada um', ou seja, o bem aparente. Dessa maneira, a distinção dos fins da

\footnotetext{
${ }^{391}$ Segundo Zingano (2008, p. 193-197), a estrutura dialética da passagem se dirige a um confronto com as teses platônica e sofística acerca da aspiração humana ao bem. Nesse sentido, Aristóteles rejeita tanto a existência isolada do bem aparente restrita apenas a perspectiva de cada agente quanto a necessidade do bem real objetivo isolado de sua manifestação aparente a cada sujeito. Ao invés disso, a capacidade da boúlesis visa abarcar ambos os aspectos da aspiração humana ao bem final.
} 
boúlesis de ENIII.4 parece oferecer o contexto apropriado para compreendermos a força da $2^{\mathrm{a}}$ objeção refletida na tese (i). De alguma forma, então, a resposta à $2^{\mathrm{a}}$ objeção também se dirige ao paradoxo socrático do Protágoras.

A resposta à $2^{\mathrm{a}}$ objeção parece, em parte, ser dirigida ao próprio paradoxo socrático do Protágoras. Como vimos, o paradoxo socrático culmina no eudaimonismo psicológico, a tese da inclinação natural do homem ao bem. No Protágoras, o hedonismo socrático apresenta uma dupla distinção do bem, a diferença entre o bem aparente (subjetivo) do prazer temporal e o bem real (objetivo) promovido pelo conhecimento do cálculo dos prazeres reais. Apenas o conhecimento objetivo do bem real pode assegurar a ação moral conforme o desejo do bem real, enquanto o erro moral decorre da ignorância derivada do bem aparente que inviabiliza o desejo do bem real. Segundo o paradoxo socrático do Protágoras, o desejo natural do bem real é universal na natureza humana. estando presente tanto no homem com conhecimento quanto no homem ignorante. Por isso, a ação conforme o desejo do bem real é voluntária enquanto o erro moral é involuntário porque é contrário à inclinação natural do bem real. Contra essa assimetria, a resposta da $2^{\text {a }}$ objeção alega que independente do 'fim', a ação voluntária está voltada aos 'meios'.

Não importa a 'condição' do bem real visto que a deliberação e a prohaíresis concernem aos fatos particulares dirigidos ao fim da ação moral. Assim como o homem bom, o homem mal igualmente delibera e escolhe os meios da ação. Dessa forma, as ações morais do homem bom e mal são voluntárias tal como seus caracteres morais. Invariavelmente, essa objeção traz à tona certas diferenças entre o paradoxo socrático de Protágoras e a Ética de Aristóteles a respeito do desejo final do 'bem real.

A caracterização da boúlesis da Ética inclina Aristóteles a uma posição ambígua perante o eudaimonismo psicológico socrático. De um lado, a boúlesis e o eudaimonismo psicológico reconhecem a existência de um fim natural externo: o bem real. De fato, Aristóteles não nega que exista um "objeto natural do querer (phýsei bouletón)" (1113a20-23). De outro lado, ambos discordam sobre o estatuto do bem aparente, o fim aparente a cada um. Para Sócrates, o bem aparente é fruto do erro moral e da ilusão da aparência devido à falta de conhecimento do bem real. Enquanto isso, Aristóteles julga que o 'bem aparente’ é um aspecto indissociável 
de nossa disposição moral e condição necessária para atingir o 'bem real' da boúlesis $^{392}$.

De qualquer maneira, a tese do 'mal voluntário' inclina Aristóteles a reconhecer, tal como Sócrates, que os homens viciosos realizam um erro moral factual relativo ao bem real (objetivo). Em última instância, os homens viciosos não dispõem da prudência (phrónesis), a sabedoria prática que assegura a execução da boa ação moral. Como veremos, isso levará Aristóteles a apreciar a tese socrática de que a akrasia consiste em um tipo de falta de conhecimento moral em ENVII.3. Dessa forma, precisamos adentrar o tópico central da akrasia sem mais delongas.

O exame da akrasia de ENVII orienta primeiro a distinguir o caráter moral acrático de outros vícios morais correlatos e apenas, depois, nos voltarmos à possibilidade do fenômeno. Sobretudo, o método investigativo dos phainómena de Aristóteles nos fornece os parâmetros fundamentais para a análise do caráter e do fenômeno da akrasia em meio a tortuosa estrutura do livro VII da Ética.

\section{6 \\ O método da ética e a akrasia em EN VII}

O livro VII da Ética a Nicômaco se dedica exclusivamente ao caráter acrático e ao fenômeno da akrasia. Dessa forma, todo o exame de EN VII 1-10 leva em conta uma série de pressupostos anteriores da Ética: a) a akrasia é uma ação voluntária e o caráter acrático é voluntário e moralmente repreensível; b) o fenômeno decorre de um conflito interno entre a razão correta e as más paixões, devido à falta da educação moral dos apetites irracionais; c) o acrático realiza um erro moral por causa de seu apetite irracional contra a prohaíresis correta, isto é, contra o propósito deliberado da melhor alternativa de ação; d) não há falta de conhecimento racional no episódio da akrasia, o agente tem plena consciência dos fatos particulares da ação e, portanto, não sofre de ignorância involuntária. A partir desses elementos, Aristóteles introduz um método dedicado especialmente a desvendar a natureza da akrasia em relação a outros estados de vício moral.

${ }^{392}$ Cf. ZINGANO, 2008, p. 198: “Aristóteles permanece fiel à tese de uma verdade na ação, um bem objetivo, mas reconhece o ambiente subjetivo ou intencional como inevitavelmente envolvendo o domínio prático. (...) Aristóteles não abandona a objetividade do bem; o que ele abandona é a naturalidade do bem; agora para sempre imerso em um contexto intencional." 
O caráter acrático ganha notável destaque ao longo de ENVII porque reflete um desafio filosófico dirigido ao âmago da ética e da psicologia moral aristotélica $^{393}$. Todavia, o problema da possibilidade da akrasia ocupa apenas um capítulo, ENVII.3. Em última instância, a defesa da possibilidade da akrasia de ENVII.3 precisa ser contextualizada no escopo mais amplo do exame do caráter moral acrático ao longo de ENVII 1-10. Nesse cenário, precisamos compreender o papel do método da ética na estrutura do exame da akrasia.

Desde o início da investigação de ENVIII, Aristóteles observa a peculiaridade do acrático frente a outros caracteres morais (tà éthe) evitáveis (1145a15-20). Dentre os maus caracteres, a akrasia não se confunde com a brutalidade (theriótes), a moleza (malakía) e nem mesmo se assemelha ao vício (kakía) ou a intemperança (akolasía) (1145a15-b20). Por conta disso, somos apresentados a um método apropriado de exame da natureza da akrasia diante dos demais caracteres morais e adotado consistentemente ao longo de ENVII1-10.

Em ENVI.1, Aristóteles define os parâmetros do método dos "fenômenos aparentes" (phainómena):

é preciso (...) estabelecer os fenômenos (tà phainómena) e, após primeiro examinar as aporias (diaporésantas), trataremos de provar, se possível, a verdade de todas as opiniões reputáveis (pánta tà éndoxa) a respeito dessas afecções - ou, se não todas, pelo menos do maior número e das mais autorizadas (tá plê̂sta kaì kuriótata); porque, se resolvermos as dificuldades e deixarmos as opiniões intactas, teremos provado o caso suficientemente. (11145b1-10)

O método exposto exibe o procedimento investigativo de ENVII1-10. A princípio, o método consiste basicamente em três etapas bem delimitadas: (1) estabelecer os "fenômenos aparentes (ta phainómena)", o que inclui, principalmente, "as opiniões reputáveis (tà éndoxa)"; (2) um "exame através das aporias (diaporeîn)", isto é, analisar os impasses derivados das impressões comuns; (3) provar ou evidenciar "todas as opiniões (pánta tà éndoxa)" ou, ao menos, aquelas que abrangem o maior número ou de maior 'autoridade' pública (kúrios).

393 Cf. COOPER, 2009, p. 16: “At this general introduction shows, his purpose, taking the psycological fact as given, is to provide na account of uncontrol (and self-control as its opposite) that will show both what exactly uncontrol is and how to resolve satisfactorily the difficulties arising when our conception of it is put together with basic philosophical principles about human psychology and basic ethical assumptions." 
Dessa forma, Aristóteles espera chegar a um denominador comum, deixar todas ou, ao menos, a maioria das opiniões intactas. Na sequência, analisaremos melhor a amplitude do método da ética sobre a estrutura de ENVII.

Primeiramente, o método designa o estabelecimento dos phainómena o que parece incluir também as éndoxa. A rigor, phainómena e éndoxa não significam a mesma coisa, mas compartilham de um domínio relativamente comum de atuação. De um lado, os phainómena designam propriamente, de modo geral e indiferenciado, os fenômenos visíveis e as opiniões gerais. Como ressalta Nussbaum (2009), a investigação dos "fenômenos" implica inevitavelmente o escrutínio das crenças compartilhadas dentro dos limites da experiência de uma comunidade humana ${ }^{394}$. De outro lado, tá éndoxa deriva de dóxa (opinião) e significa propriamente as 'opiniões reputáveis' seja da maioria ou de personalidades eminentes da sociedade. A partir desse amplo sentido, Aristóteles pretende englobar uma série de categorias das crenças humanas comuns, sejam crenças explicitamente enunciadas ou faladas, sejam implícitas em nossas ações ou simplesmente em nosso modo de falar (cf. 1098b25-30) ${ }^{395}$. Dessa maneira, éndoxa e phainómena constituem o mesmo ponto de referência no método de Aristóteles. No entanto, os fenômenos e opiniões reputáveis estão inevitavelmente sujeitas ao conflito.

Em seguida, o conflito dos phainómena e da éndoxa gera uma série de aporias ou impasses exigindo um processo investigativo (diaporeîn). Nesse estágio, Aristóteles enumera diversas dificuldades que decorrem do confronto dos phainómena de um tópico $x$ e orienta a busca de uma solução pela consistência das opiniões e a verdade dos fenômenos em relação a $x$. Ora, diante da constatação do conflito das impressões comuns de $x$ qual das opiniões Aristóteles preferia preservar? Seus critérios favoreceriam a opinião da maioria ou a opinião das personalidades e sábios eminentes? Efetivamente, não parece haver critérios indisputáveis de preferência dos phainómena. Na maioria das vezes, Aristóteles francamente tem preferência pela opinião dos sábios eminentes por conta de sua

\footnotetext{
${ }^{394}$ Cf. Ibid., p. 218: "Alcançaremos nossas evidências sobre $F$ s apenas de comunidades em que as condições relevantes de experiência são semelhantes àquelas que se obtêm em nossa própria comunidade, porque o próprio significado de " $F$ " é dado por uma definição expressa nos termos das leis e condições da nossa comunidade efetiva. Nossa habilidade de introduzir $F$ s no discurso surge da experiência efetiva, e a natureza dos $F$ s é dada por uma reflexão científica que alcança pela pesquisa no e do mundo de nossa experiência."

${ }^{395}$ Para essas implicações da éndoxa no método dos phainómena, ver BARNES, 2010, p. 195-196.
} 
reflexão mais profunda, porém mesmo assim ressalta ainda a valorização da extensa experiência dos mais velhos sem sacrificar necessariamente a 'unanimidade' da opinião dominante (cf. ENVI 1143b10-15) ${ }^{396}$. De qualquer forma, o confronto dos phainomena conflitantes exige inevitavelmente uma resolução final.

Por fim, o próprio método da akrasia se orienta a salvar "todas as opiniões" (pánta tá éndoxa) em busca de uma posição "conciliadora" dos phainómena ${ }^{397}$. Mesmo assim, o conflito das crenças comuns exige a definição de um critério. Através da apuração das aporias, deve se preservar ao menos as "de maior número e as mais autorizadas" (tà plê̂sta kaì kuriótata). Sob esse ponto de vista, Aristóteles parece comprometido com um critério seletivo depurado das éndoxa. Como veremos a seguir, essa tensão do método se refletirá especialmente no conflito dos phainómena com Sócrates acerca da possibilidade da akrasia. De qualquer modo, o que é importante ressaltar até aqui é o alcance geral do método da éndoxa e suas incongruências para além do tópico central da akrasia.

Apesar da descrição geral do procedimento investigativo da akrasia, Aristóteles permite antever um alcance mais amplo do método: "assim como nos outros casos (hósper epì tôn állon)". Efetivamente, o método da éndoxa é utilizado de forma sistemática em toda a Ética, embora seu uso também esteja associado possivelmente ainda a outros campos filosóficos, como a Metafísica ou a Física. No entanto, o exame dos phainómena está atrelado à peculiaridade e os limites próprios de cada campo de investigação filosófico ${ }^{398}$. Para todos os efeitos, devemos deixar sua aplicação a outros campos filosóficos e nos ater em sua aplicação particular na Ética. Para Aristóteles, a ética é um campo marcado pela incerteza e inexatidão onde a precisão absoluta é inviável: "todo assunto de questões práticas tem de ser expresso em linhas gerais e de modo inexato (...) o que está

\footnotetext{
${ }^{396}$ De fato, Aristóteles adota o critério de excluir a opinião dos loucos, insensatos e das crianças mais suscetíveis à influência dos apetites do conjunto da "unanimidade" da opinião dominante. Sobre essa preferência seletiva, ver também ENI3 1095a1-10, EN III1119b1-10.

${ }^{397}$ Cf. ZINGANO, 2007, p 453: "O método dialético proposto para a acrasia, embora opere com o exame de dificuldades e aporias, não somente não visa a refutação das teses opostas, como também - ou sobretudo - visa a preservar (...) as teses reputadas de modo que continuem valendo." A mesma pretensão "conciliadora" é exibida anteriormente sobre as endoxa da felicidade em ENI8 1098b2530: "e não é provável que qualquer delas esteja inteiramente equivocada e sim que tenham razão a pelo menos algum respeito, ou mesmo em quase todos os respeitos."

${ }^{398}$ De fato, Nussbaum (2009, p. 214-220) sustenta que a investigação dos phainómena tem uma ampla aplicação em diversos campos, como a Metafísica e a Física, levando em conta a filosofia aristotélica com um todo. No entanto, Barnes (2010, p. 200-207) recomenda cautela visto que o método das éndoxa pode até ser apropriado para a Ética, mas nem sempre coaduna com a inclinação natural profunda à verdade.
} 
envolvido nas ações e as coisas proveitosas nada têm de fixo (...)." (1104a1-4). De fato, Aristóteles admite que o campo das éndoxa em matéria ética são extensamente variáveis e conflitantes, de tal modo que "devemos contentar-nos em indicar a verdade aproximadamente e em linhas gerais" no campo prático da ética (1094b1820). Em especial, essa precisão inexata apropriada à ética é certamente refletida no método de investigação da akrasia em ENVII.1.

Ao longo de ENVII1-10, observamos notavelmente a aplicação do método da ética sobre a estrutura do exame da akrasia. A estrutura aparentemente tortuosa do exame de toda ENVII, repleto de desvios e novos tópicos abruptos, não deixa de transparecer o método esboçado brevemente em ENVII.

No primeiro estágio, são enumerados éndoxa relativas ao caráter acrático e os outros vícios morais em ENVIII (1145b 7-20): (1) a natureza do caráter moral da fortaleza (karterikós), moleza (malakía), enkrateia e akrasia; (2) a oposição entre o caráter acrático e encrático; (3) a confusão comum entre a intemperança e a temperança, de um lado, e a akrasia e enkrateia, de outro; (4) a relação intrigante do prudente (phrónimos) com o acrático e; (5) a possibilidade da akrasia de impulsos variados, como “ímpeto (thymós), honra (timé) e lucro (kérdos)”. Diante dos fenômenos aparentes, o conflito das impressões comuns introduz uma série de impasses da akrasia.

A partir das éndoxa da akrasia, procedemos ao segundo estágio com um conjunto de aporias do fenômeno. Em ENVII.2, Aristóteles expõe as aporias formuladas de acordo com os seguintes tópicos dentro da ampla estrutura de ENVII: (a) o conhecimento e a akrasia - em que sentido o agente acrático sabe o que é melhor, estaria em posse do conhecimento ou apenas de opinião? (1145b211146a10). Nesse tópico, são tratados a incompatibilidade dos phainómena e a negação socrática da akrasia, a possiblidade do fenômeno em relação à opinião (dóxa) e à prudência (phrónesis); (b) a natureza dos apetites - a akrasia consiste em apetites fortes e excessivos ou fracos e deficientes? (1146a10-15); (c) a aporia sofística do homem convicto ou obstinado - se a akrasia é contrária a qualquer opinião, logo haveria uma boa akrasia (tis spoudaía akrasía) contra o juízo falso (teî psudê̂), como quando se confunde o que parece ser bom com o que é mau. Será que o homem resoluto estaria mais apto à persuasão e mudança de opinião do que o homem acrático? O primeiro parece agir "por convicção e propósito deliberado (prohairoúmenous)" enquanto o segundo age contra sua prohaíresis e suas 
convicções (1146a16-35); (d) a akrasia e os impulsos variados - há uma akrasia absoluta (haplôs) ou existe akrasia em relação a qualquer impulso humano? (1146b1-5). Durante os capítulos seguintes de ENVII, Aristóteles busca encontrar uma resolução a cada uma dessas aporias.

No terceiro estágio, os impasses de ENVII2 exigem a apuração das éndoxa conflitantes ao longo de ENVII3-10. A estrutura aparentemente tortuosa dos próximos capítulos é esclarecida à medida que mantemos sob nosso foco os eixos de investigação da resolução das aporias precedentes. Em primeiro lugar, o problema do conhecimento (a) e a possibilidade da akrasia ocupam o capítulo ENVII3. Em segundo lugar, há uma preocupação em delimitar o que é a akrasia em sentido absoluto (haplôs) de outros fenômenos correlatos que só são denominados de 'akrasia' em sentido análogo. Nesse segundo eixo de investigação, ocorre a resolução das aporias (b) e (d), especialmente ao longo de ENVII4-6. Em terceiro lugar, uma outra investigação se ocupa em distinguir a akrasia de outros tipos de vícios morais, como a moleza, a brutalidade, a obstinação, a intemperança ou o vício moral, reservando o último capítulo à diferença entre a prudência e akrasia. $\mathrm{Na}$ realidade, esse terceiro eixo reflete a resolução das aporias (a) e (c) com base em um exame mais aprofundado da éndoxa do caráter acrático em ENVII7-10. Em todos esses eixos investigativos, o caráter acrático representa o mote central do método da ética esboçado desde o início de ENVIII.

Embora o método esboçado forneça as diretrizes gerais de investigação, o exame da akrasia revela um quadro mais lacunar e fragmentado. Ao fim das aporias, Aristóteles parece antever as próprias limitações de seu método: "alguns desses pontos precisam ser refutados, enquanto outros serão preservados (katalipeîn); pois a solução (lýsis) da aporia é a descoberta" (1146b5-10). Naturalmente, a 'resolução' integra o objetivo final de apuração das aporias e as dificuldades derivadas do método da éndoxa. As limitações do método refletem a natureza inexata do próprio campo e matéria da ética. No entanto, novas dificuldades surgem ao longo do caminho revelando que nem todas as aporias são rigorosamente abordadas em ENVII. $2^{399}$. De fato, devemos apenas chegar ao limite da verdade proporcionada pela depuração das aporias contidas nas éndoxa originais.

\footnotetext{
${ }^{399}$ Como salienta Cooper (2009, p. 25-26), não é absolutamente claro quais das endoxa originais são realmente preservadas ao fim do exame da akrasia. Por vezes, algumas opiniões são simplesmente adicionadas posteriormente (como a posição socrática da akrasia) e outras estão
} 
Sobretudo, o método expõe a necessidade de encontrar um denominador comum entre todas as opiniões no exame da akrasia. Como assinala Zingano (2007, p. 454), essa posição neutra do método o leva à preservação da posição socrática mesmo diante de seu evidente conflito com a opinião dominante tradicional acerca da akrasia tradicional. ${ }^{400}$ Como veremos a seguir, isso irá trazer dificuldades à descrição de Aristóteles sobre a possibilidade da akrasia em ENVII.3. Todavia, é preciso adiantar que mesmo nesse caso Aristóteles busca acomodar as opiniões divergentes aos seus próprios termos conceituais da virtude moral e da ação moral voluntária. Na verdade, é de se esperar que o mesmo ocorre no exame mais amplo da distinção do caráter acrático dos outros caracteres morais. A partir disso, devemos acompanhar o programa investigativo da akrasia para traçar um plano de investigação da akrasia em ENVII1-10.

Em primeiro lugar, devemos analisar as diferenças entre o caráter acrático e os demais caracteres morais abordados. Em seguida, nos voltaremos à natureza da akrasia absoluta (haplôs), os tipos de akrasia e a akrasia 'por analogia'. Por fim, deveremos nos concentrar mais detidamente sobre o problema da possibilidade da akrasia e a polêmica com a posição socrática em ENVII.3. Sobretudo, precisaremos analisar as implicações dos pressupostos filosóficos de Aristóteles sobre sua descrição decisiva do fenômeno. Com base nesse programa, iniciaremos um exame das distinções preliminares do caráter acrático em relação aos demais caracteres morais.

\section{7}

\section{A akrasia e os vícios da alma}

A partir do método integrado da ética, conseguimos vislumbrar o direcionamento de Aristóteles no exame da akrasia. Antes propriamente da possibilidade da akrasia, o enfoque da maior parte de ENVII recai sobre o caráter acrático, o que é compreensível dentro da preocupação central da Ética com a

implícitas durante a investigação. No entanto, Cooper acha plausível supor que tais opiniões tenham um papel na resolução final das aporias de Aristóteles.

${ }^{400}$ Cf. Ibid., p. 454-455: “Aristóteles vale-se assim de uma non-commital language: ele defende a posição socrática sem a adotar, pois demonstrar é, no caso, preservar o maior número possível de opiniões autorizadas. Para tanto, Aristóteles precisa apresentar uma visão conciliadora na qual mesmo o socratismo encerre guarida. E é isso que ele faz." (itálicos do autor) 
educação do caráter moral. Por isso, a ENVII confronta o caráter acrático com outros caracteres morais que devem ser evitados, a brutalidade (theriotes), o vício ou maldade (kakía) e, posteriormente, a intemperança (akólastos) e a moleza (malakía). Nesse sentido, é preciso compreender o que distingue o caráter moral da enkrateia e da akrasia de outros pares de caracteres morais correlatos, como a sophrosýne e a akolasía, a kartería, a malakía e, inclusive, a areté e a kakía. Como observamos anteriormente, o propósito final do método é demonstrar no que consiste e de que modo o caráter acrático específico se destaca de outros caracteres morais relativamente semelhantes.

O caráter acrático apresenta uma distinta especificidade em relação a outros caracteres morais. Ao contrário de outros vícios morais, o acrático não é propriamente mal nem propriamente bom: "não é mau (poneròs oú), visto que seu propósito é bom (he prohaíresis epieikés); de modo que o acrático é meio mau (hemipóneros)." (1152a15-18). Sem dúvida, não só sua ação é má como também suas paixões são más, o que o assemelha ao vício moral. Porém, sua prohaíresis pelo melhor o impede de ser "mau em absoluto" (phaûlos haplôs) e o aproxima, em certo sentido, do homem virtuoso: "nele se conserva o que tem de melhor, o primeiro princípio (arché)" (1151a22-26). Diante desse limiar entre virtude e vício, o caráter acrático se constitui como um desafio à teoria da virtude moral aristotélica.

A disposição moral da akrasia coloca em evidência o problema fundamental da ausência da educação moral sem o qual o estrito conhecimento racional se torna ineficaz em matéria prática. Ora, mas se o seu problema não é falta de conhecimento em relação à prohaíresis, no que consiste sua falta de educação moral? No limite, a akrasia não é uma falha cognitiva, mas fundamentalmente uma falha prática na ação moral. Dessa forma, o exame da akrasia constitui o esforço de Aristóteles de delimitar o domínio próprio ao conflito moral da enkrateia e da akrasia em relação ao prazer e a dor ${ }^{401}$. Por isso, é imprescindível mais do que esclarecer o que ocorre na akrasia ter clareza sobre o que distingue o conflito interno da akrasia de outros caracteres morais no domínio intermediário da virtude e do vício.

\footnotetext{
${ }^{401}$ Cf. PAKALUK, 2005, p. 250: "On Aristotle's view, in akrasia we dwell on the pleasantness of something, and find ourselves thereby becoming increasingly affected by this, so that we are led with increasing desire actually to take pleasure in it, but all the while we are not deliberately dwelling on its pleasantness in order to stir up an irresistible desire. It is because of this point that akrasia occupies the puzzling position of being between virtue and vice."
} 
Entre a virtude e o vício, existem diversos caracteres morais intermediários que compartilham semelhanças com a akrasia mas exibem também notáveis diferenças. Em primeiro lugar, o homem obstinado (ischurognómon) e o prudente (prhónimos) seguem os princípios de sua razão prática como o acrático, mas o comportamento deles perante suas crenças é bem distinto.

O comportamento do obstinado traz à tona a aporia sofística da boa akrasia . De acordo com o seu caráter moral, o homem obstinado mantém sua opinião (dóxa) a todo custo tendo resistência à persuasão ou mudança de opinião. Se levarmos em conta o argumento sofístico, poderia ocorrer uma boa akrasia da opinião falsa caso o homem obstinado, convicto de uma crença falsa, agisse de forma contrária à sua resolução racional. Nesse sentido, o argumento sofístico sustenta a existência de uma crença-akrasia sincrônica, uma ação contrária à crença falsa no momento da ação. No entanto, Aristóteles defende que não há diferença substancial entre conhecimento e opinião no caráter moral: "certas pessoas não hesitam quando nutrem uma opinião, mas pensam ter conhecimento exato" (1146b24-.30). Além do mais, a akrasia expressa uma ação contrária à resolução racional correta e, sobretudo, por "prazeres vergonhosos" (1151b5-25). Nesse sentido, o acrático se assemelha ao o homem prudente (phrónimos) em matéria de razão correta.

O homem prudente e o acrático são semelhantes com relação à razão correta, mas divergem em sua ação moral. A diferença de comportamento de ambos indica que o acrático não possui um elemento fundamental do homem prudente: "a prudência (phrónesis) não nos vem apenas do conhecimento mas também da capacidade de ação (tôi praktikós)" (1152a7-9). Para Aristóteles, o conhecimento racional estrito não é suficiente sem a disposição moral adequada para a prudência: “a virtude não é apenas a disposição conforme a razão correta (katà tòn orthón lógon), mas a disposição com a razão correta (metà toû orthoû lógou)" (1144b2527). A harmonia entre a razão e os apetites irracionais do prudente não é compatível com o conflito interno do caráter acrático que, mesmo possuindo a razão correta, não está apto a colocá-la em prática por causa de sua falta de virtude moral. Como seu conflito interno se deve aos seus maus apetites, cabe analisarmos que tipos de inclinações humanas estão relacionadas aos vícios morais.

A brutalidade (theriótes) se dirige aos impulsos variados, mas não está exatamente dentro do domínio moral. Tal como o herói está acima do homem comum, a brutalidade exprime um caráter sub-humano: "assim como um bruto 
(theríou) não tem vício, nem virtude, tampouco os tem um deus" (1145a25-27). Dessa forma, Aristóteles atribui o caráter brutal à toda sorte de condições adversas, sejam provenientes da selvageria, do hábito de devorar fetos, ingerir carne crua ou carne humana, sejam condições doentias ou mórbidas, como roer unhas, sofrer de epilepsia, loucura ou até a pedarastia, por vezes devido ao abuso infantil (1148b241149a10). Em qualquer um desses casos, o agente está em uma condição inteiramente passiva: “aqueles que a natureza é a causa (phýsis aitía) de tal disposição ninguém chamaria acráticos (...) e tampouco aos que [estão assim] por efeito do hábito (di'éthos)." (1148b30-1149a). Na realidade, o seu tipo de apetites e disposições de caráter ultrapassam os limites naturais da humanidade e, dessa forma, não se aplicam propriamente ao domínio moral. Por isso, a classificação de akrasia ou vício à condição brutal só pode ser análoga e não é propriamente aplicada.

Em última análise, a brutalidade remete a um tipo de compulsão psicológica. Em tal condição, o agente fica totalmente submetido ao poder de seus impulsos irracionais de tal forma que sua ação é determinada apenas pela força das paixões irracionais. De fato, não há apetites ou traços de caráter no homem bruto que estejam dentro da esfera moral humana. Ao contrário, a akrasia e a enkrateia estão integradas ao campo moral comum: "relacionam-se com o que excede a disposição característica da maioria dos homens (tôn pollôn héxeos)." (1152a25-27). Por conta disso, o caráter brutal está fora do domínio moral e é impropriamente denominado de akrasia. Tendo isso em vista, devemos investigar que tipos de apetites humanos naturais concernem ao domínio moral ao qual está vinculado o caráter acrático.

Em ENVII.3, Aristóteles fornece critérios mais claros para distinguir o domínio de apetites humanos naturais com os quais a akrasia está vinculada:

O ponto de partida de nossa investigação (archè tês sképseos) é (a) a questão se o homem encrático e acrático são diferenciados pelos seus objetos (tôi perì) ou pela sua atitude (tôi hòs échontes), (...) (b) a segunda questão é se a enkrateia e a akrasia se relacionam com todo e qualquer objeto, ou não (perì pánt'estìn è oú). (1146b14-18)

Diante da enkrateia e a akrasia, são estipulados dois critérios de classificação desses dois tipos de caráter: (a) acerca de quais objetos (tôi perì) e de que 'modo' (tôi hòs échontes) se relacionam em sua ação moral; (b) se estão 
relacionados com todo e qualquer objeto (perí pánt'estín) ou apenas com certos tipos de objetos. A partir disso, são abordados outros vícios morais relativamente próximos à akrasia, como a akolasía e a malakía. De um lado, a akolasía e a akrasia estão voltadas igualmente ao prazer imediato, mas cada um desses vícios morais reage ao prazer "de certo modo (tôi hodì échein)". O primeiro é "levado por seu próprio propósito (prohairoúmenous)" aos maus apetites, enquanto o segundo "busca (diókei) tais prazeres, embora não pense (ouk oíetai) assim” (1146b18-24). De outro lado, a akrasia e a malakía estão dirigidas à mesma categoria de prazeres e dores, embora envolvam atitudes morais diametralmente opostas: o primeiro caso se refere ao 'domínio' (krateîn) do prazer, enquanto o segundo caso à 'resistência' (kartereîn) perante as dores (Cf. 1147b22-23; 1150a12-15). Em seguida, nos concentraremos primeiramente na oposição entre malakía e akrasia e, logo depois, sobre a inclinação característica da akolasía e a akrasia ao prazer imediato.

A falta de domínio ou controle distingue a akrasia da falta de resistência da malakía. Em linhas gerais, o caráter encrático e acrático se referem ao prazer imediato enquanto a fortaleza e moleza se caracterizam pela dor. Os termos krateîn (dominar ou controlar) e kartereîn (resistir) demarcam o que é peculiar no caráter encrático em relação ao caráter forte: "resistir e dominar (tò antéchein kaì kratê̂n) diferem um do outro assim como não perder difere de ganhar (toû nikân)" (1150a31-39). A malakía, se caracteriza pela incapacidade passiva de resistência da dor e, sobretudo, a franca repulsa à dor. Por exemplo, os casos do homem preguiçoso que arrasta o manto para evitar a fadiga ou do homem viciado em jogos que escapa da fadiga do trabalho são tipos característicos de malakía. No entanto, a akrasia implica uma atitude mais ativa do 'domínio' do impulso do prazer na razão prática. Nesse aspecto, o acrático e o intemperante se caracterizam pela inclinação comum aos prazeres imediatos.

A akolasía certamente se assemelha mais à akrasia do que os outros vícios morais. Ambas se caracterizam pela inclinação aos prazeres corporais, embora manifestem atitudes morais diferentes. Invariavelmente, a akolasia constitui um estrito vício moral (kakía) em oposição à akrasia.

Em linhas gerais, o acrático se distingue do vício do intemperante em pelo menos três aspectos: (a) em termos de conhecimento, (b) na sua prohaíresis correta na ação moral e (c) em matéria de atitude moral perante os prazeres. Em primeiro lugar, a kakía estrita envolve um tipo de ignorância ausente do acrático: "o vício é 
inconsciente de si mesmo (lanthánei), a akrasia não é (ou lanthánei)" (1150b351151a2). Em outros termos, o homem intemperante manifesta uma ignorância voluntária da qual o acrático não parece sofrer pois o segundo tem plena consciência do que é preciso ser feito. Em segundo lugar, a akrasia e o vício expressam o mesmo tipo de ação, mas diferem na prohaíresis: “a akrasía é contrária ao propósito (parà prohaíresin), enquanto o vício de acordo com o propósito (katà tèn prohaíresin)" (1151a5-8). Como dissemos, a ação da akrasia ocorre contra a boa prohaíresis de acordo com a reta razão e o vício moral segue sua má prohaíresis orientada ao prazer $^{402}$. Em terceiro lugar, a atitude moral perante a prohaíresis se reflete em diferentes reações morais a respeito dos prazeres imediatos. Enquanto o homem acrático se inclina a "buscar prazeres corporais excessivos contra a reta razão (parà tòn orthòn lógon)", o intemperante busca os prazeres excessivos “por sua convicção (pepeîsthai)" (1151a11-14). Dentre outros vícios morais, a akolasía é o único vício moral que mais se aproxima das mesmas paixões excessivas do acrático.

Em todo caso, a proximidade entre a akolasía e a akrasia expõe um elemento comum, a inclinação aos prazeres imediatos. Como vimos, o caráter acrático reflete o conflito interno da inclinação dos apetites maus excessivos contra sua prohaíresis correta pela melhor ação. Ao contrário, o caráter intemperante possui sua prohaíresis e suas paixões irracionais plenamente voltadas à satisfação dos prazeres imediatos maus. Desse modo, cabe nos voltarmos em seguida à natureza própria do caráter acrático especialmente em vista do seu tipo de objeto de desejo.

\section{8}

\section{A akrasia absoluta e os tipos de akrasia analógica}

A natureza do fenômeno e do caráter moral da akrasia não é tomado de forma dada em ENVII. Ao longo da seção anterior, mostramos o esforço de Aristóteles em distinguir claramente a akrasia de diversos outros vícios morais, da enkrateia e da prudência (phrónesis). Nesse sentido, o exame dos phainómena se concentra em uma descrição negativa do caráter acrático, isto é, revelando tudo que ${ }^{402}$ Cf. EN III11 1119a1-5: "o intemperante, pois, almeja todas as coisas prazerosas ou as que mais
o são, e é levado pelo seu apetite (ágetai hypò tês epithymías) a escolhe-las a qualquer custo." 
a akrasia absolutamente não é. A descrição positiva do caráter acrático, ou seja, o que a akrasia realmente é, é o tópico da longa controvérsia em torno de ENVII4-7.

Anteriormente, Aristóteles havia notado que uma das éndoxa da akrasia gerava um impasse peculiar (5d): se há akrasia de uma variedade de impulsos diferentes, será que há uma akrasia geral, relativa a qualquer tipo de objeto, ou haveria uma akrasia absoluta (haplôs) voltada a um impulso irracional específico? Em ENVII 4-6, Aristóteles demonstra que há apenas um tipo akrasia absoluta (haplôs) em sentido genuíno enquanto outros tipos de submissão aos diferentes impulsos apenas são akrasia "por analogia" (kath'homoióteta), isto é, em sentido derivativo e impróprio. Antes de prosseguirmos propriamente ao exame da akrasia absoluta, devemos relembrar as raízes da endoxa (5) derivada da concepção da akrasia tradicional.

A endoxa (5) da submissão aos impulsos variados expressa a akrasia tradicional da 'opinião dominante' expressa primeiramente nos Diálogos de Platão. Como vimos no diálogo Protágoras, a voz da opinião dominante expressa explicitamente tal descrição tradicional da akrasia, isto é, a submissão (hettómenos) do desejo racional por impulsos variados, como o ímpeto (thymós), o prazer (hedoné), a dor (lýpe) e o medo (phóbos) (352b-d). Ao longo da República, por sua vez, a mesma descrição tradicional do fenômeno é evocada de forma mais indireta. A psicologia tripartite da República permite esclarecer o conflito interno da alma em geral apresentando, de forma indireta e preliminar, as características marcantes do caráter acrático (430e-432a). Dentro desse cenário, o exame de Aristóteles retoma tal concepção popular da akrasia tradicional e lhe fornece uma definição filosófica mais técnica e rigorosa em ENVII.

Como vimos anteriormente, o termo akrasia ainda não possuía seu sentido clássico filosófico antes de Aristóteles, mas isso não impediu que já encontrássemos nos diálogos platônicos uma descrição tradicional popular bruta do fenômeno. Desde de sua origem, a akrasia tradicional é marcada pelo conflito fundamental entre a razão correta e os impulsos irracionais na alma. Em última análise, a endoxa (5) de ENVII.1 certamente remonta à descrição popular da akrasia tradicional difundida em meio à opinião dominante grega.

Desde o início da investigação de ENVII, Aristóteles se compromete com a tarefa de salvar ou, ao menos, esclarecer os phainómena. Como observamos, Aristóteles efetivamente invoca os phainómena da akrasia contra a negação 
socrática do fenômeno (1145b20-32). Sem dúvida, o compromisso de Aristóteles com o método das éndoxa exige a preservação e a depuração acurada das impressões divergentes da akrasia. A aporia da éndoxa (5), então, coloca em xeque justamente a akrasia tradicional dos impulsos variados. Do ponto de vista aristotélico, o método dos phainómena exige uma definição mais apurada e filosófica da ampla categoria da akrasia tradicional. Por isso, Aristóteles assume primeiramente a akrasia tradicional bruta e só posteriormente esboça sua própria definição filosófica técnica do que constitui o conflito moral interno do caráter acrático $^{403}$. Dentro do contexto de ENVII, o empreendimento da definição filosófica da akrasia "absoluta" (haplôs) acompanha simultaneamente um processo de delimitação do campo moral legítimo do caráter acrático e seu conflito interno entre a razão prática correta e os maus apetites. Na realidade, o objetivo principal de Aristóteles é inserir a akrasia claramente dentro da categoria do vício moral.

A intemperança (akolasía) e a akrasia se voltam ao mesmo tipo de prazeres imediatos. Levando em conta a pluralidade de prazeres humanos, Aristóteles designa uma categoria restrita de prazeres corporais ao campo do caráter moral. Em ENVII.4, Aristóteles estabelece claramente duas classes de prazeres (1447b22-30): 1) prazeres corporais "necessários (tà anangkaîa)" e "escolhidos por si mesmos (tà hairetà kath'autá)", porém sujeitos ao "excesso" (hyperbolén), dentre os quais estão os prazeres da "nutrição (trophé)" e "desejo sexual (tôn aphrodisíon)"; 2) prazeres "não necessários (tà anankaîa ouchîl)" e "escolhidos por si mesmos (hairetà kath 'autá)", como o prazer pela vitória, honra, riqueza ou lucro ${ }^{404}$. De fato, o intemperante e o acrático estão relacionados claramente à primeira categoria de prazeres, os prazeres corporais necessários.

Ao longo ENIII10-12, Aristóteles fornece mais detalhes sobre essa categoria de prazeres corporais necessários, relacionado à akolasía. Dentre os tipos

\footnotetext{
${ }^{403}$ Cf. LORENZ, 2009, p. 76: "I think that there is good reason to opt for the broad interpretation. It would be odd for Aristotle to assert that it is clear that unqualified lack of control and some other dispositions are about pleasure and pains, right away after raising the questions whether there is such a disposition as unqualified lack of control and, if there is, what is is about. Secondly, understanding Aristotle's claim broadly in the way suggested prepares us nicely for the distinctions that follow immediately in both versions of the susbsequent discussion."

${ }^{404}$ A distinção entre prazeres necessários e não-necessários evoca indiretamente a distinção similar entre desejos necessários e não-necessários presente em Rep. VIII (599a-c). No entanto, a psicologia tripartite restringe os desejos não necessários aos apetites moralmente degenerados que tendem ao excesso. Enquanto isso, a psicologia aristotélica relaciona esses prazeres não necessários à categoria dos desejos da alma independentes das sensações corporais, o que lhes parece conferir um aspecto moral neutro.
} 
de prazeres, os "prazeres da alma (hai psychikai)", tais como "amor pela vitória (philotimía)" e o "amor pelo ensino (philomátheia)", constituem desejos em que "o corpo não é afetado de modo algum, mas sim o pensamento (tês dianoías)" (1117b26-30). Pela classificação anterior, tais desejos estão relacionados à classe de desejos não necessários 'escolhidos por si mesmos'. Todavia, os intemperantes se dirigem aos "prazeres corporais (hai somatikai)", mas não propriamente aos prazeres da sensação, visão, audição ou olfato (1118a1-25). A akolasía concerne o excesso dos prazeres corporais do "tato e do paladar" (aphè kaì geûsis), ou melhor, aos desejos "de comer, beber e do desejo sexual" (1118a25-31). A partir disso, a categoria dos prazeres corporais necessários comuns ao intemperante e ao acrático nos auxiliam a delimitar o campo moral da akrasia e da akolasía.

A inclinação dos apetites humanos necessários insere a akrasia e akolasia na mesma categoria do vicio moral. De um lado, os prazeres "necessários" atendem apenas às necessidades básicas humanas. Ao contrário dos prazeres da sensação, esses prazeres corporais estão voltados à satisfação das necessidades, dado que "o apetite natural (he physikè epithymía) se limita a preencher o que nos falta (tês endeías)" (1118b15-18). Por isso, o "excesso" dos apetites da fome, sede e sexo ultrapassa a medida necessária humana do preenchimento da falta física do corpo. De outro lado, os prazeres corporais necessários são "compartilhados (koinoneî) com outros animais" à medida que "parecem inferiores e brutais" (andrapódodeis kaì theriódeis phaínontai) (1118a24-30). A inclinação absoluta aos impulsos irracionais não condiz com a condição humana racional mas apenas à condição servil “dos animais" (theriódeis) ${ }^{405}$. A natureza animal dos prazeres inferiores inclui o caráter intemperante e o acrático na mesma esfera de vícios morais ${ }^{406}$. Ao mesmo tempo, a distinção dos prazeres necessários e não necessários fornece a delimitação filosófica da akrasia absoluta (haplôs) e suas formas derivadas.

Em ENVII4, Aristóteles distingue a akrasia "absoluta (haplôs)" e a akrasia "por analogia (kath 'homoióteta)" com base na divisão dos tipos de prazeres:

\footnotetext{
${ }^{405}$ De fato, o próprio adjetivo andrapodódeis (de forma servil ou escrava) evoca a condição servil ao domínio dos impulsos irracionais da akrasia tradicional. Como observamos anteriormente, a akrasia tradicional da opinião dominante no Protágoras aplica o mesmo vocabulário da escravidão (andrápodon) aos impulsos irracionais (352c-d).

${ }^{406}$ Sobre o papel da natureza animal dos prazeres inferiores na delimitação da akrasia absoluta, ver também LORENZ, 2009, p. 88-89.
} 
das pessoas que são acráticas com respeito aos prazeres físicos (perì tàs somatikàs) (...) aquele que busca o excesso das coisas prazerosas - e evita o das coisas dolorosas: fome, sede, calor, frio, e todos os objetos do tato e do paladar - não por propósito, mas contrariando o seu propósito e o seu juízo (parà tèn prohaíresin kaì tèn diánoian), é chamado acrático (...) num sentido absoluto (haplôs). (11148a4-13)

Nessa passagem, Aristóteles delimita claramente a disposição moral da akrasia absoluta (haplôs) propriamente dita de outras formas derivadas de “submissão a diversos impulsos". O critério de distinção do caráter moral é voltado “aos objetos” de desejo e à "atitude moral” genuína do acrático. Em primeiro lugar, o homem acrático se inclina apenas ao excesso dos prazeres corporais "necessários", os prazeres da sensação (aísthesis), como os do tato e do paladar ${ }^{407}$. Como salienta Aristóteles, a censura moral da akrasia absoluta (haplôs) advém do fato de que ela é reconhecida "não apenas como uma falha (hos hamartía mónon) mas também como um tipo de vício (kakía tis)" (1148a2-4). Por conta disso, a inclinação aos prazeres corporais inferiores (e não outros impulsos) caracteriza a reprovação moral do caráter acrático. A akrasia absoluta e a intemperança (akolasía) se voltam à mesma espécie de prazeres corporais inferiores e se assemelham quanto ao gênero do vício moral. No entanto, o tipo de vício moral da akrasia difere da atitude moral da akolasía. Além disso, o acrático age "contrariando seu propósito e juízo" (parà tèn prohaíresin kaì tèn diánoian), tendo uma postura divergente dos intemperantes que buscam os prazeres excessivos pela prohaíresis. Com base nesses critérios, Aristóteles acaba isolando a akrasia absoluta do amplo alcance da akrasia tradicional.

O conflito interno do caráter acrático exige a delimitação da akrasia propriamente dita de outros sentidos derivados do termo. De fato, Aristóteles introduz a distinção do sentido absoluto e o sentido "por analogia" (kaht'homoiótaton) derivado, com base em um sentido geral próprio e um sentido específico impróprio. Para esclarecer a distinção, Aristóteles sugere o seguinte exemplo: o vencedor dos jogos olímpicos 'Ánthropos' e seu termo homônimo 'ánthropos' (ser humano). Ambos os nomes compartilham da mesma “definição

\footnotetext{
${ }^{407}$ Aparentemente, a inclusão dos apetites derivados do calor e frio parece entrar em conflito com os apetites básicos derivados do tato e ao paladar em ENIII10. No entanto, Gauthier \& Jolif (2002, p. 621-622) reúnem diversas evidências de outros textos aristotélicos em que a sensação do tato e do paladar abrangem os prazeres derivados do calor e do frio na vida animal da qual o ser humano também faz parte.
} 
geral (koinòs lógos)" em seu uso genérico mas diferem em sua "definição do particular (toû idíou)" ou seu uso específico (1147b35-1148a3). Em sentido geral, ambos os nomes se referem ao domínio do gênero humano. Em sentido específico, o primeiro termo tem como referência $o$ homem Ánthropos e o segundo termo designa propriamente todos os homens. Para Aristóteles, o tipo de vício moral da akrasia também se aplica ao 'uso genérico' e ao 'uso específico' dos phainómena.

A distinção da akrasia absoluta e a akrasia analógica seguem os parâmetros do sentido propriamente dito e do sentido 'por analogia'. Se a akrasia absoluta (haplôs) é apenas a submissão da razão aos prazeres imediatos excessivos, a submissão a quaisquer outros 'impulsos' não é designada adequadamente de 'akrasia'. Segundo Aristóteles, a submissão aos outros impulsos envolve uma qualificação do impulso: “com a especificação, no tocante ao dinheiro (tò chremáton), à honra (timês), ao lucro (kérdous) ou cólera (thymô̂), etc." (1147b3035). No entanto, a submissão da akrasia absoluta (haplôs) está envolvida apenas com a simples satisfação dos apetites do prazer imediato, isto é, sem qualificação.

Além disso, a classe dos prazeres não necessários dos outros impulsos é substancialmente diferente da classe dos prazeres corporais inferiores do acrático. Dentro da primeira classe, há diversos prazeres, tais como o desejo por honra, vitória, lucro ou dinheiro incluídas no "gênero das coisas nobres e bons (tôn génei kalôn kaì spoudaíon)" e "por natureza dignas de escolha (phýsei hairetá)" ou objetos intermediários (1148a20-23). Em termos morais, os desejos dos prazeres não necessários são superiores aos apetites dos prazeres imediatos. Do ponto de vista ético, os objetos "nobres e bons" não recebem o mesmo tipo de reprovação moral que os prazeres corporais: "não são censurados por desejá-los ou amá-los (epithymeîn kaì philê̂n) mas por fazerem-no de certo modo- (tôi pòs) - isto é, indo ao excesso (hyperbállein)" (1148a25-27). A reprovação moral da submissão ao desejo dos objetos nobres não se relaciona propriamente ao objeto do desejo em si mesmo, mas apenas à atitude moral do agente. Como veremos, a submissão do ímpeto (tô̂ thymoû) é um caso diferenciado que merece uma análise destacada mais adiante. De qualquer modo, isso fornece os parâmetros fundamentais de revisão do sentido amplo genérico da akrasia tradicional e a delimitação do sentido específico da akrasia absoluta.

A revisão do sentido geral da akrasia tradicional de Aristóteles se reflete nos parâmetros morais que refletem a definição específica da akrasia absoluta 
(haplôs). Segundo os critérios morais, a akrasia absoluta é objeto de reprovação moral tanto por seus objetos de desejo quanto por sua atitude moral. Primeiramente, o impulso do acrático pelos prazeres corporais excessivos relativos à natureza animal inferior é por si só um motivo de reprovação moral. Além disso, o conflito interno da razão correta e os maus apetites expresso na atitude moral do acrático constitui um segundo motivo de sua reprovação moral. A akrasia absoluta merece reprovação moral completa, tanto em vista de seu objeto de desejo quanto pela atitude moral do agente. Enquanto isso, a akrasia tradicional de outros impulsos por objetos nobres merece censura moral exclusivamente pela atitude moral do agente contra a razão correta.

A submissão dos outros impulsos da akrasia tradicional constitui um sentido analógico do fenômeno: “em razão de uma semelhança quanto à paixão (tô̂ páthos), aplicasse-lhes o nome de akrasía precisando em cada caso o respectivo objeto." (1148b5-8). Por esses parâmetros, os outros casos de submissão aos impulsos variados não atendem aos requisitos morais estritos da akrasia absoluta: a) em primeiro lugar, esses casos envolvem objetos "nobres e bons" ou intermediários, como vitória, honra, lucro, etc. independente da necessidade animal dos desejos corporais necessários; b) em segundo lugar, não expressam o conflito interno entre a razão correta (orthós lógos) e os apetites corporais inferiores que resultam no erro moral da akrasia. Em um sentido genérico, o 'impulso geral da paixão' (páthos) é o que caracteriza a 'definição geral' de todos esses casos variados de submissão aos impulsos da akrasia tradicional.

A distinção da akrasia absoluta e da akrasia "por analogia" indica que é preciso apurar a éndoxa geral do fenômeno. Para todos os efeitos, a definição filosófica da akrasia absoluta (haplôs) de Aristóteles permite delimitar o tipo de "submissão ao impulso" aos prazeres corporais próprio do campo moral e à educação moral da Ética. Enquanto isso, a akrasia "por analogia" (kath’homoióteta) ou "por metáfora" (kata metáphoran) engloba outros casos de submissão aos impulsos ou bem assimilados a outros caracteres morais ou bem são colocados fora do campo moral da Ética.

Ao longo de ENVII, Aristóteles trata de diversos caracteres morais análogos à akrasia absoluta. O método dos phainómena explora uma série de disposições morais opostas correlatas ao fenômeno. Como observamos, o vício moral estrito (kakía) ou intemperança (akolasía) abrange os mesmos prazeres corporais da 
akrasia absoluta, mas difere em relação à atitude moral, a prohaíresis incorreta em vista dos maus apetites (1148b8-12). Da mesma forma, a brutalidade (theriódes) caracteriza uma espécie de 'submissão aos impulsos irracionais' em sentido analógico à akrasia. Porém, a natureza dos impulsos brutos extrapola o limite ordinário dos apetites humanos mais básicos, o que coloca tal disposição totalmente fora da esfera moral (1149a1-24). Até mesmo a moleza (malakía) compartilha de um conflito motivacional analógico à akrasia absoluta. Entretanto, o primeiro caso se dirige propriamente à fuga ou resistência às dores imediatas, enquanto o segundo caso se refere à busca ou controle dos prazeres imediatos (11503-10). De todos os casos análogos, a submissão ao ‘ímpeto’ (tô̂ thymô̂) exige uma análise destacada justamente por conta das suas similaridades e divergências com a psicologia moral platônica.

Ao contrário da psicologia moral da República, a submissão ao thymós é claramente separada da akrasia absoluta (haplôs) de Aristóteles. Como dissemos anteriormente, a psicologia moral aristotélica não dedica o mesmo destaque ao thymós do que a psicologia platônica confere ao thymoeidés. Mesmo assim, observamos que o impulso emocional do thymós da psicologia moral de Aristóteles exibe características similares ao thymoeidés platônico: a) a obediência 'parcial' do thymos à orientação da razão humana; b) a oposição natural do thymós e o raciocínio diante dos apetites corporais imediatos; c) a natureza de seu objeto de desejo - o impulso do thymós se dirige a "desejos naturais ou apetites (epithymíais) que são comuns a todos os homens (koinaì pâsi)" e "mais naturais (physikóteron)" do que os apetites "excessivos e não necessários" (1149a25-b7). Novamente, a distância psicológica da natureza do impulso do thymos aos apetites corporais será crucial na distinção da submissão do thymos da akrasia absoluta.

Em ENVII.6, Aristóteles distingue a "akrasia pelo ímpeto" (akrasía he tô̂ thymoû) analógica da akrasia absoluta:

o ímpeto (ho thymós) obedece em certo sentido à razão (tôi lógoi pos), mas o apetite não. Por isso, ele é mais censurável, pois o homem acrático com respeito ao ímpeto (toû thymoû akratès) é vencido em certo sentido pela razão (tô̂ lógou pos hettâtai) ao passo que o outro o é pelo apetite (ho tês epithymías) e não pelo raciocínio. (1149b1-4) 
A submissão do thymós não consititui o conflito interno da akrasia absoluta. Do ponto de vista da psicologia moral, o thymós é um impulso irracional diferente dos apetites corporais inferiores. O desejo de retaliação do thymós representa uma força motivacional ativa em vista do prazer nobre da honra, enquanto os apetites corporais, constituem estados passivos ligados ao prazer e a dor corporais ${ }^{408}$. Do ponto de vista racional, a submissão ao thymós exprime um tipo de conflito interno que não se verifica na akrasia absoluta. Diante disso, Aristóteles faz uma análise detalhada do raciocínio prático do homem impetuoso.

A irracionalidade da akrasia em relação aos apetites corporais difere da submissão racional ao thymós na ação moral. De certa forma, o agente sob influência do ímpeto segue parcialmente seu raciocínio prático, "como que raciocinando" ou, literalmente, "como tendo concluído [de um silogismo] (hósper syllogisámenos)". Nesse caso, o agente mal reflete sobre o insulto ou a falta imputada a si mesmo e segue logo, sem raciocinar apropriadamente pela pressa e ardência do thymós, à conclusão prática final 'é preciso reagir a $x$ '. Mesmo que as crenças do agente se refletem em seu raciocínio prático final, a proposição do raciocínio prático final se mantém moralmente injustificável ${ }^{409}$. No entanto, os apetites corporais da akrasia se desviam completamente do raciocínio prático original, de tal modo que o agente segue apenas seus apetites corporais. A natureza intermediária do impulso do thymós leva Aristóteles a conclusões alinhadas à psicologia tripartite da República.

Como vimos, a psicologia tripartite da República conferia uma capacidade 'racional' intermediária semelhante ao seu thymoeidés. De certa forma, o thymoeidés platônico constitui uma força 'intermediária' com maior afinidade à parte racional do que a parte apetitiva. Nesse sentido, o conflito interno do homem timocrático na República expressa um conflito interno semelhante à akrasia por ímpeto analógica de Aristóteles. A classificação geral da ignorância do vício moral na República permite caracterizar o conflito interno do thymoeidés como um tipo de conflito acrático. No entanto, Aristóteles não está disposto a incluir a akrasia

\footnotetext{
${ }^{408}$ Cf. LORENZ, 2009, p. 79: "It is reasonable to assume (...) that Aristotle thinks of taking revenge as something that apart from being pleasant, also is good and choiceworthy in itself. Once that is seen, it becomes clear how lack of control over anger is supposed to fit Aristotle's train of thought. His audience would not I think, have needed to be told explicitly that taking revenge for an act of abuse is good and choiceworthy in themselves."

${ }^{409}$ Para essa falta de justificativa racional do thymós ver GAUTHIER \& JOLIF, 2002, p. 632-633 Ver também CHARLES, 2011, p. 197-198.
} 
por ímpeto na categoria da akrasia absoluta. Devido aos critérios morais aristotélicos, a reprovação moral da akrasia absoluta se deve exclusivamente à inclinação aos maus apetites inferiores contrários ao raciocínio prático correto. $\mathrm{Na}$ realidade, a akrasia por ímpeto é apenas uma forma analógica da akrasia absoluta. Sobretudo, a natureza da relação entre o raciocínio prático e os apetites irracionais é crucial para a descrição aristotélica da akrasia absoluta.

Como veremos adiante, a estrutura do raciocínio prático também será fundamental na descrição da possiblidade da akrasia de ENVII.3. No entanto, devemos antes analisar brevemente dois tipos de caracteres morais relativos à akrasia absoluta em ENVII.7.

Ao fim de ENVII.7, Aristóteles distingue dois tipos diferentes de caráter acrático, a akrasia impulsiva (tò propéteia) e akrasia fraca (tò asthéneia):

alguns homens não sabem manter (ouk emménousin) o que deliberaram devido à paixão (dià tô̂ páthos), enquanto outros, por não terem deliberado (mè bouleúsasthai), são levados pela paixão (ágontai hupò toû páthos). (1150b19-23)

Os dois tipos de caráter acrático correspondem a formas diferentes de akrasia. Ambos os termos gregos, propéteia e asthéneia, expressam motivações distintas com relação aos prazeres corporais. O termo 'propéteia' designa uma precipitação impulsiva apressada pelo prazer, enquanto o segundo expressa uma fraqueza física diante do prazer ${ }^{410}$. No caso da akrasia impulsiva, o agente é "levado pela paixão (ágontai hypò tô̂ páthos)" antes mesmo de chegar ao fim de sua deliberação. O caráter acrático impulsivo expressa, por vezes, o temperamento de homens "ávidos e excitáveis (hoi oxê̂s kaì melanchokoi)", marcado por "paixões violentas (ten sphrodoteta)" (1150b25-27). No caso da fraqueza, o acrático chega ao fim de sua deliberação, mas não consegue mantê-la "por causa da paixão (dià toû páthos)". Ao contrário do primeiro caso, o agente é impedido de agir em função de uma paixão fraca mesmo diante de um raciocínio prático completo (1151a3-4).

\footnotetext{
${ }^{410}$ Cf. LIDDEL-SCOTT. O termo grego 'propéteia' significa uma precipitação impaciente ou uma inclinação abrupta do juízo, de forma irrefletida, à ação a enquanto o termo 'asthéneia' designa uma falta de vigor físico ou uma debilidade patológica devido à idade ou a alguma doença. Ao que tudo indica, o uso desses termos por Aristóteles indica que seu objetivo final é demarcar filosoficamente o campo moral dos impulsos relativos aos prazeres corporais. A partir desses termos técnicos, Aristóteles pode destacar novamente os apetites corporais da akrasia absoluta outros impulsos correlatos, como o impulso pelos prazeres nobres ou mesmo o impulso característico do thymós.
} 
Dessa forma, os dois tipos de caráter acráticos são introduzidos de forma a complementar e integral à natureza do fenômeno da akrasia absoluta.

A akrasia impulsiva e a akrasia fraca constituem a submissão dos maus apetites sobre a razão prática em vista de diferentes forças motivacionais. No primeiro caso, os impulsos fortes interrompem abruptamente o processo do raciocínio prático. Dos impulsos violentos da akrasia impulsiva, uns são levados pela paixão excitável (melancholía) de apetites excessivos que afetam o estado corporal do agente, enquanto outros são levados pela paixão ávida (oxús) e violenta. No segundo caso, os impulsos fracos inviabilizam diretamente a própria ação moral deduzida pelo raciocínio prático completo ${ }^{411}$. Ao contrário do caso anterior, o acrático fraco tem plena consciência de todo o seu raciocínio prático mas realiza uma ação irracional devido aos seus apetites fracos. De qualquer forma, a classificação desses dois caracteres acráticos é fundamental para compreendermos a controvérsia central em torno da possiblidade da akrasia absoluta em ENVII.3.

\section{9 \\ EN VII.3: A possibilidade da akrasia e a solução 'progressiva' de Aristóteles}

Ao longo da Ética, o caráter acrático é tratado como um caráter moral comum e com traços reconhecíveis na sociedade grega. Nessas ocasiões, Aristóteles lhe classifica em termos tradicionais: (a) um erro moral derivado do conflito interno entre a razão e os apetites corporais (1102b14-29); (b) um vício moral caracterizado pelos apetites contrários à prohaíresis correta (1111b10-17); e, até, (c) um ato de ignorância voluntária causado pela falta de virtude moral e não pela ausência do conhecimento racional (cf. 1095a1-12;1114a15-22). No entanto, ENVII revela que há um conjunto de impasses em torno do caráter moral e da própria existência do fenômeno. Nesse cenário, o problema da possibilidade da akrasia se destaca em torno do desafio fundamental da preservação dos phainómena morais fundamentais diante da negação socrática da akrasia.

Como vimos, o método da ética introduz uma difícil tarefa a Aristóteles: salvar os phainómena da akrasia em face da tese socrática da ignorância. Em

${ }^{411}$ Para uma análise mais profunda sobre os dois tipos de akrasia, ver CHARLES, 2011, p. 189193. 
ENVII2, a aporia do conhecimento apresenta o aparente conflito entre os phainómena e a posição de 'Sócrates'. Apesar da referência ao Sócrates histórico, as teses apresentadas refletem claramente as palavras do personagem homônimo do Protágoras $^{412}$ (1145b22-33): (1) o conhecimento não é “dominando e arrastado' (krateîn kaì periélkein) como um escravo (hósper andrápodon)" (cf. Prot. 352b-d); (2) ninguém age "contrariando o que julga melhor (parà tò béltiston)" (cf. Prot. 358c-d); (3) não há efetivamente akrasia, pois o fenômeno ocorre "por ignorância (di'ágnoian)" (cf. Prot. 357d-e). Nesses termos, Aristóteles reconhece que a negação socrática da akrasia consiste em um estado permanente de ignorância.

Ao longo de ENVII2-3, Aristóteles exprime mais simpatia com a posição socrática do que divergência teórica com a posição socrática. A princípio, ele parece assumir a tese (3) ao indagar "que tipo (tís ho trópos) de ignorância se trata?”. Ao mesmo tempo, ele considera que o acrático "não pensa (ouk oíetaî)" desse modo "antes do estado de paixão (prìn en tôi páthei)". Posteriormente, Aristóteles parece conceder a tese socrática (1) ao sustentar que apenas o "conhecimento perceptivo (tês aisthetikês)" pode ser subjugado pelos apetites, mas o conhecimento em si mesmo é preservado (1147b15-18). Para todos os efeitos, Aristóteles admite que a akrasia consiste em uma forma de ignorância temporária, porém em um sentido diferente da tese socrática do Protágoras. Ora, mas em que medida Aristóteles se afasta ou se aproxima da posição socrática? Para compreender isso, devemos ter consciência de que tal problema remonta à relação entre conhecimento e akrasia.

O desafio do poder do conhecimento constitui o desafio da possibilidade da akrasia. Para Aristóteles, a natureza do conhecimento moral é crucial na investigação da possibilidade da akrasia: (a) é necessário determinar se o acrático tem ou não tem a posse do conhecimento; (b) se ele possui um tipo de conhecimento, é preciso averiguar de que "modo (tôi pôs)" o detém e exerce no campo da ação moral (1146b15). Portanto, é necessário determinar a natureza e o modo de exercício prático do 'conhecimento' do acrático.

Como observamos, Aristóteles apenas assume que a akrasia é o efeito de uma ignorância temporária no momento da ação. No entanto, o problema da

\footnotetext{
${ }^{412}$ Como sugere Irwin (2008, p. 32-40) as teses do Protágoras enunciadas no próprio texto da Ética têm profundo efeito sobre a posição final de Aristóteles a respeito da 'superioridade' de certo tipo de conhecimento'. Na sequência, iremos analisar melhor qual a relação entre a posição de Aristóteles e a negação socrática do Protágoras.
} 
possibilidade da akrasia irá suscitar uma série de outras dificuldades: Ora, o que ocorre com o conhecimento racional durante a akrasia? Será que melhor juízo é subjugado efetivamente no momento da ação ou há outro fenômeno em curso? O que leva ao erro moral, seria uma falha cognitiva ou um erro causado pelo apetite irracional? Qual o papel dos impulsos irracionais no conflito interno entre a razão prática e as paixões na alma? Ora, há alguma diferença entre conhecimento e opinião no que se refere à akrasia? De fato, essas dificuldades são suscitadas de forma indireta ou implícita em uma análise exegética do exame de Aristóteles sobre a possibilidade da akrasia em ENVII.3.

Ao longo de ENVII.3, Aristóteles apresenta 4 propostas sucessivas de descrição do que ocorre na akrasia. Dentro dessa estrutura, as 3 teses inicias se apoiam sobre distinções preliminares: (1) os sentidos de "saber"- a distinção entre quem "tem (ho échon)" e "faz uso (ho chrómenos)" do conhecimento, o acrático possui mas não exerce seu conhecimento na prática (1146b30-34); (2) o 'silogismo prático' e a ignorância da premissa particular na ação - o acrático dispõe do conhecimento da premissa universal mas ignora, em certo sentido, a premissa particular (1146b35-1147a9); (3) a analogia do caráter moral (héxis) acrático com o estado passional de bêbados, sonâmbulos ou atores - o acrático usa a linguagem do conhecimento embora não saiba aplicá-la da forma apropriada (1147a10-24). Após essas 3 propostas preliminares, Aristóteles prossegue, então, a uma solução aparentemente definitiva denominada de 'physikôs' ('natural' ou 'da natureza') (1147a25-b28). Aparentemente as propostas sucessivas visam esclarecer progressivamente a suposição inicial de que o acrático não possui conhecimento. Mesmo assim, as propostas sucessivas não parecem estar explicitamente ou necessariamente interligadas.

A ordem sucessiva das propostas de solução ao problema indica o procedimento investigativo de Aristóteles. Por vezes, as 4 propostas parecem incompatíveis e acabam envolvendo, em certa medida, uma forma de ignorância. Nessa medida, uma corrente interpretativa ortodoxa tem alegado que Aristóteles recai facilmente na posição socrática falhando em oferecer qualquer alternativa à possibilidade da akrasia. Diante de tais dificuldades exegéticas, alguns comentadores declaram ainda que Aristóteles não pretende nem mesmo oferecer 
qualquer explicação positiva da akrasia $^{413}$. Em outra linha interpretativa, certos intérpretes buscam uma solução mais coerente da descrição definitiva da akrasia de Aristóteles ao custo de descartar propostas descritivas do fenômeno inconvenientes. Todavia, nenhuma dessas linhas interpretativas captam apropriadamente o exame investigativo da possibilidade da akrasia de ENVII.3

Em cada um dos estágios das propostas, constatamos a reiterada ocorrência do advérbio éti ('ainda, além disso'), demarcando a transição entre as diferentes propostas de descrição da akrasia. De fato, o termo 'eti' salienta a continuidade 'progressiva' de elucidação das diferentes propostas encaminhando a discussão, então, à $4^{\mathrm{a}}$ solução definitiva. ${ }^{414}$. Ademais, é notável que o exame de ENVII.3 concerne a possibilidade da akrasia absoluta (haplôs) em geral, o que abrange, ainda de forma indistinta, os dois tipos de akrasia de ENVII.7, a akrasia impulsiva e a akrasia fraca. Na sequência, devemos mostrar que nenhuma das propostas anteriores recai na tese socrática da ignorância.

Para efeitos de esclarecimento, dividiremos a estrutura das 4 propostas em duas vertentes investigativas: em um primeiro eixo, investigaremos a relação preliminar entre o conhecimento e o conflito interno moral acrático abordados nas propostas (1) e (3); em um segundo eixo posterior, pretendemos nos voltar propriamente à doutrina do 'silogismo prático' presente nas propostas (2) e (4). Em ambas as ocasiões, os argumentos de Aristóteles remetem a observações gerais sobre a natureza do conhecimento moral de ENVI. Nessa perspectiva, nos concentraremos primeiramente sobre o primeiro eixo investigativo nessa seção

\footnotetext{
${ }^{413}$ Dentro dessa perspectiva, temos as posições peculiares de Burnyeat e Robinson acerca do problema. De um lado, Burnyeat (2010, p. 177) alega que não há propriamente uma explicação da akrasia na Ética: "Julgo que muitos leitores sentem que a discussão aristotélica da acrasia deixa sem explicação o ponto que mais carece de explicação. (...) Ficam, então, insatisfeitos porque não existe uma resposta adequada para essa questão na discussão, pela boa razão que Aristóteles, segundo julgo, não pretende oferecer uma resposta a essa questão. A análise do conhecimento aponta com precisão o que tem de ser explicado. Ela não é, em si, a explicação.”. De outro lado, Robinson (2010, p. 75) recomenda descartar inteiramente a proposta physikôs como sendo desnecessária: "Aristóteles acrescenta uma explicação physikôs não para finalmente atingir a questão, mas para satisfazer aquelas pobres pessoas que não conseguem distinguir filosofia e psicologia. (...) Embora Aristóteles não o diga, penso que o ouço acrescentar a meia-voz: 'mas essa linda história psicológica nada tem a ver com a questão, cuja resposta reside ainda nas distinções lógicas que expus entre os diferentes tipos de conhecer." "Como buscamos uma linha interpretativa mais coerente com a integração das 4 propostas de explicação do fenômeno e o caráter acrático exposto na Ética, julgamos que esse tipo de abordagem inviabiliza a compreensão da tese aristotélica da akrasia.

${ }^{414}$ Cf. PICKAVÉ \& WITHING, 2008, p. 333: "We see (...) a progression in which the first stage describes a generic sort of failure of which the akrates' failure is eventually shown to be a species. Each subsequent stage is required because the previous stage does not yet capture the sort of failure distinctive of the akrates. In this sense, each stage takes us 'further' along a continuous route." (itálicos do autor)
} 
antes de prosseguir ao segundo eixo investigativo mais complexo. Em seguida, precisaremos explicitar brevemente porque deixaremos a controvérsia do 'silogismo prático' para a próxima seção.

No segundo eixo investigativo, precisaremos abordar a controversa doutrina do 'silogismo prático' presente nas propostas (2) e (4). Além da ENVII.3, outras passagens de De Motu Animalum e De Anima apresentam essa controversa doutrina sob ângulos diferentes. A partir disso, pretendemos mostrar qual o papel do silogismo prático na descrição unificada da akrasia, levando em conta a integração de todas as teses preliminares na explicação decisiva physikôs. Assim, poderemos esclarecer em que medida Aristóteles acata a tese socrática da superioridade do conhecimento moral. Com base nisso, prosseguiremos então à distinção dos sentidos de saber em (1) dado que constitui a base fundamental das próximas propostas explicativas da akrasia.

Durante sua primeira distinção preliminar, o exame busca determinar o tipo de conhecimento do acrático. Como dissemos, a tese (1) estabelece o duplo sentido de 'saber" (tò epísthastai): 'ter' ou "possuir" (échein) e "utilizar" (chrómenos) o saber. A partir desse parâmetro, Aristóteles nota que há uma diferença singular entre os que tem e exercem o conhecimento e os que não conseguem exercê-lo mesmo o possuindo:

há diferença se o agente que faz o que não deve tendo posse do conhecimento (tò échonta) mas não lhe está contemplando (mè theoroûnta), ou se lhe está contemplando: porque a segunda hipótese parece estranha, mas não a primeira. (1146b32-34)

O acrático representa claramente a categoria dos que detém o conhecimento, mas não conseguem exercê-lo de forma apropriada. A distinção entre 'ter' e 'utilizar' o conhecimento equivale, respectivamente, a 'ter' e 'contemplar' (theoreîn) o conhecimento. Nesse contexto, theoreîn designa uma atitude ativa diante do objeto de conhecimento e não uma mera recepção passiva ou meramente teórica do saber. Em linhas gerais, theoreîn parece significar simplesmente uma 'falha em agir sob o raciocínio' ${ }^{415}$, ou uma falha em aplicar o conhecimento na

\footnotetext{
${ }^{415}$ De acordo com Broadie (1991, p. 292-297), a distinção échein e theorên segue estritamente a distinção anterior entre possuir e 'usar' o conhecimento. Nessa medida, theoreîn ou 'contemplar' o conhecimento seria o equivalente a literalmente 'agir' sob um raciocínio, enquanto o erro acrático seria, então, uma falha em agir sob um raciocínio na ação moral. Por isso, sua interpretação torna a distinção échein/theoreîn totalmente incompatível com a distinção clássica dýnamis/enérgeia. No
} 
prática. No entanto, Aristóteles parece traçar um paralelo implícito com a distinção clássica de ato (enérgeia) e potência (dýnamis).

Em De Anima, a distinção de 'ato' e 'potência' estabelece uma análise similar dos modos de conhecimento. No primeiro plano, há os conhecedores em potência que dispõem do saber geral da gramática, tendo a capacidade de demonstrar as regras gerais gramaticais ou dispondo das habilidades necessárias para aprendê-las. No segundo plano, o conhecedor em ato está no exercício ativo do uso da gramática, isto é, na aplicação efetiva das regras gramaticais nos contextos apropriados seja por meio do ensino ou do aprendizado atual do conhecimento linguístico (DA II.2 417a21-b2). Dentro desse cenário, a oposição entre o gênero de conhecimento do acrático e o gênero de conhecimento do sábio fica assim demarcada. Ao invés da 'falha em agir com base no conhecimento', é preferível sustentarmos apenas que o acrático deixa de exercer seu conhecimento em ato no contexto particular da ação moral. Por essa razão, o acrático ainda dispõe do conhecimento moral em potência, mas não consegue exercê-lo em ato no momento da ação em vista as circunstâncias particulares da ação. Apesar de preparar o caminho das próximas propostas, essa primeira tese é insuficiente para explicar o que ocorre efetivamente na akrasia.

Ao prosseguir à tese (3), o exame da ineficácia do conhecimento se transfere ao caráter moral (tèn héxin). Nesse estágio, o caráter acrático é comparado a casos análogos: a condição dos "adormecidos, loucos e embriagados" (katheûdonta kaì mainómenon kaì oinoménon $)^{416}$ e, posteriormente, até mesmo aos "atores" (hypokrinómenous) (1147a10-14). Novamente, o propósito da analogia é mostrar como é possível ter conhecimento sem praticá-lo na ação moral. Para Aristóteles, tais exemplos evidenciam a influência das paixões irracionais (en tô̂s páthesin): “as explosões do ímpeto, do apetite sexual (thymoì kaì epithymíai aphrodisíon), e outras paixões que alteram materialmente a condição do corpo" (1147a14-18).

entanto, as falhas dessa interpretação peculiar da passagem foram apontadas por diversos intérpretes, como Charles (2009, p. 45 n. 7) e Bostock (2000, p. 126 n. 11).

416 Com efeito, é necessário ter em mente o que representam os exemplos de 'embriagados' e 'adormecidos' sugeridos aqui. De um lado, o caso dos adormecidos parece evocar claramente a condição de sonâmbulos que são capazes de agir e falar de forma inconsciente enquanto dormem. De outro lado, o caso dos homens embriagados descreve claramente a embriaguez por vinho (oinós) marcada na expressão 'oinoménoi' (literalmente, 'embriagados de vinho'). Acerca disso, Charles (2009, p. 190) observa que há uma sutil diferença do homem levemente embriagado (oinoménos) que tem até mais confiança e audácia em seu comportamento, e os homens absolutamente embriagados (methúontes) que mal conseguem se manter em pé e tem ilusões nas sensações. De fato, o primeiro caso será o reflexo análogo da akrasia fraca. 
Como observamos, a analogia do acrático com a condição do bêbado já havia revelado o aspecto inerentemente voluntário da akrasia (1113b34-1114a32). Diante da obscura inconsciência do agente nos exemplos anteriores, o caso do jovem aprendiz novamente é crucial para esclarecer a analogia com o fenômeno.

Novamente, Aristóteles reforça a analogia do caráter da akrasia com o estado do jovem aprendiz iniciante na proposta (3):

os que aprendem uma ciência pela primeira vez podem compor as suas proposições (syneírousi toùs lógous) mas ainda não sabelas, pois é preciso que se torne parte deles mesmos (symphyênai), e isso requer tempo. (1147a22-24)

O conhecimento moral relativo à paixão irracional está na diferença crucial do conhecimento de 'composição de proposições' e do conhecimento que se 'torna parte de si mesmo'. Segundo Aristóteles, os exemplos de estados passionais só revelam que "o fato de usarem a linguagem derivada do conhecimento (apò tês epistémes) não prova nada" (1147a20-22). Mesmo que os jovens exponham teorias complexas, como "demonstrações científicas (apodeíxeis)" ou "versos de Empédocles", só chegam ao ponto de "compor as suas proposições (syneírousi toùs lógous)", sem colocá-las efetivamente em prática. Além disso, o verbo synereîn em um sentido pejorativo se refere à habilidade de 'compor' ou 'conectar' duas

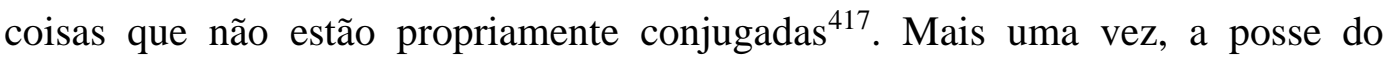
conhecimento racional teórico da ética não assegura o exercício do conhecimento moral promovido pela virtude moral.

Sem a virtude moral, o conhecimento teórico da ética tem sérias limitações no âmbito prático. Acerca das limitações do conhecimento teórico, Aristóteles salienta que a compreensão (sýnesis) pode expressar opiniões sobre a phrónesis sem propriamente manifestar seu exercício prático: “o termo 'compreensão' (sýnesis) é aplicável ao opinar (têi dóxei) para julgar o que outra pessoa diz acerca de assuntos que concernem a phrónesis." (1143a10-15). Nessa esfera, a expressão descritiva do conhecimento prático não reflete necessariamente o domínio prático prescritivo da

\footnotetext{
${ }^{417} \mathrm{Na}$ tradução oficial da Ética, Ross adota a tradução 'string together' (literalmente, entrelaçar junto) que não contempla a conotação pejorativa original do verbo synereîn relacionado ao "conhecimento" do aprendiz. Em face disso, outros intérpretes têm sugerido a tradução 'conectar' ou 'compor' salientando ainda a crítica de Aristóteles à mera exposição de proposições teóricas que carecem do conhecimento efetivo da matéria em questão. Para nossa tradução alternativa, ver BURNYEAT, 2010, p. 161 n. 6; CHARLES, 2011, p. 195 n. 14.
} 
ação. Para isso, seria necessário 'torná-lo parte de si mesmo'. Em relação ao acrático, isso significa ter o domínio efetivo do que lhe falta em seu caráter moral, isto é, a virtude moral e a capacidade executiva da prudência (phrónesis) na ação moral.

Desde ENVI.8, Aristóteles já havia notado que os jovens podem até se tornar geômetras (com relação ao conhecimento da geometria) mas dificilmente são classificados de phrónimos:

A causa (aítion) é que a prudência (he phrónesis) diz respeito não só aos universais mas também aos particulares (...) os objetos matemáticos existem por abstração, enquanto os de outras matérias provém da experiência; (...) os jovens não tem convicção (ou pisteúousin) sobre estes últimos, mas apenas usam a linguagem apropriada (légousin), ao passo que a essência dos objetos da matemática lhe é bastante clara. (1142a12-19)

O problema fundamental do jovem aprendiz não concerne seu conhecimento teórico mas à falta de domínio prático do conhecimento. A partir disso, podemos esclarecer melhor a primeira tese da posse sem o exercício do conhecimento no domínio prático da ação. O jovem aprendiz adquire o conhecimento matemático dos universais por via da abstração intelectual, mas outros saberes derivados da experiência (empeiría) de particulares, como a sabedoria (sophía) e ciência natural (physiké), estão fora de seu alcance cognitivo no campo prático. Da mesma forma, os jovens compõem proposições (lógos) teóricas mas são incapazes de adquirir a crença (pístis) do conhecimento relativo a sua aplicação nas circunstâncias particulares. O conhecimento moral da 'prudência' abrange tanto os fatos universais quanto os fatos particulares da experiência. Desse modo, a prudência moral esclarece o conhecimento moral que está ausente dos jovens aprendizes, a experiência dos fatos particulares da vida ética.

A ausência da phrónesis nos jovens manifesta de forma singular a desarmonia entre a razão prática e as paixões irracionais imaturas. Ao longo de ENVI, Aristóteles reitera que a prudência depende da formação prévia da "boa (spoudaía) prohaíresis" com a harmonia absoluta "tanto da razão verdadeira quanto do desejo correto (tòn te lógon alethê kaì tèn órexin orthén)" (ENVI 1139a20-25). Ao contrário do homem prudente, o jovem claramente se aproxima do conflito interno do acrático. De um lado, o comportamento do jovem tende a seguir os prazeres excessivos, que podem se tornar fortes e violentos ao ponto de "expelirem 
o princípio racional (tòn logismòn ekkroúousin)" (1119b3-13). De outro lado, o impulso imaturo das paixões irracionais do jovem o impede de apreciar apropriadamente o valor do conhecimento moral, tal como o acrático (1095a1-13). Por isso, o conhecimento de nada serve sem a educação moral das paixões e desejos que promove a formação do caráter moral. A imaturidade das paixões irracionais revela o conhecimento moral que falta aos jovens e embriagados a despeito de sua suposta falha cognitiva relativa ao raciocínio prático.

A analogia com o jovem aprendiz esclarece o tipo de falha moral que inviabiliza o exercício do conhecimento. Como assinala Charles (2011), a dificuldade do aprendiz em adquirir a crença no conhecimento auxilia a esclarecer a falha moral do estado passional do embriagado ${ }^{418}$. Ambos detêm o conhecimento em certo sentido, pois podem expressá-lo na 'linguagem apropriada', embora careçam da disposição (héxis) necessária para exercê-lo no contexto particular adequado. Ao aprendiz iniciante, falta-lhe a experiência imprescindível para o exercício de seu conhecimento nas ocasiões adequadas. Supostamente, suas afirmações de conhecimento não passam de suposições ou hipóteses baseadas em uma autoridade científica sem configurar uma convicção (pístis) sustentada no conhecimento científico. Ao homem embriagado, não lhe falta a experiência mas sim o amadurecimento de suas paixões irracionais que acompanha o aprendizado do conhecimento moral. Com efeito, Aristóteles ressalta que os jovens imaturos compartilham da condição dos embriagados sujeitos ao impulso excitável (melancholikós) ou a um desejo violento (1154b6-15). O comportamento moral do embriagado claramente remonta ao caráter moral do acrático impulsivo (propéteia), que não chega a concluir o raciocínio prático devido à fortes paixões irracionais contrárias. Em última instância, os casos relatados indicam que a falta de convicção racional do acrático corresponde a uma falha inerente do caráter moral.

A falha do caráter moral de que sofre o acrático não consiste estritamente em uma incapacidade da ação moral. Ao longo da Ética, Aristóteles reitera sucessivamente os traços de caráter típicos do acrático sem mencionar qualquer falha cognitiva: a) o conflito interno moral específico entre a razão e os apetites; b)

\footnotetext{
${ }^{418}$ Cf. CHARLES, 2011, p. 196: 'It is not that his [weak akratic] fails belief is fine properly held, and securely grounded, simply failling to guide his action or control his desires. Rather, his failure of belief is an essential element in his being akratic. Indeed, Aristotle appears to see it as a basic ingredient of why akrasia occurs." (itálicos do autor) Ver também, Idem, 2009, 49-52.
} 
o erro moral contra a prohaíresis correta em vista do conhecimento do bem; c) o vício moral voluntário da akrasia. Ao menos, as propostas (1) e (3) de descrição da akrasia apenas reiteram esses traços fundamentais do vício moral da akrasia.

Em especial, a análise dos casos análogos se mantém consistente com os traços típicos do vício moral acrático. De acordo com esse quadro geral, a akrasia não consiste em nenhum tipo de ignorância relativa a uma simples falha cognitiva do raciocínio prático. Ao contrário, a akrasia consiste em um erro moral derivado do conflito preferencial entre a razão correta e os maus apetites do prazer imediato. No entanto, a controversa doutrina do 'silogismo prático' inaugura uma aparente incongruência com as outras propostas (2) e (4) de descrição do fenômeno. Além disso, essa investigação é ainda mais fundamental visto que a proposta (4) fornece a explicação physikos, a descrição definitiva da akrasia. A partir disso, devemos nos concentrar em seguida sobre a controvérsia do 'silogismo prático' e da akrasia.

\subsection{0 \\ O ‘silogismo prático’ e a explicação physikôs da akrasia}

A descrição decisiva da akrasia depende especialmente da controversa teoria do 'silogismo prático'. Dentro da estrutura de ENVII.3, o silogismo prático é aplicado em duas propostas diferentes de descrição da akrasia: em um primeiro momento, o silogismo prático explica a ignorância temporária da premissa particular do acrático na proposta (2); em seguida, a teoria do silogismo prático integra enfim a proposta (4) da explicação physikos da akrasia.

Entretanto, uma linha interpretativa 'intelectualista' ou 'cognitivista' alega que a solução decisiva de Aristóteles é essencialmente a mesma da tese socrática da ignorância. Para tal vertente interpretativa, a descrição decisiva da akrasia sustenta que o acrático sofre um tipo de 'falha cognitiva' do exercício do raciocínio prático. Nesses termos, a 'solução' decisiva de Aristóteles não levaria em conta a reiterada constatação da Ética de que o acrático não sofre de 'ignorância' do raciocínio prático, mas apenas de uma falha moral inerente às suas paixões irracionais. Para evitarmos esse resultado indesejável, precisamos compreender o que constitui a natureza do 'silogismo prático'. 
A expressão técnica do 'silogismo prático’ não aparece em lugar algum da Ética ou de outros textos aristotélicos. Na Ética, mais precisamente, Aristóteles ao menos chega a se referir mais diretamente "aos silogismos a respeito de ações (syllogismoì tôn praktôn archèn)" (1144a30-32). Apesar disso, a expressão 'silogismo prático' tem sido convenientemente aplicada à doutrina esboçada em diversas passagens da Ética, do De Anima e, principalmente, de De Motu Animalum $^{419}$. Independentemente de suas diferentes formulações, o seu papel é fundamental na descrição decisiva da possibilidade da akrasia em ENVII.3. Como veremos, a estrutura do silogismo prático essencialmente reflete a estrutura básica do silogismo teórico. Em vista disso, devemos nos concentrar primeiro sobre a analogia mais fundamental entre o raciocínio teórico e o raciocínio prático de ENVI.2.

Em ENVI.2, Aristóteles estabelece os parâmetros do raciocínio prático com base no modelo do raciocínio teórico:

O que a afirmação e a negação (katáphasis kaì apóphasis) são no pensamento (en dianoíai), buscar e evitar (dióxis kaì phugé) são no desejo (en oréxei); de modo que, sendo a virtude moral um estado de caráter relacionado com o propósito (héxis prohairetiké), e sendo o propósito um desejo deliberado (órexis bouleutiké), então, é preciso que tanto o raciocínio seja verdadeiro (tòn lógon alethê) quanto o desejo correto (tèn órexin orthén) (...) e que o segundo deve buscar (diókein) as mesmas coisas que o primeiro afirma (phánai). (1139a21-27)

Os parâmetros da analogia estabelecem uma clara relação entre o conhecimento teórico e a ação moral. No âmbito do conhecimento teórico, a afirmação e a negação consistem na proposição pensada em referência a um estado de coisas da realidade, em correspondência a seu valor de verdade. No raciocínio teórico, a proposição é verdadeira quando corresponde a um estado de coisas da realidade e a proposição é falsa quando não corresponde ao estado de coisas da realidade. $\mathrm{Na}$ esfera da ação moral, o buscar e o evitar operam sob princípios semelhantes com o desejo (órexis) e as proposições teóricas. Todavia, não se trata

\footnotetext{
${ }^{419}$ Dentro da Ética a Nicômaco, o 'silogismo prático' jamais se constitui como uma doutrina abordada de forma destacada de outros interesses teóricos de Aristóteles. O 'silogismo prático' tem ampla aplicação para explicar a possibilidade da akrasia em ENVII.3, mas também é mencionado em certas ocasiões pontuais de ENVI. Em De Anima III.11, Aristóteles novamente se refere ao silogismo prático com o propósito de compreender o conflito interno do acrático. Apenas em De Motu Animalum encontramos algo que poderia ser mais próximo de uma 'doutrina' do silogismo prático.
} 
apenas da verdade ou da falsidade em relação as proposições teóricas, mas principalmente do desejo correto ou incorreto em vista do bem e do mal da prohaíresis correta na ação moral. Em DA III.7, Aristóteles elabora uma analogia similar com base na relação da sensação (aísthesis) e a proposição teórica assertiva: “quando é prazeroso ou doloroso (hedù è luperón), como o afirmado ou negado, isso é perseguido ou evitado (diókei è pheúgei)." (431a8-17). A partir dessa nova analogia, a sensação de prazer e dor também proporciona a formação do juízo de valor fundamental acerca do bem e do mal na esfera da ação moral (Cf. DA III 433a28-30). De qualquer forma, a coordenação intrínseca entre a razão e o desejo surgem como elementos complementares dentro da estrutura do raciocínio prático.

Nessa medida, Aristóteles pretende ressaltar tanto as similaridades quanto as diferenças da analogia com o raciocínio teórico. De um lado, as diferenças são demarcadas em cada esfera de atuação: o conhecimento científico visa apenas distinguir as proposições teóricas verdadeiras das falsas, enquanto o conhecimento prático concerne não apenas o "raciocínio verdadeiro (lógon alethêe)" como também o “desejo correto (órexin orthén)”. De outro lado, há similaridades notáveis que se verificam no processo do raciocínio teórico e o raciocínio prático. Ambos exibem a mesma estrutura lógica dedutiva que resulta em um 'modo de aceitação da proposição'. Na esfera teórica, o raciocínio dedutivo implica na admissão necessária da conclusão verdadeira ou falsa das premissas teóricas. Na esfera prática, o raciocínio dedutivo implica na admissão necessária da conclusão prática do bem ou do mal na ação moral ${ }^{420}$. Dentro desses parâmetros, Aristóteles constrói os princípios do 'silogismo' prático' com base nos princípios do silogismo teórico.

Antes de ENVII.3, Aristóteles já havia salientado as similaridades entre o raciocínio teórico e o raciocínio prático em ENVI. Em linhas gerais, a estrutura do silogismo teórico contém três componentes básicos: a premissa universal (tô kathólou), as premissas particulares (kath' hékasta) e uma conclusão (sympérasma). A partir dessa estrutura básica, Aristóteles delimita seu objeto de estudo, o tipo de conhecimento e o produto final do silogismo teórico ao longo de ENVI. Em primeiro lugar, o silogismo teórico não concerne objetos contingentes que "podem ser de outra forma" mas objetos imutáveis que "são por necessidade (ex anánkes)". Em segundo lugar, a formulação do silogismo teórico "procede dos universais (ek tôn

${ }^{420}$ Para essa interpretação central do 'modo de aceitação da proposição' na analogia entre o raciocínio teórico e prático, ver CHARLES, 1984, p. 84-89. 
kathólou)", isto é, dos "primeiros princípios (archaî)" conhecidos diretamente por “indução (epagogé)" (1139b20-35). Com isso, o raciocínio teórico segue das premissas necessárias para a conclusão necessária em um procedimento de dedução lógica. Por fim, o resultado final do silogismo teórico consiste em uma "qualidade demonstrativa (héxis apodeitiké)" necessária acerca da veracidade do "conhecimento científico (espitéme)". Em última instância, o silogismo teórico chega a "uma crença de um certo modo (pos pisteúei)" calcada na derivação da conclusão verdadeira a partir de premissas verdadeiras (1139b17-24). Com base nessas características essenciais do silogismo teórico, Aristóteles esboça a estrutura básica de seu silogismo prático posteriormente.

A analogia entre o silogismo teórico e o silogismo prático é apresentada em ENVII.3. Como vimos, as premissas universais estão relacionadas aos primeiros princípios enquanto as premissas particulares estão vinculadas aos objetos particulares do silogismo teórico. Na razão prática, as premissas universais estão vinculadas ao agente e as premissas particulares são predicadas das coisas particulares no silogismo prático (1147a1-10). Enquanto no silogismo teórico se deve afirmar a conclusão por necessidade, o silogismo prático implica diretamente em uma $a c ̧ \tilde{a} o$ :

\begin{abstract}
Uma das opiniões é universal (he kathólou dóxa), a outra concerne aos particulares (perì tôn kath'hékastá), e aqui nos deparamos com algo que pertence à esfera da sensação (aísthesis kuría). Quando das duas opiniões resulta uma só, num caso a alma necessariamente afirma o que é concluído (anánke tò symperanthèn), nas premissas produtivas (en tâ̂s poietikâ̂s $)^{421}$ ela age imediatamente (práttein euthús) (1147a25-30)
\end{abstract}

Nessa passagem, Aristóteles define a estrutura lógica do silogismo prático a partir da estrutura original do silogismo teórico. Em primeiro lugar, a estrutura do silogismo prático igualmente procede das premissas à conclusão. Se o silogismo teórico implica a dedução lógica da conclusão necessária a partir das premissas, o

\footnotetext{
${ }^{421}$ A edição clássica do original grego de John Burnet opta pela expressão corrente taîs praktikaîs mas um número crescente de comentadores prefere adotar a expressão taîs poetikaîs em uma edição alternativa do texto (cf. GAUTHIER \& JOLIF, 2002, p. 610). Dentro da esfera prática da filosofia aristotélica, o campo produtivo (poietikós) da ação claramente engloba o campo prático (praktikós) da ação moral na filosofia aristotélica sem qualquer incompatibilidade entre os dois campos de atuação (cf. PRICE, 2000, p. 221-222; BOSTOCK, 2000, p. 128 n.18). Como veremos a seguir, Aristóteles adota o mesmo uso de taîs poeitikaîs para explicar as ações humanas sob um amplo sentido em De motu 7. Ver também ENVI.2 1139a35-b4.
} 
silogismo prático apresenta um resultado similar da conjunção das premissas à conclusão prática. Em segundo lugar, as premissas produtivas (taîs poetikaîs) também envolvem a verdade ou falsidade da opinião (dóxa) das proposições práticas, mas se dirigem sobretudo à própria realização da ação moral. De certa forma, as 'premissas produtivas' tem ampla aplicação na esfera prática da ação humana em geral, desde a ação moral até em aplicações mais técnicas. Em todo caso, o campo de atuação prática das premissas produtivas ultrapassa o campo próprio da opinião verdadeira ou falsa.

Anteriormente, Aristóteles já havia salientado que o propósito (prohaíresis) da ação moral não coincide com a opinião: "a opinião se distingue em verdade e falsidade (tôi pseudî kaì alethê̂), não em boa ou má (tôi kakôi kaì agahtôi); o propósito sobretudo por essas últimas.” (1111b32-35). De fato, a opinião está voltada sobretudo com ‘o que já está estabelecido' ou a 'afirmação proposicional' (phásis) (1142b12-15), ao passo que a ação moral se orienta pelo propósito do que é bom ou mau. A opinião (dóxa) expressa o conteúdo proposicional das premissas particulares ou da conclusão do silogismo prático. Todavia, isso nos traz ao elemento singular do silogismo prático, a implicação lógica entre a conclusão do silogismo prático e a realização da ação moral.

Diante da analogia com o silogismo teórico, a ação moral parece ser um resultado lógico necessário do silogismo prático. De acordo com Aristóteles, a ação se segue conforme a conclusão prática de forma "simultânea (háma)" e "necessária (anánke)", "caso esteja em seu poder e não seja impedido (tôn dynámenon kaì mè koluómenon)" (1147a26-30). Diante dessas condições da ação, a correlação lógica entre o silogismo prático e a ação tem sido colocada sob suspeita.

A doutrina do 'silogismo prático' deu origem à uma extensa polêmica interpretativa. A princípio, a polêmica emerge da tradução disputada do termo prótasis que, originalmente, oscila entre 'premissa' ou 'proposição' de um raciocínio lógico. Com base nessas indicações textuais, a doutrina do 'silogismo prático' dá origem à duas linhas interpretativas divergentes: a) para a primeira corrente do silogismo prático forte, o termo 'prótasis' significa propriamente 'premissa' e a conclusão prática é a própria ação ${ }^{422}$; b) para uma segunda corrente

\footnotetext{
${ }^{422}$ A corrente do silogismo prático forte abrange uma grande corrente interpretativa tradicional,
} especialmente os autores que adotam a tradução de prótasis por 'premissa' (cf. NUSSBAUM, 1978, 
do silogismo prático moderado, a conclusão prática é uma 'proposição' e não uma ação propriamente dita ${ }^{423}$. A primeira corrente é a mais influente na interpretação mais literal e costumeira da passagem, inclusive dentro da recepção analítica do silogismo prático. Enquanto isso, a segunda corrente não recebe a mesma adesão dos intérpretes aristotélicos, porém tem mostrado cada vez mais coerência com a teoria da virtude moral e o poder da phrónesis na Ética. Por enquanto, devemos apenas assumir provisoriamente a segunda hipótese mais aberta de 'proposição' diante da analogia com o silogismo teórico sem nos comprometer ainda com a disputa de tradução do termo. A partir disso, podemos compreender o modelo do silogismo prático eficiente dentro das condições ideias da ação moral voluntária.

Para efeitos de esclarecimentos, podemos contextualizar o silogismo prático com base no caso anterior do homem diabético. Em condições ideais, um diabético pode exibir a seguinte estrutura lógica em seu silogismo prático: 1) a premissa universal - 'doces não devem (dê̂) ser provados' e 'eu sou um homem' relacionado ao próprio agente; 2) a premissa particular - 'isto é um doce' derivada da esfera da sensação (aísthesis) relacionada ao objeto particular; 3) a conclusão - 'eu devo evitar esse doce' que resulta em uma ação simultânea e necessária conforme a inferência do silogismo prático (1147a1-10; 25-30). Ora, esse caso ideal não reflete o processo do raciocínio prático da akrasia de ENVII.3.

Antes de prosseguirmos propriamente ao caso acrático, precisamos compreender a natureza do silogismo prático. Ora, o que se quer dizer com a condição 'caso esteja em seu poder e não seja impedido'? Seriam esses impedimentos, obstáculos externos (físicos) ou internos (fisiológicos/psicológicos)? Diante do caso da akrasia, o silogismo prático ineficiente do acrático não esboça diretamente nenhuma solução para essas lacunas interpretativas em ENVII.3. A princípio, a breve aplicação do silogismo prático ao conflito interno do acrático em De Anima III 11 também não oferece nenhuma resolução satisfatória do problema ${ }^{424}$. Com efeito, uma exposição mais detalhada

cap. 4; PRICE, 2006, p. 218-226; BOSTOCK, 2000, p. 140-141). Em larga medida, a tradição analítica segue a mesma linha interpretativa.

${ }^{423}$ Para a defesa dessa interpretação minoritária ver CHARLES, 1984, p. 84-96; Idem, 2009, p. 5257. De fato, essa corrente adota a tradução diferenciada de prótasis por proposição sendo mais consistente com a doutrina da virtude moral e da prudência (phrónesis) na Ética.

${ }^{424}$ A respeito das discrepâncias da teoria do silogismo prático presente em de De Motu, DA 11 e ENVII.3, Nussbaum (1978, p. 202-203) ressalta: "It is particularly important to note (as few commentators have) that neither of these passages suggests the rule-case model as a general theory, which will cover every practical case. Unlike the $M A$ model, which is explicitly claimed to offer a 
da natureza do silogismo prático só surge com a investigação geral da origem do movimento animal em De Motu Animalum.

Em De Motu Animalum 7, Aristóteles recorre ao silogismo prático com o objetivo de desvendar a origem (arché) do movimento animal em geral (700b10). O exame tem início na análise da ação do ser vivo mais complexo, o homem, para depois prosseguir ao movimento de outros animais mais simples. Novamente, a analogia com o silogismo teórico é crucial para compreender a natureza do raciocínio prático humano. Em vista da analogia, Aristóteles ressalta mais uma vez o resultado final do silogismo prático: "a conclusão das duas premissas gera a ação (tò sumpérasma gínetai he práxis)" (701a10-12). Ao longo de De Motu 7, a mesma fórmula surge reiteradamente, isto é, a ‘conclusão é a ação' ou a ‘conclusão gera a ação'. De um lado, o texto parece sugerir, por vezes, que a conclusão é a própria ação. De outro lado, o texto parece sugerir que a conclusão 'se torna' a ação, isto é, a ação é o resultado da conclusão prática ${ }^{425}$. De qualquer maneira, Aristóteles em momento algum sustenta uma tese forte de identidade ontológica entre a 'conclusão' e a 'ação'. Para todos os efeitos, a 'conclusão' é efetivamente uma proposição final que implica na ação, mas não é a própria ação. Além disso, a ação claramente segue a conclusão final diante de certas condições ideais de ação: "caso nada lhe impeça ou compele (àn mé ti kolúei è anankázei)" (701a15-16). Nesses termos, Aristóteles aplica a doutrina do silogismo prático a uma variedade de exemplos práticos da ação envolvidos no sucesso ou no fracasso da ação.

O texto de De Motu 7 apresenta diversos tipos de silogismo prático adequados aos mais diversos contextos da ação humana. De início, Aristóteles aborda duas categorias de silogismos práticos tipicamente humanos que geram a ação, os "silogismos do bem e do possível (dià te toû agathoû kaì dià toû dynatoû)" (701a20-30). De um lado, há silogismos possíveis que orientam ações cotidianas: (1) 'todo homem deve caminhar'; (2) 'eu sou um homem'; e, portanto, (3) 'eu

\footnotetext{
general explanation of motion towards a goal, this theory is introduced only in the context of explaining akrasia, and no wider relevance is claimed for it.". Para Nussbaum (Ibid., p. 205-206), a explicação geral do movimento animal de De Motu enfatiza a formação de silogismos práticos compostos a partir da aplicação de um modelo 'regra geral-caso' específico' que apresenta certas incompatibilidades com o silogismo dedutivo clássico. Em última instancia, o silogismo prático seria uma doutrina aplicável aos desejos e objetivos fundamentais do agente humano ou animal. ${ }^{425}$ Como salienta Charles (1984, p. 91-92), Aristóteles parece sublinhar a fórmula 'a conclusão é uma ação' em diversas passagens (cf. 70a11-13; 701a8-25, 701a4-16,33), mas em outras ocasiões ele parece admitir uma fórmula mais branda assumindo que 'a conclusão antecede a ação' (701a1321). Sobre o modo de aceitação do silogismo, ver CHARLES, 1984, p. 87.
} 
caminho imediatamente'. De outro lado, há silogismos do bem que visam à produção de uma casa: (1) 'eu preciso fazer algo bom'; (2) 'uma casa é uma coisa boa', então, (3) 'eu faço uma casa imediatamente'. A princípio, esses exemplos reproduzem o sentido ordinário geral amplo da prudência (phrónesis) na Ética. Em ENVI, a phrónesis ordinária possui um alcance amplo na esfera produtiva (poietiká), desde a produção técnica de objetos até o ramo específico da ação moral (1141b15-20). Por isso, o silogismo prático possui ampla aplicação na esfera prática. Todavia, Aristóteles apresenta também um silogismo simplificado ligado ao apetite.

Após tratar do silogismo prático ordinário, Aristóteles passa a considerar um silogismo peculiar do apetite. A iminência da ação humana dá início ao processo questionador do raciocínio prático "assim como indagamos questões (hósper tôn erónton)" (701a25). O processo humano de indagação de si mesmo promove o raciocínio prático ordinário do agente, isto é, a implicação lógica da conclusão prática a partir das premissas. Em certas ocasiões, no entanto, "o intelecto (he diánoia) não se fixa nem examina a segunda premissa (tèn hetéran prótasin), a mais evidente" levando imediatamente à ação. Nesse caso, o agente nem mesmo reflete se o predicado ‘homem’ é aplicado a si mesmo nas premissas práticas (701a25-27). Para Aristóteles, isso ocorre justamente no silogismo imediato do apetite:

Então, qualquer coisa que fazemos sem raciocínio (mè logisámenoi), nós fazemos rapidamente. Pois quando a criatura está usando efetivamente a sensação (têi asithései) ou a imaginação (têi phantasíai) ou a intuição (tôi nôi) em vista da coisa pela qual age, faz imediatamente o que deseja (euthùs poieî). Pois a atividade do desejo (he tês oréxeos enérgeia) toma o lugar do questionamento ou do pensamento (ant'erotéseos è noéseos). (701a29-33) ${ }^{426}$

Ao contrário dos silogismos anteriores, o silogismo imediato do apetite opera "sem raciocínio (mè logisámenoi)": (1) 'eu preciso beber'; (2) 'isto é uma bebida’; então, (3) 'eu bebo'. Particularmente, é notável que não há qualquer menção aqui à premissa universal do silogismo prático. Desde o início, a premissa inicial 'eu preciso beber' expressa o desejo final da ação do agente ao invés de uma

\footnotetext{
${ }^{426}$ Sigo a tradução inglesa de Nussbaum (1978), com ligeiras adaptações de modo a manter a consistência entre os termos técnicos gregos e o vocabulário em português. Atualmente, não possuímos traduções portuguesas disponíveis do texto original grego de De Motu Animalum.
} 
regra universal. Nessa estrutura lógica, a premissa (1) é fornecida pelo apetite (epithymía), enquanto a premissa (2) é gerada pela atividade de uma das capacidades psicológicas, a aísthesis, a phantasía ou o noûs, que impelem ao movimento imediato. Enfim, o passo (3) é assegurado pela 'atividade do apetite que acata a conclusão final da proposição (701a32-35).

A phantasía e o noûs estão intimamente ligados à esfera da aisthesis em termos psicológicos. De um lado, a phantasía expressa a capacidade da formação seletiva de imagens dos objetos percebidos ao qual relacionamos ao equivalente moderno 'imaginação' ${ }^{427}$. Em DA III.7, a phantasía exerce um papel fundamental na preservação das “imagens e pensamentos na alma (tô̂s en têi psychêi phantásmasin è noémasin)" dos objetos percebidos no raciocínio prático (431b58). De outro lado, o noûs designa a 'intuição' relacionada aos “primeiros princípios (archaî)" do conhecimento teórico ou o conhecimento prático em ENVI. Na esfera teórica, tais princípios são alcançados "sem a razão (ou lógos)" e constituem "os termos primeiros e imutáveis" pressupostos nas demonstrações teóricas. Na esfera prática, a razão intuitiva (noûs) "envolvida no raciocínio prático apreende o fato último e variável, isto é, a premissa menor (tês hetéras protáseos)" (1143a32-b6). O silogismo imediato do apetite indica, assim, que a "atividade do desejo (oréxeos enérgeia)" ligada à aísthesis, phantasía ou nóesis pode substituir o processo ordinário do questionamento ou do intelecto do silogismo prático da razão humana. $\mathrm{Na}$ realidade, o silogismo apetitivo revela um elemento comum animal compartilhado entre o ser humano e outros animais inferiores.

A parte animal do ser humano se expressa particularmente através do silogismo apetitivo imediato. Em De Motu, Aristóteles atribui a "causa (aitías)" da ação animal à operação da oréxis em vista da aísthesis, phantasía ou noûs (701a35). Para Aristóteles, o movimento e a ação animal decorrem das mais diversas fontes de motivações irracionais: "com criaturas que desejam agir é, por vezes, através do apetite (di'epithymían) ou do ímpeto (thymón) ou do querer (boúlesin) que fazem ou atuam." (701a37-b1). A alma animal inferior corresponde à imagem do autômato, uma espécie de marionete cujo movimento é manipulado pelos impulsos

\footnotetext{
${ }^{427}$ Sobre o aspecto seletivo da phantasía ver NUSSBAUM, 1978, cap. 5. De fato, nos referimos a faculdade passiva da 'imaginação' na falta de um termo correspondente mais adequado ao que está sendo designado de phantasía na psicologia aristotélica. Como veremos adiante, Aristóteles estabelece um domínio específico para a phantasía dentro de sua explicação physikôs da akrasia.
} 
de múltiplas cordas (701b1-13). Nesse sentido, a psicologia animal reflete o Modelo Hidráulico das forças motivacionais, isto é, o domínio da motivação mais forte sobre quaisquer outros impulsos humanos mais fracos ${ }^{428}$. Por meio da aísthesis, phantasía ou noûs, os impulsos irracionais provocam alterações de tamanho e de qualidade nas partes do corpo animal que estão ligados à ação (701b15-30).

Na esfera prática da ação, a busca do prazer e a fuga da dor ligada às paixões animais conduzem a ação animal. Para Aristóteles, a ação animal resulta do conflito direto entre os elementos de atividade (tò poietikón) e passividade (tò pathetikón) internos: "a rapidez (tachù) e simultaneidade (háma) resulta do fato de que a atividade e passividade são naturalmente (tèn phýsin) relativos entre si” (702a1520). Diante disso, cada capacidade animal pode, por si mesma, criar seu próprio silogismo prático simplificado em vista do desejo final da ação. O conflito animal das motivações internas resulta na admissão da proposição final da motivação mais forte contra a inclinação de outras motivações mais fracas na ação. Por isso, as motivações irracionais podem efetivamente constituir fatores internos de impedimento da ação humana. De certa forma, o conflito interno da akrasia parece indicar a persistência dos traços animais em nossa natureza humana racional.

O conflito entre razão e apetite coloca em evidência o domínio animal inferior que persiste na natureza humana. Como vimos, a influência das paixões irracionais expõe uma característica fundamental da akrasia na proposta (3) de ENVII.3: "paixões que alteram materialmente a condição do corpo (tò sôma methistâsin)" (1147a15-17). Em De Motu, Aristóteles revela como as sensações e paixões atuam conjuntamente na ação animal imediata. Como certos elementos animais também estão na natureza humana, o silogismo apetitivo humano irrefletido segue os dados sensíveis da phantasía e da aísthesis humana. Ao mesmo tempo, os animais inferiores não compartilham de razão e, portanto, não podem ser acráticos: “eles não possuem juízo universal (ouk échei tôn kathólou hypólepsin), mas apenas imaginação e memória (phantasía kaì mnémen) de particulares." (1147b1-6). Em outras palavras, os animais inferiores não manifestam um conflito entre razão e paixão porque são destituídos de um raciocínio calculativo sofisticado,

\footnotetext{
${ }^{428}$ Segundo Nussbaum (1978, p. 245-247), essa imagem também é compatível com o Modelo Hidráulico da alma presente em Rep. VI. Todavia, deve-se ter cuidado para não se confundir o Modelo Hidráulico com o conflito específico do princípio da força relativa dos desejos. Para Santas (1969, p. 186-188), o princípio da força relativa dos desejos é formulado em termos de um conflito humano entre o juízo valorativo da razão e as motivações irracionais do agente.
} 
seguindo apenas suas capacidades cognitivas limitadas em vista da aísthesis e da phantasia (433b28-30; 434a1-10). Sendo a estrutura psicológica humana mais complexa, o conflito interno da akrasia não pode ser equiparado ao conflito direto das paixões irracionais animais. A akrasia constitui um conflito peculiar entre a parte animal e a parte racional da natureza humana. De certa maneira, o conflito da akrasia é essencial para compreender a natureza do silogismo prático humano.

A analogia do silogismo prático exibe não só as semelhanças como as diferenças do raciocínio teórico. De um lado, a estrutura do silogismo teórico exibe a mesma estrutura lógica do silogismo prático. A analogia revela que uma parte fundamental do silogismo teórico, a implicação lógica necessária entre as premissas e a conclusão, se mantém inalterada no silogismo prático. No entanto, Aristóteles não pretende pressionar a analogia com o raciocínio teórico dedutivo chegando ao ponto de sustentar que a conclusão prática é a própria ação. Nessa medida, defendemos que o silogismo prático resulta na proposição final da conclusão prática e não na ação em si mesma. O silogismo prático impõe claras condições restritivas à ação, como nas expressões condicionais "caso esteja em seu poder e não é impedido", ou também, "caso nada lhe impeça ou compele”. Diante das indicações anteriores, sustentamos que há referências aqui a impedimentos externos e internos da eficácia ação em relação à conclusão prática. Dos impedimentos externos, Aristóteles trata longamente ao definir o campo das "ações compulsórias" durante ENIII.1 (1109b30-1110b15). Dos impedimentos internos, não há uma menção explícita, mas as diversas referências ao conflito das paixões irracionais na Ética mostram como as motivações irracionais podem comprometer a eficácia do silogismo prático na ação ${ }^{429}$. Como veremos adiante, o apetite exercerá um papel decisivo na interferência da eficácia prática da conclusão no homem acrático. Dessa forma, devemos adentrar diretamente na parte mais fundamental da explicação da possibilidade da akrasia, o processo do silogismo prático durante o fenômeno.

O silogismo prático ganha destaque na descrição da akrasia de ENVII.3. Ao contrário das propostas anteriores, as propostas (2) e (4) dependem fundamentalmente do silogismo prático. Sobretudo, a doutrina do silogismo prático marca a transição significativa à investigação final phsysikôs ('natural' ou 'da natureza') da proposta (4) (Cf. 1147a26; 1147b7). Em termos aristotélicos, o exame

${ }^{429}$ Sobre a interferência do apetite na ação moral após a conclusão do silogismo prático, ver 1147a 15-20; 11147a-35-b1; 1119b10-15; De Motu 702a15-20; De Anima 434a10-16. 
physikôs natural do fenômeno se dirige à "causa" (tèn aitían) de forma mais precisa e detalhada do que o exame logikôs anterior voltado aos princípios gerais e imprecisos das propostas anteriores (1)-(3 $)^{430}$. Na esfera physikôs, Aristóteles claramente chama atenção aos princípios básicos de sua psicologia moral integrando as propostas anteriores na resolução defnitiva do problema da akrasia.

Nessa perspectiva, há significativas diferenças entre a proposta (2) e a proposta definitiva (4). De um lado, o silogismo prático da proposta (2) é mais simplificado do que o silogismo complexo da explicação physikôs da akrasia. Por vezes, cada proposta parece introduzir uma forma diferente de akrasia, abordando a ignorância temporária do agente sob uma ótica diferente. Como veremos, as diferenças ficarão mais claras à medida que contextualizarmos a passagem de acordo com os dois tipos de akrasia mencionados anteriormente, a akrasia impulsiva e a akrasia fraca. Nessa medida, pretendemos mostrar como as propostas anteriores (1) e (3) contribuem para explicar o tipo de ignorância do agente acrático. Dessa forma, analisaremos a seguir a forma simplificada do silogismo prático da proposta (2).

Na proposta (2), Aristóteles considera a akrasia como um tipo de ignorância temporária da premissa particular. É necessário esclarecer em que sentido é possível ter o conhecimento e, mesmo assim, não exercê-lo na ação. Nessa ocasião, Aristóteles defende a seguinte tese: "nada impede que um homem haja contrariando o seu conhecimento embora possua (échonta) ambas as premissas, desde que utilize (chrómenon) apenas a universal, porém não a particular." (1146b35-1147a3). Nesses termos a ignorância temporária do agente diz respeito à falta de exercício da premissa particular relevante.

Para analisar tal proposta, devemos adaptar o caso anterior do diabético a um caso de akrasia. Retomemos, então, o 'silogismo impeditivo' do caso anterior adaptando-o à proposta (2) de possibilidade do fenômeno (1147a1-10): (1) premissa universal - 'doces não são benéficos a todos os homens' ${ }^{431}$; (2) premissas

\footnotetext{
${ }^{430}$ De acordo com Gatuhier \& Jolif (2002, p. 609-610), o termo physikos traça uma clara diferença com relação as propostas antecedentes (1)-(3): "L'emploi du terme physikôs en tête de ce quatriéme argument implique à la fois que les solutions precedentes ont fait appel à des príncipes trop généraux et eloingnés du sujet, et que c'est maintenat soulement qu'on va examiner em lui-même le mécanisme de l'incontinence."

${ }^{431} \mathrm{Na}$ realidade, Aristóteles usa literalmente a premissa universal "comidas secas beneficiam (symphérei) todos os homens". Dessa forma, tivemos de adaptar o exemplo do diabético levando em conta a formulação específica da premissa universal. Em última instância, buscamos preservar a
} 
particulares - ‘eu sou um homem’ e 'isto é um doce'; (3) conclusão - 'eu não devo comer este doce'. Com base nos "modos de saber (toùs trópous eidénai)", Aristóteles afirma que "não ter (ouk échei) ou não atualizar (ouk energê̂)" a premissa particular seria compreensível, mas em relação à premissa universal seria estranho (1147a6-10). A princípio, a premissa particular ausente parece se referir a uma das premissas (2), especificamente 'isto é um doce'. De fato, essa tem sido a interpretação tradicional da passagem ${ }^{432}$. Entretanto, devemos salientar algumas dificuldades à interpretação tradicional.

A princípio, a proposta (2) da ignorância da premissa particular parece incorrer em uma forma de ignorância involuntária. Sendo assim, devemos retomar aqui a distinção da ação 'por ignorância' (di'ágnoian) e do 'estado de ignorância' (agnooûnta) de ENIIII (1110b25-30). Como vimos, a ignorância dos fatos particulares é realizada 'por ignorância', isto é, a ignorância do agente representa a causa eficiente da ação (1110b25-32). Há diversos fatores particulares sujeitos a serem ignorados: o ato, o modo, o instrumento, o objeto da ação ou o objetivo final. Nessas circunstâncias, a ignorância expressa uma ação involuntária. Por sua vez, a ignorância da prohaíresis ou do universal expressa o 'estado de ignorância', ou seja, o agente é censurável pelo resultado da ação (1110b25-32). O acrático negligencia de forma temporária os valores morais fundamentais e comete erros morais repreensíveis. Nessas condições, a ignorância constitui uma ação voluntária. Apesar do caráter acrático se enquadrar no segundo tipo de ignorância, a ignorância da premissa particular 'isto é um doce' ligaria a akrasia à ignorância involuntária ${ }^{433}$.

Diante dessa objeção, a ignorância temporária da premissa particular seria involuntária. Nesses termos, a akrasia seria uma ação involuntária da qual o agente não pode ser censurado ou reprovado moralmente. Certamente, o acrático não pode sofrer da ignorância temporária da premissa particular 'isto é um doce', visto que isso constituiria ignorância dos fatos particulares, ou seja, uma ação involuntária. Na verdade, a ignorância temporária da premissa particular parece atingir outro tipo

forma original do 'silogismo do bem' que será particularmente fundamental na explicação physikôs da akrasia subsequente.

${ }^{432}$ Cf. GAUTIHIER \& JOLIF, 2002, p. 606; SANTAS, 1969, p. 184-185; PRICE, 1995, p. 129130; Idem, 2009, p. 220-221; KENNY, 1966, p. 172-173; ANSCOMBE, 1981, p. 72.

${ }^{433}$ Em certo, sentido, a interpretação tradicional da proposta (2) facilmente a aproxima de uma forma comum de ignorância. Por conta disso, diversos intérpretes costumam descartá-la integralmente em favor da proposta definitiva (4). Para uma objeção similar sobre a distinção entre os aspectos contingentes e os aspectos essenciais da akrasia, ver BROADIE, 1991, p. 297. 
de exerício de premissa particular que manteria a ação voluntária do agente. De fato, Aristóteles indica reiteredamente que os acráticos, tal como bêbados e intemperantes, são responsáveis por seus atos morais voluntários.

De acordo com a proposta (3), a ignorância temporária seria efeito da influência do apetite. Os exemplos análogos do bêbado, dos adormecidos ou loucos implicam um estado passageiro de inconsciência do objeto particular. Por isso, eles se limitam a 'usar a linguagem apropriada' mas não usá-la no sentido relevante, ou seja, sem reconhecer a premissa particular ligada à ação. Em todo caso, tal ignorância inconsciente incorre em um tipo de falha cognitiva da premissa particular no momento da ação. Novamente, a tese (2) parece reincidir em uma forma de ignorância pautada no desconhecimento da premissa particular.

Para todos os efeitos, a ignorância cognitiva da premissa particular 'isto é um doce' não parece favorecer a proposta (2). Dessa forma, precisamos investigar de forma mais detalhada a proposta (2) a fim de encontrar um parâmetro de leitura mais viável ao caráter moral do homem acrático. Ora, se analisarmos com mais atenção a proposta (2) veremos que Aristóteles não se refere à premissa da forma 'isto é $x$ ', mas a um outro tipo de premissa particular "isto é tal e tal (tò toiónde)" (1147a5-6). Diante disso, não temos mais uma premissa vinculada à mera apreensão cognitiva do objeto particular, mas sim uma premissa estreitamente ligada ao objeto particular qualificado pelo princípio universal. Nesses termos, uma nova proposta interpretativa tem sido sugerida a fim de permitir uma coerência integral com o resto do silogismo prático ${ }^{434}$. Ao invés da premissa 'isto é um doce', a premissa ignorada teria a forma intermediária: "este doce não é benéfico a mim". De fato, essa leitura é preferível pois evita recair na ignorância dos fatos particulares.

Dentro dessa linha interpretativa, o agente tem plena consciência dos fatos particulares embora não conceba a premissa particular relevante na ação. Tendo em vista a proposta (1), podemos compreender melhor o que torna o conhecimento ineficaz. Seguindo o silogismo anterior, podemos sugerir que o raciocínio do agente perpassa todos os passos fundamentais do silogismo até a premissa 'este doce não é benéfico à mim'. De fato, o agente pode ter plena consciência da gravidade de sua

\footnotetext{
${ }^{434}$ Cf. GOTTLIEB, 2009, p. 211: “A função explanatória do temo médio no silogismo prático é exercida pela parte da premissa menor que se refere ao agente. (...) A parte da premissa menor que se refere ao agente não apenas permite mover-se das premissas para a conclusão, mas também explica por que o agente age da maneira como ele age." Ver também CHARLES, 2009, p. 46-49; BOSTOCK, 2000, p. 128-129.
} 
diabetes, dos efeitos nocivos dos doces, da necessidade de emagrecer ou dos conselhos médicos. No entanto, há um problema fundamental: o agente não relaciona seu conhecimento universal à sua ação particular tal como possui mas não exerce o conhecimento da premissa relevante. Mesmo o silogismo prático não fica completo, pois isso implicaria a presença da conclusão que culmina na ação, isto é, 'eu não devo comer este doce’ ou "evite isso! (pheúgein toûto)" (1147a33-b3). Nesses termos, o agente sofre claramente de ignorância temporária do exercício da premissa particular relevante. Com efeito, há uma ignorância absoluta da conclusão do silogismo prático. Em todo caso, a explicação physikôs definitiva contempla um outro tipo de caso de akrasia.

A explicação definitiva (4) marca a transição da investigação logikos anteriores à proposta physikos. Como vimos, a explicação physikos pretende fornecer a causa natural (aitía) da akrasia assimilando as propostas anteriores. Durante a proposta (4), acompanhamos o processo do raciocínio prático da akrasia dessa vez a partir de dois silogismos paralelos ${ }^{435}$ : o silogismo do bem e o silogismo de prazer. Dessa forma, Aristóteles expressa seu argumento principal nos seguintes termos:

\begin{abstract}
quando sucede estar presente o apetite (epithymía enoûsa), uma das opiniões nos diz 'evite isso!', mas o apetite noz conduz (epithymía ágei) para ele (...); e sucede, assim, que um homem age de maneira acrática sob a influência (em certo sentido) de uma razão e de uma opinião (hypò lógou pos kaì dóxes) que não é contrária em si mesma, porém apenas acidentalmente, à reta razão (tôi orthôi lógoi) (pois o apetite lhe é contrário (epithymía enantía), mas não a opinião (ouch he dóxa). (1147a33-b2)
\end{abstract}

De acordo com o argumento, a akrasia ocorre quando o agente segue o silogismo do prazer contra o bom silogismo. Segundo Aristóteles, a opinião (doxa) relativa ao silogismo de prazer fica em ato quando o apetite nos leva a fazer a ação acrática. Diante da "presença do apetite (epithymía enoûsa)" e a "atualização (energê̂)" da premissa particular comum 'isto é um doce', o agente realiza a ação

\footnotetext{
${ }^{435}$ Dentre os intérpretes consultados, apenas Kenny (1966, p. 180) defende expressamente que há apenas um silogismo em curso na explicação definitiva (4) (na mesma linha, ver também PRICE, 2009 , p. 222-224). Como observaremos a seguir, a explicação do raciocínio do silogismo prático da proposta (4) difere substancialmente da proposta (2) de tal modo que a reconstrução artificial de um único silogismo entra em conflito com o que é sugerido no próprio texto. Com efeito, a interpretação tradicional opta por manter dois silogismos paralelos de modo a dar conta da estrutura do raciocínio prático pela explicação physikôs da akrasia.
} 
ligada ao silogismo de prazer (1147a30-1147b). Como a premissa particular pertence à esfera da "sensação (aísthesis)" sob a influência do apetite, recomendase consultar os 'estudiosos da natureza' (physiológos) para determinar a ineficácia do bom silogismo no momento da ação (1147a25-30). Nessa ocasião, Aristóteles afirma que o agente não possui ou não atualiza a protasis final (teleutaía prótasis), expressão controversa da protasis. Novamente, devemos aplicar o argumento ao caso anterior do diabético acrático a fim de esclarecer o que está ocorrendo aqui na proposta definitiva (4).

A explicação physikôs atribui dois silogismos paralelos à akrasia, o bom silogismo e o silogismo de prazer. Além do silogismo impeditivo anterior, podemos imaginar também o diabético realizando o seguinte silogismo de prazer: (1) universal - 'todas as coisas doces são prazerosas aos homens'; (2) particulares 'isto é um doce' e 'este doce é prazeroso’; 3) (suposta) conclusão - 'eu como esse doce imediatamente'. Embora Aristóteles não se refira à conclusão do silogismo de prazer, podemos reconstruí-la à luz do silogismo apetitivo de De Motu. De todo modo, fica claro aqui que ambos os silogismos levam aparentemente à conclusões não só opostas como também contraditórias, que culminam em ações contrárias e incompatíveis. Em face disso, devemos nos atentar à controvérsia do silogismo prático e a explicação definitiva da akrasia.

Ao longo de ENVII.3, Aristóteles se refere à forma invariável da akrasia absoluta (haplôs). Nesse estágio, ainda não temos a distinção posterior dos tipos de akrasia, a akrasia impulsiva e akrasia fraca. No entanto, Aristóteles antecipa tal distinção ao se referir à duas categorias diferentes de acráticos: enquanto um tipo "não possui [a protasis final (teleutaía prótasis)] em estado de paixão (en tôi páthei)", o outro a possui mas apenas no sentido de "falar como o bêbado que declama os versos de Empédocles" (1147b9-12). Seguindo as indicações anteriores dos tipos de akrasia, poderemos classificar os casos de akrasia de acordo com a conclusão prática do silogismo.

Em ambos os casos, é necessário determinar se o agente não possui ou não exerce a 'proposição' conclusiva do silogismo prático. $\mathrm{O}$ acrático impulsivo não possui a conclusão do silogismo em absoluto enquanto o acrático fraco a possui, mas não a exerce na ação. De um lado, a akrasia impulsiva claramente condiz com a proposta (2), o caso do agente que segue todos os passos do silogismo prático e, no entanto, não ativa a premissa fundamental no contexto da ação. Nesse caso, a 
paixão forte impede a própria derivação da conclusão prática. No entanto, o caso da akrasia fraca é mais complexo, já que o agente possui a conclusão, mas não a exerce na ação. A explicação physikôs seria dirigida justamente a explicar como ocorre a ignorância temporária da conclusão do silogismo prático diante de uma paixão fraca. De qualquer modo, o desafio central perpassa a controversa tradução da 'última prótasis' e a própria natureza do silogismo prático.

Em última análise, o sentido da ignorância envolve a controvérsia interpretativa da expressão a 'protasis final' (teleutaía prótasis), ou o "último termo (tòn héchaston hóron)", supostamente inativo durante a ação (1147b13). De forma literal, o termo 'prótasis' significa simplesmente 'o que é colocado à frente', se referindo primordialmente às 'premissas', mas também admitindo a tradução 'proposição' nos contextos lógicos apropriados ${ }^{436}$. No entanto, a expressão específica 'teleutaía prótasis' parece indicar que há algo além das 'premissas' na explicação physikôs da akrasia. Como indicamos anteriormente, a tradução do termo prótasis envolve a extensa polêmica interpretativa em torno da doutrina do silogismo prático.

No caso do silogismo prático, alguns preferem traduzir o termo prótasis por 'premissa', outros por 'proposição'. Independentemente da disputa de tradução, o que está em jogo é fundamentalmente o problema interpretativo da explicação physikôs da akrasia. Afinal, estaria a teleutaía prótasis se referindo à premissa particular final ou à própria conclusão final do bom silogismo, ou seja, o que é efetivamente deixado inoperante, a premissa ou a conclusão do silogismo prático? No centro dessa controvérsia interpretativa está o significado real da explicação physikôs do fenômeno.

Tendo em vista essa longa controvérsia, a tese aristotélica da possibilidade da akrasia tem sido colocada em xeque. O problema central reside na interpretação adequada do silogismo prático da akrasia em um sentido cognitivo ou em um sentido motivacional.

\footnotetext{
${ }^{436}$ Cf. LIDDEL-SCOTT, 1996. De fato, 'prótasis' se refere no sentido primordial às 'premissas' do silogismo prático tanto em ENVII.3 como em De Motu 7 ou De Anima 11. Apesar disso, o termo prótasis também admite ser traduzido como proposição em referência ao conjunto do argumento constituído por todo o silogismo.
} 
Para a primeira corrente interpretativa designada 'cognitivista'437, o fenômeno deve consistir no bloqueio da 'premissa' do bom silogismo. Como observamos, essa corrente adere ao silogismo prático forte, isto é, o princípio de que a conclusão é a ação ou a conclusão resulta necessariamente na ação. Nesse sentido, o erro acrático seria um tipo de falha cognitiva, seja pela consideração, percepção ou crença racional da 'premissa relevante'. Essa linha interpretativa é particularmente predominante desde Tomás de Aquino tendo influenciado, inclusive, a recepção da akrasia antiga na filosofia analítica contemporânea ${ }^{438}$. No entanto, uma leitura interpretativa alternativa se destaca cada vez mais no cenário dos estudos sobre a akrasia na Ética a Nicômaco.

De acordo com a segunda corrente interpretativa classificada de motivacional, o bloqueio do bom silogismo ocorre efetivamente na 'conclusão' do bom silogismo ${ }^{439}$. Como salientamos, essa corrente adere a uma doutrina moderada do silogismo prático, ou seja, de que a conclusão é apenas a proposição final do silogismo prático e não está vinculada, necessariamente, à ação. Nesse sentido, o erro acrático seria um erro preferencial do desejo, em face do conflito entre a razão correta e a presença do desejo irracional do prazer imediato. Na sequência, devemos verificar qual das duas propostas interpretativas representa adequadamente o termo prótasis e a solução final da akrasia em ENVII.3.

A tradução de prótasis por 'premissa' torna a explicação definitiva da akrasia inerentemente problemática. Para visualizarmos isso, devemos recorrer ao exemplo anterior da 'inatividade' à premissa particular e o bloqueio do bom

\footnotetext{
${ }^{437}$ Para essa interpretação cognitivista, ver BROADIE, 1991, p. 298-303; CHARLTON, 1988, p. 46-49; PRICE, 1995, p. 129-135; Idem, 2009, p. 218-226; ROBINSON, 2010, p. 76-77; IRWIN, 2008, p. 39-40; SANTAS, 1969, p. 181-184; Para a assimilação dessa interpretação cognitivista na tradição analítica ver DAVIDSON, 2001b, p. 32-33; Idem, 2001a, p. 16; Idem, 2004a, p. 175-176; HARE, 1992, p. 110-111 (De fato, Hare segue a mesma interpretação defendida por Robinson). Dentro dessa corrente, Santas (1969, p. 183-184) adota a tradução 'proposição', embora sua interpretação se incline mais à primeira corrente interpretativa. Em última instância, Santas acredita que as inferências práticas são modelos explicativos da ação teleológica do agente.

${ }^{438}$ Com efeito, Charles $(2009$, p. 42$)$ relata que essa disputa interpretativa já ocorria desde os tempos medievais. Sobretudo, a leitura cognitivista de que o acrático não tem consciência da boa conclusão prevaleceu especialmente na reinterpretação da akrasia antiga com Tomás de Aquino enquanto a tese de que o acrático tem ciência do bom silogismo defendida por Walter Burley caiu em esquecimento.

${ }^{439}$ Para essa corrente cognitiva-motivacional, ver CHARLES, 1984, cap. 3; Idem, 2007, p. 201-205; Idem, 2009, p. 52-66; Idem, 2011, p. 200-206; KENNY, 1966, p. 181-182; DAHL, 2009, p. 506510; ZINGANO, 2009, p. 117-132; BRICKHOUSE \& SMITH, 2010, p. 227-228; PICKAVÉ \& WHITING, 2008, p. 360-363. De fato, Kenny (1966) é o único que adota a tradução 'premissa', mas defende, ao mesmo tempo, que a falha acrática advém da motivação irracional do apetite e não de uma falha no interior do próprio silogismo prático.
} 
silogismo. Como salientamos, devemos rejeitar a ignorância da premissa 'isto é um doce', que tornaria sua ação involuntária. Dessa forma, podemos sugerir então que a 'premissa final' seria a 'premissa relevante' do bom silogismo, 'este doce não é benéfico a mim'.

Durante a akrasia, podemos dizer que o diabético acrático não contempla ou não usa a premissa 'este doce não é benéfico a mim' do bom silogismo. No entanto, ele reconhece, simultaneamente, a premissa, 'este doce é prazeroso' do silogismo de prazer devido à influência do apetite ${ }^{440}$. O agente possui, mas não exerce apropriadamente a premissa relevante do bom silogismo a ponto de resultar na conclusão correta ou verdadeira do bom silogismo. Invariavelmente, se a conclusão correta estivesse sendo derivada das premissas, a ação correta decorreria por necessidade lógica. Nessa perspectiva, o acrático fraco não exerce o conhecimento da conclusão prática e o acrático impulsivo nem mesmo possui a conclusão prática. Por conta disso, Aristóteles alegaria que isso seria devido uma falha cognitiva no processo do silogismo prático.

A interpretação tradicional cognitivista costuma enxergar uma falha na proposta definitiva da akrasia. De fato, as limitações da visão cognitiva se refletem nas críticas dirigidas ao suposto intelectualismo de Aristóteles. Por causa da forte conexão implícita entre o estado cognitivo e a ação do agente, essa linha interpretativa assume que o silogismo prático necessariamente implica na ação. Qualquer erro na realização da ação deve envolver um erro cognitivo ou a obscuridade do raciocínio prático do agente. Nessa perspectiva, a akrasia consiste na tese de que a ignorância temporária do agente é um tipo de falha cognitiva promovida pelos apetites irracionais. Essa corrente cognitivista não só marcou a interpretação tradicional da akrasia como também foi decisiva na recepção analítica contemporânea de ENVII.3.

Dentro da corrente cognitivista, David Bostock (2000, p. 134-135) sintetiza o problema central do suposto intelectualismo de Aristóteles:

The explanation that Aristotle offers is that the desire on the one side defeats the reasoning on the other, by preventing it from coming fully to the agent's consciousness. This explanation, however, is wholly unconvincing. It would be better to say that

\footnotetext{
${ }^{440} \mathrm{Cf}$. ROBINSON, 2010, p. 70: "a premissa particular pertencente à premissa universal correta não é a mesma que aquela pertencente à premissa universal errada, pois a última premissa particular é atual na alma do acrático.”
} 
desire on the one side defeats desire on the other, but the reasoning is in each case quite unaffected. (itálicos do autor)

A objeção central de Bostock se dirige à suposta 'ignorância' da premissa relevante do silogismo prático. Para Bostock, há uma inconsistência inerente à explicação definitiva da akrasia. Se há ignorância de qualquer uma das premissas, o caso do acrático fica totalmente inconvincente. A princípio, o agente pode refletir plausivelmente tanto nas premissas 'isto é um doce' ou 'este doce não é benéfico a mim' como também na conclusão 'não devo comer isto" ${ }^{441}$. De acordo com Bostock (Ibid., p. 134), é necessário admitir que o bloqueio do bom silogismo depende de alguma forma de inconsciência do agente: "for if the reasoning (...) is blocked from consciousness, then of course the agent will not, at the time of acting, be aware of any inner conflict.”. O conflito interno das motivações presente no silogismo prático do bem paralelo não se manifesta explicitamente na akrasia. No máximo, isso explica a akrasia impulsiva mas não a akrasia fraca. Para todos os efeitos, o conflito interno entre razão e apetite desaparece da explicação definitiva da possibilidade do fenômeno.

A ausência do conflito interno da alma na possibilidade da akrasia é claramente incompatível com a teoria da virtude moral da Ética. Como observamos, o caráter moral acrático, bem como seu oposto o caráter encrático, depende da existência do conflito interno entre razão e paixão. Supor que Aristóteles simplesmente teria ignorado esse dado indispensável do caráter moral (reiterado frequentemente na Ética), seria simplesmente abrir mão dos princípios básicos da psicologia moral. Do ponto de vista da psicologia moral, o conflito interno da razão e a paixão irracional é crucial na divisão da parte racional e a parte irracional da alma (1102b10-1103a5). A própria existência do caráter acrático manifesta a necessidade de uma educação moral diferenciada do conhecimento racional estrito (1095a1-13). Em última análise, a proposta (3) dos casos análogos à akrasia representa um desafio à leitura cognitivista.

O estado dos casos análogos da akrasia, dificilmente recai em uma mera falha cognitiva. Ao invés disso, os exemplos mencionados exibem domínio aceitável da linguagem do conhecimento no nível teórico, mas não conseguem

\footnotetext{
${ }^{441}$ De fato, esse tipo de objeção do intelectualismo de Aristóteles tem sido explorada de forma similar por diversos autores da corrente cognitivista, ver CHARLTON, 1988, p. 44-50; ROBINSON, 2010, p. 73-77; PRICE, 1995, p. 129-135; Idem, 2009, p. 224-225.
} 
exercê-lo no campo da ação prática (1147a20-25). No caso dos jovens estudantes, a sua inexperiência de vida não lhes permite aplicar o conhecimento moral de forma adequada na ação por conta das paixões irracionais excessivas. No caso dos embriagados ou sonâmbulos, há conhecimento e experiência, mas lhe faltam a disposição (héxis) para seu exercício na ação. Nenhum dos casos acima reflete qualquer falha no raciocínio prático, seja em um tipo de autoengano ou cegueira intelectual de parte do bom silogismo, ou mesmo na obscuridade de algum estágio do bom silogismo devido à sensação ${ }^{442}$.

Em última instância, a redução à falha cognitiva oblitera a divisão fundamental entre a akrasia impulsiva e akrasia fraca. O bloqueio do bom silogismo pode explicar porque o agente não reflete apropriadamente na premissa particular no primeiro caso, mas deixa o segundo caso inexplicável pois a condição do acrático fraco exige plena consciência do raciocínio prático completo. A akrasia fraca percorre todas as etapas do silogismo prático até a conclusão e, mesmo assim, não resulta na ação correta. Não há mais uma estrita falha cognitiva, mas uma falha prática na ação moral.

Ao longo da Ética, a falha do acrático jamais é vinculada a um problema no raciocínio prático em si mesmo. Particularmente, o erro deliberativo está dissociado da akrasia (cf. 1141b15-20; 1141a20-23). Em ENVI, Aristóteles assinala que o acrático, tal como o homem mal, realiza uma deliberação correta: "alcançam o que propuseram alcançar pelo raciocínio ( $e$ tô̂ logismoû), de modo que terão deliberado corretamente (orthôs), mas colhem um grande mal." (1142b17-22). Além disso, Aristóteles salienta que a akrasia, como a esperteza (tèn deinóteta), diferem pela prohaíresis mas não pelo raciocínio da phrónesis: "[a esperteza e a phrónesis] estão próximos uma da outra em relação ao raciocínio (katà tòn lógon), mas diferem em seu propósito (katà tòn prohaíresin)." (1152a12-15). De fato, a ação do prudente decorre da harmonia da prohaíresis e o raciocínio correto, enquanto o acrático age manifestamente contra o raciocínio e o propósito correto

\footnotetext{
${ }^{442}$ Apesar de se alinhar à corrente cognitivista, Price (2009, p. 225) concede que a ação moral não pode ser reduzida à categorias lógicas: "Não podemos simplesmente apelar para o poder da lógica, uma vez que os relata não são valores de verdade de proposições, mas estados e ações de agentes, e não uma verdade lógica (nem uma verdade como um todo) que esses são sempre lógicos." Como indica ainda Pakaluk (2005, p. 254-255), a explicação final da akrasia não envolve qualquer limitação ou alteração da percepção ou imaginação do agente. Cf. CHARLES, 2007, p. 195-199.
} 
(1111b15-20). Nesse sentido, a segunda corrente interpretativa parece ter mais atenção à natureza da ação moral e sua relação com o silogismo prático na akrasia.

A tradução de prótasis por 'proposição' sugere uma nova forma de compreender a akrasia. Mais do que a 'premissa final' do silogismo prático, o agente também dispõe da 'proposição final' 'que constitui a conclusão final. Seguindo o caso anterior, seria como se o diabético acrático considerasse todas as premissas e a conclusão e, no entanto, deixa de transformar a conclusão 'eu não devo comer este doce' em uma ação no momento de agir. Nesse sentido, o acrático possui a conclusão, mas ela se torna 'inativa' durante a ação, ou seja, não é exercida no domínio prático. Ora, isso parece ser incompatível com um princípio básico do silogismo prático forte, isto é, a conclusão resulta necessariamente na ação. Contra essa linha interpretativa, a segunda corrente alega que a akrasia depende antes da relação fundamental entre razão prática e ação moral do que apenas da operação do silogismo prático em si mesmo.

A segunda corrente instaura uma divisão fundamental entre dois componentes da ação moral, a razão prática e as paixões irracionais. De fato, essa linha interpretativa leva em conta a distinção entre o domínio da virtude moral e o domínio das virtudes intelectuais da razão prática de ENVI. Em ENVI.2, Aristóteles enfatiza a necessidade de integração entre razão e o desejo para a ação moral:

o princípio da ação (práxeos archè) (...) é o propósito (prohaíresis), e a do propósito é o desejo (órexis) e o raciocínio em vista de algo (....) o bem agir (eupraxía) e o seu contrário não podem existir sem uma combinação de pensamento e caráter (áneu dianoías kaì héthous) (1139a31-34)

O paradigma do caráter prudente (phronimos) oferece o equilíbrio fundamental entre a razão correta e o desejo correto, marcado pela posse da prudência (phrónesis). Sem a phrónesis, o acrático possui apenas a razão correta mas exibe maus apetites em seu caráter moral (1152a1-4). Como vimos, a educação moral das paixões irracionais efetivamente precede o desenvolvimento prematuro da razão, desenvolvida após uma longa experiência de vida. Portanto, a hipótese de que o erro acrático está ligado a uma falha cognitiva revela-se incoerente com a doutrina da virtude moral da Ética. A akrasia consiste em um erro preferencial do propósito, o propósito orientado pela reta razão. De fato, a phrónesis ausente do 
acrático não condiz com uma falha do silogismo prático e sim com uma falha do caráter moral relativa à paixão irracional.

Apesar dessas indicações reveladoras, essa hipótese interpretativa corre o risco de estabelecer uma cisão absoluta entre a razão prática e a ação moral. De certa maneira, a hipótese interpretativa de Norman Dahl ilustra bem a natureza dessa incompatibilidade prática. De acordo com Dahl (2009, p. 509) há uma falha de integração do conhecimento com seu caráter moral:

He [the akrates] lacks full and complete practical knowledge of what he should do in that situation, because he has failed to fully integrate that knowledge and the general knowledge on which it is based into his character. As a result, he isn't sufficiently motivated to act on that knowledge in the face of a strong, conflicting motive.

O erro da akrasia consiste apenas na falta do conhecimento prático derivado da phrónesis. De acordo com Dahl (Ibid., p. 508-509), o problema fundamental do acrático não se trata de qualquer conhecimento, mas a falta do 'conhecimento prático completo' que integra os fins da ação ao seu próprio caráter moral. Nessa perspectiva, a conclusão do silogismo prático pode permitir que o acrático reconheça o que precisa fazer e, simultaneamente, sofra a influência de uma força motivacional conflituosa ${ }^{443}$. Nesses termos, a akrasia se transforma em um fenômeno exclusivamente motivacional independente do estado cognitivo do agente. Na realidade, Aristóteles simplesmente assumiria a akrasia tradicional, isto é, a possibilidade da submissão da razão prática aos impulsos irracionais no momento da ação, sem fazer qualquer concessão à tese socrática da ignorância.

A falha motivacional dos impulsos irracionais contempla os casos análogos da proposta (3) mas deixa em aberto justamente todas as outras propostas (1), (2) e (4). Como observamos, o raciocínio prático se fundamenta em uma analogia com o raciocínio teórico (1139a15-b6). Por toda ENVI, Aristóteles reitera a analogia a fim

\footnotetext{
443 Apesar de se referir a 'premissa', Kenny (1966, p. 180) também adota uma interpretação motivacional na mesma linha: "we do, after all, have a full-blooded conflict between reason and desire: the syllogism of reason runs through to its conclusion; but the conclusion is not carried out in action because of the opposition of unreasoning desire. (...) when Aristotle says that the conclusion of a practical syllogism is an action, he need only mean that the conclusion of a practical syllogism must be the description of an action to be done." No entanto, Kenny sustenta que a falha motivacional ocorre devido a um conflito direto entre a razão e a paixão diante de um único silogismo prático. No mesmo espírito, Broadie (1991, p. 297-306) atribui o erro acrático a uma falha motivacional relativa ao 'uso' apropriado do conhecimento.
} 
de evidenciar as similaridades entre o raciocínio teórico e o raciocínio prático. De fato, a mesma analogia é aplicada na descrição dos tipos de falha no exercício do conhecimento nas propostas (1), (2) e (4) da akrasia. Mesmo os casos análogos da proposta (3), são associados posteriormente à falha no ‘exercício' do conhecimento: "nem [o acrático] é como o homem que sabe e contempla (hos ho eidos kaì theorôn), mas como o adormecido e embriagado." (1152a15-16). A akrasia parece consistir em um erro moral que não se reduz à estrita falha cognitiva nem à uma exclusiva falha motivacional, mas algo que compreende ambos os aspectos cognitivomotivacionais da ação moral.

A coordenação entre a razão correta e o desejo irracional é explorada na análise interpretativa aprofundada de David Charles. Apesar de aderir à essa corrente motivacional, sua posição peculiar se afasta da divisão radical da razão e do desejo irracional em dois elementos inteiramente distintos da ação moral. Em Aristotle's Philosophy of Action (1984) e em outros artigos recentes ${ }^{444}$, Charles defende de forma sistemática uma 'terceira via': a relação complementar entre o estado cognitivo e as motivações irracionais do agente. Desse modo, Charles (1984, p. 192-193) traça algumas considerações gerais sobre a explicação final da akrasia dentro de uma teoria moderada do desejo:

\begin{abstract}
Although desire has non-cognitive sources, Aristotle treats it as a mode of accepting a propsition and not as a non-cognitive state completely separate from those which play a role in thinking or reasoning. (...) In his theory it is because desire may have a noncognitive source (...) that clear-eyed acrasia can occur, and because it is a mode of accepting a proposition when one's aims to do what is good that the acratês is irrational in accepting decisively a proposition which is not justified by his reasoning. (itálicos do autor)
\end{abstract}

\footnotetext{
${ }^{444}$ Para a defesa enfática de uma Teoria Moderada do Desejo aplicada a ação moral em Aristóteles, ver CHARLES, 1984, ch. 4, p. 161-194; Idem, 2007, p. 201-213, Idem, 2009, p. 64-66. De acordo com Charles (1984, p. 161-168), a Teoria Moderada do desejo permite explicar a ação humana com base na divisão complementar do juízo valorativo e da força motivacional das paixões. Nesse cenário, a Teoria Moderada do Desejo diverge de outras duas teorias rivais: a Teoria Intelectualista e a Teoria do Desejo Extremo. Em linhas gerais, a primeira teoria reduz a ação a aspectos cognitivos enquanto a teoria extrema atribui a ação humana à força dos desejos motivacionais. Diante desse impasse, Charles (Ibid., p. 167) alega que a Teoria Moderada do Desejo pode dar conta da descrição aristotélica da akrasia: "The failure of knowledge is a failure of pratcial rather than theoretical knowledge; it is the acrates' preferential desire that is flawed, because of the presence of an opposed sense desire, and so he does not want appropriately to do what he judges best."
} 
De acordo com Charles (Ibid., p. 190-194), a descrição aristotélica da akrasia lúcida (clear-eyed acrasia) só é admitida sob a forma de um 'modo de aceitação de uma proposição' racionalmente injustificada pela razão. Nessa perspectiva, não se trata apenas de um erro intelectual da crença enganosa da conclusão do silogismo prático ou de um erro causado diretamente pelas paixões irracionais na ação moral. Para Charles, a explicação definitiva da akrasia representa uma falha específica de raciocínio prático sem constituir apenas uma falha cognitiva da razão (como autoengano, ou uma forma de cegueira intelectual temporária, etc.) ou um erro moral derivado exclusivamente da intervenção do desejo irracional independente das crenças do agente. Em vista da consistência da analogia anterior, é preciso que o raciocínio e o desejo formem um todo integrado na explicação aristotélica da akrasia.

Sob esse ângulo, Charles defende que a descrição aristotélica da akrasia exige um ponto de vista psicológico do desejo irracional. $\mathrm{O}$ fenômeno resulta da interação conflituosa entre o estado cognitivo e a condição motivacional do agente. Por sua vez, o erro moral do agente representa um erro preferencial do desejo, fruto da incompatibilidade entre a avaliação racional do bem e a atração imediata por um objeto de desejo prazeroso ${ }^{445}$. Nessa perspectiva, isso nos permite compreender o tipo de conflito interno do acrático: a falha específica de integração da razão correta com as paixões irracionais inapropriadas na ação moral. $\mathrm{O}$ exame da possibilidade da akrasia evoca reiteradamente a analogia central entre o raciocínio teórico e o raciocínio prático apresentada desde ENVI.

De certa maneira, as indicações do raciocínio prático de ENVI já evidenciam que o tipo de falha do raciocínio prático que acomete o homem acrático. O problema do acrático não reside efetivamente em seu silogismo prático, mas no domínio prático ligado ao campo perceptivo dos apetites. Ao seguirmos o caso analógico dos jovens aprendizes, poderíamos dizer que a imaturidade no aprendizado do conhecimento teórico seria equivalente à imaturidade dos desejos irracionais sem a educação moral necessária. Em última instância, a condição do acrático fica mais

\footnotetext{
${ }^{445}$ Cf. Idem, 2007, p. 202-203: "the weak akrates does not see correctly the best thing to do, but her failure registers that she is not properly attracted by the goodness of the action she sets herself to do. As such, her fault can be described either as a fault in desire or in grasp of the relevant conclusion. If there is something amiss with her perception of what is best to do, there will therein be a failure in her preferential desire." (itálicos do autor)
} 
clara à medida que notamos a ausência da virtude moral que constitui a base fundamental da prudência (phrónesis).

A ausência da virtude moral manifesta o que falta efetivamente ao acrático. Em ENVII.8, Aristóteles traça uma diferença crucial entre virtude e vício moral que novamente recorre à analogia com o raciocínio teórico:

\begin{abstract}
A virtude e o vício preservam e destroem, respectivamente, o primeiro princípio (tèn archèn), e nas ações o fim proposto é o primeiro princípio, como na matemática são as hipóteses; nem naquele caso é a razão (ho lógos) que ensina os primeiros princípios, nem [neste caso] - é a virtude (aretè), seja natural ou moral (physikè è ethistè), que ensina a reta opinião (tôे orthodoxeîn) sobre os primeiros princípios. (11151a15-20)
\end{abstract}

Nessa passagem, o raciocínio prático do caráter moral é comparado ao modelo matemático das hipóteses. As hipóteses (ou axiomas) matemáticas e o fim proposto da ação representam ambos os primeiros princípios (arché) do raciocínio. No caso matemático, os axiomas matemáticos são os primeiros princípios sob os quais não há dedução lógica, mas apenas indução dos fatos particulares, sem raciocínio (lógos) (cf. 1139b25-30). Na ação moral, ocorre um processo similar, porém em sentido inverso: os primeiros princípios da ação são fornecidos pelo caráter moral e não pela razão. No caso da virtude moral, a "reta opinião (orthodoxeîn)" dos primeiros princípios é 'ensinada' através da "virtude moral (aretê)". Ora, em que sentido a virtude 'ensina' a 'reta opinião' dos primeiros princípios sem a contribuição da razão ou da argumentação racional? De fato, a educação moral da virtude se forma antes mesmo da constituição amadurecida da razão humana.

Ao fim de ENVI, Aristóteles realiza uma distinção entre a virtude natural e a virtude moral. As "disposições naturais (hai physikaì héxeis)" da virtude natural já são possuídas antes mesmo do desenvolvimento da virtude moral nas crianças e nos brutos (1144b7-14). Da mesma forma, as habilidades naturais do raciocínio prático são explicadas pela causalidade natural: "como se a causa fosse natural (hos tês phýseos aitías oúses)" (1143b5-10). Em ambos os casos, Aristóteles separa as capacidades naturais, disposições humanas potenciais, das capacidades adquiridas ou habilidades aperfeiçoadas pela experiência e exercício. Nesse sentido, as 
capacidades naturais nos habilitam à virtude moral, mas apenas isso não nos garante o desenvolvimento da virtude moral.

As disposições naturais só promovem a virtude moral sendo acompanhadas da razão. No entanto, essas disposições também podem ser danosas "sem razão (áneu nô̂)"446: "como ocorre a um corpo robusto que se move sem visão cair robustamente” (1144b7-14). A imagem do 'corpo robusto sem visão' reflete a condição das disposições naturais humanas sem a orientação racional. Como observamos, essa condição de desvirtuamento prático da razão se aplica também à diposição do vício moral em face do desenvolvimento dos maus apetites contrários à razão correta. $\mathrm{O}$ desvirtuamento das capacidades naturais humanas em relação à razão correta pode se aplicar, então, à explicação physikôs da akrasia. Ao longo da Ética, há ainda diversas referências à imaturidade das paixões irracionais das crianças e dos jovens.

A imaturidade dos apetites dos jovens e das crianças emerge da ausência da formação do caráter moral. Como salientamos, as crianças e os jovens exibem diversas características que lhes aproximam da natureza animal: 1) eles tendem a seguir seus apetites excessivos de prazer sem se ater à razão (Cf. 1119b3-13; 1104b30-1105a5; 1154b5-20); 2) eles também são carentes da experiência e do exercício prático do ensino moral (1095a5-12); 3) eles realizam ações voluntárias mas não possuem a prohairesis formada e seguem apenas suas paixões irracionais (Cf. 1111a20-32;1111b7-10). A imaturidade infantil das paixões se perpetua tardiamente, por exemplo, nos jovens e no homem intemperante (akólastos) (1119a32-b12). Para Aristóteles, a imaturidade das paixões compromete o exercício da razão prática: “o que vive pela paixão (ho katà páthos zôn) não ouvirá o argumento (ou akoúseie lógou) que o dissuade e, se o ouvir, não compreenderá (oud' sunéie)" (1179b 25-26). Independentemente da idade, a imaturidade das paixões nos mantém mais próximos dos impulsos inferiores do que da razão amadurecida.

Em última análise, o comportamento infantil das paixões é semelhante, de certa forma, ao comportamento animal instintivo. Como vimos anteriormente em De Motu, certas características animais se mantêm na psicologia humana. $\mathrm{O}$

\footnotetext{
${ }^{446}$ Cf. LIDDEL-SCOTT, 1996. O termo noûs geralmente se refere ao termo técnico 'intuição', embora aqui sua referência é o sentido mais geral de 'razão'. Nessa ocasião, Aristóteles não está se referindo ao sentido técnico de noûs, mas a um sentido genérico da razão.
} 
silogismo apetitivo de De Motu nos mostra que o homem pode agir com base na phantasía ou na aísthesis sem raciocínio. De forma semelhante, o acrático segue a phantasía ou a aísthesis, sem reflexão apropriada e sem dar atenção à orientação racional (Cf. 1147b15-18; 1150b25-28). Como veremos adiante, o conhecimento perceptivo da ação moral está para além do conhecimento do silogismo prático.

Ao voltarmos a ENVI, notamos que Aristóteles se preocupa em definir o domínio específico dos primeiros princípios da ação. Em uma passagem crucial de ENVI.8, Aristóteles distingue a phrónesis da intuição (noûs):

Ela [a phrónesis] é oposta, então, à intuição, pois a intuição (ho noûs) tem por objeto os termos (tôn hóron) das quais não há razão (lógos), enquanto a prudência tem por objeto o particular último (toû eschátou), sobre o que não há conhecimento mas sensação (aisthesis) (...). (1142a23-36)

Mesmo sendo controversa, essa passagem indica de que forma podemos compreender a passagem anterior de ENVII.8 (1151a15-20) ${ }^{447}$. Anteriormente, observamos que há uma distinção entre os primeiros princípios teóricos e os primeiros princípios da ação. O noûs estabelece "os termos (tôn hóron)"448 do raciocínio através da indução na "sensação (aísthesis)": 1) os "termos primeiros e imutáveis' no raciocínio teórico; 2) 'termos últimos e variáveis' da "premissa particular (tês hetéras protáseos)" no raciocínio prático (1143b5-10). Na esfera teórica, os 'termos primeiros e imutáveis' são os primeiros princípios teóricos do conhecimento científico. Na esfera prática, os 'termos últimos e variáveis' fornecem apenas os 'termos variáveis' da premissa particular. De fato, os "primeiros princípios da ação (tàs praktikàs archás)" dos fins propostos são definidos pelo desenvolviento do caráter moral antes da razão (1144a33-35). A partir disso, podemos esclarecer então o que distingue o domínio da sensação (aísthesis) próprio da phrónesis do amplo campo perceptivo do noûs.

A phrónesis abrange um domínio do conhecimento perceptual relacionado ao "particular último (tô̂ eschátou)". Ao contrário do noûs, a phrónesis não envolve a indução dos 'termos' das premissas particulares do silogismo prático,

\footnotetext{
${ }^{447}$ Sobre a controvérsia em torno dessa passagem, ver BOSTOCK, 2000, p. 100-102.

${ }^{448} \mathrm{Na}$ Ética, o termo hóros substitui, por vezes, o termo prótasis em referência a 'premissa particular' embora seu significado lógico também esteja ligado aos 'termos' da proposição. Cf. CHARLES, 2009, p. 63 n. 39.
} 
mas a realização com base na percepção dos fatos morais particulares ${ }^{449}$. Além disso, a prudência não é alcançada "sem o auxíio da virtude moral (áneu aretês)" (1144a29). De fato, a prudência é indissociável do desenvolvimento pleno da virtude moral. $\mathrm{O}$ ensino dos primeiros princípios da ação depende da virtude moral que fornece a educação moral prévia das paixões irracionais. Somente com as paixões irracionais educadas e adequadas à razão correta, a prudência pode assegurar a realização da ação moral correta. Ora, o acrático não tem a capacidade de realizar a ação moral correta não só porque não possui a phrónesis, mas principalmente porque carece da virtude moral. Nesse sentido, seu erro moral integra uma contradição prática entre o silogismo pratico completo e suas paixões irracionais imaturas.

$\mathrm{O}$ acrático não sofre qualquer falha ou erro cognitivo pois todo seu silogismo prático se mantém correto. Nem mesmo seu erro moral reside apenas na força relativa de suas paixões irracionais, pois isso não lhe distinguiria do homem intemperante. Diante da ausência fundamental da phrónesis, seu principal erro está na ação moral que depende da harmonia da razão correta e as paixões irracionais. A contradição prática do acrático assegura que a expressão específica da prótasis final (teleutaía prótasis) da akrasia só pode significar a 'proposição final', isto é, a conclusão de todo o silogismo prático.

A expressão da prótasis final do silogismo prático tem causado uma infindável controvérsia sobre a descrição decisiva da akrasia. Notavelmente, a disputa de tradução parece improfícua porque o termo 'prótasis' significa tanto 'premissa' quanto 'proposição' (cf. BOSTOCK, 2000, p. 131-132). Em geral, as ocorrências de prótasis acompanhadas de supérasma nos textos de Ética e De Motu se referem aos respecitvos termos opostos 'premissa' e 'conclusão' do silogismo prático. Todavia, a 'prótasis final' se refere claramente à “opinião sobre um objeto perceptível e também o que determina nossas ações (dóxa te aisthetoû kaì kuría tôn práxeon)" (1147b9-10). Ao longo de ENVII.3, a prótasis significa também a “opinião (dóxa)", o que se aplica em geral à 'proposição', seja em referência às premissas ou a conclusão isoladas, ou seja relativa ao conjunto de todo o silogismo

\footnotetext{
${ }^{449}$ Segundo Bostock (2000, p. 96), a phrónesis difere do noûs justamente na forma como apreende os objetos da sensação: "It shows itself in the ability simply to perceive the morally salient features of particular situations, and consequently to say what action is here and now required, and that is why Aristotle so stress the imporance of perception for practical wisdom." (itálicos do autor)
} 
prático $^{450}$. A expressão 'proposição final' nos permite compreender a falha de caráter moral específica da akrasia fraca.

A condição passional do acrático parece ser esclarecida após seu erro moral. Para explicar o que ocorre após a akrasia, Aristóteles reforça mais uma vez a analogia com o raciocínio teórico levando em conta a disposição (héxis) do agente:

Como a ignorância (he ágnoia) é dissolvida e o homem acrático recupera seu conhecimento é a mesma explicação (ho autòs lógos) que no caso dos homens embriagados e adormecidos e não tem nada de peculiar à esta condição (tô̂ páthous). (1147b6-10)

Após a akrasia, a ignorância temporária desaparece permitindo a retomada do bom juízo pelo agente. De alguma forma, a retomada do conhecimento coincide com a "mesma explicação (ho autòs lógos)" do "estado (páthos)" dos embriagados e adormecidos. Com isso, Aristóteles recomenda "escutar os estudiosos da natureza (physiólogos)" (1147b6-10). Ora, mas em que sentido o acrático recupera seu conhecimento? De que tipo de ignorância temporária o acrático se livra? Estaria Aristóteles se referindo, à akrasia impulsiva ou a akrasia fraca? Para compreender o tipo de ignorância temporária da akrasia, é necessário ter em mente a disposição moral específica do agente.

A explicação physikôs se refere à akrasia absoluta (haplôs) mas cada tipo de akrasia exprime um tipo diferente de ignorância. Em ambos os casos, os apetites exercem um papel fundamental na condição do agente. Como vimos, o acrático impulsivo sofre uma ignorância temporária da premissa relevante por causa de suas paixões excessivas que o impedem de chegar à conclusão do bom silogismo. No entanto, o caso do acrático fraco parece diferente: não há um bloqueio ou um obscurecimento de seu silogismo prático, nem suas paixões fracas atropelam seu raciocínio prático. Para entendermos a 'ignorância' da akrasia fraca, devemos retomar o silogismo paralelo acrático tendo atenção ao conflito interno psicológico que reflete sua disposição moral.

\footnotetext{
${ }^{450}$ Cf. CHARLES, 2009, p. 57: "if the proposition that emerges from two others is the last or final one in a sequence of propositions, we have discrovered a direct contextual route fo fix the reference of the key unique phrase 'the final proposition' (...)." (itálicos do autor). Ver também, Idem, 1984, p. 117-132. Em nossa perspectiva, a tradução de 'proposição' nos permite fazer referência a cada um dos elementos que compõem o silogismo prático e oferece mais hipóteses interpretativas do que a tradução restritiva da 'premissa'. Todavia, reconhecemos que a oposição prótasis e sympérasma se referem respectivamente à 'premissa' e a 'conclusão' do silogismo prático.
} 
O silogismo paralelo do acrático não é uma 'ignorância’ no sentido ordinário ou uma falha cognitiva. Como vimos, há um duplo silogismo simultâneo na akrasia, o bom silogismo e o silogismo de prazer. Ambos os silogismos práticos constituem, respectivamente, respostas à impulsos humanos divergentes: o desejo racional pelo bem e o apetite (epithymía) pelo prazer imediato. Se admitirmos que há akrasia fraca, o agente está plenamente ciente de ambos os silogismos no momento da ação.

A akrasia absoluta ocorre "pela influência de uma razão e opinião (hypò pos lógou kaì dóxes)", sendo essa 'opinião' "contrária não por si mesma mas por acidente (katà symbebekós) (...) à reta razão (tôi orthôi lógoi)" (1147a35-1147b1). A oposição acidental à reta razão coincide com a opinião do silogismo de prazer, mas a oposição por si mesma à reta razão deriva do próprio apetite (epithymía). Ao mencionar a oposição à opinião em geral, Aristóteles estabelece a distinção entre o que é "por si mesmo (kath' autós)" e que é "por acidente (katà symbebokós)": "por acidente" se refere ao que é buscado como um meio no interesse de outra coisa, enquanto "por si mesmo" é buscado como um fim, pela coisa em si mesma (1150a35-1151b1).

Com base nesses princípios, a atitude moral diante da opinião marca o caráter encrático em face do caráter acrático. Nesse sentido, Aristóteles destaca dois tipos de abadono da opinião 'em absoluto' (haplôs) ou 'por si mesmo' e 'por acidente': 'Logo, um sustenta e o outro abandona toda e qualquer opinião; mas em absoluto (haplôs) a opinião verdadeira (têi alethê̂).” (1151b3-4). Portanto, há dois tipos de oposição contra a opinião, uma oposição "por acidente" a qualquer tipo de opinião e uma oposição "por si mesma" a um tipo de opinião. Em sentido absoluto, o acrático abandona a opinião verdadeira e o encrático a preserva. A akrasia absoluta consiste no confonto do apetite irracional à reta opinião "por si mesma", mas pode também constituir uma oposição a qualquer opinião "por acidente" em sentido derivado. Somente o apetite é contrário "por si mesmo" à reta razão. Ao mesmo tempo, a oposição entre os silogismos paralelos do acrático ocorre "por acidente". Na verdade, não há qualquer oposição lógica fundamental entre o bom silogismo e o silogismo de prazer pois ambos coexistem no raciocínio prático do agente. Se há conflito interno no acrático, isso se deve à atividade psicológica dos apetites corporais contra a opinião do bom silogismo.

Em De Anima 11, há uma explicação psicológica da akrasia em linhas similares a ENVII.3. Novamente, Aristóteles estabelece uma conexão entre o 
silogismo prático e o conflito interno da akrasia. De um lado, o silogismo prático (syllogismós) é formado da opinião através das imagens perceptíveis da phantasía. Como vimos, a phantasía perceptiva (aisthetiké) é uma capacidade central ligada ao prazer e a dor. O próprio silogismo prático constitui uma seleção e classificação prévia das impressões sensíveis realizada pelos desejos com base nas necessidades e objetivos práticos do agente ${ }^{451}$. De outro lado, a akrasia exprime um conflito interno entre a boúlesis e a órexis, uma vez que "o desejo (oréxis) não tem capacidade deliberativa (tò bouleutikòn ouk échei)" (434a10-12). Com o conflito interno da alma, a órexis se dirige diretamente à ação humana contra o desejo racional (433b29-31). A parte irracional da órexis e da phantasía do acrático pode conduzir à ação humana independentemente da razão correta.

A psicologia moral é aplicada à estrutura do silogismo prático do acrático. Levando em conta as duas opiniões do acrático, uma das premissas universais e a outra das premissas particulares, Aristóteles indica qual a causa da akrasia: "ou é esta última opinião a que move, e não a universal, ou então são ambas, embora aquela seja mais estática enquanto a outra não."(434a16-22). O conflito da akrasia registra justamente o caso em que a opinião dos particulares move o agente sem o apoio da opinião universal (mais estática). O erro moral da akrasia decorre do movimento da orexis em vista da opinião particular pela phantasía contra a opinião universal do desejo racional pelo bem ${ }^{452}$. Ao que tudo indica, Aristóteles adota uma estratégia semelhante na explicação physikôs da akrasia na Ética.

A explicação physikos da akrasia segue parâmetros similares em sua descrição final do fenômeno em ENVII. Na mesma medida, Aristóteles se refere aqui à 'opinião' "ativa (energê̂)" do silogismo de prazer no campo da "presença (enoûsa)" da epithymía (1147a35). Justamente, é essa opinião (particular) ativada pelo apetite que leva ao erro acrático. Contudo, não há rigorosamente uma oposição

\footnotetext{
${ }^{451}$ Cf. NUSSBAUM, 2009, p. 269: “As considerações de Aristóteles do chamado silogismo prático, igualmente atribuem aos desejos um poder classificador ou discriminador: entre as muitas coisas apresentadas ao agente pelo pensamento ou pela percepção, o desejo selecionará algumas e não outras para serem fundamentadas na ação. Por vezes, esse papel selecionador é desempenhado por um desejo ou "querer" racional; mas as formas apetitivas do desejo, também "falam" informando toda criatura de suas necessidades e respondendo diretamente à presença que satisfará suas necessidades."

${ }^{452}$ Diante de um conflito entre razão e apetite, a orexis será responsável pela ação. Em De Anima III 10, Aristóteles observa que a orexis leva a ação com base no pensamento ou na phantasía: "o que faz mover seria de uma única espécie: a capacidade de desejar (tò orektikón) enquanto tal - e antes de tudo o desejável (tò orektón) que, mesmo não estando em movimento, move por ser pensado ou imaginado (tôi noethênai è phantasthênai)" (433b6-10).
} 
lógica em si mesma entre o bom silogismo e o silogismo de prazer. Só há oposição absoluta entre o bom silogismo (reta razão) e o apetite em si mesmo (1147b1-4). Da mesma forma, Aristóteles jamais menciona o obscurecimento de alguma premissa particular ou etapa do raciocínio prático do bom silogismo. Apenas a opinião particular de prazer permanece ativa, com a 'proposição final' ligada ao 'objeto perceptível' e o ‘domínio da ação' (1147b10-11). Na verdade, a ignorância temporária advém da premissa universal (estática) e não das premissas particulares do bom silogismo. Em especial, a akrasia fraca depende de um conflito integral entre a razão correta e os apetites de prazer.

$\mathrm{O}$ apetite do homem acrático da explicação physikôs exibe as mesmas características do silogismo apetitivo simples de De Motu 7. No entanto, há uma diferença fundamental no acrático, o conflito interno do apetite do prazer imediato contra o bom silogismo (reta razão) do agente. Em especial, a akrasia fraca depende da consciência do bom silogismo e seu conflito consciente com o apetite irracional. $\mathrm{O}$ apetite irracional torna o silogismo de prazer eficaz contra o bom silogismo na ação acrática.

O acrático tem plena consciência de todo o bom silogismo. No entanto, o que o agente consegue enunciar apenas é a proposição descritiva da conclusão do bom silogismo, "evite isso! (phêugein toûto)", sem eficácia prática. Nesses termos, a proposição conclusiva não tem efeito 'prescritivo' na ação, mas apenas efeito 'descritivo', como “o bêbado que declama versos de Empédocles”. Ao contrário dos jovens estudantes, o que falta ao acrático não se trata da crença (pístis) racional, mas a convicção prática nos fatos particulares. Por isso, Aristóteles enfatiza que a verdade prática depende do conhecimento na experiência de vida: "a verdade nas coisas práticas (tò alethès en tôis praktikoîs) é discernida nos fatos da vida (ek tôn érgon toû bíou krínetai), pois estes são o fator decisivo (tò kúrion)" (1179a15-20). Diante disso, o que falta ao acrático é o discernimento prático no domínio dos fatos particulares da ação. Sem esse discernimento prático, o acrático fica à mercê da satisfação imediata do apetite e ignora a orientaçao da razão correta no domínio dos fatos particulares da ação.

Em última instância, o apetite ativo orienta o acrático à phantasia perceptiva das premissas particulares do silogismo de prazer (1150a25-27). Ao mesmo tempo, a opinião universal do bom silogismo fica temporariamente inativa durante a 
realização da ação ${ }^{453}$. A premissa particular comum a ambos os silogismos, "isto é um doce", é um elemento decisivo na contradição prática do agente. Há uma incompatibilidade inerente entre o que é dito segundo a razão correta e a ação moral conforme o silogismo de prazer. A partir disso, podemos elucidar o que efetivamente ocorre no caso do diabético acrático.

A partir disso, podemos enfim descrever o que ocorre efetivamente no caso do diabético acrático na explicação physikôs da akrasia. Segundo a descrição physikôs, o diabético acrático está plenamente consciente de ambos os silogismos durante toda a ação, o bom silogismo e o silogismo de prazer. Por isso, ele expressa conhecimento de que não deveria comer este doce antes, durante e após a akrasia. Mesmo no caso mais simples da akrasia forte, a ignorância temporária do agente não se deve fundamentalmente a ausência da conclusão do bom silogismo, mas a atuação do apetite forte excessivo contra a premissa particular "este doce não é benéfico a mim". Sobretudo, isso fica mais claro quando observamos o caso complexo da akrasia fraca.

No complexo caso da akrasia fraca, o conhecimento do bom silogismo revela sua ineficácia diante do ato acrático de comer este doce no momento da ação. Ora, o que ocorreu então? A presença do apetite leva ao exercício das premissas particulares do silogismo de prazer no domínio da ação, “eu devo comer esse doce prazeroso imediatamente". Na descrição physikôs, a premissa universal do bom silogismo "Doces não devem ser ingeridos" é preservada, mas fica temporariamente inativa, sem eficácia prática, na conclusão prática diretamente envolvida na ação. Invariavelmente, o domínio absoluto da ação é exercido pelo apetite em vista do conhecimento perceptual das premissas particulares do silogismo de prazer. De certa forma, isso só é possível porque o apetite expressa seu próprio silogismo simples no domínio da ação. De fato, o agente pode até mesmo exibir conhecimento da conclusão prática "eu não devo comer isso", mas é incapaz de aplicá-lo efetivamente na ação moral sob domínio do apetite. Nesses termos, o apetite vence a razão correta no campo da ação, ou seja, o apetite submete a razão correta expressa

\footnotetext{
${ }^{453}$ Contra a tendência majoritária, Pickavé \& Whiting (2008, p. 356) defendem que a ignorância da premissa universal é mais consistente com a teoria do mal voluntário do que uma ignorância da premissa particular: "This, we argue, explains why Aristotle focuses on her failure to use or activate some sort of universal knowledge. Since her action must be voluntary, he cannot allow (as he did in the theoretical case) that she fails to use or activate her knowledge of the relevant particular. And since he cannot say that her belief in the relevant universal propositions is corrupted, he concludes that her access to these universal beliefs must be temporarily impeded." (itálicos dos autores)
} 
no propósito (prohaíresis) do bom silogismo. O erro acrático não está na posse do conhecimento (universal) do bem, mas no exercício do conhecimento do bem na ação particular. Por isso, a ignorância temporária do bom silogismo não é uma simples ignorância cognitiva, mas uma ignorância prática da ação.

A ignorância temporária da akrasia no momento da ação não é uma forma de ignorância cognitiva. Em nenhum dos casos de akrasia, a ignorância é efetivamente causada por um efeito ilusório de prazer, um processo inconsciente, ou autoengano relativo ao bom silogismo. Nesses termos, a ignorância temporária de Aristóteles não é compatível com a ignorância socrática. Como vimos, a ignorância socrática expressa um estado de ignorância permanente causado pela ilusão da aparência dos prazeres temporais. Por conta disso, o Sócrates do Protágoras defende a negação da existência da akrasia à medida que representa um fenômeno fundamentalmente cognitivo derivado das crenças ilusórias do prazer aparente. Nessa medida, o fenômeno é classificado como um tipo de ignorância involuntária, ou melhor, a ignorância fundamental do bem real.

Ao contrário, Aristóteles defende que a akrasia consiste em uma ignorância temporária derivada da ineficácia do exercício do bom silogismo e do conflito interno da alma. Com efeito, o agente tem a posse do conhecimento do bom silogismo, mas não o exerce na ação moral devido à influência de suas paixões irracionais imaturas. Em ambos os casos de akrasia, a impulsiva e a fraca, os apetites imaturos têm um papel fundamental no desvio da razão correta. Nesse cenário, a psicologia moral de Aristóteles segue os passos da psicologia tripartite ao reconhecer o papel fundamental do conflito interno moral no fenômeno. Fundamentalmente, o 'estado de ignorância' da akrasia é classificado como uma forma de ignorância voluntária, ou mesmo, um tipo de vício moral voluntário. O acrático é moralmente repreendido por conta da negligência temporária $\mathrm{e}$ consciente do bom silogismo diante do silogismo de prazer. Na verdade, a sua negligência tem origem em suas paixões irracionais e não em um fenômeno de ilusão cognitiva. A ignorância voluntária de Aristóteles é, de certo modo, compatível com o conflito interno da akrasia, enquanto a ignorância socrática nega a própria manifestação do fenômeno.

Em todo caso, Aristóteles parece concordar enfaticamente com Sócrates em uma posição fundamental, o conhecimento moral não é submetido pela paixão da akrasia. Como veremos a seguir, a estranha adesão à 'salvação' socrática do 
conhecimento na passagem final de ENVII.3 é realizada nos termos conceituais aristotélicos.

\subsection{1 \\ A akrasia e a posição de 'Sócrates': a 'salvação' do conhecimento moral}

A descrição da akrasia de Aristóteles apresenta a ignorância temporária da escolha preferencial da ação do agente. A 'ignorância' temporária se reflete em uma falha da escolha preferencial relativa à 'conclusão' do silogismo prático. Por isso, não há qualquer falha cognitiva ou uma inclinação irracional exclusiva do apetite contra o silogismo prático. Mesmo assim, Aristóteles parece aderir francamente à negação socrática do conhecimento-akrasia na passagem final de ENVII.3.

A posição socrática da akrasia perpassa a descrição decisiva do fenômeno em ENVII. Como vimos, o método das endoxa leva Aristóteles francamente a 'salvar' todas as opiniões correntes do fenômeno, entre as quais se inclui a opinião socrática contrária à akrasia tradicional. Em todo caso, a postura de Aristóteles é ambígua perante a posição de 'Sócrates'. Apesar de se contrapor inicialmente à negação socrática da akrasia do Protágoras (1145b23-25), a explicação final physikôs visa preservar o conhecimento moral em favor de 'Sócrates' (1147b1518). Nessa medida, é preciso saber em que medida a descrição da akrasia de Aristóteles realmente pretende seguir a posição socrática.

A posição socrática do Protágoras é inteiramente desfavorável à descrição tradicional da akrasia. Como observamos, a posição socrática do Protágoras sustenta que a descrição tradicional é incorreta pois o fenômeno consiste em um estado de 'ignorância' permanente da ilusão da percepção temporal dos prazeres no campo da aparência. Por sua vez, Sócrates conclui que o conhecimento da virtude não é submetido pelos impulsos irracionais do agente sendo incompatível com o estado de 'ignorância' do agente. Ao fim de ENVII.3, Aristóteles parece francamente inclinado à defesa socrática do conhecimento. Além disso, ele também assume a descrição da akrasia como um tipo de ignorância temporária.

Dentro desse quadro, a corrente cognitivista alega que a descrição aristotélica physikôs da akrasia reproduz em alguma medida a tese socrática da 
'ignorância'. Nessa medida, haveria uma espécie de falha cognitiva no silogismo prático durante o fenômeno tal como a posição socrática do Protágoras. Por mais que a adesão à 'Sócrates' seja uma evidência textual, é bem provável que Aristóteles pretende assumir as teses socráticas 'sob seus próprios termos'. De qualquer forma, temos reiterado constantemente que a 'ignorância' temporária da akrasia não condiz com uma obstrução cognitiva do silogismo prático. Para todos os efeitos, precisamos nos voltar à referência decisiva de ENVII.3 levando em conta o conflito interno da akrasia.

Ao fim de ENVII.3, Aristóteles enfatiza sua concordância com a defesa socrática do conhecimento a partir da explicação physikôs da akrasia:

\begin{abstract}
parece mesmo resultar a posição que Sócrates procurou estabelecer; pois não é na presença (ou paroúses gínetai) ${ }^{454}$ do que é considerado conhecimento propriamente dito (tês kuríos epistémes) que a paixão ocorre (nem é isso que é 'arrastado' pela paixão), mas [na presença do conhecimento] da sensação (tês aisthetikês). (1147b14-19)
\end{abstract}

A adesão à defesa socrática do conhecimento distingue claramente dois domínios do conhecimento moral, "o conhecimento propriamente dito (tês kúrios epistémes)" e o "conhecimento perceptivo (tês aisthetikês)". Como vimos, a 'proposição final' relativa à opinião do objeto sensorial no domínio da ação é oposta ao "termo universal (tôi kathólou)" relativo ao "objeto de conhecimento científico (epistemonikòn)" (1147b10-15). Seguindo as indicações anteriores, o acrático age de acordo com o apetite em vista do conhecimento perceptivo da aísthesis e da phantasía do silogismo de prazer contra à opinião correta do conhecimento do bom silogismo.

A falha do acrático consiste na disposição moral contrária à conclusão' do silogismo prático. No entanto, não há nenhuma observação explícita aqui sobre o domínio do 'conhecimento universal' na ação. Ao contrário, Aristóteles enfatiza

\footnotetext{
${ }^{454}$ Nessa passagem, adotamos a edição do texto grego de Bywater com a expressão grega 'paroúses gínetai', isto é, 'ocorre quando está presente' (cf. CHARLES, 2009, p. 62-63; ROSS, 2009, p. 247; PICKAVE \& WHITING, 2008, p. 367-368). Entretanto, outros intérpretes preferem uma emenda do texto grego (sugerida na edição de Stewart), o termo 'perígignetai', isto é, prevalecer ou submeter (cf. GAUTHIER \& JOLIF, 2002, p. 617; BROADIE, 1991, p. 311, n. 38; ROBINSON, 2007, p. 77). Com efeito, a expressão perígignetai dá um sentido bem diferente à essa sentença: 'não é o que consideramos como conhecimento propriamente dito que é submetido (perígnetai) pela paixão'. Mesmo Bostock (2000, p. 130 n. 21) que adota essa edição revisada do texto grego, reconhece sua 'implausibilidade paleográfica'.
} 
que o "pensamento em si mesmo nada move (diánoia aute outhèn kinê̂)", separando explicitamente, inclusive, o campo do 'conhecimento científico' (epistéme) do campo da prudência (phrónesis) (cf. 1139b35-b1; 1142a23-25). Além disso, Aristóteles apenas estabelece que a paixão ocorre quando "não está na presença (ou paroúses gínetai)” do 'conhecimento propriamente dito'. Desse modo, a referência dessa expressão emblemática não pode ser simplesmente a 'premissa universal' que não exerce domínio efetivo na ação. É preciso haver outra referência à expressão 'kúrios espitémes'. Com efeito, uma crítica anterior de Aristóteles à concepção socrática unitária de ‘conhecimento' fornece uma indicação mais clara.

A concepção socrática do 'conhecimento' é confrontada com a prudência (phrónesis) em ENVI.13. Nessa ocasião, Aristóteles defende que 'Sócrates' estava certo e errado, ao mesmo tempo, a respeito do conhecimento: errado, por um lado, ao defender que todas as virtudes são 'prudência', mas certo, por outro lado, ao sustentar que elas não ocorrem "sem prudência (áneu phronéseos)" (1144b17-20). Na sequência, a crítica de Aristóteles à concepção socrática da virtude é reforçada:

Sócrates, portanto, pensava que as virtudes fossem princípios racionais (lógous) (pois julgava que todas eram ciência (epistémas eînai pásas), enquanto nós pensamos que elas acompanham a razão (metà lógou). (1144b27-29)

Nesse sentido, Aristóteles rejeita claramente a concepção socrática da virtude que reduz todas as virtudes a um único conhecimento racional, mas admite que há uma virtude intelectual, a prudência (phrónesis), que pressupõe a posse da virtude moral em geral. Como vimos, o acrático não apenas não possui a virtude moral como, principalmente, não exibe a prudência. Apesar de suas paixões irracionais imaturas, o acrático ao menos possui a razão correta. Ora, o 'conhecimento propriamente dito' que falta ao acrático não parece ser um 'conhecimento racional' estrito, o principal alvo de sua crítica à posição socrática.

Diante da crítica anterior à 'Sócrates', a referência ao 'conhecimento propriamente dito' definitivamente não se refere ao 'conhecimento universal'. A referência mais provável e coerente com a expressão singular kúrios epistéme seria a prudência (phrónesis) diante de ENVI.13. De forma similar, Aristóteles declara que a "virtude propriamente dita (kuríos areté)" consiste na conexão intrínseca entre a virtude moral e a prudência (1144b16). Como vimos anteriormente, é necessário ter não apenas a disposição "conforme a razão correta (katà tòn orthòn 
lógon)" mas também a "disposição com a razão correta (metà toû orthoû lógou héxis)" (1144b27-29). Nesses termos, a primeira coincide com a virtude moral promovida pela educação moral das paixões irracionais relativa ao prazer e a dor, enquanto a segunda consiste na 'virtude propriamente dita' promovida pela 'prudência'. A virtude moral fornece a disposição moral das paixões conforme a 'razão correta', porém apenas a prudência assegura o exercício efetivo da 'razão correta'. Ao esclarecermos essa diferença, podemos ter mais clareza sobre o que realmente está faltando ao homem acrático.

Para Aristóteles, a virtude moral visa ao propósito (prohaíresis) correto e a prudência ao domínio executivo da ação: "a virtude faz o propósito correto (tên prohaíresin orthèn); mas o que compete fazer (práttesthai) naturalmente em vista dele não compete à virtude, mas à outra capacidade [a phrónesis].” (1144a20-22). A virtude moral determina o "propósito correto (prohaíresin orthèn)" em vista do fim (télos) proposto da ação e a prudência é responsável pela execução dos meios adequados na realização prática do fim (1144a6-9).

Há uma relação intrínseca de dependência entre a prudência e a prohaíresis correta estabelecida antecipadamente no desenvolvimento da virtude moral. Sem a prohaíresis correta, é impossível promover a realização da boa ação pela prudência. Em última instância, o homem que é um "ser propriamente bom (agathòn eînai kuríos)" possui não só a prudência como, principalmente, a virtude moral (144b3032). Ora, o acrático não possui nem a virtude moral e, muito menos, dispõe da phronesis do homem 'propriamente bom'. De fato, as referências à virtude 'propriamente dita' e ao homem bom 'propriamente dito' implicam claramente o caráter 'prudente' (phrónimos) e ao exercício da phrónesis na ação moral. Por conta disso, é plausível admitirmos que o 'conhecimento propriamente dito' ausente do acrático se trata da prudência e não do 'conhecimento universal ${ }^{455}$. Desse modo, o exame da akrasia reflete o exame anterior da phrónesis ao longo de ENVI.

O exame do fenômeno da akrasia reflete o exame anterior da prudência de ENVI.13. Em ambos os contextos, Aristóteles trava uma discussão direta com as posições de 'Sócrates' a fim de definir os parâmetros de seu próprio tipo de

\footnotetext{
${ }^{455}$ Cf. PRICKAVÉ \& WHITING, 2008, p. 368: "the original text makes perfectly good sense: if (as we suggest) Aristotle uses the phrase 'what seems to be episteme in the strict sense' to indicate that he is referring to phronesis and not to what he himself calls episteme proper, then the original text simply states a corollary of the view (defended in $N E 6.13$ ) that one cannot be phronimos without being fully virtuous (....)." (itálicos dos autores)
} 
conhecimento moral. Primeiramente, a crítica dirigida à concepção unitária da virtude visa esclarecer a natureza específica da phrónesis. Assim como em ENVII, há um compromisso na preservação parcial da verdade da opinião reputada de Sócrates com relação à virtude segundo seus próprios termos, isto é, dentro da unidade pressuposta da phrónesis e a virtude moral (1144b35-1145a5). Contra Sócrates, Aristóteles alega que apenas o 'conhecimento racional' em si mesmo não assegura a 'virtude propriamente dita' (1144b20-25). Por isso, a prudência não apenas pressupõe a educação prévia da virtude moral como também assegura a realização da ação moral. Notavelmente, Aristóteles não está preocupado em ser fiel à tese socrática da unidade das virtudes presente em diversos diálogos socráticos, como o Protágoras. Por questão de coerência, a adesão artificial a Sócrates no exame da akrasia também não condiz exatamente com a 'salvação socrática’ do conhecimento moral.

O exame da akrasia leva adiante a reflexão sobre o 'conhecimento propriamente dito' da prudência. Dessa vez, Aristóteles expressa mais simpatia com a visão socrática só que novamente segundo seus próprios parâmetros. De um lado, a akrasia consiste em uma forma de ignorância temporária em oposição à ignorância permanente ilusória de Sócrates. Como vimos, a ignorância permanente da akrasia resulta na negação absoluta da akrasia tradicional enquanto Aristóteles expressamente defende que a akrasia consiste na ignorância voluntária temporária, um vício moral repreensível do agente. De outro lado, o 'conhecimento propriamente dito' incompatível com a akrasia não é nada além da própria phronesis e não a um tipo de conhecimento cognitivo universal.

Com efeito, Aristóteles expressamente distingue o caráter acrático do prudente em termos de atitude moral e não de conhecimento racional: "estão próximos no tocante à razão (katà tòn lógon), mas distinguem quanto ao propósito (katà tèn prohaíresin)" (1152a10-13). De fato, o acrático preserva a razão correta e o "propósito bom (prohaíresis epieikés)" mas age de forma contrária ao seu propósito e razão estando a mercê de suas paixões irracionais imaturas (1152a1517). Como vimos anteriormente, Aristóteles reitera em diversas ocasiões que o conhecimento universal não tem domínio efetivo na ação.

O conhecimento moral da phrónesis constitui uma virtude intelectual executiva da ação moral voltada à percepção dos fatos particulares e não ao conhecimento do universal. Nesses termos, a akrasia é a ignorância fundamental 
da phrónesis, do conhecimento executivo da ação correta, diante da ausência da virtude moral. Para todos os efeitos, Aristóteles não pode estar se referindo ao 'poder' do conhecimento universal sobre a akrasia, como alegava a corrente tradicional cognitivista. Na realidade, essa passagem indica que a diferença crucial da phrónesis em relação a akrasia não está no silogismo prático, mas na capacidade de colocá-lo em prática na ação. A concepção peculiar da phrónesis desvela um abismo que separa o conhecimento moral defendido por Aristóteles do princípio moral universal reivindicado nas teorias morais modernas.

O conhecimento moral da phrónesis, por vezes, causa confusão aos leitores modernos acostumados com as teorias morais modernas do 'dever moral'. Com efeito, esses leitores esperam encontrar um princípio moral absoluto equivalente ao dever moral refletido, por exemplo, na 'premissa universal' do silogismo prático ${ }^{456}$. Sobretudo, o uso de deîn (dever) na formulação da premissa universal leva a crer que a opinião universal teria o valor de um 'dever moral' absoluto (1147a25-30). Nesse caso, a competência moral seria exercida apenas com a dedução lógica da premissa universal moral à conclusão prática aplicada ao caso particular da ação. No entanto, o caso da akrasia frustra essas expectativas da leitura moderna pois o acrático não age de acordo com o bom silogismo. Em contraste, o prudente poderia representar um caso da eficácia do bom silogismo na ação moral. Nesses termos, o conhecimento moral do prudente seria análogo à ação conforme o 'dever moral'.

O reconhecimento do poder efetivo da phrónesis não é compatível com os termos morais modernos. Como vimos em outro capitulo, é fundamental ressaltar que a moralidade grega de forma geral desconhece conceitos morais absolutos que não admitem quaisquer exceções particulares, como as categorias modernas de 'dever', 'correto' ou 'bem absoluto' ${ }^{457}$. Diante disso, também não devemos atribuir

\footnotetext{
${ }^{456}$ Para um exemplo claro de uma leitura que favorece a superioridade da premissa universal, ver BOSTOCK, 2000, p. 139: "he [Aristotle] is (wihtout noticing) accepting a Socratic preconception; the desire for what is good is universal, goes without saying, and need not to be considered; so if anything goes wrong it must be with reasoning." Ver também ROBINSON, 2010, p. 69; BOSTOCK, 2000, p. 138-139; BROADIE, 1991, p. 300-303; GOSLING, 1990, p. 33-34; IRWIN, 2008, p. 3940; PRICE, 2009, p. 226; CHARLES, 2009, p. 62-63.

457 Como vimos, Williams (1993, p. 158-160) atribui a emergência da psicologia ética à tradição filosófica representada por Platão e Aristóteles. No entanto, Williams também concede que a psicologia moral de Aristóteles depende menos das categorias éticas internas do que da psicologia tripartite da República de Platão. Definitivamente Aristóteles não destaca muito espaço em sua psicologia moral ao thymós grego como na psicologia tripartite platônica, embora sua divisão da psicologia moral claramente segue os critérios platônicos de racionalidade e irracionalidade.
} 
esses conceitos à phrónesis ou a outros conceitos morais técnicos presentes na Ética de Aristóteles.

A eficácia distinta da phrónesis é reconhecida por Aristóteles em uma passagem emblemática para a leitura moderna: “esta última [a phronesis] é prescritiva (epitatiké), visto que o seu fim é o que se deve ou não deve fazer (tí dể práttein è mé, tò télos autês estín)" (1143a5-12). Ora, os termos epitatiké e deîn nessa passagem não precisam ser encarados em função de uma teoria do dever moral.

Em primeiro lugar, a capacidade epitatiké deriva do verbo epitásso que significa simplesmente "impor ordens ou comandos em geral" de forma a preservar a autoridade no domínio prático, sem um caráter necessário de universalidade. Sobretudo, é importante notar que as referências de ambos os termos estão relacionadas em sua maior parte ao domínio da phrónesis. ${ }^{458}$

Em segundo lugar, a expressão "o que deve e não se deve fazer (tí dề práttein è)" significa apenas cumprir a ordem ditada pela razão e não um dever moral necessário. Como assinala Kraut (2006), os termos modernos do dever moral não têm espaço na Ética justamente porque a teoria ética aristotélica gira em torno do bem prático, o fim último das atividades humanas e das ações morais ${ }^{459}$. Nessa perspectiva ética, o modelo central da ação moral não é a obediência ao princípio moral universal e sim a excelência das técnicas produtivas, com suas próprias finalidades específicas. Principalmente, o paradigma máximo da ação moral se apoia no exemplo concreto do homem prudente: "a virtude é a disposição do propósito (héxis prohairetiké), (..) delimitada pela razão (lógoi), isto é, como o prudente (ho phrónimos) a delimitaria." (1107a1-5). A prescritividade efetiva da ação moral só é assegurada no raciocínio prático do prudente (phrónimos) ou no homem que age de acordo com sua excelência moral. Como vimos, o prudente reúne dois fatores imprescindíveis para a realização da ação moral: a virtude moral,

\footnotetext{
${ }^{458}$ Cf. 1143b34; 1145a6. É interessante notar que a própria phronesis pode estar sob a autoridade de outros tipos de saberes superiores, como a philosophía. Em De Anima III.9 (433a1-4), no entanto, há uma breve passagem que atribui a "prescrição (epitáttontos)" ao "intelecto (toû nô̂), mas a prescrição prática se torna ineficaz diante dos maus apetites no caso do acrático. De fato, a capacidade prescritiva (epitatiké) da phrónesis tem um lugar especial na psicologia moral de Aristóteles.

${ }^{459} \mathrm{Cf}$. Ibid., p. 180-181: "the reason why the Ethics contains no examination of dein or orthos is that for Aristotle these terms do not designate a single aspect of our lives or a single feature of our actions. (...) One selects some goal that one takes to be good (or one is drawn to it, without ever having decided to seek it), and one draws conclusions about what dei to do —about what one must or ought or should do-in the light of that goal and one's understanding of it."
} 
que promove os apetites corretos, e a phrónesis, a capacidade executiva da ação moral. Na verdade, apenas o silogismo prático do prudente preserva a força prescritiva sobre a ação moral, pois ele dispõe da razão correta e do desejo correto. A partir disso, podemos esclarecer uma controvérsia permanente em torno da natureza do silogismo prático e a akrasia.

O contraste entre a phrónesis e a akrasia revela algo sobre a natureza do próprio silogismo prático. Ao retornamos ao caso da akrasia fraca, observamos que a conclusão do bom silogismo do acrático perde sua força prescritiva no domínio da ação moral. A partir das indicações anteriores, constatamos que isso não se deve ao fato de que o conhecimento 'universal' não é submetido pela paixão, mas pela ausência fundamental da phrónesis. De fato, a phrónesis é uma capacidade 'prescritiva' (epitatiké) que assegura o silogismo prático forte, isto é, que a conclusão das premissas práticas resulta necessariamente na ação moral correta. Nessa medida, a phrónesis envolve o domínio dos fatores morais particulares da ação ao invés da obediência a um princípio moral universal. No entanto, o caso do acrático é diferente justamente porque seu apetite está em conflito com a conclusão do bom silogismo.

A leitura cognitivista, na qual está incluída a tradição analítica, atribui o silogismo forte à doutrina geral do silogismo prático quando o silogismo forte só se aplica ao caso específico do homem prudente. Nesse sentido, a corrente cognitivista elimina o papel das motivações irracionais da relação fundamental entre o silogismo prático e a ação moral. A partir disso, a descrição da akrasia de Aristóteles passa a ser reconhecida como uma falha ou erro cognitivo no silogismo prático, algo ausente das indicações textuais de ENVII.3. Como veremos, a tradição analítica segue os passos dessa interpretação cognitivista da Ética. Particularmente, a fraqueza de vontade contemporânea herda as dificuldades do silogismo prático forte e a abordagem cognitivista da akrasia antiga. 


\section{6. O prescritivismo moral de Hare e a negação da fraqueza de vontade}

\section{1 \\ A recepção analítica da akrasia antiga e a fraqueza de vontade contemporânea}

A akrasia antiga e a fraqueza de vontade contemporânea constituem problemas filosóficos distintos. Notavelmente, a formulação original da fraqueza de vontade contemporânea se ampara na recepção analítica da akrasia antiga. Como observamos, os historiadores desse problema assumem tradicionalmente a continuidade do mesmo problema filosófico da ação contrária ao 'melhor juízo' (better judgement) em ambos os contextos, tanto na filosofia antiga como na filosofia analítica anglo-saxã ${ }^{460}$. Ao contrário, defendemos a descontinuidade essencial de dois problemas filosóficos distintos, o problema da akrasia antiga e o problema da fraqueza de vontade contemporânea.

Como indicado anteriormente, a natureza dos dois fenômenos reflete igualmente dois problemas filosóficos diferentes. De um lado, a akrasia decorre da submissão da razão aos impulsos irracionais enquanto a fraqueza de vontade apenas se refere à ação irracional contra o 'melhor juízo' do agente. De outro lado, os problemas filosóficos também são formulados de forma diferente: a akrasia antiga representa um problema acerca da natureza do conhecimento moral, enquanto a fraqueza de vontade contemporânea inaugura o problema da consistência lógica da razão prática. Invariavelmente, a formulação original da fraqueza de vontade contemporânea retoma, em certo sentido, o debate original da akrasia antiga.

A recepção analítica da akrasia antiga marca a controvérsia inaugural da fraqueza de vontade contemporânea. Dentro da filosofia contemporânea, Richard

\footnotetext{
${ }^{460}$ Sobre a história do problema filosófico da fraqueza de vontade, ver a Introdução da tese. Como mostramos anteriormente, Charlton (1988) e Gosling (1990) reconhecem as diferenças etimológicas entre a akrasia e a fraqueza de vontade mas insistem na ideia de que há apenas um problema filosófico sendo discutido. Ao longo desta Tese de Doutorado, buscamos ressaltar que há duas formulações bem distintas do problema filosófico: a akrasia antiga e o problema do conhecimento moral e a fraqueza de vontade contemporânea e o problema do domínio prático do 'melhor juízo' do agente.
} 
M. Hare e Donald Davidson são reconhecidos como os precursores da formulação original do problema contemporâneo. Em especial, ambos os filósofos apresentam dois paradigmas clássicos da fraqueza de vontade contemporânea, a fraqueza moral ou a 'retração' (backsliding) de Hare e a ação intencional contrária ao juízo de 'todos os fatores considerados' (all things considered) de Davidson. Basicamente, o debate analítico posterior da fraqueza de vontade contemporânea elabora uma resposta às formulações consagradas do fenômeno fornecidas nos textos de Hare e Davidson ${ }^{461}$. Por isso, é imprescindível analisar o impacto da recepção da akrasia antiga na própria constituição original do problema da fraqueza de vontade contemporânea.

Antes disso, porém, é preciso assinalar uma diferença fundamental em relação à akrasia antiga. A existência ou inexistência do fenômeno real é dispensável quando o problema moderno central gira em torno de sua existência interna no agente. A fraqueza de vontade constitui um problema filosófico contemporâneo em face da inconsistência interna das razões do agente. Nesse aspecto, a fraqueza contemporânea adentra o amplo debate analítico do internalismo e o externalismo das razões do agente para a ação.

O debate analítico das razões 'internas' e ‘externas' para a ação envolve a fraqueza de vontade contemporânea. ${ }^{462}$ De um lado, o internalismo da razão prática implica na conexão necessária entre as razões do agente para a ação e a realização concreta da ação. Nessa perspectiva, a sentença ' $A$ tem uma razão para fazer $x$ '

\footnotetext{
${ }^{461}$ No campo da fraqueza de vontade contemporânea, Hare e Davidson são referências fundamentais para se compreender o estatuto do debate analítico atual (ver CHARLTON, 1988, ch. 5-8; GOSLING, 1990, cap. 8-9; MORTIMORE, 1971; STROUD, 2014). Como ressaltamos, ambos os filósofos apresentam paradigmas filosóficos clássicos do problema filosófico contemporâneo, a fraqueza moral e a ação contrária ao juízo de 'todos os fatores considerados'. No prescritivismo moral de Hare, o problema da fraqueza se constitui como um problema moral. Por sua vez, Davidson exime o fenômeno das considerações morais tratando da incompatibilidade lógica entre a ação irracional e o 'melhor juízo' do agente. De fato, outros filósofos, como Alfred Mele e David Pears, elaboraram críticas e respostas a esses paradigmas da fraqueza de vontade. Infelizmente, não teremos a oportunidade de abordar com maior profundidade o debate analítico posterior. De qualquer forma, o foco da minha investigação recai sobre a recepção da akrasia antiga na formulação original da fraqueza de vontade contemporânea.

${ }^{462}$ Sobre o debate analítico em torno do internalismo e o externalismo, ver HARE, 1999, cap. 8; WILLIAMS, 1982, cap. 8; CALLARD, 2013, p. 32. Desde o início, o debate analítico do internalismo e externalismo emergiu no campo mais restrito da filosofia moral moderna. Nessa esfera, a preocupação central do internalismo moral era assegurar que a ação moral necessariamente reflete as razões morais internas do agente. Todavia, a discussão analítica posterior se abriu a um campo mais amplo envolvendo a razão prática e a filosofia da ação intencional. Como veremos depois, a filosofia da ação de Davidson se refere apenas ao 'internalismo' da razão prática. Dessa forma, seu parâmetro da 'racionalidade' ou 'irracionalidade' prática sempre dizem respeito às crenças e desejos internos do agente.
} 
significa dizer que o agente $A$ possui uma motivação para agir que será satisfeita caso a ação $x$ seja realizada. A realização da ação $x$ reflete os objetivos, crenças e desejos do agente expressos na descrição proposicional de suas razões internas. De outro lado, o externalismo da razão prática diz respeito à presença de razões externas às crenças e desejos internos do agente. Dessa forma, a sentença ' $A$ tem uma razão para fazer $x$ ' reflete fatores externos independentes das razões internas do agente que levam a realização de $x$. Por isso, a existência das razões externas implica a negação da conexão necessária entre as razões internas e a realização concreta da ação. Dentro desse debate analítico, a fraqueza de vontade apenas constitui um problema autêntico na perspectiva do internalismo da razão prática.

A fraqueza de vontade representa um desafio central ao 'internalismo' da razão prática. A princípio, a existência do fenômeno indica que as razões do agente para a ação $x$ não são suficientes para a realização concreta da ação $x$. A fraqueza de vontade inviabiliza a conexão necessária das razões práticas do agente e sua ação intencional. Nessa esfera, a existência do fenômeno representa um problema ao internalismo de Hare e Davidson. No prescritivismo moral de Hare, a fraqueza moral representa um desafio à conexão interna necessária do juízo moral do agente e a ação moral. Para Davidson, a fraqueza de vontade coloca em xeque a conexão necessária das razões do agente e sua ação intencional. Dentro dessa perspectiva da filosofia analítica, o problema contemporâneo é inaugurado inevitavelmente nos termos lógicos de um fenômeno interno irracional da razão prática.

A formulação original analítica do problema da fraqueza de vontade surge de formas mais contundente nas obras de Hare e Davidson. Em um primeiro momento, Hare introduz o problema no campo da ética e da psicologia moral. Ao longo de suas principais obras, o prescritivismo moral de Hare leva à negação absoluta da fraqueza moral. Nesse aspecto, o conflito prático genuíno característico do fenômeno é reduzido ao mero conflito de deveres morais. Em um segundo momento, Davidson revitaliza a possibilidade da fraqueza de vontade, livrando o problema do campo moral mais restrito em seu influente artigo 'How is Weakness of Will Possible?' (1969). Dentro dessa perspectiva, ambos os autores alegam estar retomando o problema clássico da akrasia antiga de Platão e Aristóteles.

Notadamente, a recepção analítica da akrasia antiga de Platão e Aristóteles marca a formulação original do problema da fraqueza de vontade. Diante disso, 
devemos indicar de que modo o debate analítico emergente de Hare e Davidson sobre a fraqueza de vontade contemporânea se apropria da akrasia antiga.

Em primeiro lugar, o debate antigo do poder do conhecimento moral se transfere ao debate analítico acerca do 'melhor juízo’ prático do agente. A defesa da superioridade do conhecimento moral em Platão e Aristóteles equivale à superioridade lógica do 'melhor juízo' na razão prática. De qualquer forma, a conexao intrínseca entre o juízo do bem e a ação humana da filosofia antiga favorece a defesa do internalismo da razão prática de Hare e Davidson.

Em segundo lugar, a estrutura lógica da razão prática renova o interesse da filosofia analítica sobre a doutrina do 'silogismo prático' de Aristóteles. Como veremos, reflexão analítica inicial em torno do 'silogismo prático' fundamenta as bases da noção moderna da 'inferência prática' de Hare. De qualquer modo, a tradição analítica simplesmente assume a teoria lógica estrita do silogismo prático forte, ou seja, a derivação lógica direta da ação, dispensando o papel do silogismo prático moderado presente nos textos de Aristóteles. Dessa forma, a leitura analítica simplesmente dispensa a eficácia prática do silogismo prático aliado ao conhecimento moral da phrónesis e a virtude moral na Ética aristotélica. Naturalmente, essas inconsistências se refletem na recepção analítica da descrição aristotélica da akrasia antiga.

Em terceiro lugar, a irracionalidade prática de Davidson não contempla apropriadamente o papel das motivações irracionais na razão prática. Como veremos, a descrição final da fraqueza de vontade de Davidson insiste em caracterizar a irracionalidade prática como um elemento constitutivo da razão prática do agente. No entanto, a irracionalidade prática antiga traz à tona a possibilidade da descoordenação da razão correta e os desejos irracionais fundamental para a akrasia antiga. Dessa forma, pretendemos esclarecer as diferenças fundamentais da 'irracionalidade' antiga e a 'irracionalidade' prática de Davidson. De qualquer forma, Hare e Davidson comprovam os efeitos da recepção analítica da akrasia antiga no problema da fraqueza contemporânea.

Para analisar os efeitos da recepção analítica da akrasia antiga, devemos iniciar a investigação a partir o prescritivismo moral de Hare. Como veremos adiante, a doutrina do prescritivismo moral de Hare se fundamenta na noção moderna de inferência prática estreitamente relacionada à apropriação analítica do ‘silogismo prático' de Aristóteles. 


\section{2}

\section{O problema da fraqueza de vontade e o prescritivismo moral de Hare}

A formulação precursora da fraqueza de vontade contemporânea ganha destaque com Richard M. Hare (1919-2002). Em suas principais obras, The Language of Morals (1952), Freedom and Reason (1963) e Moral Thinking $(1981)^{463}$, Hare defende sistematicamente a negação da fraqueza de vontade em função de sua teoria do prescritivismo moral da linguagem. De fato, a existência da ação contrária ao juízo moral do agente ameaça os princípios básicos do prescritivismo, isto é, a doutrina segundo a qual os juízos morais prescrevem as ações morais. Particularmente, a fraqueza de vontade assume o caráter de um problema eminentemente moral, ou seja, descrito especificamente em termos de 'fraqueza moral' (moral weakness) ${ }^{464}$. Todavia, Hare reconhece que o problema em si mesmo tem raízes mais arcaicas na tradição da akrasia antiga.

A fraqueza de vontade em si mesma constitui um desafio e, ao mesmo tempo, a fundamentação teórica do prescritivismo moral. De acordo com Hare (1963, 5.1, p. 68), a existência da 'fraqueza moral' só representa um problema filosófico em face da natureza inerentemente prescritiva da linguagem moral: "if moral judgements were not prescriptive, there would be no problem about moral weakness; but there is a problem; therefore, they are prescriptive." ${ }^{465}$. $\mathrm{Na}$ perspectiva de Hare, o problema da fraqueza moral não se restringe apenas à defesa de seu prescritivismo moral, mas se estende aos que supostamente compartilham

\footnotetext{
${ }^{463}$ De agora em diante, irei me referir às obras de Hare em termos abreviados: ' $L M$ ' para 'The Language of Morals', 'FR' para 'Freedom and Reason' e 'MT' para 'Moral Thinking'. De fato, deixei de mencionar explicitamente o livro Sorting out Ethics (Ética: Problemas e Propostas, em português), justamente por se tratar de uma introdução geral à filosofia da linguagem moral, na qual Hare basicamente reitera todas as suas teses e teorias desenvolvidas ao longo das obras anteriores. ${ }^{464}$ Em The Language of Morals, Hare parece não distinguir explicitamente o significado de 'fraqueza de vontade' e 'akrasía' (no sentido grego original). Em Freedom and Reason, no entanto, Hare passa a se referir a uma expressão mais restrita de 'fraqueza moral' (moral weakness) e a diferencia da 'akrasía' grega. Em ambas as obras, o que está em jogo é uma concepção moral comum denominada de 'fraqueza moral' que está no centro de sua análise da linguagem moral prescritiva. Em relação a akrasía grega, Hare parece tomar consciência apenas nesse último livro de que a experiência designada de 'akrasía' pelos gregos não corresponde efetivamente ao que denominamos atualmente de 'fraqueza de vontade' ou 'fraqueza moral'. Ver também, Idem, 1999, cap. 9.

${ }^{465}$ Cf. Idem, 1996, 11.3, p. 182: “A melhor forma de estabelecer o interesse lógico primário do sentido avaliatório de 'dever' é demonstrar que, não fosse a existência desse sentido, nenhum dos conhecidos problemas gerados pela palavra surgiriam.”. Ver também, Idem, 1963, 5.9, p. 84.
} 
dos mesmos princípios morais prescritivos, como Platão e Aristóteles (cf. Ibid., 1999, p. 109-110). Em que medida Platão e Aristóteles efetivamente concordam com o prescritivismo moral, é algo que analisaremos posteriormente. No entanto, o mais fundamental aqui é o reconhecimento explícito da tradição filosófica da akrasia antiga. Nessa perspectiva, o problema da fraqueza moral emerge da conexão internalista das razões morais do agente e suas ações morais.

De acordo com Hare (1963, 5.3, p. 71), a conexão lógica entre o juízo moral do 'bem' e a ação moral reflete o internalismo das razões morais do agente:

To draw attention to the close logical relations, on the one hand between wanting and thinking good, and on the other between wanting and doing something (...), is to play into the hands of the prescriptivist; for it is to provide yet another link between thinking good and action.

Diante do prescritivismo moral, a negação da fraqueza moral é um resultado inevitável do internalismo moral da razão prática. A negação da fraqueza moral é uma conclusão necessária derivada da própria rigidez do presritivismo moral de Hare. Segundo o prescritivismo moral, termos morais, como 'dever' (ought), 'bem' (good) ou 'correto' (right), possuem o valor lógico primordial de orientar as ações humanas. Ao longo de suas obras, Hare defende fundamentalmente a mesma estratégia de negação do fenômeno. Nessa perspectiva, nenhum dos pretensos casos do fenômeno (que poderiam contestar os princípios do prescritivismo moral), constituem descrições genuínas de fraqueza moral, mas apenas casos espúrios.

Em linhas gerais, os diversos casos de fraqueza moral possuem outras descrições alternativas da falha de prescritividade dos juízos morais, como o uso 'entre aspas' (inverted-commas) dos termos morais gerado (1) pela 'retração proposital' (purposive backsliding); (2) pelo 'autoengano' (self-deception) do agente; e, até mesmo, (3) a compulsão ou impossibilidade psicológica ligada a um forte impulso irracional. Em Moral Thinking, Hare enfim reduz o fenômeno a um típico conflito entre 'deveres' morais incompatíveis. Com isso, a fraqueza moral deixa de ser um fenômeno genuíno diante do prescritivismo moral.

A rigidez do prescritivismo moral de Hare não contempla a irracionalidade da fraqueza de vontade. Em relação ao prescritivismo moral, pretendemos mostrar que as bases rígidas dessa doutrina moral analítica derivam da recepção analítica do silogismo prático forte de Aristóteles. $\mathrm{O}$ debate analítico inicial da inferência 
prática é fundamental para a fundamentação do prescritivismo moral de Hare. Nesse aspecto, o prescritivismo moral ignora a dimensão da educação moral dos apetites irracionais na eficácia do silogismo prático de Aristóteles. Em relação à fraqueza moral, devemos mostrar que nenhum dos casos apresentados de fraqueza moral de Hare representa adequadamente o conflito prático genuíno da fraqueza de vontade. A associação insistente da fraqueza de vontade ao campo da moralidade moderna reduz o fenômeno basicamente a um conflito genérico de 'deveres' morais. De forma contundente, isso reflete a repercussão da recepção analítica da akrasia antiga no prescritivismo moral de Hare. Com efeito, a tradição analítica não compreende efetivamente o papel fundamental do conhecimento moral antigo na constituição do problema original da akrasia antiga.

Para todos os efeitos, a fraqueza moral dilui o verdadeiro problema original da fraqueza de vontade. Ao final, a crítica contundente de Williams à fraqueza moral revelará que é preferível abandonar as categorias do dever moral por uma noção mais original de fraqueza de vontade. Dessa forma, precisamos primeiro compreender os princípios básicos do precritivismo moral de Hare e o debate analítico primordial em torno da noção moderna da inferência prática.

\section{3 O prescritivismo moral e a implicação lógica da ação moral}

Os fundamentos do prescritvismo moral são apresentados em A Linguagem da Moral (1952), embora a teoria seja ligeiramente reformulada em Freedom and Reason (1963) e Moral Thinking (1981). Desde A Linguagem da Moral, Hare sustenta que a linguagem moral não só descreve fatos da realidade, mas tem a função primordial de prescrever ações humanas futuras, orientando a conduta moral no domínio humano (Cf. Idem, 1996, p. 163-165). Dentro desse quadro, a teoria do prescritivismo moral de Hare está incluída na tradição analítica que se ocupa basicamente em explicar filosoficamente o nosso comportamento linguístico, isto é, o uso habitual das sentenças da linguagem moral humana.

Em linhas gerais, essa doutrina se sustenta em três princípios básicos: (1) os juízos morais se expressam em sentenças morais contendo termos valorativos, como 'bom' (good), 'correto' (right) e 'dever' (ought); (2) esses termos possuem 
um 'significado' (meaning) eminentemente prescritivo ${ }^{466}$ em seu uso cotidiano, isto é, dirigido a orientar as ações humanas inclusive sob o modo imperativo. Tal princípio é denominado de 'prescritividade' (prescriptivity); (3) a prescritividade dos juízos morais é universal pois se aplica em ‘todos os casos semelhantes’ de ação moral, o que resulta em sua 'universalizabilidade' (universalizability). Com base nesses princípios, o prescritivismo moral estabelece relações lógicas entre os juízos morais prescritivos e a necessidade lógica da realização concreta da ação moral. O desafio da fraqueza moral coloca em xeque a necessidade lógica irrevogável da ação moral em vista dos juízos morais prescritivos. Invariavelmente, o sucesso do prescritivismo nasa ação depende principalmente da consistência do princípio (2). Entretanto, o princípio (2) fica comprometido justamente contra seus principais adversários na filosofia analítica, o descritivismo e o emotivismo. Dessa forma, é necessário compreendermos a coerência dos princípios do prescritivismo moral em face do significado ordinário das sentenças declarativas ordinárias.

O prescritivismo moral é apresentado contra as teorias analíticas tradicionais da linguagem em A Linguagem da Moral. Sobretudo, tal doutrina do prescritivismo moral precisa confrontar o descritivismo e, em menor grau, do emotivismo na filosofia da linguagem ${ }^{467}$. Como mencionamos, o prescritivismo moral defende que termos ou expressões valorativas da linguagem, tais como 'bom' (good), 'correto' (right) e o verbo 'dever' (ought) $)^{468}$. Para Hare (1996, p. 3), esses termos morais têm a função primordial de dirigir a ação moral: "a função dos princípios morais é orientar a conduta (guide conduct).”. No entanto, ambas as teorias filosóficas anteriores negam o 'significado' especial desses termos morais

\footnotetext{
${ }^{466}$ Como especificaremos a seguir, a expressão 'eminentemente' visa salientar que os juízos morais possuem valor prescritivo, embora isso não implica negar que mantenham também seu sentido descritivo derivado.

${ }^{467}$ A seguir, devemos apenas mencionar as correntes do descritivismo (naturalismo) e emotivismo de forma geral sem nos deter especificamente sobre nenhum de seus diferentes representantes. Em última instância, meu propósito é apenas elucidar de que modo o prescritivismo moral se destaca das outras teorias analíticas concorrentes da linguagem e o que tipo de inovação filosófica tal doutrina pretende trazer ao campo da filosofia da linguagem. Ver também, Idem, 1996, p. 10-11.

468 É preciso ressaltar que o mesmo termo 'dever', presente na tradução portuguesa de The Language of Morals, se refere aos termos ingleses ought and duty da obra original que contém significados distintos. Nesse caso, contudo, a palavra 'dever', como bem salienta o tradutor, contém significados diferentes se é tratada como verbo ou substantivo. Se for considerada como substantivo, a palavra designa a própria regra moral, estabelecida pelos costumes ou pela lei, que se aproxima do significado de duty. Se for considerado como um verbo, o termo designa uma ação exigida por uma obrigação habitual ou moral e, nesse sentido, está mais próxima da palavra ought. Em seu sistema filosófico, Hare irá se ocupar mais com o termo ought uma vez que o termo costuma aparecer mais em sentenças imperativas ordinárias com o propósito explícito de prescrever ações, um ponto central do prescritivismo moral.
} 
tendo em vista o comportamento comum dos termos descritivos nas sentenças declarativas ordinárias. Como vimos, Hare defende que a impossibilidade do prescritivismo moral resulta inevitavelmente na inviabilidade de próprio problema da fraqueza moral. Dessa maneira, ilustraremos esses aspectos fazendo uma breve comparação entre sentenças declarativas e sentenças valorativas e morais. O propósito final será elucidar a consistência do prescritivsmo moral e a necessidade lógica da ação moral.

As afirmações declarativas parecem diferir claramente das sentenças que contenham termos valorativos. Ora, as sentenças declarativas, como "o elefante é branco" ou "o semáforo é vermelho" parecem ter um significado diferente das sentenças valorativas, como "este é um bom homem" ou "dizer a verdade é correto". Entretanto, a corrente descritivista alega que essas sentenças expressam rigorosamente afirmações de fato: se referem a aspectos ou qualidades dos objetos da realidade dos falantes. Dessa forma, as sentenças anteriores teriam a função significativa fundamental de descrição dos fatos da realidade. Invariavelmente, Hare reconhece que termos valorativos presentes em afirmações de fato ou sentenças morais compartilham da universalidade de seu significado avaliativo ${ }^{469}$ : assim como 'branco' apresenta o mesmo significado em diversas sentenças afirmativas que se aplicam a coisas particulares sob 'circunstâncias similares', o termo 'bom' (good) apresenta o mesmo significado valorativo em relação a ações morais semelhantes. No entanto, as sentenças valorativas ou morais expressam ainda outro tipo de função que não se reduz a mera descrição de fatos.

Em A Linguagem Moral, Hare (1996, p. 149) salienta um significado primário moral de "bom" estendido a outros termos de valor com conotações morais:

Comovemo-nos com a bondade dos homens porque somos homens. Isso significa que a aceitação de um juízo, de que tais e tais atos de um homem são bons em certos tipos de circunstâncias, envolve a aceitação do juízo que seria bom, se estivéssemos em circunstâncias semelhantes, agir da mesma forma.

\footnotetext{
${ }^{469}$ Cf. HARE, 1963, 2.1, p. 10: "It is important to emphasize that moral judgements share this feature [universalizability] with descriptive judgements. (...) Nevertheless, in so far as moral judgements do have descriptive meaning, in addition to other kind of meaning which they have, they share this characteristic, which is common to all judgements which carry descriptive meaning." (itálicos do autor)
} 
O significado primário de ‘bom’ em termos morais prevalece, então, sobre seu significado secundário descritivo. Embora o significado descritivo seja apropriado no uso comum relativo de 'bom' aplicado a uma 'boa maçã' ou um 'bom automóvel', esse uso não corresponde ao uso corrente do termo moral 'bom' relativo a 'bom homem' ou a uma 'boa ação moral'. De um lado, não usamos os termos morais em geral com o propósito de descrever certas características ou qualidades de certo objeto. Nem mesmo usamos esses termos em geral, como alega o emotivismo, para expressar sentimentos, emoções ou estados subjetivos da mente humana. Certamente, a expressão 'bom gosto' ligado ao meu juízo estético pessoal não equivale a 'boa atitude' em referência a atitude moral de um agente. Por mais que tais significados secundários de ‘bom’ sejam legítimos, eles não contemplam o significado primário específico em sentenças morais para aprovar ou orientar ações morais ou um comportamento moral. Nesses termos, o sentido primário prescritivo do termo moral 'bom' torna o sentido descritivo secundário (cf. Idem, FR, 1963, p. 24).

O termo moral 'bom' salienta qualidades morais que tornam um 'homem bom' ou uma 'boa ação' a fim de orientar ou prescrever a conduta moral. Nesse sentido, estamos aprovando e, mais ainda, recomendando que certas ações morais sejam realizadas em vista de circunstâncias similares de ação. Da mesma maneira, as mesmas características se verificam no significado primário de outros termos morais, como 'correto' (right), o substantivo 'dever' (duty) e o verbo 'dever' (ought). De fato, Hare (1996, p. 169) reconhece que o verbo 'dever' (ought) e o termo 'bem' (good) expressam o mesmo tipo de significado prescritivo: “"Dever' também compartilha (..) as características de 'bom' que dizem respeito às relações entre suas forças descritiva e avaliatória ou prescritiva". Assim como 'bom', o verbo 'dever' (ought) possui igualmente um significado descritivo e um significado prescritivo. Da mesma forma, o sentido moral prescritivo de 'dever' supera seu uso descritivo primário: "sua função primária não é dar informação, é prescrever, aconselhar ou instruir, e esta função pode ser desempenhada quando nenhuma informação é transmitida" (Ibid., p. 170). Sobretudo, o termo dever (ought) evidencia de forma mais decisiva a prescritividade dos juízos morais no modo imperativo além das sentenças indicativas usuais.

O caráter prescritivo da linguagem moral se expressa com mais clareza nas sentenças imperativas contendo o verbo moral 'dever' (ought). Em diversos 
imperativos comuns dirigidos ao agente, o caráter prescritivo se sobressai: 'Você deve trazer esses documentos' ou 'Faça $x$ ou $y$ ', etc. De fato, não é qualquer tipo de imperativo que traz à tona um problema moral, mas apenas o modo imperativo peculiar do 'comando' (command) em primeira pessoa dirigido ao próprio agente em contextos morais.

Em situações morais, nas quais é preciso tomar uma decisão, a escolha do agente reflete uma questão avaliatória prévia do 'dever (ought). Diante da questão do 'dever' (ought), “O que eu devo (ought) fazer?”, emerge a resposta que está no domínio do próprio agente, "Que eu faça $a$ " (Let me do $a)^{470}$. Nessas circunstâncias, Hare (1963, 4.3, p. 54) reconhece que o 'dever' (ought) possui total força prescritiva (de forma universal): "we give our hearers to understand that we think that the questions arises which this is a possible answer (...) unless the person in question were able to do the acts referred." ${ }^{471}$. Em vista da razão prática, o comando particular resulta de uma avaliação moral universal da ação derivada da questão prática do 'dever': o assentimento ao juízo moral do agente lhe compromete a considerar se todos os homens (incluindo ele mesmo) devem realizar a mesma ação em 'circunstâncias similares'. Nesses termos, os juízos morais expressam a prescritividade universal dos princípios morais (Ibid., p. 73). Apenas nesses termos, a questão prática toma forma do dilema do 'dever' moral de Kant em termos de princípios morais de ação: 'que máxima (ou princípio moral) posso aceitar como um princípio universal aplicado a casos morais similares? ${ }^{472}$. Em face disso, a universalidade do prescritivismo moral leva Hare (1996, p. 190) a sustentar a necessidade lógica entre princípios morais e ação moral:

a universalidade completa (complete universality) do juízo moral significa que não podemos "nos livrar dele" e, portanto, sua aceitação é uma questão muito mais séria do que a aceitação de um imperativo de cuja esfera de aplicação podemos escapar.

\footnotetext{
${ }^{470}$ Para as condições de emergência da questão prática do 'dever moral' ver HARE, 1996, p. 30; Idem, 1963, p. 54-55

${ }^{471}$ Cf. Idem, 1963, 4.3, p. 54: "if we say that somebody ought to do a certain thing, and 'ought' has its full (i. e. universally prescriptive) force, then we give our hearers to understand that we think that the question arises which this is a possible answer, which it would not, unless the person in question were able to do the acts referred to."

${ }^{472}$ Sobre as implicações do 'dever' moral de Kant no prescritivismo moral, ver HARE, 1996, p. 73 74; Idem, 1963, p. 71-72.
} 
O precritivismo moral culmina na derivação lógica necessária dos princípios morais genuínos à ação moral. Em $F R$, essa derivação lógica é formulada de uma forma peculiar: a máxima “dever implica em poder (ought implies can)". Para Hare, a expressão do verbo 'dever' (ought) no juízo moral depende necessariamente da possibilidade da ação, em que o contexto moral demanda a questão prática do 'dever' ao agente (cf. Idem, 1963, p. 55).

Ora, o problema central, então, seria explicar como há casos evidentes, como os de fraqueza moral, em que o 'dever' não implica no 'poder'. De uma forma preliminar, é possível sustentar que há casos em que o significado de 'dever' (ought) não revela sua prescritividade total (de forma universal) e, portanto, recai em um significado secundário descritivo. Como veremos adiante, a solução de Hare investe justamente nessa possibilidade do sentido descritivo de 'dever'. Antes disso, porém, devemos investigar ainda as relações lógicas fundamentais sobre os quais se apoia o prescritivismo moral de Hare. Em particular, nos ocuparemos com o conceito fundamental da 'inferência prática' (practical inference). Como veremos a seguir, a controvérsia analítica em torno da possibilidade da inferência prática envolve a recepção analítica do silogismo prático aristotélico.

\section{4 \\ A inferência prática e o silogismo prático}

O prescritivismo moral de Hare se apoia em uma análise das relações lógicas fundamentais da possibilidade da 'inferência prática' (practical inference). Assim como Aristóteles, Hare também recorre a uma analogia entre o raciocínio teórico e o raciocínio prático. Assim como o raciocínio teórico leva a crença no fato descritivo, o raciocínio prático deve conduzir à realização de uma ação. A noção moderna da 'inferência prática' fornece as bases do projeto analítico da criação de uma linguagem proposicional clara e adequada da ação intencional humana.

A inferência prática faz parte do domínio do raciocínio prático humano. Para Hare, a 'inferência prática' consiste, particularmente, na formulação lógica especifica da 'inferência imperativa'. Seguindo a tradição analítica, Hare assume que o 'silogismo prático' de Aristóteles possui uma dimensão inerentemente prescritiva na ação. Como veremos, isso reflete a leitura cognitivista do silogismo 
prático forte de que a conclusão prática é a própria ação. No silogismo prático moderado de Aristóteles, o raciocínio prático correto não tem eficácia na ação sem o papel crucial dos desejos irracionais adequados. Desse modo, a controvérsia em torno da 'inferência prática' moderna é indissociável da recepção analítica da Ética de Aristóteles.

A controvérsia da 'inferência prática' tem suas raízes na recepção analítica da doutrina do 'silogismo prático' aristotélico. A recepção analítica do 'silogismo prático' ganha maior destaque na obra Intention (1957) de Elizabeth Anscombe. Segundo Anscombe (2000), o silogismo prático clássico pode ser adaptado, nos termos lógicos modernos, ao modelo da inferência prática ${ }^{473}$. Em geral, a estrutura lógica básica se mantém a mesma em ambos os casos: (1) a premissa universal, correspondente ao fim desejado da ação ${ }^{474}$; (2) a premissa particular, expressa os fatos particulares envolvidos na ação; (3) a conclusão, a realização da ação a partir dos fatos particulares necessários para alcançar o fim da ação. Assim como a inferência teórica, a inferência prática constitui uma implicação lógica, isto é, a admissão das premissas práticas implica necessariamente na admissão da conclusão prática. Se a inferência teórica resulta efetivamente na crença da conclusão teórica, a inferência prática, por sua vez, resulta na ação derivada da admissão da conclusão prática. Mesmo assim, Anscombe sustenta francamente que o silogismo prático não pode ter a mesma natureza do silogismo teórico demonstrativo ${ }^{475}$. De fato, há um debate analítico intenso acerca da natureza distintiva do silogismo prático moderno.

A polêmica analítica da 'inferência prática' emerge do próprio estatuto lógico peculiar do silogismo prático ${ }^{476}$. De um lado, uma corrente analítica influente

\footnotetext{
${ }^{473}$ Sobre a aplicação moderna do silogismo prático na inferência prática moderna, ver ANSCOMBE, 2000, parágrafos 33-44; ver também, Idem, 1981, p. 72-74.

${ }^{474}$ Cf. Ibid., p. 66: "The role of ' wanting ' in the practical syllogism is quite different from that of a premise. It is that whatever is described in the proposition that is the starting-point of the argument must be wanted in order for the reasoning to lead to any action."

${ }^{475}$ Cf. Idem, 1981, p. 74: "It looks as if in his enthusiasm for making practical reasoning like theoretical reasoning and explaining its power to set in motion (...) Aristotle, did not notice some significant features of his discovery; the fact that tough it is perfectly correct to call practical reasoning 'reasoning', and though some practical syllogisms are also (in my sense) proof syllogisms, i. e. entailments, in general practical syllogisms have a different form from proof syllogisms."

${ }^{476}$ Para a relação intrínseca entre a inferência prática moderna e o silogismo prático aristotélico, ver algumas indicações dessa controvérsia analítica em BERTI, 1997, p. 216-227; BARNES, 1977. Por conta do nosso foco sobre a fraqueza de vontade contemporânea, não poderemos explorar em maiores detalhes a extensa controvérsia analítica em torno da inferência prática moderna. A seguir, nos concentraremos apenas em algumas críticas dirigidas à possibilidade de sua formulação lógica nos termos da 'inferência imperativa' de Hare. Dessa forma, não ignoramos que há outras formas possíveis de formular inferências práticas em termos lógicos. Entretanto, deveremos salientar que a
} 
alega que há uma distinção fundamental entre o silogismo científico demonstrativo e o silogismo prático. De outro lado, outra corrente analítica minoritária nega que há qualquer diferença lógica crucial entre ambos os tipos de silogismo. Devido ao meu foco na fraqueza de vontade, não poderemos adentrar profundamente nessa polêmica analítica. A princípio, a identidade absoluta com o silogismo teórico não esclarece o que há de distintivo no próprio silogismo prático. No entanto, a própria formulação da 'inferência imperativa' de Hare mostra as dificuldades inerentes da definição precisa de seu domínio prático.

O aspecto distintivo do raciocínio prático é salientado na polêmica analítica em torno da 'inferência prática'. Na sequência, nos ocuparemos então sobre a concepção distintiva de 'inferência prática' de Hare. O prescritivismo moral de Hare parte do princípio que há uma diferença fundamental entre o raciocínio teórico e o raciocínio prático.

A 'inferência prática' de Hare se apoia sobre uma analogia fundamental entre afirmações teóricas e comandos práticos na ação. Em A Linguagem da Moral, Hare (1996, 2.2, p. 22) esboça os princípios lógicos sob os quais devemos compreender os comandos práticos no modo imperativo:

podemos caracterizar provisoriamente a diferença entre afirmações e comandos (statements and commands) dizendo que, embora o assentimento sincero ao primeiro envolva acreditar (believing) em algo, o assentimento sincero ao segundo implica (na ocasião adequada e se estiver ao nosso alcance) fazer (doing) algo. (...) não podemos assentir sinceramente a um comando (....) dirigido a nós e ao mesmo tempo não realizá-lo, se agora é a ocasião de realizá-lo e está ao nosso alcance (físico e psicológico) fazê-lo (itálicos do autor)

De acordo com Hare, o agente procede a um comando prático tal como assentimos a uma afirmação de fato. A analogia entre afirmações e comandos parece bem direta: (1) o assentimento a afirmações leva necessariamente à crença na verdade expressa na sentença afirmativa; (2) o assentimento à comandos práticos, por sua vez, leva necessariamente a realização da ação correspondente, dadas certas condições (físicas e psicológicas) de ação. Diante disso, o assentimento sincero (sincere assent) a um comando prático implica, por necessidade lógica, na

própria noção de inferência prática não parece comtemplar a realização necessária da ação como supõe o prescritivismo moral de Hare. 
realização de uma ação particular prescrita tal como o assentimento sincero à afirmação de fato implica, por necessidade lógica, na crença acerca da veracidade da proposição expressa na afirmação de fato. Em outros termos, a necessidade lógica expressa nessa analogia possui certa inspiração na distinção aristotélica fundamental entre o raciocínio teórico e o raciocínio prático acompanhado do desejo coreto.

A necessidade lógica sugerida pela analogia se ampara em uma relação tautológica entre o comando prático e a ação. Em termos lógicos, a tautologia significa aqui apenas uma sentença analítica cujo atributo do predicado está necessariamente contido no sujeito de tal forma que a sentença permanece sempre verdadeira. Nessas condições, a negação da sentença analítica implica automaticamente em uma autocontradição ${ }^{477}$. Assim como o assentimento sincero a uma afirmação de fato implica, simultaneamente, a crença correspondente na afirmação de fato, algo similar ocorre com os comandos. A relação lógica entre o assentimento sincero do comando prático e a ação é igualmente tautológica.

As condições de realização da ação derivadas do assentimento sincero ao comando prático são de vital relevância ao prescritivismo moral. Segundo Hare (Ibid., p. 22), a ação resulta logicamente do assentimento sincero ao comando em vista de duas condições: (a) o alcance físico, dado que a ocasião externa adequada da ação está presente e acompanhada da decisão de agir pelo comando prático; (b) o alcance psicológico, dado que os estados psicológicos do agente (motivações, sentimentos ou desejos) não lhe impeçam de realizar a ação. Em geral, o critério último para determinar o assentimento sincero do comando se baseia na própria realização concreta da ação particular do comando prático. Como veremos a seguir, essas condições ideias da ação se amparam nas condições da eficácia do silogismo prático de Aristóteles. Para isso, precisaremos antes examinar o que constitui a inferência prática e de que forma ela estabelece as relações lógicas fundamentais entre o comando prático e a ação.

Assim como na analogia anterior, a constituição da inferência prática segue as regras lógicas fundamentais da inferência assertórica clássica. Para Hare (Ibid.,

\footnotetext{
${ }^{477}$ Cf. Ibid., p. 43: "Uma sentença é analítica se, e somente se, (1) o fato de uma pessoa dissentir da sentença é critério suficiente para dizer que interpretou mal o significado do falante ou (2) ela é implicada por alguma sentença que é analítica no sentido (1).” Segundo Hare, os princípios da ação podem ser interpretados de forma analítica caso sua negação seja autocontraditória.
} 
2.5, p. 29-30), a comparação com a inferência teórica permite esclarecer a própria inferência prática:

(1) Nenhuma conclusão indicativa pode ser extraída validamente de um conjunto de premissas que não possa ser extraído validamente apenas dos indicativos dentre elas.

(2) Nenhuma conclusão imperativa pode ser extraída validamente de um conjunto de premissas que não contenha pelo menos um imperativo. (itálicos do autor)

De um lado, a inferência teórica se constitui de (ao menos) duas premissas $^{478}$ e uma conclusão no modo indicativo. Em termos lógicos, a inferência teórica é válida caso a conclusão se siga validamente do conjunto das premissas anteriores. Nas inferências práticas, há igualmente (ao menos) duas premissas e uma conclusão imperativa. No entanto, a conclusão imperativa, nesse caso, deve seguir um conjunto de premissas que contenham ao menos uma sentença imperativa. Para Hare, a própria presença de regras práticas expressas na forma imperativa evidencia que há uma implicação lógica de (ao menos) um comando na linguagem ordinária (Cf. Ibid., p. 27). Nesses termos, a inferência prática se baseia inevitavelmente na concepção de inferência imperativa.

Em Practical Inference, Hare (1971, p. 63) estabelece uma regra específica que deve governar as inferências práticas, a lógica da satisfação:

in this logic 'satisfaction,' is a value which is preserved in the same way as truth in ordinary sentences. Just as, in valid assertoric inferences, if the premisses are true the conclusion is true, so, in an imperative inference in the logic of satisfaction, if the premisses are satisfied and the indicative premisses (if any) are true, then the imperative conclusion is satisfied.

Tal como a verdade das premissas indicativas implica na verdade da conclusão indicativa da inferência assertórica, a satisfação das premissas imperativas implica na satisfação da conclusão prática da inferência imperativa. Em termos lógicos, poderíamos formular a lógica da satisfação da seguinte forma: o imperativo da ação $x$ implica um imperativo da ação $y$ se o primeiro só pode ser satisfeito caso o segundo também seja satisfeito (Ibid., p. 62-63). Nesse contexto, é

\footnotetext{
${ }^{478}$ Ao ressaltar a expressão 'ao menos', deixamos em aberto a possibilidade de existirem mais de duas premissas em uma inferência. No entanto, preferimos manter a formulação tradicional das duas premissas a fim de facilitar a comparação posterior com o silogismo prático aristotélico.
} 
possível expressar um comando conjuntivo do tipo 'Faça $x$ e $y$ ' e derivar logicamente o comando particular 'Faça $x$ '. Da mesma forma, a lógica da satisfação permite igualmente a conversão inversa do comando original: a derivação lógica 'Faça $x$ e $y$ ' do comando simples 'Faça $x{ }^{\text {'479. }}$. Além disso, há também comandos disjuntivos tais como 'Faça $x$ ou $y$ ', que implicam logicamente na realização concreta de uma ação particular em lugar da ação contrária. A possibilidade da inferência imperativa estabelece regras lógicas ao comando prático, embora sua consistência lógica seja tema de uma ampla controvérsia analítica.

Com efeito, há diversos problemas envolvendo a noção de 'inferência' aplicada particularmente ao modo imperativo. Em especial, há problemas ligados à conversão lógica dos comandos disjuntivos. Para tratarmos desses problemas, precisaremos analisá-los em uma seção posterior. Por enquanto, pretendemos apenas exemplificar adiante como a possibilidade da inferência prática emerge e, simultaneamente, se destaca do silogismo prático aristotélico original.

A distinção entre a lógica da inferência prática e a lógica do silogismo prático é fundamental para compreendermos a recepção analítica do silogismo prático aristotélico. Para isso, sugiro adaptarmos um exemplo consagrado de $D e$ Motu Animalum (7.701a19-22) para observarmos melhor as diferentes formulações lógicas $^{480}$ :

(1) Eu tenho necessidade (déomai) de uma vestimenta

(2) Um manto é uma vestimenta

(3) Eu tenho necessidade de um manto

(4) Que eu faça um manto

(II)

(5) Se eu tenho necessidade de um manto, eu devo fazer tal e tal coisa

(6) Eu tenho necessidade de um manto

(7) Eu devo fazer tal e tal coisa

O exemplo de De Motu Animalum é especialmente interessante justamente por exibir um comando prático em primeira pessoa. Como vimos, o prescritivismo

\footnotetext{
${ }^{479} \mathrm{Cf}$. Ibid., p. 62: "it must always be possible to reason in accordance with ordinary assertoric logic from a premiss to the effect that a certain imperative is satisfied to the coclusion that a certain other imperative is satisfied."

${ }^{480}$ Tal adaptação do exemplo De Motu 7 é sugerida em Price (2004). Em particular, a adaptação de Price se concentra na formulação lógica da parte (II) do silogismo prático original de modo a tornálo compatível com as regras da inferência imperativa de Hare. Dessa forma, busquei resgatar a complexidade do exemplo original (I-II) de De Motu 7, com o objetivo de esclarecer eventualmente as semelhanças e, principalmente, as diferenças entre a estrutura lógica do silogismo prático de Aristóteles e a inferência imperativa de Hare.
} 
moral de Hare é formulado em termos de um autocomando dirigido a si mesmo. A partir disso, pretendemos fazer uma análise destacada da inferência prática (II). Pelos princípios da inferência imperativa, a inferência (II) se expressa na fórmula 'Eu preciso fazer um manto $e$ eu preciso fazer tal e tal coisa'. Sendo as premissas (2) e (3) verdadeiras, isso significa que a satisfação da premissa (1) implica automaticamente na satisfação da conclusão prática (4). Em última instância, isso resulta no autocomando 'Eu preciso fazer tal e tal coisa'. A inferência imperativa se insere na categoria da lógica deôntica, isto é, a inferência prática do comando prático deriva da satisfação de normas práticas. No entanto, o silogismo prático aristotélico jamais se estabelece a partir de puras normas práticas.

A lógica da satisfação de Hare revela a proximidade da inferência prática e da inferência assertórica ordinária. Na visão Hare, Aristóteles teria dado a impressão equivocada de que descobriu uma lógica imperativa radicalmente diferente da lógica ordinária assertiva ${ }^{481}$. No entanto, o silogismo prático original de Aristóteles não esboça uma lógica imperativa distinta da lógica ordinária. Como vimos, Aristóteles não deixa de notar que o silogismo prático segue a mesma estrutura lógica básica do silogismo teórico demonstrativo. Seguindo essas indicações, devemos reconsiderar o exemplo anterior dentro dos parâmetros originais do silogismo prático aristotélico.

De acordo com o contexto original do silogismo prático aristotélico, teríamos a seguinte estrutura lógica do exemplo anterior de De Motu 7:

(I)

(1) Eu tenho necessidade (déomai) de uma vestimenta

(2) Um manto é uma vestimenta

(3) Eu tenho necessidade de um manto

(4) O que eu tenho necessidade, eu devo fazer (déomai poietéon)

(5) Eu tenho necessidade de um manto

(6) Eu devo fazer um manto

O silogismo prático aristotélico em nada difere do silogismo demonstrativo teórico ou o 'silogismo do conhecimento científico' (epistéme) em seus elementos lógicos básicos: a premissa universal, a premissa particular e a conclusão. Assim

\footnotetext{
${ }^{481}$ Cf. HARE, 1971, p. 67: "for not only he [Aristotle] generated endless paradoxes, but also created the impression that he had discovered a type of 'imperative logic' radically different from ordinary logic - whereas in fact the logic of reasoning to sufficient conditions is a well-establshed application of ordinary logic."
} 
como no silogismo teórico, o silogismo prático também segue o princípio lógico de que a admissão conjunta das premissas resulta na admissão da conclusão por necessidade (anánke) (cf. ENVII 3 1125-30; De Motu 7 701a 5-10). Com isso, Aristóteles dá uma ampla aplicação aos elementos do silogismo prático em (II): (1) a premissa universal ligada a uma 'opinião universal' (referente ao agente e ao objeto da ação); (2) a premissa particular expressa uma 'opinião particular' relativa aos fatos particulares; (3) a conclusão prática deriva das premissas anteriores e está ligada diretamente à ação ${ }^{482}$. De fato, o domínio prático marca o fator diferencial do silogismo prático em relação ao silogismo científico.

$\mathrm{Na}$ Ética, Aristóteles enfatiza algumas diferenças crucias do silogismo prático: (a) o princípio (arché) do silogismo prático se refere ao objetivo final ou o ‘bem' da ação “dado que o fim e o que é melhor (kaì télos kaì tò áriston) é desse tipo" (1144a29-33); (b) se o silogismo 'demonstrativo' está voltado às 'coisas inalteráveis' e 'eternas', o silogismo prático concerne ao que "pode ser de outro modo" e a tudo relacionado ao campo de produção ou ação humana (1139b18114a6); (c) ao invés da pura afirmação da conclusão, a conclusão do silogismo prático deve resultar em uma ação, dadas certas condições físicas e psicológicas da ação (1147a25-30). Diante dessas características do silogismo prático, notamos diferenças cruciais com a concepção de inferência imperativa de Hare.

A noção 'inferência prática' de Hare não segue os mesmos princípios do 'silogismo prático' de Aristóteles. Dentro dessa perspectiva, pretendemos destacar essas diferenças em três aspectos fundamentais: (1) a categoria lógica deôntica de Hare; (2) a precisão das 'normas práticas' de Hare e a premissa universal peculiar do silogismo prático; (3) a analogia do silogismo teórico e o silogismo prático de Aristóteles e a aplicação lógica da inferência prática de Hare. Dessa forma, analisaremos primeiro a categoria lógica deôntica da inferência imperativa.

Em primeiro lugar, a categoria lógica deôntica de Hare não comporta a categoria lógica do desejo-fim de Aristóteles. Como indica Barnes (1977, p. 211217), o silogismo prático exibe uma lógica do desejo 'orético' distinta da lógica deôntica moderna. Nesse aspecto, Barnes ressalta que a lógica 'orética' tem como ponto de partida o conteúdo proposicional do próprio desejo humano “desejar, é

\footnotetext{
${ }^{482}$ Cf. EN VII 3 1147a1-10; 25-30; De Anima III 11. De fato, os exemplos de Aristóteles nem sempre são apropriados às regras lógicas estabelecidas na estrutura do silogismo prático. Na sequência, daremos destaque a algumas dessas inadequações.
} 
desejar que qualquer coisa se passe" (itálicos do autor) ${ }^{483}$. Por sua vez, a lógica deôntica é muito restritiva pois apenas assimila um esquema lógico predeterminado ao modelo das normas práticas. Dessa forma, a lógica do desejo-fim de Aristóteles marca a formulação da premissa universal do silogismo prático.

Em segundo lugar, a 'premissa universal' do silogismo prático não coincide com a precisão das 'normas práticas' de Hare. Com efeito, a 'premissa universal' nem sempre contém a forma lógica tradicional do quantificador universal 'Todos' (as) ou 'Nenhum' (a). Embora a Ética mostre alguns exemplos adequados à forma lógica clássica do silogismo, os exemplos de De Motu são mais simplificados em vista da esfera animal (cf. ENVI 7-8, ENVII 3/ De Motu 7 701a 10-24). Como vimos anteriormente, os exemplos de De Motu exibem o 'princípio' do desejo orético do agente na 'premissa universal' e não 'normas práticas' absolutas da ação.

As 'normas práticas' predeterminadas não tem lugar na natureza prática e contingente do ensino moral da Ética. Como ressalta Nussbaum (1978), as 'regras práticas' do silogismo prático aristotélico não procedem da implicação lógica de princípios práticos a priori, mas de sua utilidade prática na orientação geral da ação com base em um ideal concreto de excelência moral ${ }^{484}$. De fato, Aristóteles reconhece a imprecisão inerente dos assuntos morais na Ética: "os assuntos envolvidos na ação e nas coisas benéficas (en taîs práxesin kaì symphéronta) nada tem de fixo, assim como os assuntos que concernem à saúde." (1104a1-5) ${ }^{485}$. Diante dessa imprecisão inerente à matéria da Ética, compreendemos melhor as diferenças fundamentais do silogismo teórico e o silogismo prático.

Em terceiro lugar, a analogia do silogismo teórico e do silogismo prático demarca uma diferença fundamental da 'inferência prática' de Hare. Ao contrário de Hare, Aristóteles não admite que a 'verdade' ou a 'satisfação' lógica seja suficiente (isoladamente) para a eficácia do raciocínio prático. Para Aristóteles, a excelência da razão prática consiste na integração do raciocínio verdadeiro e o desejo correto: “da parte prática e intelectual (tô̂ praktikoû kaì dianoetikoû) o bom

\footnotetext{
${ }^{483}$ Cf. Ibid., p. 214: "De plus, la discussion nous introduit à un autre sujet de recherche: la logique orectique. Cette logique, qui est à mon avis beaucoup plus important que la logique pratique, est aujourd'hui presque inconnue: je me permets de vous suggérer qu'Aristote en a été le fondateur." ${ }^{484}$ Cf. Ibid., p. 211: "Aristotle urges agents not themselves practically wise to adopt a general principle based upon the particular choices of agents generally agreed to be competent; a rule can be a guide for moral learning and a tool for securing orderly behavior in those who, for whatever reason, have not attained full virtue."

${ }^{485}$ Ver também outras passagens que reconhecem a imprecisão da natureza prática da ética $E N$ I 3 1094a25-27, EN I 7 1098a20-30
} 
estado é a verdade em acordo com o desejo correto (alétheia homólogos échousa têi oréxei tei orthei)." (1139a30-32). Por isso, o silogismo prático depende de condições 'físicas' e 'psicológicas' do agente na ação, estando 'em seu poder' e 'sem ser forçado nem impedido' (cf. ENVII 3 1147a26-30/ cf. De Motu 701a1516). Dessa forma, o silogismo prático assimila a contradição prática entre o raciocínio verdadeiro e a ação moral errada. No precritivismo moral, a ação moral errada impele a uma revisão completa do próprio 'significado' do juízo moral do agente. Em verdade, a ação moral em si mesma não parece ser um critério adequado para compreender a razão prática humana. Diante disso, o 'silogismo prático' aristotélico exibe as próprias inconsistências do prescritivismo moral de Hare.

Dentro da Ética de Aristóteles, o campo da ação humana exige mais precisão no domínio contingente dos fatos particulares do que nos fatos universais:

nos discursos relativos às ações (en toîs perì tàs práxeis lógois), os universais são mais amplos, ao passo que os que concernem as partes atingem mais a verdade: com efeito, as ações dizem respeito às coisas particulares (perì tà kath'hékasta hai práxeis), devendo harmonizar-se a elas. (ENII 7 1107a25-30)

O silogismo prático tem uma aplicação abrangente no campo produtivo dos fatos particulares da ação humana. No entanto, a tradição analítica costuma ignorar o papel secundário do silogismo prático no campo amplo da razão prática ${ }^{486}$. No campo prático, os fatos particulares têm prioridade sobre os fatos universais no exercício do raciocínio prático. Dentro da Ética, o ‘silogismo prático’ em qualquer esfera prática visa igualmente ao 'bem' da ação humana.

O 'silogismo prático' é aplicado indistintamente ao domínio da conduta moral e ao domínio técnico, da medicina à construção civil, integrando a ampla esfera prática da ação humana (ENVI 7-8/ De Motu 7). No entanto, toda ação humana, seja moral ou produtiva, tem em vista um objetivo final, o 'bem' relativo a cada esfera prática no domínio humano. De fato, isso é totalmente plausível na perspectiva da ética das virtudes de Aristóteles.

Assim como em outras esferas do campo produtivo humano, o aperfeiçoamento ético depende do exercício complementar do raciocínio prático

486 Cf. BERTI, 1997, p. 227: “o silogismo prático, em Aristóteles, é apenas um aspecto muito particular e, tudo somado, secundário daquela que poderia se denominar a "racionalidade prática" (..) Contudo, o aspecto mais importante é, para Aristóteles, a discussão acerca do fim, isto é, do bem, a qual compete a filosofia prática verdadeira (..)." 
correto e a prática da virtude moral. Invariavelmente, Aristóteles e Hare reconhecem igualmente o valor prescritivo do raciocínio prático, isto é, na orientação da ação moral. No entanto, Aristóteles mostra ter consciência das limitações da eficácia prática do silogismo prático na condução da ação moral. Resta saber, se Hare também reconhece as limitações da eficácia prática do prescritivismo moral em sua 'inferência imperativa'.

A própria 'fraqueza moral' coloca em xeque a eficácia prática do prescritivismo moral de Hare. De fato, a fraqueza moral constitui uma forte objeção aos princípios do prescritivismo moral. Na sequência, deveremos nos ocupar com o problema da fraqueza moral e seus desdobramentos à consistência do prescritivismo moral de Hare.

\section{5}

\section{A fraqueza moral e o sentido 'entre aspas' de dever (ought)}

Até aqui, nos ocupamos com a eficácia do prescritivismo moral de Hare. De forma geral, relatamos casos genéricos em que a precritividade do juízo moral determina com sucesso a implicação lógica entre princípios morais e ações morais. Em todos esses casos, o 'dever' (ought) moral implica no 'poder' (can). No entanto, há evidentemente casos mais complexos em que o 'dever' não implica no 'poder', isto é, casos em que ocorre uma falha na prescritividade do juízo moral. Nessas circunstâncias, a fraqueza moral coloca em xeque o prescritivismo moral de Hare.

O desafio da fraqueza moral reforça o descritivismo contra os princípios do prescritivismo moral. Para Hare (1996, 11.1, p. 175), a falha da prescritividade pode indicar que não há qualquer diferença entre juízos de valor e afirmações de fato: "pode-se sustentar que os juízos de valor são orientadores da ação num sentido não mais forte que essas afirmações de fatos". Como vimos, Hare defende uma posição diametralmente oposta acera do internalismo do juízo de valor na linguagem moral, ou melhor, de que o juízo moral implica necessariamente na realização da ação moral. De certa forma, a primeira posição representa o descritivismo dos juízos de valor e a segunda posição reflete o precritivismo moral.

Se o descritivismo assinala a um tipo de externalismo dos juízos de valor, o prescritivismo moral defende uma forma de internalismo dos juízos morais na ação 
moral. No prescritivismo moral, os juízos morais autênticos apresentam uma implicação lógica necessária na realização da ação do agente. Para o descritivismo, por outro lado, não há qualquer conexão lógica especial entre os juízos de valor e a ação moral, de tal forma que juízos de valor expressam apenas a descrição factual das qualidades das ações morais ou do caráter moral. Contra o descritivismo, Hare precisa resguardar o precritivismo moral contra os casos complexos de 'dever' mas não 'poder', sobretudo a fraqueza moral ou 'retração' (backsliding) ${ }^{487}$. A estratégia fundamental de Hare consiste em um tipo de negação absoluta da fraqueza moral.

A resposta de Hare ao desafio da fraqueza moral apresenta diferentes descrições de 'dever' mas não 'poder'. Em linhas gerais, a negação da fraqueza se apoia basicamente na substituição do uso primário prescritivo pelo uso secundário descritivo de 'dever' (ought) e outros termos valorativos, como observamos em A Linguagem da Moral e Freedom and Reason. Para Hare, os diversos casos típicos da fraqueza, na realidade, correspondem a outros tipos de fenômenos: (1) o uso indevido 'entre aspas' (inverted-commas) de 'dever' (ought), em que se encontram a hipocrisia e o 'autoengano' (self-deception); (2) a compulsão psicológica, ligada a um forte impulso irracional (ou, em sua própria perspectiva, o que seria equivalente à akrasia antiga). Em Moral Thinking, Hare insere a fraqueza definitivamente na classificação geral dos conflitos de princípios morais intuitivos fora do campo superior dos princípios morais efetivamente prescritivos.

Ao final, o prescritivismo moral revela as inconsistências fundamentais da redução da fraqueza de vontade a um problema moral, restrito ao mero conflito de deveres morais. Dentre os casos mencionados, Hare não apresenta nenhum caso que contempla a experiência da fraqueza de vontade. A negação da fraqueza moral resulta da preservação do prescritivismo moral e da eficácia lógica da inferência prática na ação moral. Em especial, o problema genuíno da fraqueza de vontade tende a desaparecer diante da descaracterização da irracionalidade inerente ao fenômeno original. Primeiramente, precisamos analisar a primeira descrição

\footnotetext{
${ }^{487}$ Em $F R$, os casos de fraqueza moral são classificados de forma geral pelo termo 'retração' (backsliding). A partir dessa obra, Hare busca classificar o fenômeno pelos critérios da psicologia moral saindo da pura análise analítica da linguagem moral de A Liguagem Moral. Basicamente, a ideia central se refere à retração perante os princípios morais do prescritivismo moral expressa na ação do agente. Como veremos, há dois tipos de retração dos princípios morais, a 'retração proposital' (purposive backsliding) e a retração inconsciente do 'autoengano' (self-deception). Dentro dessa nova abordagem, a descrição psicológica da fraqueza moral fica bem mais explícita.
} 
fundamental de Hare da fraqueza moral, o uso indevido 'entre aspas' (invertedcommas) do dever moral.

Em Linguagem da Moral, Hare pretende mostrar que certos casos típicos da 'fraqueza moral' refletem apenas juízos morais mal fundamentados no sentido secundário descritivo de 'dever' (ought). Se o prescritivismo moral estabelece a conexão lógica necessária entre juízos morais e ações morais, a manifestação de juízos morais sem as ações correspondentes só pode decorrer da falta de prescritividade dos termos morais. Ao invés de exibirem o sentido primário prescritivo, os termos morais são utilizados em seu sentido secundário descritivo ${ }^{488}$. Em LM, Hare (1996, 11.1, p. 177) ressalta que os termos morais, como 'dever' (ought), podem ser colocados, por assim dizer, em um sentido 'entre aspas' (inverted-commas sense):

se um homem não tem intenção de fazer o que deve (...), isso meramente mostra que, na medida em que aceita que deve fazer tais e tais coisas (e, claro, nenhuma premissa permite uma conclusão a menos que seja aceita), ele o aceita somente num sentido não-avaliatório, entre aspas (inverted-commas sense), como significando que tais e tais coisas enquadram-se numa classe de ações geralmente considerada (generally held) (mas não por ele) obrigatórias, que implica imperativos. (itálicos do autor)

Em casos como o relatado acima, o termo 'dever' (ought) não expressa um comando prático, no sentido avaliatório, mas simplesmente expressa uma afirmação de fato. Não há nenhum problema aqui com a forma da inferência prática, mas apenas com seu conteúdo efetivo, isto é, o significado dos termos morais.

Como vimos anteriormente, o assentimento sincero ao comando prático do juízo moral implica necessariamente na realização da ação moral. No sentido prescritivo, a conclusão expressa no conteúdo proposicional do comando prático deriva logicamente das premissas assentidas pelo agente. No sentido 'entre aspas' (inverted-commas sense) não-avaliatório, os juízos morais não expressam a prescritividade universal necessária para a ação.

Em FR, Hare (1963, 4.2, p. 53) sustenta que o assentimento do agente não envolve mais a crença na prescritividade universal de seu juízo moral, mas apenas

\footnotetext{
${ }^{488}$ Cf. Idem, 1963, p. 75-76: "The human word 'ought' (...) not only faces both ways in the sense of having both descriptive and prescriptive menaning (...) but can sometimes look in the direction that suit's its user interests, and bury its other face in the sand."
} 
uma crença em sua prescritividade geral: "He is, that is to say, prescribing in general terms, but exempting himself because of the impossibility, in his case, of obeying this general prescription.”. De acordo com a prescrição universal, o princípio moral do dever é válido universalmente a todos os agentes humanos dentro das mesmas circunstâncias de ação. Nesse sentido, a prescrição geral envolve excetuar a si mesmo da prescrição aplicável a todos os outros homens. Resta saber, então, o que distingue precisamente o sentido secundário 'entre aspas' do sentido primário prescritivo usual dos termos morais.

Em $L M$, Hare estabelece parâmetros preliminares para distinguir os juízos morais genuínos dos juízos morais entre aspas. Para termos maior clareza sobre essa distinção, exemplificaremos a seguir três tipos de sentenças morais com significados proposicionais bem distintos ${ }^{489}$ :

(1) 'Tenho a obrigação social de respeitar o próximo e dizer a verdade' (em conformidade a um padrão social - fato social)

(2) 'Tenho o sentimento de que devo dizer a verdade' (fato psicológico)

(3) 'Devo dizer a verdade' (juízo de valor)

Diante desses exemplos, podemos distinguir, portanto, três significados distintos dos termos morais. Nos casos relatados acima, a mesma máxima 'dizer a verdade' aparece nas sentenças morais com significados distintos. Apenas no caso (3) dispomos de um juízo moral prescritivo no sentido primário, enquanto os casos (1) e (2) exibem o sentido 'entre aspas' não-avaliatório.

Os termos avaliatórios ou morais, como presentes nas sentenças (1) e (2), não expressam rigorosamente juízos de valor, mas apenas afirmações de fato. De início, o caso (1) expressa a mera conformidade a padrões sociais, sejam estas obrigações religiosos ou culturais, ligados a certa comunidade (fato social). Em seguida, o caso (2) expressa um 'sentimento' (feeling), uma motivação pessoal de obrigação (fato psicológico) (cf. LM, 1996, p. 178-179; FR, 1963 p. 52-54). Para Hare, essa 'elasticidade' (elasticity) dos termos avaliatórios nos fornece a possibilidade de, por vezes, assumir seu sentido descritivo no primeiro plano em lugar do sentido prescritivo primário deixado em segundo plano ${ }^{490}$. Assim, a ação

\footnotetext{
489 Foi necessário fazer uma adaptação nos exemplos de sentenças morais apresentadas em $A$ Linguagem da Moral (1996, p. 179), sem perder de vista o significado da distinção original de Hare. Eventualmente, o meu propósito fundamental é apenas exemplificar de forma preliminar os diferentes sentidos possíveis do uso dos termos morais em diferentes tipos de proposições morais. ${ }^{490}$ Cf. Ibid., p. 181: "O problema [da fraqueza de vontade] surge porque nossos critérios, no discurso comum, para dizer "Ele pensa que deve" são muitíssimo elásticos."
} 
moral não é realizada porque não há o comprometimento efetivo do agente com o 'melhor juízo' ou o juízo moral.

O emprego de ought (dever) 'entre aspas' ocorre sob duas classificações diferentes em LM: (1) um 'uso consciente' (consciously) de aspas que representa a conveniência social; (2) um 'uso inconsciente' (unconsciously) de aspas que constitui um fato psicológico (Ibid., 11.2, p. 177-179). Nesses termos, o uso consciente das aspas descreve um fato sociológico tal que ' $x$ é necessário segundo um padrão social aceito de forma geral em certa comunidade', enquanto o uso inconsciente descreve um fato psicológico como 'Tenho um sentimento que 'devo fazer $x$ '. Nenhum dos dois usos coincide com o juízo de valor absoluto 'Devo fazer $x$ '. No entanto, o uso consciente das aspas parece criar menos dificuldades do que o uso inconsciente das aspas em relação ao 'dever' moral.

O sentido consciente das aspas remete a um padrão social claro e objetivo da comunidade linguística dentro da qual estamos inseridos. Segundo Hare (1996, 7.5, p. 134), o desvio das normas sociais comuns pode expressar um "emprego convencional" das aspas: "no qual o falante meramente sustenta uma convenção da boca para fora (...) simplesmente porque todas as outras pessoas fazem o mesmo". Nessas circunstâncias, o padrão social pode ser tão rígido e estável na comunidade linguística que chega ao ponto de tornar o significado dos termos morais 'ossificado' (ossified), isto é, leva o significado avaliatório primário a perder sua força em vista da fixidez do significado descritivo secundário (Ibid., p. 155-156).

O emprego convencional consciente das aspas pode ser facilmente detectado a partir do padrão social objetivo da comunidade linguística. Entretanto, o uso inconsciente das aspas expressa um fator psicológico que não pode ser detectado por parâmetros exclusivamente linguísticos. Posteriormente, Hare classifica o primeiro tipo de uso das aspas como um tipo de 'hipocrisia insincera' ou 'retrocesso proposital' (purposive backsliding) e o segundo tipo como um tipo de 'autoengano' (self-deception) em FR (Cf. 1963, p. 82-83).

Certamente, o primeiro caso não representa um grande desafio ao prescritivismo moral. De um lado, a insinceridade implica apenas que o agente não está sinceramente comprometido a obedecer ao comando prático em sua prescritividade universal, isto é, ele está explicitamente eximindo a si mesmo da necessidade de obediência moral. De outro lado, a própria linguagem moral acomoda a possibilidade de substituição do sentido prescritivo primário pelo 
sentido secundário descritivo. No entanto, o segundo caso é mais complexo porque o agente pretende adotar com sinceridade o uso prescritivo de 'dever', embora não tenha consciência de que não está aplicando o sentido primário prescritivo universal. Assim como o autoengano, a fraqueza moral depende de uma análise mais profunda da psicologia moral humana.

Para dar conta dos tipos de fraqueza moral, Hare precisa ultrapassar os estreitos limites da linguagem moral e prosseguir à uma análise da psicologia moral. No limite, A Linguagem da Moral apenas reconhece que há casos em que o agente 'pensa que deve fazer $x$ ' mas não realiza a ação $x$, isto é, usos não-avaliatórios de dever (ought). Em Freedom and Reason, Hare apresenta uma classificação de diversos tipos de fenômenos psicológicos que representam uma falha da prescritividade moral. Novamente, o sucesso do prescritivismo moral depende de uma resposta satisfatória ao desafio da fraqueza moral.

\section{6 \\ A classificação da fraqueza moral: os casos de autoengano e da compulsão psicológica}

A Linguagem da Moral revela que há casos nos quais os termos morais ou avaliatórios, como 'dever' (ought), não implicam na realização da ação moral. Nesses casos, o emprego do termo 'dever' (ought) expressa um sentido descritivo 'entre aspas' destituído de prescritividade universal. No entanto, Linguagem da Moral deixa de oferecer qualquer descrição mais detalhada ou aprofundada sobre a dimensão psicológica da fraqueza moral. A fraqueza moral permanece sendo um desafio fundamental aos princípios do prescritivismo moral. A partir de Freedom and Reason, Hare fornece uma classificação mais detalhada dos diversos tipos de fraqueza moral.

Os diversos tipos de fraqueza moral descritos estão intimamente conectados à negação absoluta da fraqueza moral. Em última instância, Hare está comprometido a mostrar que não há fraqueza moral visto que nenhum dos casos reputados do fenômeno se refere efetivamente aos princípios morais prescritivos. Com efeito, não pretendemos analisar todos os casos relatados de fraqueza moral mas precisamos, ao menos, tratar dos mais desafiadores ao prescritivismo moral de Hare. 
Ao longo de suas obras, Hare fornece diversas descrições diferentes dos casos reputados de fraqueza moral. Sobretudo, devemos analisar a seguir o autoengano e a compulsão psicológica que representam um grande desafio ao prescritivismo moral em Freedom and Reason. De qualquer forma, nos limitaremos agora a fornecer uma listagem preliminar dos casos de fraqueza moral mais complexos reunidos nos diversos textos de $\mathrm{Hare}^{491}$ :

(1) a hipocrisia insincera ou o retrocesso proposital (purposive backsliding). Em sentido absoluto, o agente afirma 'devo fazer $x$ ' mas isso não coincide com o que ele realmente pensa ou the falta 'convicção moral completa' (complete moral conviction) no princípio moral. Em sentido qualificado, o agente pode afirmar 'devo fazer $x$ ' excetuando-se a si mesmo no sentido descritivo do padrão social vigente. (LM 11.1)

(2) o autoengano (self-deception) ou retrocesso inconsciente. Nesse caso, o agente afirma 'devo fazer $\mathrm{x}$ ' no sentido descritivo expresso pelo sentimento (feeling) de obrigação (acompanhado de remorso ou culpa). (LM 11.2/ FR 5.6)

(3) a impossibilidade física. O agente afirma 'devo fazer $x$ ' mas não the ocorre que não está realmente em seu poder (can) fazer $x$. (FR 4.5)

(4) a impossibilidade psicológica. $O$ agente afirma 'devo fazer $x$ ' embora a presença de um impulso psicológico lhe impeça de fazer x. (FR 5.7)

(5) a ignorância da prescrição particular da ação. O agente afirma 'devo fazer x' e falha em aplicar a prescrição moral no seu próprio caso particular presente. (na visão de Hare, essa seria a descrição aristotélica do fenômeno).

A partir dessa listagem geral, podemos destacar os casos que realmente representam um desafio ao prescritivismo moral. Em primeiro lugar, há diversos casos que já podem ser descartados simplesmente por não satisfazer as relações lógicas necessárias da prescritividade do juízo moral e a ação moral, a máxima 'dever (ought) implica poder (can)'. De acordo com a máxima, a situação moral da possibilidade da ação moral ao alcance do agente necessariamente suscita a 'questão' interna sobre seu 'dever' moral. Com base nesse critério, o caso (3) é automaticamente descartado, simplesmente porque a ausência do alcance físico do 'poder' (can) inviabiliza a emergência do 'dever' (ought) ao próprio agente. De

\footnotetext{
${ }^{491}$ A listagem mais completa dos possíveis casos de fraqueza moral está reunida no artigo Weakness of Will, 1999, cap. 9, p. 111-113; ver também FR, 1963, 5.9, p. 82-83; MT, 1981, p. 57-60. Por conta do espaço limitado, apenas reuniremos aqui uma listagem mais modesta composta apenas dos casos mais relevantes de fraqueza moral que efetivamente representam uma ameaça ao prescritivismo moral de Hare.
} 
acordo com Hare, (1963, 4.3. p. 56) a ausência da questão prática no domínio do 'poder' do agente inviabiliza o 'dever' moral: "there is no point in asking the 'ought'- question when the practical question does not arise.". Da mesma forma, a insinceridade absoluta do agente apenas indica que não há qualquer assentimento sincero ao comando prático da ação moral. Em ambos os casos, não há sequer um problema filosófico da fraqueza moral em pauta.

Como observamos, a hipocrisia insincera (1), expressa no sentido descritivo do padrão social geral, não representa rigorosamente qualquer desafio ao prescritivismo moral. Simplesmente, o agente troca o sentido prescritivo de 'dever' pelo sentido descritivo secundário, sem constituir qualquer fenômeno psicológico. Em geral, essas descrições mais simples dispensam uma análise mais aprofundada da psicologia moral do agente como as outras descrições do fenômeno exigem.

Ao contrário das descrições anteriores, os casos relatados em (2), (4) e (5) um fator adicional além da mera análise pragmática dos usos indevidos de 'dever'. Em especial, o suposto caso da descrição aristotélica do fenômeno (5) remete ao problema central dos conflitos morais destacado na próxima seção. Por enquanto, os casos (2) e (4), o autoengano e a impossibilidade psicológica, realmente representam um desafio ao prescritivismo moral. Ambos os fenômenos psicológicos são analisados de forma mais detalhada em $F R$.

O problema da fraqueza moral reaparece sob um ângulo diferente em Freedom and Reason. Dessa vez, Hare pretende examinar principalmente dois tipos específicos do fenômeno, os casos (2) e (4), que não podiam ser contemplados na análise linguística do 'dever' de Linguagem da Moral. Na realidade, esses casos de fraqueza moral representam um risco ainda maior ao prescritivismo moral do que os outros casos mencionados. Diante disso, devemos analisar primeiro o 'autoengano' (self-deception) antes de prosseguir ao caso mais complexo da impossibilidade psicológica.

O caso do autoengano reflete ainda o exame do sentido descritivo secundário 'entre aspas' de 'dever' (ought) apresentado em LM. Da mesma forma, a universalidade prescritiva original dá lugar à prescritividade geral descritiva do termo ought em sentenças morais. Entretanto, Hare (1963, 5.6, p. 76-77) ressalta mais o papel psicológico do "sentimento (feeling)" da culpa na formação do autoengano do agente em $F R$ : 
To restore the appearance of prescriptive universality, we substitute, in our own case, for genuine prescriptiveness, a mere feeling, varying in strength, that we are not playing our part in the scheme which we claim to be accepting (...) This feeling is called a guilty conscience. (itálicos do autor)

$\mathrm{O}$ "sentimento (feeling)" de "culpa consciente (guilty conscience)" toma o lugar, virtualmente, da prescritividade universal genuína do princípio moral. Ao contrário da descrição anterior de $L M$, a culpa consciente substitui temporariamente o sentido prescritivo original do princípio moral relegado ao inconsciente do agente no momento da ação. Na verdade, Hare ressalta que o agente sequer nota o uso inapropriado de 'dever': "he has escaped his own notice using 'ought' in an offcolour way" (Ibid., p. 83). Nesses termos, a desobediência do princípio moral no autoengano sequer chega à consciência do agente no momento da ação. Após a ação, o sentimento de culpa apaziguado na consciência do agente permite a restauração da prescritividade universal do princípio moral e a exortação da ação moral. De qualquer forma, o sentimento de culpa persiste no interior do agente para recordá-lo do princípio moral que deveria estar sendo aplicado na ação.

O autoengano acompanha um tipo de sentimento moral expresso na fraqueza moral do agente. Em $M T$, Hare afirma ainda que tal sentimento moral se trata mais de um tipo de "compunção (compuction)" persistente ao longo da falha moral do agente do que um mero "arrependimento (regret)" posterior à ação ${ }^{492}$. Independente da classificação, o que importa aqui realmente é a explicação da falha moral do agente a partir do efeito psicológico do sentimento moral. Tal como Platão e Aristóteles, Hare reconhece o papel especial da educação moral na formação desses sentimentos morais na conduta moral do agente ${ }^{493}$. Em especial, a presença do sentimento de culpa no agente transmite a aparência da prescritividade universal do juízo moral. No entanto, o que ocorre, na realidade, é a desobediência do

\footnotetext{
492 De acordo com Hare, o sentimento de 'compunção' (compuction) difere substancialmente do mero 'arrependimento' (regret): (1) o arrependimento expressa um sentimento 'não-moral' que nos aflige apenas após a ação enquanto a compunção é um sentimento moral mais prolongado ao longo da ação; (2) a compunção geralmente é um sentimento mais atenuado e menos forte do que o arrependimento (cf. $M T, 2.2,1981$, p. 28-31). Por essas razões, a compunção tem maior valor para $\mathrm{o}$ aprendizado moral do que o simples arrependimento.

${ }^{493}$ Nessa perspectiva, Hare (Ibid., p. 31) salienta o valor do sentimento de culpa na formação da psicologia moral do agente: "there is no doubt that the most of us have, during our upbringing, acquired these sentiments, and not much doubt that this is, on the whole, a good thing, (...). So then, if I felt guilty, it looks like as if there is a sense of 'thinking that I ought' in which I could have been correctly described as 'thinking that I ought not to be telling a lie'. Feeling guilty is inseparable from, in this sense thinking that I ought not."
} 
princípio moral refletida na falha moral. Durante o autoengano, o termo 'dever' apenas expressa o sentimento psicológico da culpa do agente e promove a crença ilusória da obediência do princípio moral.

Nesses termos, o autoengano não atinge os princípios fundamentais do prescritivismo moral. Como veremos posteriormente, a descrição do autoengano é crucial sobretudo na explicação final decisiva do conflito moral de deveres. Dessa forma, devemos desconsiderar o autoengano por enquanto e analisar em seguida o caso da compulsão psicológica Ao contrário dos casos anteriores, o caso (4) da impossibilidade psicológica parece representar um autêntico caso de 'dever', mas não 'poder'. Para isso, devemos nos concentrar sobre a análise da compulsão psicológica presente em FR (cf. HARE, 1963, p. 77-82).

Para Hare, a impossibilidade psicológica representa o fenômeno denominado de akrasia pelos gregos ou, em outras palavras, a fraqueza de vontade nos termos atuais. Como logo observamos, Hare não está se referindo aqui ao conflito cognitivo-motivacional entre a razão e os apetites irracionais que havíamos classificado anteriormente de akrasia antiga. Rigorosamente, Hare acaba confundido a akrasia grega com um tipo particular de fraqueza de vontade. $\mathrm{Na}$ realidade, até seus exemplos, como o forte impulso erótico da Medéia por Jasão em Metamorfoses $(7,20)$ e a tentação de São Paulo pelo pecado (Romanos 7$)^{494}$, ilustram um tipo peculiar de fraqueza passiva, isto é, um forte impulso psicológico que leva à ação contrária ao juízo moral do agente. Ao contrário do caso anterior, o agente efetivamente possui o princípio moral prescritivo mas não consegue exercêlo em sua ação. Em ambos os contextos, Hare (FR, 1963, p. 79) destaca que a impossibilidade psicológica do agente explica a desobediência do imperativo moral: "It is not in Medea's power or St. Paul's psychological power to act on the imperatives that are entailed by the moral judgements (...)”. Com essa descrição

\footnotetext{
${ }^{494}$ A escolha desses exemplos em $F R$ é, no mínimo, curiosa. Como observamos anteriormente, a personagem Medéia de Eurípides não sofre da mesma tentação erótica expressa nos versos de Metamorfoses de Ovídio. Na Medéia de Eurípides, a personagem é resoluta em relação a seu objetivo de assassinar seus próprios filhos e vacila apenas no momento derradeiro da ação por causa de seu impulso materno mais brando. Dessa forma, o exemplo da Medéia de Metamorfoses reforça a tese da impossibilidade psicológica do agente de tal forma que a personagem homônima de Eurípides não é apropriada. Da mesma forma, o caso de São Paulo é especialmente conveniente para retratar a condição submissa do homem moral perante a tentação ao pecado. Ao final, ambos os exemplos de Hare refletem a submissão completa do agente ao forte impulso irracional e reforçam então a ideia da compulsão psicológica.
} 
peculiar da akrasia, Hare pretende eliminar mais um caso de fraqueza que supostamente desafia seu prescritivismo moral.

Ao analisarmos melhor a descrição de Hare da akrasia ou fraqueza, constatamos que o fenômeno não constitui qualquer objeção ao prescritivismo moral. Com efeito, Hare sustenta que há uma analogia entre a impossibilidade psicológica da fraqueza e a impossibilidade física da ação. Durante a impossibilidade física, o comando prático fica, por assim dizer, "retraído (withdraw)" simplesmente porque não há o alcance físico necessário para a realização da ação. Como vimos, a ausência da questão prática do 'dever' implica na ausência do próprio comando prático na ação moral.

A retração do princípio moral na impossibilidade física permite explicar a falha moral da impossibilidade psicológica. Segundo Hare (1963, p. 80), a akrasia é análoga ao recuo do princípio moral em face do impedimento físico da ação: "um dever (ought) não precisa ser retraído (withdraw) mas apenas rebaixado (downgraded).”. Em verdade, o princípio moral pode manter sua prescritividade universal, mesmo que isso não se aplique em seu caso particular por conta do rebaixamento do princípio moral. Por mais que a força de vontade do agente seja revitalizada em alguns casos, nada assegura que isso ocorrerá em todos os casos de impossibilidade psicológica: "the cases we have been considering may be supposed to lie beyond the reach of such help on the part of fellow humans (...)." (Ibid., p. 81). Para todos os efeitos, a fraqueza passiva deixa o agente inteiramente submisso aos impulsos irracionais.

A fraqueza passiva nada mais seria do que uma forma de compulsão psicológica, a submissão absoluta da razão diante de fortes impulsos irracionais. Dessa forma, a compulsão psicológica se acomoda à descrição geral do uso indevido descritivo de 'ought' mas pode, inclusive, ser explicada pela metáfora da personalidade dividida. Em especial, Hare ressalta que essa influente metáfora marca o combate interno entre dois oponentes psicológicos no interior do agente: "the person (...) is actually giving commands to himself but unable to obey them because of a recalcitrant lower nature or 'flesh' (FR, 1963, p. 81). Por isso, o conflito psicológico da razão e dos desejos corporais em ambos os casos de compulsão psicológica representa a possibilidade de revogação dos princípios morais pelos fortes impulsos irracionais. De acordo com o prescritivismo moral, todos os casos mencionados anteriormente envolvem princípios morais revogáveis. 
Ora, parece que nenhum dos casos (1)-(5) acima mencionados contempla efetivamente a fraqueza de vontade. Curiosamente, a lista dos tipos de fraqueza apenas exibe uma série de fenômenos irracionais diferentes que jamais correspondem ao fenômeno original. Na realidade, o desafio do prescritivismo moral envolve apenas a análise central do fenômeno da fraqueza moral. Para todos os efeitos, a preservação do prescritivismo moral exige a negação absoluta da descrição tradicional da 'fraqueza de vontade'. Como veremos adiante, a redução ao campo moral acaba reduzindo o conflito psicológico característico do fenômeno a um problema geral dos conflitos morais.

\section{7 O conflito moral e a fraqueza moral}

A negação absoluta da fraqueza moral apresenta sua formulação mais decisiva na última obra sistemática de Hare, Moral Thinking. O problema da fraqueza moral é, enfim, classificado dentro do dilema geral do conflito moral. Dentro dessa perspectiva, Hare alega que todos os casos de fraqueza moral podem ser encarados como um genêro de conflito de princípios morais intuitivos.

Ao longo de $M T$, Hare fornece uma descrição final da fraqueza moral com base na divisão de dois planos da reflexão moral de $M T$, 'o nível intuitivo e o nível crítico do pensamento' (intuitive and critical thinking). Em linhas gerais, a divisão dos níveis de pensamento moral decorre de dois tipos de princípios morais: o nível intuitivo opera com princípios morais intuitivos e contingentes, enquanto o nível crítico abrange princípios morais absolutos e universalmente válidos. A partir dessa divisão, Hare afirma que a fraqueza moral constitui essencialmente um tipo de conflito de deveres morais incompatíveis, derivado da 'sobreposição' (overridingness) dos princípios morais do nível intuitivo. Para compreendermos isso, precisamos antes esclarecer a distinção fundamental de dois níveis de pensamento moral.

A distinção do nível intuitivo e do nível crítico do pensamento moral pretende manter a consistência do prescritivismo moral diante dos conflitos morais ordinários, como a fraqueza moral. Nessa perspectiva, a maior parte dos problemas 
acerca da moralidade envolvem a falta de uma distinção adequada entre esses dois níveis de pensamento moral.

Em primeiro lugar, o nível intuitivo abrange princípios morais intuitivos prima facie compartilhados pelos valores morais do meio social em que estamos inseridos. Para Hare (1981, p. 38), esses princípios morais expressam prescrições universais constituídas desde o início da educação moral: "they are just univversal prescriptions, (...) associated, owing to our upbringing, with very firm and deep dispositions and feelings.”. Sobretudo, as disposições e sentimentos formados pelo aprendizado dos princípios intuitivos funcionam como um 'guia prático' geral do agente diante de novas situações morais contingentes (Ibid., p. 36-37). No entanto, o nível intuitivo permanece inevitavelmente sujeito ao conflito de princípios morais inconsistentes.

Além do nível intuitivo, é preciso então introduzir o nível crítico do pensamento moral isento de intuições morais substanciais: "It proceeds in accordance with cannons established by philosophical logic and thus based on linguistic intuitions only.” (Ibid., p. 40). O nível crítico do pensamento moral consegue abstrair dos conflitos morais intuitivos particulares colocando em perspectiva todos os outros casos morais similares simultaneamente. Na realidade, isso permite a formulação do juízo moral superior do 'melhor juízo' apropriado a todas as situações morais semelhantes: "no judgement will be acceptable to him which does not do the best, all in all, for all the parties." (Ibid., p. 42). O raciocínio crítico envolve não só casos morais atuais mas também avalia simultaneamente casos morais hipotéticos ${ }^{495}$. Desse ponto de vista privilegiado, o nível crítico é capaz de constituir princípios morais mais rigorosos e específicos do que os princípios gerais prima facie intuitivos ${ }^{496}$. A própria constituição do nível reflete

\footnotetext{
495 O nível crítico do pensamento moral fornece as bases do utilitarismo moral exposto em $M T$, mas já delineado desde $F R$. De acordo com Hare, a constituição dos juízos morais no nível crítico inclui a reflexão filosófica acerca dos princípios morais válidos universalmente em todas as circunstâncias morais. De alguma forma, o nível crítico consegue contemplar simultaneamente em casos atuais e casos hipotéticos dentro do mesmo contexto moral chegando ao 'melhor juízo' absoluto, ou seja, ao juízo de 'todos os fatores considerados' (all things considered). De qualquer forma, não poderemos abordar as implicações do nível critico no utilitarianismo consequencialista de Hare em maiores detalhes por conta do nosso foco atual de investigação sobre o problema da fraqueza moral.

${ }^{496}$ Cf. Ibid., p. 63: "In critical thinking the principles used can be as sepecific as required, and therefore we can use hypothetical cases exactly similar in their universal properties, and differing only in their roles played by individuals. It is only when we come to intuitive principles, guided by relatively general prima facie principles, that we need to be able to pick out the morally relevant features of the situations, so as to leave out of consideation all the other features."
} 
adequadamente o rigor sistemático do projeto do prescritivismo moral. No entanto, não há apenas uma substituição do nível intuitivo pelo nível crítico do pensamento moral, mas sim uma interação complementar sob o domínio superior do nível critico do pensamento moral.

O nível crítico é filosoficamente autojustificado e tem prioridade epistemológica sobre o nível intuitivo do pensamento moral (Ibid., p. 46). Por isso, é responsabilidade do nível crítico fazer a supervisão do nível intuitivo de dois modos: 1) selecionar os princípios morais adequados ao nível inuitivo em diferentes situações morais; 2) resolver definitivamente os conflitos morais intuitivos que permanecem insolúveis dentro do nível intuitivo (Ibid., p. 49-50). Por prioridade epistemológica, o nível crítico precisa remediar as limitações inerentes aos princípios morais do nível intuitivo. De toda forma, a fraqueza moral reside justamente na classe dos conflitos morais intuitivos que são inerentemente insolúveis.

O problema fraqueza moral aparece em meio ao dilema geral do conflito de princípios morais intrínseco do nível intuitivo do pensamento moral. Segundo Hare (Ibid., p. 53), os conflitos morais intuitivos permanecem insolúveis no nível intuitivo: "Those who insist that there can be conflict of duties are quite right as regards the intuitive level; for there can indeed be conflicts of duties which are irresoluble at that level (...)." (itálicos do autor). Dentro do nível intuitivo moral, todos os conflitos de deveres morais, tal como a fraqueza moral, se mantêm irremediavalmente insolúveis. Para Hare, a principal falha dos adeptos do intuicionismo moral é justamente ignorar a existência do nível crítico superior da reflexão moral. Os intuicionistas alegam que os conflitos morais intuitivos são insolúveis justamente porque não há nenhum princípio moral superior de segunda ordem para além dos princípios morais prima facie.

A irresolução dos conflitos morais intuitivos representa uma característica diferencial dos princípios prima facie intuitivos em relação aos princípios morais críticos. Ora, os princípios morais críticos não estão sujeitos aos conflitos insolúveis do nível inferior de reflxão moral porque não são efetivamente anulados tal como os princípios morais intuitivos. Com efeito, a ‘sobreposição' (overridingness) é um elemento inerente dos princípios morais intuitivos que não se encontra no nível crítico da reflexão moral. A introdução desse novo elemento promove uma breve revisão da doutrina oriignal do prescritivismo moral. 
A 'sobreposição' (overridingness) dos princípios intuitivos ganha destaque ao longo de $M T$. Embora $F R$ já reconheça a 'sobreposição' dos princípios morais, apenas $M T$ destaca seu papel fundamental no conflito de princípios morais intuitivos. Segundo Hare (Ibid., p. 56), a sobreposição dos princípios prescritivos pode ser classificada nos seguintes termos:

To treat a principle as overriding then, is to let it always override other principles when they conflict with it and, in the same way, let it override all other prescriptions, including nonuniversalizable ones (e. g. plain desires).

Em relação à ‘sobreposição' dos princípios prescritivos, há um componente ativo e um componente passivo simultaneamente. Para Hare (1963, p. 167-169), esse fator é fundamental dentro do conflito de princípios prescritivos: "not only we in fact act on the one and the other, but we think that we ought to act on one even tough it involves disregarding the others." (itálicos do autor). De um lado, os princípios prescritivos particulares, como simples desejos ou gostos preferenciais subjetivos, são sobrepostos ou sofrem 'sobreposição' de outras prescrições mais universalizáveis, como princípios morais. De outro lado, princípios prescritivos absolutos universais sobrepõem ou exercem 'sobreposição' integralmente quaisquer princípios prescritivos inferiores. Em certos contextos práticos, é preciso abdicar do gosto estético pessoal em vista de princípios morais superiores. Por exemplo, há situações em que não queremos desapontar as preferências tradicionais dos outros familiares ou de amigos em nome de nossas preferências pessoais. Nesse sentido, agimos conforme o princípio moral pela preferência dos outros em detrimento do princípio prescritivo estético. Em especial, o conflito moral revela que os princípios morais superiores sempre prevalecem sobre outros princípios prescritivos: "moral principles are (...) superior to or more authoritative than other kind of principle.” (Ibid., 1963, p. 169). Em última instância, a 'sobreposição' permite determinar o que ocorre nos conflitos morais em geral, como no caso da fraqueza moral.

O elemento da 'sobreposição' é a peça-chave na explicação dos conflitos morais do nível intuitivo do pensamento moral. Conforme ressalta Hare (1981, p. 59-60), os princípios morais intuitivos possuem duas características que acentuam a sobreposição: a) a formulação lógica simples e genérica de uma regra geral de ação; b) a admissão de exceções à regra geral do princípio moral. Ao longo da vida 
social ordinária, estamos acostumados a assumir simplesmente princípios morais prima facie universais, como 'Não devo mentir' ou 'Não devo quebrar promessas'. Diante das circunstâncias particulares, porém, somos levados com frequência a fazer uma revisão dos princípios morais intuitivos por conta de exceções às regras gerais iniciais: "Não devo mentir, exceto contra o inimigo em uma guerra". Tais características da 'sobreposição' dos princípios intuitivos são fundamentais para esclarecer a divisão lógica dos dois níveis de reflexão moral. Os princípios morais superiores do nível crítico possuem uma universalidade mais precisa e completa em relação aos princípios morais inferiores do nível intuitivo.

No nível intuitivo, a universalizabilidade do princípio moral permanece limitada e incompleta às regras gerais de conduta moral. Apesar de estabelecer uma regra universal de ação, o princípio moral intuitivo admite exceções e especificações à regra precritiva original. Nesse sentido, o reconhecimento de exceções aos princípios prima facie visa torná-los mais precisos e rigorosos logicamente, isto é, mais aperfeiçoados ${ }^{497}$. Ao mesmo tempo, isso deixa esses princípios intuitivos mais suscetíveis à 'sobreposição' de sua prescritividade universal na ação moral.

De acordo com Hare (1981, p. 59-60), a ‘sobreposição' dos princípios prescritivos em geral se aplica aos princípios morais intuitivos: "it is likely that a principle which has this feature of overridability will also be overriden by other non-moral precriptions". De forma geral, o efeito de sobreposição se aplica a todos os conflitos morais presentes no nível intuitivo do pensamento moral. Podemos considerar brevemente, por exemplo, o caso de um homem que mente mesmo tendo consciência do princípio 'Não devo mentir'. Embora tenha consciência desse princípio moral, ele pode deixar de agir sob o princípio moral no momento da ação por conta de outro princípio prescritivo qualquer (em vista de seu gosto estético, preferências pessoais ou desejos particulares). Com efeito, isso ocorre porque os princípios morais intuitivos são suscetíveis à sobreposição por outros princípios prescritivos. Se a fraqueza moral está no campo conflito de princípios morais intuitivos, é possível explicar o fenômeno igualmente pelo efeito de 'sobreposição'.

\footnotetext{
497 Sobre a precisão de princípios morais por meio do reconhecimento de exceções às regras universais, Hare (1996, 3.6, p. 54) assinala: "O fato de que se fazem exceções a eles [os princípios de conduta] não é sinal de alguma imprecisão essencial, mas de nosso desejo de torná-los tão rigorosos quanto possível. Pois o que estamos fazendo ao permitir classe de exceções é tornar o princípio não mais impreciso, mas mais rigoroso."
} 
Nesse ponto, Hare julga que a sua descrição final da fraqueza moral coincide, de alguma forma, com a descrição aristotélica da akrasia.

A incompatibilidade entre dois princípios morais contraditórios de Hare marca a propria recepção analítica da descrição aristotélica da akrasia. Em Weakness of Will, Hare (1999, 9.4, p. 113-114) traça suas derradeiras considerações finais sobre a fraqueza moral. Ao final, Hare insere a fraqueza moral na classe de conflitos dos princípios morais em um sentido aristotélico particular:

The problem is analogous to the problem of duties. (...) In either case, we shall act on one of the principles, and which we act reveals what we finally prescribe to ourselves. But that does not stop the principle that is not acted on remaining in our conciousness and nagging us, so that we can go on saying that we know we ought to be observing it. (itálicos do autor)

A 'fraqueza moral' ' é plenamente explicada a partir de uma analogia direta com o conflito de 'deveres' morais. Diante de um conflito moral, não podemos simplesmente agir conforme ambos os princípios morais incompatíveis. Invariavelmente, a ação deve expressar a conformidade a um princípio moral em detrimento do outro princípio moral incompatível. Nesse cenário, a ação deve enfim revelar o princípio moral que efetivamente 'prescrevemos a nós mesmos'. Simultaneamente, o princípio sob o qual não agimos pode permanecer em "nossa consciência' 'nos importunando' (nagging us). Desde MT, Hare (1981, 3. 7, p. 59) reconhece que princípios prima facie podem ser 'sobrepostos' de tal forma que ainda seria possível sustentá-los, mas sem agir sobre eles: "it is possible to go in holding them even when one does not obey them in a particular case". Na visão de Hare, o conflito de princípios morais coincidira de certa forma com a inconsciência de uma parte do silogismo prático aristotélico, relativo à premissa particular do bom silogismo (1147a32). No entanto, precisamos enfatizar então as diferenças entre a fraqueza moral de Hare e descrição aristotélica da akrasia.

A 'fraqueza moral' e a akrasia antiga certamente não representam o mesmo fenômeno. Como vimos, a 'fraqueza moral' é um conflito moral geral de princípios morais decorrente da ação contrária ao juízo moral. No entanto, a akrasia antiga reflete um conflito moral específico relacionado a um estado psicológico cognitivomotivacional do agente, o conflito do desejo racional e os impulsos irracionais. Consequentemente, Aristóteles e Hare adotam parâmetros psicológicos 
substancialmente diferentes para descrever seus respectivos fenômenos, a fraqueza moral e a akrasia antiga.

O prescritivismo moral de Hare revela a apropriação analítica da akrasia aristotélica. Na sequência, salientaremos ao menos dois aspectos dessa apropriação analítica da Ética: (a) a assimilação do silogismo prático ao prescritivismo moral de Hare; (b) a ‘sobreposição’ do princípio moral e a ineficácia do silogismo prático acrático.

A recepção analítica do silogismo prático é fundamental na formação da inferência prática e o prescritivismo moral de Hare. Como mostramos, Hare adota a leitura tradicional do silogismo prático forte, a tese de que a conclusão prática é a própria ação. Em Weakness of Will, Hare (1999, p. 109-110) atribui o prescritivismo moral à Aristóteles com base na 'prescritividade' (epitatiké, 1143a8) da phrónesis. Como observamos, no entanto, o termo epitatiké expressa o 'comando' ou a 'autoridade' do conhecimento moral da phrónesis, pressupondo a integração harmônica da razão prática e a virtude moral do agente (cf. ENVI.13 1144b201145a12). Da mesma forma, a 'premissa universal' do silogismo prático não tem função 'prescritiva' eficiente sem o auxílio da experiência e da educação moral apropriada do agente. $\mathrm{O}$ 'prescritivismo moral' inerente ao 'significado' primário dos termos morais não tem espaço correspondente na teoria original do silogismo prático moderado e na ética prática de Aristóteles.

A Ética de Aristóteles não contém uma análise destacada da linguagem moral independente da formação do caráter moral no campo prático da ação moral. Não há nenhum significado 'prescritivo universal' inerente aos termos morais ou princípios morais absolutos determinando a conduta moral correta. Ao contrário, as regras práticas ou morais são provisórias e destinadas a alcançar a excelência moral do ideal concreto do homem prudente (phrónimos) (Cf. ENII 4, 1105b5-10). Na Ética aristotélica, a 'eficácia' do silogismo prático depende da harmonia da razão prática e a educação moral das paixões irracionais. De fato, a incompreensão do sentido aristotélico 'prescritivo' do ‘silogismo prático’ aliado a phrónesis se reflete em seguida na incompreensão do conflito interno da akrasia.

A fraqueza moral não contempla a explicação natural (physikôs) da akrasia de ENVII.3. Os diversos tipos de fraqueza moral de Hare jamais chegam a constituir o conflito interno original da akrasia antiga. Dos casos de fraqueza moral, a impossibilidade física e a impossibilidade psicológica são mais claramente 
incompatíveis com o conflito da razão e dos apetites irracionais da akrasia. Como vimos, o acrático está em pleno controle de sua ação moral voluntária (hekón) e de seus impulsos irracionais naturais. ${ }^{498}$ Além disso, a hipocrisia ou o retrocesso proposital também é inadequada pois envolve o assentimento insincero e convencional do princípio moral. Em nenhum desses casos, o prescritivismo moral representa um genuíno conflito interno psicológico do agente.

De certa forma, os únicos casos que exigem o assentimento sincero do agente ao juízo moral são a ignorância da prescrição particular e o 'autoengano' (self-deception). Para Hare, a ignorância da prescrição particular corresponde à descrição clássica aristotélica da akrasia. Mesmo assim, a descrição decisiva do autoengano parece inspirada na descrição aristotélica da akrasia. Em sua descrição final da fraqueza, Hare (Ibid., p. 113-114) reduz a explicação natural (physikôs) da akrasia a um mero conflito de princípios morais.

O duplo silogismo acrático da explicação physikôs da akrasia de ENVII.3 se transfere a um conflito de deveres morais no prescritivismo moral de Hare. Na sequência, mostraremos que a akrasia não diz respeito a qualquer falha cognitiva do raciocínio prático e nem mesmo a um conflito de deveres morais.

Como vimos anteriormente, Aristóteles salienta dois tipos de akrasia em ENVII, a akrasia impulsiva e a akrasia fraca (1150b19-30). Em ambos os tipos de akrasia, o agente possui, mas não exerce o conhecimento prático da ação: no primeiro caso, o agente possui, mas não exerce a premissa particular, enquanto, no segundo caso, o agente possui mas não exerce a conclusão prática (1147b8-12). Desse modo, não há nenhuma ignorância cognitiva dos fatos particulares ou da prescrição particular na akrasia.

Além disso, o duplo silogismo do acrático jamais constitui um explícito conflito de deveres morais. Na explicação natural de ENVII.3, Aristóteles ressalta que não há oposição 'em si' (kath 'autén) entre o silogismo do bem e o silogismo de prazer, mas apenas uma oposição 'acidental' (katà symbebekós) (1147a35-b2). Em verdade, a ‘oposição' acidental só existe por causa da presença ativa do 'apetite'

\footnotetext{
${ }^{498}$ Sobre a relação do caráter voluntário acrático e os apetites irracionais naturais, cf. 1111b10-15; 1152a15-20; 1148b30-1149a20. Em ENVII.5, Aristóteles distingue explicitamente os impulsos irracionais naturais da akrasia dos impulsos 'brutos' incontroláveis. Nessa perspectiva, Aristóteles demarca um campo de impulsos 'brutos' mais apropriados aos desejos dos casos de compulsão psicológica. A partir disso, Aristóteles ressalta posteriormente que a akrasia está ligada ao nível natural dos impulsos irracionais da maioria dos homens (1152a25-30).
} 
inclinado ao 'conhecimento perceptível' (tês aisthetikês) da conclusão final do silogismo de prazer contra o bom silogismo (1147b10-15). Na esfera prática, as premissas particulares têm uma influência mais decisiva na ação do que propriamente a premissa universal. Sendo assim, seria absurdo atribuir a eficácia prática do silogismo prático simplesmente aos princípios morais em si mesmos.

Não há um genuíno conflito de deveres morais no conflito interno acrático porque não há um efetivo confronto lógico direto dos dois silogismos práticos paralelos na explicação physikôs da akrasia. Invariavelmente, ambos os silogismos são plenamente conscientes ao agente, mas apenas o silogismo de prazer tem eficácia prescritiva. De fato, a sua eficácia prescritiva se deve à influência cognitiva do apetite no domínio prático dos fatos particulares e não à falta de 'prescritividade' universal das normas práticas morais.

Para Aristóteles, os feitos particulares da vida são mais decisivos na ação do que a convicção nos argumentos dos sábios: "a verdade em assuntos práticos (tò alethès en toîs praktikoîs) é discernida dos feitos da vida (ek tôn ergôn kaì toû bíou); pois estes são o fator decisivo (tò kúrion).” (1179a15-20). Assim, os princípios morais não possuem valor em si mesmos independente da formação do caráter moral na Ética. Nesse cenário, a explicação phisikôs da akrasia expõe a redução do conflito de deveres morais de Hare. Além disso, a 'fraqueza moral' de Hare elimina a dimensão motivacional do caráter moral crucial no caso do duplo silogismo acrático. Em última instância, a descrição final do conflito de deveres morais não representa adequadamente a explicação natural da akrasia de Aristóteles. Nesse cenário, precisamos ressaltar ainda outros problemas enfrentados pela concepção reduzida da fraqueza moral e do conflito de deveres morais de Hare.

\section{8 O desafio do prescritivismo moral e da fraqueza moral}

O problema da fraqueza moral é um desafio à consistência do prescritivismo moral de Hare. Como vimos, o precritivismo moral se baseia em três princípios básicos da linguagem moral prescritiva: (a) a prescritividade dos juízos morais pautado na presença de termos valorativos, como 'bom', 'correto' ou 'dever' cuja função primordial é orientar a ação humana na forma de comandos práticos imperativos; (b) a universalizabilidade dos juízos morais ou a aplicação universal 
dos princípios morais universais a todos os casos semelhantes da ação moral; (c) a ‘sobreposição' (overridingness) dos princípios morais, a capacidade de sobrepor ou sofrer sobreposição de outros princípios prescritivos.

A partir disso, o prescritvismo moral sustenta a máxima o 'dever' (ought) moral implica no 'poder (can) da ação moral. Sem dúvida, a implicação lógica das inferências práticas em ações morais é fundamental para a consistência do prescritivismo moral de Hare. No entanto, a fraqueza moral apresenta um desafio ao expor casos em que há uma ação contrária ao princípio moral do agente.

Como vimos, Hare alega que tais casos aparentes de fraqueza moral correspondem a outros tipos de fenômenos irracionais. A partir disso, são enumeradas diferentes descrições diferentes de fraqueza moral, como (I) a hipocrisia, conforme a prescrição geral social; (II), o autoengano, relativo a um sentimento de 'obrigação' moral do agente; (III) a compulsão psicológica, gerada por um forte impulso irracional. Em sua última obra $M T$, Hare assimila enfim casos gerais de fraqueza moral a simples casos de conflitos morais intuitivos. Nenhuma das descrições anteriores da fraqueza moral atinge os princípios fundamentais do prescritivismo moral. De fato, o prescritivismo moral leva à negação absoluta da fraqueza moral. No entanto, resta saber se esses casos de fenômenos irracionais coincidem efetivamente com a fraqueza de vontade ou mesmo se o prescritivismo moral resiste ao desafio imposto pela fraqueza moral.

A fraqueza moral constitui uma forte objeção ao prescritivismo moral de Hare. Nesses termos, a objeção central da fraqueza moral toma duas formas distintas: (1) um desafio à conexão lógica do prescritivismo moral da inferência prática e a ação moral; (2) um desafio à descrição específica da irracionalidade envolvida na fraqueza de vontade.

A existência da fraqueza moral desafia a derivação lógica do comando prático na ação moral a partir da noção moderna da inferência prática. Em primeiro lugar, a inferência prática expressa no modo imperativo está sujeita às suas próprias controvérsias lógicas. Além disso, a fraqueza moral revela que o significado prescritivo do juízo moral nem sempre predomina sobre o significado descritivo secundário. Nesse sentido, isso fortalece o descritivismo externo dos juízos morais contra o significado prescritivo primordial dos princípios morais. O fenômeno irracional representa uma objeção fundamental ao internalismo moral de Hare, a conexão fundamental entre o juízo moral e a ação humana. 
Os diversos tipos de irracionalidade não contemplam adequadamente a fraqueza moral. A princípio, a enumeração sucessiva de casos de irracionalidade visa reforçar a consistência do prescritivismo moral e não fornecer uma explicação do fenômeno em si mesmo. O prescritivismo moral não fornece nenhuma descrição autêntica da irracionalidade do fenômeno. Na sequência, mostraremos que a redução do fenômeno ao conflito de deveres morais nos desvia da experiência irracional com que realmente devíamos nos ocupar, 'a fraqueza de vontade'. Por fim, essa constatação nos dará a oportunidade de considerar a crítica de Williams ao perspectivismo da fraqueza moral em Shame and Necessity. Antes disso, é necessário primeiro analisar a consistência do próprio prescritivismo moral calcado na possibilidade da inferência prática.

A doutrina da inferência prática estabelece a base lógica fundamental do prescritivismo moral. Como vimos anteriormente, o assentimento sincero do agente a um comando prático implica necessariamente na realização concreta da ação correspondente (dado o alcance físico e psicológico da ação). Nesse sentido, a inferência prática procede de forma lógica das premissas à conclusão do comando prático expresso no modo imperativo. No entanto, há usos não-prescritivos dos termos valorativos ou morais que admite 'graus' diferentes de assentimento do agente e colocam em xeque o prescritivismo moral.

A inferência prática do prescritivismo moral envolve inevitavelmente a noção de inferência imperativa. No entanto, há uma longa controvérsia em torno da própria consistência lógica da inferência imperativa. Na sequência, devemos analisar algumas objeções lógicas dirigidas à inferência imperativa.

No prescritivismo moral de Hare, a inferência imperativa estabelece a conexão lógica fundamental entre o comando prático e a ação. Como observamos, a lógica de satisfação dos imperativos estabelece que um imperativo $p$ implica outro imperativo $q$, ou melhor, $p$ só será satisfeito se $q$ também for satisfeito. Ora, em casos simples, como no comando conjuntivo, a sentença 'Faça $x$ e $y$ ' implica logicamente dois comandos práticos 'Faça x' e 'Faça y' que devem ser igualmente satisfeitos.

No entanto, há casos mais complexos e controversos de comandos disjuntivos do tipo 'Faça $x$ ou $y$ ' composto de dois comandos mutuamente excludentes. Para compreendermos isso, consideramos o polêmico exemplo de 
Hare, "Poste a carta ou queime-a"499 . De acordo com a lógica da satisfação, a seguinte derivação lógica seria possível:

(I) Poste a carta

Poste a carta ou queime-a

A conclusão do comando 'Poste a carta ou queime-a' a partir da premissa 'Poste a carta' é logicamente válida na lógica de satisfação. No entanto, ela nos parece imediatamente paradoxal pois a conclusão final é contraditória. Ora, como derivar uma conclusão contraditória de dois comandos incompatíveis a partir de um único comando 'Poste a carta'? A princípio, o comando 'Poste a carta' está em franca contradição com o comando 'Queime-a'. Diante disso, Williams (1973b, p. 153-154) alega que inferências como (I) são inválidas. Ao invés disso, ele sugere que comandos práticos constituem, na realidade, 'pressuposições permissivas', ou seja, a permissão "implicitamente dada ou concedida pelo comandante". Nesses termos, poderíamos considerar outro tipo de derivação lógica de 'Poste a carta ou queime-a' segundo a fórmula ' $p$ ou $q$; não $p$, então $q$ ':

(II) Poste a carta ou queime-a; não queime-a, poste a carta

Eu permito que você poste a carta

Eu não permito que você queime a carta, se você postá-la

A conclusão da permissão final (II) é totalmente incompatível com o comando final 'Poste a carta ou queime'. De acordo com Williams (1973b, p. 155), a formulação lógica dos comandos disjuntivos em pressuposições permissivas tem o "efeito de cancelamento" dos comandos prévios das premissas: "the sucessive utterance of the commands involved in the supposed inferences has a cancelling effect, the effect of withdrawing what has already been said (...).”. Em um comando disjuntivo 'Faça $x$ ou $y$ ', a realização do comando $x$ implica necessariamente a negação do comando $y$. Em outras palavras, a sucessão de comandos revela apenas que o comando original 'Poste a carta ou queima-a' é rejeitado pela mudança de ideias do agente. Para todos os efeitos, Williams (1973b, p. 157-158) conclui que um conjunto de imperativos sequer constitui um conjunto de premissas de uma

\footnotetext{
${ }^{499} \mathrm{O}$ exemplo mencionado é particularmente apresentado em 'Some Alleged Differences between Imperatives and Indicatives', embora o exemplo também reapareça em outros artigos reunidos no compêndio 'Practical Inferences' (1971) de Hare.
} 
inferência ${ }^{500}$. Desse modo, a própria fundação do prescritivismo moral a partir da noção de inferência imperativa é colocada em xeque.

Para preservar a inferência imperativa, Hare (1971, p. 28-30) alega que as permissões disjuntivas são implicaturas conversacionais. As implicaturas conversacionais são essencialmente implicações implícitas ou subentendidas por certas convenções linguísticas. Em contextos especiais, tais implicaturas podem ser canceladas, como a implicatura 'Você não pode fazer $x$ ' é cancelada diante do comando 'Faça $x$ '. Todavia, implicaturas não podem ser diretamente inferidas de comandos disjuntivos: "Do $a$ or do $b$ ' does not entail 'You may do $a$ ' but only conversationally implicates it." (1971, p. 32). Desse modo, a inferência 'Poste a carta ou queima-a' (I) não implica logicamente 'Você pode postar a carta' mas apenas implica no sentido específico da implicatura conversacional. Pela lógica da satisfação, esse comando disjuntivo não permite o cancelamento da premissa precedente 'Poste a carta'. Desse modo, Hare sustenta que comandos e permissões supostamente respeitam as mesmas regras de consistência lógica do prescritivismo $^{501}$.

Em última instância, o prescritivismo moral estabelece que a ação realizada é o principal critério de determinação do comando prático do agente. Por termos lógicos, a ação realizada $x$ reflete logicamente o comando prático que orienta a fazer $x$. No entanto, comandos disjuntivos não resultam objetivamente na realização da ação de qualquer comando prático. Com efeito, há indicações de que a inferência disjuntiva 'Faça $x$ ou $y$ ' a partir da premissa 'Faça $x$ ' é totalmente inválida ${ }^{502}$. Em termos práticos, fazer $x$ ou $y$ pode ser um modo de fazer $x$, embora fazer $x$ por si só não garante que também faremos $y$. Diante disso, os comandos práticos novamente não chegam a constituir uma inferência lógica, ao menos na derivação lógica da conclusão de um conjunto de premissas práticas imperativas.

\footnotetext{
${ }^{500}$ Cf. WIILIAMS, 1973b, p. 157-158: "both the previous order and the subsequent one are required in order that from the combination of them the recipient may infer what he is to do." (itálicos do autor).

501 Cf. HARE, 1971, p. 27: "two commands, or a command and a permission, are logically inconsistent with the statement that the other is going to be acted on (...) if it is logically impossible to act on both."

${ }^{502}$ Cf. ANSCOMBE, 2011, p. 166: "Effecting two things may indeed often be a way of effecting one of them; but the admission of arbitrary conjuncts is one of those forced and empty requirements of a view which shew that there is something wrong with it. It is in this respect like the derivation of $(p v q)$ ! from $p$ ! in Hare's system." (itálicos da autora).
} 
Os comandos práticos no modo imperativo têm outras funções além de estritamente orientar a conduta humana. É frequente usarmos comandos práticos, por exemplo, para dizermos, induzirmos ou recomendarmos a alguém para fazer alguma coisa mesmo sem ter o propósito específico de ordenar, de forma impositiva, uma ação ${ }^{503}$. Particularmente, Hare tem consciência desses outros usos possíveis do imperativo lógico, porém esses outros usos secundários ficam subordinados ao significado primário prescritivo dos comandos práticos. $\mathrm{Na}$ realidade, a evidência dessas funções secundárias dos comandos coloca em xeque o internalismo forte do prescritivismo moral, a conexão lógica entre juízos morais e a ação moral. Na linguagem ordinária, podemos reconhecer que considerações morais nos fornecem motivos ou razões para a ação, mas isso não nos compromete a agir como se estivéssemos obedecendo a uma ordem de um comando prático ${ }^{504}$.

Nessa perspectiva, o prescritivismo moral esbarra com os casos de fraqueza moral amaplamente reconhecidos na linguagem ordinária humana. Como indica Lukes (1971, p. 158-159), o prescritivismo moral incorpora o ideal da linguagem angélica, puramente prescritiva, para o qual nossa linguagem ordinária jamais está à altura $^{505}$. Por isso, a fraqueza moral expõe as vicissitudes da irracionalidade humana na linguagem moral e impõe um desafio intransponível ao forte internalismo do prescritivismo moral.

A negação da fraqueza moral é uma tese controversa destinada a preservar o precritivismo moral de Hare. Ao contrário do que parece, a negação da fraqueza moral não coincide com a negação socrática da akrasia. No entanto, a diferença crucial não é aquela assinalada por Hare (1963, p. 72-72), isto é, de que a negação socrática do fenômeno não é nada além do mero 'assentimento de prescrições

\footnotetext{
${ }^{503}$ Sobre os diversos usos de 'dever' e sua aplicação em múltiplos contextos discursivos, ver PRICE, 2004, p. 136-137: "it plausibly makes a difference that imperatives have a practical function that is essential to the kind, even if not invariable within its instances: that of telling people to do things as a way of getting or inducing or leading them to do them (the last even holding of advice)." (itálicos do atuor).

${ }^{504}$ Cf. IRWIN, 2009, p. 757: "Hence we might agree with Hare, if he asserts no more than an internal connexion between morality and justifying reasons. But this internal connexion does not support prescriptivism; if I simply recognize a reason for doing $\mathrm{x}$, I may not commend it to myself or to anyone else, and I may not intend any imperatives."

${ }^{505}$ Cf. Ibid., p. 158: "His [Hare] logical-cum-psychological ideal of rational language-cumbehaviour leads him to give one particular, and I think often misleading, account of what ordinarily happens when sincere people do what they believe they should not be doing or do what they believe they should be doing."
} 
particulares' derivadas de desejos particulares ${ }^{506}$. Como vimos anteriormente, a negação socrática da akrasia no Protágoras estabelece a absoluta incompatibilidade do conhecimento moral e a ignorância das reais dimensões dos prazeres humanos. Em momento algum, o personagem Sócrates do Protágoras negligencia a irracionalidade inerente ao conflito interno da akrasia. Entretanto, a crítica de Hare à posição socrática do Protágoras acaba expondo as inconsistências de sua própria negação da fraqueza moral.

A experiência geral da 'fraqueza moral' abarca diversas descrições diferentes de irracionalidade prática. Dentre os casos mencionados, ao menos três representam um desafio ao prescritivismo moral: (I) a hipocrisia; (II) o autoengano e a (III) compulsão psicológica. Ora, se examinarmos cada um desses casos separadamente, observaremos que nenhum deles representa a irracionalidade inerente à fraqueza de vontade. Como dissemos anteriormente, a hipocrisia e o autoengano coincidem com o uso indevido de dever (ought). Na realidade, a hipocrisia nem mesmo apresenta qualquer dificuldade já que o agente está sendo insincero ao assentimento do comando prático. Por sua vez, o caso do autoengano constitui um desafio mais complexo ao prescritivismo moral.

No autoengano, o próprio agente se engana acerca do uso indevido de dever moral (ought). A expressão do sentimento de culpa transmite a aparência de obediência ao princípio moral universal na perspectiva interna do próprio agente. De fato, isso não nos impede de agir segundo um outro princípio prescritivo em detrimento do princípio moral sob o qual não agimos. Como veremos posteriormente, esse fenômeno pode ser explicado apenas com base no conflito de princípios intuitivos $^{507}$. No entanto, a compulsão psicológica não permite ser explicada sob os mesmos parâmetros dos conflitos morais de deveres.

A compulsão psicológica confronta a descrição geral do uso indevido de 'dever' (ought). Por isso, há um desafio ainda maior ao forte internalismo do

\footnotetext{
${ }^{506}$ Para Hare (Ibid., p. 72-73), Sócrates estaria ignorando a universalidade dos juízos morais: "That's why Socrates. who paid insufficient attention to the universalizability of moral judgements, found himsef sayng that there was no such thing as weakness of will." No entanto, o exame socrático da opinião dominante no Protágoras chega a conclusões extremamente coerente com as nossas convicções humanas mais profundas sobre a relação dos juízos do bem e a ação humana. Em verdade, o próprio paradoxo socrático é o reconhecimento da inclinação natural humana ao bem. Desse modo, a crítica de Hare à posição socrática é absolutamente anacrônica.

${ }^{507}$ Na próxima seção, abordaremos as críticas de Williams dirigidas ao conflito de deveres morais e ao perspectivismo da fraqueza moral. Com isso, poderemos ter maior clareza das limitações da concepção de fraqueza moral de Hare.
} 
prescritivismo moral. Na compulsão, a ação ocorre por um forte impulso irracional contra o princípio moral. Para Hare, há uma analogia com a impossibilidade física: ao invés da retração pelo impedimento físico, o princípio moral é "rebaixado (downgraded)" diante do forte impulso irracional. Ora, mas será que a compulsão psicológica realmente reflete a fraqueza moral ou o conflito interno da akrasia antiga, como alega Hare?

O conflito interno entre a razão e os desejos irracionais poderia aproximar a fraqueza de vontade da akrasia antiga. Como assinala Watson (1977, p. 327), a maior força dos impulsos irracionais atenua o limite entre a compulsão e fraqueza: "the desires which motivate the weak contrary to their judgments are "too strong" (...) and explanations of weakness and compulsion come to the same thing.". Nessa perspectiva, a vontade racional só fica mais fraca apenas em relação à maior força dos desejos irracionais na ação do agente. O princípio da força relativa dos desejos esclarece a noção obscura da 'força interna' ou do 'impulso interno'. Como observamos, a força superior dos desejos irracionais na ação moral reflete a noção de 'desejos cegos' (blind desires), isto é, desejos absolutamente irracionais ao juízo avaliativo do bem ${ }^{508}$. Sem dúvida, os desejos cegos refletem impulsos irracionais fortes ou violentos contrários à razão no fenômeno da compulsão psicológica. No entanto, nem sempre é necessário ter a presença de impulsos fortes para encararmos o fenômeno da fraqueza de vontade.

Além do poder dos fortes impulsos, há também o domínio psicológico de impulsos fracos, como o célebre exemplo mencionado no artigo de J. L. Austin (1958, p. 24), A Plea for Excuses:

I am very partial to ice cream, and a bombe is served divided into segments corresponding one to one with the persons at High Table: I am tempted to help myself to two segments and do so, thus succumbing to temptation and even conceivably (but why necessarily?) going against my principles. But do I lose control of myself? Do I raven, do I snatch the morsels from the dish and wolf them down, impervious to the consternation of my colleagues? Not a bit of it. We often succumb to temptation with calm and even with finesse.

\footnotetext{
${ }^{508}$ Como vimos, o conceito de 'desejos cegos' está estreitamente associado ao fenômeno moderno da compulsão psicológica, ver WATSON, 1977, p. 323-326; PENNER, 1990, p. 51-61; CHARLTON, 1988, p. 155-161. Como mostramos anteriormente, estamos o conceito de desejos cegos é tão controverso que pretendemos mantê-lo afastado da akrasia antiga. Sobretudo, os impulsos irracionais na psicologia antiga não necessariamente excluem concepções cognitivas do bem como ocorre na psicologia moderna da vontade.
} 
A submissão ao impulso fraco coloca em xeque a condição da compulsão psicológica e a fraqueza moral. No exemplo acima, o homem 'cai em tentação' por uma fatia maior de segmentos do sorvete contra seu princípio de comer apenas a fatia apropriada que lhe cabe na mesa. A partir desse exemplo, Austin indica que a fraqueza de vontade não necessariamente envolve um impulso forte pois pode resultar de um impulso fraco. Nessa perspectiva, não há um impulso forte ou violento contrário à razão do agente, mas um impulso suave e fraco que toma conta do próprio agente.

Ora, isso nos remete à clássica distinção aristotélica da akrasia impulsiva e akrasia fraca de ENVII. Em primeiro lugar, os apetites fortes irracionais da akrasia impulsiva impedem que o agente alcance a conclusão do silogismo prático. Nesse caso, a ação resulta do domínio dos apetites fortes dos prazeres excessivos contra a razão prática. Em segundo lugar, os fracos apetites da akrasia fraca, por sua vez, permitem o conhecimento da conclusão do silogismo prático mas inviabilizam seu exercício na ação moral. Novamente, a ação reflete a fragilidade da própria razão prática mesmo perante os apetites irracionais fracos. Em ambos os casos, os apetites irracionais da akrasia jamais constituem desejos cegos, isto é, desejos completamente irracionais e absolutamente contrários ao desejo racional pelo bem.

A categoria dos desejos irracionais cegos da compulsão psicológica é incompatível com o tipo de conflito prático da akrasia ou da fraqueza de vontade. De um lado, o conflito interno da akrasia reside no predomínio temporário dos apetites irracionais sobre o desejo racional do bem durante a ação e não no predomínio absoluto dos desejos cegos do ato compulsivo. De outro lado, a fraqueza de vontade representa o conflito prático fundamental entre a ação irracional e a avaliação racional do melhor juízo do agente levando em conta o controle de seus impulsos irracionais. Em ambos os contextos, a fraqueza de vontade não surge como um fenômeno autêntico enquanto não se definir claramente o que constitui o termo 'desejo' dentro do prescritivismo moral de Hare.

Para Hare (1963, 9.4, p. 170), o termo 'desejo' (desire) admite um duplo significado usual que corresponde a diferentes tipos de prescrições práticas:

This wide sense in which we are here using 'desire' is that in which any felt disposition to actions counts as a desire; there is also a narrower and commoner sense which desires are 
contrasted with other dispositions to action, such as a feeling of obligation (which in the wider sense of 'desire' could be called a desire to do what one ought). (itálicos do autor)

O termo 'desejo' (desire) apresenta dois significados prescritivos diferentes: um significado amplo mais preciso e outro significado ordinário mais estreito. Pelo significado amplo, 'desejo' (desire) é aplicado a "any evaluation, just beacause it is prescriptive, incorporates the desire to have or do something rather than something else", isto é, uma avaliação prescritiva geral de uma motivação à ação. Para Hare, o 'desejo' em sentido amplo corresponde ao 'querer' (want) do agente expresso em "any felt disposition to action count as a desire" (itálicos do autor, Ibid., p. 170). Pelo significado mais estreito e comum, há uma distinção fundamental entre desejos particulares e outras disposições da ação, como o sentimento de obrigação e juízos de valor em geral (estéticos, prescritivos e morais). Como vimos, os desejos particulares são mais simples do que as prescrições morais universais justamente por constituírem prescrições singulares da ação (Ibid, 5.4).

Ao contrário do juízo prescritivo universal, a classe dos desejos particulares envolve apenas prescrições particulares. Para Hare, o termo 'desejo' em si mesmo pode ter uma aplicação geral prescritiva, mas isso nem sempre é necessário especialmente em relação aos desejos particulares ${ }^{509}$. Entretanto, a caracterização geral do 'desejo' como uma disposição avaliativa da ação apresenta dificuldades ao prescritivismo moral. Como assinala Taylor (1980, p. 513-515), há dois problemas fundamentais com essa noção prescritiva de 'desejo’: (1) não há qualquer evidência de que os juízos de valor efetivamente expressam algum tipo de 'desejo'; (2) os juízos valorativos não implicam necessariamente em um compromisso com a realização concreta da ação ${ }^{510}$. Como vimos anteriormente, a fraqueza moral abrange uma enumeração de diferentes descrições do uso indevido do 'dever' moral. De forma geral, a preocupação de Hare se volta mais à adequação dos casos

\footnotetext{
${ }^{509}$ Cf. HARE, 1963, 9.1, p. 156: "it is perfectly possible to have a universal desire (a desire that in a certain kind of circumstances some event of a certain kind should always take place), desires do not have to be universal. To want to have something does not commit the wanter to wanting other people, in the same circumstances, to have it."

${ }^{510}$ Cf. Ibid., p. 515: "It clearly will not do to say that the commitment arises because evaluative judgements express desires, and desires carry a commitment to action. For firstly, it is just false that, on any ordinary understanding of the word 'desire', all evaluative judgements express some desire of the person making them. And secondly, in trying to elucidate the notion of the incorporation of desires in evaluative judgements, Hare is obliged to explain his 'wide' sense of 'desire' (...) and we in turn have to been obliged to elucidate 'felt disposition', as commitment." Ver também TAYLOR, 1965 , p. 295-296.
} 
mencionados aos termos do prescritivismo moral do que efetivamente a compreensão de sua inerente irracionalidade ${ }^{511}$. Ao final, o prescritivismo moral o compromete a tratar da fraqueza moral como um tipo de ação contrária ao princípio moral e em favor de um outro princípio prescritivo inuitivo.

De acordo com o prescritivismo moral, a ação realizada determina a expressão do juízo valorativo prescritivo do agente. O problema da fraqueza moral surge em função do próprio prescritivismo moral, isto é, diante da evidência de que há juízos morais prescritivos. Por sua vez, a negação da fraqueza moral de Hare visa comprovar que o fenômeno geral, em suas diversas manifestações, corresponde a usos não-prescritivos de 'dever' (ought). Entretanto, a própria fraqueza moral abrange de forma mais fundamental o problema do conflito de princípios morais intuitivos de $M T$.

O conflito dos deveres morais é a estratégia final da preservação do prescritivismo moral puro de Hare diante o fenômeno da fraqueza moral. De fato, isso é crucial dentro da divisão do nível intuitivo e o nível crítico do pensamento moral. O conflito de princípios morais permanece restrito ao nível intuitivo enquanto o nível crítico do pensamento moral se mantém isolado e coerente com a doutrina superior do prescritivismo moral. Diante disso, Hare (1981, p. 52) estabelece um princípio de cooperação entre o nível intuitivo e o nível crítico do pensamento moral:

A person with any deep experience of such situations will have acquired some methodological prima facie principles which tell him when to launch into critical thinking and when not; they too would be justified by critical thinking in a cool hour. (itálicos do autor)

A cooperação entre o nível crítico e o nível intuitivo do pensamento moral permite resolver os conflitos de deveres morais. Como observamos, a fraqueza moral reflete a possibilidade de 'sobreposição' (overridingness) dos princípios morais intuitivos por outros princípios prescritivos não-morais. Na esfera do nível intuitivo, os conflitos morais são insolúveis justamente porque os princípios

\footnotetext{
${ }^{511}$ Cf. LUKES, 1971, p. 156: "Hare can always say that if a man does not do what he purports to think he ought to be doing, the choice is between less than full sincere and sincere belief, yet to say this is to presuppose a certain psychological doctrine about the practicality of belief, i. e., that really believing something involves or perhaps even just is a disposition to act in certain specified ways." (itálicos do autor)
} 
intuitivos da educação moral são intrinsecamente revogáveis diante das contingências particulares. Todavia, os princípios críticos mantêm a predominância da sobreposição sobre outros princípios intuitivos em quaisquer circunstâncias. Por conta disso, a coordenação do nível crítico sobre o nível intuitivo poderia enfim fornecer uma resolução final aos conflitos morais insolúveis no nível intuitivo.

O nível crítico poderia fornecer assim princípios prima facie metodológicos ajustados ao momento decisivo da ação particular. Sob esse ângulo, é possível enfim resolver definitivamente quaisquer conflitos morais intuitivos, como a fraqueza moral. Com base em uma analogia militar, Hare (Ibid., p. 52) sustenta que a cooperação entre o nível crítico e o nível intuitivo ocorre por um "mesmo processo reflexivo (thought-process)", tal como o comandante coordena princípios gerais e detalhes táticos particulares da batalha: "like saying that in a battle a commander cannot at the same time be thinking of the details of tatics, overall aim of victory, and the principles (...) which he has learnt when learning his trade.” Em última análise, o precritivismo moral de Hare pressupõe a harmonia entre o nível intuitivo e o nível crítico. Entretanto, não há uma necessária harmonia entre esses dois níveis da reflexão moral.

Segundo Williams (1988, p. 190), há uma incompatibilidade intransponível entre o ponto de vista das respostas emocionais intuitivas e o ponto de vista privilegiado do nível crítico:

they [intuitive responses] constitute a way of seeing the situation; and you cannot combine seeing the situation in that way, from the point of view of those dispositions, with seeing in the archangel's way, in which all that is important is maximum preference satisfaction, and the dispositions themselves are merely a means towards that. (itálicos do autor)

O ponto de vista privilegiado do nível crítico não coincide necessariamente com o ponto de vista do nível intuitivo das respostas intuitivas emocionais (Ibid., p. 189-190). No ponto de vista intuitivo, as disposições da ação são formadas pela experiência em situações morais particulares envolvendo as 'fortes respostas emocionais' da educação moral. No ponto de vista crítico, as respostas emocionais do nível intuitivo se transformam apenas em um meio para alcançar um fim maior, a máxima satisfação da preferência racional do agente. A subordinação do nível intuitivo ao nível crítico trata as reações intuitivas de forma instrumental e 
provisória em vista do fim último, a máxima satisfação preferencial do agente. Todavia, a coordenação suprema do nível crítico não reflete o que realmente estamos sentido ou pensando nos dilemas morais particulares do nível intuitivo.

Da mesma forma, a autoridade da 'sobreposição' do princípio moral está igualmente aberta à objeção. Como salienta Irwin (2009, p. 770-772), a supremacia imperativa dos princípios morais não se justifica apenas pelo fato de que o ponto de vista moral geralmente sobrepõe outras considerações avaliativas no campo da ação moral ${ }^{512}$. Mesmo os princípios morais do nível crítico não determinam que a ação moral prescrita será efetivamente realizada pelo agente. Com isso, não há mais como assegurar que o nível crítico resolverá defnititivamente todos os conflitos morais prima facie.

A redução da fraqueza moral ao conflito de deveres morais não assegura o desaparecimento do problema da fraqueza de vontade. Em última instância, o prescritivismo moral é insuficiente para justificar a negação da fraqueza moral. Dentro desse cenário, é preciso compreender como a fraqueza moral envolve considerações morais inuitivas e o inerente conflito de deveres morais. Com base em Shame and Necessity de Bernard Williams, mostraremos por quais motivos a fraqueza de vontade em si mesma é intrinsecamente irredutível ao conflito de deveres morais.

\section{9 \\ A crítica de Bernard Williams à fraqueza moral e ao conflito de deveres morais}

A fraqueza moral é um fenômeno complexo sujeito à diferentes tipos de descrição de sua irracionalidade. Como vimos, o prescritivismo moral de Hare culmina na negação absoluta da fraqueza moral. Sobretudo, a fraqueza de vontade acaba sendo reduzida ao controverso conflito de deveres morais. Na verdade, a crítica de Bernard Williams revela que as categorias dos princípios morais

\footnotetext{
${ }^{512}$ Cf. Ibid., p. 771: "One might argue that moral principles claim to be overriding, and that the moral point of view claims to assess other points of view by reference to considerations that are taken to override them. But agreement on this point does not support Hare's claim that anyone who holds, or even to some extent acts on, moral principles must accept the claim of morality to supremacy."
} 
modernas são intrinsecamente problemáticas e não dão conta do fenômeno autêntico da fraqueza de vontade.

Em Shame and Necessity, Williams leva adiante a crítica à fraqueza moral e ao conflito de deveres morais. Para Williams, as categorias morais contribuem para um tipo de perspectivismo da fraqueza moral, isto é, o próprio fenômeno está intrinsecamente sujeito ao ponto de vista moral do agente. Nessa perspectiva, o perspectivismo moral implica, de certa forma, em um tipo de negação da fraqueza da vontade.

O perspectivismo moral de Williams revela a necessidade de destacar claramente a fraqueza de vontade das categorias morais modernas. Além disso, Williams ainda salienta que o conflito de deveres morais está sujeito à aglomeração indiscriminada de deveres morais incompatíveis. É imprescindível, então, destacar claramente a fraqueza de vontade das categorias modernas do dever moral. Sob esse ângulo, sustentaremos que o perspectivismo da fraqueza moral de Williams não justifica a negação da fraqueza de vontade. Diante disso, prosseguiremos ao problema da fraqueza moral apresentado no capítulo 2, "Centres of Agency", de Shame and Necessity.

No capítulo 2 "Centres of Agency" de $S N^{513}$, Williams coloca em xeque as categorias morais da fraqueza de vontade. Dando prosseguimento à crítica da psicologia eticizada antiga, seu foco recai em seguida sobre o problema da fraqueza de vontade. Ao contrário de outros filósofos analíticos, Williams (1993, p. 44) reconhece explicitamente que nenhum dos termos modernos, 'fraqueza de vontade' ou 'incontinência', contemplam a experiência original da 'akrasia'. ${ }^{514}$ Assim como seus antecessores, no entanto, Williams também assume que a continuidade de um mesmo problema filosófico acerca do conflito prático do fenômeno em termos invariavelmente éticos e antagônicos: o conflito entre a razão ética e os impulsos irracionais, o conflito entre a razão de curto prazo e a razão de longo prazo em vista do melhor curso de ação. Em suma, o seu objetivo primordial é analisar os

\footnotetext{
${ }^{513}$ Daqui em diante, adotaremos a nomenclatura abreviada $S N$ em referência ao título original da obra 'Shame and Necessity'.

${ }^{514}$ Nesse ponto, Williams demonstra mais consciência da distinção do termo akrasia de outros termos modernos, como incontinência ou fraqueza de vontade, do que Hare ou mesmo Davidson. De certa forma, Williams concorda com o reestabelecimento do problema da fraqueza de vontade de Davidson em 'How is Weakness of Will Possible?' (2001b). Assim como Davidson, Williams acredita que é preciso retirar o fenômeno das categorias morais modernas contra o prescritivismo moral de Hare. No entanto, Williams deixa de reconhecer a existência da fraqueza de vontade na medida em que o fenômeno dependente exclusivamente da perspectiva interna do agente.
} 
desdobramentos de uma teoria da akrasia: "A theory of akrasia is supposed to offer a structure to explain such happenings." (Ibid., p. 45). Nesse ponto, Williams se preocupa em analisar a fraqueza de vontade para além das categorias morais modernas associadas ao fenômeno.

A fraqueza moral ou teoria ética da akrasia inevitavelmente representa inevtiavelmente o conflito interno do fenômeno como um conflito de valores morais. Em termos éticos, o conflito psicológico-moral depende fundamentalmente do ponto de vista interno do agente acerca de sua ação moral.

Com uma ilustração da fraqueza moral, Williams (Ibid., p. 45) recorre a um exemplo moral de adultério: um homem casado tendo um relacionamento com sua amante pode ter o firme propósito de terminar definitivamente seu caso extraconjugal no último encontro mas acaba cedendo à paixão no momento decisivo da ação. Sob o ponto de vista moral, a predominância da paixão irracional sobre a aversão do princípio moral contra o adultério na ação constitui um típico caso de fraqueza moral. No entanto, o mesmo episódio pode ser descrito sob outro ponto de vista: de acordo com sua própria escala de valores pessoais, o adúltero pode reconhecer que a paixão pela amante estava, na realidade, do lado das razões superiores da ação justamente após a separação de sua esposa em nome da paixão proibida. Em retrospectiva, a mudança do ponto de vista do agente influencia na forma relativa como ele mesmo compreende sua ação moral.

Nesses termos, Williams (1993, p. 45-46) sustenta que o ponto de vista retrospectivo do agente influencia na perspectiva da akrasia ou fraqueza moral:

It is an illusion to suppose there had to be at the time of those episodes a particular kind of psychological event that occurred if things turned in one of those ways, and not if they turned out in the other; yet akrasia, to the extent that it offers a psychological explanation, is supposed to explain an event. We have reasons to say that akrasia is not so much a psychological concept as (in the broad sense) an ethical one, and an element that serves to provide an ethically significant narrative.

O perspectivismo moral da fraqueza de vontade reflete a ilusão do agente sobre a descrição definitiva de sua ação moral. A descrição da fraqueza representa um fenômeno psicológico diferente em função da perspectiva do agente sobre sua ação. Em outras circunstâncias da ação, o agente sequer iria encarar sua ação como uma fraqueza moral, nem mesmo teria feito uma ação contrária ao seu princípio 
moral. Nessa perspectiva, a fraqueza moral não depende tanto de categorias psicológicas como depende de categorias morais sob as quais descrevemos o relato moral do agente sobre sua prórpria ação.

Segundo Williams, a avaliação retrospectiva do agente altera a sua perspectiva sobre a fraqueza moral em dois aspectos: (1) a descrição valorativa das razões internas do agente; (2) a descrição ontológica após o episódio de fraqueza. $\mathrm{Na}$ esfera epistemológica, a fraqueza moral depende de uma reavaliação retrospectiva do agente sobre suas próprias razões internas: "only restrospectively, as part of an interpreation that establishes or reestablishes one's identifications and the importance of one reason rather than another." (Ibid., p. 45). Na esfera ontológica, o fenômeno é determinado de forma decisiva após o evento crucial da ação: "whether an episode was an episode of akrasia at all may depend crucially on later understandings." (Ibid., p. 45). O ponto de vista retrospectivo do agente sobre sua condição de fraqueza é decisivo na descrição final do fenômeno.

Devido às circunstâncias contingentes da ação, é possível reexaminar a avaliação valorativa do agente sobre suas razões e, consequentemente, modificar a própria descrição do fenômeno pela perspectiva do agente. A perspectiva do agente expressa a descrição psicológica do evento enquanto a fraqueza moral apenas fornece uma descrição puramente ética. Em outras circunstâncias, o agente pode se dar conta de que não cometeu nenhum erro moral. $\mathrm{O}$ fenômeno depende propriamente da perspectiva particular do agente e não possui nenhuma realidade em si mesma. Desse modo, o perspectivismo retrospectivo do fenômeno resulta, então, na negação da fraqueza moral. Embora isso efetivamente seja coerente em relação às categorias morais, isso não comprova propriamente a negação da fraqueza de vontade.

Os problemas relativos às categorias morais psicológicas modernas não se aplicam propriamente ao conflito da fraqueza de vontade. Não há nenhuma certeza de que o ponto de vista retrospectivo pode fornecer uma descrição mais verdadeira ou genuína do fenômeno do que a própria fraqueza moral. Em uma resenha crítica de $S N$, Irwin assinala (1994, p. 60) que o papel constitutivo da descrição retrospectiva do erro moral já pressupõe a negação da fraqueza, “I don’t see why whe should believe these claims (...) if we are not already convinced that incontinence has no psychological reality." Ora, as descrições retrospectivas da ação por si mesmas não esclarecem a avaliação das razões internas do agente e nem 
podem, por decorrência, comprovar que não há efetivamente fraqueza de vontade $^{515}$. Mesmo sob o ponto de vista retrospectivo, ainda é possível assegurar que a ação contrária ao melhor juízo descreve um fenômeno psicológico real.

A crítica de Williams de $S N$ expõe claramente a incompatibilidade entre as categorias morais modernas e a fraqueza de vontade. Como vimos anteriormente, a fraqueza moral baseada no prescritivismo moral promove, em última instância, o conflito de princípios morais intuitivos. O prescritivismo moral de Hare está comprometido com a máxima o 'dever' (ought) implica no 'poder' (can), isto é, o problema prático do dever moral exige, por necessidade lógica, a possibilidade da ação moral. O conflito de deveres morais reflete uma inconsistência lógica entre dois princípios morais, 'eu devo fazer $a$ ' e 'eu devo fazer $b$ ' de tal forma que não se pode, simultaneamente, fazer $a$ e $b$. A resolução do conflito moral intuitivo ocorre quando há a 'sobreposição' de um dos princípios prescritivos pelo outro princípio, isto é, $a$ 'sobrepõe' $b$, e, então, o agente faz $a$ ao invés de $b$. Entretanto, os princípios do prescritivismo moral não fornecem parâmetros objetivos para a resolução definitiva do conflito moral.

O problema do conflito de deveres morais não admite uma resolução simples pelo princípio de 'sobreposição' de princípios intuitivos. Em Ethical Consistency, Williams (1971a, p. 180) assinala que o conflito de deveres morais pode gerar a aglomeração de deveres morais incompatíveis. Segundo o 'princípio de aglomeração', seria possível ampliar a máxima 'dever implica poder' à princípios morais incompatíveis. Por exemplo, a conjugação das premissas "eu devo fazer $a$ ' e 'eu devo fazer $b$ ' implicam a conclusão 'eu devo fazer $a$ e $b$ '. Nesse sentido, teríamos uma clara inconsistência lógica:

(I) Eu devo fazer $a$

(II) Eu devo fazer $b$

(III) Eu devo fazer $a$ e $b$

No entanto, seguindo a regra da incompatibilidade de princípios morais incompatíveis seria necessário inserir uma negação à proposição (III):

(IV) Não é o caso que 'eu devo fazer $a$ e $b$ '

${ }^{515}$ Cf. Ibid., p. 60: "No plausible way of filling in the details however, supports his conclusion that there was no behaviour that is truly explained as a display of incontinence." 
Na sequência lógica, a proposição final (IV) 'Não é o caso que eu devo fazer $a$ e $b^{\prime}$ resulta da conjunção das premissas (I) - (III) derivada do princípio de aglomeração. Para Williams, a inconsistência de (I) - (IV) expressa uma 'genuína contradição” segundo a formulação lógica do tipo “devo - não devo (ought - not ought)" e não a formulação do tipo "devo - devo não (ought - ought not)". Nesse sentido, não se trata de uma incompatibilidade lógica exclusiva entre dois princípios práticos, como 'eu devo fazer $a$ e devo não (ought not) fazer $b$ '. Na realidade, o princípio aglomerativo resulta na negação lógica da proposição completa contendo ambos os princípios práticos, como 'não é o caso que 'eu devo fazer $a$ e $b$ ' ou simplesmente 'não devo (ought not) fazer $a$ e $b$ '. A contradição reside na incompatibilidade lógica dos 'deveres morais' em si mesma e não na incompatibilidade prática dos princípios práticos e a ação moral. Por isso, a inconsistência lógica dos 'deveres morais' reflete o próprio conflito de deveres morais.

Como alerta Williams (Ibid., p. 181), o conflito de deveres existe apenas em um episódio contingente de impossibilidade de obediência a ambos os princípios morais incompatíveis. Diante de um conflito moral real, o agente pode invariavelmente ter o 'dever' moral e até mesmo o 'poder' de cumprir cada um dos deveres morais mesmo sem ter a possibilidade de fazer ambos ao mesmo tempo.

Anteriormente, notamos que a resolução dos conflitos morais intuitivos segundo o prescritivismo moral ocorre pela 'sobreposição' dos princípios morais. Nesses termos, há o cancelamento ou exclusão de um princípio em vista de outro princípio prescritivo. Conforme salienta Williams (Ibid., p. 183), o cancelamento lógico dos princípios não procede necessariamente nos conflitos morais: "it is surely falsifying of moral thought and to represent its logic as demanding that in a conflict situation one of the conflicting ought's must be totally rejected." (itálicos do autor). Sem dúvida, precisamos realizar uma ação necessariamente seguindo um dos princípios morais ao invés de outro princípio em face de um conflito moral. No entanto, isso não confere uma necessidade lógica inerente à incompatibilidade dos princípios morais destacados do contexto prático contingente em que estão inseridos. É imprescindível abrir mão do conceito de 'cancelamento lógico' dos princípios morais intuitivos. Em última instância, é necessário então destacar o dilema dos conflitos morais do conflito prático peculiar da fraqueza de vontade. 
O conflito dos deveres morais evoca parâmetros morais incompatíveis com o fenômeno da fraqueza de vontade. A incompatibilidade da ação de deveres morais não necessariamente implica em uma incompatibilidade lógica de princípios morais. É importante ressaltar ainda que o conflito interno da akrasia antiga também não se aplica aos parâmetros dos deveres morais absolutos. Nesse sentido, Charlton (1988, p. 50) enfatiza que a ética antiga de Platão e Aristóteles não obedece a princípios morais absolutos:

(...) the ancient Greeks did not, like the Jews and Christians, accept what are sometimes called 'moral absolutes', rules admitting of no exceptions. (...) Plato and Aristotle seem to have held that no moral principle is ever more than prima facie (...) no general rule can ever determine what is right or wrong in every possible case.

Diante disso, não há sentido em atribuir à ética antiga princípios morais absolutos que são essencialmente modernos. Como observamos antes, a ética antiga de Platão e Aristóteles está amparada principalmente na psicologia moral e na formação do caráter moral através da educação prática dos apetites irracionais antes mesmo do aprendizado intelectual ético do agente. Por isso, as críticas de Williams aos princípios morais absolutos não se aplicam apropriadamente à ética antiga ou, mesmo ao conflito interno entre razão e paixão da akrasia antiga.

As inconsistências do conflito dos deveres morais apenas nos revelam que é preferível abrir mão da categoria de princípios morais absolutos na filosofia analítica da ação intencional. Como alerta Anscombe (2010, p. 24-29), o 'dever moral' recupera uma concepção legalista de ética, no sentido restritivo de uma obrigação legal. Em termos absolutos, só há espaço na ética legalista para o moralmente correto e o moralmente errado. Por isso, o 'dever' moral não tem aplicação adequada fora do contexto moral legalista e nem admite o desempenho gradual da excelência moral da ética aristotélica ${ }^{516}$. A partir dessas indicações, Anscombe leva adiante sua crítica da ética legalista à leitura analítica tradicional do silogismo prático aristotélico.

Em Intention, Anscombe já havia ressaltado que o 'silogismo prático' aristotélico não depende de princípios morais absolutos. Para Anscombe (2000, p.

\footnotetext{
${ }^{516}$ Cf. ANSCOMBE, 2010, p. 28: "Ele [o termo dever moral] não faz sentido razoável fora de uma concepção legalista em ética; [os nossos escritores atuais] não defendem essa concepção; e você pode fazer ética sem ela, como nos mostra o exemplo de Aristóteles."
} 
64-72), os termos 'dever', 'é preciso', ou 'é necessário' da premissa universaldo silogismo prático não tem essencialmente valor ético ou moral intrínseco. A presença desses termos na 'premissa universal' expressa sobretudo o 'ponto de partida' do que é desejado (wanted) pelo agente. ${ }^{517}$. Como vimos, o 'fim desejado' é efetivamente central na formação do 'silogismo prático' aristotélico, mas sua aplicação geral no campo prático não deixa de ter implicações morais em sua ética das virtudes. Em particular, Anscombe se ocupa em formular sua própria concepção moderna do 'silogismo 'prático'.

Embora a crítica de Anscombe seja dirigida adequadamente às normas morais da inferência imperativa de Hare, ela não se aplica à ética em geral ou ao próprio silogismo prático de Aristóteles ${ }^{518}$. Em especial, Anscombe busca fornecer uma aplicação moderna do 'silogismo prático' independente dos pressupostos aristotélicos ou da inferência imperativa de Hare. Em última instância, as categorias do dever moral e os princípios morais não representam adequadamente o resultado final do 'silogismo prático'. Ao invés disso, Anscombe (Ibid., p. 80) defende que o resultado final genuíno do 'silogismo prático' moderno é a 'intenção' da ação:

But if Aristotle's account were supposed to describe actual mental processes, it would in general be quite absurd. The interest of the account is that it describes an order which is there whenever actions are done with intentions; the same order as I arrived at in discussing what ' the intentional action ' was (...).

Independente dos 'processos mentais atuais', Anscombe alega que o ‘silogismo prático' expressa sobretudo a intenção da ação ou a ação intencional do agente. Assim, o silogismo prático moderno deve abrir mão das categorias morais aristotélicas ou dos princípios morais absolutos. De um lado, o silogismo prático de Aristóteles mostra que a conclusão prática resulta inevitavelmente na ação. De

\footnotetext{
${ }^{517}$ Cf. Idem, 2000, p. 64: "The occurrence of 'should ' (...) has no doubt helped the view that the practical syllogism is essentially ethical, but the view has no plausibility (...) and Aristotle nowhere suggests that the starting point is anything than something wanted.. In thinking of the word for 'should ', ' ought ' etc. (dê̂) as it occurs in Aristotle, we should think of it as it occurs in ordinary language (...) and not just as it occurs in the examples of ' moral discourse ' given by moral philosophers." (itálicos da autora)

${ }^{518}$ Cf. MOTHERSILL, 1962, p. 450: "Aristotle does say, or seems to say, that standards and procedures of practical reason are what they are because practical reason deals with particular human actions and problems of choice. It is not obvious that this is an insufficient basis for speaking of a special form of reasoning. And if someone thought it was a sufficient basis, he would not be constrained to recognize the Mince Pie Syllogism (an argument which belongs in any case, I suppose, under the heading of productive reason)."
} 
outro lado, a inferência imperativa de Hare estabelece que a conclusão prática resulta antes em um comando prático da ação. Particularmente, Anscombe sustenta que o silogismo prático resulta em uma 'intenção' de agir conforme razões internas do agente e não chega a constituir um comando prático ou a realização concreta da ação.

A partir disso, Anscombe inaugura um novo 'internalismo motivacional' da ação. Para Anscombe, as razões internas práticas do agente representam, na realidade, a 'intenção' ou a 'ação intencional'. Antes de expressar um comando prático ou a realização concreta da ação, o raciocínio prático constitui a 'intenção' do agente no momento imediato da ação. Desse modo, a ação realizada não constitui mais o critério decisivo de descrição proposicional das razões internas do agente. Como veremos, a concepção de 'intenção' será fundamental na teoria causal da ação de Davidson. Antes disso, devemos recapitular alguns aspectos centrais do prescritivismo moral e da 'fraqueza moral' de Hare.

\subsection{0 As limitações do prescritivismo moral e da fraqueza moral}

As limitações dos princípios morais absolutos do 'dever' se abatem sobre o prescritivismo moral e a fraqueza moral de Hare. De um lado, o prescritivismo moral de Hare estabelece um rígido internalismo moral das razões, isto é, a implicação lógica necessária dos princípios morais absolutos na ação moral. De outro lado, as diversas formas de fraqueza moral jamais chegam próximas à irracionalidade prática da fraqueza de vontade. A redução do fenômeno ao conflito irresoluto de deveres morais faz desaparecer o problema original da fraqueza. $\mathrm{Na}$ sequência, devemos relembrar alguns aspectos centrais do prescritivismo moral de Hare e a fraqueza moral.

Com base em um rígido internalismo moral, o prescritivismo moral surge estreitamente ligado à ação moral. O prescritivismo moral exibe uma doutrina do ‘significado’ primário prescritivo inerente aos juízos morais do agente. De acordo com o prescritivismo moral, os juízos morais prescritivos têm implicação lógica necessária na condução da ação moral. O internalismo moral de Hare estabelece uma conexão necessária entre as razões morais e a ação moral. A ação realizada 
constitui o critério final para determinar a 'prescritividade' ou a falta de 'prescritividade universal' do juízo moral do agente. Nessa perspectiva, os princípios morais universais possuem absoluta predominância na ação moral.

O princípio moral absoluto nem sempre prevalece sobre outros princípios prescritivos singulares, ligados às intuições morais, desejos ou emoções. A absoluta autoridade dos princípios morais críticos na ação moral não está assegurada. Sem dúvida, há uma dimensão prescritiva inerente aos juízos morais na orientação da conduta moral, mas isso não demonstra sua eficácia prática na ação moral. De fato, Hare admite que os juízos morais podem expressar também sentimentos, emoções e outros estados psicológicos. No entanto, essas outras funções dos princípios prescritivos ficam relegados ao significado 'secundário' dos juízos morais. Particularmente, o ‘significado' secundário dos juízos morais ficam mais explícitos no desafio da fraqueza moral.

A fraqueza moral de Hare jamais chega a constituir o problema genuíno da fraqueza de vontade. A autoridade suprema dos princípios morais críticos sobre os princípios morais intuitivos se reflete na descrição final da fraqueza moral. Desde $L M$, Hare isola a fraqueza moral ao campo do significado 'entre aspas' do juízo moral fora do significado 'prescritivo' universal genuíno dos princípios morais absolutos. Por isso, a fraqueza moral jamais constitui um conflito prático efetivo da ação contrária ao melhor juízo, pois falta ao princípio moral a 'prescritividade' fundamental na ação. Com efeito, os diversos tipos de fraqueza moral apenas confirmam essa impressão inicial.

Dentre os casos de fraqueza moral, nenhum chega a constituir um caso genuíno de fraqueza de vontade. Em primeiro lugar, os casos de impossibilidade física ou impossibilidade psicológica não cumprem as exigências mínimas do alcance físico e psicológico do agente. A compulsão psicológica exibe impulsos irracionais fortes que eliminam a possibilidade de domínio do agente sobre sua ação moral. Em segundo lugar, a hipocrisia não cumpre o requisito de assentimento sincero do agente ao princípio moral. Nessa esfera, o princípio moral é meramente convencional e não há implicação prática do agente na ação. Mesmo no autoegano, o caso mais decisivo, o princípio moral expressa apenas um sentimento psicológico sem o significado prescritivo autêntico. Sobretudo, a redução final da fraqueza moral ao conflito de deveres morais nos afasta ainda mais do problema original da fraqueza de vontade. 
O conflito de deveres morais deixa a fraqueza moral subordinada ao perspectivismo moral do agente. Como vimos, as categorias morais do 'dever' transformam inevitavelmente a fraqueza moral em um conflito de deveres morais. No entanto, restam dúvidas se continuamos tendo um problema genuíno de fraqueza de vontade. Como mostra Williams, o ponto de vista interno do agente é fundamental na percepção do conflito de deveres morais. Nem sempre o princípio moral predomina sobre outros valores pessoais legítimos do agente. Além disso, há conflitos morais que são simplesmente insolúveis independentemente dos valores morais do agente. Para todos os efeitos, é preferível destacar as categorias morais do 'dever' do problema da fraqueza de vontade. 


\section{7. \\ A possibilidade da fraqueza de vontade e a irracionalidade prática em Davidson}

\section{1 \\ O desafio da fraqueza de vontade e a irracionalidade prática}

A negação da fraqueza moral depende da redução da fraqueza de vontade ao conflito de deveres morais. Como vimos, o prescritivismo moral não explica satisfatoriamente a irracionalidade prática e sequer apresenta uma descrição consistente da ação contrária ao princípio moral. Ora, o controverso conflito de princípios morais é irredutível e distinto do conflito prático específico da fraqueza de vontade. O problema filosófico da fraqueza permanece vivo e intacto independentemente das categorias do dever moral.

Após a negação do fenômeno, Donald Davidson reestabelece o problema da possibilidade da fraqueza de vontade na filosofia analítica da ação ${ }^{519}$. Ao longo de dois artigos clássicos, 'How is Weakness of Will Possible?' (1969) e 'Paradoxes of Irrationality' (1982), o filósofo fornece uma descrição lógica coerente do fenômeno a fim de torná-la compatível com nossos princípios intuitivos básicos da conexão causal entre a razão prática e a ação intencional.

Assim como Hare, Davidson confronta a fraqueza de vontade a partir do internalismo das razões para a ação e a ação intencional do agente. O seu ponto de partida, entretanto, é diferente de seu antecessor. Segundo Davidson (2001b, p. 29), o problema filosófico persiste independente de outros tipos de comportamentos irracionais:

Does it never happen that I have an unclouded, unwavering judgement that my action is not for the best, all things considered, and yet where the action I do perform has no hint of compulsion

\footnotetext{
519 Apesar do título do artigo se referir à 'fraqueza de vontade' como conhecemos atualmente o fenômeno, Davidson prefere designá-lo de 'incontinência' (incontinence) praticamente ao longo de todo o artigo. Dentre os termos e expressões que dispomos para denominar o fenômeno, este é uma das piores alternativas pelos motivos indicados anteriormente no primeiro capítulo. Em 'Paradoxes of Irrationality' (1982), Davidson retorna ao fenômeno, desta vez lhe denominando pelas expressões 'fraqueza de vontade' e 'akrasia', o que comprova ser um termo bem mais apropriado. Em todo caso, com o propósito de manter nossa coerência e evitar obscuridades, iremos nos referir ao fenômeno pela expressão mais consagrada, 'fraqueza de vontade'.
} 
or of the compulsive? There is no proving such actions exist; but it seems to me absolutely certain that they do. And if this is so, no amount of attention to the subtle borderline bits of behaviour will resolve the central problem. ${ }^{520}$

Dessa forma, a fraqueza de vontade é um fato psicológico incontornável. Por vezes, temos discernimento firme e claro de que a ação realizada não é a melhor, levando em conta "todos os fatores considerados (all things considered)", mesmo sem sofrer qualquer pressão externa física ou pressão interna psicológica. A impressão intuitiva interna do fenômeno precede qualquer necessidade ulterior de comprovar a sua existência factual. Sobretudo, Davidson está interessado na sua manifestação interna na razão prática do agente e não em sua manifestação externa.

O reconhecimento da possibilidade da fraqueza de vontade fornece uma nova perspectiva do fenômeno. Ao contrário de Hare, a perspectiva de Davidson exige a estrita desvinculação da 'fraqueza de vontade' do campo da 'moralidade' 521 . Em primeiro lugar, o isolamento do fenômeno do conflito de deveres morais permite uma distinção mais clara de sua descrição lógica particular. Em segundo lugar, a descrição lógica da fraqueza apresenta mais claramente a incompatibilidade lógica do melhor juízo e a ação intencional do agente. A partir disso, Davidson inaugura um campo de investigação promissor da irracionalidade prática humana. A transição de 'Weakness' a 'Paradoxes ${ }^{\text {'522 }}$ marca um deslocamento do enfoque de Davidson acerca da fraqueza de vontade.

Apesar da renovação do problema filosófico, a descrição lógica da fraqueza de vontade de Davidson não é inteiramente satisfatória. Posteriormente, a literatura crítica tem indicado que há duas descrições incompatíveis do fenômeno presentes em ambos os artigos. No primeiro artigo, Davidson alega que há uma incompatibilidade lógica fundamental entre a ação intencional e o 'melhor juízo'

\footnotetext{
${ }^{520}$ Até onde sabemos, não dispomos de nenhuma tradução portuguesa especializada dos artigos de Davidson reunidos recentemente em cinco compêndios diferentes. Desse modo, as traduções em português apresentadas a seguir são de minha própria autoria e foram confrontadas com traduções já disponíveis em outras línguas estrangeiras.

${ }^{521}$ Sob esse ângulo, Davidson (2001b, p. 30) recomenda destacar a fraqueza de vontade do campo estritamente moral: "As a first positive step in dealing with the problem of incontinence, I propose to divorce the problem entirely from the moralist's concern that our sense of the conventionally right may be lulled, dulled, or duped by a lively pleasure.". Sobre a necessidade de destacar a fraqueza de vontade dos parâmetros morais, ver também WILLIAMS, 1993, p. 45-46.

${ }^{522}$ Para efeitos pragmáticos, devemos nos referir ao primeiro artigo clássico de 1969 pelo título 'Weakness' e ao segundo artigo de 1982 pelo título singular 'Paradoxes'. Sobretudo, esses dois artigos centrais acompanham dois estudos mais amplos de Davidson sobre a razão prática: o estudo inicial sobre a teoria causal da ação intencional e o estudo posterior concentrado na irracionalidade prática.
} 
do agente, ou melhor, o juízo intencional da ação e o juízo de todos os fatores considerados (all things considered) na fraqueza. No segundo artigo, a fraqueza é classificada pela ignorância ou 'sobreposição' irracional do princípio da continência, o princípio segundo o qual é preciso agir de acordo com o 'melhor juízo'. Ora, o enfoque de Davidson sobre a irracionalidade prática exige uma nova teoria de partilha da mente. Embora tais posições não sejam explicitamente incongruentes, uma análise mais detalhada faz emergir a inconsistência fundamental.

Em linhas gerais, defendemos que a primeira descrição lógica é mais correta e consistente do que a segunda descrição do fenômeno. Sobretudo, indicaremos que a partilha da mente e a segunda descrição da fraqueza fornecem uma concepção inconsistente de irracionalidade prática. Para isso, devemos ter em mente que o desafio da fraqueza de vontade contemporânea precisa ser esclarecido dentro do plano da recepção analítica da akrasia antiga.

O estatuto da fraqueza de vontade de Davidson reflete a recepção analítica da akrasia antiga. Para Davidson, o 'silogismo prático' aristotélico ou a teoria da ação aristotélica fornece a possibilidade de uma teoria causal da ação independente do papel intermediário dos 'atos da vontade' no novo campo da filosofia da ação analítica $^{523}$. A teoria causal da ação de Davidson resgata a concepção antiga da explicação da ação voluntário com base nas crenças, motivações e desejos internos do agente. Sob os novos parâmetros modernos, a concepção da fraqueza de vontade de Davidson retoma, em certo sentido, o debate da akrasia antiga.

A concepção da fraqueza de vontade de Davidson está marcada pela akrasia antiga de Platão e Aristóteles. Com efeito, a primeira descrição da fraqueza em 'Weakness' se inspira na própria estrutura lógica do duplo silogismo acrático de ENVII.3. Além disso, o paradoxo da irracionalidade de 'Paradoxes' emerge de dois princípios claramente derivados da akrasia antiga: o Princípio de Platão ou a pura racionalidade, e o Princípio de Medéia ou a pura irracionalidade dos impulsos irracionais. Sem dúvida, o problema da fraqueza de vontade de Davidson se apoia

\footnotetext{
${ }^{523}$ Cf. DAVIDSON, 2005, p. 279: "One feature of Aristotle's theory of action is particularly striking, for it goes against the general subsequent tradition [of the concept of will]: he left no role for the concept of the will. Deliberation plays a role, but no separate act of decision enters the causal chain."
} 
na recepção analítica da akrasia antiga. Diante disso, devemos nos voltar primeiramente à formulação original do problema da fraqueza de vontade em 'Weakness'.

\section{2 \\ O problema da fraqueza de vontade em How is Weakness of Will Possible? (1969)}

O problema da fraqueza de vontade (weakness of will) contemporânea é reestabelecido no clássico artigo 'How is Weakness of Will Possible?' (1969). A princípio, a crença comum na fraqueza de vontade está em aparente contradição com outros princípios intuitivos da conexão entre o juízo avaliativo do agente e a ação intencional. Diante disso, Davidson alega que não há contradição em nossos princípios intuitivos quando analisamos mais detalhadamente a razão prática e a fraqueza de vontade. $\mathrm{O}$ desafio da possibilidade da fraqueza envolve a descrição lógica fundamental do fenômeno dentro dos parâmetros da teoria causal da ação e as dificuldades inerentes à irracionalidade prática.

Em 'How is Weakness of Will Possible?', Davidson (2001b, p. 23) salienta que o problema da 'fraqueza emerge de uma aparente contradição diante de nossa crença comum no fenômeno e dois outros princípios intuitivos:

PI. If an agent wants to do $x$ more than he wants to do $y$ and he believes himself free to do either $x$ or $y$, then he will intentionally do $x$ if he does either $x$ or $y$ intentionally.

P2. If an agent judges that it would be better to do $x$ than to do $y$, then he wants to do $x$ more than he wants to do $y$.

P3. There are incontinent actions. (itálicos do autor)

Nessa passagem, as "ações incontinentes (incontinent actions)" de P3 correspondem ao que designamos anteriormente de ações fracas ou da 'fraqueza de vontade'. De fato, a existência da 'fraqueza' expressa em P3 parece entrar em conflito com a conjunção de P1-P2. Primeiramente, P1 estabelece a conexão intrínseca da força motivacional (querer (want), desejos (desires) ou inclinações (urges)) e a ação intencional do agente. Em seguida, P2 fornece um tipo de 'internalismo' motivacional da ação, a relação direta do juízo valorativo e a 
motivação da ação (independemente das categorias 'morais' absolutas) ${ }^{524}$. Com base em P1-P2, teríamos então um princípio internalista mais forte, segundo o qual o juízo avaliativo ' $x$ é melhor que $y$ ' implica necessariamente em fazer $x$ em lugar de fazer y (Ibid., p. 23). Ora, o princípio P3, ou seja, o pressuposto inuitivo de que há ações contrárias ao ‘melhor juízo’ do agente colocam em xeque o princípio forte resultante de P1-P2 (cf. MELE, 1982, p. 347-348).

De acordo com Davidson (Ibid., p. 22), a aparente contradição de P1-P3 é superada ao nos depararmos com a descrição comum da fraqueza de vontade:

D. In doing $x$ an agent acts incontinently if and only if: $(a)$ the agent does $x$ intentionally; $(b)$ the agent believes there is an alternative action $y$ open to him; and $(c)$ the agent judges that, all things considered, it would be better to do $y$ than to do $x$. (itálicos do autor)

A descrição comum da fraqueza de vontade de Davidson evoca, em certo sentido, a descrição tradicional da akrasia antiga do Protágoras (352d-e). Nesse sentido, é importante fazer uma análise comparativa da akrasia tradicional e da fraqueza de vontade. Em primeiro lugar, a liberdade de escolha do agente em relação às alternativas de ação é fundamental em ambos os fenômenos descritos. Entretanto, a akrasia antiga depende necessariamente da possibilidade factual (objetiva) do erro moral voluntário do agente, enquanto a fraqueza expressa apenas a crença interna do agente em sua liberdade de escolha durante sua ação irracional (independente de fatores externos) $)^{525}$. Em segundo lugar, a avaliação lógica sintética de 'todos os fatores considerados' (all things considered) ou o juízo TFC da fraqueza de vontade substitui, em contrapartida, a avaliação prática do que é melhor na akrasia antiga. Em terceiro lugar, o conflito prático do agente nesses dois fenômenos não pode ser da mesma natureza. Na fraqueza, a ação intencional do agente é realizada contra o juízo de 'todos os fatores considerados', enquanto a akrasia consiste no conflito interno entre o desejo racional e os desejos irracionais.

\footnotetext{
${ }^{524}$ Como mostraremos a seguir, Davidson rejeita a predominância superior de princípios morais absolutos sobre outros tipos de juízos valorativos da ação. Dessa forma, ele consegue claramente distinguir com sucesso o problema da fraqueza de vontade do dilema geral dos conflitos morais. ${ }^{525}$ Cf. SEGVIC, 2006, p. 66-67 n. 27: "Davidson's remark is appropriate given his perspective on weakness of will. But Socrates is not in error here. His characterization reflects his approach to akrasia. Unlike us (and, to some extent, unlike Aristotle), Socrates approaches akrasia from outside in." De certa forma, há uma interlocução curiosa entre Davidson e Santas acerca da invariável imprecisão da existência factual da fraqueza de vontade, ver DAVIDSON, 2001b, p. 22, n... ; SANTAS, 1979 , p. 318 n. 3
} 
Em especial, essa descrição puramente lógica da 'fraqueza' permite a Davidson considerar o fenômeno segundo os parâmetros de uma nova teoria causal da ação.

A resolução da possibilidade da fraqueza de vontade reside na distinção fundamental dos tipos de juízos valorativos de P1-P3. Na realidade, a avaliação de 'todos os fatores considerados' da fraqueza de P3 não é compatível com o juízo valorativo absoluto presente em P1-P2. Dessa forma, Davidson sustenta que não há qualquer contradição entre a existência da fraqueza e nossas crenças intuitivas tradicionais da ação intencional. Para analisarmos a solução engenhosa de Davidson, precisamos antes expor os princípios fundamentais de sua inovadora teoria causal da ação.

\section{3}

\section{A teoria causal da ação e os tipos de juízos avaliativos}

O internalismo motivacional da ação de P1-P2 se baseia em uma teoria causal da ação. Para Davidson, a ação humana decorre de um evento mental causado pelas razões do agente para realizar uma ação. No nível causal, a descrição e a explicação racional da ação intencional se dá a partir do conjunto de razões e desejos internos do agente. ${ }^{526}$ Como veremos adiante, a teoria causal da ação se ampara, em certa medida, na psicologia antiga e sua explicação racional da ação. A princípio, a fraqueza de vontade assinala apenas a descrição de uma ação contrária à razão prática. Nesses termos, o desafio da fraqueza exige uma teoria da ação causal consistente que elimine a contradição de P1-P3.

Em Actions, Reasons and Causes, Davidson (2001a) delineia os princípios da relação causal das razões práticas e a ação intencional do agente. A teoria causal da ação de Davidson está fundada em dois princípios interligados: (1) a explicação racional da ação pelas razões internas do agente; (2) a relação causal entre as razões para a ação e as ações intencionais do agente. Primeiramente, precisamos definir o que constitui a explicação racional da ação humana.

\footnotetext{
${ }^{526} \mathrm{Cf}$. Idem, 2001, p. 121: "To say someone did something intentionally is to describe the action in a way that bears a special relation to the beliefs and attitudes of the agent; and perhaps further to describe the action as having been caused by those beliefs and attitudes."
} 
A explicação racional da ação fornece as condições necessárias da descrição proposicional da ação intencional. Para Davidson (2001a, p. 3), a descrição proposicional da ação corresponde a um processo de racionalização da ação: "we call such explanations rationalizations, and say that reason rationalizes the action" (itálicos do autor). A racionalização da descrição da ação envolve dois elementos internos do agente (Ibid., p. 3-4): as crenças e as 'pró-atitudes' (pro attitudes) ou, melhor, as 'motivações' para a ação ${ }^{527}$. Nesses termos, a descrição proposicional da ação abrange o composto de crenças-desejos do agente designado de razão primária $^{528}$. O processo de racionalização da ação de Davidson é largamente instrumental, dado que os desejos e crenças do agente fornecem um meio para alcançar um fim da ação ${ }^{529}$. Com base na explicação racional, Davidson sustenta uma teoria causal da ação intencional.

A conexão causal da ação explica a ação intencional em vista das crenças e desejos do agente. Na sequência, Davidson (Ibid., p. 10) sugere que é preciso inserir a ação intencional dentro de um contexto causal descritivo mais amplo:

One way we can explain an event is by placing it in the context of its cause; cause and effect form the sort of pattern that explains the effect, in a sense of 'explain' that we understand as well as any.

Dentro da relação causal, as razões internas do agente fornecem uma justificação racional da ação intencional. De um lado, temos a oportunidade de isolar claramente as razões do agente e suas ações intencionais dentro de um contexto descritivo de causa e efeito. De outro lado, isso também oferece a possibilidade de fazer redescrições da ação em vista das razões do agente. Nesse caso, a causalidade se restringe aqui apenas ao contexto da descrição proposicional

\footnotetext{
527. Por 'crenças' entende-se um amplo conjunto de fenômenos cognitivos como 'percepção, lembrança, saber, etc.', enquanto por 'pró-atitudes' compreenda-se um amplo conjunto de motivações tais como 'querer, (wantings), 'impulsos' (urges), 'incitações' (promptings). A conjunção entre 'crenças' e 'pró atitudes' resulta em uma razão primária pela qual o agente realiza ação. Uma razão só é considerada razão primária da ação quando ela representa as 'crenças' e 'próatitudes' do agente na medida em que realiza determinada ação.

${ }^{528}$ Cf. Ibid., p. 5: " $R$ is a primary reason (...) if $R$ consists of a pro attitude of the agent towards actions of certain property, and a belief of the agent that $A$, under the description $d$, has that property."'(itálicos do autor)

${ }^{529}$ Cf. MELE, 2003, p. 71: "Davidson's notion of rationalizing is a broadly instrumental one. In some cases, the belief component of a reason for $A$-ing representes $A$-ing as a means to $E$. In others, the belief represents $A$-ing as an instance of $E$ (e.g., the belief that going for a swim would be a good way of exercising today in someone who desires to exercise today).” (itálicos do autor)
} 
da ação sem aplicação geral a leis causais estritas ${ }^{530}$. Nessa perspectiva, a teoria causal da ação de Davidson não é nenhuma inovação inédita pois tem suas raízes na tradição da psicologia antiga.

A teoria causal da ação se inspira na tradição da psicologia antiga. Com efeito, Davidson (2001a, p. 11) reconhece seu débito à doutrina do silogismo prático aristotélico: "the best argument for a scheme like Aristotle is that it alone promises to give an account of the 'mysterious connection' between reasons and actions.". Como veremos, isso não o impede também de tecer suas críticas e fazer sua reformulação do silogismo prático ${ }^{531}$. Entretanto, observamos que a conexão causal da ação voluntária e as razões internas do agente têm raízes filosóficas anteriores desde Platão. Particularmente, o hedonismo socrático do Protágoras e a psicologia tripartite da República já expõem uma psicologia moral da ação calcada nas crenças e desejos do agente.

Na seção final, devemos explorar as diferenças da psicologia moral antiga e a teoria causal da ação de Davidson. Por enquanto, devemos ressaltar que a teoria causal da ação fornece parâmetros básicos para o esclarecimento da natureza da razão prática e a resolução da aparente contradição de P1-P3.

A aparente incompatibilidade de P1-P3 desaparece à medida que distinguimos o juízo intencional da ação do juízo avaliativo de 'todos os fatores considerados' da fraqueza. Ao contrário do que parece, os juízos da 'intenção' não são necessariamente derivados e, nem mesmo tem a mesma expressão lógica, da avaliação de 'todos os fatores'.

Em Intending, Davidson (2001c, p. 97-98) salienta que a 'pura intenção' (pure intending), abstraída de qualquer contexto particular da ação, designa uma classe de ação "simplesmente desejável" e não bom ou desejável segundo uma qualificação lógica. Os juízos valorativos ordinários comuns são determinados

\footnotetext{
530 É importante salientar que essa relação causal não representa uma lei causal necessária. Na realidade, Davidson (Ibid., p. 13-17) alerta contra essa proposta interpretativa literal da teoria causal da ação como uma lei causal estrita entre diferentes eventos mentais: "If the causes of a class of events (actions) fall in a certain class (reasons) and there is a law back each singular causal statement, it does not follow that there is any law connecting events classified as reasons with events classified as actions - the classifications may even be neurological, chemical, or physical.". Dessa forma, a teoria causal da ação apenas estabelece uma conexão causal dentro da descrição proposicional dos eventos mentais (razões e ações intencionais) e não uma lei causal literal dos eventos mentais.

${ }^{531}$ Tal como Anscombe, Davidson (2001c, p. 96) alega que a conclusão do silogismo prático constitui uma intenção antes de uma ação propriamente dita: "It is an important doctrine that the conclusion of a piece of practical reasoning may be an action; it is also important that the conclusion may be the formation of an intention to do something in the future."
} 
logicamente por certas categorias valorativas, como 'bom', 'desejável' ou 'moralmente obrigatório'. Enquanto isso, o juízo intencional está vinculado a um 'relato interno' do futuro imediato: "given what I now know and believe, here is my judgement of what kind of action is desirable.” (Ibid., p. 100). De fato, os juízos avaliativos comuns ordinários não possuem a mesma equivalência lógica do juízo intencional da ação.

Para esclarecer isso, Davidson (Ibid., p. 98) distingue duas categorias lógicas de juízos, o juízo sans phrase da 'intenção' do agente e os juízos denominados de prima facie:

Prima facie judgments cannot be directly associated with actions, for it is not reasonable to perform an action merely because it has a desirable characteristic. (...) The judgement that corresponds to, or perhaps is identical with, the action cannot, therefore, be a prima facie judgement; it must be an all-out or unconditional judgement which, if we were to express it in words, would have a form like 'This action is desirable'.

Dentro desses parâmetros, Davidson estabelece uma distinção dos juízos avaliativos segundo sua forma lógica: (a) juízos prima facie condicionais, isto é, juízos valorativos 'à primeira vista' de acordo com categorias avaliativas predeterminadas (moral, desejável, etc.) indiretamente ligadas à ação; (b) juízos sans phrase incondicionais, ou melhor, os juízos 'sem ressalvas' (all-out judgements) que estão diretamente ligados à 'intenção' da ação. De acordo com essa distinção, o juízo absoluto intencional da ação não corresponde logicamente ao juízo prima facie relacionado a um padrão avaliativo condicional expresso em ‘uma caracterítica desejável' qualificada. Mesmo o juízo de ‘todos os fatores' ainda faz parte da classe lógica dos juízos prima facie e não pode ser diretamente deduzido do juízo intencional da ação ${ }^{532}$. Diante disso, precisamos compreender melhor como a distinção dos juízos valorativos permite superar a contradição de P1-P3 no artigo 'Weakness'.

De acordo com Davidson (2001b, p. 34-39), os juízos do tipo sans phrase expressam uma avaliação incondicional das alternativas de ação, enquanto juízos

\footnotetext{
${ }^{532} \mathrm{Cf}$. Idem, 2001c, p. 98: "all we can deduce is that the action has a feature that argues in its favour. (...) reasons (...) do not generally constitute all the reasons the agent considered in acting, and so knowing the intention with which someone acted does not allow us to resconstruct his actual reasoning."
} 
prima facie são condicionados por um critério de avaliação geral, como 'bom', 'correto', 'desejável' 'moralmente obrigatório'. Por um lado, a fórmula lógica prima facie pode ser expressa da seguinte forma: $x$ é melhor que $y$, em vista de $r$ (uma razão ou $n$-razões para a ação). Dessa forma, $r$ corresponde a uma ou mais razões para a ação determinadas pelo padrão avaliativo prima facie das opções $x \mathrm{e}$ $y$. Por outro lado, consideramos que ' $x$ é melhor que $y$ ' de forma absoluta segundo a formulação lógica dos juízos sans phrase. Em termos lógicos, os juízos sans phrase exibem a seguinte expressão incondicional: ' $x$ é melhor que $y$, sem levar em conta quaisquer outros fatores'. Na realidade, os juízos absolutos da ação intencional são logicamente incompatíveis com os juízos prima facie avaliativos.

De forma ilustrativa, os juízos valorativos comuns, como ' $x$ é melhor (mais correto, desejável ou moralmente obrigatório) que $y^{\prime}$, fornecem razões prima facie da avaliação preferencial da ação. Enquanto isso, os juízos absolutos, como ' $x$ é melhor que $y$ ' ou ' $y$ é pior que $x$ ' expressam a intenção direta do agente ao realizar sua ação. Nessa medida, podemos explicar em que sentido a ação intencional não corresponde ao juízo de 'todos os fatores' na descrição lógica original da fraqueza de vontade.

O cálculo de 'todos os fatores considerados' (all things considered) é mais amplo e mais específico do que o juízo prima facie comum. Ora, o juízo TFC calcula as razões a favor e contra uma ação particular. Para Davidson (2001b. p. 40), os juízos comuns prima facie exibem uma clara limitação em relação ao cálculo do juízo TFC: “The phrase 'all things considered' must, of course, refer only to things known, believed, or held by the agent, the sum of his relevant principles, opinions, attitudes, and desires." Todavia, o cálculo de todos os fatores não deixa de ter uma equivalência na forma lógica a um juízo prima facie condicional: "Every judgement is made in the light of all reasons in this sense, that it is made in the presence of, and is conditioned by, that totality." (Ibid., p. 40). Diante disso, podemos constatar que o cálculo de todos fatores não deixa de ter a mesma forma lógica que um juízo prima facie, e, ao mesmo tempo, dá um passo adiante na avaliação total das razões do agente.

Ao substituirmos, então, $r$ (razão (ões) da ação) das razões prima facie pelo termo $t$ em referência a 'todos os fatores considerados' não há alteração da formulação lógica. Nesses termos, o juízo TFC é expresso na mesma formulação que o juízo condicional prima facie: 'em vista de $t, x$ é melhor do que $y$ '. Para 
Davidson, há uma distinção crucial entre os juízos avaliativos de P1-P3: os juízos de valor de (P1) e (P2) são autênticos juízos sans phrase, enquanto a avaliação de 'todos os fatores' da descrição tradicional da 'fraqueza' (P3) constitui um juízo prima facie.

O modelo do silogismo prático aristotélico seria incompatível com a natureza da razão prática e a descrição lógica da fraqueza de vontade de Davidson. Em sua perspectiva, o duplo silogismo acrático não contempla claramente o juízo TFC e, por isso, recai novamente no problema dos conflitos morais incompatíveis. Com base na distinção dos juízos valorativos, Davidson ressalta o principal equívoco relacionado ao modelo do silogismo prático aristotélico e o conflito dos princípios morais.

\section{4}

\section{A reestruturação do silogismo prático e a primeira descrição da fraqueza de vontade}

A resolução do problema da fraqueza de vontade de 'Weakness' está intrinsecamente ligada à reestruturação lógica do silogismo prático aristotélico. A crítica de Davidson ao modelo do silogismo prático se dirige à suposta incompatibilidade do duplo silogismo acrático e não propriamente à explicação physikôs da akrasia de Aristóteles ${ }^{533}$. Em alguma medida, Davidson considera que sua própria solução da fraqueza de vontade reflete a descrição aristotélica da akrasia antiga. Como veremos, a reestruturação do silogismo prático de Davidson se dirige à própria recepção analítica do silogismo prático e ao conflito de princípios morais. Para prosseguirmos, é preciso retomar brevemente a formulação do duplo silogismo acrático e analisar, em seguida, a reestruturação lógica de Davidson.

Como vimos, Aristóteles defende que a akrasia reflete o conflito entre dois silogismos práticos antitéticos de ENVII.3 (1147a25-b20): (I) o silogismo do bem

\footnotetext{
${ }^{533}$ Cf. DAVIDSON, 2001b, p. 32-33. Para Davidson, o silogismo prático aristotélico aplicado à formulação da akrasaa efetivamente é obscuro e rústico, mas o modelo mais sofisticado de Tomás de Aquino apresenta-se de forma logicamente mais consistente. Em todo caso, a fórmula lógica do silogismo prático permanece essencialmente a mesma e as críticas dirigidas ao modelo de Aquino, portanto, seriam dirigidas também ao modelo do silogismo prático de Aristóteles. Todavia, se as críticas são ou não são pertinentes ao modelo do silogismo prático de Aristóteles é algo que veremos adiante.
} 
e (II) o silogismo do prazer. Em linhas gerais, podemos relembrar os dois silogismos antitéticos do acrático em um quadro comparativo:

(I)

(1) 'Doces não devem ser provados'

(2) 'Isto é um doce'

(3) 'Eu não devo comer este doce'

(II)

(1) 'Doces são prazerosos'

(2) 'Isto é um doce'

(3) 'Eu devo comer este doce'

Em 'Weakness', Davidson reconstrói o modelo do silogismo prático aristotélico (derivado também de Tomás de Aquino) e constata sua inevitável sujeição à contradição do conflito moral. Para Davidson (Ibid., p. 33), o duplo silogismo acrático resulta em uma patente conclusão contraditória dos princípios morais: “(...) this picture of moral reasoning is not mereley inadequate to account for incontinence; it cannot give a correct account of simple cases of moral conflict.". (itálicos do autor). Nesse sentido, teríamos assim um juízo moral contraditório do tipo 'é melhor comer este doce do que não comê-lo e, simultaneamente, é melhor não comer este doce do que comê-lo'. Por conta disso, o modelo do silogismo prático não só é inadequado para a descrição lógica da fraqueza de vontade, mas principalmente para o conflito moral em geral.

Assim como Hare, Davidson está assumindo a leitura tradicional do silogismo prático forte, isto é, a tese de que a conclusão prática é a ação. No entanto, observamos que isso não contempla o silogismo prático 'moderado' de Aristóteles e o conflito interno do desejo racional e das paixões irracionais da akrasia antiga. Em todo caso, a crítica de Davidson fica mais clara diante do conflito de juízos morais prima facie do que propriamente do silogismo prático aristotélico original.

O conflito de juízos morais prima facie resulta no conflito insolúvel de princípios morais. Para Davidson, a formulação lógica dos juízos morais prima facie permite afirmar apenas que a fraqueza expressa um confronto de razões internas do agente: há razões tanto em favor do juízo ' $x$ é melhor que $y$ ' como também há razões contrárias em favor do juízo ' $y$ é melhor que $x$ ' (cf. Ibid. p. 32). Como vimos, o prescritivismo moral de Hare classifica igualmente a fraqueza moral como um tipo de conflito de princípios morais intuitivos. Todavia, o prescritivismo 
moral assumia que o princípio moral crítico do dever moral é predominante sobre quaisquer outros princípios morais inuitivos na ação humana.

No entanto, Davidson sustenta que todos os princípios morais, por mais que sejam superiores, ainda refletem juízos prima facie. Por conta disso, os princípios morais não se dirigem estritamente à ação intencional. Em última instância, os juízos morais, enquanto prima facie, permanecem sujeitos ao conflito insolúvel de princípios morais. Além disso, Davidson (Ibid., p. 30) salienta que a fraqueza de vontade não exige a necessidade ou a superioridade das categorias do dever moral: "it is a good ideia to dwell on cases whether morality simply doesn't enter the picture as one of the contestasts of our favour". Para todos os efeitos, é preferível abrir mão da superioridade das categorias do dever moral e da psicologia da vontade moral. Conforme salienta Charlton (1988, p. 116), a distinção lógica de Davidson entre juízos prima facie e juízos sans phrase destaca mais claramente a fraqueza de vontade do dilema moderno do conflito de princípios morais:

Moral philosophers also (witness Hare) tend to think that general moral principles purport to determine what is absolutely right and wrong, and not just right and wrong prima facie. The result in the philosophy of action is that not only weakness of will but the whole phenomenon of moral conflict appears puzzling.

A distinção primordial dos juízos prima facie e dos juízos sans phrase destaca o problema da fraqueza de vontade do âmbito restrito do conflito moral. Com isso, o juízo prima facie moral não reflete necessariamente a ação realizada pelo agente. Nem mesmo serve de parâmetro para a formulação lógica do juízo avaliativo absoluto dos princípios intuitivos P1-P2.

O internalismo de P1-P2 não é o mesmo tipo de internalismo forte do prescritivismo moral de Hare. Como vimos, o intermalismo moral de Hare estabelece que o juízo moral genuíno necessariamente resulta na ação moral. Dessa maneira, o 'significado' (meaning) prescritivo dos termos morais determina o uso apropriado prescritivo do dever moral da ação moral e os usos indevidos descritivos do 'dever' moral, como no caso da fraqueza moral. Ora, o prescritivismo moral resulta inevitavelmente na redução da fraqueza moral ao simples conflito de princípios morais.

Ao contrário, o internalismo 'moderado' de Davidson (Ibid., p. 26-27) não depende do 'significado' dos juízos valorativos do agente, mas apenas da conexão 
lógica formal do juízo valorativo e a motivação da ação. Na realidade, os juízos sans phrase incondicionais de P1-P2 estabelecem a relação lógica fundamental do juízo avaliativo absoluto da intenção de forma independente da forma lógica dos juízos prima facie. Por isso, o problema da fraqueza da vontade emerge de forma mais determinada diante da incompatibilidade lógica da ação intencional contra o juízo prima facie TFC. Sobretudo, a reformulação do duplo silogismo acrático tem o propósito de fornecer uma solução destacada do conflito moral prima facie.

A resolução da contradição dos princípios prima facie exige a formulação lógica de um cálculo superior das razões a favor e contra a ação, o juízo TFC. Somente a introdução do cálculo de ‘todos os fatores' evita o conflito de princípios prima facie e expressa adequadamente a estrutura lógica da razão prática: "It is not enough to know the reasons on each side: he [the agent] must know how they add up.” (Ibid., p. 36). Em outras palavras, os juízos de valor prima facie opostos são computados em uma escala de medida única no juízo TFC, isto é, 'em vista de $t, x$ é melhor que $y$ '.

Mesmo assim, a mera formulação do juízo TFC é insuficiente para dar conta da possibilidade da fraqueza de vontade. Nesse terceiro estágio, Davidson alerta que não há mais um silogismo propriamente dito: “our third 'practical syllogism' is no syllogism at all; the conclusion simply doesn't follow by logic from the premisses." (Ibid., p. 36). A estrutura lógica do juízo TFC corresponde a um novo raciocínio prático independente dos juízos prima facie anteriores. Nesses termos, o juízo TFC não segue a inferência do silogismo prático clássico mas obedece a um outro tipo de lógica, a lógica da 'evidência probabilística'.

Há uma analogia entre a lógica do raciocínio prático prima facie e o modelo lógico da probabilidade indutiva de Hempel (Ibid., p. 37-39) ${ }^{534}$ : assim como os fatos empíricos justificam a crença na ocorrência provável de certo fenômeno, os juízos prima facie oferecem a razão (ou $n$-razões) em virtude da provável realização da ação. No caso do raciocínio probabilístico, podemos refletir com base em evidências empíricas condicionais: 'Se o barômetro cair, quase certamente irá

\footnotetext{
${ }^{534} \mathrm{Em}$ virtude de nosso presente foco na fraqueza de vontade, não investigaremos em maiores detalhes a lógica da probabilidade indutiva de Hempel. De certa forma, a lógica científica da probabilidade indutiva se concentra apenas na justificação das evidências empíricas: a assunção de certas evidências empíricas condicionais justifica a derivação de uma conclusão provável. Em Weakness, o raciocínio probabilístico científico de Hempel é aplicado ao próprio modelo do raciocínio prático de Davidson.
} 
chover' ou 'Se o céu está avermelhado à noite, quase certamente não choverá'. Da mesma forma, é possível construir um juízo TFC probabilístico na seguinte expressão lógica: 'em vista de TFC, quase certamente não choverá'. Em qualquer cenário, a expressão 'quase certamente' (almost certainly) tem a função lógica de um conectivo de probabilidade e não modifica o consequente da premissa: 'Que o barômetro caia, torna provável que irá chover'.

A expressão 'quase certamente' tem uma função conectiva análoga à expressão 'prima facie' de juízos avaliativos proposicionais: "the concept of prima facie, as it is needed in moral philosophy, relates propositions." (Ibid., p. 38). No caso de juízos morais prima facie, a descrição proposicional da ação 'o ato de mentir é errado' adquire uma formulação prima facie como 'o ato de mentir é, prima facie, errado'. Em termos lógicos, poderíamos expressar essa formulação da seguinte forma: 'em vista de $r, x$ é um ato de mentir e $x$ é errado'. Do mesmo modo, é possível formular o juízo TFC em uma forma lógica prima facie: 'em vista de $t$, não comer o doce é melhor do que comê-lo'. No entanto, Davidson (Ibid., p. 39) ressalta que toda categoria prima facie ainda está restrita às condições lógicas qualificadas: "reasoning that stops at conditional judgements (...) is practical only in its subject, not in its issue". Por isso, a ação intencional, expressa nos juízos incondicionais de P1-P2, difere substancialmente dos juízos condicionais prima facie. A fraqueza de vontade consiste então na incompatibilidade lógica da ação intencional contrária ao juízo TFC do agente.

Para Davidson (Ibid., p. 39) a solução da possiblidade da fraqueza de vontade consiste em uma reestruturação lógica do silogismo prático aristotélico:

This modified account of acting on a reason leaves PI and P2 untouched, and Aristotle's remark that the conclusion (of a piece of practical reasoning) is an action remains cogent. (...) The logical difficulty has vanished because a judgement that $a$ is better than $b$, all things considered, is a relational, or $p f$, judgement, and so cannot conflict logically with any unconditional judgement. (itálicos do autor)

Ao retomarmos P1-P2 constatamos, então, que nenhum desses princípios efetivamente exibe o juízo valorativo TFC de P3. A ação intencional da fraqueza não deriva diretamente do juízo TFC (que permanece logicamente prima facie). Para Davidson (Ibid, p. 37), a categoria prima facie expressa a avaliação de $x$ e $y$ dentro de um contexto descritivo específico: "we must give up the idea that we can 
detach conclusions about what is desirable (or better) or obligatory from principles that lend those conclusions colour.”. Dessa forma, a razão (ões) para a ação depende do contexto lógico de cada tipo de juízo avaliativo do agente.

É impossível, a rigor, abstrair a avaliação condicional 'desejável', 'melhor', 'obrigatória' ou mesmo ‘todos os fatores considerados', da fórmula prima facie da qual são intrinsecamente dependentes. Do mesmo modo, a própria intenção do agente está diretamente ligada à ação na forma incondicional sans phrase, ' $y$ é melhor que $x$, sem quaisquer outras condições'. Diante disso, não há nenhum conflito lógico direto entre a ação intencional da fraqueza e o juízo TFC do agente.

Em verdade, a ação intencional da fraqueza é contrária ao cálculo TFC e, ao mesmo tempo, em favor de uma razão prima facie para a ação. Nesses termos, Davidson reconhece a possibilidade da fraqueza contra o juízo TFC. Todavia, essa primeira descrição lógica da fraqueza implica também a negação direta da fraqueza intencional, isto é, a ação contrária ao juízo incondicional (sans phrase). Nesse caso, precisamos compreender melhor em que medida Davidson concorda ou discorda do modelo do silogismo prático forte e a implicação lógica necessária da ação da 'conclusão de uma parte do raciocínio prático'.

Para tornar P1-P3 compatíveis e explicar a possibilidade da fraqueza de vontade, Davidson investe em uma reformulação do silogismo prático. Por isso, Davidson se volta ao modelo do silogismo prático forte, ou seja, a doutrina segundo a qual a conclusão do silogismo prático é a própria ação. O modelo do silogismo prático forte fornece a possibilidade de explicar a ação irracional da fraqueza necessariamente em vista das próprias razões do agente.

A reestruturação do silogismo prático forte endossa a solução compatibilista de Davidson, a preservação lógica da distinção do 'melhor juízo' e da ação intencional. Entretanto, Davidson alega também que a descrição final aristotélica da akrasia é insatisfatória porque depende de uma falta de consciência do bom silogismo.

Para Davidson, a descrição aristotélica da akrasia incorre em ao menos dois equívocos principais: 1) apresenta um modelo lógico inconsistente da razão prática na medida em que apresenta dois silogismos práticos conflitantes que resultam apenas em um juízo moral contraditório (Ibid., p. 32-34); 2) recorre a um tipo de falta de consciência ou distorção do 'melhor juízo' pelo efeito do prazer para explicar a falha prática do agente (Ibid., p. 28-29). Na sequência, devemos salientar 
que as críticas de Davidson ignoram aspectos significativos da descrição aristotélica da akrasia.

O reestabelecimento da possibilidade da fraqueza de vontade de Davidson claramente se inspira na concepção aristotélica do silogismo prático e a descrição final da akrasia. Todavia, o duplo silogismo paralelo acrático de ENVII.3 jamais se configura em uma inconsistência lógica direta das crenças do agente durante o fenômeno.

Em primeiro lugar, o duplo silogismo paralelo jamais entra em conflito lógico direto, pois o conflito efetivo com o bom silogismo decorre apenas da influência dos apetites irracionais (1147a30-b5). Na realidade, os apetites desempenham um papel fundamental no exercício da ação irracional contra o silogismo do bem. Por isso, a apropriação analítica de Davidson segue a linha interpretativa do silogismo prático forte desconsiderando o conflito interno entre razão e paixões irracionais.

Em segundo lugar, a descrição aristotélica da ignorância do fenômeno não reincide em uma forma de falta de consciência ou distorção do bom juízo do agente. Como vimos, a ignorância da premissa particular só pode ser associada, em certa medida, à akrasia impulsiva e não à akrasia fraca propriamente dita (1147b9-13; 115015-28). Em ambos os casos, a ignorância não é propriamente cognitiva, mas está ligada à falta de exercício do 'melhor juízo' devido à inclinação contrária das más paixões irracionais. De fato, Aristóteles reconhece que a akrasia consiste efetivamente no pleno conhecimento do 'melhor juízo' (cf. 1151a20-28). A falha prática em conformidade à conclusão do bom silogismo decorre da força contrária dos apetites irracionais em vista do silogismo de prazer.

A perspectiva de Davidson está marcada pela atribuição de um tipo de ignorância cognitiva à akrasia antiga derivada da leitura tradicional do silogismo prático forte. Dada a implicação lógica necessária da ação no silogismo prático forte, a falha do agente só pode ser explicada pela ignorância ou a falta de consciência de algum estágio do raciocínio prático. Todavia, a descrição lógica da fraqueza de Davidson não está isenta de uma forma de ignorância. Em sua perspectiva, a 'continência', a qualidade contrária à fraqueza, constitui um princípio lógico derivado da ação conforme todas as razões relevantes. Dessa forma, a fraqueza só pode ser uma ignorância relativa ao princípio da continência. 
A partir da analogia com o raciocínio probabilístico, Davidson estabelece a virtude contrária à fraqueza de vontade como uma violação de um princípio da ação correta. Em termos teóricos, o princípio do 'requerimento da evidência total' determina que devemos apenas dar crédito a hipóteses devidamente sustentadas por 'todas as evidências relevantes'. Em termos práticos, a virtude consiste, de forma similar, ao princípio da continência: "perform the action judged best on the basis of all available relevant reasons." (Ibid., p. 41). Dessa forma, a fraqueza de vontade corresponderia, então, à negligência ou ignorância a respeito do princípio da continência contra o juízo TFC.

A violação do princípio da continência impõe novos parâmetros à descrição lógica da fraqueza de vontade. Na realidade, a primeira descrição formal da fraqueza leva Davidson a um retorno ao tema da fraqueza de vontade dessa vez pelo campo inexplorado da irracionalidade prática. Por enquanto, devemos nos concentrar ainda sobre as críticas posteriores dirigidas à primeira descrição formal da fraqueza exposta em 'Weakness'.

\section{5 \\ A controvérsia da fraqueza contra o juízo TFC}

A primeira descrição lógica formal da fraqueza de vontade de Davidson renovou o interesse da filosofia da ação na possibilidade do fenômeno. Ao mesmo tempo, essa primeira descrição rendeu diversas críticas e dúvidas sobre a possibilidade da ação contrária ao juízo TFC.

Dessa forma, destacaremos a seguir ao menos dois tipos de objeções às teses de Davidson: (a) as críticas dirigidas ao internalismo de P1-P2, especialmente acerca do sentido de 'querer' (want); (b) a objeção à negação da fraqueza intencional, a possibilidade da ação contrária à intenção ou ao juízo incondicional do agente. Ambas as críticas são dirigidas à primeira descrição da fraqueza do juízo TFC. Em geral, essas críticas reunidas colocam sob suspeita a consistência dos princípios P1-P3. Para avaliarmos a pertinência dessas objeções, precisamos avaliar a consistência do internalismo motivacional de P1-P2.

$\mathrm{O}$ primeiro desafio se dirige à ambiguidade do termo 'querer' (want) no internalismo motivacional da ação dos princípios P1-P2. Para uma corrente crítica 
influente, o termo want pode ter ao menos três sentidos diferentes ${ }^{535}$ : (1) 'querer fazer' no sentido da motivação mais forte de agir que prevalece na ação intencional realizada; (2) 'preferir' em vista do reflexo da ação realizada no juizo avaliativo do agente, ou melhor, em termos da preferência avaliativa da ação; (3) o 'desejo mais forte' levando em conta simplesmente o maior grau de intensidade do impulso ou força do desejo. Para efeitos de esclarecimento, designaremos esses três sentidos de 'querer' na seguinte ordem, (1) sentido motivacional da ação, (2) sentido avaliativo e (3) sentido desiderativo. Em qualquer um desses sentidos, teremos dificuldades para sustentar o internalismo de P1-P2.

Os princípios P1-P2 podem ser falsificados dependendo do sentido de want. Como indica Watson (1977, p. 320-321), a distinção do plano avaliativo e do plano motivacional da ação leva a reconsideração de P1-P2. Segundo o plano avaliativo, P2 seria verdadeiro dado que a preferência de fazer $x$ ao invés de $y$ está logicamente relacionada à maior motivação do agente para fazer $x$. Entretanto, P1 seria falso no plano avaliativo pois a preferência do agente não revela nada sobre a ação realizada. Segundo o plano motivacional, P1 seria verdadeiro pois a ação realizada determina a maior motivação da ação, embora P2 seria falsa à medida que a força motivacional nada revela sobre a preferência do agente.

Ainda restam dúvidas sobre a relação obscura entre a motivação da ação e a ação realizada. Em primeiro lugar, o sentido motivacional implica uma relação de dependência entre a ação realizada e a força motivacional predominante. Nesse sentido, Davidson estaria assumindo algo próximo ao prescritivismo moral, dado que a ação realizada seria o critério primordial para determinar a motivação mais forte do agente. Como vimos, no entanto, há diversos exemplos ordinários que contestam P1. Por exemplo, um homem quase embriagado pode tomar um terceiro copo de uísque mesmo tendo uma forte aversão à embriaguez. De fato, a ação intencional do agente não expressa necessariamente a motivação da ação. Em segundo lugar, o sentido preferencial exclui diretamente a possibilidade da ação contrária ao melhor juízo intencional, isto é, a fraqueza de vontade. Nesse cenário,

\footnotetext{
${ }^{535}$ Para as diferentes versões dessa objeção geral, ver TAYLOR, 1980, p. 511-512; CHARLTON, 1988, p. 126-129. De fato, diversos comentadores de Platão e Aristóteles incorreram no equívoco parcial de atribuir o mesmo equívoco à psicologia antiga. De acordo com esses críticos, a psicologia antiga compartilha, em algum nível, dos princípios expressos em P1-P3. No entanto, mostraremos que a formulação lógica estrita desses princípios não é compatível com os princípios amplos da psicologia antiga de Platão e Aristóteles.
} 
a motivação da ação está subordinada à preferência avaliativa do agente de fazer $x$ ao invés de $y$. Em terceiro lugar, o sentido desiderativo torna o internalismo de P1P2 completamente falso. A intensidade do desejo é independente tanto do juízo avaliativo doa agente quanto da motivação mais forte da ação. A ação realizada está relacionada apenas ao princípio da força relativa dos desejos. Como vimos, o puro conflito de forças motivacionais não reflete o conflito prático da fraqueza de vontade, mas apenas a compulsão psicológica. Ao contrário, o internalismo motivacional original de P1-P2 não entra em conflito com a fraqueza.

A rigor, não há uma incompatibilidade estrita entre o plano preferencial e o plano motivacional. Como assinala Charlton (1988, p. 128), a psicologia platônica e aristotélica supunha que ambos os planos são, de alguma forma, complementares: "The Greeks supposed, allegedly, that if an agent thinks one course more advantangeous than a second he desires more intensely to pursue it, and also the more intense desire prevails." A psicologia antiga de Platão e Aristóteles assume que o plano preferencial e o plano motivacional não são excludentes. Por isso, o agente pode crer que $x$ é mais vantajoso que $y$ e, ao mesmo tempo, ter uma motivação contrária mais forte para fazer $y$ ao invés de $x$.

Dentro da psicologia antiga, a ação expressa tanto o melhor juízo do agente quanto a motivação mais forte da ação. Como vimos, o desejo racional pode prevalecer sobre as paixões irracionais e, ao mesmo tempo, os impulsos irracionais também podem prevalecer sobre a razão. Assim como na psicologia antiga, o internalismo de P1-P2 não precisa exprimir qualquer contradição entre o sentido motivacional e o sentido avaliativo.

$\mathrm{Na}$ realidade, os diferentes sentidos de 'querer' são demasiado restritivos para contemplar os princípios intuitivos de Davidson. O sentido desiderativo entra em conflito direto com o internalismo motivacional de P1-P2. A intensidade do desejo não é exclusivamente independente da motivação da ação ou da preferência avaliativa do agente. Além disso, o sentido motivacional é demasiadamente dependente da ação realizada pelo agente. No sentido motivacional, a própria ação realizada é o critério último de descrição da motivação da ação, o que tornaria o princípio P1 equivalente ao prescritivismo moral de Hare. Por fim, o sentido avaliativo se baseia em uma suposta reflexão transparente da motivação da ação no próprio juízo avaliativo do agente. Como vimos, a preferência avaliativa do agente por si só é insuficiente para esclarecer a motivação mais forte da ação de P2. 
A formulação de P1-P3 parece antecipar, de certo modo, essa linha de objeção das críticas à Davidson. De fato, Davidson (2001b, p. 27) insiste que o problema da fraqueza surge independente dos múltiplos sentidos atribuídos a 'querer' (want): “a problem about incontinence will occur in some form as long there is any word or phrase we can convincingly substitute for 'wants' in both P1 and P2.”. O internalismo 'moderado' de P1-P2 estabelece uma conexão lógica fundamental do juízo avaliativo e da motivação da ação dentro do sentido amplo de 'querer'.

Nesse sentido, a ação intencional do agente atende tanto a critérios verbais quanto a critérios não verbais da descrição proposicional da ação ${ }^{536}$. Dentro dos critérios verbais, temos a expressão genuína das crenças, preferências e dos juízos avaliativos de nossas alternativas de ação. Pelos critérios não verbais, temos o comportamento, as atitudes, os desejos ou a motivação da ação. Ambos os critérios integram a teoria causal da ação de Davidson expressa no par de crenças-desejos que representam as razões internas do agente. Entretanto, o internalismo de P1-P2 expressa apenas o complexo de crenças e desejos do agente no momento imediato da ação intencional sem subordiná-los exclusivamente ao plano avaliativo ou motivacional da ação. Na verdade, o problema da fraqueza de vontade emerge justamente da pertinência premente do internalismo motivacional.

O problema da fraqueza emerge do aparente conflito com o internalismo motivacional P1-P3. Como vimos, o internalismo de P1-P2 e o fenômeno da fraqueza contém juízos avaliativos logicamente distintos: o internalismo motivacional se expressa em juízos incondicionais da ação intencional, enquanto o juízo $T F C$ da fraqueza coincide com a forma lógica dos juízos prima facie condicionados por uma categoria lógica de avaliação predeterminada. A partir disso, Davidson sustenta a possibilidade da fraqueza contra o juízo TFC levando em conta que a ação irracional expressa a intenção do agente. O desafio de Davidson se transfere, então, para a negação da fraqueza intencional, a possibilidade da ação contra ao juízo incondicional da intenção.

A negação da fraqueza intencional deixa em aberto a possibilidade da fraqueza de vontade em (P3). Com efeito, a fraqueza intencional falsifica inteiramente o internalismo motivacional de P1-P2. Sem o juízo TFC da fraqueza,

${ }^{536}$ Cf. PEREIRA, 2005, p. 189: “A atribuição de juízos de valor tem também por critério ou princípio o comportamento não-verbal dos agentes, ou seja, a conduta que realizam." 
a contradição de P1-P3 ficaria bem mais explícita. A fraqueza consiste efetivamente em uma falha intencional da ação conforme o juízo TFC. Com facilidade, poderíamos elaborar uma situação em que não há qualquer falha de intenção relativa ao juízo TFC e, ainda assim, há uma ação contrária à intenção do agente.

$\mathrm{O}$ desafio da fraqueza intencional coloca em xeque, portanto, todos os princípios P1-P3. Em Akrasia, Reasons and Causes, Mele (1983, p. 347-348) apresenta um exemplo de fraqueza intencional para revelar as limitações da prmeira descrição da fraqueza de Davidson. Para efeitos de esclarecimento, precisaremos sintetizar a situação hipotética de Mele.

De acordo com o exemplo de Mele (Ibid., p. 348), um estudante de biologia tem a tarefa de extrair seu próprio sangue apesar de ter pavor de extrair sangue. Por mais que seu medo forneça razões contrárias à ação, podemos supor que ele chega ao ponto de realizar claramente um juízo TFC, 'em vista de $t$, é melhor extrair meu sangue do que não extraí-lo’. De fato, seu raciocínio pode ir até um estágio adiante formando um juízo incondicional de que "é melhor extrair o sangue agora mesmo". Mesmo assim, o estudante acaba falhando em realizar a tarefa no momento decisivo da ação. Nessa ocasião, o estudante age não só contra seu juízo TFC mas também contra seu próprio juízo incondicional, ou seja, sua própria intenção da ação. Nessas condições, temos a possibilidade da fraqueza intencional sem interferência de fatores externos.

Para Mele (Ibid., p. 349), a falha da fraqueza intencional compromete a descrição original da fraqueza de Davidson:

What he [Davidson] is denying is that this failure is ever an akratic failure. For Davidson, weakness may explain why an agent fails to intend to do what he judges to be best, all things considered; but it cannot explain an agent's failing to act in accordance with a here and now intention, i. e., with an unconditional judgment about what is best to do here and now.

A descrição original da fraqueza de Davidson deixa então a fraqueza intencional inexplicável. Como vimos, o juízo TFC pode facilmente prosseguir ao juízo incondicional no processo do raciocínio prático. Para Mele, o juízo incondicional do agente deriva de um juízo TFC anterior. Em termos lógicos, os juízos incondicionais podem até expressar razões suficientes em favor da ação, isto 
é, razões fortes para a ação ${ }^{537}$. De fato, as razões fortes dos juízos incondicionais implicam em um compromisso lógico direto na realização da ação. Todavia, Davidson admite que a fraqueza ocorre quando a ação é contrária ao juízo TFC, mas rejeita que a ação contrária à intenção do 'melhor juízo' absoluto constitua um exemplar legítimo do fenômeno.

A ação da fraqueza de vontade necessariamente reflete o juízo incondicional da intenção. Em última instância, a intenção do agente é derivada de uma razão prima facie anterior, isto é, uma razão prima facie contrária à razão expressa no juízo TFC. De acordo com Davidson (2001b, p. 41), as mesmas crenças podem servir para apoiar razões de lados diferentes da balança das razões práticas:

there is no paradox in supposing a person sometimes holds that all that he believes and values supports a certain course of action, when at the same time those same beliefs and values cause him to reject that course of action. If $r$ is someone's reason for holding that $p$, then his holding that $r$ must be, I think, a cause of his holding that $p$. But, and this is what is crucial here, his holding that $r$ may cause his holding that $p$ without $r$ being his reason; indeed, the agent may even think that $r$ is a reason to reject $p$. (itálicos do autor)

A incompatibilidade lógica dos juízos de valor é mais fundamental que as próprias razões do agente na fraqueza de vontade. Na fraqueza, o juízo incondicional da intenção do agente é supostamente desviado do juízo derivado do cálculo TFC. Em termos comparativos, o juízo TFC expressa, por exemplo, 'em vista de $t, a$ é melhor que $b$ ', enquanto o juízo da intenção incondicional expressa ' $b$ é melhor que $a$ ' resultando na fraqueza de vontade. Todavia, as mesmas razões do cálculo TFC (levando em conta 'a soma de seus princípios, opiniões, atitudes e desejos') pode justificar proposições opostas, como a proposição afirmativa ' $a$ é melhor que $b$ ' e a proposição negativa ' $a$ não é melhor que $b$ '. Para Davidson (Ibid., p. 40), a mesma razão $r$ em favor da ação $a$ pode ser incluída a outras razões $r$ ' $(r$ e mais $n$-razões) contra a própria ação $a$.

A intenção não é derivada estritamente da razão original $r$ do cálculo TFC mas de uma outra razão contrária derivada de $r$ e outras razões. De acordo com

\footnotetext{
${ }^{537}$ Cf. Ibid., p. 359: 'I propose to reserve the term 'unconditional judgement' for judgments which commit the agent to action in the sense explained. All judgments based on and supported by a consideration of the sum of the agent's values and beliefs qualify as unconditional judgements in my sense, as do judgments made from the perspective of a segment of this sum which, in the agent's opinion, constitute sufficient reason for action."
} 
Davidson (Ibid., p. 42), a razão mais fraca não justifica a ação intencional da fraqueza: "if the question is read, what is the agent's reason for doing $a$ when he believes it would be better, all things considered, to do another thing, then the answer must be, for this, the agent has no reason”. Durante a fraqueza, $r$ pode ser a causa lógica da proposição ' $a$ é melhor que $b$ ', mas deixa de ser uma razão em termos de uma justificação racional da ação. Por isso, a fraqueza nada mais expressa do que a intenção incorreta do agente, uma intenção irracional injustificável segundo as próprias razões internas do agente. Ao considerar a intenção errada, Davidson se esquiva da necessidade de reconhecer um tipo de fraqueza intencional, a ação contrária à intenção do melhor juízo intencional.

A intenção errada da fraqueza de vontade inviabiliza a possibilidade da fraqueza intencional. Como vimos, a primeira descrição do fenômeno expressa a ação contrária ao juízo TFC mas não se transfere ao plano do juízo incondicional da intenção. Pelos parâmetros racionais, a intenção errada da fraqueza é uma violação ao próprio princípio da continência. Segundo o princípio de continência, o sucesso da razão prática consiste justamente na derivação lógica do juízo incondicional ' $a$ é melhor $b$ ' de acordo com o cálculo TFC. Entretanto, a fraqueza representa o fracasso da razão prática, a interrupção ou o 'desvio' irracional do cálculo TFC expresso na intenção errada do agente. Sobretudo, é necessário explicar a natureza irracional da intenção errada.

A irracionalidade da fraqueza de vontade exige definir os parâmetros internos de racionalidade e irracionalidade da razão prática. Em Mental Events, a teoria causal da ação insere o internalismo motivacional no campo mais amplo do holismo mental. Dentro do holismo mental de Davidson (2001d, p. 217) o conjunto de crenças e desejos expressos na ação intencional só pode ser relacionado, modificado ou explicado com base em outras crenças e desejos que fazem parte do ‘todo’ (hole) mental do agente. Somente a interação dinâmica das atitudes, crenças e desejos internos dentro do próprio sistema mental do agente pode explicar o conjunto de crenças e desejos da descrição de sua ação intencional.

De acordo com Davidson (Ibid., p. 221), o limite da racionalidade e irracionalidade prática depende de um 'largo grau de consistência' do campo mental interno do agente: "it is unavoidable if we are to be in a postition to accuse them meaningfully of error and some degree of irrationality.” Dentro desses parâmetros, não há sentido em atribuir simplesmente um equívoco global ou um erro universal 
ao agente quando eliminamos completamente o contexto lógico de racionalidade que constitui a consistência interna de sua mente. Assim, teríamos uma irracionalidade inteiramente inexplicável pelos parâmetros racionais. De outro lado, o equívoco local ou erro temporal particular preserva o grau de consistência interna racional que permite a descrição proposicional inteligível da ação intencional. Definitivamente, esse é o caso do erro local da fraqueza de vontade.

A intenção errada da fraqueza exige adentrar o novo campo de investigação da irracionalidade prática. Apesar da consistência da primeira descrição da fraqueza, Davidson deixa em aberto a própria explicação da irracionalidade do fenômeno. Seguramente, o internalismo motivacional de P1-P2 e a divisão lógica clara do juízo intencional e do juízo prima facie TFC permanecem consistentes. Até aqui, porém, Davidson apresenta apenas uma descrição formal lógica da fraqueza e não uma explicação efetiva de sua ação irracional.

Nessa esfera, a violação irracional do princípio da continência compromete a consistência lógica da primeira descrição e reforça a contradição de P1-P3. Sobretudo, o campo da irracionalidade exige uma distinção clara entre a fraqueza de vontade e outros tipos de fenômenos irracionais. Por conta disso, Davidson se preocupa em preencher essas lancunas com base em uma investigação inovadora da irracionalidade prática.

\section{6 \\ O Paradoxo da Irracionalidade e a akrasia antiga em Paradoxes of Irrationality (1982)}

A irracionalidade da fraqueza de vontade abre o caminho para uma nova descrição do fenômeno. Com o exame da irracionalidade prática em 'Paradoxes of Irrationality' (1982), Davidson fornece uma nova descrição da fraqueza. A princípio, essa descrição da irracionalidade do fenômeno é incompatível com a primeira descrição lógica da fraqueza presente em 'Weakness'.

A primeira descrição de 'Weakness' exibe uma descrição puramente formal enquanto a segunda descrição de 'Paradoxes' apresenta uma descrição explicativa 
da irracionalidade prática ${ }^{538}$. De um lado, a fraqueza reflete a inconsistência lógica de dois juízos valorativos diferentes, o juízo TFC e o juízo da ação intencional na primeira descrição de 'Weakness'. Nesse estágio, o fenômeno consiste apenas na ação contra o próprio juízo TFC. De outro lado, a violação do princípio da continência inaugura uma segunda descrição do fenômeno apresentada em 'Paradoxes': a ação contra o princípio da continência, o princípio segundo o qual deve se agir em conformidade ao cálculo TFC.

Apesar da suposta continuidade de ambos os artigos, indicaremos que a segunda descrição não só é explicitamente incompatível, mas também é mais controversa e polêmica do que a primeira descrição do fenômeno. Em todo caso, Davidson adentra o campo da irracionalidade prática em função das exigências intrínsecas do internalismo motivacional anterior em confronto com a recepção analítica da akrasia antiga.

A partir de 'Paradoxes', Davidson retorna ao tema da fraqueza de vontade de uma perspectiva mais ampla, o campo da irracionalidade prática. Em especial, o artigo introduz os paradoxos inerentes da irracionalidade prática, travando um debate mais direto com a tradição da akrasia antiga, ilustrado inclusive pelo confronto do princípio de Medéia e o princípio de Platão (remetido à tese socrática do Protágoras). Como veremos adiante, entretanto, o paradoxo da irracionalidade apenas reestabelece novamente a inconsistência anterior de P1-P3 e não estritamente as fontes originais da akrasia antiga. De qualquer modo, as inconsistências dos princípios e a instauração da uma partilha da mente delimita o desafio de explicar a irracionalidade prática e, ao mesmo tempo, manter o mínimo da racionalidade da razão prática.

A presença da irracionalidade na ação humana impõe um desafio à própria natureza da razão prática. Em 'Paradoxes', Davidson (2004a, p. 184) expõe de forma sintética os paradoxos sob a qual a irracionalidade prática se apoia:

\footnotetext{
${ }^{538}$ Efetivamente, Davidson não é francamente explícito sobre a incongruência das duas descrições da fraqueza de vontade. Em Paradoxes, Davidson (2004a, p. 181) reconhece brevemente que essa primeira descrição é "mais descritiva do que explicativa", dando a entender que a segunda descrição estaria dirigida a oferecer uma explicação mais definitiva da irracionalidade do fenômeno. Sobretudo, a crítica posterior de Ariela Lazar (1999) expõe com maior clareza a inconsistência de ambas as descrições da fraqueza. Em resposta a Lazar (1999, p. 403), Davidson admite claramente sua insatisfação com a primeira descrição da fraqueza de vontade: “(...) I felt that there was something wrong with the idea that someone could simply lack, or forget, the principle of continence."
} 
The underlying paradox of irrationality, from which no theory can entirely escape, is this: if we explain it too well, we turn it into a concealed form of rationality; while if we assign incoherence too glibly, we merely compromise our ability to diagnose irrationality by withdrawing the background of rationality needed to justify any diagnosis at all.

O paradoxo da irracionalidade emerge do conflito de princípios derivados das descrições tradicionais da akrasia antiga (Ibid., p. 174-175). De acordo com Davidson, os dois paradoxos centrais da irracionalidade emergem do confronto arcaico entre o Princípio de Platão e o Princípio de Medéia.

Em primeiro lugar, o Princípio de Platão, inspirado no paradoxo socrático 'ninguém faz o mal voluntariamente' do Protágoras, estabelece um modelo de 'pura racionalidade' da ação intencional que elimina inteiramente a irracionalidade da razão prática. Nessa perspectiva, não há efetivamente ação acrática, mas apenas ignorância cognitiva do bem. Segundo Davidson (Ibid., p. 173-174), tal princípio reflete o primeiro paradoxo da irracionalidade: "all intentional actions, whether or not they are in some further sense irrational, have a rational element at the core." Em compensação, o Princípio de Medéia restauraria o poder da irracionalidade perante o paradoxo da pura racionalidade.

Em segundo lugar, o Princípio de Medéia ${ }^{539}$, estabelece que a ação acrática resulta da submissão absoluta do melhor juízo pela força das paixões irracionais. A força externa da paixão irracional compromete o ponto de vista interno do agente sobre a racionalidade da ação: "From the agent's point of view, what he did was the effect of a cause that came from the outside, as if another person had moved him" (Ibid., p. 175). O princípio de Medéia reflete, então, o modelo de 'pura irracionalidade'. Consequentemente, recaímos no segundo paradoxo da irracionalidade na medida em que a causa da ação corresponde à uma força 'cega',

\footnotetext{
${ }^{539}$ De fato, o Princípio de Medéia não se ampara propriamente no conflito entre o desejo de vingança e a preservação da vida dos filhos relatado pela personagem homônima da tragédia de Eurípides. Como elucida Penner (1990, p. 43-44, n. 9), o princípio de Medéia representa o reconhecimento da existência de desejos completamente irracionais, supostamente ligada à parte irracional da psicologia tripartite da República. Como veremos adiante, o conflito psicológico do princípio de Medéia representa mais a compulsão psicológica da Medéia de Ovídio citada na obra de Hare do que o conflito interno da personagem homônima da tragédia de Eurípides.
} 
isto é, completamente irracional, e não mais às razões do agente (ao conjunto de crenças e atitudes proposicionais de sua racionliadade mental) ${ }^{540}$.

Para Davidson (Ibid., p. 169), o desafio central da irracionalidade emerge de dentro do próprio campo interno da razão prática: "irrationality is a failure within the house of reason". Nessa medida, o conflito dos princípios reestabelece a contradição preliminar de P1-P3 de 'Weakness'. Todavia, o Princípio de Platão e o Princípio de Medéia jamais poderiam reproduzir de modo fidedigno suas respectivas fontes originais, o paradoxo socrático do Protágoras ou o impulso violento do thymós da personagem homônima de Eurípides.

Os princípios de Platão e de Medéia de Davidson representam, na realidade, a recepção analítica do debate original da akrasia antiga. Como vimos, a psicologia grega antiga representa os impulsos humanos em termos intrinsecamente cognitivomotivacionais. De fato, a estrita divisão moderna do campo racional e irracional é simplesmente externa aos parâmetros psicológicos antigos. Desse modo, os princípios de Platão e de Medéia não passam de uma apropriação analítica da akrasia antiga.

Em primeiro lugar, o conflito da personagem Medéia na tragédia homônima de Eurípides representa o conflito interno de duas motivações igualmente racionais, o thymós vingativo e o instinto maternal. Em nenhum momento o thymós vingativo corresponde à uma força absolutamente irracional, mas sim à uma forte motivação predominante sobre a fraca motivação materna. De fato, a mesma apropriação analítica da akrasia antiga ocorre em relação ao paradoxo socrático do Protágoras.

Em segundo lugar, o paradoxo socrático do Protágoras de Platão apenas constata a impossibilidade da akrasia, isto é, a negação crucial do conflito entre o desejo racional e outros impulsos irracionais contrários. A tese socrática paradoxal estabelece um forte princípio psicológico, isto é, a existência de uma inclinação natural humana ao bem. Em última instância, o objetivo final de Sócrates no Protágoras é salvaguardar a distinção fundamental entre o conhecimento moral e a ignorância do fenômeno irracional. A rigor, essas formulações da akrasia antiga

\footnotetext{
${ }^{540} \mathrm{Cf}$. Ibid., p. 180: "if we think of the cause in a neutral mode, disregarding its mental status as a belief or other attitude - if we think of it merely as a force that works on the mind without being identified as a part of it - then we fail to explain, or even describe, irrationality. Blind forces are in the category of non-rational, not the irrational."
} 
divergem da apropriação analítica dos princípios de Medéia e de Platão de Davidson.

Mais do que reproduzir fidedignamente a akrasia antiga, Davidson se preocupa em fazer uma reformulação dos princípios anteriores P2 e P3. Definitivamente, o princípio de Platão seria o equivalente ao princípio P2, a conexão entre o juízo avaliativo e a motivação da ação, enquanto o princípio de Medéia corresponderia ao princípio P3 anterior, ou seja, a possibilidade da ação irracional em geral. Dessa forma, a contradição dos princípios anteriores passa a ser agora o confronto entre a pura racionalidade e a pura irracionalidade da razão prática. Em termos mais diretos, Davidson confronta o internalismo motivacional e sua teoria causal da ação com o novo domínio da irracionalidade prática.

O modelo da pura irracionalidade coloca em evidência a apropriação analítica específica do impulso violento de Medéia. Como vimos, o impulso de Medéia foi representado como um tipo de compulsão psicológica desde a obra $F R$ de Hare. A princípio, o forte impulso irracional do caso de Medéia seria apenas um 'desejo' cego', completamente irracional. Diante dessas indicações, podemos reconhecer a transmissão de um modelo psicológico da submissão absoluta aos impulsos irracionais dentro da tradição analítica independente da descrição original do caso de akrasia de Medéia.

O desafio do paradoxo da irracionalidade exige a introdução da irracionalidade dentro do campo da teoria causal da ação intencional. De forma fundamental, a modificação do ponto de vista de Davidson é registrada em sua segunda descrição da fraqueza de vontade.

\section{7 \\ A segunda descrição da fraqueza de vontade: a negligência do princípio da continência}

O novo campo da irracionalidade leva Davidson a fazer uma revisão da descrição original da fraqueza de vontade. Anteriormente, o primeiro artigo 'Weakness' fornecia uma descrição formal do fenômeno, a ação intencional contra o juízo TFC. Dessa vez, o segundo artigo 'Paradoxes' exige uma descrição mais explicativa da ação contrária ao princípio da continência. A ampla concepção da 
irracionalidade tem um papel central no redimensionamento do problema da fraqueza de vontade.

A manifestação da irracionalidade prática coloca em evidência as limitações da descrição lógica proposicional das razões práticas do agente. Nessa medida, não é suficiente apenas demonstrar que não há contradição lógica entre o juízo TFC em vista da ação $a$ e o juízo incondicional em vista da ação $b$.

Em 'Paradoxes', a fraqueza não é só a ação contra o juízo TFC, mas a ação intencional contrária a um princípio lógico de segunda ordem, o princípio da continência. Segundo Davidson (Ibid., p. 177), a violação do princípio da continência envolve uma inconsistência interna: "Pure internal inconsistency enters only if I also hold - as in fact I do - that I ought to act on my own best judgment, what I judge best or obligatory, everything considered". Por isso, a descrição da fraqueza precisa contemplar agora a possibilidade de uma inconsistência interna pura, ou seja, a irracionalidade pelos padrões de racionalidade internos do próprio agente $^{541}$. Para compreendermos melhor isso, precisamos recorrer ao próprio exemplo de Davidson a fim de ilustrar a modificação na descrição original do fenômeno.

O exemplo de 'Paradoxes' ilustra o tipo de irracionalidade apresentada na segunda descrição da fraqueza. De certa forma, Davidson se inspira em um caso curioso de neurose obsessiva ${ }^{542}$. Para todos os efeitos, devemos descrevê-lo apenas em linhas gerais e nos ocuparemos sobretudo com o estado psicológico do agente. Como relata Davidson (Ibid., p. 172-173), um homem a caminho de sua casa retorna a um parque para transferir um galho de volta à sua posição original de onde lhe havia retirado antes, mesmo tendo julgado, considerando todos os fatores, que não devia ter voltado ao parque. Nessas circunstâncias, o retorno ao parque pode ter uma razão (remover um perigo), mas fornece um motivo da falha da ação conforme o princípio prático (de não retornar ao parque pelo juízo TFC). Diante disso, a

\footnotetext{
${ }^{541}$ Cf. Ibid., p. 170: "The sort of irrationality that makes conceptual trouble is not the failure of someone else to believe or feel or do what we deem reasonable, but rather the failure, within a single person, of coherence or consistency in the pattern of beliefs, attitudes, emotions, intentions, and actions."

${ }^{542}$ A inspiração de Davidson para esse exemplo inusitado é explicitamente retirada de 'Notas sobre um caso de neurose obsessiva' de Freud. De acordo com o exemplo, o homem havia retirado o galho inicialmente do caminho no parque e o isola em uma cerca porque representava um risco aos transeuntes desavisados que passariam por ali. Dentro de um bonde a caminho de casa, ele teria mudado de ideia acreditando que o galho ainda representa uma ameaça estando na cerca e considera então que seria melhor retornar ao parque e retornar o galho à sua posição original. Supostamente, o exemplo ilustrativo representa uma atitude irracional obsessiva do agente.
} 
desobediência do princípio da continência constitui uma nova forma de ação irracional.

De acordo com Davidson (Ibid., p. 178), a irracionalidade emerge a partir da violação do princípio de continência:

Irrationality entered when his desire to return made him ignore or override his principle. For though his motive for ignoring his principle was a reason for ignoring the principle, it was not a reason against the principle itself, and so when it entered in this second way, it was irrelevant as a reason, to the principle and to the action.

A desobediência do princípio da continência constitui um estágio posterior destacado da descrição proposicional da fraqueza. Certamente, o retorno ao parque pode ser explicado simplesmente pelo desejo inerente de recolocar o galho na posição original e remover um perigo iminente. Nos termos da primeira descrição do fenômeno, há um conflito prático entre dois juízos na fraqueza: o juízo incondicional de retornar ao parque e recolocar o galho na posição original expressa ação intencional do agente e o juízo TFC representa o desejo de não retornar mais ao parque. Nesse estágio, ainda podemos mencionar que a ação do agente decorre de uma razão proveniente de seu juízo intencional.

A motivação irracional de recolocar o galho na posição original no parque também constitui um forte desejo para a ignorância do princípio da continência. Assim, Davidson (Ibid., p. 177) apresenta uma nova descrição da ação contra o juízo TFC: "For to explain his behaviour we need only say that his desire to do what he held to be best, all things considered, was not as strong as his desire to do something else". Nesse segundo estágio, o desejo de recolocar o galho na posição original não constitui uma razão forte para retornar ao parque, mas fornece um motivo ou desejo forte para 'ignorar' ou 'sobrepor' o princípio da continência. Por isso, não há efetivamente uma razão contra o princípio da continência em si mesmo porque o desejo ou motivo mais forte prevalece na atitude irracional do agente. Nessa esfera, a irracionalidade do fenômeno exige uma extensão dos limites da razão prática da teoria causal da ação de Davidson.

A resolução do conflito do princípio de Platão e o principio de Medéia estreita os limites entre o campo racional e irracional da razão prática. Para Davidson, é preciso manter o núcleo e, ao mesmo tempo, ir além do princípio de 
Platão ${ }^{543}$ explicando a ação intencional e a irracionalidade da fraqueza. Sobretudo, a superação do paradoxo depende de uma definição da irracionalidade a partir dos parâmetros internos de racionalidade do agente.

Em Incoherence and Irrationality, Davidson (2004b, p. 192) define efetivamente a irracionalidade pela inconsistência interna do agente: "It is only when beliefs are inconsistent with other beliefs according to principles held by the agent himlsef - in other words, only when there is an inner inconsistency - that there is a clear case of irrationality". A irracionalidade, então, não se refere literalmente à inconsistência lógica de crenças contraditórias, mas especificamente à incoerência do conjunto de crenças do sistema interno de 'racionalidade' do próprio agente. Do ponto de vista do agente, a irracionalidade prática emerge da sua própria racionalidade interna: “(...) the failure, within a single person, of coherence or consistency in the pattern of beliefs, attitudes, emotions, intentions, and actions." (Idem, 2004a, p. 170). Por esses parâmetros internos, a fraqueza de vontade abrange a incoerência específica da intenção do agente com outras atitudes e princípios proposicionais de seu sistema mental. Novamente, a falha do princípio de continência se reflete na falha do princípio probabilístico do raciocínio indutivo.

A analogia do princípio da continência e o princípio probabilístico permite esclarecer a segunda definição da fraqueza de vontade. Em Deception and Division, Davidson (2004c, p. 201-202) leva essa analogia a um novo patamar ao comparar a fraqueza de vontade com a 'fraqueza de justificação' (weakness of warrant).

A fraqueza de justificação e a fraqueza de vontade possuem uma descrição lógica bem similar. De um lado, a fraqueza de justificação representa uma falha do princípio do requerimento da evidência total, pois o homem não acredita na hipótese justificada pela crença relativa a todas as evidências disponíveis. Por sua vez, a fraqueza de vontade decorre de uma falha semelhante do princípio da continência, isto é, o agente não age com base em 'todas suas razões disponíveis'. Para Davidson (Ibid., p. 202), a diferença crucial entre a fraqueza de justificação e a fraqueza de vontade está nas atitudes proposicionais do agente: "the former involves an irrational belief in the the face of conflicting evidence, the latter an irrational

\footnotetext{
${ }^{543}$ Cf. Ibid., p. 177-178: "The explanation must, it is evident, contain some feature that goes beyond Plato Principle; otherwise the action is perfectly rational. On the other hand, the explanation must retain the core of the Plato Principle; otherwise the action is not intentional."
} 
intention (and perhaps also action) in the face of conflicting values." Por isso, a fraqueza de justificação caracteriza um erro cognitivo da crença enquanto a fraqueza de vontade constitui um erro avaliativo da intenção. Ora, esses fenômenos irracionais evidenciam que há ações ou crenças que não podem mais ser explicadas dentro da teoria causal da ação simplesmente pelas razões internas do agente.

O campo da irracionalidade inaugurado em Paradoxes abrange uma série de outros fenômenos irracionais além da fraqueza de vontade. A partir de Paradoxes, Davidson se preocupa em explorar as fronteiras desse fenômeno com outros fenômenos irracionais correspondentes, como o 'pensamento ilusório' (wishful thinking), a 'fraqueza de justificação' (weakness of warrant) e, mais especificamente, o 'autoengano' (self-deception) ${ }^{544}$. Devido ao nosso foco atual, não poderemos explorar em maiores detalhes a definição de cada tipo fenômeno irracional. Em última instância, o que é necessário destacar aqui é o que é comum a todas essas formas de irracionalidade, a inconsistência interna diante do próprio padrão de racionalidade do agente. A própria possibilidade da fraqueza de vontade depende, então, de uma resolução do paradoxo da irracionalidade.

Nessa medida, retomamos então ao paradoxo da irracionalidade inicial mencionado anteriormente. Como vimos, o paradoxo consiste em explicar a ação intencional irracional sem a transformamos em um modelo de pura racionalidade ou eliminamos completamente o contexto lógico descritivo das razões internas doa gente. A partir disso, Davidson busca uma solução intermediária à pura racionalidade e à pura irracionalidade da razão prática.

$\mathrm{Na}$ realidade, isso significa basicamente extrapolar as relações lógicas da teoria causal da ação, ou seja, a explicação causal das ações pelas razões do agente. Para isso, é preciso considerar uma causa mental que não é, estritamente, uma razão. Nesse momento, Davidson apresenta uma complexa partilha da mente humana destinada a acomodar a possibilidade da inconsistência interna irracional.

\footnotetext{
544 Ao longo dos artigos reunidos em Problems of Rationality (2004), Davidson examina cada um desses fenômenos em maiores detalhes. Devido ao nosso foco presente, apenas nos referimos ao fenômeno irracional que está mais próximo da fraqueza de vontade de vontade, a 'fraqueza de justificação' (weakness of warrant). Todavia, não teremos oportunidade de abordar os outros fenômenos irracionais. Dentre os fenômenos mencionados, a experiencia designada de wishful thinking é a mais difícil de traduzir e caracterizar na língua portuguesa. Em linhas gerais, o fenômeno envolve a representação idealizada de desejos contrafactuais do agente. De fato, a tradução 'pensamento ilusório' continua inadequada, mas é a que mais se aproxima da expressão correspondente em inglês.
} 


\section{8}

\section{A causa mental não racional (CMNR) e a partilha da mente de Davidson}

A causa mental não racional ultrapassa os limites das relações lógicas da teoria causal da ação de Davidson. Na teoria causal da ação, as razões desempenham um papel crucial na explicação causal das ações intencionais. Com a irracionalidade, no entanto, Davidson (2004a, p. 179) reconhece um novo tipo de causa mental desvinculada das razões do agente: “(...) there is a mental cause that is not a reason for what it causes". Assim, designaremos essa relação causal direta entre eventos mentais de 'causa mental não racional' (CMNR). A presença da CMNR exige uma nova teoria da partilha da mente para além das relações lógicas da teoria causal da ação inicial de Davidson.

A nova teoria da partilha da mente fornece uma resolução ao paradoxo da irracionalidade prática de Paradoxes. A explicação da CMNR e da inconsistência interna da razão prática depende da partilha da mente. Ao mesmo tempo, a partilha da mente de Davidson deriva de um controverso modelo psicológico interpessoal, isto é, o paradigma da interação social de dois agentes diferentes. A partir disso, pretendemos salientar adiante que a divisão mental é imprescindível na explicação da irracionalidade interna da razão prática. $\mathrm{Na}$ verdade, é possível dar conta da CMNR e da inconsistência interna do agente sem o modelo interpessoal de partilha da mente de Davidson. De todo modo, as inconsistências da partilha da mente de Davidson se refletem ainda na segunda descrição da fraqueza. Para mostrarmos isso, precisamos antes ressaltar os parâmetros da partilha da mente em Paradoxes.

Diante das teorias tradicionais de divisão mental, Davidson dirige suas críticas à divisão moralista e à divisão psicológica da mente ${ }^{545}$. De um lado, a divisão moralista recorre à oposição absoluta entre razão e paixão ou virtude e tentação. De outro lado, a divisão psicológica introduz um terceiro elemento de avalição superior sobre a razão, a 'vontade', capaz de calcular as razões de ambos os lados do conflito de desejos. Todavia, a 'vontade' apenas representa a

\footnotetext{
${ }^{545}$ Desde 'Weakness', Davidson já apresentava suas críticas às teorias tradicionais da divisão da mente, ver DAVIDSON, 2001b, p. 35-36 (Cf. também Idem, 2004a, p. 182). Mesmo com suas críticas aos modelos psicológicos anteriores, Davidson tem mais preferência pelo modelo dos três atores psicológicos do que pelo modelo do conflito moral de dois elementos psicológicos. De qualquer forma, Davidson não pretende dar qualquer papel proeminente executivo para a 'vontade' além da função lógica exclusiva de fazer o cálculo de todos os fatores.
} 
formulação lógica do juízo TFC não tendo um papel executivo na ação intencional. A divisão mental de Davidson dispensa fatores externos ao campo mental, sejam fatores morais ou psicológicos, pois atende às categorias internas da própria razão prática $^{546}$. Afinal, a partilha da mente permite dar conta da irracionalidade prática inerente à ação intencional da fraqueza.

A explicação da irracionalidade da CMNR depende do 'contexto da racionalidade' da razão prática. Em Paradoxes, Davidson (Ibid., p. 181) fornece a seguinte divisão da mente:

Indeed, if we are going to explain irrationality at all, it seems we must assume that the mind can be partitioned into quasiindependent structures that interact in ways the Plato Principle cannot accept or explain. (...) The idea is that if parts of the mind are to some degree independent, we can understand how they are able to harbour inconsistencies, and to interact on a causal level.

Como dissemos, a partilha da mente de Davidson é uma hipótese teórica (inspirada, principalmente, em Freud) ${ }^{547}$ e não uma doutrina rígida de setores mentais destacados entre si. De forma geral, a partilha se apoia sob dois princípios básicos que se implicam mutuamente: (a) a divisão da mente em 'estruturas semiindependentes' (quasi-independent structures), isto é, compartimentos mentais que não são inteiramente independentes das relações lógicas do núcleo racional principal; (b) a analogia da estrutura interativa dos diferentes setores mentais e a interação social entre indivíduos. De certo modo, a partilha da mente preserva e ultrapassa o princípio de Platão, o princípio de pura racionalidade.

A preservação da racionalidade do princípio (a) permite explicar a irracionalidade na razão prática. Para Davidson (Ibid. p. 181), as partes da mente preservam certo grau de autonomia da razão sob certas condições: “(...) a part of the mind must show a larger degree of consistency or rationality than is attributed to the whole." Os subsistemas mentais precisam, então, manter necessariamente

\footnotetext{
${ }^{546}$ Cf. CALLARD, 2013, p. 45: "Davidson's diagnosis of the failure of moral and psychological partitioners is that they bring in some external fact - be it morality or psychology - to solve what is a problem within practical reason. He makes no such distinctions between kinds of desire, and therefore is not pressured top lace any restriction on which desires can conflict with one another. But his solution does involve distinguishing, at a later stage of the process of practical reason, between forms or kinds of rationality."

${ }^{547}$ Como mencionamos em uma nota anterior, a partilha da mente de Davidson é uma teoria aberta que não se reflete necessariamente nas categorias do inconsciente de Freud ou de qualquer modelo psicológico anterior.
} 
uma relação interdependente com um núcleo central de racionalidade do agente. Todavia, a partilha da mente se constitui a partir de ao menos duas partes semiautonomas independente do número exato ou dos tipos de partes mentais: "having two or more semi-autonomous structures" (Ibid., p. 184). A separação de compartimentos mentais ocorre em 'territórios sobrepostos' (overlapping territories) mutuamente implicados e não em partes isoladas destacadas entre si. Por conta disso, a divisão mental de Davidson decorre necessariamente da ruptura das relações lógicas da razão: "The breakdown of reason relations defines the boundary of a subdvision" (Ibid., p. 185). O objetivo principal da partilha da mente é acolher a inconsistência pura interna dentro da razão prática, determinando que as crenças contraditórias do agente pertençam a domínios mentais diferentes. Para isso, é preciso então ultrapassar os limites lógicos estreitos do Princípio de Platão e fornecer uma explicação da manifestação da CMNR.

A possibilidade de uma causa não racional de eventos mentais extrapola os limites lógicos da racionalidade. Sob o princípio (b), Davidson explica a CMNR com base na interação de diferentes domínios da mente. Levando em conta o parâmetro das 'interações sociais', é possível constatar conexões causais de fenômenos mentais que não seguem as regras lógicas racionais. Com efeito, Davidson (Ibid., p. 180-181) recorre à seguinte analogia de interação social fornecendo uma explicação da CMNR: o desejo de uma pessoa $A$ de que uma outra pessoa $B$ aprecie sua rosa suscita a entrada de $B$ no jardim de $A$ sem que tal desejo constitua, necessariamente, uma razão para a ação de $B$. Nesse aspecto, a ação irracional é explicada exclusivamente pela força das motivações irracionais independente das relações lógicas das razões do agente. A partir da interação social, Davidson alega que a mesma conexão causal da relação interpessoal pode ser transferida a "uma única pessoa e mente". Com isso, a partilha da mente expande o domínio da mente para além da conexão causal das razões e ações intencionais.

A partilha da mente estende os territórios sobrepostos do campo da racionalidade da razão prática. De acordo com Davidson (Ibid., p. 182), a divisão da mente deve se localizar no limite da racionalidade:

the concepts employed must be treated as mixed, owing allegiance partly to their connections with the world of nonmental, and partly to their character as mental and directed to a propostional content. 
A causa mental não racional exige o uso de 'conceitos mistos' aliando o mundo não mental ao mundo mental racional. De um lado, o campo do mental "não pode formar um sistema fechado" sob o risco de não poder explicar o que pertence ao campo não mental. De outro lado, é preciso descrever relações causais em “desconsideração parcial das relações lógicas” de eventos mentais. Nesse aspecto, a preservação do núcleo de racionalidade promove a descrição racional da ação em termos "mentais e dirigidos a um conteúdo proposicional". Assim como a interação social, a relação interativa entre o domínio mental e não mental fornece uma explicação da CMNR. A liberdade das relações lógicas da teoria causal da ação abre o caminho à explicação da irracionalidade.

A partilha da mente permite acolher a inconsistência pura de diversos fenômenos irracionais. Com a localização das crenças contraditórias em diferentes domínios mentais, não há mais uma patente contradição nas crenças do agente. Sobretudo, o modelo interativo dos domínios da mente oferece a oportunidade de explicar a inconsistência irracional da segunda descrição da fraqueza.

Assim como outros fenômenos irracionais, a segunda descrição da fraqueza depende igualmente da divisão dos diferentes domínios mentais. Como vimos, a desobediência do princípio da continência se esclarece pelo desejo forte contra o 'melhor juízo' e não simplesmente pela razão mais fraca da ação intencional. Nesses termos, o desejo forte constitui uma causa não racional da atitude de rejeição do princípio da continência. A partilha da mente situa duas crenças contraditórias do agente em fontes diferentes de sua mente. De um lado, a crença do juízo TFC pelo melhor curso de ação constitui a causa racional da ação. De outro lado, o desejo forte irracional dirigido ao pior curso de ação constitui a causa não racional. Nessas condições, as crenças contraditórias da fraqueza ficam em domínios mentais destacados.

Em Deception and Dividson, Davidson (2004c, p. 211) ressalta que os territórios mentais sobrepostos da mente permitem explicar a inconsistência interna dentro da razão prática do agente:

Contradictory beliefs about passing a test must each belong to a vast and identical network of beliefs (...) if they are to be contradictory. Although they must belong to strongly overlapping territories, the contradictory beliefs do not belong to 
the same territory; to erase the line between them would destroy one of the beliefs.

A separação das crenças contraditórias em diferentes territórios deve explicar também a segunda descrição da fraqueza de vontade. Nesse sentido, a desobediência do princípio da continência pode acomodar uma inconsistência interna de crenças desde que as crenças incompatíveis se localizem em hemisférios diferentes da mente. A princípio, a partilha interativa da mente em uma zona mental e outra zona não mental supera assim o desafio do paradoxo da irracionalidade anterior.

O paradoxo da irracionalidade recebe uma resolução provisória com a partilha da mente. Certamente, a existência da CMNR e a inconsistência interna constituem o domínio característico da irracionalidade. Da mesma forma, a separação do domínio racional e o domínio irracional é fundamental para a expansão da razão prática.

No entanto, a partilha da mente e a segunda descrição da fraqueza incorre em sérias dificuldades. Em primeiro lugar, devemos averiguar adiante as críticas fundamentais dirigidas ao modelo interpessoal da mente e a concepção de irracionalidade prática de Davidson. Em segundo lugar, faremos, então, uma comparação final da irracionalidade prática 'internalista' de Davidson e a irracionalidade prática 'objetiva' da psicologia antiga de Platão e Aristóteles.

\section{9 \\ As inconsistências da partilha da mente e da segunda descrição da fraqueza de vontade}

A partilha da mente e a segunda descrição da fraqueza de Davidson fornecem uma teoria da irracionalidade 'interna' da razão prática. Em primeiro lugar, a partilha da mente estabelece uma divisão fundamental entre o domínio racional e o domínio irracional da razão prática. Em segundo lugar, a segunda descrição da fraqueza caracteriza a intenção irracional da ignorância do princípio da continência. Em princípio, a irracionalidade prática muda inteiramente o foco de Davidson sobre a teoria causal da ação e a fraqueza de vontade. 
O campo da irracionalidade expande os limites da teoria causal da ação de Davidson. Como mencionamos, Davidson acerta ao ressaltar o desafio do paradoxo da irracionalidade, especialmente em relação à existência da CMNR e à inconsistência interna na razão prática. No entanto, a nova teoria da irracionalidade prática de Davidson também gera suas próprias controvérsias internas.

A seguir, devemos nos ocupar com duas controvérsias derivadas da concepção de irracionalidade de Davidson: (a) as inconsistências da segunda descrição da fraqueza de 'Paradoxes' em relação à primeira descrição de 'Weakness'; (b) o modelo interpessoal pressuposto da partilha da mente e a multiplicação mental de agentes semiautônomos. Nesse aspecto, pretendemos ressaltar ainda a pertinência de P2 e a correta distinção lógica do juízo TFC e do juízo absoluto da ação intencional. Sobretudo, devemos comparar a concepção da irracionalidade de Davidson com a distinção dos desejos racionais e os desejos irracionais da psicologia antiga. Dentro desse plano investigativo, precisamos primeiro investigar os problemas relacionados à segunda descrição da fraqueza.

A segunda descrição da fraqueza supostamente constitui uma correção da primeira descrição do fenômeno. Como vimos, a primeira descrição estabelece uma distinção lógica, a separação do juízo TFC e do juízo absoluto da ação intencional. A partir disso, Davidson conclui em 'Weakness' que a ação intencional da fraqueza não deriva logicamente do juízo TFC. No entanto, isso só nos fornece uma descrição lógica formal e não uma explicação efetiva da irracionalidade da ação intencional. A segunda descrição do fenômeno em 'Paradoxes' visa preencher essa lacuna da primeira descrição de 'Weakness'. Na segunda descrição, a ação irracional ocorre pela presença de um desejo forte contra o princípio da continência. No entanto, o problema reside dessa vez em explicar o que constitui a atuação direta do forte desejo irracional contra o princípio da continência.

A crítica de Ariela Lazar à segunda descrição da fraqueza de Davidson expõe as limitações lógicas do princípio da continência. Como mostra Lazar (1999, p. 389-392), a ignorância ou a rejeição do princípio da continência compromete o estatuto do próprio agente racional. Supostamente, um genuíno 'princípio orientador da ação' (action-guiding principle) implica que sua falha em guiar a ação não afeta diretamente a constituição da racionalidade do agente em si mesmo. De acordo com Lazar (Ibid., p. 390), o princípio da continência não representa efetivamente um princípio orientador da ação: “An agent who shows no concern 
for acting in accordance with her better judgement is not an agent: she does not act in the same sense that we do." Nesse sentido, o princípio da continência não serve para explicar o comportamento humano porque se dirige propriamente à constituição de seu agenciamento ou sua constituição enquanto um agente racional $^{548}$. De fato, algumas observações de Davidson sobre o próprio princípio da continência efetivamente reforçam a crítica de Lazar.

O princípio da continência de Davidson faz parte da própria racionalidade do agente. Em Incoherence and Irrationality, o princípio da continência, como o princípio da evidência total, faz parte dos princípios básicos da lógica da racionalidade interna humana. Como ressalta Davidson (2004b, p. 195), as normas lógicas da racionalidade interna do agente servem de parâmetro para todas as criaturas racionais: “(...) all thinking creatures subscribe to my basic standards or norms of rationality." (itálicos do autor). Nesse sentido, o princípio da continência é constitutivo do conjunto de atitudes proposicionais dentro da perspectiva interna do agente racional. No entanto, a ação irracional da fraqueza justamente não 'subscreve' às normas internas da racionalidade.

A irracionalidade impõe um desafio aos princípios lógicos da racionalidade do agente. Para Davidson (Ibid., p. 196-197), os princípios lógicos não são matéria de decisão ou escolha pois simplesmente são características intrínsecas ao ponto de vista interno do agente:

For it is only by interpreting a creature as largely in accord with these principles that we can intelligibly attribute propositional attitudes to it, or that we can raise the question whether it is some respect irrational. We see then that my word "subscribe" is misleading. Agents can't decide whether or not to accept the fundamental attributes of rationality: if they are in a position to decide anything, they have those attributes. (itálicos do autor)

Os parâmetros do campo racional e do campo irracional da mente humana dependem da atribuição de atitudes proposicionais a uma criatura inteligível e racional. Os princípios constitutivos da racionalidade não são alguma coisa ao qual

\footnotetext{
${ }^{548}$ Cf. Ibid., p. 387-388. De acordo com Lazar, isso envolveria o agente em dois tipos de descrição proposicional da ação quando pensávamos que havia somente uma única descrição proposicional da ação: (1) a ação em favor da razão mais fraca contra o juízo TFC; e (2) a ação de ignorar o princípio da continência. Nesse sentido, a ignorância do princípio da continência representa uma ação justamente porque a razão mais fraca não atinge diretamente o princípio da continência. Em sua reposta à Lazar, Davidson (Ibid., p. 403) indica que a ignorância do princípio da continência não constitui, na realidade, uma ação propriamente dita.
} 
o agente 'subscreve' ou 'nega', como se pudesse decidir ou escolher deliberadamente sobre eles. Se pudesse abnegar dos princípios lógicos racionais, isso inviabilizaria sua própria constituição racional enquanto agente humano. A rigor, o agente não pode aceitar ou desobedecer intencionalmente ao princípio da continência $^{549}$. Por isso, a ignorância do princípio da continência não é assim uma ação propriamente dita, mas apenas uma motivação irracional do agente, isto é, a causa não racional da ação.

A partir disso, Davidson (2004c, p. 205) ressalta que a fraqueza de vontade, tal como a fraqueza de justificação, reflete uma causa não racional da ação: "It is no part of the analysis of weakness of the warrant or weakness of the will that the falling off from the agent's standards is motivated (...).”. Ora, isso significa simplesmente caracterizar a ignorância do princípio da continência apenas pela predominância do desejo mais forte sobre o princípio da continência desconsiderando o papel lógico das razões na fraqueza de vontade.

O desejo mais forte seria, então, um tipo de causa cega, isto é, uma motivação completamente irracional independente do juízo do bem. Como alerta Pereira (2005, p. 196-197), o desejo cego não seria dirigido propriamente contra o princípio da continência, mas contra as melhores razões do agente expressas no juízo TFC $^{550}$. Além disso, o desejo cego desperta novamente o risco da compulsão psicológica expressa no princípio de Medéia, a pura irracionalidade.

A compulsão psicológica ameaça novamente a recairmos no paradoxo original da pura irracionalidade (P3). Como vimos, esse fenômeno se caracteriza pela incapacidade de ação do agente em face de um forte impulso irresistível. Como vimos, a distinção filosófica entre a fraqueza e a compulsão psicológica constitui um problema filosófico da fraqueza de vontade contemporânea. Em seguida, devemos analisar as objeções de Watson e Charlton sobre o limite tênue da fraqueza e da compulsão psicológica.

\footnotetext{
${ }^{549}$ Em sua réplica a Lazar, Davidson (1999, p. 404) acata a crítica ao estatuto do princípio da continência: "To think of it this way is, I agree, to hold the principle to be like a rule of inference rather than a premise. Thre is no reason, though, to suppose that an agent cannot articulate a rule of inference, and consciously employ it in reasoning, just as she can, on occasion, fail to employ it." ${ }^{550}$ Cf. Ibid., p. 196: “(...) o desejo rebelde não constitui qualquer razão contrária ao princípio de continência, ele só poderia fazer com que tal princípio fosse ignorado a partir do momento em que não fosse identificado por tal princípio, ou seja, a partir do momento em que se localizasse em um sistema intencional relativamente independente daquele no qual o princípio se localiza.”
} 
Para Watson (1977, p. 330-335), a submissão dos desejos mais fortes contrários ao melhor juízo torna a fraqueza da vontade similar à compulsão contra o juízo prático. Diante disso, Watson sugere adotar um padrão social relativo ao autocontrole dos desejos irracionais. Por esse critério, seria possível destacar mais claramente a 'fraqueza' e o caso do homem compulsivo: no primeiro caso, os desejos irracionais podem ser controlados por um exercício contínuo de treinamento e disciplina enquanto, no segundo caso, nenhum grau de controle garante o domínio dos apetites. Assim, apenas os desejos compulsivos seriam efetivamente incontroláveis em quaisquer circunstâncias de ação. Segundo Watson (Ibid., p. 332), há um padrão social externo de autocontrole: "In the case of weakness, one acts contrary to one's better judgment because one has failed to meet standards of reasonable or normal self-control (...)." (itálicos do autor). Com efeito, o parâmetro social de Watson é explicitamente inspirado no próprio método dos phainómena aristotélico ${ }^{551}$.

No entanto, a predominância do padrão externo de classificação do fenômeno não permite à Watson observar mais profundamente a análise aristotélica da natureza interna da akrasia. Invariavelmente, como temos alertado, a akrasia e a fraqueza de vontade são fenômenos distintos que não podem ser confundidos. Sobretudo, é arriscado caracterizar a irracionalidade da fraqueza puramente por critérios exclusivamente externos sem considerar o ponto de vista interno do agente. De fato, outros autores são ainda mais céticos sobre a distinção da fraqueza e a compulsão psicológica.

Em uma visão mais cética, Charlton (1988, p. 155-161) alega que não há qualquer diferença entre a fraqueza e a compulsão psicológica. Segundo Charlton (Ibid., p. 157), ambos expressam o mesmo tipo de incapacidade de resistência aos desejos compulsivos: “(...) the akrates is psychologically incapable of refraining if his inability is of the same general order as inability to resist an obsessional compulsion or a phobia." Nesse caso, o impulso irracional não só é mais forte mas, principalmente, constitui um impulso inerentemente irresistível. A 'impossibilidade psicológica' traz à tona novamente a metáfora da 'coerção' física externa. Com efeito, há inúmeros exemplos de comportamentos compulsivos parecidos com a

\footnotetext{
${ }^{551}$ Cf. Ibid., p. 331: "In this manner, we can distinguish among "temperance" and "continence" (in Aristotle's sense), weakness and compulsion. And we can avoid saying either that no desires are irresistible or that weakness is a case of compulsion".
} 
fraqueza: fobias, pânico, psicose, neurose obsessiva, o vício (em drogas ou em qualquer outra substância) entre outros tipos de compulsão. Em especial, Charlton (Ibid., p. 156-157) ressalta que esses casos compulsivos refletem certas características fundamentais da fraqueza: a) a fraqueza pode ser ativa ou passiva, tal como a fobia que leva à ação ou inação em relação a diversos tipos de medo; b) os casos de fraqueza, por vezes, podem se calcar em desejos e crenças inconscientes do agente, tal como ocorre com os casos de obsessão sexual. Em todos esses casos, há um fato psicológico comum: o impulso irracional representa um tipo de 'força externa' do ponto de vista racional 'interno' do agente.

O impulso forte se mantém totalmente fora do campo característico da racionalidade interna do agente. Como vimos anteriormente, a 'impossibilidade psicológica' de Hare é estritamente vinculada à submissão completa do melhor juízo pela força violenta do impulso irracional. Novamente, os desejos cegos, os desejos completamente irracionais, comprometem qualquer possibilidade de explicar a irracionalidade em termos racionais. Com efeito, os desejos irresistíveis se colocam inteiramente fora do campo da razão prática intervindo diretamente na ação independente do melhor juízo do agente. De qualquer modo, a compulsão psicológica torna inviável o problema da fraqueza de vontade.

Diante da compulsão psicológica radical, não haveria mais nenhum problema da fraqueza de vontade. A submissão completa do impulso forte na ação implica que a força motivacional do impulso irresistível sempre prevalece sobre o juízo avaliativo do agente. Nesse caso, isso tornaria falso o princípio (P2), isto é, a conexão necessária entre o juízo avaliativo e a motivação da ação. Consequentemente, o próprio problema formulado em torno dos princípios (P1)(P3) também desapareceria. Sobretudo, a negação de (P2) ainda resulta na absoluta rejeição de qualquer papel fundamental do juízo avaliativo do agente na explicação racional da ação intencional. Dessa forma, é preferível preservar a racionalidade sem abnegar do princípio (P2) para dar conta da irracionalidade da fraqueza.

A preservação de (P2) exige a clara distinção da fraqueza de vontade e da compulsão psicológica. Sobretudo, devemos rejeitar a categoria de desejos irresistíveis ou desejos cegos relacionados à impossibilidade psicológica. No entanto, isso não significa abrir mão do desafio de explicar a irracionalidade da fraqueza de vontade. Por isso, é imprescindível nos voltarmos adiante aos desafios ligados à existência da causa não racional (CMNR). 
A causa não racional ultrapassa os limites das relações lógicas da teoria causal da ação de Davidson. O paradoxo da irracionalidade apresenta o desafio da explicação da CMNR. Mesmo com a formulação correta do paradoxo da irracionalidade, restam dúvidas sobre a resolução da partilha de mente de Davidson. A seguir, devemos analisar principalmente as críticas dirigidas à analogia do modelo interpessoal da mente.

$\mathrm{O}$ modelo interpessoal da mente gera dificuldades à partilha da mente de Davidson. Sem dúvida, a divisão mental é imprescindível para sua concepção da irracionalidade prática e a existência da causa não racional na ação. No entanto, a analogia interpessoal elimina qualquer possibilidade de dar conta da irracionalidade da razão prática.

Assim, nos ocuparemos com duas categorias de objeções: a) o modelo interpessoal reduplica a personalidade dos agentes, retornando novamente ao problema do homunculus ${ }^{552}$; b) a explicação da causa não racional, a rigor, não depende do modelo interpessoal da mente mas da força motivacional da ação. Nesse sentido, pretendemos ressaltar que a CMNR não depende de qualquer teoria da partilha da mente. De fato, os parâmetros 'objetivos' da irracionalidade antiga fornecem categorias psicológicas fundamentais para dar conta da presença da causa não racional na ação humana. Para isso, precisamos primeiro compreender as inconsistências do modelo interpessoal da divisão mental de Davidson.

A partilha da mente de Davidson se apoia em uma controversa analogia interpessoal. Para Davison, a partilha da mente é imprescindível para dar conta da atuação da causa não racional (CMNR) na ação intencional. A subdivisão mental das partes semiautonomas permite manter um grau de independência das relações lógicas causais de racionalidade. A analogia da interação social é crucial para compreender a estrutura interativa das diferentes partes mentais. A interação social direta entre as diferentes atitudes de agentes racionais explica, de certa maneira, a conexão causal da atuação direta dos desejos ou emoções na ação intencional. Particularmente, a divisão de subsistemas mentais deve explicar a ignorância do

\footnotetext{
552 Dentre as críticas do homunculus dirigidas à partilha da mente de Davidson, destacamos principalmente as objeções de Gosling (1990, p. 145-147) e de Charlton (1988, p. 168-176). Como veremos adiante, as críticas à partilha da mente geralmente se referem ao esvaziamento explicativo da duplicação do agente humano. Nesse sentido, a divisão psicológica antiga não está sujeita à mesma objeção porque não se restringe a reproduzir a estrutura mental humana.
} 
princípio da continência. No entanto, essa analogia corre o risco de reduplicar a estrutura mental do agente racional.

O problema do homисulus emerge da própria estrutura da partilha da mente de Davidson. Como vimos, o modelo do homunculus representa a estrutura mental do agente em uma subdivisão de miniagentes dentro da própria razão prática humana. De fato, a ação humana permanece inexplicável se apenas reduplicarmos a complexidade dos agentes humanos que, a princípio, precisaria ter sido explicada.

Em especial, Gosling (1990) ressalta que esse agrupamento de subagentes na mente não contribui em nada para explicar a fraqueza de vontade. Em primeiro lugar, a divisão de dois subsistemas mentais simplesmente reproduz novamente a ação irracional descrita no fenômeno ${ }^{553}$. A princípio, há um conflito de dois sistemas mentais paralelos: o sistema racional, conforme o princípio da continência dirigido ao 'melhor juízo' absoluto ou às razões mais fortes, e outro sistema irracional, dirigido ao ato de fraqueza e às razões mais fracas. A ignorância do princípio da continência é o resultado da intenção errada do sistema irracional em vista das razões mais fracas rejeitadas pelo sistema racional do agente.

Em segundo lugar, o paradigma do animal racional é eficaz para dar conta do sucesso da ação intencional, mas não da falha da ação irracional, presente na fraqueza. Segundo Gosling (Ibid., p. 147), o modelo do animal racional compromete a possibilidade de explicar o caso acrático:

Given that we want to associate with 'rational' animals the rational system usually predominates, and this is what makes them count as rational, the akratic case has to be the exception on pain of the agent ceasing to be a rational one.

A analogia interpessoal fracassa justamente durante o ato de fraqueza de vontade. De fato, o modelo interpessoal só faz sentido se as partes mentais do agente refletem em alguma medida a interação social de animais racionais. No entanto, a ação irracional reflete justamente uma outra parte mental que representa imperfeitamente o sistema racional (de razões, deliberação e decisões) constitutivo de um agente racional. Por isso, o modelo interpessoal é inadequado para dar conta da irracionalidade da fraqueza de vontade. Novamente, a ignorância do princípio

\footnotetext{
${ }^{553}$ Cf. Ibid., p. 147: "The proposed explanation simply states the situation over again, leaving it as puzzling as in the original why the conclusion reached is overturned for a reason previously rejected and without any reason for overturning the earlier rejection."
} 
racional da continência compromete a própria constituição do agente racional. Todavia, a existência de uma causa não racional não nos obriga necessariamente a adotar a partilha da mente de Davidson.

A existência da CMNR na fraqueza não implica necessariamente em admitir um modelo interpessoal de partilha da mente. Em Irrationality (1987), Alfred Mele sustenta que a CMNR pode ter espaço no mesmo sistema mental do agente sem necessidade de uma partilha da mente. Em linhas gerais, Mele (Ibid., p. 75-80) dirige duas críticas principais à partilha da mente de Davidson: 1) a CMNR estabelece uma relação de causa e efeito concebida de forma inteligível e coerente dentro de um único sistema mental da razão prática; 2) a fraqueza de vontade não demanda a divisão de diferentes partes mentais para estabelecer a separação da causa não racional e seu efeito mental na ação. Particularmente, o exercício mental irrefletido contínuo de memorização ou imaginação de autocontole auxilia no domínio do impulso irracional imediato sem qualquer 'inconsistência interna' nas razões do agente. Sendo assim, devemos avaliar outros fatores motivacionais que auxiliam a explicar a CMNR.

Os casos de fraqueza manifestam o poder das forças motivacionais na ação irracional do agente. De fato, os casos de fraqueza revelam a influência de fatores emocionais, como ansiedade ou medo, em atitudes irrefletidas contrárias ao melhor juízo no momento da ação. A partir disso, Mele (Ibid, p. 92-93) atribui esse fenômeno ao efeito da proximidade sobre a atenção e motivação que abrange vários fatores: (a) a proximidade percebida da recompensa da ação irracional; (b) a força motivacional para exercer a ação correta ou a ação irracional; (c) a falha efetiva do exercício do autocontrole; (d) a condição da atenção ou do foco do agente. Com base nesses aspectos, Mele (Ibid., p. 95) chega a uma conclusão controversa acerca da relação entre o juízo avaliativo e a força motivacional:

The point (...) is that reasons (broadly conceived) for action have two importantly different dimensions: the agent's evaluation of them (when he does evaluate them) and their motivational force or valence. These features are not wholly independent of each other; evaluations of reasons seem often to influence their motivational impact and vice versa. But, at least in some cases, the influence is just that-influence. (itálicos do autor) 
A existência da CMNR expõe, na verdade, o desalinhamento do juízo avaliativo e a força motivacional. Ao contrário de Davidson, Mele rejeita a necessidade de postular uma partilha da mente para dar conta da causa não racional da ação. Na realidade, é possível explicar a CMNR dentro de um mesmo sistema mental quando reconhecemos que o juízo avaliativo e a força motivacional nem sempre coincidem. A partir disso, Mele reconhece apenas que há uma influência da motivação humana sobre o juízo avaliativo do agente mas não uma conexão necessária. Ora, isso equivale a reconhecer novamente que (P2) é falso. Nesse cenário, reconhecemos que o modelo interpessoal de Davidson é inconsistente, mas estamos dispostos a preservar o internalismo de (P2). Em verdade, o erro da partilha da mente de Davidson está ligado à sua própria defesa do holismo mental.

O erro principal da partilha da mente se deve ao seu compromisso com o holismo mental do agente. De acordo com Davidson (2004a, p. 183), a irracionalidade exige um pressuposto estratégico de descrição proposicional das ações intencionais do agente racional:

(...) the strategy is to assume that the person to be understood is much like ourselves. That is perforce the opening strategy, from which we deviate as the evidence piles up. We start out assuming that others have, in the basic and largest matters, beliefs and values similar to ours.

A estratégia de Davidson consiste em estabelecer a divisão mental com base no paradigma de um agente racional tal como nós mesmos. Nesse aspecto, o sistema racional de crenças, valores e desejos do agente é coincidente com nosso próprio sistema racional subjetivo. Supostamente, o desvio dos princípios racionais, isto é, a irracionalidade seria explicada com base nos mesmos parâmetros de racionalidade. No entanto, o ponto da analogia social se perde quando a partição da mente simplesmente reflete a própria constituição dos agentes racionais. Em última análise, a partilha da mente sequer auxilia a esclarecer a segunda descrição da fraqueza de vontade de Davidson. Nesse cenário, podemos recorrer a um outro modelo de divisão mental sem incorrer na controversa analogia interpessoal.

A partilha da mente de Davidson é inviável para dar conta da irracionalidade e da fraqueza de vontade. O modelo interpessoal ainda permanece sujeito à objeção do homunculus uma vez que apenas reproduz a complexidade do agente inteiro em miniagentes. Como vimos anteriormente, a psicologia platônica (e, de certo modo, 
também a psicologia moral de Aristóteles) não incorre na reprodução do agente racional. Ao contrário, a psicologia antiga revela que há outro modelo psicológico similar a mente humana, a psicologia animal. O paradigma psicológico animal compartilha certas características com a psicologia humana mas, de modo algum, há uma identificação completa de ambos os modelos psicológicos. Desse modo, não teríamos mais o problema do homuculus.

Ao invés da divisão mental literal, podemos adotar a distinção psicológica antiga dos tipos de desejos e juízos avaliativos próprios de cada seção mental. ${ }^{554}$ Dentro dessa estrutura, poderíamos destacar mais claramente diferentes tipos de juízos avaliativos e desejos específicos das 'partes' da mente. Sobretudo, analisaremos essa possibilidade quando compararmos a irracionalidade prática 'interna' de Davidson e a concepção antiga 'objetiva' da irracionalidade. Antes, precisamos traçar as últimas considerações acerca das duas descrições da fraqueza e a consistência do internalismo de Davidson.

Há uma franca incompatibilidade entre a primeira e a segunda descrição de Davidson da fraqueza de vontade. Em 'Weakness', Davidson fornece uma descrição formal com base na distinção lógica do juízo prima facie TFC e do juízo incondicional da ação intencional. A partir de 'Paradoxes', há uma nova descrição mais explicativa do fenômeno, a violação do princípio da continência da ação conforme o juízo TFC. Como vimos, a diferença crucial está no reconhecimento de que a ação é contrária ao princípio normativo do juízo TFC e não decorre apenas da intenção errada. Com base nas observações anteriores, podemos avaliar melhor ambas as descrições da fraqueza de Davidson.

A segunda descrição apresenta mais inconsistências do que a primeira descrição do fenômeno. Em primeiro lugar, a segunda descrição envolve a controversa desobediência consciente do princípio da continência. De início, o princípio da continência deveria ser apenas um princípio orientador da ação ou um princípio prescritivo da conduta do agente. No entanto, o princípio da continência integra, junto a outros princípios lógicos, a própria racionalidade do agente. A rigor,

${ }^{554}$ Cf. CHARLTON, 1988, p 175: "If we want to liberate ourselves from this model [interaction between mental states] we must see teleology as a genuine, thoroughgoing alternative. We confine ourselves to a single owner of mental states, the person. Instead of partioning the person we divide desires and modes of thinking into different groups." 
não pode haver violação do principio da continência sem deixar de comprometer o estatuto do agente racional.

Em segundo lugar, a segunda descrição exige um modelo interpessoal controverso da partilha da mente. Diante da inconsistência interna, Davidson localiza as crenças incompatíveis do juízo TFC e da ação intencional em hemisférios mentais diferentes. Entretanto, isso o compromete então a sustentar que há uma motivação cega irracional (sejam desejos ou emoções) contrária a orientação do princípio racional da continência. De qualquer forma, o estatuto da racionalidade do agente fica seriamente comprometido e não podemos efetivamente explicar o comportamento da fraqueza de vontade. No entanto, essas inconsistências da segunda descrição em nada afetam as conclusões da primeira descrição do fenômeno.

Ao contrário da segunda descrição, a primeira descrição se mantém logicamente correta. Por um lado, a desvinculação lógica do juízo TFC e do juízo intencional é preservada em ambas as descrições da fraqueza. Como vimos, a intenção do agente não pode ser derivada logicamente do juízo TFC porque a ação irracional do agente não corresponde ao melhor curso de ação. A segunda descrição da fraqueza apenas ratifica a mesma conclusão, isto é, a rejeição do princípio da continência da ação conforme o juízo TFC. Por outro lado, a distinção lógica dos tipos de juízos avaliativos elimina o conflito dos princípios intuitivos (P1-P3). De fato, o internalismo forte de (P1-P2) é composto dos juízos incondicionais da ação intencional enquanto a descrição da fraqueza (P3) exibe o juízo prima facie TFC. A partir disso, Davidson mostra que o 'internalismo’ de (P1-P2) é fundamental para a preservação da racionalidade mesmo na fraqueza de vontade.

\subsection{0}

\section{A irracionalidade 'internalista' de Davidson e a irracionalidade 'objetiva' da psicologia antiga}

O 'internalismo’ de (P1-P2) de Davidson constitui a defesa da preservação da racionalidade da ação intencional. Como vimos, o princípio (P2) estabelece a conexão fundamental do juízo avaliativo e a motivação da ação enquanto o princípio (P1) constitui a relação lógica da motivação da ação e a ação intencional. 
Ambos os princípios (P1-P2) constituem a relação lógica necessária entre as razões e a ação intencional de acordo com o ponto de vista interna da racionalidade do agente.

Devido a sua consistência interna, os princípios não podem ser destacados nem no sentido exclusivamente avaliativo, nem no sentido exclusivamente motivacional. O 'internalismo’ de Davidson se sustenta na conexão causal do par de crenças-desejos do sistema mental do agente e sua ação intencional. A teoria causal da ação de Davidson e sua relação interna das crenças-desejos do agente e a ação intencional se ampara na concepção cognitivo-motivacional da psicologia antiga de Platão e Aristóteles.

Apesar dessas controvérsias, o internalismo de (P1-P2) se mantém firme ao longo do tempo tendo suas raízes desde as obras de Platão e Aristóteles. Como vimos, a explicação causal da ação em vista das crenças e desejos do agente já era influente na psicologia antiga. De fato, a psicologia moral de Platão e Aristóteles se fundamenta na concepção cognitivo-motivacional da psicologia grega antiga. Dentro dessa concepção da psicologia antiga, a divisão dos diferentes tipos de desejos humanos se caracteriza por seus atributos cognitivos e motivacionais característicos. Com isso, há uma 'racionalização' da ação humana já presente desde a psicologia antiga. Como vimos, o próprio Davidson reconhece essa tradição antiga na filosofia da ação de Aristóteles e planeja recuperar essa posição filosófica a partir de sua teoria causal da ação ${ }^{555}$. Entretanto, o papel distintivo dos desejos irracionais na psicologia antiga coloca em xeque a plausibilidade dos princípios (P1-P2) de Davidson.

Os princípios (P1-P2) ganham uma releitura diante do papel fundamental do caráter moral e das motivações irracionais da psicologia antiga. Como indica Charles (1984, p. 193-194), o caráter do homem virtuoso e do homem encrático na Ética de Aristóteles impõem uma revisão dos princípios (P1-P2) do internalismo de Davidson ${ }^{556}$.

\footnotetext{
${ }^{555}$ Como vimos anteriormente, Davidson explicitamente atribui as raízes da teoria causal da ação à formulação pioneira do silogismo prático em Aristóteles (cf. 2001a, p. 11; Idem, 2005). Em todo caso, a conexão causal das razões e a ação já estava presente ao menos desde os diálogos platônicos como mostrarmos anteriormente nos capítulos sobre o Protágoras e a República de Platão.

${ }^{556}$ De acordo com Charles (Ibid., p. 193-194), Aristóteles não aceitaria nenhum dos dois princípios de Davidson. Particularmente, a avaliação racional e a força motivacional por si mesmas não contempla a relação intrínseca da racionalidade e do desejo na teoria aristotélica da ação. Basicamente, Charles alega que P2 só faz sentido em relação ao caráter virtuoso, enquanto P1 só faz
} 
Em primeiro lugar, o homem virtuoso, dotado da phrónesis, reflete uma harmonia completa entre o 'melhor juízo' e seus desejos irracionais. Nesse aspecto, o seu caráter moral é compatível com o internalismo de (P1)-(P2). No entanto, o homem encrático possui um alinhamento parcial do melhor juízo e seus desejos irracionais. Mesmo que a ação correta decorra do melhor juízo no caráter encrático, há um conflito persistente entre o seu melhor juízo prático e suas motivações irracionais. De fato, o conflito interno do encrático coloca o internalismo de (P1)(P2) sob suspeita. Ambos os casos refletem ainda o sucesso da razão prática, isto é, a eficácia prática do melhor juízo na ação moral. Entretanto, o conflito interno do encrático revela que há uma descoordenação da razão prática e as motivações irracionais.

Em segundo lugar, o caso do homem acrático revela o efeito do conflito interno da razão prática e os desejos irracionais na ação moral. Sobretudo, o fracasso da razão prática no caso do acrático expõe de forma mais enfática o desalinhamento do melhor juízo e as motivações irracionais. O conflito interno acrático acaba preservando (P1) ao mesmo tempo que coloca (P2) sob suspeita. A predominância do desejo irracional não afeta diretamente a relação lógica entre a força motivacional e a ação intencional, mas compromete a conexão lógica do juízo avaliativo e a motivação mais forte da ação. Nessa esfera, o melhor juízo da razão prática não parece ter nenhum valor explicativo eficaz no caso da ação acrática.

A possibilidade da akrasia antiga revela o poder da predominância dos desejos irracionais sobre a razão prática. A psicologia antiga fornece um espaço fundamental à interação dinâmica da razão prática e das motivações irracionais. De certa forma, a segunda descrição de Davidson reconhece de forma mais clara o papel das motivações irracionais na fraqueza de vontade. Nesse sentido, a ignorância do princípio da continência se aproxima mais do conflito interno da akrasia antiga.

A plena consciência do agente acerca de seu 'melhor juízo' é fundamental para compreender a ação irracional da fraqueza. Assim como Aristóteles, Davidson está comprometido a preservar a consciência do agente sobre o melhor juízo ao longo de toda a ação irracional. No entanto, Davidson deixa de reconhecer com mais precisão as raízes aristotélicas de sua descrição final da fraqueza. Em sua 
perspectiva, a teoria aristotélica da akrasia apela à consciência parcial do raciocínio prático: a inconsciência do 'melhor juízo' do agente em vista da consciência do 'juízo de prazer' no momento do ato de fraqueza. Em Paradoxes, Davidson (2004a, p. 186) enfatiza que a irracionalidade do fenômeno depende da consciência integral do raciocínio prático ao contrário da suposta doutrina aristótelica:

The standard case of akrasia is one in which the agent knows what he is doing, and why, and knows that it is not for the best, and knows why. He acknowledges his own irrationality. If all this is possible, then the description cannot be made untenable by supposing that sometimes some of the thoughts or desires involved are unconscious.

A leitura tradicional do silogismo prático forte não permite a Davidson enxergar com mais profundidade seu débito à teoria aristotélica da akrasia. Como vimos anteriormente, o modelo tradicional do silogismo prático forte sustenta que a conclusão prática é a ação. Por isso, o erro acrático representa uma falha cognitiva do próprio raciocínio prático, seja pela ausência ou inconsciência de uma parte do raciocínio prático. Ora, isso até poderia servir para explicar a akrasia impulsiva, mas não a akrasia fraca. O primeiro tipo de acrático se caracteriza pela ausência da conclusão prática, enquanto o segundo tipo de acrático tem absoluta consciência da conclusão prática durante a ação irracional. O silogismo prático moderado de Aristóteles indica de forma mais decisiva que a razão prática não é eficaz sem as motivações irracionais apropriadas. Nesse aspecto, a teoria aristotélica da akrasia é incompatível com a violação do princípio da continência de Davidson.

Ao contrário de Davidson, a teoria aristotélica da akrasia independe de qualquer violação do princípio da continência. Como vimos, o princípio da continência estabelece a ação intencional conforme o juízo TFC. Em linhas gerais, podemos salientar duas diferenças crucias com a teoria aristotélica da akrasia $^{557}$ : (a) a akrasia independe de uma falha no processo do raciocínio prático, particularmente pela falha na derivação do juízo TFC na conclusão prática da ação

\footnotetext{
${ }^{557}$ Novamente, estamos seguindo aqui algumas considerações de Charles (1984, p. 156-160) sobre as diferenças da teoria aristotélica da akrasia e a descrição da fraqueza de vontade de Davidson. Sobretudo, Charles (Ibid., p. 157) salienta que a teoria aristotélica não se baseia na falha da derivação lógica da conclusão prática apropriada como a teoria de Davidson: "For Aristotle, by contrast, the acratês does not violate a principle of reasoning through failing to draw an appropriate conclusion from his antecedent premisses; for there is no step in argument to a further propositional conclusion (for Aristotle) after the acratês has judged 'doing x seems best' at the point where the acratic failure occurs. His acratês fails only to accept a judgement of this type appropriately." (itálicos do autor)
} 
do agente; (b) não há qualquer violação do princípio lógico da continência na akrasia, visto que a ação acrática não é explicitamente contrária ao melhor juízo do agente mas apenas os desejos irracionais são efetivamente contrários. Dessa forma, a akrasia não coincide com nenhuma das duas descrições de fraqueza de vontade de Davidson.

O princípio da continência de Davidson é um princípio lógico da razão prática e sua violação compromete a própria racionalidade do agente. Ao contrário, a akrasia depende da violação de um princípio prático orientador da ação e não de um princípio constitutivo da própria razão prática. Como vimos, a teoria aristotélica da akrasia sustenta que a ação acrática decorre do desvio dos apetites irracionais do silogismo do bem para parte do silogismo do prazer. A deficiência moral dos desejos irracionais é central para compreender a desarmonia da razão prática e os desejos irracionais. Sobretudo, a ausência de uma teoria mais abrangente das motivações irracionais compromete a intenção irracional do agente na fraqueza.

Para vermos isso mais claramente, precisamos fazer um exame comparativo da irracionalidade objetiva da psicologia antiga e a irracionalidade prática de Davidson. Como a akrasia e a fraqueza de vontade são fenômenos distintos, devemos considerar que correspondem a categorias mentais distintas da 'irracionalidade' humana. Para todos os efeitos, devemos comparar dois paradigmas distintos de irracionalidade prática: a irracionalidade objetiva da psicologia tripartite platônica e a irracionalidade interna de Davidson.

Dessa maneira, precisamos considerar as seguintes diferenças entre a irracionalidade antiga e a irracionalidade prática de Davidson: (1) a irracionalidade prática de Davidson está estreitamente vinculada à noção da pura inconsistência interna, isto é, a inconsistência de certa crenças com outras crenças incompatíveis do agente dentro de seu sistema racional mental; (2) a irracionalidade prática platônica e o paradigma do conflito de desejos opostos com base na divisão psicológica antiga entre a parte racional e a parte irracional e, consequentemente, a distinção dos desejos racionais e desejos irracionais. Sobretudo, devemos ressaltar que a psicologia platônica atribui à parte racional e à parte irracional suas categorias próprias de juízos avaliativos e motivações da ação. Como vimos anteriormente, isso é plenamente compreensível dentro da psicologia antiga cognitivomotivacional. A estrutura da psicologia tripartite platônica permite explicar o papel das motivações irracionais na ação humana. No entanto, a concepção estreita da 
irracionalidade de Davidson não o permite conceber outros tipos de irracionalidade prática além da pura inconsistência interna. Em seguida, iremos salientar o problema fundamental da irracionalidade interna de Davidson.

A irracionalidade prática de Davidson envolve necessariamente a inconsistência interna. Como vimos, a inconsistência interna emerge da incompatibilidade de crenças contraditórias segundo os padrões normativos de racionalidade do próprio agente. A 'irracionalidade', então, só faz sentido dentro do sistema de crenças integrado da mente do agente, isto é, depende do holismo mental ${ }^{558}$. Por isso, a irracionalidade prática fica restrita à um tipo de inconsistência lógica e não auxilia a esclarecer a irracionalidade da própria fraqueza de vontade.

A falha da ação conforme o princípio da continência constitui a segunda descrição da fraqueza de vontade de Davidson. A violação ou 'sobreposição' do princípio da continência sugere que seria possível simplesmente 'aceitar' ou 'rejeitar' a conclusão prática do 'melhor juízo'. Como observamos, isso não procede à um elemento constitutivo da racionalidade do agente, como é o caso do princípio da continência. Em Deception and Division, Davidson (2004c, p. 204) ressalta que a inconsistência interna em geral expressa o próprio desvio das normas fundamentais de racionalidade:

For where the norms are basic they are constitutive elements in the identification of attitudes and so the question whether someone 'accepts' them cannot arise. All genuine inconsistencies are deviations from the person's own norms.

A pura inconsistência interna deve explicar, em princípio, todos os tipos de irracionalidade prática. De acordo com Davidson, todas as formas de inconsistência interna são propriamente desvios das normas de racionalidade do agente. Dessa forma, a inconsistência interna envolve basicamente a sustentação de crenças incompatíveis ( $p$ e não- $p$ ) no sistema mental do agente. Não há sentido propriamente em afirmar que o agente 'aceita' ou 'rejeita' os princípios lógicos constitutivos de sua própria racionalidade. A ação irracional reflete a presença de

\footnotetext{
${ }^{558}$ Cf. DAVIDSON, 2004b, p. 197: "The possibility of (objective) inconsistency depends on nothing more than this, that an agent, a creature with propositional attitudes, must show much consistency in his thought and action, and in this sense have the fundamental values of rationality; yet he may depart from these, his own, norms." (itálicos do autor)
} 
uma causa não racional, um desejo ou emoção, que rompe a cadeia causal das relações lógicas da racionalidade.

A causa não racional constitui propriamente a formação da intenção irracional do agente. Invariavelmente, a irracionalidade é formada a partir do próprio papel do desejo irracional na ampla rede mental do par de crenças-desejos que compõe a razão prática do agente. ${ }^{559}$ No caso particular da fraqueza, por exemplo, a ação irracional contra o princípio da continência reflete a atuação direta do forte 'desejo' irracional em vista das razões fracas contra as razões fortes do 'melhor juízo' absoluto. De qualquer modo, a irracionalidade prática não parece consistir propriamente na 'aceitação' ou 'rejeição' do princípio da continência.

A irracionalidade prática não pode ser explicada pelo desvio dos princípios constitutivos da racionalidade. Como salienta Stroud (2013, p. 495-501), a descrição final da fraqueza de Davidson e a estreita concepção de inconsistência interna não fornecem uma definição satisfatória da irracionalidade prática. De fato, a descrição final da fraqueza transforma simplesmente toda ação contrária a qualquer princípio racional do agente em uma ação irracional. Nessa medida, a 'aceitação' do princípio da continência representa um conceito virtualmente vazio. Se a fraqueza é a ação contrária a um princípio já assumido de antemão pelo agente racional, a 'aceitação' do princípio lógico não faz mais sentido. O mesmo gênero de problemas compromete a concepção estrita de 'inconsistência pura' da irracionalidade prática.

Além disso, Stroud (Ibid., p. 500-501) ressalta ainda que a irracionalidade prática pode constituir um tipo incoerência ou inconsistência sem, no entanto, resultar em uma franca inconsistência lógica de proposições incompatíveis ${ }^{560}$. Todavia, não é preciso assumir que atitudes proposicionais incompatíveis expressam necessariamente crenças contraditórias, pois também podem expressar outros estados psicológicos incompatíveis, como desejos, emoções ou impulsos. Como vimos, a ideia de uma partilha interna da mente é desnecessária quando não

\footnotetext{
${ }^{559} \mathrm{Cf}$. LAZAR, 1999, p. 394: "In a nutshell, the role of a desire within practical reason is assessable only within its role in a larger network of desires (and beliefs). Roughly, the status of a desire qua reason depends on how it relates to other desires, e. g., which desires - if any - it is instrumental towards fulfilling, which desires would be incompatible with fulfilling it, which desires are likely to arise if it is satisfied, etc." (itálicos da autora)

${ }^{560} \mathrm{Cf}$. Ibid., p. 500: "While the boundaries of inconsistency and incoherence are not obvious, they seem to extend well beyond cases in which you have one and the same propostional attitude, namely belief, toward propositions that are logically incompatible."
} 
estamos nos referindo a uma reduplicação do sistema mental do agente. Nesse sentido, a irracionalidade da fraqueza não envolve simplesmente a ação contra o princípio da continência.

A fraqueza de vontade pode ser esclarecida se tratarmos o princípio da continência como um princípio normativo da ação e não mais como um princípio constitutivo da racionalidade. Como vimos, o princípio normativo da continência é capaz de explicar o comportamento humano, tanto no sucesso quanto no fracasso da razão prática na ação humana. Sendo um princípio prático da ação, a segunda descrição da fraqueza constituiria simplesmente na desobediência ao princípio normativo da continência, em vista do padrão ideal de excelência da racionalidade prática. Como um princípio constitutivo, não há distinção clara entre o princípio da continência de outros princípios lógicos. Por isso, a irracionalidade prática de Davidson se constitui como qualquer inconsistência lógica a partir do puro conflito de crenças incompatíveis. Nessa medida, o princípio orientador da ação permite dar maior relevo à interação dinâmica entre a razão prática e as motivações irracionais.

A segunda descrição da fraqueza de vontade de Davidson leva em conta o ‘internalismo’ da razão prática. Como vimos, o internalismo e o externalismo estão no centro da controvérsia analítica da razão prática. De um lado, o 'internalismo' estabelece uma conexão interna necessária das razões do agente e a ação intencional. Em contraposição, o 'externalismo' nega a existência de tal conexão necessária, levando em conta o papel de outros fatores motivacionais na ação. Assim como Hare, Davidson tem consciência de que o ‘internalismo’ é fundamental ao problema da fraqueza de vontade.

A defesa da relação do juízo avaliativo e a motivação da ação em (P2) é central ao ‘internalismo’ da razão prática. Todavia, isso não exime (P2) de críticas 'externalistas' que evidenciam o papel de outros fatores motivacionais, como a atenção irrefletida, emoções ou desejos irracionais, na ação intencional. De fato, ambas as posições podem ser levadas ao extremo radical. Nesse caso, elas podem se tornar excludentes, isto é, a admissão do 'internalismo' necessariamente implica na eliminação da 'externalismo' ou vice-versa. Em contraposição, a psicologia antiga apresenta a possibilidade de uma interação dinâmica entre o juízo avaliativo e as motivações irracionais. 
O ponto de vista 'objetivo' da psicologia antiga está vinculado à natureza das diferentes motivações e desejos humanos. ${ }^{561}$ Nessa perspectiva 'objetiva', a dicotomia analítica do 'internalismo' e 'externalismo' não tem um lugar claramente definido. Certamente, a psicologia antiga reconhece a relação necessária 'interna' da ação humana em vista das razões para a ação em função do par de crençasdesejos do agente. Ao mesmo tempo, não se ignora o papel 'externo' das motivações irracionais formada pelo caráter moral do agente. O papel distintivo das motivações irracionais na ação intencional está ausente da irracionalidade 'internalista' de Davidson.

A irracionalidade 'internalista' de Davidson difere da concepção antiga de ‘irracionalidade' objetiva. Como vimos, a irracionalidade de Davidson se constitui por uma inconsistência lógica interna da própria racionalidade do agente. Por sua vez, a 'irracionalidade' antiga está fundada na distinção objetiva da natureza do desejo racional e os desejos irracionais. Sobretudo, isso nos fornece um novo ângulo sobre a fraqueza de vontade contemporânea. Para exemplificarmos isso, podemos retomar brevemente o modelo da psicologia tripartite platônica.

A teoria tripartite de Platão da República ilustra de forma mais clara o ponto de vista 'objetivo' da psicologia antiga. ${ }^{562}$ Em especial, devemos recapitular aqui dois aspectos centrais da psicologia tripartite platônica: (1) o critério objetivo do princípio do conflito desejos (PC) que estabelece as três 'partes' da alma; (2) a interação dinâmica dos elementos da alma e a condição moral do agente. Como observamos, ambas as teorias psicológicas têm ampla repercussão na psicologia moral de Aristóteles. De todo modo, a divisão platônica da alma permite definir parâmetros 'objetivos' de racionalidade e irracionalidade humana independente da perspectiva interna do agente.

\footnotetext{
561 Seguimos aqui a distinção geral do modelo antigo 'objetivo-participante' em contraponto ao modelo moderno 'subjetivista-individualista', tal como apresentada em GILL, 1996, p. 9-10: "My key underlying thought is that, if we are to understand ancient Greek thinking on (what we call) 'personality' and 'selfhood', we need to counteract the subjective, individualist, and subjectiveindividualist strands of thought which have played such a large role in shapaing modern thinking about these notions, and to frame a more 'objective participant' account of them."

562 Como vimos no capítulo da República, a 'alma 'platônica é formada pela interação dinâmica entre o campo 'interno' da alma e o mundo 'externo' da cidade. Na estrutura psicológica tripartite da alma, a natureza dos desejos de cada parte da alma é esclarecida em função da natureza de seus 'objetos' naturais de desejos. Nesse aspecto, a psicologia tripartite interna da alma depende de sua relação com os objetos externos naturais e não pode ser explicada somente do ponto de vista interno exclusivo das crenças e desejos do agente.
} 
Com base na psicologia tripartite platônica, poderemos esclarecer o papel das motivações irracionais na razão prática. Especificamente, pretendemos mostrar a influência das motivações irracionais na fraqueza de vontade contemporânea. Assim, nos voltaremos primeiro aos princípios fundamentais de divisão psicológica da alma.

A natureza das diferentes motivações humanas determina a divisão triparite da psicologia moral platônica. Como vimos, a teoria tripartite platônica estabelece três 'partes' da alma humana encarnada: a parte racional (logistikón), a parte impetuosa (thymoeidés) e a parte apetitiva (epithymetikón). Como indicamos anterioremente, não há 'três partes' literais da alma humana, mas apenas três 'elementos' ou 'setores' psíquicos relativos aos diferentes objetos naturais de desejo humano.

Independentemente da existência ou inexistência da 'alma' humana, a teoria platônica pode ser adaptada às categorias mentais da filosofia analitica da ação. Sobretudo, cada parte da alma não só possui diferentes tipos de desejos como também contempla ainda outros elementos psicológicos. Em especial, a divisão da alma acompanha um critério lógico 'objetivo', o princípio do conflito de desejos opostos (PC).

A demonstração (apódeixis) da teoria tripartite da alma segue os parâmetros lógicos do Princípio do Conflito (PC). Como vimos, o Princípio do Conflito (PC) é composto do Princípio dos Opostos (PO) e do Princípio dos Relativos (PR). Primeiramente, o Princípio dos Opostos (PO) estabelece o princípio lógico que não é possível à mesma 'coisa' sofrer ou realizar efeitos contrários nas mesmas 'partes' da alma (436e-437a). Em segundo lugar, o Princípio dos Relativos (PR) estabelece que cada parte da alma mantém uma relação natural com seus diferentes objetos de desejo (438d-e). Ambos os critérios revelam que a teoria tripartite não estabelece uma simples oposição dos desejos mas estabelece uma oposição absoluta da inclinação dos diferentes objetos naturais de desejo. Mais do que uma mera distinção de desejos particulares, a divisão tripartite busca uma distinção da natureza relativa dos objetos de desejo humano.

Em vista do conflito dos desejos, a teoria tripartite fornece um novo parâmetro para compreender a distinção objetiva do lado 'racional' e do lado ‘irracional' da mente humana. Ao invés da 'irracionalidade' interna da razão 
prática, a psicologia platônica investe em um parâmetro mais 'objetivo' de irracionalidade prática.

A princípio, a divisão clássica do 'elemento racional' (logistikón) e o 'elemento irracional' (alógiston) parece corresponder à distinção absoluta entre o desejo racional pelo bem e os desejos irracionais contrários ao bem (439d). Nesse caso, os desejos irracionais seriam equivalentes a desejos cegos, completamente destituídos de reflexão cognitiva sobre o bem. Como observamos, no entanto, essa objeção hipotética bloqueia justamente essa linha interpretativa moderna, reconhecendo a inclinação natural do 'desejo do que é bom' (438). Na verdade, cada parte da alma concebe seu próprio objeto natural de desejo como um bem. Por isso, não há efetivamente uma distinção absoluta do 'racional' e do 'irracional' mas sim uma distinção relativa ao objetos naturais de desejo de cada parte da alma.

Ao longo da República, o desejo racional se refere à inclinação do bem relativo à toda a alma enquanto os desejos irracionais são classificados em função dos apetites humanos e emoções violentas com concepções cognitivas restritas do bem e contrárias ao bem integral da alma. Além disso, a teoria tripartite da alma não atribui apenas desejos específicos, mas também outros estados psicológicos à cada parte da alma.

Como indicamos anteriormente, Sócrates atribui elementos cognitivomotivacionais à cada uma das partes da alma em Rep. IV:

a alma do que deseja busca (ephíesthai) o objeto dos seus desejos, ou traz para perto de si (proságesthai) o que queria que lhe sucedesse, ou ainda, (...) faz sinal de assentimento (epineúein) a si mesma (...) na sua procura de o obter? (437b-c)

A teoria tripartite platônica fornece a classificação de diversos tipos de elementos cognitivo-motivacionais de cada parte da alma. Como mencionamos anteriormente, a teoria tripartite platônica constitui um modelo interativo e dinâmico dos elementos psicológicos da alma. Dessa forma, são destacados ao menos três estados psicológicos gerais (437b): (1) o sinal de assentimento (tó epineúein) ou dissentimento (tôi ananeúein) diante da disponibilidade do objeto de desejo; (2) o impulso de buscar (tò ephíesthai) ou de evitar (tôi aparneîsthai) o objeto de desejo; (3) a atitude motivacional de trazer para si (tò proságesthai) ou repelir (tôi apotheîsthai) em relação ao objeto de desejo. Sob parâmetros modernos, o primeiro aspecto corresponde ao juízo avaliativo do agente, o segundo aspecto 
corresponde ao impulso do desejo e o terceiro à motivação da ação. Dentro da estrutura tripartite platônica, os elementos cognitivo-motivacionais aparecem intrinsecamente integrados.

A estrutura completa da psicologia tripartite exibe a integração desses elementos cognitivo-motivacionais derivados da psicologia grega antiga. De fato, cada parte da alma possui seus objetos naturais de desejo e, respectivamente, seus diferentes conjuntos de crenças-desejos específicos. A interação dinâmica das três partes da alma permite explicar tanto a harmonia interna quanto o conflito interno psicológico do agente. Em Plato's Utopia Recast, Bobonich já havia ressaltado a coerência da tripartição platônica da alma em vista dos objetos naturais de desejo. Nessa perspectiva, Bobonich (2002, p. 242-247) salienta dois fatores centrais da psicologia tripartite: (1) a persuasão e a interação racional da razão com as partes irracionais da alma; (2) a inclinação de cada parte da alma por seu objeto natural de desejo. De um lado, a 'persuasão' promove a 'comunicação' das partes irracionais com a parte racional em função de uma inclinação comum ao bem. Sob o ponto de vista do bem global da alma, a parte racional pode promover a concepção local do bem relativo a cada uma das partes irracionais da alma. ${ }^{563}$ No entanto, a inclinação de diferentes objetos de desejo reflete a falha da interação racional e o conflito das diferentes partes da alma. Por suas limitações epistêmicas, as partes irracionais inferiores nem sempre são capazes de integrar seus objetivos específicos ao bem global da alma. De fato, essa dimensão interativa da alma é crucial para explicar de forma mais consistente a divisão tripartite da alma.

A interação dinâmica das partes da alma é esclarecida quando observamos o quadro completo da psicologia tripartite platônica. Dessa forma, devemos recapitular as características centrais da parte racional (logistikón), a parte impetuosa (thymoeidés) e a parte apetitiva (epithymetikón). Posteriormente, pretendemos salientar de que forma o modelo tripartite da alma permite esclarecer os princípios básicos do internalismo de Davidson. Na sequência, devemos nos ocupar primeiro da parte racional da alma.

\footnotetext{
${ }^{563}$ No entanto, salientamos que isso não confere à parte apetitiva em si a capacidade de fazer raciocínios instrumentais de meios-fins. Ao contrário, essa habilidade deve ser reservada apenas à parte racional da alma a fim de mantermos a consistência da teoria tripartite da alma. Como já salientamos anteriormente, a própria interação das partes da alma permite explicar o cálculo econômico por dinheiro sem incluirmos um raciocínio de meios-fins à parte apetitiva da alma.
} 
Em primeiro lugar, a parte racional (logistikón) possui prioridade epistêmica sobre as outras partes da alma, mas também expressa seus próprios desejos e a motivação prática racional. Do ponto de vista epistêmico, a parte racional tem uma visão global da alma pois é capaz de 'velar pela alma toda' (441e). No entanto, isso não lhe impede de expressar também seus próprios desejos e motivação da ação, o desejo do "amor de aprender e saber (philomathès kaì philosophos)" (581c) e o comando (árchein) prático da razão sobre os outros elementos da alma. Diante dessa estrutura psicológica, a parte impetuosa é mais próxima da natureza da parte racional do que a parte apetitiva irracional.

Em segundo lugar, a parte impetuosa (thymoeides), notavelmente a sede das emoções, também possuem aspectos cognitivos e desejos característicos. A parte impetuosa responde pela emoção primitiva da raiva e, de forma mais complexa, a reação emocional pelos valores morais do belo-vergonhoso. Em virtude disso, seu desejo caraterístico se manifesta no "amor da vitória e das honrarias (philónikon kaì philótimon)" (581b). A motivação impetuosa da ação se inclina ao auxílio natural da parte racional (440e). Em contraposição à parte impetuosa, a parte apetitiva é a mais afastada da parte racional.

Em terceiro lugar, a parte apetitiva caracterizada primordialmente pelos apetites irracionais brutos, da fome e da sede, ainda possui capacidades cognitivas e motivacionais limitadas. De um lado, o "amor ao dinheiro e ao lucro" (philochrématon kaì philokerdés)" (581a) da parte apetitiva exige uma mínima dimensão cognitiva ligada ao domínio da parte racional (553d). De outro lado, a atitude motivacional é marcada pelo impulso bruto característico da pura satisfação dos apetites imediatos (437e). Sobretudo, a interação dinâmica das diferentes partes da alma é fundamental na atribuição de diferentes elementos cognitivomotivacionais à psicologia tripartite platônica.

A teoria tripartite platônica da alma ressalta um modelo integrado das partes mentais da psicologia humana. Dessa forma, a psicologia tripartite rejeita a compartimentalização da partilha da mente de Davidson em setores mentais destacados. A divisão psicológica da República mantém a integração da razão prática e as motivações irracionais dentro da relação dinâmica das 'partes' da mente.

Na psicologia platônica tripartite, cada 'parte' mental expressa seu próprio juízo avaliativo, desejo e motivação da ação. Sobretudo, a divisão psicológica segue 
o parâmetro 'objetivo' dos objetos naturais de desejo das partes da alma. Por conta dos objetos naturais de desejo, surgem diferentes classes de razões práticas relativas a cada parte da alma. Nesse aspecto, o ponto de vista 'objetivo' da psicologia platônica difere do ponto de vista 'internalista' de Davidson. Como vimos, o 'internalismo’ de Davidson estabelece uma conexão causal necessária entre razões e ações intencionais. Todavia, a distinção platônica objetiva das motivações racionais e irracionais permite uma revisão do 'internalismo' de Davidson.

A divisão platônica fundamental das motivações racionais e motivações irracionais traz nova luz ao internalismo de Davidson. Ao recapitularmos os princípios (P1-P2) do 'internalismo’ de Davidson, podemos manter sua veracidade lhes tornando mais consistentes ao adotarmos uma qualificação da motivação da ação do agente.

Primeiramente, podemos formular P2 de forma a restringi-lo estritamente à motivação racional do agente:

P2. Se um agente julgar que seria melhor fazer $x$ do que fazer $y$, então ele quer fazer (racionalmente) $x$ mais do que ele quer fazer $y$.

A 'avaliação' do melhor juízo fornece apenas a motivação racional do agente. Nesse sentido, o juízo avaliativo racional apenas constitui a motivação racional da ação e nada menciona acerca de suas motivações irracionais ${ }^{564}$. De fato, é possível que as motivações irracionais sejam convergentes ou mesmo divergentes da motivação racional do agente. Da mesma forma, nada se menciona aqui a respeito da relação causal da motivação da ação e a realização da ação. Enfim, a motivação racional de P2 apenas fornece a avaliação das razões fortes de $x$ contra as razões fracas de $y$ segundo um cálculo total das razões práticas. No entanto, para a relação da força motivacional sobre a ação realizada devemos nos voltar a P1.

Em seguida, a formulação de P1 pode se manter intocada desde que relacionada à motivação da ação em geral:

\footnotetext{
564 Sobretudo, não nos comprometemos aqui com a tese da suficiência da razão prática para a realização da ação (cf. CHARLES, 1984, p. 112-114). De acordo com essa tese, o juízo avaliativo racional expresso na conclusão prática é suficiente para a realização da ação. Levando em conta o papel dos desejos irracionais, pretendemos salientar a necessidade primordial da coordenação da razão prática com as motivações irracionais na realização da ação intencional.
} 
P1. Se um agente quer fazer $x$ mais do que ele quer fazer $y$ e ele acredita que está livre para fazer $x$ ou $y$, então ele irá fazer intencionalmente $x$ se ele fazer $x$ ou $y$ intencionalmente.

A 'motivação em geral', nesse caso, em sentido amplo se refere às motivações racionais e as motivações irracionais indistintamente. Nesse aspecto, (P1) coloca em cena a relação da força motivacional e a ação realizada. No entanto, a reformulação de (P1) não menciona nada sobre a predominância das motivações irracionais. Em grande parte, a tradição analítica assume que a força motivacional das motivações irracionais geralmente predomina sobre as motivações racionais na ação intencional. Em particular, isso se deve ao fato de que o juízo avaliativo preferencial não expressa mais uma motivação racional dentro da psicologia moderna. Como observamos, a psicologia tripartite platônica assinala que as motivações racionais e as motivações irracionais possuem a mesma capacidade motivacional na ação. De fato, elas só diferem em sua força motivacional devido à disposição prévia do próprio agente.

Não há incompatibilidade em afirmar que tanto as razões fortes quanto os desejos irracionais fortes são causas da ação intencional. De um lado, as razões fortes prevalecem quando a motivação racional é mais forte do que as motivações irracionais. Da mesma forma, os desejos fortes prevalecem quando a motivação irracional é mais forte do que a motivação racional do agente. Em última instância, o que vai definir a força motivacional é a formação do caráter moral do próprio agente e não a natureza das motivações em si mesmas.

A interação dinâmica entre a razão prática e as motivações irracionais é determinada pelo caráter moral do agente. Em especial, isso se reflete posteriormente na distinção clássica aristotélica do caráter encrático e o caráter acrático. Como vimos, o caráter encrático marca a predominância das razões fortes sobre os desejos irracionais do agente. Por sua vez, o caráter acrático marca a predominância dos desejos irracionais em função de razões fracas sobre as razões fortes do agente. Em ambos os casos, o caráter moral predispõe o agente a seguir o desejo racional em vista das razões fortes ou a atração imediata dos desejos irracionais e suas razões mais fracas. Sobretudo, a formação do caráter moral é indispensável na relação dinâmica das diferentes partes da alma. 
A relação das partes da alma é marcada pela condição do caráter moral do agente. A condição da excelência moral ou do vício moral influencia diretamente no sucesso ou no fracasso da razão prática. De fato, esse fator não só é reconhecido na psicologia tripartite platônica, mas também é reforçado na psicologia moral da Ética de Aristóteles. Como ressaltamos, a divisão fundamental da parte racional e da parte irracional tem raízes no Princípio do Conflito de desejos (PC) platônico.

Em especial, o PC platônico é fundamental para o esclarecimento do conflito interno da akrasia antiga. Na sequência, indicaremos que a falta de reconhecimento do papel distintivo das motivações irracionais na ação traz dificuldades similares à possibilidade da fraqueza de vontade contemporânea. Antes, é preciso retomar os princípios éticos da formação do caráter moral apresentados em Platão e Aristóteles.

A psicologia moral de Platão fornece os princípios éticos básicos do caráter moral na Ética de Aristóteles. Como observamos, há profundas diferenças nas relações das partes da alma justa e da alma injusta, ou melhor, do caráter virtuoso e do caráter vicioso (586e-587a). De um lado, a alma justa expõe uma relação harmônica das partes da alma de acordo com suas respectivas funções naturais e seus objetos naturais de desejo. De outro lado, a alma injusta reflete a relação desarmônica das partes da alma diante de seus objetos naturais de desejo e o desvio da função natural de cada elemento com o domínio desproporcional de uma das partes sobre as outras. Esse exame da condição interna da alma justa e da alma injusta ganha uma nova dimensão na psicologia moral de Aristóteles.

Do mesmo modo, Aristóteles reconhece o papel da formação do caráter moral na psicologia moral da Ética. Na Ética aristotélica, o caráter moral define a relação da razão prática e as motivações irracionais (1102b12-1103a5). A virtude moral expressa a coordenação da razão prática e as motivações irracionais, enquanto o vício moral marca a descoordenação da razão prática e as motivações irracionais. Em ambos os casos, o caráter moral é indispensável para revelar o estado psicológico do agente. Sobretudo, a conflito interno da akrasia é especialmente marcado pelo raciocínio prático correto e as motivações irracionais contrárias.

O conflito interno da akrasia é marcado pelo desalinhamento da razão prática e das motivações irracionais. Em linhas gerais, a akrasia decorre do fracasso da razão prática na ação pelos prazeres corporais excessivos. De fato, há um 
raciocínio prático correto, mas as paixões más lhe impedem de executá-lo na ação moral. Para mostrar isso, Aristóteles alia a doutrina peculiar do silogismo prático ao conflito interno do caráter acrático.

O desalinhamento das motivações irracionais no silogismo prático é crucial para esclarecer a distinção específica da akrasia impulsiva e a akrasia fraca de ENVII.3. Primeiramente, a akrasia impulsiva mostra que as paixões irracionais violentas impedem o agente de chegar à conclusão do silogismo prático. Em segundo lugar, a akrasia fraca revela que a derivação da conclusão prática não garante o exercício da conclusão prática na ação mesmo diante de paixões fracas. Em ambos os casos, o processo do silogismo prático em si mesmo é insuficiente para explicar a irracionalidade do fenômeno. Como indicamos, o raciocínio prático simples das paixões irracionais explica o desvio do bom silogismo ao silogismo de prazer (1147a30-b25). De forma substancial, isso impede de reconhecer qualquer falha no raciocínio prático do acrático. A formação do caráter moral é mais fundamental que o ensino racional propriamente dito na coordenação da razão prática com as paixões irracionais.

O conflito interno do acrático reflete uma deficiência marcada no caráter moral e não no raciocínio prático. Em EN X.9, Aristóteles deixa claro que a educação ética de nada serve sem o auxílio prévio do desenvolvimento do caráter moral:

Em geral, a paixão (tò páthos) não parece ceder ao discurso (lógoi), mas à força (allà bíai). É preciso, portanto, que o caráter (tò êthos) tenha previamente certa afinidade com a virtude (pos oikeîon tês aretês), amando o que é nobre (tò kalòn) e detestando o que é vergonhoso (tò aischrón). (1179b25-30)

O desvio das motivações irracionais da razão prática é central para compreender o conflito interno da akrasia. De certa forma, a conclusão prática do bom silogismo prático ou o 'melhor juízo' não terá nenhuma eficácia na ação sem já possuirmos previamente 'certa afinidade com a virtude'.

Em função do caráter moral, as paixões irracionais podem ser orientadas pelo 'discurso' (lógos) ou a 'força' (bía). Diante da ausência da virtude moral, a 'força' das motivações prevalece sobre o 'discurso' devido às más paixões irracionais do agente. Como vimos anteriormente, a psicologia tripartite platônica já estabelece uma dicotomia semelhante das forças motivacionais pela 'persuasão' 
(peítho) e a 'força' (bía) ${ }^{565}$ (411d-e; 548b-c). Do mesmo modo, a falta da educação moral promove as relações de 'força' ou 'violência' da parte irracional da alma sobre a parte racional. De fato, o domínio da 'força' da parte apetitiva sobre a parte racional expressa o conflito interno da alma. Por isso, a ineficácia da 'razão' prática e a ausência da virtude moral são imprescindíveis na falha de caráter característica da akrasia.

A falha de caráter da akrasia tem origem no conflito interno da razão prática correta e os apetites excessivos do agente. As partes da alma do acrático já estão mais predispostas à orientação da 'força' das paixões irracionais do que ao ‘discurso' da razão prática. Por isso, a akrasia na Ética jamais é abordada como um fenômeno relacionado exclusivamente à natureza da razão prática. Em ambos os casos, seja na akrasia impulsiva ou na akrasia fraca, as paixões irracionais cumprem um papel decisivo na realização da ação contrária ao bom silogismo do agente.

Na Ética, a akrasia reflete a incompatibilidade do silogismo prático correto na razão prática e as paixões irracionais contrárias. Entretanto, as paixões irracionais aqui não se equiparam aos desejos cegos completamente irracionais. Nesse caso, teríamos um caso de compulsão psicológica e não mais de akrasia $^{566}$. A Ética mostra que o conflito prático fundamental da descoordenação da razão prática correta e as paixões irracionais. Com base nesse tipo de conflito prático, podemos compreender melhor a fraqueza de vontade dispensando a presença de uma causa cega completamente irracional.

Dentro dos parâmetros da psicologia antiga, Aristóteles não deixa de atribuir às paixões irracionais seu juízo avaliativo e seu papel motivacional específicos em função dos objetos imediatos da percepção sensorial (aísthesis) (1147b15-18). Da mesma maneira, a razão prática expressa um desejo racional e um papel

\footnotetext{
${ }^{565}$ Em especial, a 'persuasão' e a 'foça' são dois elementos fundamentais para esclarecer, respectivamente, a condição interna da alma justa e da alma injusta na República (443d-444e). De um lado, a 'persuasão' marca a relação harmônica das partes da alma justa justamente pela conformidade das partes irracionais ao domínio da parte racional. De outro lado, a 'força' marca a relação desarmônica das partes da alma por causa do domínio ilegítimo das partes irracionais sobre a parte racional da alma. Sobre a condição interna das partes da alma, cf. 411e; 548b-c.

${ }^{566}$ Com efeito, os casos mais próximos da compulsão psicológica na Ética são relacionados aos homens brutos (1148b30-1149b20). Sobretudo, os homens brutos nem mesmo desenvolveram a razão prática ao nível dos homens comuns (1156a1-8). Ao contrário dos acráticos, os homens brutos agem de forma instintiva pois possuem desejos irracionais incontroláveis para a maioria dos homens. Enquanto isso, os acráticos tem paixões irracionais dos quais a maioria dos homens é capaz de resistir (1151a25-26).
} 
motivacional vinculado ao juízo avaliativo racional. Dentro da psicologia antiga cognitivo-motivacional, tem origem o conflito fundamental da razão prática e das paixões irracionais da akrasia. Por isso, Aristóteles insiste tanto na analogia do jovem estudante que não consegue colocar em prática seu 'conhecimento' teórico. Fundamentalmente, o conflito da akrasia decorre da falta de caráter moral e da educação moral dos apetites irracionais necessários para colocar em prática o 'conhecimento' particular no momento decisivo da ação moral.

O conflito prático da razão prática e das paixões irracionais da akrasia pode ser expresso da seguinte maneira: a razão prática acompanha o bom silogismo em vista do melhor juízo de que $x$ é melhor do que $y$, enquanto as paixões irracionais se apropriam de parte do silogismo de prazer pelo prazer imediato de $y$. Durante a akrasia, a 'força' das paixões irracionais em vista do prazer de $y$ predomina sobre a 'razão' correta do bom silogismo de $x$. De qualquer maneira, a ação irracional emerge propriamente da influência decisiva das paixões irracionais contra a razão pratica correta na ação. Todavia, é necessário destacar o que significa a 'influência' das paixões irracionais contra a razão prática na akrasia.

A akrasia antiga não se reflete claramente em nenhum dos fenômenos irracionais modernos. Não há um problema exclusivo da 'razão' ou do raciocínio prático avaliativo ou uma falha no silogismo prático em si mesmo. Nem mesmo há um problema intrínseco à 'força' das motivações irracionais. Como vimos, a incompatibilidade inerente entre o princípio ‘avaliativo' racional e o princípio da 'força' relativa das motivações reconhecida atualmente é externa aos parâmetros da psicologia antiga. Como a razão não deixa de constituir uma 'força' motivacional racional e nem as paixões irracionais deixam de constituir um 'juízo avaliativo' irracional, ambos os princípios são equivalentes na psicologia antiga ${ }^{567}$. Nessa perspectiva, a interação cognitivo-motivacional da razão prática e das paixões irracionais contrárias constitui o conflito prático fundamental da akrasia.

\footnotetext{
${ }^{567}$ Sobre essa controvérsia contemporânea do princípio do juízo avaliativo racional e o princípio relativo das forças motivacionais, ver SANTAS, 1979, p. 211-219. Invariavelmente, Santas recorre à incompatibilidade dos dois princípios para atribuir uma incoerência a negação socrática da akrasia no Protágoras de Platão. Como vimos anteriormente, no entanto, o argumento hedonista fundamental contra a akrasia tradicional trata ambos os princípios de forma indistinta e, mesmo assim, mantém sua consistência interna. Com efeito, a indistinção entre os princípios é plenamente compreensível dentro dos parâmetros da psicologia antiga mesmo que isso não seja especialmente claro dentro da separação moderna mais estrita da razão e das paixões irracionais na psicologia moderna.
} 
Sem a interação fundamental da razão prática e as motivações irracionais, não podemos compreender realmente o conflito interno da akrasia na Ética. A descoordenação fundamental da razão prática e das paixões irracionais cumpre um papel fundamental na irracionalidade do fenômeno antigo. De alguma forma, esse conflito prático fundamental pode nos esclarecer também sobre o que constitui a experiência da fraqueza de vontade contemporânea.

Como vimos, a segunda descrição da fraqueza de Davidson recorre a existência de uma causa não racional na mente humana. Para Davidson, a violação do princípio da continência pelo 'melhor juízo' decorre da interferência direta de um desejo cego na ação irracional. No entanto, observamos que essa segunda descrição da fraqueza relaciona o fenômeno à um tipo de compulsão psicológica. Para evitarmos essa conclusão desfavorável, pretendemos analisar o papel das motivações irracionais na razão prática. De certo modo, Alfred Mele propõe retomar o sentido original da akrasia aristotélica a fim de investigar o papel das motivações e do caráter moral em sua teoria causal da ação.

Em seu artigo anterior de 1983, Mele propõe uma reformulação da teoria causal da ação de Davidson retomando o sentido original da akrasia. Para Mele (Ibid., p. 360), a existência da fraqueza da vontade exige a postulação de uma nova teoria causal da ação ('CTA'):

\begin{abstract}
The key here to what I am most motivated to do, and hence to what I $d o$, lies in my character, or more specifically, in my selfcontrol or deficiency therein; and a CTA which ignores the causal significance of this trait of character lacks the necessary equipment to account for akratic action against a here-and-now intention. (itálicos do autor)
\end{abstract}

Dessa maneira, Mele recupera o sentido original da akrasia para trazer a tona novamente a força motivacional para a teoria causal da ação de Davidson. De fato, o sentido grego original da akrasia, assim como seu oposto enkrateia, expressam originalmente a 'falta de controle' e o 'autocontrole'. Nesse aspecto, essas expressões modernas retomam, de certo modo, o sentido original da akrasia que constitui o desvio da condição ideal do agente pautada na conformidade do juízo prático absoluto e a força motivacional. Diante disso, Mele (Ibid., p. 360-361) sustenta que a fraqueza de vontade só será plenamente compreendida quando 
reconhecermos o papel da força motivacional dentro da teoria causal da ação de Davidson.

O papel das motivações irracionais é central na explicação da ação irracional da fraqueza de vontade. Como vimos, Mele salienta principalmente o papel da atenção proximal, das emoções irracionais do medo e da ansiedade para mostrar o papel das motivações irracionais. Em Irrationality, Mele (1987, p. 84-9) ressalta principalmente a influência dessas forças motivacionais irracionais na ação irracional independente do juízo prático racional do agente. Como vimos anteriormente, o princípio da força motivacional das motivações irracionais exclusivamente é insuficiente para explicar a ação irracional da fraqueza de vontade. De forma isolada, as motivações irracionais representam apenas causas cegas na ação irracional, trazendo novamente o risco da compulsão psicológica. Ao contrário, a fraqueza de vontade depende do conflito prático fundamental entre a razão prática e as motivações irracionais do agente. Nessa medida, devemos eliminar definitivamente as causas cegas, ou seja, os impulsos completamente irracionais, da descrição original da fraqueza de vontade.

A psicologia antiga revela que há uma dimensão dinâmica entre o lado racional e o lado irracional na mente do agente inerente à eficácia da razão prática na ação humana. As motivações irracionais não são independentes do juízo prático racional na ação irracional da fraqueza. Em alguma medida, a 'força' das motivações irracionais depende consequentemente da 'fraqueza' do desejo racional do agente. Da mesma forma, isso se reflete na incompatibilidade fundamental da avaliação racional e da avaliação irracional da ação irracional da fraqueza. Nesses termos, o conflito prático da razão prática e os desejos irracionais dão a oportunidade de explicar a ação irracional da fraqueza de vontade.

A fraqueza de vontade no conflito prático fundamental entre a razão prática e as motivações irracionais. De fato, as motivações irracionais expressam um conjunto de crenças-desejos irracionais incompatível com o conjunto de crençasdesejos racionais da razão prática do agente. Nos termos da Ética, o conflito prático do agente se dá por causa da disposição habitual (êthos) prévia do agente dirigida às motivações irracionais imediatos contrárias às crenças e motivações racionais do juízo racional TFC. Sem nos restringirmos ao campo moral estrito, devemos considerar a disposição habitual de forma neutra e ampla sem atribuir princípios morais absolutos ao ‘melhor juízo’ prático do agente. De qualquer forma, o conflito 
prático fundamental da razão prática e os impulsos irracionais se mantém em qualquer descrição da irracionalidade da fraqueza de vontade.

O valor preferencial do juízo avaliativo e as forças motivacionais são dois fatores complementares na explicação da ação irracional da fraqueza. Dentro dessa perspectiva, o conflito prático da fraqueza se constitui de dois gêneros de conflito: (1) o conflito dos juízos avaliativos do agente; (2) o conflito dos diferentes fatores motivacionais da ação. Na sequência, mostraremos que ambos os aspectos integrados esclarecem a natureza do conflito prático e da ação irracional da fraqueza de vontade. Para ilustrarmos isso, devemos considerar a seguir o caso de um exfumante que está resoluto em parar de fumar e, subitamente, cede ao impulso imediato de um cigarro ${ }^{568}$.

Durante uma festa casual, um ex-fumante recebe a oferta de um cigarro de um colega de trabalho. De início, o ex-fumante chega a considerar que dar uma tragada lhe traria prazer. De outro lado, ele também traça outras considerações a longo prazo: há grandes chances de comprometer sua saúde futuramente e, inclusive, há a possibilidade de retornar aos velhos hábitos de fumante. Em termos comparativos, recusar a oferta do cigarro e se manter saudável é consideravelmente melhor do que aproveitar o intenso e curto prazer ao dar uma tragada no cigarro. Levando em conta 'todos os fatores considerados', o homem chega à uma conclusão prática: "Eu devo recusar este cigarro". No momento da ação, o ex-fumante aceita o cigarro e exclama de forma inusitada: "Vou fumar esse último cigarro, só dessa vez".

Aparentemente, estamos diante de um caso de fraqueza de vontade. Ao aceitar o cigarro, a ação irracional do agente é explicitamente contrária ao 'melhor juízo' da conclusão pratica. Dessa forma, o juízo prima facie TFC do agente 'em vista de TFC, é melhor recusar o cigarro do que aceitá-lo' passa efetivamente a um juízo absoluto da ação intencional: "Eu devo recusar esse cigarro". A ação irracional da fraqueza entra em conflito com as próprias razões práticas internas do agente. Nessa medida, o agente está plenamente consciente do conflito prático da razão prática e suas motivações irracionais na ação irracional. O conflito prático do

\footnotetext{
568 O exemplo integral do fumante foi adaptado de LAZAR, 1999, p. 381. De qualquer forma, é importante ressaltar que o 'ex-fumante não pode ser um adicto ou viciado como um fumante comum. Se fosse esse o caso, estaríamos nos referindo a um caso de compulsão psicológica. Na verdade, insistimos que o ex-fumante tem condições de resistir ao seu impulso imediato pelo cigarro.
} 
agente não está ligado estritamente à coerência interna das razões do agente, mas sim à incompatibilidade de suas razões internas e suas motivações irracionais contrárias.

Nessa perspectiva, há duas descrições possíveis do conflito prático do agente, o conflito de suas razões internas e o conflito de suas motivações. Dessa forma, vamos mostrar que ambas as descrições integradas auxiliam a explicar a irracionalidade característica da fraqueza de vontade.

Em primeiro lugar, podemos expressar o conflito interno de duas razões diferentes na mente do ex-fumante, a razão mais forte do 'melhor juízo’ para recusar o cigarro e a razão mais 'fraca' para aceitar o cigarro pelo prazer imediato. Nesse nível, o simples conflito de razões parece realmente insuficiente para dar conta da ação irracional do agente. Ora, por qual razão o agente agiria conforme sua razão mais fraca desconsiderando sua razão mais forte para a ação?

A princípio, poderíamos explicar tal fenômeno com base na incomensurabilidade das razões, isto é, a ideia de que as razões não são comparadas dentro de uma mesma escala comum de avaliação ${ }^{569}$. Supostamente, o agente prudente age conforme o 'melhor juízo' respeitando uma escala racional comum 'objetiva' de suas alternativas de ação. Como esse não é o caso da fraqueza, a razão mais fraca da ação irracional supostamente corresponde a uma escala qualitativamente distinta das alternativas de ação. No entanto, o agente fraco tem plena consciência de que a ação irracional é contrária ao seu 'melhor juízo' absoluto em função da melhor ação.

A fraqueza não parece coincidir com a incomensurabilidade das razões internas nem com a inconsistência interna dos valores da ação no juízo avaliativo. De fato, o 'melhor juízo' é compatível com a existência de uma escala comum de valores racionais 'objetivos'. Todavia, a razão mais fraca por si mesma é insuficiente para dar conta da ação irracional da fraqueza. Desse modo, precisamos prosseguir ao conflito de motivações da fraqueza.

De forma semelhante, podemos expressar o conflito de duas motivações diferentes do ex-fumante: a motivação racional da recusa do cigarro conforme o 'melhor juízo' e a motivação irracional para aceitar o cigarro pelo prazer imediato. Diante disso, recorremos apenas ao conflito das forças motivacionais para explicar

${ }^{569}$ Sobre a relação do valor da incomensurabilidade das razões e a possibilidade da akrasia, ver NUSSBAUM, 2009, p. 100-102. 
a ação irracional do agente. A ação irracional revela que a motivação irracional pelo cigarro é mais forte que a motivação racional pela rejeição do cigarro. No entanto, o simples conflito de forças motivacionais por si só é pouco explicativo para dar conta da fraqueza de vontade. Sobretudo, o risco de caracterizar simplesmente a predominância das motivações irracionais nos faz recair novamente na compulsão psicológica. Nessa medida, seria necessário compreender o papel das razões internas na explicação do conflito interno da fraqueza de vontade.

Para termos maior clareza, devemos necessariamente ter atenção à disposição habitual dos desejos irracionais em contraposição ao desejo racional do agente. Com isso, podemos estabelecer a presença de uma disposição irracional contrária ao desejo racional do 'melhor juízo' do agente durante a ação irracional. Assim, o conflito de motivações permite explicar mais claramente o conflito dos juízos avaliativos na razão prática. Em verdade, a incompatibilidade do 'melhor juízo' e o juízo do prazer imediato está ligado ao conflito fundamental da motivação racional e a motivação irracional. Com efeito, a disposição irracional auxilia a compreender a origem da incomensurabilidade na razão prática. Nessa esfera, podemos compreender a natureza da descoordenação da razão prática e dos desejos irracionais na fraqueza de vontade.

O conflito prático da fraqueza de vontade não se restringe exclusivamente ao conflito interno das razões do agente e nem mesmo ao conflito da força motivacional. Durante a fraqueza, o agente preserva simultaneamente o 'melhor juízo' intencional e a disposição das motivações irracionais. De um lado, o 'melhor juízo’ intencional do agente se mantém logicamente consistente em sua razão prática. De outro lado, a disposição irracional promove motivação irracional contra a motivação racional. O conflito prático da fraqueza de vontade expressa, então, a descoordenação fundamental entre a razão prática e as motivações irracionais. Em especial, há uma incompatibilidade fundamental das crenças e dos desejos do lado racional e do lado irracional da mente humana. Por isso, a fraqueza não pode consistir em uma incoerência lógica interna da racionalidade do agente e nem em um fenômeno exclusivamente irracional. Nesses termos, a segunda descrição da fraqueza de vontade de Davidson não é suficiente para explicar a ação irracional da fraqueza.

O princípio lógico da continência de Davidson não explica apropriadamente a ação irracional da fraqueza. De acordo com Davidson, a fraqueza de vontade 
constitui a violação do princípio lógico racional da continência. Certamente, Davidson tem razão ao reconhecer mais explicitamente o 'melhor juízo' incondicional na segunda descrição do agente. No entanto, a violação do princípio da continência compromete a racionalidade constitutiva do agente e recorre a existência de uma causa cega não racional. Ao contrário de Davidson, acreditamos que o princípio da continência não é um princípio lógico essencial, mas um princípio prático normativo cuja função é orientar as ações humanas.

Como vimos, o princípio prático mantém a racionalidade do agente humano intacta. Assim como alertam Platão e Aristóteles, é preciso ter uma ideia clara da eficácia distinta do conhecimento prático. Invariavelmente, ambos os filósofos têm plena consciência da necessidade da disposição moral dos apetites irracionais para a eficácia do conhecimento moral no campo da ação. Certamente, a concepção antiga do conhecimento moral reflete o desenvolvimento da disposição irracional apropriada dos desejos irracionais em vista da razão prática correta. Sem dúvida, a eficácia do conhecimento moral antigo pode esclarecer o efeito da ausência da disposição apropriada dos desejos irracionais no domínio da ação prática.

Sobre o domínio prático do conhecimento moral, Aristóteles já ressaltava suas características específicas em Ética X.9:

onde há coisas a serem feitas o fim (télos) não é examinar e reconhecer (tò theorêsai kaì gnômai) cada uma delas, mas é preciso fazê-las (tò práttein). No tocante à virtude (perì aretês), pois, não basta saber (eidénai), devemos tentar possuí-la e usá-la (échein kaì chrêstai) ou tentar por qualquer outro meio nos tornarmos bons. (1179a35-b5)

O conhecimento moral de Aristóteles não implica simplesmente o 'saber' teórico, mas o 'fazer prático’ da ação. Como vimos anteriormente, Aristóteles se referia constantemente ao acrático como aquele que 'possui' (échein) o conhecimento, mas não consegue 'exercê-lo' (energê̂) na prática na descrição da akrasia em ENVII.3. Sobretudo, salientamos também que sua incapacidade de exercício do conhecimento está inevitavelmente ligada à sua disposição moral (êthos), especialmente relativa aos seus maus apetites irracionais contrários à razão correta. Dessa forma, ressaltamos que o conflito prático do acrático é caracterizada pela descoordenação da razão prática e os desejos irracionais do agente. 
Em EN.X.9, Aristóteles novamente ressalta que a ausência do exercício da virtude moral compromete também o exercício do próprio conhecimento moral na ação. Como vimos, a ausência da disposição moral apropriada acaba comprometendo a própria assimilação do conhecimento teórico e do ensino moral. A disposição apropriada é mais primordial ao exercício do conhecimento prático do que qualquer princípio lógico da continência. Dessa forma, acreditamos que conclusões similares sobre a disposição irracional do agente podem ser tiradas no caso da fraqueza de vontade.

A descoordenação da razão prática e os desejos irracionais pode explicar o conflito prático fundamental da fraqueza de vontade. De fato, a consistência lógica do 'melhor juízo' do agente é preservada e não há uma incoerência fundamental entre as razões internas do agente. Dessa maneira, o princípio prático da continência está em plena atividade exortando à realização da melhor ação. No entanto, a disposição irracional dos desejos irracionais promove crenças e desejos irracionais. Por isso, a presença dos desejos irracionais fornece motivações irracionais e reforça as razões fracas do agente contra as motivações e razões fortes da razão prática. Invariavelmente, o conflito motivacional da razão prática e dos desejos irracionais se transfere ao conflito avaliativo das razões internas do agente. Nessa medida, o conflito prático fundamental se instala na fraqueza de vontade sem comprometer a racionalidade do agente ou a irracionalidade prática da ação.

Ao longo dessa última seção, buscamos aproximar a akrasia antiga da fraqueza de vontade contemporânea. De certa forma, a descrição final da fraqueza de vontade de Davidson permite uma comparação mais próxima com a akrasia antiga. Sobretudo, pretendemos mostrar que a recepção analítica da akrasia antiga ainda é fundamental para esclarecer a fraqueza de vontade contemporânea.

Em linhas gerais, o objetivo fundamental é salientar principalmente as diferenças centrais da irracionalidade prática de Davidson e a irracionalidade antiga da akrasia antiga. No entanto, nosso objetivo jamais foi simplesmente propor uma resolução final ao problema da fraqueza de vontade iniciado a partir das obras fundamentais de Hare e Davidson. De certa forma, pretendemos apenas mostrar que a relação da akrasia antiga e a fraqueza de vontade contemporânea esclarece a especificidade desses problemas filosóficos e também suscita novas formas de compreender a natureza da razão prática. 


\section{8. \\ Conclusão}

O fio condutor da minha investigação foi destacar dois problemas filosóficos distintos, a akrasia antiga e a fraqueza de vontade contemporânea. A formulação original do problema da fraqueza de vontade contemporânea em Richard Hare e Donald Davidson está atrelada à recepção analítica da akrasia antiga de Platão e Aristóteles. Com base nessa hipótese, examinei os elementos de descontinuidade da akrasia antiga e da fraqueza de vontade contemporânea.

A akrasia antiga e a fraqueza de vontade contemporânea não tratam do mesmo tema filosófico. De forma geral, a história tradicional da filosofia parte do princípio de que há um mesmo problema filosófico essencial da fraqueza de vontade na filosofia antiga e na filosofia contemporânea. Apesar das semelhanças, há notáveis diferenças entre a akrasia antiga e a fraqueza de vontade contemporânea. Durante nossa investigação, ressaltamos essas diferenças em ao menos dois níveis: (i) a akrasia e a fraqueza de vontade se referem a fenômenos distintos relacionados a diferentes categorias psicológicas; (ii) as formulações do problema antigo e o problema contemporâneo são essencialmente diferentes. A partir disso, apresentamos primeiro as categorias psicológicas inerentes a ambos os fenômenos.

A natureza dos fenômenos da akrasia e da fraqueza de vontade refletem descrições fenomenológicas diferentes. Em seu sentido original, a akrasia se refere estritamente à 'falta de poder ou controle' diante dos impulsos irracionais. Nesse sentido clássico, a akrasia é o oposto da enkrateia, isto é, o 'poder ou o controle' dos impulsos irracionais. Ambos os fenômenos resultam de um conflito interno psicológico entre a razão prática e as paixões irracionais. De outro lado, a 'fraqueza de vontade' constitui o fracasso da razão prática na ação irracional devido à incapacidade da vontade de colocar em prática o princípio racional do 'melhor juízo' do agente. Em oposição, a 'força de vontade' é a condição do sucesso da razão prática ou reflexo da capacidade efetiva da vontade de colocar o princípio racional do 'melhor juízo' do agente na ação. Dentro desses parâmetros gerais, é possível compreender a gênese original do problema da akrasia antiga e da fraqueza de vontade contemporânea. 
Diante de diferentes fenômenos, se apresentam, respectivamente, problemas filosóficos de natureza distinta. Na filosofia antiga, o problema da akrasia antiga formulado nos textos de Platão e Aristóteles diz respeito à natureza do conhecimento moral do homem acrático. Dentro da filosofia analítica, a formulação original do problema da fraqueza de vontade contemporânea concerne exclusivamente à natureza da razão prática do agente durante o ato de fraqueza. Diante disso, examinamos o conjunto de questões filosóficas relacionados a ambos os problemas filosóficos tradicionais.

A submissão da razão diante dos impulsos irracionais na akrasia antiga gera o problema clássico acerca da natureza do conhecimento moral. Em defesa do conhecimento moral, Platão e Aristóteles confrontam a descrição tradicional da akrasia e a impotência da razão prática. De forma geral, o problema da akrasia antiga gira em torno das seguintes questões: será que é possível agir contra o conhecimento moral do bem pelos impulsos irracionais? Será que o agente acrático possui ou não possui conhecimento moral? Se possui o conhecimento, qual a natureza prática do conhecimento moral na ação? Se não a possui, estaria o acrático agindo por um tipo de ignorância? Em linhas gerais, Platão e Aristóteles defendem, de forma diferente, a tese de que o acrático não detém o conhecimento moral mas age de forma acrática por um tipo de ignorância do bem. No Protágoras de Platão, a defesa do conhecimento moral leva o personagem Sócrates a sustentar a negação absoluta da akrasia e a classificação do fenômeno como um tipo de ignorância. De certa forma, o debate antigo subsequente assume a mesma posição fundamental evitando a negação absoluta da akrasia. Na República, o personagem Sócrates apresenta a teoria tripartite da alma reconhecendo as características fundamentais do conflito interno da alma relacionado ao caráter moral acrático. Diante dessa tradição dos textos platônicos, Aristóteles assume uma posição intermediária na Ética: reconhece a possibilidade do conflito interno da akrasia mantendo, ao mesmo tempo, a condição de ignorância voluntária do homem acrático. A ampla controvérsia de Platão e Aristóteles acerca do conhecimento moral diante da akrasia antiga marca a preservação lógica do 'melhor juízo' do agente em face da fraqueza de vontade contemporânea.

Diante da fraqueza de vontade contemporânea, já não há mais um problema do conhecimento moral mas um problema sobre a natureza da razão prática do agente. No contexto contemporâneo, a formulação original do problema da 
fraqueza de vontade nas obras de Hare e Davidson concerne a possibilidade geral da ação irracional contrária ao 'melhor juízo' (better judgement). Para a tradição analítica, é necessário esclarecer a constituição lógica do 'melhor juízo' do agente e a natureza da ação irracional da fraqueza. Em geral, o problema da fraqueza contemporânea gira em torno das seguintes questões: será que é possível agir contra o melhor juízo no momento da ação? Teria o agente consciência de que está agindo realmente contra seu 'melhor juízo'? Qual a natureza lógica do 'melhor juízo' do agente durante a ação irracional da fraqueza de vontade? Será que o agente não está sob efeito de outros fenômenos irracionais correlatos, como o autoengano ou a compulsão psicológica? Por razões diferentes, Hare e Davidson defendem a preservação da consistência lógica do 'melhor juízo’ do agente na razão prática diante da ação irracional do agente. Assim como na filosofia antiga, Hare e Davidson acabam defendendo posições divergentes sobre a descrição tradicional do fenômeno. De um lado, a preservação do prescritivismo moral dos juízos morais leva Hare a sustentar a negação absoluta da fraqueza de vontade, reduzindo o fenômeno a um conflito de princípios morais. De outro lado, Davidson defende a possibilidade da fraqueza de vontade destacando logicamente o 'melhor juízo' do agente do juízo avaliativo da ação intencional. Em certo sentido, a formulação original do problema contemporâneo reflete efetivamente o problema antigo da akrasia. De forma intrigante, ambos os filósofos alegam estar dando prosseguimento ao debate original da akrasia antiga de Platão e Aristóteles.

As similaridades entre o problema antigo e o problema contemporâneo tem suas raízes na recepção analítica da akrasia antiga. A formulação original do problema da fraqueza de vontade contemporânea em Hare e Davidson está relacionada à renovação dos estudos analíticos do problema da akrasia nos textos clássicos de Platão e Aristóteles. Invariavelmente, a assimilação moderna tardia da akrasia antiga à fraqueza de vontade contribui para diversos equívocos interpretativos modernos sobre a natureza original do fenômeno antigo. Em última instância, a fraqueza de vontade e a akrasia antiga refletem categorias psicológicas totalmente diferentes. Ao longo dessa investigação, buscamos salientar algumas diferenças fundamentais da psicologia grega antiga e da psicologia da vontade moderna.

As categorias psicológicas da psicologia grega antiga e da psicologia moderna da vontade reforçam a distinção primordial da akrasia antiga e da fraqueza 
de vontade contemporânea. Dentro do cenário antigo, a psicologia grega antiga apresenta um modelo cognitivo-motivacional dos impulsos humanos. Nesse modelo psicológico, os impulsos humanos constituem um conjunto de crenças, desejos e motivações interrelacionadas. A rigor, não há uma distinção rigorosa dos elementos psicológicos demarcados em funções psicológicas destacadas.

$\mathrm{Na}$ psicologia antiga, os impulsos humanos se caracterizam pelo internalismo objetivo, isto é, pelas crenças, motivações e desejos relativos aos respectivos objetos naturais de desejo. Por exemplo, o impulso do thymós, estreitamente ligado às emoções humanas, também está associado a crenças e desejos relativos à preservação da honra ou reputação social. Mesmos os apetites irracionais, como a fome, a sede ou o desejo sexual, não são apenas impulsos cegos mas representam também crenças e motivações características na ação. Da mesma forma, a razão, definida atualmente apenas por sua função cognitiva, não deixa de expressar uma motivação racional e um desejo racional pelo bem. Por isso, o conflito interno entre a razão e as paixões irracionais constitui um genuíno conflito cognitivo-motivacional dos impulsos humanos. Diante do conflito interno da alma, a akrasia representa a submissão do desejo racional pelos impulsos irracionais enquanto a enkrateia constitui o domínio da razão sobre as paixões irracionais. Dentro dos parâmetros da psicologia antiga, não há uma divisão estrita entre a razão e as paixões irracionais.

Ao contrário da psicologia antiga, a psicologia moderna da vontade não apresenta as mesmas categorias psicológicas. Dentro da psicologia da vontade, as categorias mentais são adequadamente isoladas e refletem funções determinadas. Particularmente, a 'vontade' cumpre um papel intermediário fundamental entre a razão prática e os outros impulsos irracionais. A 'vontade' representa assim uma faculdade moral que possui, essencialmente, a função executiva da ação em conformidade ao juízo avaliativo da razão prática. Entretanto, a razão prática apenas expressa o juízo avaliativo da ação na psicologia da vontade e perde sua eficácia prática na motivação da ação ou no desejo humano. Por sua vez, os impulsos irracionais (as emoções ou apetites) são reconhecidos exclusivamente por sua força motivacional e sua motivação prática na ação sem ter mais a dimensão cognitiva anterior inerente à psicologia antiga. Por conta disso, a fraqueza de vontade reflete a submissão absoluta da razão aos impulsos irracionais enquanto a 'força' de vontade constitui a obediência racional da vontade à razão prática. 
Consequentemente, a psicologia moderna da vontade instaura uma separação absoluta entre a razão prática e os impulsos irracionais. Com efeito, essas diferenças cruciais das categorias psicológicas da psicologia antiga e a psicologia moderna se refletem na recepção analítica da akrasia antiga de Platão e Aristóteles.

A recepção analítica da akrasia antiga tem repercussão marcante na formação do problema da fraqueza de vontade contemporânea. Como vimos, a formulação original do problema da fraqueza de vontade contemporânea reflete a recepção analítica da akrasia antiga.

De forma retrospectiva, mostramos que o debate pioneiro da fraqueza de vontade contemporânea de Hare e Davidson reverbera na tradição analítica interpretativa da akrasia antiga em Platão e Aristóteles. Dessa forma, destacamos os seguintes aspectos marcantes da leitura analítica tradicional da akrasia antiga: (i) o internalismo objetivo da psicologia antiga e o internalismo contemporâneo das razões internas; (ii) a diferença fundamental entre a negação absoluta da fraqueza moral de Hare pelo prescritivismo moral e a negação socrática da akrasia em defesa do conhecimento moral no Protágoras de Platão; (iii) a divisão estrita da razão e os impulsos cegos irracionais da psicologia moderna da vontade e a distinção relativa dos desejos racionais e irracionais da psicologia tripartite platônica da República; (iv) a apropriação analítica do silogismo prático forte e a tese da possibilidade da akrasia na Ética de Aristóteles. Dentro desses quatro eixos investigativos, buscamos ressaltar que a fraqueza de vontade contemporânea obscurece a natureza real do fenômeno da akrasia e do problema original antigo do conhecimento moral nos textos de Platão e Aristóteles. Dessa forma, foi preciso destacar claramente as categorias psicológicas modernas da fraqueza de vontade do fenômeno original da akrasia antiga. Para restaurar a compreensão original da akrasia antiga, empreendemos uma investigação aos antecedentes gregos populares do conflito interno da alma característico do fenômeno.

Antes de constituir um problema filosófico, o fenômeno da akrasia já era reconhecido em uma descrição popular tradicional. Em sua etimologia, a akrasia envolve originalmente um conflito interno da alma extremamente comum na psicologia grega antiga. A presença de uma descrição tradicional da akrasia remonta, ao menos, aos textos clássicos de Platão e Aristóteles. Desde o Protágoras, o personagem Sócrates atribui explicitamente a descrição tradicional do fenômeno, isto é, a submissão da razão por diversos impulsos irracionais, à voz 
da opinião dominante grega (352b-e). Do mesmo modo, Aristóteles assinala a mesma concepção da akrasia tradicional na Ética a respeito dos phainómena, isto é, os 'fatos aparentes' da opinião geral comum (1145b20-32).

Dentro da tradição literária grega, os antecedentes gregos do conflito interno da alma revelam suas raízes na akrasia tradicional antiga. Todavia, há uma corrente helenista tradicional influente que ainda busca a origem de um conflito absoluto entre a razão e as paixões irracionais derivado das categorias da psicologia moderna. Desde Homero aos tragediógrafos, o que encontramos é, na realidade, o registro do mesmo tipo de conflito interno entre diversos impulsos, cada um refletindo um conjunto característico de crenças-motivações na alma humana. De forma marcante, as tragédias Hipólito e Medéia de Eurípides são registros mais próximos da experiência da akrasia tradicional. Em todos esses casos, acompanhamos o mesmo conflito interno entre diferentes motivações cognitivas humanas. A psicologia grega tradicional representa o conflito interno da alma com base em impulsos humanos intrinsecamente cognitivo-motivacionais. Por conta disso, a apreensão original da akrasia tradicional nos permite compreender a primeira formulação filosófica do problema da akrasia no Protágoras.

O problema filosófico da akrasia antiga é apresentado primeiramente nos Diálogos de Platão. Dentro dos Diálogos, a negação socrática da akrasia no Protágoras é efetivamente incompatível com a psicologia tripartite e o conflito interno da alma na República. Apesar dessa diferença fundamental, revelamos que Platão mantém de forma consistente a negação da akrasia tradicional e a descrição do fenômeno como um tipo de ignorância.

O Protágoras inaugura o problema da akrasia antiga no campo epistemológico do conhecimento moral. Dentro desse plano, o exame conjunto de Sócrates e Protágoras visa salvar o conhecimento contra as crenças tradicionais da opinião dominante da akrasia tradicional. Com o argumento hedonista, Sócrates revela que as crenças hedonistas implícitas da opinião dominante implicam em uma descrição tradicional absurda do fenômeno. Em síntese, o argumento hedonista do absurdo da akrasia repousa sobre duas teses principais: (a) a adesão da opinião dominante ao hedonismo quantitativo do bem real; (b) o reconhecimento de que o agente não detém o conhecimento do bem real diante do relato tradicional de que seu erro moral advém do impulso pelo prazer. Diante disso, o exame socrático negativo conclui que a akrasia tradicional não pode consistir no conhecimento do 
bem real, mas apenas em um tipo de ignorância. O argumento hedonista constitui a negação socrática da akrasia ou a refutação da akrasia tradicional.

A negação socrática da akrasia resulta na clara distinção entre conhecimento moral e ignorância. Mesmo assim, Sócrates não deixa de reconhecer que o efeito ilusório dos prazeres aparentes produz o conflito interno da alma e o estado permanente de ignorância do agente. $\mathrm{O}$ argumento hedonista socrático não exclui simplesmente o papel dos desejos irracionais por um suposto intelectualismo do desejo. Invariavelmente, o paradoxo socrático estabelece a conclusão final de que 'ninguém faz o mal de bom grado' (358d). De fato, o paradoxo socrático estabelece duas conclusões socráticas bem definidas: (1) a negação absoluta do conhecimento-akrasia e, simultaneamente, também a negação da crença-akrasia; (2) a tese de que ninguém faz o mal involuntariamente, isto é, o princípio psicológico da inclinação natural humana pelo bem. Após a refutação da akrasia tradicional, o exame socrático negativo da opinião dominante nos leva a reconhecer a plausibilidade do princípio psicológico humano. Dentro dessa esfera, a República não apresenta nenhuma contestação direta das conclusões socráticas do Protágoras.

Diante do Protágoras, a República não apresenta claramente o problema da akrasia antiga. Todavia, a psicologia tripartite e o conflito interno da alma na República são fundamentais para a constituição do caráter moral acrático.

Dentro dessa perspectiva, a teoria tripartite da alma na República reflete as categorias do modelo cognitivo-motivacional da psicologia grega antiga. A divisão psicológica tripartite do logistikón, thymoeidés, e epithymetikón, abrange um conjunto próprio de crenças, motivações e desejos de cada parte da alma. Dentro da psicologia tripartite, cada parte da alma possui sua própria concepção cognitiva do bem relativa a seus objetos naturais de desejo. De fato, a própria distinção clássica platônica da parte 'racional' e as partes inferiores 'irracionais' da alma está ligada à separação dos objetos do conhecimento e dos objetos das paixões irracionais (580d-581c). Por isso, não encontramos aqui ainda a divisão estrita da razão e das paixões irracionais da psicologia moderna da vontade. Sendo assim, o reconhecimento da parte irracional da alma na República não atinge essencialmente a inclinação natural ao bem do paradoxo socrático anterior. Até mesmo o conflito interno da alma na República não se dirige propriamente contra a negação socrática da akrasia. 
O exame do conflito interno da alma na República acompanha um exame amplo do caráter moral. Na realidade, a República jamais aborda o conflito interno da alma da akrasia independente do exame amplo do caráter moral injusto. Por isso, o conflito interno da alma está relacionado ao exame da corrupção moral do caráter injusto e a desarmonia das partes da alma em Rep. VIII-IX. Dentro desse exame, Sócrates apresenta dois modelos explicativos e intercambiáveis do conflito interno da alma, o Modelo Hidráulico e o Modelo da Ignorância. Como vimos, o primeiro modelo representa o princípio do conflito das forças motivacionais enquanto o segundo modelo reflete o domínio das partes irracionais inferiores sobre a parte racional superior da alma. Dentre os tipos de alma injusta, o conflito interno do caráter timocrático e do caráter oligárquico apresentam diversos traços morais marcantes do caráter acrático. No entanto, a psicologia tripartite apenas expõe traços gerais do caráter acrático mas não reconhece diretamente o fenômeno da akrasia antiga. Para isso, tivemos de nos voltar para a análise clássica da akasia antiga da Ética de Aristóteles.

Ao longo da Ética, Aristóteles delineia traços gerais do caráter acrático em uma reflexão tardia das teorias do caráter moral e o conhecimento moral esboçadas nos diálogos anteriores de Platão. De um lado, o conflito interno da razão e os maus apetites do caráter acrático reflete a falta de educação moral das paixões irracionais apresentada na psicologia tripartite da República. De outro lado, a classificação do vício moral voluntário do acrático apresenta uma teoria moral contrária ao paradoxo socrático do 'mal involuntário' no Protágoras. Em oposição ao paradoxo socrático, Aristóteles delineia duas posições centrais (ENIII.5): (1) assim como o vício moral, a akrasia resulta das ações morais voluntárias do agente; (2) o vício moral e a akrasia não procedem da ignorância involuntária mas de um tipo de ignorância voluntária. Diante dessas características, Aristóteles apresenta sua análise clássica do caráter acrático e da possibilidade da akrasia ao longo de ENVII.

A definição clássica da akrasia e o caráter moral acrático aparece de forma madura na Ética de Aristóteles. Dentre outros tipos de vícios morais, o caráter acrático se destaca justamente por causa do conflito interno específico entre a razão correta e os maus apetites do agente. A compreensão do conflito interno acrático esclarece a própria possibilidade da akrasia de ENVII.3.

Durante ENVII.3, as 3 propostas preliminares de descrição do fenômeno culminam na $4^{\mathrm{a}}$ explicação physikôs decisiva da akrasia. Nessa estrutura, a proposta 
explicativa final da akrasia se refere a um confronto entre dois silogismos práticos paralelos do acrático, o silogismo do bem e o silogismo de prazer. Como vimos, a controvérsia em torno da doutrina do silogismo prático de Aristóteles destaca duas propostas interpretativas divergentes, o silogismo prático forte e o silogismo prático moderado. Em linhas gerais, o silogismo prático forte estabelece que a conclusão das premissas práticas é a própria ação, enquanto o silogismo prático moderado estabelece que a conclusão prática é ainda uma proposição prática que resulta em uma ação. Diante do conflito interno acrático, denfedemos que apenas o silogismo prático moderado contempla a descoordenação da razão correta e as paixões irracionais. Com efeito, o caso acrático é marcado pela ausência do conhecimento moral fundamental, relacionado à educação moral das paixões irracionais e a eficácia prática da phronesis. Na descrição definitiva da akrasia, o silogismo do prazer tem predominância sobre o silogismo do bem por causa da influência das paixões irracionais nas premissas práticas particulares da ação. De qualquer modo, o erro do acrático não se restringe a uma falha essencialmente cognitiva e nem mesmo a uma falha exclusivamente motivacional. $\mathrm{O}$ acrático não sofre qualquer falha em seu raciocínio prático ou obscurecimento de parte do bom silogismo, nem mesmo é simplesmente arrastado pelas paixões irracionais.

A descoordenação da razão prática e as paixões irracionais revela a ausência fundamental da phrónesis no caráter acrático. Apenas a phrónesis integra a capacidade executiva da ação a partir da virtude moral apropriada. Por isso, a phrónesis assegura efetivamente a eficácia do silogismo prático forte na ação. Com efeito, o acrático está totalmente destituído do exercício do conhecimento moral encarnado no paradigma do homem prudente. De qualquer modo, o silogismo prático forte tem ampla repercussão na fraqueza de vontade contemporânea.

A formulação original da fraqueza de vontade contemporânea decorre da recepção analítica da akrasia antiga. Em primeiro lugar, a negação absoluta da fraqueza de vontade de Hare reflete a assimilação da akrasia grega à compulsão psicológica e a outros tipos de irracionalidade prática. Em segundo lugar, a possibilidade da fraqueza de vontade de Davidson é formada a partir da reestruturação do silogismo acrático de Aristóteles. Em ambos os casos, a akrasia antiga em Platão e Aristóteles esclarece a formulação original da fraqueza de vontade contemporânea presente nas obras de Hare e Davidson. 
O problema da fraqueza de vontade contemporânea ganha destaque em face do prescritivismo moral de Hare. Segundo o prescritivismo moral, os juízos morais do 'dever' moral têm precritividade universal, isto é, tem o sentido primordial de orientar a ação moral de todos os agentes humanos. A força do prescritivismo moral reside na implicação lógica necessária da inferência imperativa de Hare na ação moral. Por sua vez, a noção moderna da inferência prática é elaborada a partir da apropriação analítica do silogismo prático forte de Aristóteles. De todo modo, a fraqueza moral constitui um desafio à doutrina do prescritivismo moral.

A negação absoluta da fraqueza moral de Hare se dirige à preservação da consistência do precritivismo moral. Nesses termos, a fraqueza de vontade adquire o estatuto de um problema eminentemente moral. Para Hare, a fraqueza moral não é um fenômeno genuíno porque resulta de um sentido derivado 'entre aspas' do 'dever' moral. A partir dessa posição radical, Hare destaca três exemplos de fenômenos irracionais que não refletem a autêntica fraqueza moral: (1) a hipocrisia insincera ou o sentido descritivo dos valores sociais; (2) o autoengano ou o sentido psicológico da obrigação moral; (3) a compulsão psicológica ou a akrasia grega. Após a negação da fraqueza moral de Hare, a tradição analítica tem associado reiteradamente a akrasia antiga à compulsão psicológica e a outros fenômenos irracionais. No entanto, isso não nos revela absolutamente nada sobre a natureza original da akrasia antiga e nem mesmo sobre a própria fraqueza de vontade.

Em última análise, a negação da fraqueza moral reduz a fraqueza de vontade ao dilema do conflito de deveres morais. Na verdade, o conflito de deveres morais logicamente incompatíveis resulta efetivamente no conflito insolúvel de princípios morais intuitivos. Em especial, a crítica de Williams à fraqueza moral alerta para o fato de que os princípios morais absolutos estão inevitavelmente sujeitos ao perspectivismo interno do agente. Do ponto de vista interno do agente, o juízo moral pode plausivelmente perder seu valor diante de outras considerações igualmente legítimas do agente. Para todos os efeitos, o conflito prático genuíno da akrasia antiga e a fraqueza de vontade passam longe dos limites estreitos do campo restrito da teoria moral do dever.

A possibilidade da fraqueza de vontade no cenário contemporâneo é renovada a partir dos artigos fundamentais da filosofia analítica da ação de Davidson. Para Davidson, o problema da fraqueza vontade deriva do aparente conflito dos princípios intuitivos: o internalismo do juízo avaliativo e a ação (P1- 
P2) e a possibilidade da ação contrária ao melhor juízo, isto é, a fraqueza de vontade (P3). A tese da possibilidade da fraqueza de vontade de Davidson exige um esclarecimento da relação lógica causal entre as razões do agente e a ação intencional.

A resolução do conflito aparente reside na clara distinção entre os juízos condicionais prima facie e os juízos incondicionais absoluto da ação intencional. Em 'Weakness', a possibilidade da fraqueza de vontade se baseia em uma suposta reestruturação do duplo silogismo acrático a partir do juízo lógico sintético de 'todos os fatores considerados' (TFC). Para Davidson, há uma incompatibilidade lógica inerente entre dois juízos da fraqueza de vontade: o juízo prima facie TFC do 'melhor juízo' é desvinculado do juízo incondicional da ação intencional do agente. A partir de 'Paradoxes', no entanto, o foco sobre a irracionalidade prática apresenta uma nova descrição da fraqueza de vontade. De acordo com a segunda descrição do fenômeno, a fraqueza consiste na negligência do princípio da continência, isto é, o princípio racional de que é preciso agir conforme o juízo TFC. Nessa medida, o juízo TFC resulta efetivamente no juízo incondicional do 'melhor juízo’ relativo à ação intencional do agente. A ação irracional ocorre por conta de um desejo forte contrário às melhores razões do agente. Diante dessas descrições incompatíveis do fenômeno, mostrarmos que a primeira descrição formal da fraqueza mantém sua consistência lógica diante da segunda descrição explicativa da irracionalidade prática.

A irracionalidade prática interna constitui o problema central da descrição explicativa da fraqueza de Davidson. De fato, a irracionalidade prática da fraqueza de vontade sofre críticas posteriores em dois aspectos fundamentais: (a) a negligência do princípio lógico da continência inviabiliza a própria racionalidade do agente humano; (b) a irracionalidade prática interna depende da existência da causa mental não racional (CMNR) e de uma controversa partilha da mente. Sobre a primeira crítica, salientamos que a violação do princípio lógico da continência abre espaço para a causa cega e a compulsão psicológica do agente. O princípio da continência tem mais eficácia prática como um princípio normativo da ação do que como um princípio lógico constitutivo da racionalidade do agente. Sobre a segunda crítica, indicamos que podemos admitir a existência da CMNR sem nos comprometer com a partilha da mente em setores mentais semiautônomos. Ao final, 
fizemos uma análise comparativa da irracionalidade prática 'interna' de Davidson e a irracionalidade 'objetiva' da psicologia grega antiga.

A 'irracionalidade' objetiva da psicologia antiga dá nova luz sobre o problema da fraqueza de vontade contemporânea. Com efeito, há duas diferenças fundamentais entre a 'irracionalidade' interna de Davidson e a 'irracionalidade' objetiva da psicologia antiga: (a) a irracionalidade 'interna' se refere apenas a uma incompatibilidade interna das crenças dentro do sistema mental do agente; (b); a 'irracionalidade' da psicologia antiga se refere aos parâmetros objetivos do conflito de desejos do agente. Sobretudo, a distinção clássica do campo 'racional' e o 'irracional' da psicologia antiga decorre de diferentes objetos naturais do desejo. A dimensão cognitivo-motivacional da psicologia antiga atribui um conjunto específico de crenças, motivações e desejos às partes da psicologia humana. Sob esse ângulo, a razão prática e os impulsos irracionais têm aspectos intrinsecamente cognitivo-motivacionais. A partir da psicologia antiga, temos a oportunidade tornar o internalismo (P1-P2) e a descrição explicativa da irracionalidade prática de Davidson mais consistentes.

A psicologia antiga e a irracionalidade objetiva fornece um novo ângulo sobre a consistência dos princípios intuitivos (P1-P3) de 'Weakness'. Em primeiro lugar, a psicologia antiga deixa o internalismo (P1-P2) mais consistente com a possibilidade da fraqueza de vontade. Pelos parâmetros da psicologia antiga, o princípio (P1) pode se referir efetivamente à relação da força motivacional geral e a ação intencional e o princípio $(\mathrm{P} 2)$ diz respeito exclusivamente à relação intrínseca do juízo avaliativo do agente e a motivação racional. Nessa esfera, o 'internalismo' forte de (P1-P2) se mantém consistente mesmo diante da fraqueza de vontade. Em segundo lugar, a irracionalidade da fraqueza de vontade depende da consciência do conflito prático fundamental da razão prática e as motivações irracionais. Durante a fraqueza, as motivações irracionais comprometem a motivação racional do melhor juízo. No entanto, não há nenhuma falha interna da razão prática, obscuridade do raciocínio prático, ou uma causa cega intervindo na ação. Como mostra Aristóteles, há uma descoordenação fundamental da razão prática e das motivações irracionais. De fato, não se pode isolar a razão prática nem os impulsos irracionais do conflito prático característico da fraqueza de vontade. Ao contrário, a fraqueza de vontade consiste essencialmente na incompatibilidade essencial da razão prática e as 
motivações irracionais na ação irracional. Nessa medida, temos uma dimensão mais significativa do que envolve a experiência da fraqueza de vontade.

A relação da akrasia antiga e a fraqueza de vontade contemporânea é uma investigação promissora de um tema complexo e de vasta abrangência. Diante das múltiplas possibilidades de abordagem, destacamos um recorte da interlocução da origem da fraqueza de vontade contemporânea com o debate clássico da akrasia antiga. Sem dúvida, não temos pretensão alguma de esgotar o tema ou estabelecer conclusões definitivas sobre a relação entre o problema antigo e o problema contemporâneo. Ao contrário, nosso objetivo foi apenas traçar considerações de que a formulação original da fraqueza de vontade contemporânea em Hare e Davidson se constitui a partir da recepção da akrasia antiga de Platão e Aristóteles. Nesse horizonte, o objetivo principal era mostrar a natureza original do problema filosófico da akrasia antiga e do problema da fraqueza de vontade contemporânea. Independente de suas marcantes diferenças, o estatuto original da fraqueza de vontade é efetivamente esclarecido à medida que temos consciência do impacto da recepção da akrasia antiga dentro do contexto da filosofia analítica anglo-saxã. 
9

\section{Referências bibliográficas}

\section{Bibliografia primária}

ARISTÓTELES. De Anima. Apresentação, tradução e notas de Maria Cecília Gomes Reis. São Paulo. Ed. 34, 2006.

. Ética a Nicômaco. Tradução de Leonel Vallandro e Gerd Bornheim In: Coleção Os Pensadores. São Paulo: Abril Cultural, 1984, p. 44-236.

ARISTOTLE. De Anima, with translation, introduction and notes by R. D. Hicks, Amsterdã, 1965.

Nichomachean Ethics translated by W. D. Ross in: The

Complete Works of Aristotle, The Revised Oxford Translation. Edited by Jonathan Barnes. Oxford: Princeton University Press, 1997.

DAVIDSON, D. Essays on Actions and Events, Oxford, Clarendon Press, 2001.

. Problems of Rationality, with introduction by Marcia Cavell and interview with Ernest Lepore, Oxford, Clarendon Press, 2004.

Actions, Reasons and Causes. In: Essays on Actions and

Events, Oxford: Clarendon Press, 2001a, p. 3-19. 
. How is Weakness of the Will Possible? In: Essays on Actions and Events, Oxford: Clarendon Press, 2001b, p. 21-42.

. Intending. In: Essays on Actions and Events, Oxford:

Clarendon Press, 2001c, p. 83-102.

. Mental Events. In: Essays on Actions and Events, Oxford: Clarendon Press, 2001d, p. 207-227.

. Paradoxes of Irrationality. In: Problems of Rationality, with introduction by Marcia Cavell and interview with Ernest Lepore, Oxford: Clarendon Press, 2004a, p. 164-187.

. Incoherence and Irrationality. In: Problems of Rationality, with introduction by Marcia Cavell and interview with Ernest Lepore, Oxford: Clarendon Press, 2004b, p. 189-198.

. Deception and Division. In: Problems of Rationality, with introduction by Marcia Cavell and interview with Ernest Lepore, Oxford: Clarendon Press, 2004c, p. 199-212.

. Aristotle's Action. In: Truth, Language and History:

Philosophical Essays, with Introduction by Marcia Cavell, Oxford: Clarendon Press, 2005, p. 277-294.

EURÍPIDES. Medéia. Tradução de José Antônio Alves Torrano. São Paulo: Hucitec, 1991.

Hipólito. Tradução do grego, introdução e notas de Frederico Lourenço. 2. ed. Lisboa: Colibri, 1996.

Hipólito. Trad. Trajano Vieira. São Paulo: Editora 34, 2015.

EURIPIDES. Hippolytus. In: Children of Heracles, Hippolytus, Andromache, Hecuba. Trad. David Kovacs. London: 1995. Harvard University Press.

EURIPIDES. Medea. In: Cyclops, Alcestis, Medea. Trad. David Kovacs. 
London: 1994. Harvard University Press.

ÉSQUILO. Agamêmnon. Estudo e trad. J.A.A. Torrano. São Paulo: lluminuras / FAPESP, 2004.

Tragédias: Os persas, Os sete contra Tebas, As suplicantes, Prometeu cadeeiro. Estudo e trad. J.A.A. Torrano. São Paulo: lluminuras / FAPESP, 2009.

HOMERO. llíada. Tradução de Carlos Alberto Nunes. Rio de Janeiro: Ediouro, 2009.

. Ilíada. Tradução Lourenço, F. São Paulo: Companhia das Letras/Penguin, 2013.

. Odisséia. Tradução de Carlos Alberto Nunes. Rio de Janeiro: Ediouro, 2009.

. A Linguagem da Moral. Tradução de Eduardo Pereira Ferreira. São Paulo: Martins Fontes, 1996.

Ética: Problemas e Propostas. São Paulo: Unesp, 2003.

Freedom and Reason. Oxford: Clarendon Press, 1963.

Moral Thinking: Its Levels, Method and Point. Oxford:

Clarendon Press, 1981. 
. Weakness of the Will. in: Objective Prescriptions and Other

Essays. Oxford: Clarendon Press, 1999, p. 109-114.

Objective Prescriptions and Other Essays. Oxford: Clarendon Press, 1999.

. Practical Inferences. London: Macmillan, 1971.

PLATÃO. Protágoras de Platão. Tradução, ensaio introdutório e notas de Daniel R. N. Lopes. $1^{\text {a }}$ ed. São Paulo: Perspectiva, 2017.

. República. Tradução Maria Helena da Rocha Pereira. $14^{\mathrm{a}} \mathrm{ed}$. Lisboa: Fundação Calouste Gulbenkian, 2014.

A república. Tradução de Anna Lia Amaral de Almeida Prado; Revisão Técnica e Introdução de Roberto Bolzani Filho. 2 ed. São Paulo: Martins Fontes, 2014.

PLATO. Complete Works. Edited, with Introductions and Notes, by John. M. Cooper. Cambridge: Hackett, 1997.

. Laches, Protagoras, Meno, Euthydemus. Translated by W. R. M. Lamb. Loeb Classical Library. Cambridge: Harvard University Press, 1924.

Protagoras. Translated with notes by C. C. W. Taylor. Clarendon Plato Series. New York: Oxford University Press, 1991.

. Republic, Books 1-5. Edited and Translated by Chris EmlynJones and William Preddy. Loeb classical library, 237. Cambridge, MA, London, England: Harvard University Press, 2013. 
. Republic, Books 6-10. Edited and Translated by Chris EmlynJones and William Preddy. Loeb classical library, 276. Cambridge, MA, London, England: Harvard University Press, 2013.

PLATON. La République, livre I-III. Texte établi et traduit par Émile Chambry. In: . Oeuvres Complètes. Paris: Les Belles Lettres, 1970.

PLATON. La République, livres IV-VII. Texte établi et traduit par Émile Chambry. In: . Oeuvres Complètes. Paris: Les Belles Lettres, 1946. t. 7, 1re partie.

PLATON. La République, livres VIII-X. Texte établi et traduit par Émile Chambry. In: 1934. t. 7, 2e partie. . Oeuvres Complètes. Paris: Les Belles Lettres,

SÓFOCLES. Antígona. Trad. Maria Helena da Rocha Pereira. $6^{\underline{a}}$ ed. Lisboa: Calouste Gulbenkian, 2003. UnB, 1996.

As traquínias. Trad. Maria do Céu Zambujo Fialho. Brasília:

WILLIAMS, B. Shame and Necessity. Berkeley/Los Angeles/Oxford: University of California Press, 1993.

THE PERSEUS PROJECT. Perseus Digital Library. Produced by Gregory R. Crane. Disponível em: <http:/www.perseus.tufts.edu>. Acesso em: 30 jan. 2020.

\section{Bibliografia secundária}

ADAM, J. (ed.). The Republic of Plato. Edited with critical notes, comm. and appendices by James Adam. 1 ed., Cambridge, 1902. 
ANNAS, J. An introduction to Plato's Republic. Oxford: Clarendon Press. 1981.

. Hedonism in the Protagoras. In: Platonic Ethics, Old and New. New York: Ed. Cornell University Press, 1999, p. 167-171.

ANGIONI, L. Aristóteles - Ética a Nicômaco Livro VI. In: Dissertatio, v. 34, 2011a, p. 285-300

Phronesis e virtude do caráter em Aristóteles: comentários a Ética a Nicômaco VI. In: Dissertatio, v. 34, 2011b, p. 303-345.

ANSCOMBE, G.E.M. A Filosofia Moral Moderna. In: ZINGANO, M (org.) Sobre a Ética Nicomaquéia de Aristóteles: Textos selecionados e coordenação de Marco Zingano. São Paulo, Odysseus Editora, 2010, p. $19-41$.

2000.

Intention. Cambridge, Harvard University Press, 2nd. edition,

Thought and Action in Aristotle: What is Practical Truth? In: From Parmenides to Wittgenstein: The Collected Philosophical Papers of G. E. M. Anscombe, Vol. I. Oxford: Blackwell and Minneapolis: University of Minnesota Press, 1981, p. 66-77.

Practical Inference. In: Human Life, Action and Ethics. GEACH, M.; GORMALLY, L. (Eds.). St. Andrews Studies in Philosophy and Public Affairs. Exeter: Imprint Academic, 2011, p. 102-140.

BARNES J. Aristote dans la philosophie anglo-saxonne. In: Revue Philosophique de Louvain. Quatrième, tome 75, n. 26, 1977, p. 204218.

Aristóteles e o Método da Ética In: ZINGANO, M. (Ed.) Sobre a Ética Nicomaquéia de Aristóteles. São Paulo, Odysseus Editora, 2010, p. $183-207$. 
BARRET, W. S. (ed.) Euripides, Hyppolitus. Edited with Introduction and Commentary by W. S. Barret, M.A. Oxford: Clarendon Press, 2001.

BERTI, E. Aristóteles no século XX. Edições Loyola: São Paulo, Brasil, 1997.

BOBONICH, C. DESTRÉE, P. (Eds.). Akrasia in greek philosophy: from Socrates to Plotinus. Boston: Ed. Brill, 2007.

. Plato on Akrasía and Knowing your Own Mind. In: BOBONICH, C.; DESTRÉE, P. (Eds). Akrasia in greek philosophy, from Sócrates to Plotinus. Boston: Ed. Brill, 2007, p. 41-60.

Plato's Utopia Recast: His Later Ethics and Politics. Oxford: Oxford University Press, 2002.

BOSTOCK, D. Aristole's Ethics. Oxford: Clarendon Press, 2000.

BROADIE, S. Ethics With Aristotle. Oxford: Oxford University Press, 1991.

BURNYEAT, M. Aprender a ser bom segundo Aristóteles. In: ZINGANO, M. (Ed.) Sobre a Etica Nicomaquéia de Aristóteles. São Paulo, Odysseus Editora, 2010, p. 155-182. . The Presidential Address: The Truth of Tripartition. In:

Proceedings of the Aristotelian Society, v. 106, 2006, p. 1-23.

BRICKHOUSE, T. C.; SMITH, N. D. Socratic Moral

Psychology. Cambridge: Cambridge University Press, 2010.

CALLARD, A. Ignorance and Akrasia-Denial in the Protagoras. In: Oxford Studies in Ancient Philosophy, n. 47, 2014, p. 31-80. 
Practical Reason. In: LEPORE, E.; LUDWIG, K. (eds.). A

Companion to Donald Davidson. Oxford: Wiley-Blackwell, 2013, p. 3247.

CHARLES, D. Aristotle's philosophy of action. London: Duckworth. 1984.

Aristotle's Weak Akrates: What does her Ignorance Consists in? In: $\mathrm{BOBONICH}, \mathrm{C}$.; DESTRÉE, P. (Eds). Akrasia in greek philosophy: from Socrates to Plotinus. Boston: Ed. Brill, 2007, p. 193-214.

. Akrasia: The Rest of the Story? In: Moral Psychology and Human Action in Aristotle. PAKALUK, M.; PEARSON, G. (Eds.), New York: Oxford University Press, 2011, p. 187-210. . Nicomachean Ethics VII. 3: Varieties of akrasia. In: NATALI, C. (Ed.). Aristotle: Nicomachean Ethics, Book VII Symposium Aristotelicum. Oxford: Oxford University Press, 2009, p. 41-71.

CHARLTON, W. Weakness of Will. Oxford: Basil Blackwell, 1988.

CLAUS, D. Phaedra and the Socratic Paradox. In: Yale Classical Studies, Vol. 22, 1972, p. 223-238.

Toward the Soul: An Inquiry into the Meaning of Pysche Before Plato. New Haven, 1981.

COOPER, J. M. Plato's Theory of Human Motivation. In: History of Philosophy Quarterly, vol. 1, 1984, p. 3-21.

Nicomachean Ethics VII. 1-2: Introduction, Method, Puzzles. In: NATALI, C. (Ed.). Aristotle: Nicomachean Ethics, Book VII Symposium Aristotelicum. Oxford: Oxford University Press, 2009, p. 9 39.

COOPER, N. Oughts and wants. in: MORTIMER, G. W. (Ed.) Weakness 
of Will. New York: Saint Martin' Press, 1971, p. 190-199.

DAHL, N. Aristotle on Action, Practical Wisdom and Weakness of Will. In: ANAGNOSTOPOULOS, G. (ed.) A Companion to Aristotle.

Chichester/Malden, Wiley-Blackwell, 2009, p. 498-511.

DENYER, N. Plato: Protagoras. Cambridge: Cambridge University Press, 2008.

DODDS, E. R. The Greeks and the Irrational. Berkeley: University of California Press, 1956.

. Euripides the Irrationalist. The Ancient Concept of Progress and other Essays on Greek Literature and Belief. Oxford: Oxford University Press, 1973, p. 78-91.

DOVER, K.J. Greek Popular Morality in the time of Plato and Aristotle. Indianapolis: Hackett Publishing Company, Inc., 1994.

FOLEY, H. Medea's Divided Self. in: Classical Antiquity, Vol. 8, n. 1, 1989, p. 61-85.

FERRARI, G R. F. Akrasia as Neurosis in Plato's Protagoras. In: Proceedings of the Boston Area Colloquium in Ancient Philosophy, 6, 1990, p. 115-140.

. The Three-Part Soul. In: FERRARI, G. R. F. (ed.) The Cambridge Companion to Plato's Republic. Cambridge: Cambridge University Press, 2007, p. 165-201.

FREDE, M. Introduction. In: Plato: Protagoras. Trans. K. Bell and S. Lombardo. Indianapolis, p. vii-xxxvi, 1992a. 
. Plato's Arguments and the Dialogue Form. In: Oxford Studies in Ancient Philosophy: Methods of Interpreting Plato and his Dialogues, 1992b, p. 201-219.

GAUTHIER, R. A.; JOLIF, J. Y. La continence et l'incontinence, In: L'Éthique à Nicomaque. Volume II.2. Paris: Louvain-la-Neuve, 2002, p. 579-654.

GASKIN, R. Do Homeric Heroes Make Real Decisions? In: Classical Quarterly, New Series, Vol. 40, n. 1, 1990, p. 1-15.

GILL, C. Personality in Greek Epic, Tragedy, and Philosophy. Oxford: Clarendon Press, 1996.

GOSLING, J.C.B.; TAYLOR, C. C. W. The Greeks on Pleasure, Oxford: Clarendon Press, 1982.

GOSLING, J. C. B. Weakness of the Will. London and New York: Routledge, 1990.

GOTTLIEB, P. O Silogismo Prático. In: KRAUT, R. (ed.) Aristóteles e a Ética a Nicômaco. Tradução de Alfredo Storck et al. Porto Alegre: Artmed, 2009, p. 204-216.

GUTHRIE, W. C. K. A History of Greek Philosophy IV: Plato The Man and his Dialogues: Earlier Period. Cambridge: University Press, 1975.

HARE, R. M. Freedom and Reason. Oxford: Clarendon Press (1963). Review of Freedom and Reason. Oxford: Clarendon Press (1963).

TAYLOR, C. C. W. 'Critical Notices' In: Mind, vol. 74, n. 294, 1965, p. $280-$ 298.

HOFFMAN, T. (ed.), Weakness of Will from Plato to the Present. Washington: Catholic University of America Press, 2008. 
IGLÉSIAS, M. Platão: A descoberta da alma. In: Boletim do CPA, Campinas, UNICAMP, ano 3, n. 5/6, 1998, p. 13-58.

IRWIN, T. H. Aristotle Reads the Protagoras. In: HOFFMANN, T.

(Ed.). Weakness of Will from Plato to the Present. Washington: Catholic University of America Press, 2008, p. 22-41.

$\overline{183-197}, 1983$.

Euripides and Socrates. In: Classical Philology, v. 78, n. 3, p.

. The Development of Ethics: A Historical and Critical Study. Vol. III From Kant to Rawls. Oxford: Oxford University Press, 2009.

Plato's ethics. London: Oxford University Press, 1995.

KAHN, C. H. Plato and the socratic dialogue: the philosophical use of a literary form. London: Cambridge University Press, 1996.

Plato's theory of desire. In: Review of Metaphysics, vol. 41, 1987, p. 77-103.

KAMTEKAR, R. Plato's Moral Psychology. Oxford University Press, 2017.

. The Powers of Plato's Tripartite Psychology. In: Proceedings of the Boston Area Colloquium in Ancient Philosophy, vol. 24, 2008, p. 127-50.

KITTO, H. D. F. A Tragédia grega: estudo literário. Vol. II. Traduzido do inglês por José Manuel Coutinho de Castro. Coimbra: Arménio Amado, 1972. 
KOVACS, D. On Medea's Great Monologue. In: Classical Quarterly, Vol. 36, n. 02, 1986, p. 343-352.

. Shame, Pleasure, and Honor in Phaedra's Great Speech (Euripides, Hippolytus 375-87). In: The American Journal of Philology, Vol. 101, No. 3, 1980, p. 287-303.

KNOX, B. O Hipólito de Eurípides. In: EURÍPIDES. Hipólito. Trad. Trajano Vieira. São Paulo: Editora 34, 2015, p. 167-205.

. Second Thoughts in Greek Tragedy. In: Word and Action:

Essays on Ancient Theater. Baltimore and London, John Hopinks University Press, 1979, p. 231-249.

. The Medea of Euripides. In: SEGAL, E (Ed.). Oxford Readings in Greek Tragedy. Oxford, 1983, p. 272-293.

KENNY, A. The Practical Syllogism and Incontinence. In: Phronesis, v. 10, 1966, p. 163-84.

KRAUT, R. (ed.) Aristóteles e a Ética a Nicômaco. Tradução de Alfredo Storck et al. Porto Alegre: Artmed, 2009.

Doing without Morality: Reflexions on the Meaning of Dein in Aristotle's Nichomachean Ethics. In: Oxford Studies in Ancient Philosophy, vol. 30, 2006, p. 159-200.

LAZAR, A. Akrasia and the prinnciple of continence or what the tortoise would say to Achilles. In: HAHN, L. E. (Ed.). The Philosophy of Donald Davidson, Library of Living Philosophers. Volume XXVII, Chicago: Open Court, 1999, p. 381-401.

LEAR, J. Inside and Outside the Republic. in: WAGNER, E. (Ed.). Essays on Plato's Psychology. Lanham, MD: Lexington Books, 2001, p. 169202. 
LEPORE, E.; LUDWIG, K. (Eds.). A Companion to Donald Davidson. Oxford: Wiley-Blackwell, 2013.

LESSES, G. Weakness, Reason, and the Divided Soul in Plato's Republic. In: History of Philosophy Quarterly, vol. 4, n. 2, 1987, p. 147-61.

LORENZ, H. The Brute Within: Appetitive Desire in Plato and Aristotle. Oxford: Clarendon Press, 2006.

Nichomachean Ethics VII. 4: Plain and Qualified akrasia. in: NATALI, C. (Ed.). Aristotle's Nicomachean Ethics, Book VII. Oxford: Oxford University Press, 2009, p. 82-101.

LOVIBOND, S. Plato's theory of mind. In: EVERSON, S. (Ed.)

Companions to Ancient Thought 2: Psychology. Cambridge:

Cambridge University Press, 1991, p. 35-55.

LUKES, S. Moral weakness. In: MORTIMER, G. W. (Ed.). Weakness of Will. New York: Saint Martin' Press, 1971, p. 147-159.

MATTHEWS, G. Weakness of Will. In: MORTIMER, G. W. (Ed.).

Weakness of Will. New York: Saint Martin' Press, 1971, p. 160-174.

MELE, A. R. Akrasia, Reasons, and Causes. In: Philosophical Studies, vol. 44, 1983, p. 345-368.

Philosophy of Action. in: LUDWIG, Kirk (Ed.). Donald Davidson: Contemporary Philosophy in Focus. New York: Cambridge University Press, 2003, p. 64-84.

. Irrationality: An Essay on Akrasia, Self-deception, and

Self-control. New York: Oxford University Press, 1987.

MEYER, S. O voluntário segundo Aristóteles. In: KRAUT, R. (Ed.)

Aristóteles e a Ética a Nicômaco. Tradução de Alfredo Storck et al. Porto Alegre: Artmed, 2009, p. 132-150. 
MOTHERSILL, M. Anscombe's Account of the Practical Syllogism. In: The Philosophical Review, Vol. 71, n. 4, 1962, p. 448-461.

MORTIMER, G. W. (Ed.) Weakness of Will. New York: Saint Martin' Press, 1971.

MOLINE, J. Euripides, Socrates and Virtue. In: Hermes, v. 1., n. 103, 1975, p. 45-67.

Plato on the Complexity of the Psyche. In: Archiv für

Geschichte der Philosophie, vol. 60, 1978, p. 1-26.

MORRIS, M. Akrasia in the Protagoras and the Republic. In: Phronesis, n. 51, 2006, p. 195-229.

MUNIZ, F. D. P. A Potência da Aparência: um estudo sobre o prazer e a sensação nos Diálogos de Platão. São Paulo: Annablume Clássica, 2011.

NATALI, C. (Ed.). Aristotle's Nicomachean Ethics, Book VII, Oxford:

Oxford University Press, 2009.

NUSSBAUM, M. C. A fragilidade da bondade: fortuna e ética na tragédia e na filosofia grega. Tradução de Ana Aguiar Cotrim. São Paulo: Editora WMF Martins Fontes, 2009.

Aristotle 's De Motu Animalium, Text with Translation, Commentary, and Interpretive Essays by Martha Nussbaum. Princeton, N.J: Princeton University Press, 1978.

NORTH, H. Tragedy In: Sophrosyne, self-knowledge and self-restraint in Greek literature. New York: 1966. Cornell University Press.

O'BRIEN, M. J. The Socratic Paradoxes and the Greek Mind. Chapel Hill: North Carolina, 1967. 
PAGE, D. (Ed.). Euripides Medea. The Text edited with introduction and commentary by Denys L. Page. M.A. Oxford: Clarendon Press, 2001.

PAKALUK, M. Aristotle's Nicomachean Ethics: An Introduction, Cambridge: Cambridge University Press, 2005.

PENNER, T. Plato and Davidson: Parts of the soul and weakness of will. In: Canadian Journal of Philosophy, vol.16, 1990, p. 35-74.

. Sócrates e os primeiros diálogos. In: KRAUT, R. (org.). Platão.

Tradução de Saulo Krieger. São Paulo: Ideias \& Letras, 2013, p. 147-199.

Socrates on the Strength of Knowledge: Protagoras 351B-357E

in: Archiv für Geschichte der Philosophie, n. 79, 1997, p. 117-49.

PICKAVÉ, M.; WHITING, J. Nicomachean Ethics 7.3 on Akratic Ignorance. In: Oxford Studies in Ancient Philosophy, vol. 34, 2008, p. 323-72.

PRICE, A. W. Acrasia e autocontrole. In: KRAUT, R. (Ed.) Aristóteles e a Ética a Nicomaco. Tradução de Alfredo Storck et al. Porto Alegre: Artmed, 2009, p. 217-235.

Mental Conflict. London and New York: Routledge, 1995.

On the so-called Logic of Practical Inference. In: O' HEAR, A. (Ed.). Modern Moral Philosophy, Philosophy, Supplement 54, 2004, p. 119-40.

. Richard Mervyn Hare. In: Stanford Encyclopedia of Philosophy, 2014. Disponível em: <https://plato.stanford.edu/entries/weaknesswill/>. Acesso em: 06 jan. 2020.

PEREIRA, R. H. S. O paradoxo da irracionalidade segundo Davidson. In: SMITH, P. J.; FILHO, W. J. S. Significado, verdade, interpretação: 
Davidson e a filosofia. Ed. Loyola, 2005, p. 169-197.

REEVE, M. D. Euripides, Medea 1021-1080 in: The Classical Quarterly (New Series), vol. 22, n. 1, 1972, p. 51-61.

REEVE, C.D.C. Philosopher-Kings: The Argument of Plato's Republic. Princeton: Princeton University Press, 1988.

RICKERT, G. A. Akrasia and Euripides' Medea. In: Classical Philology, Harvard Studies, Vol. 91, 1987, p. 91-117.

ROMILLY, J. Eurípides o la tragédia de las pasiones. In: La tragédia grega. Madrid: Gredos, 2011, p. 113-151.

ROWE, C. A Problem in the Gorgias: How is Punishment Supposed to Help with Intellectual Error? In: BOBONICH, C.; DESTRÉE, P. (Eds.). Akrasia in Greek Philosophy: from Socrates to Plotinus. Boston: Ed. Brill, 2007, p. 19-40. . Interpreting Plato. In: BENSON, H. H. (Ed.). A companion to Plato. Oxford: Blackwell Publishing, 2006, p. 13-24.

RUDEBUSCH, G. Ethical Protagoreanism. In: Socrates, Pleasure and Value. New York: Oxford University Press, 1999a, p.19-31.

- O hedonismo de Cálicles. Tradução de Fernando Muniz e Michael Marsden. In: O que nos faz pensar. Rio de Janeiro, n. 13, $1999 \mathrm{~b}$.

ROBINSON, R. Sobre a Akrasía em Aristóteles. In: ZINGANO, M. (Ed.). Sobre a Ética Nicomaquéia de Aristóteles. São Paulo, Odysseus Editora, 2010, p. 65-83.

SANTAS, G. Aristotle on Practical Inference, the Explanation of Action, and Akrasia. In: Phronesis, vol. 14, 1969, p. 162-189. 
. Virtue and Knowledge II: An Argument against Explanation of Weakness. In: Socrates: Arguments of the Philosophers. New York: Routledge, 1979, p. 195-217.

SANSONE, D. Plato and Euripides. In: Illinois Classical Studies, Vol. 21, 1996, p. 35-67.

SCHOFIELD, M. Money and the Soul. In: Plato: Political Philosophy. Oxford: Oxford University Press, 2006, p. 250-281.

SEGVIC, H. No One Errs Willingly: The Meaning of Socratic Intellectualism. In: BURNYEAT, M. (Ed.) From Protagoras to Aristotle: Essays in Ancient Moral Philosophy New Jersey: Princeton University Press, 2009, p. 47-86.

SHARPLES, R. W. But Why Has My Spirit Spoken with Me Thus? In: Greece and Rome, Second Series, Vol. 30, n. 1, 1983, p. 1-7.

SHIELDS, C. Unified Agency and Akrasia in Plato's Republic In: BOBONICH, C.; DESTRÉE, P. (Eds). Akrasia in greek philosophy, from Sócrates to Plotinus. Boston: Ed. Brill, 2007, p. 41-60.

SINGPURWALLA, R. Reasoning with the Irrational: Moral Psychology in the Protagoras. In: Ancient Philosophy, vol. 26, 2006, p. 243-258.

SMITH, N. Plato's Analogy of Soul and State, in: WAGNER, E. (ed.), Essays on Plato's Psychology, Lanham, MD: Lexington Books, 2001, p. 115-135.

SNELL, B. A Cultura Grega e as Origens do Pensamento Europeu. Tradução de Pérola de Carvalho. São Paulo, Perspectiva, 2001.

. Passion and Reason: Medea and Phaedra in Hippolytos II. In:

Scenes from Greek Drama. Los Angeles: University of California Press, 1964, p. 47-69. 
STROUD, S. Irrationality. in: LEPORE, E.; LUDWIG, K. (Eds.). A Companion to Donald Davidson. Oxford: Wiley-Blackwell, 2013, p. 489505.

. Weakness of Will. In: Stanford Encyclopedia of Philosophy, 2014. Disponível em: <https://plato.stanford.edu/entries/weaknesswill/>. Acesso em: 30 jan. 2020.

TAYLOR, C. C. W. Plato, Hare and Davidson on Akrasia. In: Mind, vol. 89, no 356,1980 , p. 499-518.

WATSON, G. Skepticism About Weakness of Will. in: Philosophical Review, 86, 1977, p. 316-339.

WEISS, R. Thirst as Desire for Good in: BOBONICH, C.; DESTRÉE, P. (Eds.) Akrasia in Greek Philosophy, from Socrates to Plotinus.

Boston: Ed. Brill, 2007, pp. 87-100.

. The socratic paradox and it's enemies. Chicago: University of Chicago Press, 2006.

WILBURN, J. Akrasia and the Rule of Appetite in Plato's Protagoras and Republic. In: Journal of Ancient Philosophy, n. 8, 2014, p. 57-91.

WILLIAMS, B. The Analogy of City and Soul in Plato's Republic. in: FINE, G. (org.) Plato 2: Ethics, Politics, Religion, and the Soul. Oxford: Oxford University Press, 1999, p. 255-264.

Ethical Consistency. in: Problems of the Self: Philosophical Papers 1956-72 (New York: Cambridge University Press), 1973a, p. 166186.

Imperative Inference. in: Problems of the Self. Cambridge:

Cambridge University Press, 1973b, p. 152-165. 
. Internal and External Reasons. in: Moral Luck, Cambridge:

Cambridge University Press, 1981, p. 101-113.

. Shame and Necessity. Berkeley/Los Angeles/Oxford: University of California Press, 1993. Review of Shame and Necessity. Berkeley/Los Angeles/Oxford: University of California Press, 1993. IRWIN, T. 'Critical Notice of Bernard Williams, Shame and Necessity' in: Apeiron, vol. 27, n. 1, 1994, p. 45-76.

Shame and Necessity. Berkeley/Los Angeles/Oxford: University of California Press, 1993. Review of Shame and Necessity. Berkeley/Los Angeles/Oxford: University of California Press, 1993. STRIKER, G. 'Are we any better'. In: London Review of Books, Vol. 15, n. 16, 1993, p.1718.

Shame and Necessity. Berkeley/Los Angeles/Oxford: University of California Press, 1993. Review of Shame and Necessity. Berkeley/Los Angeles/Oxford: University of California Press, 1993. KRAUT, R. in: Ethics, Vol. 105, n. 1, 1994, p. 178-181.

Shame and Necessity. Berkeley/Los Angeles/Oxford: University of California Press, 1993. Review of Shame and Necessity. Berkeley/Los Angeles/Oxford: University of California Press, 1993. WOODRUFF, P. in: Ancient Philosophy, vol. 16, n. 1, 1996, p. 177-180.

Shame and Necessity. Berkeley/Los Angeles/Oxford: University of California Press, 1993. Review of Shame and Necessity. Berkeley/Los Angeles/Oxford: University of California Press, 1993. WHITE, N. in: The Journal of Philosophy, vol. 91, n. 11, 1994, p. 619-622.

Shame and Necessity. Berkeley/Los Angeles/Oxford: University of California Press, 1993. Review of Shame and Necessity. Berkeley/Los Angeles/Oxford: University of California Press, 1993. KNOX. B. 'The Greek Way' in: The New York Review of Books, Vol. 40, n. 19, 1993.

. The Structure of Hare's Theory. In: SEANOR, D.; N. FOTION (eds). Hare and Critics: Essays on Moral Thinking, Oxford: Clarendon Press, 1988, p. 185-196. 
WOOLF, R. Consistency and Akrasia in Plato's Protagoras. In: Phronesis, v. 47,2002 , p. 224-52.

WOODRUFF, P. The Skeptical Side of Plato's Method. In: Revue Internationale de Philosophie, n. 40, 1986, p. 22-37.

WOLFSDORF, D. The Ridiculousness of Being Overcome by Pleasure: Protagoras 352b1-358d4. In: Oxford Studies in Ancient Philosophy, v. 31, 2006, p. 113-36.

VERNANT, J. P.; VIDAL-NAQUET, P. Mito e Tragédia na Grécia Antiga. Rio de Janeiro: Paz e Terra, 1990.

VERNANT, J. P. Esboços da Vontade na Tragédia Grega. In: VERNANT, J. P.; VIDAL-NAQUET, P. Mito e Tragédia na Grécia Antiga. Rio de Janeiro: Paz e Terra, 1990, p. 25-52.

VLASTOS, G. The Socratic elenchus: method is all. In: Socratic Studies edited by Myles Burnyeat. New York: Cambridge University Press: 1994, p. 1-29.

. Socrates on Acrasia. In: Phoenix, Vol. 23, 1969, p. 71-88.

ZINGANO, M. Aristóteles: Ethica Nicomachea I 13-III 8: Tratado da Virtude Moral. Tradução, notas e comentários de Marco Zingano. São Paulo. Odysseus Editora, 2008.

. Estudos de Ética Antiga. São Paulo: Discurso Editorial, 2007. 
(Ed.). Sobre a Ética Nicomaquéia de Aristóteles: Textos

selecionados e coordenação de Marco Zingano. São Paulo, Odysseus Editora, 2010.

ZEYL, D. J. Socrates and Hedonism: Protagoras 351b-358d. In:

Phronesis, v. 25, n. 3, 1980, p. 250-269.

\section{Dicionários e gramáticas}

BAILLY, A. Dictionnaire Grec-Français. Édition revue par L. Séchan et P. Chantraine. Paris: Hachette, 1957.

CHANTRAINE, P. Dictionnaire étymologique de la langue grecque:

Histoire des mots. Paris: Klinckssieck, 1968.

LIDDEL, H. G.; SCOTT, R. Greek-English Lexicon. Oxford: Oxford University Press, 1996.

SMYTH, H. W. Greek Grammar. Harvard University Press, 1984. 